
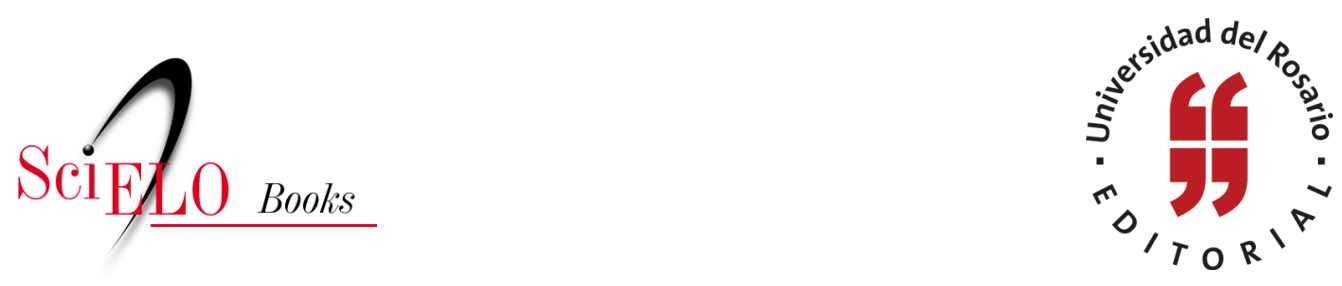

\title{
Imaginando América Latina historia y cultura visual, siglos XIX al XXI
}

\author{
Sven Schuster \\ Óscar Daniel Hernández Quiñones \\ (Editores académicos)
}

\section{SciELO Books / SciELO Livros / SciELO Libros}

SCHUSTER, S., and HERNÁNDEZ QUIÑONES, Ó.D., ed. Imaginando América Latina: historia y cultura visual, siglos XIX al XXI [online]. Bogotá: Editorial Universidad del Rosario, 2017, 450 p. Textos de ciencias Humanas collection. ISBN: 978-958-738-945-6. Available from: http://books.scielo.org/id/cw5zr. https://doi.org/10.12804/th9789587389456.

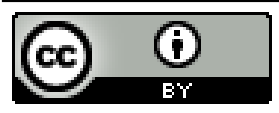

All the contents of this work, except where otherwise noted, is licensed under a Creative Commons Attribution 4.0 International license.

Todo o conteúdo deste trabalho, exceto quando houver ressalva, é publicado sob a licença Creative Commons Atribição 4.0.

Todo el contenido de esta obra, excepto donde se indique lo contrario, está bajo licencia de la licencia Creative Commons Reconocimento 4.0. 


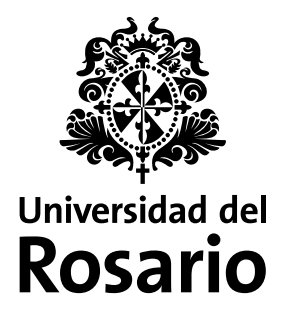




\section{Imaginando América Latina \\ Historia y cultura visual, siglos XIX-XXI}




\section{Imaginando América Latina. Historia y cultura visual, siglos XIX a XXI}

\section{Resumen}

¿Pueden las imágenes incidir en la historia? ¿Son fieles evidencias del pasado? Esta compilación aparece frente al renovado interés de la disciplina histórica y las ciencias humanas, por interpretar las fuentes visuales como producciones intencionalmente elaboradas y difundidas tanto en momentos como en espacios particulares. Alejándose de la vista inocente y contemplativa, los autores del libro proponen desde sus contribuciones, situar la función social de las imágenes en el centro de sus análisis de caso, los cuales abarcan un amplio conjunto de procesos latinoamericanos ocurridos entre los siglos XIX y XXI en países como Chile, Brasil, Perú, Colombia y Argentina. De esta manera, cada capítulo invita al lector a "pensar visualmente" temas como la propaganda política, la construcción de la nación, el ensamblaje de identidades o de memorias colectivas, etc., partiendo del supuesto metodológico que sugiere rastrear las imágenes desde su producción hasta su recepción, donde adquieren múltiples sentidos en su respectivo presente, así como en su preservación actual.

Imaginando América Latina se presenta entonces como una iniciativa abierta a diferentes perspectivas disciplinares no solo limitadas a la lectura del historiador. Los doce capítulos contenidos en este libro, buscarán reflexionar sobre la capacidad de la imagen para conectar realidades en escalas globales y locales, insistiendo en mostrar la doble relación entre una historicidad de lo visual y una visualidad de la historia.

Palabras clave: Historia, América Latina, violencia política, imaginarios sociales, cultura visual, siglos XIX-XXI.

\section{Imagining Latin America. History and visual culture, 19th to 21 st centuries}

\section{Abstract}

Can images influence history? Are they true evidence of the past? This compilation appears in the light of the renewed interest showed by the discipline of history and human sciences in interpreting visual sources as productions that were intentionally elaborated and disseminated in specific times and spaces. Moving away from an innocent and contemplative view, the authors of the book, through their contributions, propose to place the social function of images at the center of their case analyses, which cover a broad set of Latin American processes that took place between the 19th and the 21 st centuries in countries such as Chile, Brazil, Peru, Colombia, and Argentina. Thus, each chapter invites the reader to "visually think" about issues such as political propaganda, nation building, the assemblage of identities or collective memories, etc., based on the methodological assumption that suggests tracking images from their production to their reception, where they acquire multiple meanings in their respective presents, as well as in their current preservation status.

Imagining Latin America is, then, an initiative open to different disciplinary perspectives that are not limited only to readings from historians. The twelve chapters included in this book seek to reflect on the capacity of the image to connect realities at global and local scales, insisting on demonstrating a double relationship between the historicity of the visual and the visuality of history.

Keywords: history, Latin America, political violence, social imaginaries, visual culture, 19th-21st centuries.

Citación sugerida:

Schuster, Sven y Hernández Quiñones, Oscar D. (eds.) Imaginando América Latina. Historia y cultura visual, siglos XIX a XXI. Bogotá: Editorial Universidad del Rosario, 2017.

DOI: https://doi.org/10.12804/th9789587389456 


\title{
Imaginando América Latina Historia y cultura visual, siglos XIX-XXI
}

\author{
Sven Schuster \\ Óscar Daniel Hernández Quiñones \\ -Editores académicos-
}




\footnotetext{
Imaginando América Latina: historia y cultura visual, siglos XIX al XXI / Sven Schuster, Óscar Daniel Hernández Quiñones, editores académicos -- Bogotá: Editorial Universidad del Rosario, 2017.

ix, 450 páginas. -- (Colección Textos de Ciencias Humanas)

Incluye referencias bibliográficas.

Fotografía -- América Latina -- Historia / Fotografía -- Aspectos sociales -- América Latina / Violencia política -- América Latina -- Historia / I. Schuster, Sven / II. Hernández Quiñones, Óscar Daniel / III. Universidad del Rosario. Escuela de Ciencias Humanas / IV. Título. / V. Serie.

770.98

SCDD 20

Catalogación en la fuente -- Universidad del Rosario. CRAI
}

\section{Universidad del}

Colección Textos de Ciencias Humanas

(c) Editorial Universidad del Rosario

(c) Universidad del Rosario, Escuela de Ciencias Humanas

(C) Varios autores

(C) Alejandra Matiz, Acervo de la Fundación Leo Matiz, Colombia, por imagen de cubierta y página 107

Editorial Universidad del Rosario

Carrera 7 No. 12B-41, of. 501 • Tel.: 2970200 Ext. 3114

Bogotá, Colombia

editorial.urosario.edu.co
Primera edición: Bogotá, D. C., septiembre de 2017

ISBN: 978-958-738-944-9 (impreso)

ISBN: 978-958-738-945-6 (digital)

ISBN: 978-958-738-946-3 (pdf)

DOI: https://doi.org/10.12804/th9789587389456

Coordinación editorial: Editorial Universidad del Rosario

Corrección de estilo: Ella Suárez

Diagramación: William Yesid Naizaque Ospina

Diseño de cubierta: Precolombi UE, David Reyes

Impresión: Paramericana Formas e Impresos S. A.

Impreso y hecho en Colombia

Printed and made in Colombia

Los conceptos y opiniones de esta obra son de exclusiva responsabilidad de sus autores y no comprometen a la universidad ni sus políticas institucionales.

El contenido de este libro fue sometido al proceso de evaluación de pares, para garantizar los altos estándares académicos. Para conocer las políticas completas visitar: editorial.urosario.edu.co

Todos los derechos reservados. Esta obra no puede ser reproducida sin el permiso previo escrito de la Editorial Universidad del Rosario. 


\section{Contenido}

Presentación.

1

I. Historia a través de la fotografía: la objetividad de la cámara en pugna .. 21

La Masacre de las Bananeras: la imagen fotográfica y la literatura ........................ 23

Liliana Gómez-Popescu

Entre blanqueamiento y paraiso racial: el Imperio de Brasil y la legitimación visual de la esclavitud en las exposiciones universales

Sven Schuster

Alejandra Buenaventura

Sobre máquinas y titanes: la autorrepresentación fotográfica del gremio industrial colombiano (1945-1960)

Óscar Daniel Hernández Quiñones

II. Imágenes para la nación

La Pola, alegoría de la nación: memorias y silencios en las representaciones de Policarpa Salavarrieta

Daniela Prada

Fragmentando la unidad: análisis de la representación territorial chilena en el atlas de 1854

Camila Ramirez Maldonado 
Alegorías, ornamentaciones y heroínas: la presencia de las representaciones femeninas en los billetes colombianos y su aporte al imaginario nacional.

Lery Munar

Sebastián Gacha

III. Propaganda política e imagen

Difundir el Estado: la propaganda del Estado Novo en Brasil durante

la Segunda Guerra Mundial y su contradicción posterior.

Paulo Córdoba

Representando la revolución: la propaganda política del Gobierno

de Juan Velasco Alvarado en Perú (1968-1975)

Anna Cant

IV. Fuentes visuales en la cultura de masas: producción y consumo de estereotipos

El blanqueamiento de Blanquita: las imágenes del ascenso social y la disputa identitaria de la población negra en Colombia.

Andrés Pérez Carvajal

Carlos Gardel: de la imagen al mito

Laura Andrea Vigoya Arango

V. Construcción de memorias e identidades políticas en clave gráfica.

Un conflicto entre viñetas: historietas de la violencia política en el Perú (1989-2010)

Natalia Mahecha Arango

¿El mito Allende? Representaciones visuales y murales de Salvador Allende en el movimiento estudiantil de Chile (2011-2013).

Christiane Hoth

Los autores 
Aparece una imagen. Se presenta como un nervio vivo que se retuerce y late. Su destello marca una tensión silenciosa a la que es dificil dar un sentido, es pura vibración. ¿Cómo traducir el silencio que nos inunda en el encuentro con la imagen?, ¿desde qué lugar podemos aproximarnos a ella e intentar significarla sin pretender clausurar su potencia?

1 Sofía Sienra et al., "Introducción”, en La imagen como pensamiento, ed. por Sofía Sienra, Adriana Pérez, Leonardo Rodríguez y Juan Mojica (Toluca, Estado de México: Universidad Autónoma del Estado de México, 2015), 13. 


\section{Presentación}

Es un lugar común decir que una imagen vale más que mil palabras. En los albores del siglo XXI, en la era de la globalización informática, económica y cultural, estamos saturados de imágenes provenientes de cualquier contexto geográfico y social imaginable, lo cual hace que la primera constatación resulte casi banal hoy en día. En los países industrializados, los jóvenes pasan una gran parte del día absorbiendo informaciones visuales transferidas por sus portátiles, tablets y smartphones. Todos están inmersos en un mundo "hipervisual", cuyos contenidos circulan entre millones de personas en "tiempo real" y cambian de sentido constantemente, dependiendo del contexto social de cada destinatario. No obstante, debido al aparente digital divide que aún excluye millones de personas en África, Asia y América Latina de la supuesta aldea global imaginada por Marshall McLuhan en los años sesenta, la "vieja” televisión todavía cumple un papel importante al llevar imágenes colectivas hasta los últimos rincones del planeta, sea el Amazonas o África Central. Así, estamos compartiendo películas, fotografías digitales o imágenes generadas por computador que, en su conjunto, forman una masa de datos tan vasta que hasta hace pocos años habría fácilmente excedido la capacidad de internet. Desde entonces, también han evolucionado las tecnologías de almacenamiento, y nos han dado la oportunidad de guardar y difundir imágenes en cantidades nunca antes imaginadas.

En la sociedad mediática del siglo Xx, resultaba común pensar que las imágenes generadas de manera técnica y electrónica eran las únicas con el poder de "hacer historia”. Gracias a su reproducibilidad y a la velocidad de su difusión, estas eran capaces de penetrar sociedades y transcender fronteras, al adquirir en su transcurso una dimensión global y omnipresente. A partir de la masificación experimentada por este nuevo tipo de imágenes, se introdujo hace algunos años el término íconos mediáticos. ${ }^{1}$ La principal diferencia entre estos íconos y sus pares pertenecientes a la

1 Gerhard Paul, "Bilder, die Geschichte schrieben. Medienikonen des 20. und beginnenden 21. Jahrhunderts", en Bilder, die Geschichte schrieben. 1900 bis heute, ed. por Gerhard Paul (Göttingen: Vandenhoeck \& Rupprecht, 2011), 8-10. 
historia del arte consiste en el hecho de que el contenido de los primeros depende o se ve estructuralmente alterado por los soportes y canales en que se desplazan. Esto significa, según el ya citado McLuhan, que el tipo de medio siempre determina las características del mensaje ("The medium is the message"). ${ }^{2}$ Además, en muchos casos se trata de imágenes producidas y difundidas bajo criterios comerciales o políticos, razón por la que influyen en nuestras diferentes cotidianidades y experiencias colectivas.

De todas formas, muy pocas imágenes en este mar de visualizaciones efímeras llegan a obtener el estatus de "icónicas" hoy en día. ¿Será entonces que la generación de imágenes verdaderamente auténticas y poderosas, portadoras de una herencia cultural vinculada a lugares y tiempos concretos, finalmente ha cesado en la "era de su reproducción técnica”, como escribió Walter Benjamin de manera casi profética en 1936? ¿Será que los métodos de reproducción masiva del siglo XIX, como la litografía o la fotografía, han preparado el terreno para quitarles el "aura" a las que antes eran obras de arte únicas, cargadas de una genealogía simbólica, vieja y extensa? Según Benjamin, los procesos de mercantilización y difusión masiva, que se habrían intensificado entre finales del siglo XIX y comienzos del xx, habrían cambiado la función social de las imágenes y fomentado, por un lado, la posibilidad de compartir colectivamente lo que antes era el privilegio de una pequeña élite que usaba la cultura para distinguirse. ${ }^{3}$ Por otro, este potencial emancipador y democrático de la masificación de la imagen también podría entenderse como una amenaza. El mayor peligro que veía Benjamin en la nueva estética colectiva de las imágenes masificadas era su posible instrumentalización política, ejemplificada en la iconografía de los movimientos fascistas contemporáneos a él. ${ }^{4}$

Inspirándose en las ideas benjaminianas, el historiador Gerhard Paul comenta que la "hipervisualidad" de nuestros días, probablemente, haga cada vez más difícil la creación de nuevos íconos mediáticos. ${ }^{5}$ A primera vista, esta idea puede parecer paradójica si pensamos que fue justamente la posibilidad de su reproducción ilimitada y la difusión masiva, por medio de agencias de imágenes, televisión e internet,

2 Marshall McLuhan, Understanding Media: The Extensions of Man (New York: McGraw-Hill, 1964), 8-13.

3 Walter Benjamin, "Das Kunstwerk im Zeitalter seiner technischen Reproduzierbarkeit”, en Gesammelte Schriften, vol. 1, ed. por Rolf Tiedemann (Frankfurt am Main: Suhrkamp, 1980 [1936]), 475.

$4 \quad$ Ibid., 506.

5 Paul, "Bilder, die Geschichte schrieben”, 11. 
aquello que permitió la aparición de íconos, al transformar imágenes particulares en productos sin lugar y sin pertenencia concreta. Por otra parte, resulta evidente que la multiplicación y la filtración de información visual en cantidades nunca antes vistas desvía, cada vez más, la atención de los posibles destinatarios. En la medida en que los íconos mediáticos se separan de su contexto original —autonomizándose de sus soportes materiales y transformándose en símbolos con nuevos significados - resulta más difícil crear y difundir algo original e impactante que logre ocupar nuestras mentes cada vez más distraídas. Según la teoría del agenda setting, es la impertinencia (obstrusiveness) de las informaciones visuales transmitidas - por ejemplo la repetición continua de una imagen en un comercial — aquello que obtiene un efecto duradero, aunque no cumpla necesariamente con las expectativas de quienes encomendaron la producción de la imagen. ${ }^{6}$

Así, por ejemplo, la fotografía omnipresente del Che Guevara con su boina, originalmente tomada durante un evento oficial en Cuba en los años sesenta, se encuentra hoy en millones de camisetas, discos, tazas, relojes y pancartas. Los consumidores de esta imagen, sin embargo, no son necesariamente personas que luchan contra la represión capitalista en algún lugar del “Tercer Mundo”. Más bien, la imagen del Che se ha transformado en un plano de proyección universal, sin sentido político concreto, pero con buenas posibilidades de comercialización. Lo que se vende, de hecho, es la imagen descontextualizada y vaga de alguna forma de "heroísmo noble"; cada uno tendrá otras asociaciones particulares al apropiarse de la imagen del revolucionario fallecido. Más allá de profundizar en esto, el ejemplo anterior reitera cómo se presenta en la actualidad una fuerte tendencia de descontextualización de las imágenes, lo cual incluye la eliminación de las huellas documentales — como leyendas escritas o márgenes "inútiles" en el caso de la fotografía - y ello posibilita, de esta forma, su posterior iconización. La lógica comercial o política de su distribución, así como la movilidad y la multiplicación masiva, sacan estas imágenes de su contexto de origen y las desplazan a contextos más abstractos, a sociedades y culturas completamente ajenas. En este proceso, sin duda, las imágenes pierden su lugar y su genealogía, para poder transformarse en íconos mediáticos. Pero ¿pierden también su "aura”, es decir, el poder que radica supuestamente en la sacralización de la estética original, en su “aquí y ahora”, en palabras de Benjamin?

6 Maxwell McCombs, Setting the Agenda: The Mass Media and Public Opinion (Cambridge: Polity Press, 2004), 1-20; 134-145. 
Es bastante cuestionable que sea así. Por un lado, debemos entender que la "unión mística" entre el espectador y la obra de arte es algo "real", aunque sea un producto de nuestra experiencia subjetiva. La noción de que la comunicación entre el original y el observador sea un privilegio que no puede ser alcanzado siquiera por la copia más perfecta predomina entre todos nosotros, aunque muchas veces de manera inconsciente. Si no fuera así, nadie visitaría un museo hoy en día, sobre todo si consideramos que puede ser más fácil e incluso más íntimo apreciar una obra de arte en el computador de nuestros hogares. Así, por ejemplo, Google ofrece versiones digitalizadas en alta resolución de reconocidas obras localizadas en el Museo del Prado de Madrid. ${ }^{7}$ De hecho, la resolución de estas imágenes es tan alta que el "espectador digital" puede acercarse varios milímetros y ver detalles que serían imposibles de observar en el museo, porque se activaría la alarma. En este sentido, la obra de arte ha pasado por una especie de reauratización, en la cual los lazos íntimos entre observador y cuadro se dinamizan constantemente; los conocimientos sobre la técnica y la historia de la obra, combinados con una mirada más intensiva en un ambiente privado, hacen que el "aura" cobre fuerza nuevamente bajo nuevas modalidades.

Por eso, como historiadores, debemos fijarnos en las distintas convenciones históricas y culturales que definen las posibles maneras de ver e interpretar una imagen; en otras palabras, analizar las distintas oscilaciones que determinan los “modos de ver", como lo señala Jonathan Crary. ${ }^{8}$ A propósito, la gente nunca iría a venerar la imagen de la Virgen de Guadalupe en Ciudad de México si no creyera en los poderes espirituales de este “original", creado directamente por Dios, según reza la voz popular. El significado y la función social de la imagen de la Virgen solo pueden entenderse si nos acercamos al mundo religioso de sus discípulos católicos. También tenemos que aceptar que los millones de imágenes de la "Guadalupana" que circulan hoy en México y Centroamérica, encima de varillas de carros o en forma de tatuajes y artesanías, no son menos auráticas. Aun cuando no siempre aparezcan en el contexto familiar del catolicismo oficial, pueden volverse imágenes sacralizadas, llenas de significados divergentes. Así, la imagen de la Virgen se

7 Museo Nacional del Prado, "Masterpieces of the Prado Museum with Google Earth", https://www. museodelprado.es/en/the-collection/sueltas/masterpieces-of-the-prado-museum-with-googleearth/ (31/03/2017).

8 Jonathan Crary, Techniques of the Observer: On Vision and Modernity in the Nineteenth Century (Cambridge, MA: MIT Press, 1992). 
adapta perfectamente al universo simbólico de una banda de narcotraficantes, al igual que cuando cumplió efectivamente su función en las banderas de la lucha por la independencia de México, hace más de doscientos años. Como historiadores con una fuerte afinidad antropológica, nos llaman la atención las formas en que grupos sociales pequeños o grandes emplean estas imágenes para crear universos simbólicos que dan un sentido a sus vidas y al accionar del grupo. En consecuencia, lo que nos interesa no es tanto la estética de la imagen, sino su función social y política dentro de discursos históricamente constituidos. Creemos que una imagen se complementa con el espectador, por lo cual no puede ser analizada fuera de su contexto social y cultural, como si fuera un fenómeno aislado, la obra de un "genio" o la representación del "espíritu de una época” en el sentido de Hegel. Este, sin demeritar sus alcances, sería el campo de la historia del arte más tradicional.

Otro aspecto fundamental que ha marcado nuestra manera de acercarnos a las imágenes en las últimas décadas es la conciencia creciente acerca de posibles manipulaciones. Como ejemplificaron las imágenes que Colin Powell presentó ante las Naciones Unidas, en 2003, para justificar la invasión estadounidense a Iraq — con el fin de detectar "armas de destrucción masiva” inexistentes-, las fotografías y planos presentados por supuestos expertos eran simples falsificaciones. Aunque herramientas como Photoshop facilitan en la actualidad la manipulación de imágenes electrónicas o fotografías digitales, la alteración de contenidos visuales no es un fenómeno reciente. En el siglo xx, el “maestro" en el empleo de estas técnicas era, sin duda, Stalin, quien mandó a borrar varios de sus adversarios políticos de las fotografías oficiales de la Unión Soviética, hasta tal punto que apareció prácticamente solo en algunos "retratos grupales". Aparte de este episodio representativo, muchas otras fotografías, supuestamente verídicas, han sido manipuladas desde el siglo Xx. Otro caso famoso sería, por ejemplo, la fotografía tomada por Robert Capa del soldado caído en la Guerra Civil Española, sobre la cual sabemos que no fue directamente una manipulación, pero sí una descontextualización deliberada; Capa tomó la foto durante un entrenamiento y no en el frente, como hizo creer a los medios masivos de la época. No obstante, era una guerra, y los republicanos necesitaban urgentemente ayuda internacional. Fotografías emotivas de este tipo podían fungir como aliados tan poderosos como las armas o el apoyo de tropas.

Frente a esta encrucijada que — dependiendo de momentos y lugares — sitúa la interpretación de lo visual entre la credibilidad y el escepticismo, este libro se guía por la convicción de que la historia puede hacer un aporte significativo al estudio 
de las imágenes, al usarlas como fuentes primarias de climas sociales complejos. ${ }^{9}$ A partir de una mayor contextualización, y por medio de una crítica rigurosa de fuentes, la historia puede arrojar nuevas luces sobre el uso concreto de las imágenes materiales y su inserción en discursos específicos. Sin embargo, los ensayos aquí reunidos no privilegian algún método fijo que defina las coordenadas en las cuales dicho acercamiento analítico debe realizarse. Como la materialidad y el contexto cultural de las fuentes visuales aquí trabajadas — desde fotografías del siglo XIX hasta películas y obras de arte contemporáneas - son bastante dispares, preferimos articular una pluralidad de herramientas interpretativas, las cuales, más allá de caer en un eclecticismo sin criterio, se encuentran orientadas por las necesidades específicas que demanda cada imagen. En este sentido, los siguientes capítulos tienen la finalidad de demostrar el potencial historiográfico de vestigios visuales, entendiendo imágenes y textos como fuentes del mismo rango, pero principalmente con alcances explicativos complementarios.

Para el desarrollo del libro, un poco en contracorriente a la mayoría de discusiones adelantadas por los estudios culturales — donde lo particular frecuentemente desaparece detrás de "discursos" supraindividuales que asumen el papel de "agentes históricos" - queremos identificar algunas de estas imágenes concretas en su dimensión material, así como localizar sus productores y destinatarios. Las leeremos, las contextualizaremos y las interpretaremos dentro de los marcos discursivos y las tensiones de su época; también indagaremos acerca de su elaboración, su difusión y su recepción. Todo esto con el fin de entender por qué y cómo han podido desempeñar un papel como agentes de la historia, y no como simples representaciones pasivas. Con este horizonte en la mira, nos interesan los diferentes "modos de ver"; averiguar, a grandes rasgos, sobre las convenciones y negociaciones culturales de distintos periodos que definieron las maneras de leer y transmitir imágenes. Más allá de sus condiciones palpables, apostamos por pensar la imagen como el soporte codificado de un proceso comunicativo que solo puede ser entendido al ampliar nuestra base empírica. No obstante, en América Latina estudios de este tipo todavía son muy escasos. Nos gustaría entonces contribuir a llenar dicho vacío historiográfico, ofreciendo abordajes particulares que indagan respecto de los usos (y abusos) de imágenes en la historia del continente entre los

9 Este uso conceptual de las “imágenes” excluye explícitamente las imágenes mentales (images), cuya relación con las fuentes visuales tangibles todavía no ha sido tratada lo suficiente. 
siglos XIX y XXI, incluso mostrando los alcances transnacionales que varias de las representaciones analizadas llegaron a tener.

La apuesta por una variedad de acercamientos interpretativos procura alejarse de los estudios inspirados por la historia del arte más tradicional, todavía fundamentados en el modelo "clásico" de Erwin Panofsky, que va de la "descripción preiconográfica” al “análisis iconográfico e histórico” y, por último, al "entendimiento del sentido documental". ${ }^{10}$ Consideramos que esta metodología aún es válida, pero que puede ampliarse con las dimensiones de la circulación, la apropiación y la recepción. Como propuesta de cierre para esta reflexión introductoria, quisiéramos hacer un aporte a una nueva corriente de estudios visuales, cuyo auge podría enmarcarse en lo que se ha llamado pictorial turn (W. J. T. Mitchell) o iconic turn (Gottfried Boehm); es decir, una tendencia cuyo enfoque está en los múltiples usos sociales de imágenes materiales. ${ }^{11} \mathrm{Al}$ igual que los representantes de este campo, creemos que ciertas imágenes pueden extenderse al espacio público, donde ejercen un poder político dentro de contextos históricos definidos. Con esto, nos acercamos de manera más específica a lo que Gerhard Paul ha bautizado como historia visual (visual history), o sea, una visión constantemente repensada que además de comprender las imágenes como insumos temáticos, las entiende como actos en sí mismos que nos muestran en sus modulaciones y latencias una historicidad de "lo visual", al igual que una visualidad de la historia.

\section{Contenido}

Esta antología, organizada y editada por los miembros del grupo de investigación Historias Conectadas, Memoria e Imagen, de la Escuela de Ciencias Humanas de la Universidad del Rosario, en colaboración con académicos de otras universidades, es una especie de "laboratorio". Busca, desde líneas transdisciplinares de acción, sugerir horizontes y modos de investigar la serie de pulsiones y silencios que guarda la imagen en sus apariciones, idealizaciones y, no menos importante, sus controversias desatadas. La inquietud por materializar el interés del grupo en el protagonismo de "lo visual" desde la historia latinoamericana permitió, luego de

10 Erwin Panofsky, Studies in Iconology: Humanistic Themes in the Art of the Renaissance (New York: Oxford University Press, 1939).

11 W.J. T. Mitchell, Picture Theory: Essays on Verbal and Visual Representation (Chicago: The University of Chicago Press, 1994); "El giro icónico: una carta entre Gottfried Boehm y W.J. Thomas Mitchell", en Filosofía de la imagen, coord. por Ana García Varas (Salamanca: Ediciones Universidad de Salamanca, 2011), 57-70. 
varias reuniones, que algunos artículos procedentes de tesis de posgrado, pregrado, ponencias de invitados internacionales o trabajos afines a los intereses temáticos del equipo, lograran concretarse en la selección de los escritos aquí presentados.

Los capítulos del tomo están distribuidos en cinco ejes o debates específicos sobre el estudio de fuentes visuales y, principalmente, sobre los usos y apropiaciones que estas —en medio de sus especificidades materiales y simbólicas — han tenido en el desarrollo de casos históricos concretos. Habría resultado poco conveniente, en un primer momento, organizar estos conjuntos de escritos en función de la composición o naturaleza de las fuentes (grafiti, fotografía, pintura, etc.), precisamente porque varios textos han hecho análisis transversales entre los diferentes tipos de representaciones que se pueden encontrar de un personaje reconocido, un lugar, un régimen político o, incluso, un acontecimiento presente en memorias grupales e individuales. A raíz de esta dificultad y con excepción del primer apartado dedicado a la fotografía y la pregunta por su "transparencia”, preferimos articular las temáticas de los ensayos bajo el criterio de los usos o dinámicas en que operan las imágenes consultadas. Esto permite visibilizar mejor aquellos "puntos comunes" donde cada acercamiento puede dialogar con los demás, a partir de fenómenos o preguntas cercanas. A continuación, presentamos una explicación concisa de los criterios que guían cada uno de los ejes, así como una descripción general de las contribuciones hechas por los autores del proyecto.

\section{Fotografía y objetividad: la autoridad de la cámara en pugna}

Como mencionábamos, la representación fotográfica o "el acto fotográfico", en el sentido de Philippe Dubois, es un ejercicio cuyo análisis necesita distanciarse de la vista inocente que encuentra en sus dimensiones técnicas y sistemáticas un soporte ilustrativo cercano a la verdad de algo ocurrido. ${ }^{12}$ Dubois señala que la decisión de tomar una foto conlleva una acción precisa de "golpe" o de "corte", es decir, un ejercicio intencional de selección que extrae o aísla una imagen de su continuidad en el tiempo y el espacio. ${ }^{13}$ Esta intencionalidad puede rastrearse, en gran medida, desde los juegos de escalas y tonalidades que apreciamos en una pieza fotográfica hasta la serie de textos que complementan su significación. Para este primer eje decidimos, entonces, acercarnos a la fotografía como fuente primaria por medio

12 Para referencia completa, revísese: Philippe Dubois, El acto fotográfico y otros ensayos, $2^{\mathrm{a}} \mathrm{ed}$. (Buenos Aires: La Marca, 2015).

Ibid., 147. 
de una actitud crítica que permitiera explicar las limitaciones de su objetividad, así como los marcos de sentido y las audiencias dispares donde esta adquiere un carácter polisémico. El procedimiento mecánico ejecutado por la cámara gozó durante su emergencia en el siglo xIX y su desarrollo masivo en el XX, un auge inimaginable que pensaba la fotografía como una "evidencia” indiscutible. A partir de dicho estatus documental, los ensayos de este bloque buscan comprender y matizar distintas experiencias de producción y recepción fotográfica atravesadas por circunstancias históricas particulares.

La primera contribución está a cargo de Liliana Gómez-Popescu, quien realiza una lectura reflexiva de la conocida Masacre de las Bananeras, de 1928, ocurrida en Ciénaga, Magdalena, a partir de la doble representación que esta gozó por parte del archivo fotográfico de la United Fruit Company y por parte de la novela literaria, cuyo ejemplo más representativo continúa siendo Cien años de soledad, de Gabriel García Márquez. Esta doble lectura - en términos de fuentes- permite a Gómez contraponer la materialidad químico-técnica de la fotografía asociada a su "veracidad" con la semántica "ficticia" de la literatura, la cual reivindica y visibiliza aquello que la narrativa de la cámara ensombrece, en este caso, detrás del sesgo documental de la United Fruit como agente político-global. Así, aportando una mirada novedosa a la relación propuesta entre fotografía y literatura, GómezPopescu sugiere pensar ambas como archivos con relatos y naturalezas diferentes, pero a su vez entrecruzadas, a fin de contrastar el carácter "evidente" de la primera - cuyo testimonio no habla por sí mismo - con el ejercicio alternativo de memoria o el punto de inflexión que representa la novela de García Márquez.

Luego, Sven Schuster y Alejandra Buenaventura nos presentan un capítulo sobre los modos en que el Imperio brasileño, bajo el mandato de don Pedro II, recurrió a la fotografía para justificar y representar de manera benigna su sistema esclavista vigente, en el marco de las exposiciones universales de la segunda mitad del siglo xIX. Con el ánimo de posicionarse como una nación moderna y civilizada, la participación de Brasil en estos certámenes del progreso internacional fue, sin duda alguna, la que más recursos destinó de toda América Latina para enaltecer el prestigio de su pabellón frente a millones de visitantes. No obstante, los reconocidos avances económicos del Imperio se vieron simultáneamente criticados por naciones donde el creciente debate abolicionista condenaba con mayor fuerza la continuidad de la esclavitud, lo que denuncia así una situación paradójica en la que el progreso brasileño coexistía con una institución no civilizada, según rezaban las críticas. De esta forma, Schuster y Buenaventura explican cómo los pabellones del imperio de 
don Pedro, aprovecharon las grandes exposiciones como plataformas globales para ofrecer, desde la fotografía, una imagen positiva del polémico sistema económico y social. Más allá de representar este último como un modelo de trabajo forzado, los esclavos fueron fotografiados como una población en vías de civilización y, consecuentemente, como un sector en proceso de "blanqueamiento" racial y cultural; una estrategia que, según se aprecia en los comentarios de los visitantes o la misma prensa, tuvo muy buenos resultados al plasmar la esclavitud desde la cámara como un proyecto educacional y un acompañamiento paternalista del imperio hacia aquellos grupos raciales en mora de "hacerse modernos".

Cerrando este primer bloque se encuentra el texto de Óscar Daniel Hernández, quien busca responder cómo el empresariado industrial colombiano entre 1945 y 1960 hizo de la fotografía documental una tecnología de autorrepresentación adecuada para fijar una "identidad de gremio" que separó visualmente su actividad de las de otras comunidades empresariales y, consecuentemente, presionó la modernización económica nacional. A partir del análisis de fotografías publicadas en revistas empresariales de circulación privada e internacional, el autor recoge algunos elementos estilísticos compartidos por las imágenes seleccionadas, vinculando sus características observadas con la serie de discusiones que en aquel periodo se desarrollaban en torno al debate por industrializar el país. Las revistas alusivas al sector fabril operaron como productos ícono-textuales para alfabetizar en sus oficios a industriales de todo tipo o condición; pero, además, apelaron a la fotografía documental como uno de varios recursos para definir desde la imagen qué personajes, actividades y espacios encarnaban la consigna nacional de la industrialización y la modernización productiva. Esto permite al autor, en primera instancia, problematizar el lugar designado a la fotografía sobre la industria como un simple "registro técnico" y, en una reflexión más amplia, plantear las modalidades visuales con las que un fenómeno económico se pensó en términos de identidad a través de las máquinas, las fábricas y sus portavoces o “titanes” del progreso.

\section{Imágenes para la nación}

El proceso de formación de la nación en América Latina sigue despertando interés investigativo en las ciencias sociales, debido a su aparición temprana, que marcó en los albores del siglo XIx la emergencia de discursos patrióticos, tradiciones y poderosas narrativas hegemónicas alrededor de la nación como máxima entidad política y cultural. Esta construcción de relatos colectivos no puede entenderse por fuera del uso deliberado que han tenido las imágenes materiales para generar referencias 
conceptuales sobre lo que debe y no debe ser la nación; una división simbólica que involucra necesariamente a grupos sociales, prácticas, espacios y legados históricos destinados intencionalmente a ser reconocidos $\mathrm{u}$ olvidados, dependiendo de los intereses en juego. Según Hans-Joachim König, las imágenes de corte nacionalista desempeñan, en su gestación y reproducción, un rol metafórico capaz de comprimir contextos políticamente complejos en ofertas visuales simples de asimilar. ${ }^{14}$ Desde esta breve mirada, el segundo eje del libro está compuesto por tres capítulos con diferentes temas y enfoques que permiten relacionar el papel alegórico de ciertas representaciones visuales con los procesos de construcción nacional que estas han ayudado a forjar. Lo interesante de la relación entre imágenes y formación de discursos nacionales es que su análisis no se agota en discusiones pasadas del periodo republicano; por el contrario, la constante reinvención y actualización de símbolos patrióticos abre la posibilidad de encontrarlos en el presente, así como de apreciar sus cambios y apropiaciones en coyunturas donde han sido instrumentalizados.

El debate inicia con el capítulo de Daniela Prada, quien busca indagar en los diferentes criterios políticos y culturales bajo los cuales se han regido las representaciones de Policarpa Salavarrieta como heroína de la nación. A partir de diferentes tipos de fuentes, como estatuas, estampillas o pinturas, Prada destaca el caso de "la Pola" como un ejemplo que ilumina las disputas y tensiones para crear alegorías o relatos del pasado nacional, incluso doscientos años después de su muerte, donde el legado de la prócer independentista ha adquirido nuevas expresiones o modalidades de representación visual. No obstante, la autora señala que cada una de estas alegorías ha surgido después de negociaciones y luchas simbólicas por conquistar la memoria patriótica bajo principios atribuidos a un personaje. De este modo, se problematiza la “espontaneidad” de aquellas imágenes de Policarpa que la han proyectado, a veces, como mártir pasiva de la Reconquista española o como heroína altiva de la Independencia con un halo de inmortalidad presente en los mitos fundacionales del Estado-nación. Prada logra matizar, entonces, los elementos y contextos temporales que han hecho y hacen de la Pola un ícono en disputa, al igual que una figura cuyas definiciones cambiantes se han debatido entre la exaltación y el silencio.

14 Hans-Joachim König, "La función de las imágenes en el proceso de construcción de las naciones latinoamericanas", en La nación expuesta: cultura visual y procesos de formación de la nación en América Latina, ed. por Sven Schuster (Bogotá: Universidad del Rosario, 2014), 3. 
La segunda contribución de este bloque es el capítulo de Camila Ramírez Maldonado, titulado "Fragmentando la unidad: análisis de la representación territorial chilena en el atlas de 1854". A partir de un diálogo disciplinar entre geografía e historia, la autora destaca el papel de la cartografía como un saber especializado, que hacia mediados del siglo XIX tuvo una importancia crucial en la delimitación y legitimación del Estado chileno. A partir de esta premisa, Ramírez analiza el caso del atlas geográfico elaborado por el naturalista francés Claudio Gay, cuyos estudios y representaciones de diferentes regiones chilenas no se limitaron a levantamientos físicos del espacio; el atlas contó también con obras gráficas sobre los elementos naturales, sociales y culturales del país, que robustecieron una narrativa coherente acerca de la nación chilena, sus fronteras, recursos y población. De este modo, los mapas — como fuentes privilegiadas del capítulo— lograban articular elementos sociales y territoriales como un "todo unificado". De manera más explícita, la representación visual del espacio fijaba los límites y alcances de la nación y permitía, incluso, plantear la existencia de una "historia común", de una realidad exterior y homogénea compartida por todos los sujetos que se ubicaran dentro de dichos límites, institucionalizados en soportes físicos como los atlas. En este sentido, la autora reconstruye los aspectos principales de la obra de Gay que lograron posicionar simbólicamente una definición territorial del Estado chileno, así como una caracterización hegemónica de sus componentes, organizados por la práctica cartográfica en aras de configurar identidades nacionales.

Al final de esta sección se encuentra el texto de Lery Munar y Sebastián Gacha, que hace un recorrido histórico por la iconografía numismática colombiana, buscando identificar la presencia alegórica de figuras femeninas en billetes. El papel moneda - y el dinero en general - suele relacionarse estrictamente con su uso cotidiano como medio universal para el intercambio de valores. Frente a esta definición algo funcional, los autores proponen analizar un objeto tan rutinario y común desde su valor simbólico; específicamente, como un dispositivo cuyas ilustraciones temáticas (paisajes, personajes u objetos) forjan identidades e imaginarios cambiantes de la nación. Así, Munar y Gacha exploran desde los billetes — como vehículos visuales de circulación dinámica - representaciones de mujeres en diferentes etapas de la construcción nacional colombiana, indagando por la visibilidad, los significados y el lugar alegórico que tales figuras han ocupado en la definición "colectiva" de atributos y comportamientos ejemplares. Generalmente, dicha fijación de un epos patriótico ha contado con más rostros y legados masculinos, representados desde relatos oficiales por próceres, héroes y "hombres ilustres" con 
mayor reconocimiento histórico. Frente a esta asimetría, resulta pertinente para los autores explorar cómo la reducida aparición de mujeres en el dinero ha estado enmarcada por determinadas condiciones políticas de producción que manifiestan una constante reinvención y actualización de aspectos nacionales "dignos" de ser recordados, lo que reitera que la misma noción de lo "memorable” también se encuentra sujeta a cambios e interpretaciones distintas. Por lo tanto, no se trata de un análisis reducido a la materialidad de los billetes como piezas con estética nacionalista; al contrario, el dinero ilumina toda una serie de disputas simbólicas para monopolizar la memoria nacional, una discusión que sin duda conserva su vigencia, teniendo en cuenta que hasta el 2016 el Banco de la República remplazó algunos de sus billetes por nuevos diseños que incluyeron rostros femeninos.

\section{Propaganda política e imagen}

El tercer bloque está conformado por dos capítulos: el primero, escrito por Paulo Córdoba, sobre la propaganda proestatal utilizada en el régimen de Getúlio Vargas para legitimar la participación de Brasil en la Segunda Guerra Mundial; el segundo es el texto de Anna Cant acerca del uso de imágenes por parte del Gobierno de Juan Velasco Alvarado para impulsar mediáticamente la Reforma Agraria de 1969 en Perú. Un análisis histórico sobre propaganda política resultaría incompleto si no incluyera los alcances de las imágenes materiales producidas y difundidas estratégicamente en audiencias masivas. En medio de múltiples definiciones que nutren la discusión, la propaganda puede entenderse, a grandes rasgos, como la manipulación de mensajes y símbolos en búsqueda de cambios pragmáticos en la opinión pública. En ese sentido, la propaganda opera sobre predisposiciones, acomoda y sintetiza discursos específicos con base en experiencias previas de aquellos grupos que se desea influenciar y que, además, se consideran necesarios para apoyar o rechazar ideas en el corto plazo. ${ }^{15}$ Con el ánimo de aportar reflexiones puntuales respecto de la elaboración y significación de estos “mensajes visuales” en América Latina, los textos de esta sección trabajan gobiernos o regímenes políticos concretos a partir de los cuales se identifiquen motivaciones, procesos e impactos de la propaganda en climas contextuales con su propia complejidad.

Paulo Córdoba realiza un análisis concentrado en la prensa brasileña publicada durante el periodo conocido como Estado Novo (1937-1945), bajo el Gobierno

15 Tom Bryder, "Conceptual Elements for a Theory of Visual Political Propaganda", Psicología Politica, n. ${ }^{\circ} 37$ (2008): 102-104. 
centralizado de Getúlio Vargas. El autor plantea que, en medio de las inestabilidades del régimen, la Segunda Guerra Mundial fue la oportunidad perfecta para canalizar la atención y las críticas internas hacia un discurso de unidad nacional proclamado por el mismo Vargas, quien estratégicamente habría tomado posición en el conflicto, al prestar su apoyo político a Estados Unidos y los países aliados. Así, la percepción negativa que se tenía del Estado Novo como un aparato administrativo represor fue manipulada mediante discursos y ensamblajes visuales para legitimar el régimen como un gobierno heroico, protector de intereses comunes y receptor de una modernidad prometida por los protagonistas "occidentales" de la segunda conflagración mundial. De este modo, Córdoba intenta explicar cómo el uso de propaganda política en la prensa permitió la representación idealizada de las nuevas alianzas internacionales de Brasil, así como una mediación adecuada entre las contradicciones del Gobierno varguista y la exaltación de su papel en una guerra que ahora acaparaba la atención del país entero.

Por su parte, Anna Cant trae a colación la importancia de la propaganda política en el marco de la Reforma Agraria de Perú (1969), fomentada por el Gobierno militar de Juan Velasco Alvarado. Curiosamente, no favorecía los intereses de las élites terratenientes, como sí llegaron a hacerlo otros regímenes militares de América Latina. Por el contrario, este buscaba generar cambios drásticos en la distribución de la tierra, la cual para principios de los años sesenta reflejaba desigualdades abismales entre pequeñas y grandes unidades agropecuarias. Así, las transformaciones propuestas por Velasco y su aparato estatal debían ser estructurales y no simples medidas provisionales; surgía la necesidad de movilizar a sectores populares — principalmente campesinos - que apoyaran la iniciativa del Gobierno, dirigir "desde arriba" en palabras de la autora, una revolución contra el gran latifundio, a fin de perseguir una democratización de la tierra sustentada en un modelo de cooperativas agrarias. Cant destaca las modalidades en que dicha revolución fue representada visualmente, a través de una compleja comunicación de masas donde el Estado empleó símbolos tanto indígenas como campesinos para personificar la consigna de la reforma en rostros y sectores sociales específicos. Sin embargo, la autora también hace hincapié en que tal proceso tuvo partes problemáticas, donde la imagen idealizada de las clases populares no siempre reflejaba una agencia política asignada por el Gobierno a estos; una ruptura que invita inevitablemente a pensar la representación como ejercicio de poderes en permanente definición. 


\section{Fuentes visuales en la cultura de masas: producción y consumo de estereotipos}

Señalábamos en los primeros párrafos de esta introducción lo problemática que parecería ser la tesis sobre una eventual "pérdida del aura" en las imágenes movilizadas y contempladas actualmente. Hasta cierto punto, los debates sostenidos por la Escuela de Fráncfort —entre estos los de Benjamin — sobre la denominada cultura de masas tuvieron cabida en el mundo contemporáneo, principalmente cuando apreciamos cómo, cada vez más, las distintas formas simbólicas producidas y consumidas industrialmente son degradadas a la categoría económica de mercancías. ${ }^{16} \mathrm{El}$ mundo hipervisual al que nos hemos referido se distingue por una multiplicidad de tecnologías como la publicidad, la televisión o el cine, encargadas de estandarizar la masificación de productos visuales en contextos y soportes heterogéneos. Mediante complejas industrias y mecanismos persuasivos, algunos rostros o personajes (reales o ficticios) han llegado a resultarnos familiares, al naturalizar asociaciones inmediatas como aquella que relacionaba a Marilyn Monroe con la sensualidad femenina universal durante el siglo xx o, en un escenario más contemporáneo, aquellos esfuerzos mediáticos e incluso artísticos por simbolizar la figura de Osama bin Laden como la principal amenaza del hemisferio occidental, la democracia y la cristiandad. No obstante, los capítulos que componen esta sección rebaten desde sus respectivos temas el supuesto de la cultura de masas que concibe a las audiencias consumidoras de productos visuales como "contenedores vacíos" y sin criterio; como grandes cuerpos sociales de tendencias homogéneas. De cierta manera, los dos textos de este eje, escritos por Andrés Pérez y Laura Vigoya, se acercan más a una noción de audiencias activas, capaces de redefinir los significados de algunas imágenes habituales, apropiarse de estas tanto geográfica como culturalmente, así como sugerir alternativas para que sean representadas bajo nuevos sentidos e interpretaciones.

Andrés Pérez Carvajal ofrece una explicación contemporánea sobre las formas en que se ha representado a las mujeres afrodescendientes en Colombia durante los últimos treinta años, específicamente a la luz del personaje publicitario conocido como Blanquita. Para el autor, el caso de esta mujer — cuyo nombre y atributos fueron diseñados para una extensa campaña de limpiadores - resulta significativo, en la medida en que permite observar cómo ciertos imaginarios procedentes del

16 Antonio Ariño, Sociología de la cultura: la constitución simbólica de la sociedad (Barcelona: Ariel, 1997), 149. 
interior del país sobre la población negra han sido materializados en representaciones simbólicas de inferioridad y subordinación tanto económica como social. Así, las apariciones de Blanquita en distintas pautas comerciales constituyen, en palabras de Pérez, un proceso de "racialización"; es decir, la construcción de relaciones de dominación a través de las diferencias fenotípicas y culturales como principales fundamentos de exclusión. Sin embargo, lo que el autor resalta de dicho ejemplo es la forma en que la representación de Blanquita la ha inscrito, durante sus treinta años, en un proceso de movilidad social e incluso de "blanqueamiento" (racial y cultural), donde la mujer pasó de ocupar labores de empleada doméstica a ser en los últimos años de su aparición publicitaria un ama de casa ahorradora, independiente y con rasgos fenotípicos "menos negros” que en sus orígenes de los años ochenta. Más allá del personaje en sí mismo, el capítulo de Pérez Carvajal hace una lectura crítica sobre las transformaciones de dichos imaginarios en una temporalidad reciente, conectando el conjunto de representaciones visuales mencionadas con las luchas reivindicativas que la población afrodescendiente ha sostenido y sigue sosteniendo en torno a su identidad y visibilidad masiva.

Luego, encontramos el capítulo de Laura Vigoya Arango, titulado "Carlos Gardel: de la imagen al mito”. En el texto la autora recorre las principales etapas artísticas del reconocido cantautor y actor argentino, al mostrar cómo su legado e iconización póstuma fueron configurados por las incipientes industrias culturales de América Latina, pero también por distintos sectores sociales que hicieron del tanguero una figura de identidad colectiva, no solo restringida al espacio argentino, sino a otros contextos como el colombiano. De hecho, la producción mediática, y en gran medida artificial de Gardel como producto cultural, puede considerarse un caso exitoso de las primeras iniciativas por masificar la imagen de un artista latinoamericano, tal como se hacía con celebridades estadounidenses. Sin embargo, volviendo a la noción de las audiencias activas, Vigoya otorga un papel igual de importante a las clases populares urbanas que integraron la vida y obra de Gardel a sus propios relatos, expresiones e identidades. Así, algunos aspectos, por ejemplo, la apariencia física escenificada, el contenido de sus letras, los itinerarios por el mundo e, incluso, su muerte repentina, son analizados en el texto a modo de insumos que no solo permiten referirse a Gardel como figura mítica del tango, sino también como un personaje que encarna memorias y narrativas sociales, presentes en fuentes visuales, entre ellas la publicidad, la fotografía, el arte urbano y el cine. 


\section{Construcción de memorias e identidades políticas en clave gráfica}

Los capítulos reconstruidos hasta el momento comparten un rasgo fundamental: se trata de casos en los cuales el uso deliberado de imágenes ha perseguido alcanzar consensos o fijar opiniones parcializadas desde lugares hegemónicos de enunciación, como los Estados nacionales modernos, entidades imperiales, regímenes autoritarios o ciertas instituciones influyentes en la esfera económica y cultural. En buena medida, aquellas imágenes parecerían gozar de mayor visibilidad, precisamente por haber circulado en soportes legítimos y ortodoxos, con mejores posibilidades de perdurar en la discusión pública, de seguir siendo reproducidas a través del tiempo. Sin embargo, consideramos que esta exploración en materia de fuentes, pero también de problemas históricos, se complementa de forma valiosa al incluir espacios y modalidades poco convencionales, donde la imagen también ha facilitado articular memorias grupales e inscribirse en agendas políticas. Los dos textos de este último eje funcionan de cierta manera como un contrapunto: abordan representaciones visuales que en su momento han evocado experiencias dolorosas y definido los símbolos de luchas reivindicativas llevadas a cabo por sectores no oficiales. De esta forma, se trata de investigaciones en que el elemento popular no solo es receptor e intérprete de contenidos "unidireccionales", sino también artífice y productor de alegorías locales en las cuales se fortalecen tanto identidades como prácticas conmemorativas, no siempre manifiestas en clave formal o legítima.

Dicho esto, el primer capítulo del bloque es escrito por Natalia Mahecha Arango, quien se acerca a la historieta como fuente principal para analizar las narrativas gráficas realizadas sobre la violencia política en Perú entre 1980 y 2000. Mahecha contrapone los casos de dos historietas con estilos y tendencias ideológicas distantes y muestra cómo cada una de estas realizó, desde sus relatos ícono-textuales, lecturas diferentes sobre las relaciones problemáticas entre el Estado, la población y la guerrilla Sendero Luminoso. Las historietas figuraron entonces, para el caso peruano, como productos culturales de realización artesanal, los cuales llegaron a recoger experiencias populares y construyeron posteriormente memorias y percepciones sobre la agitada situación política, ya fuera — dependiendo de la publicación - desde la posición de las víctimas o desde la propaganda estatal a favor de la contrainsurgencia. De este modo, uno de los propósitos del texto es explicar las condiciones de producción en que se gestó cada una de las historietas contrastadas, indagando por aquellos elementos estéticos e ideológicos con los cuales estas se 
constituyeron como ejercicios gráficos capaces de representar la dimensión “indecible" y traumática de la violencia en todas sus expresiones cotidianas.

A manera de cierre, Christiane Hoth explica cómo el movimiento estudiantil chileno ha tenido una apropiación simbólica del expresidente socialista Salvador Allende, cuya figura idealizada ha desempeñado un rol fundacional y familiar en el marco de las movilizaciones por la educación gratuita, intensificadas desde el 2011. En otras palabras, el argumento central de la autora es que el legado de Allende ha sido representado visualmente por la comunidad estudiantil como un "mito" que - a pesar de haber fallecido hace más de cuarenta años en el Golpe de Estado (1973) - personifica los ideales y fundamentos del debate por la democratización educativa. Hoth entiende a los estudiantes como un movimiento social que justifica su accionar político apelando a referentes históricos que otorguen sentido a su movilización, y Salvador Allende es aquel rostro instrumentalizado en tiempo presente. Lo interesante, en términos empíricos, es que el análisis de Hoth se enfoca en las representaciones murales del expresidente, las cuales adquieren relevancia al insertarse en el espacio público concurrido por todo tipo de transeúntes. Tanto el mural como el grafiti son mensajes y "síntomas" políticos informales, reflejados en ofertas visuales que codifican problemáticas y críticas en lugares cotidianos, donde la contemplación del observador es involuntaria e inevitable. De cierto modo, se trata de una representación visible en las mismas espacialidades donde se llevan a cabo las movilizaciones, lo que permite que la figura póstuma de Allende no solo ocupe una importancia simbólica, sino que unifique a sus seguidores en la práctica contemporánea.

Agradecemos la participación y entusiasmo de todos los autores para la realización de este libro. Igualmente, agradecemos a Joan Manuel López y Ana María Jiménez, por sus valiosos aportes en la revisión de textos; a Andrés Vargas Valdés, por su meticulosa revisión del manuscrito final; a cada uno de los miembros del semillero, por sus comentarios y sugerencias durante el proceso; a la Editorial de la Universidad del Rosario, por su apoyo, y a todos los investigadores que en diferentes momentos estuvieron prestos a dar un vistazo al tomo que aquí presentamos, el cual esperamos contribuya a la curiosidad por historizar una realidad social cada vez más poblada de huellas visuales.

\section{Bibliografía}

Ariño, Antonio. Sociología de la cultura: la constitución simbólica de la sociedad. Barcelona: Ariel, 1997. 
Benjamin, Walter. "Das Kunstwerk im Zeitalter seiner technischen Reproduzierbarkeit”. En Gesammelte Schriften, editado por Rolf Tiedemann, 471-508. Frankfurt am Main: Suhrkamp, 1980.

Boehm, Gottfried. "El giro icónico: una carta entre Gottfried Boehm y W. J. Thomas Mitchell”. En Filosofía de la imagen, coordinado por Ana García Varas, 57-70. Salamanca: Universidad de Salamanca, 2011.

Bryder, Tom. "Conceptual Elements for a Theory of Visual Political Propaganda”. Psicología Politica, n. 37 (2008): 101-117.

Crary, Jonathan. Techniques of the Observer: On Vision and Modernity in the Nineteenth Century. Cambridge, MA: MIT Press, 1992.

Dubois, Philippe. El acto fotográfico y otros ensayos (2a ed.). Buenos Aires: La Marca, 2015.

König, Hans-Joachim. "La función de las imágenes en el proceso de construcción de las naciones latinoamericanas". En La nación expuesta: cultura visual y procesos de formación de la nación en América Latina, editado por Sven Schuster, 1-28. Bogotá: Universidad del Rosario, 2014.

McCombs, Maxwell. Setting the Agenda: The Mass Media and Public Opinion. Cambridge: Polity Press, 2004.

McLuchan, Marshall. Understanding Media: The Extensions of Man. New York: McGraw-Hill, 1964.

Mitchell, W.J. T.Picture Theory: Essays on Verbal and Visual Representations. Chicago: The University of Chicago Press, 1994.

Museo Nacional del Prado, "Masterpieces of the Prado Museum with Google Earth", https://www.museodelprado.es/en/the-collection/sueltas/masterpiecesof-the-prado-museum-with-google-earth/ (31/03/2017).

Panofsky, Erwin. Studies in Iconology: Humanistic Themes in the Art of the Renaissance. New York: Oxford University Press, 1939.

Paul, Gerhard. "Bilder, die Geschichte schrieben. Medienikonen des 20. und beginnenden 21.Jahrhunderts". En Bilder, die Geschichte schrieben. 1900 bis heute, editado por Gerhard Paul, 7-16. Göttingen: Vandenhoeck \& Rupprecht, 2011.

Sienra, Sofía et al. “Introducción”. En La imagen como pensamiento, editado por Sofía Sienra, Adriana Pérez, Leonardo Rodríguez y Juan Mojica, 13-17. Toluca, Estado de México: Universidad Autónoma del Estado de México, 2015. 


\section{Historia a través de la fotografía: la objetividad de la cámara en pugna}




\title{
La Masacre de las Bananeras: la imagen fotográfica y la literatura
}

\author{
Liliana Gómez-Popescu
}

Articular el pasado históricamente no significa reconocerlo "de la manera que fue realmente" [...]. Significa asir una memoria que emerge en un momento de peligro. El materialismo histórico desea retener esa imagen del pasado que se le aparece inesperadamente al hombre resaltada por la historia en un momento de peligro.

Walter Benjamin ${ }^{1}$

Tanto el momento de peligro como la memoria, de acuerdo con Walter Benjamin, dan forma a la cuestión de la representación, que es lo que está aquí en juego, ya que ambas configuran la masacre como un topos de las agitaciones sociopolíticas en la historia de América Latina. Esto se revela al observar los relatos de la infame masacre en la que devino la huelga bananera de Ciénaga, en 1928, y las fotografías de la United Fruit Company que quedan de ese momento de peligro. Lo que Benjamin analiza es de doble importancia: primero, repensar la materialidad en los términos del materialismo histórico, dentro de un proceso del conocimiento; segundo, concebir la representación no como una expresión de algo esencial o arquetípico que refleja el afán de persistencia de la cultura, sino como un síntoma de algo desplazado. Como imagen del pasado, la Masacre de las Bananeras debe concebirse como un síntoma de la modernización, que es un elemento constitutivo de la configuración geopolítica de América Latina. Además, en su calidad de

\footnotetext{
1 Walter Benjamin, “Theses on the Philosophy of History”, en Illuminations (New York: Schocken Books, 1962), 225 (traducción de la autora).
} 
imagen-síntoma, la estructura de la imagen es un síntoma, en el que latencias y crisis, repeticiones y diferencias, represiones y "acciones retardadas" se entrecruzan. ${ }^{2}$

El momento de peligro funge como punto de partida para examinar una serie de imágenes del archivo fotográfico de la United Fruit Company relacionadas con los sucesos de la huelga bananera de 1928. Analizo la Masacre de las Bananeras narrada por Gabriel García Márquez en Cien años de soledad contra la serie de fotografías de la United Fruit Company. Así mismo, muestro que esta serie particular de fotografías es cuestionada por lo que luego devendría la imaginación de Macondo como un archivo ficticio creado con la novela. ${ }^{3} \mathrm{Al}$ hacer esta comparación, abordo cómo la ficción funciona aquí como una semántica alternativa a las fotografías y como un trabajo crítico de memoria. Una de las tesis es que, a pesar de que la invención químico-técnica de la fotografía prometía hacer permanentemente visible la realidad, el archivo fotográfico de la United Fruit Company hace invisible la Masacre de las Bananeras; mientras que la ficción de García Márquez tiene el potencial de restablecer su visibilidad. En consecuencia, analizo la serie de fotografías de la compañía no como documentos, en cuanto el alegado carácter documental consiste en presentar un resultado visible o una información, sino según la fenomenología de las imágenes, que es "todo lo que las hace un suceso".4 Una propuesta sería que la literatura no se orienta en primera instancia hacia el potencial mimético y nemotécnico, que son aspectos inherentes a la fotografía, entendida como documento, sino hacia los atributos premoderno y mágico, que pueden compararse con el momento performativo del acto de la fotografía. ${ }^{5}$ En esta medida, resulta pertinente la relectura de la Masacre de las Bananeras, de la serie de fotografías de la United Fruit Company y de la relación de la novela con la historia en la que se enmarca su realidad ficticia.

A continuación, analizo la Masacre de las Bananeras desde la perspectiva doble de ambos archivos: el archivo fotográfico de la United Fruit Company, que contiene fotos relacionadas con la huelga de 1928, y el archivo ficticio creado por

2 Georges Didi-Huberman, Images in Spite of All (Chicago: University of Chicago Press, 2008).

3 Con archivo ficticio me refiero, conceptualmente, a un archivo creado por la novela Cien años de soledad (1967). En el ámbito de la metaficción de la novela, se trata de un archivo que ofrece una semántica alternativa a la historiografía oficial o ausente sobre la Masacre de las Bananeras de 1928 en el Caribe colombiano.

4 Didi-Huberman, Images in Spite of All, 36.

5 Irene Albers y Bernd Busch, “Fotografie/Fotografisch”, en Ästhetische Grundbegriffe, ed. por Karlheinz Barck (Stuttgart: Metzler, 2001), 550. 
la novela. Con esto no quiero decir que ambos archivos, el fotográfico y el literario, conforman necesariamente una unidad, pues ambos proponen dos relatos muy diferentes; sin embargo, cuando se leen paralela y simultáneamente, se entrecruzan en tanto contemplan la Masacre de las Bananeras como un momento de peligro, memoria y testimonio. Así, reflexionaré sobre la relación entre la fotografía y la historia y sobre la fotografía en la literatura. Mientras que la novela de García Márquez se publicó en 1967 y dio a conocer la Masacre de las Bananeras como un episodio traumático de la historia colombiana, el archivo fotográfico de la United Fruit Company se presentó parcialmente recién en 2008, cuando se entregaron 28 fotografías a Colombia, en el marco de la conmemoración de la masacre. Esta fue la primera vez que la historia olvidada de los trabajadores de aquella época pudo plasmarse en una imagen pública que mostraba la presencia de la United Fruit Company en esa región. ${ }^{6}$

Así, propongo reflexionar sobre la materialidad de la imagen en el intersticio de los dos archivos, el real y el ficticio, en cuanto a su actualidad y su evocación del suceso. Recientemente, el concepto de materialidad ha sido reabordado, especialmente en la literatura y en la teoría de la comunicación, en términos alternativos a la clásica oposición entre la forma y lo material. La literatura buscaba un medio de diferenciar entre las dimensiones de lo material, como lo no expresado, lo implícito y lo concreto. ${ }^{7}$ De esta manera, la cuestión de la materialidad reveló el potencial de algunos tipos de textos literarios, en los que los objetos y las situaciones se hacen accesibles semánticamente. ${ }^{8}$ Con la materialidad de la imagen no me refiero a la fotografía como un objeto material; más bien, subrayo el proceso material del suceso de la imagen, el cual se relaciona con el proceso del conocimiento. En otras palabras, me refiero a la materialidad para asir la relación entre la fotografía y la historia, tomando la imagen no en el sentido de síntesis, sino concibiéndola como "un acto y no una cosa". 9 Considerar la materialidad en los términos del materialismo histórico significa comprender la imagen de la manera en que sugirió Benjamin:

6 Aviva Chomsky, "Repatriating Photographs", ReVista: Harvard Review of Latin America 8, n. 26 (2009): 64 .

$7 \quad$ K. Ludwig Pfeiffer, “Materialität der Literatur?”, en Materialität der Kommunikation, ed. por Hans U. Gumbrecht y K. Ludwig Pfeiffer (Frankfurt am Main: Suhrkamp, 1988), 17.

8 Pfeiffer, Materialität der Literatur?, 19-20.

9 Jean Paul Sartre en Didi-Huberman, Images in Spite of All, 50. 
El índice histórico de las imágenes no solo dice que la imagen pertenece a un tiempo particular, sino que también dice, sobre todo, que ellas cobran legibilidad [Lesbarkeit] solo en un tiempo particular. [...] La imagen real —en otras palabras: la imagen en el ahora de su reconocibilidad - alberga en el mayor grado posible la huella del momento crítico y peligroso en el cual se fundamenta toda lectura. ${ }^{10}$

La serie de fotografías de la United Fruit Company cobra legibilidad a la luz del archivo ficticio creado con la Masacre de las Bananeras de Cien años de soledad, ya que fue la novela la que primero la imaginó como tal, al configurarla como un topos de las agitaciones sociopolíticas y como un trauma no nombrado en la historia de Colombia: algo que está desplazado y que permanece como una imagen-síntoma. En consecuencia, el análisis de las fotografías no tiene que ver con una búsqueda de la imagen como un hecho, sino más bien en su función de testimonio. Resulta interesante que el concepto de testimonio revela que la imagen no puede ser simplemente una evidencia, ya que las imágenes requieren un análisis crítico para extraer de ellas su enunciado y su conocimiento. El testimonio se sitúa más allá de la historización y la lógica de la evidencia, porque rendir testimonio es fundamentalmente diferente al de dar evidencias. ${ }^{11}$ En efecto, las imágenes producen este desplazamiento en la medida en que configuran una visibilidad particular que hace que la masacre pase desapercibida. Ellas articulan un punto de fractura, de lo no dicho, y ocultan la violencia; sin embargo, este silencio se rompió cuando las imágenes regresaron a Colombia y su vacío se hizo evidente. Así, su significado perdurable puede ahora yacer en la importancia de lo que una "lectura cuidadosa pueda revelar sobre el devenir de la historia en un [pueblo] corriente en un momento de una terrible transformación" ${ }^{12}$ Hoy en día, ¿qué significa observar una serie de fotografías a la luz de la novela de García Márquez y de las violentas agitaciones políticas que ha sufrido Colombia desde entonces? La masacre como un topos de las agitaciones sociopolíticas "sigue siendo un lugar controvertido dentro de la

10 Didi-Huberman, Images in Spite of All, 89 (traducción de la autora).

11 Heike Schlie, "Bemerkungen zur juridischen, epistemologischen und medialen Wertigkeit des Zeugnisses", en Zeugnis und Zeugenschaft: Perspektiven aus der Vormoderne, ed. por Heike Schlie y Wolfram Drews (München: Wilhelm Fink, 2011), 26.

12 Darren Newbury, “'Picturing an 'Ordinary Atrocity': The Sharpeville Massacre”, en Picturing Atrocity: Photography in Crisis, ed. por G. Batchen (London: Reaktion Books, 2012), 209 (traducción de la autora). 
memoria nacional". ${ }^{13}$ De esta manera, las fotografías aumentan su legibilidad, por lo que deben releerse desde la perspectiva de los dos archivos.

A continuación, al reinterpretar la Masacre de las Bananeras, a la luz del momento de peligro y memoria, describo cómo la novela se entrecruza con el archivo fotográfico de la United Fruit Company. Además, la creación por parte de García Márquez de un archivo ficticio plantea la pertinente pregunta acerca del otro relato creado por la serie de fotografías sobre la huelga en la zona bananera incluida en el archivo fotográfico de la United Fruit Company. A través de la materialidad de la imagen en la ficción de García Márquez y en el archivo fotográfico, muestro cómo los archivos se configuran a partir del olvido de la Masacre de las Bananeras. Como afirmó Benjamin, el texto literario, desde luego, no articula "el pasado históricamente [...] 'de la manera que fue realmente", sino que da forma a "una memoria que emerge en un momento de peligro". ${ }^{4}$ Por lo tanto, la imagensíntoma articula la Masacre de las Bananeras como un lugar de memoria y como una apelación política. Con el reciente acceso a la serie de fotografías, esta apelación política queda aún sin respuesta, ya que la imagen de archivo pone en tela de juicio al testimonio y la evidencia histórica. Como consecuencia, el punto de partida no es nada menos que comprender la fotografía como una reflexión histórica.

\section{La Masacre de las Bananeras y Cien años de soledad}

El texto literario Cien años de soledad narra el suceso histórico de la huelga bananera como una masacre, lo que permite el acceso de los lectores del mundo a una situación histórica específica, al apelar a una imaginación particular de reivindicación histórica. En la novela, la Masacre de las Bananeras se convierte en un episodio clave y en el "punto culminante en la extensa crónica que hace García Márquez de Macondo". ${ }^{15}$ Sin lugar a dudas, la obra de García Márquez significó un punto de inflexión en el boom de América Latina, lo que produjo un cambio considerable en la recepción de la literatura latinoamericana. Así mismo, es su mérito haber rescatado del olvido la Masacre de las Bananeras, que había sido borrada de la historia colombiana hasta entonces. La razón de esto es que la novela es un producto

13 Newbury, "Picturing an 'Ordinary Atrocity”, 222 (traducción de la autora).

14 Benjamin, "Theses on the Philosophy”, 225 (traducción de la autora).

15 Gene H. Bell-Villada, "Banana Strike and Military Massacre. One Hundred Years of Solitude and What Happened in 1928”, en Garcia Márquez's One Hundred Years of Solitude, ed. por Gene H. BellVillada (Oxford: Oxford University Press, 2002), 127 (traducción de la autora). 
semiótico complejo, el cual se amplifica infinitamente a sí mismo a través del proceso de la lectura: el significado se produce, no se descubre, en la medida en que la recepción de la novela crea una experiencia social de lectura. ${ }^{16}$

La huelga del 6 de diciembre de 1928 en la zona bananera del Caribe colombiano se narró como ficción por primera vez de la mano de escritores colombianos como Álvaro Cepeda Samudio, en La casa grande (1962); Efraín Tovar Mozo, en Zigzag en las bananeras (1964); Gabriel García Márquez, en Cien años de soledad (1967), y Javier Auqué Lara, en Los muertos tienen sed. El drama de las bananeras (1969). No obstante, fue particularmente Cien años de soledad la que narró la masacre como un suceso histórico que moldeó el ficticio Macondo y su trágico destino. La huelga bananera es una de las escenas clave de la novela y de la lectura del declive de Macondo. Como metáfora de la experiencia de la modernización, es el episodio en el que la historia y la ficción se entrecruzan, creando una amplia variedad de lecturas, ya que están entretejidas de manera fantástica y grotesca. ${ }^{17}$ Ya en La hojarasca (1955), García Márquez había empezado a delinear su imaginación literaria del pequeño pueblo de Macondo y la construcción mágica de la historia familiar de los Buendía como una suerte de prehistoria. De hecho, hubo varias razones históricas para el declive real de la industria bananera en la región del Magdalena. Así, la novela deja un margen para imaginar un "pueblo épico y olvidado”, donde la masacre parece ser el clímax de la experiencia de la modernización. Esto es importante en la medida en que la novela fue la primera en crear un espacio de memoria a modo de lugar de trauma nacional, al articular una experiencia ampliamente compartida por los lectores. Aún más, esta nueva calidad de probabilidad o verosimilitud fue lo que hizo que el curso de los años sesenta fuera un momento crucial para la recepción de este tipo de ficcionalización de sucesos reales. La emergente sensibilidad de la década de los sesenta permitió que se compartiera una sensación de modernización en Colombia, predominantemente a través de la urbanización, y que hubiera una apertura hacia la literatura relacionada con la experiencia de la Violencia. Esta confluencia allanó el camino del éxito de ficciones como Cien años de soledad y contribuyó a que "[la Masacre de las Bananeras] cobrara legibilidad [Lesbarkeit] solo en un tiempo particular". Como tal, la experiencia receptiva del lector se vuelve un elemento constitutivo de un momento de reconocibilidad, el

16 Carlos Rincón, “Las artes de la memoria en la plague of insomnia de Cien años de soledad", Literatura y Filosofia 1, n. ${ }^{\circ} 1$ (2003): 21.

17 Bell-Villada, “Banana Strike”, 129. 
cual "alberga en el mayor grado posible la huella del momento crítico y peligroso en el cual se fundamenta toda lectura". 18

Aunque ya en 1929 existían otras descripciones testimoniales o periodísticas de la Masacre de las Bananeras — como el informe del general Carlos Cortés Vargas o el debate en el Congreso, iniciado por el carismático líder político liberal Jorge Eliécer Gaitán-, el incidente nunca fue aceptado oficialmente por el Gobierno colombiano en esa época. El asesinato de Gaitán, en 1948, fue el acto final que echó al olvido el incidente y la historia de los trabajadores. Como se observará, este relato del olvido también es narrado por la serie de fotografías de la United Fruit Company. De este modo, la propagación de los testimonios rápidamente se volvió muy limitada; por un breve espacio de tiempo formó parte de una controversia política en Colombia entre los conservadores y los liberales, antes de que cayera en el olvido, hasta que la novela de García Márquez sacó a la luz el retrato literario de este suceso histórico en forma de masacre.

La masacre que García Márquez narra en su ficción -él mismo y su familia son nativos del vecino pueblo de Aracataca - fue el resultado de las frustradas negociaciones entre los trabajadores de la United Fruit Company y los representantes nombrados. Sin duda, uno de los problemas fue que los representantes supuestamente no pertenecían a la United Fruit Company y la compañía se negó a asumir la responsabilidad por las negociaciones. Aunque los estudios históricos empezaron más tarde a reconstruir el suceso, aún no es posible establecer claridad sobre la situación concreta y la relación entre los huelguistas y la compañía. Los trabajadores alegan que el ejército colombiano, bajo las órdenes del general Carlos Cortés Vargas, abrió fuego contra los huelguistas, porque estos insistían en que se abordaran algunos aspectos esenciales de sus demandas; sin embargo, la pregunta cardinal de “qqué provocó la horrible matanza indiscriminada?” permanece aún sin respuesta. ${ }^{19}$ El momento más oscuro de la masacre — que articula una característica común de las acciones represivas en el supuesto estado de emergencia- es con "el alegato [del ejército colombiano] de que ellos abrieron fuego como respuesta a una amenaza genuina e inminente por parte de los huelguistas nunca estuvo respaldado por las evidencias". ${ }^{20}$ Esta puede ser la afirmación más riesgosa del texto literario: García Márquez moldea el material "crudo" de la historia en un relato

18 Walter Benjamin en Didi-Huberman, Images in Spite of All, 89 (traducción de la autora).

19 Newbury, "Picturing an ‘Ordinary Atrocity”, 218 (traducción de la autora).

20 Ibid., 218 (traducción de la autora). 
ficticio y especula sobre la posición omnipotente de la compañía con respecto a sus trabajadores:

La inconformidad de los trabajadores se fundaba esta vez en la insalubridad de las viviendas, el engaño de los servicios médicos y la iniquidad de las condiciones de trabajo. Afirmaban, además, que no se les pagaba con dinero efectivo, sino con vales que solo servirían para comprar jamón de Virginia en los comisariatos de la compañía. José Arcadio Segundo fue encarcelado porque reveló que el sistema de los vales era un recurso de la compañía para financiar sus barcos fruteros, que de no haber sido por la mercancía de los comisariatos hubieran tenido que regresar vacías desde Nueva Orleans hasta los puertos de embarque del banano. Los otros cargos eran del dominio público. ${ }^{21}$

La violenta reacción hacia los huelguistas refleja indiscutiblemente un nuevo tipo de relación entre los trabajadores y la corporación transnacional extranjera que operaba en la costa colombiana, casi como un Estado dentro de un Estado, donde se privaba a los trabajadores asalariados de muchos de sus derechos básicos. De hecho, la compañía controlaba casi todo tipo de producción y distribución de recursos en la zona bananera: la infraestructura ferroviaria, los telégrafos, los sistemas de drenaje y los comisariatos. A principios de los años veinte, la United Fruit Company disfrutaba del monopolio bananero, apoyada y altamente subsidiada por el Gobierno colombiano. En 1928, cuando estalló el conflicto en forma de una huelga bien organizada, la compañía solicitó protección militar al Estado, el cual envió un regimiento de infantería, bajo las órdenes del general Carlos Cortés Vargas, a Santa Marta el 13 de noviembre de 1928. Como reacción a los planes públicos de los trabajadores de destruir las plantaciones y la infraestructura de transporte y comunicación, se cuenta que la compañía envió un telegrama al Ministerio de Industria en Bogotá, el cual dio la orden al general de abrir fuego contra los huelguistas; sin embargo, todavía no se ha aclarado si el citado telegrama realmente se envió. No obstante, la masacre como un topos de las agitaciones sociopolíticas revela un patrón común de aquella época que hizo posible que la huelga desembocara en una masacre. Hay que destacar que las huelgas se convirtieron en una forma de resistencia contra la presencia monopolista y omnipotente de la United Fruit Company en Latinoamérica. Ahora bien, la respuesta de la compañía fue

21 Gabriel García Márquez, Cien años de soledad (Bogotá: Norma, 1997), 293-294. 
anular estas agitaciones al calificarlas como una amenaza comunista, en línea con la retórica y la política de la “amenaza roja”. Estas acciones contra las huelgas estaban apoyadas por diferentes redes gubernamentales y semioficiales de las divisiones de la compañía y más allá de ella. No era poco común que el Gobierno decretara el estado de emergencia para restringir mayores manifestaciones políticas y facilitar el empleo de la fuerza militar; sin embargo, a pesar de que la crisis fue aparentemente corta, las consecuencias de la Masacre de las Bananeras no lo fueron. La novela de García Márquez demostró esto al crear un espacio imaginario de apelación y reivindicación histórica.

En 1929 el exgeneral Carlos Cortés Vargas publicó el informe Los sucesos de las Bananeras, en el que describe su misión en la zona bananera y argumenta a favor de su violenta “corrección” de la huelga. Al parecer, García Márquez usó este informe como fuente histórica para reimaginar la masacre en su ficción; sin embargo, no usó este material histórico de manera mimética, sino que lo moldeó estéticamente en una imagen literaria que describe la masacre como un suceso exagerado y grotesco, que resulta ser el clímax de la novela. Además, parece que también conocía el informe sobre el suceso escrito por Jorge Eliécer Gaitán; de hecho, es posible que este informe presentado por Gaitán ante el Congreso, y publicado como folleto hacia 1972, fue transformado e incorporado por García Márquez en su ficción. Por otro lado, el abuelo materno de Gabriel García Márquez, en su época como tesorero de Aracataca, se encontraba entre los testigos de la audiencia ante el Congreso. ${ }^{22}$ Naturalmente, este hecho revela en vínculo potencial entre el testigo ocular y el escritor. Además, parece que García Márquez adaptó particularmente la historia de los testigos del informe de Gaitán sobre el pelotón de fusilamiento en la plaza en largos pasajes de su novela. ${ }^{23}$ En la manera en que García Márquez configura estos episodios clave de la ficción hace explícita otra circunstancia que luego condujo a lecturas divergentes de la masacre, es decir, la participación del ejército colombiano en la batalla de la United Fruit Company contra los trabajadores colombianos. Sin embargo, Cien años de soledad es ambivalente; mientras que, al mismo tiempo, crea un lugar de memoria de uno de los momentos más oscuros de la historia colombiana.

A propósito, permítanme usar este pasaje de García Márquez como punto de partida para releer los documentos e informes testimoniales abordados por Gaitán.

\footnotetext{
22 Bell-Villada, "Banana Strike”, 134.

23 Gabriel García Márquez, One Hundred Years of Solicitude (London: Viking, 2007), 309-313; $315-331$.
} 
A través de los relatos de testigos oculares, Gaitán reconstruye meticulosamente los antecedentes del incidente en su narración y demuestra que la huelga comenzó de forma pacífica. Él cita con gran énfasis la declaración del Gobierno provincial de que la actitud de los huelguistas no era violenta. ${ }^{24}$ Pero, ¿ cómo se refiere la novela a las evidencias históricas y a los testigos oculares? En otras palabras, ¿qué relación tiene la ficción con el testimonio? Al comprender esta relación como la materialidad de la literatura, las situaciones no mencionadas se vuelven semánticamente accesibles a través de la ficción. Lo anterior, genera dos preguntas: ¿qué relación tienen el testimonio y la literatura? y ¿qué relación tienen las fotografías del archivo de la United Fruit Company con estos testimonios y con la ficción de García Márquez?

No obstante, durante la Masacre de las Bananeras, el ejército se comportó como un cuerpo independiente que, al parecer, le favorecía el estado de sitio para poder intervenir sin ninguna pauta del Gobierno colombiano. De hecho, los testimonios esbozan la hipótesis de que a Bogotá se enviaron varios telegramas para legitimar este estado de sitio, una situación muy propicia para los planes de la United Fruit Company de no negociar con los trabajadores. Algunos testigos sugirieron que los sabotajes no fueron obra de los trabajadores, sino de la misma United Fruit Company. Así mismo, numerosos documentos del informe de Gaitán muestran esta visión de la huelga. Obviamente, la participación del ejército en este acontecimiento histórico es el aspecto más controvertido y García Márquez parece ser lo suficientemente prudente como para no dar demasiados detalles que hablen por sí mismos. Por el contrario, incorpora su hipótesis en la novela mediante la transformación literaria hiperbólica: es esta misma falta de claridad la que se convierte en el medio para comprender el episodio clave de la masacre.

Como Salman Rushdie observó, el realismo mágico se inscribe aquí, indudablemente, dentro de una realidad concreta, por lo que "sería un error pensar que el universo literario de Márquez es un sistema inventado, autorreferencial y cerrado. Él no escribe sobre la Tierra Media, sino sobre la que habitamos todos nosotros; Macondo existe. Esa es su magia”. ${ }^{25}$ Desde luego, esta realidad concreta está atada a y contenida en los dos archivos, pero, en relación con el interés por el testimonio del archivo fotográfico, es importante considerar que cualquier observación a un depósito de documentación nos recordará "que un archivo no le da a la memoria ese

24 Jorge Eliécer Gaitán, El debate sobre las bananeras (Bogotá: Centro Gaitán, 1988), 80.

25 Salman Rushdie, Imaginary Homelands: Essays and Criticism, 1981-1991 (London: Penguin, 1991), 301- 302 (traducción de la autora). 
significado fijo que le da la imagen fija [...]. Siempre es —infatigablemente - una 'historia en construcción cuyo resultado nunca es del todo perceptible".26

\section{La fotografía en la literatura}

A continuación, analizaré la imagen del pasado, la Masacre de las Bananeras, tal como se recuerda en Cien años de soledad, como un lugar controvertido dentro de la memoria nacional. Al parecer, aquí la literatura funciona como una semántica alternativa a la fotografía y opera como un trabajo crítico de memoria en sí y sobre sí misma. Así mismo, es relevante destacar que la metaficción de la novela es la vía por la cual el texto reflexiona sobre su propia materialidad. Aunque la fotografía, por lo general, se emplea como un moderno dispositivo de la evidencia, en la novela se emplea como un medio de investigación de las imágenes inmateriales, es decir, de lo que no está materializado en forma de fotografía; por lo tanto, es más testimonio que evidencia. En el texto literario encontramos un gran interés en la naturaleza dual de la materialización y la inmaterialidad de la fotografía, sobre todo en el personaje de Melquíades y sus experimentos con daguerrotipos. Melquíades es claramente un elemento clave para revelar la metaficción de la novela, como muestra otro episodio importante:

Melquíades terminó de plasmar en sus placas todo lo que era plasmable en Macondo, y abandonó el laboratorio de daguerrotipia a los delirios de José Arcadio Buendía, quien había resuelto utilizarlo para obtener la prueba científica de la existencia de Dios. Mediante un complicado proceso de exposiciones superpuestas tomadas en distintos lugares de la casa, estaba seguro de hacer tarde o temprano el daguerrotipo de Dios, si existía, o poner término de una vez por todas a la suposición de su existencia. ${ }^{27}$

Mediante la daguerrotipia, Melquíades pretende documentar el pueblo de Macondo y plasmar sus transformaciones. En efecto, los daguerrotipos y el laboratorio de Melquíades le permiten al patriarca José Arcadio Buendía conectarse tanto con sus fantasías como con la historia o genealogía de su familia, la cual luego podrá leer en el libro de Melquíades. En este episodio, José Arcadio Buendía intenta probar la existencia de algo tan inmaterial como Dios - tanto desde el punto de vista

26 Didi-Huberman, Images in Spite of All, 98-99 (traducción de la autora).

27 García Márquez, Cien años, 60. 
científico como material—, irónicamente, a través de la fotografía como dispositivo para crear la evidencia. Así, la novela reflexiona sobre el concepto de testimonio, en tanto cuestiona la fotografía como evidencia histórica. Este peculiar episodio está lleno de ironía, porque las prácticas fotográficas empleadas por Melquíades para materializar a Dios, en forma de una imagen concreta, como evidencia de su existencia, son llevadas al absurdo por el autor. Sin embargo, al nivel de la metaficción, la novela combina lo material y lo inmaterial de manera interesante, por cuanto el episodio plantea las preguntas de lo no material y de la idea de material en el testimonio como algo intangible para nuestros sentidos, por lo que el testimonio es pensado como una práctica que implica una situacionalidad social y cultural constitutiva de una epistemología social. ${ }^{28}$

En consecuencia, el testimonio se hace posible a través de la experiencia receptiva de los lectores, en la que necesariamente está enclavado el significado de la literatura y de las imágenes de archivo. Este episodio es fundamental para mi lectura de la materialidad de la imagen, en la medida en que permite comprender los límites de la fotografía como generadora de imágenes fidedignas, lo cual cuestiona la idea de la imagen-documento, es decir, de la evidencia histórica. La novela, en su nivel de la metaficción, aborda la cuestión del testimonio, reenmarcando el incidente histórico de la Masacre de las Bananeras, desplazado y no expresado en la historia colombiana. Como hay una diferencia entre la inasequibilidad de la "imagen de Dios" (la de lo inimaginable) y la inasequibilidad de la masacre (por ser una imagen borrada de la memoria), ambas relegadas al plano de la no imaginibilidad, es precisamente el efecto "mágico-realista" de la yuxtaposición lo que relaciona aquí los dos archivos.

En sus comienzos, a menudo, se percibía la fotografía como un procedimiento que parecía reproducir indiferentemente una gran variedad de sujetos y transferirlos a un solo estrato material. Originalmente se excluyó la fotografía de las artes, al clasificarlas como proceso de reproducción mecánica. ${ }^{29}$ Por consiguiente, se creía que "la fotografía compartía cierta adaptabilidad con algunos materiales sintéticos, desde el hierro fundido, pasando por la goma, hasta el plástico, y, como ellos, al prin-

28 Oliver Scholz, "Das Zeugnis anderer-Prolegomena zu einer sozialen Erkenntnistheorie”, en Positionen zwischen Tradition und Gegenwart, ed. por T. Grundmann (Paderborn: Mentis, 2001), 354-375.

29 Monika Walter, “Material”, en Ästhetische Grundbegriffe, ed. por Karlheinz Barck (Stuttgart: Metzler, 2001), 882 . 
cipio tuvo que superar el estigma de ser considerada un sustituto". ${ }^{30}$ No obstante, mientras que la fotografía fue excluida del temprano discurso positivista de las artes, por considerarse un material inferior, en la literatura parece que se le concedió el estatus de material capaz de reproducir y captar imágenes inmateriales. Así, resulta pertinente la observación de Valeria de los Ríos, quien afirma que la aparición y el uso de las tecnologías visuales en las literaturas latinoamericanas mantienen lo fantasmagórico como un componente importante, que describe la relación entre la ficción literaria y la imagen fotográfica. ${ }^{31}$ Esto también se observa en la ficción de García Márquez: allí, la fotografía parece ser un estrato de autorreflexión de la medialidad literaria, una especie de contraparte de la literatura "contra la cual la literatura demarca sus propias limitaciones y posibilidades" ${ }^{32}$ Además, en la literatura latinoamericana la visualidad se impugnó e incorporó tanto en el ámbito temático como en el retórico. ${ }^{33}$ De esta manera, en la literatura, la fotografía se convirtió en la materialización de lo invisible, como en el caso de la literatura fantástica, en la que funge como una especie de semántica contraria a lo fotográfico, a otras formas de representación literaria de la imagen fotográfica o de la idea de la écfrasis - como correspondencia retórica de ambas formas-, que la asocia a la mimesis de lo visible. ${ }^{34}$

Como constata Irene Albers, en la literatura, la fotografía parece ser el medio que hace visible lo invisible y les da a las visiones inmateriales, las alucinaciones y las apariciones una forma material, que puede ser también una optique fantastique. Por ejemplo, lo que antes parecía una fantasía literaria se convierte en la segunda mitad del siglo XIX en objeto de estudio científico o paracientífico. Esta trasposición en particular hace de la fotografía una práctica y un objeto ambivalente, misterioso. ${ }^{35}$ Así, en el contexto de los discursos realistas y naturalistas de la fotografía, la imagen fotográfica se reduce principalmente a la estética, aquí esencialmente entendida como una copia o representación exacta; mientras que la literatura fantástica usa el concepto de fotografía como un medio de rastreo asociado con emociones de lo asombroso y con la presencia y la ausencia simultáneas, con la realidad y la

\footnotetext{
$30 \quad$ Ibid., 882.

31 Valeria de los Ríos, Espectros de luz (Santiago de Chile: Cuarto Propio, 2011), 15.

32 Albers y Busch, "Fotografie/Fotografisch", 535 (traducción de la autora).

33 Ríos, Espectros de luz, 18.

34 Albers y Busch, "Fotografie/Fotografisch”, 543.

35 Ibid., 543.
} 
irrealidad. ${ }^{36}$ Esta comprensión más amplia de la fotografía en la literatura es pertinente para discutir la Masacre de las Bananeras, desplazada como imagen del pasado. Por consiguiente, lo que la novela de García Márquez suscita es el reconocimiento de un momento de peligro y memoria que pone en duda la misma cuestión de la representación.

Por otro lado, se encuentra la ambivalencia de lo invisible y el juego con la visibilidad en los experimentos de Melquíades a través de la daguerrotipia en su laboratorio alquimista. Es importante destacar que Melquíades tiene la función de historiador, pues es él quien narra y predice la historia de Macondo y de la familia Buendía. ${ }^{37}$ En la novela, Macondo se recupera y se vuelve a desarrollar una vez curado el estado de amnesia colectiva de sus habitantes, el cual se produjo por la peste del insomnio. Melquíades no es solo el historiador sui generis mediante el cual, en la metaficción de la novela, observamos una concepción desafiante de la historia y el testimonio, sino que es quien cura al pueblo de la amnesia colectiva, la cual simboliza el silencio sobre la Masacre de las Bananeras. Así, al nivel de la autorreflexividad de la novela, no se intenta reescribir la historia como un mito, sino como un despertar, al usar el archivo a manera de actualidad y como posibilidad de una futura reivindicación.

Tanto la ficción literaria de García Márquez como el archivo fotográfico de la United Fruit Company representan fuentes para dos formas diferentes de memoria, una desplazada y otra actualizada, que remiten a la Masacre de las Bananeras como un suceso ficticio-histórico. Sin embargo, no quiero decir con esto que la memoria y el archivo sean lo mismo, ni que el archivo sea una metáfora de todas las formas de almacenamiento. Al parecer, existe una atracción mutua entre medios como la literatura y la fotografía y determinadas tecnologías de almacenamiento relacionadas con el "afuera" del texto o la imagen. En el espacio de la apelación, la memoria podría entenderse como un efecto compuesto que surge de la situación abierta del archivo, en el sentido de que está "siempre en el límite inestable entre lo público y lo privado, entre la familia, la sociedad y el Estado, entre la familia y una intimidad aún más privada que la familia, entre uno mismo y uno mismo". 38

36 Ibid., 544.

37 Lucila Mena, “La huelga de la compañía bananera como expresión de lo 'real maravilloso' americano en Cien Años de Soledad”, Bulletin Hispanique 74, n. 3-4 (1972): 157. 
Con respecto a la novela y la peste del insomnio, el texto literario no solo aborda la dificultad del trabajo de memoria contra el olvido de manera carnavalizada, sino que, como metaficción, archivo y simulacro, también reflexiona sobre el concepto de memoria, al liberarlo para hacer posible una comprensión alternativa. ${ }^{39}$ Así mismo, el concepto de archivo se usa en el texto literario como un medio para salvar la Masacre de las Bananeras del olvido prescrito por el silencio oficial, materializado en la novela como la peste del insomnio. Sin embargo, la peste del insomnio ocurre mucho antes que la masacre, por lo que representa un tipo de presagio y repetición cíclica de sucesos que tiene sentido en la estructura temporal de la novela. Además, la idea de la actualidad del archivo se manifiesta a través del tiempo circular de la historia de los Buendía. Así, el texto esboza un lapso productivo como predicción y repetición en el intersticio de la memoria y el olvido. Como una "miríada de simetrías" entre José Arcadio Buendía, el coronel Aureliano Buendía y José Arcadio Segundo, el instigador de la huelga, estas repeticiones forman los ciclos entrecruzados y sucesos simétricos que deben leerse a la luz de la Masacre de las Bananeras como el clímax de la novela. ${ }^{40}$ Como repetición de la historia de la familia Buendía, especialmente la de los protagonistas masculinos, la novela crea un poderoso archivo ficticio que permite el desarrollo de un proceso de memoria crítica y la construcción de una imagen del pasado en un momento de peligro. De hecho, es esta repetición lo que queda grabado en el lector y lo que la novela reproduce como un archivo.

Pero volvamos a la fotografía. En general, parece que la fotografía refleja una concepción doble de la materialidad: primero, la fotografía como un artefacto visual y objeto material; segundo, la materialidad de la fotografía arraigada en las prácticas institucionales y sociales, que determinan su estatus y su efecto, así como la autoridad necesaria que le da sentido. Como objeto material, las fotografías se coleccionan y se archivan. La fotografía crea un recurso material y sensorial para comprender y estudiar un tipo de memoria visual. Es posible describir este proceso fotográfico comofotomnemotécnico en los experimentos de Melquíades con la daguerrotipia y la imagen inmaterial. Además, en cuanto a la amnesia, manifestada como el estado más crítico de la peste del insomnio, el proceso fotográfico en la novela permite lograr una percepción y una conciencia del tiempo, de la imaginación y de la memoria, lo cual puede entenderse como una semántica alternativa a la de la serie de fotografías

39 Rincón, "Las artes de la memoria”, 10.

40 Bell-Villada, “Banana Strike”, 132. 
de archivo de la United Fruit Company. Es importante indicar que la peste del insomnio coincide con la fiebre del banano; dicho de otra forma, el insomnio colectivo guarda correlación con la fiebre del banano. Melquíades es quien, como en la tradición del deus ex machina, pone fin a la peste del insomnio al darle de beber al patriarca José Arcadio Buendía una poción mágica inidentificable. Así, la peste del insomnio no solo es una metáfora del olvido colectivo en el que cae la Masacre de las Bananeras - tanto al nivel de la trama como al nivel político, debido al silencio oficial que suprimió el incidente histórico en aquella época en Colombia-, sino también de la urbanización y la modernización radical de Macondo. El pequeño pueblo de Macondo se convierte en una ciudad moderna con ferrocarril, teléfono, electricidad y otros inventos modernos relacionados con la fiebre del banano. En la novela, la máquina del patriarca José Arcadio Buendía parece fungir como un modelo especial de mnemotécnica usado contra las manifestaciones del olvido. ${ }^{41}$ De igual manera, se debe destacar que la metáfora del insomnio está relacionada con otras metáforas, como la del daguerrotipo; al fin y al cabo, al rescatar la imagen del pasado, ambas metáforas configuran y reclaman "una memoria que emerge en un momento de peligro". ${ }^{2}$

Este episodio de autorreflexividad de la novela es un momento clave de la intersección de la historia con la imaginación literaria, que crea el archivo ficticio de la novela. Además, como acciones predictivas y performativas, los experimentos de daguerrotipia de Melquíades cuestionan el olvido histórico y la invisibilidad fotográfica de la Masacre de las Bananeras, de la cual José Arcadio Segundo se convertiría en el único testigo ocular de la novela: así, se repite la experiencia cíclica de la familia Buendía de enfrentar al pelotón de fusilamiento. Así mismo, la idea de ver y testimoniar que radica en el núcleo de la autorreflexión de la novela impugna el acto fotográfico, como fotomnemotécnica, contra una concepción ingenua de la fotografía, entendida como mímesis. Los actos de ver, presenciar y atestiguar están aquí unidos, lo que articula el archivo ficticio de la novela y, por consiguiente, una memoria colectiva.

\section{Imágenes de sabotaje}

Ahora, veamos el álbum fotográfico llamado Colombia, del archivo de la United Fruit Company, que incluye la serie de fotos relacionadas con la huelga bananera

\footnotetext{
41 Rincón, "Las artes de la memoria”, 24.

42 Benjamin, “Theses on the Philosophy”, 225.
} 
de diciembre de 1928. Es notable que el álbum no destaque esta serie específica ni ninguna otra fotografía. A partir de un orden bastante burocrático, el álbum agrupa las fotografías por temas, todos relativos a la división colombiana de la compañía, lo que permite articular una imaginación geográfica. Como nos recuerda el análisis de la relación entre la historia y la fotografía, al tener estas imágenes de archivo en la mano:

[la] imagen, y especialmente la fotografía como instantánea sacada del constante flujo del movimiento, como una muestra característica de una realidad perdida, se corresponde con lo que ha devenido nuestra relación con el pasado: una relación de discontinuidad gobernada por una mezcla de desapego y aproximación, de distancia radical y desconcertante confrontación. ${ }^{43}$

No obstante, las fotografías del álbum hablan con nosotros y nos pueden dejar vislumbrar los contornos visuales de la compañía y, posiblemente, la historia de la gente. Por ejemplo, en el álbum encontramos una fotografía asombrosa y digna de mención (figura 1), cuya leyenda al dorso reza: "Native People-Family Group. Birth Control is unknown here. Santa Marta, April 24, 1925”.44

43 Pierre Nora en Clément Chéroux y Ilsen About, Fotografie und Geschichte: Vortrag an der Hochschule für Grafik und Buchkunst (Leipzig: Institut für Buchkunst, 2004), 10 (traducción de la autora).

44 La sospecha de que el álbum pretende ocultar lo político se confirma especialmente en esta fotografía, que muestra una leyenda secundaria añadida posteriormente, pegada debajo de la fotografía: "Native People-Family Group. Santa Marta, April 24, 1925”. Esta leyenda oculta el mensaje original, ya que la leyenda al dorso de la fotografía reza: "Aquí no se conocen los anticonceptivos". Al parecer, la compañía se dio cuenta posteriormente de la naturaleza política de este mensaje, enclavada en el intersticio entre la imagen y su leyenda, y decidió tomar el control sobre su significado. 


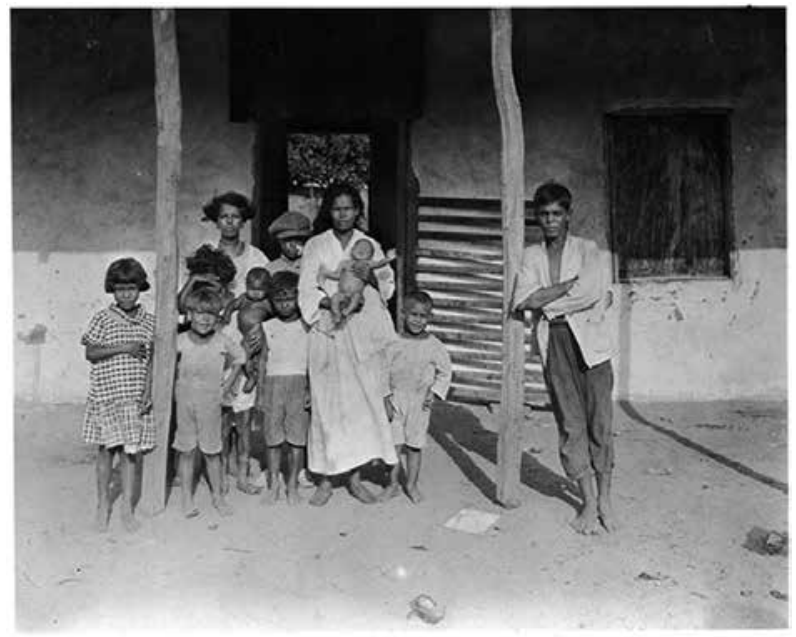

Figura 1. Fotógrafo anónimo, 1925, "Native People-Family Group. Santa Marta, April 24, 1925” (descripción al dorso: "no. 299. Native People-Family Group. Birth Control is unknown here. Santa Marta, April 24, 1925", gelatina de plata en papel, $8 \times 10$ pulgadas, United Fruit Company Photograph Collection, Baker Library, Harvard Business School).

A primera vista, la fotografía da testimonio de un encuentro cultural en una región con rápido desarrollo, que luego sería conocida como Macondo, una zona de contacto, movida y rica. Como informa la leyenda de la foto, fechada en 1925, se trata de un retrato de "nativos" de Santa Marta. La fotografía se encuentra en el grupo “MISC", o sea "miscelánea”. No se sabe mucho del autor; probablemente haya sido un fotógrafo de la región contratado por la compañía, ya que hay pocos rastros de él en los álbumes fotográficos; sin embargo, la composición y la estética de la foto indican que se trataba de un profesional. No hay evidencia de que la imagen circulaba en ese momento.

La fotografía muestra una familia de trabajadores que posa delante de su casa bien dispuesta para lograr una buena composición de la imagen: en el centro se encuentra la madre, la trabajadora, a quien se adscribe la lógica de la reproducción; no obstante, ni ella ni el resto de los miembros de la familia parecen someterse a esta lógica, ni parecen despojados de poder. Más bien, su expresión parece casi heroica: resiste la mirada fotográfica. Otras dos mujeres cargan (sus) bebés con aire de dignidad y seguras de sí mismas, con la mirada clavada en la cámara. Esta fotografía se destaca en especial, porque parece persuadir estéticamente al observador y se vuelve casi icónica. Mientras las demás fotografías del álbum reflejan una actitud burocrática, esta articula un momento de reivindicación. El significado particu- 
lar de esta imagen, como recordó Aviva Chomsky, fue reconocido más tarde, de inmediato, por los trabajadores colombianos de la región, cuando circuló en el contexto de conmemoración de la Masacre de las Bananeras, ya que la fotografía se relaciona con la historia de las familias, cuyas imágenes aún están vivas, lo que permite la confrontación con el suceso. De esta manera, se desarrolla un proceso dinámico de memoria. ${ }^{45}$

Por otra parte, podría incluso ser una fotografía de resistencia, de una posible semántica alternativa configurada contra la omnipotente compañía, asunto que cuestiona la relación de la imagen con el pasado. Hay que destacar que esta fotografía parece articular el vacío del archivo fotográfico de la compañía, ya que las demás imágenes del álbum demuestran negligencia visual para mostrar exactamente lo que ocurría en las divisiones. Esta imagen es una de las pocas que permiten ver más allá del aparato corporativo, en tanto se enfoca en la expresión facial, los gestos sutiles y las poses “inconscientes" de personas, más bien, casualmente fotografiadas por la compañía. Con respecto a la invisibilizada Masacre de las Bananeras, como veremos, se articulan una visibilidad y una presencia que piden a gritos que las recuerden. Incluso, la leyenda discriminante no es capaz de menguar su potencial de semántica contraria. De esta manera, se hacen visibles los posibles testigos oculares de la masacre que se avecinaba. Infaliblemente, esta fotografía da voz a quienes más tarde estarían envueltos en la huelga que devino en la masacre, en tanto reconoce a aquellos que podrían defender sus derechos. No obstante, ¿esta imagen refleja el interés de la compañía en registrar otra cosa? O ¿simplemente es una fotografía casual que se coló en el álbum de la compañía?

En el álbum fotográfico Colombia se encuentran fotografías que pretenden mostrar la vida cotidiana en la división colombiana de la compañía, la cual tiene cierta relación con la huelga de 1928. En su mayoría fechadas en 1929, estas fotografías muestran actividades como la construcción de un comisariato en Sevilla (Magdalena) (figura 2) o documentan el proceso de creación de otros edificios e instalaciones de la compañía (figura 3), por ejemplo, el hospital en Aracataca, el pueblo natal de García Márquez, o una oficina de agricultura. Como lectores de hoy, tenemos la capacidad de reconocer en las imágenes los contornos visuales del pasado conflictivo. En las fotografías se observa un campamento de trabajadores de veinte albergues en Nicoya, fechada el 31 de enero de 1929, y un campamento de doce albergues en Indiana (figura 3), fechada el 10 de octubre de 1928, es decir,

45 Chomsky, "Repatriating Photographs", 64. 
antes de la masacre. Ambas muestran posibles testigos oculares que podrían atestiguar sobre el episodio o, incluso, ser posibles víctimas, como los trabajadores que vemos en el campamento de Indiana. A pesar de que las fotografías no presentan ninguna huella de violencia, revelan las desoladas condiciones de vida y hacen emerger la cuestión de la ética de la visión, ya que nosotros, los observadores de hoy, estamos informados sobre la masacre. Por otro lado, ellas ocultan el violento incidente por cuanto solo muestran las actividades "normales" de la división colombiana de la compañía. No obstante, constituyen un testimonio e, incluso, una justicia visual cuando las leemos hoy en día: ¿cómo deberíamos recordar a los trabajadores que vivían en los campamentos y en estas barracas? ¿Qué nos recuerdan ellos? En estas fotografías, los trabajadores pueden ser los únicos "testigos oculares" hechos visibles por uno de los álbumes fotográficos de la compañía, que no es tan inocente como pretende hacernos creer, ya que oculta intencionalmente la masacre. Como tal, se trata de engañosos "documentos históricos" que adquieren una información visual en la medida en que se enviaron a la sede de la compañía en Boston y circularon solo como parte de la comunicación interna corporativa.

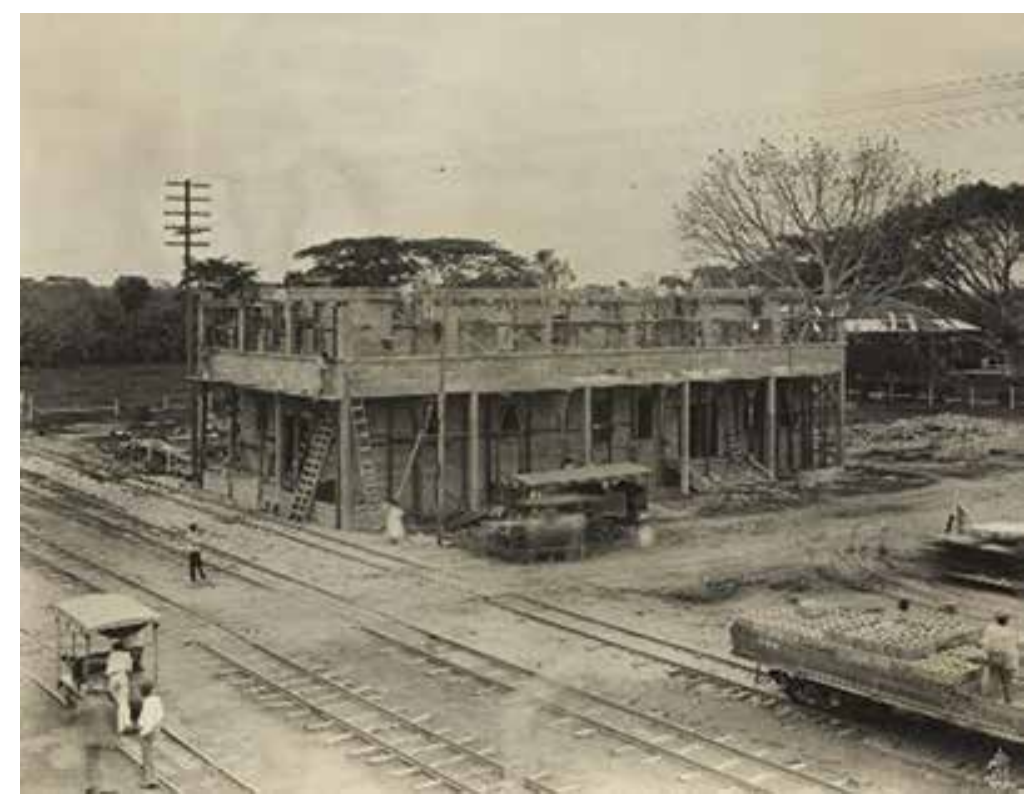

Figura 2. Fotógrafo anónimo, 1929, “Commissary under construction, Sevilla, Colombia, May 8, 1929” (descripción al dorso: "no. 665", gelatina de plata en papel, $8 \times 10$ pulgadas, United Fruit Company Photograph Collection, Baker Library, Harvard Business School, olvwork719192). 


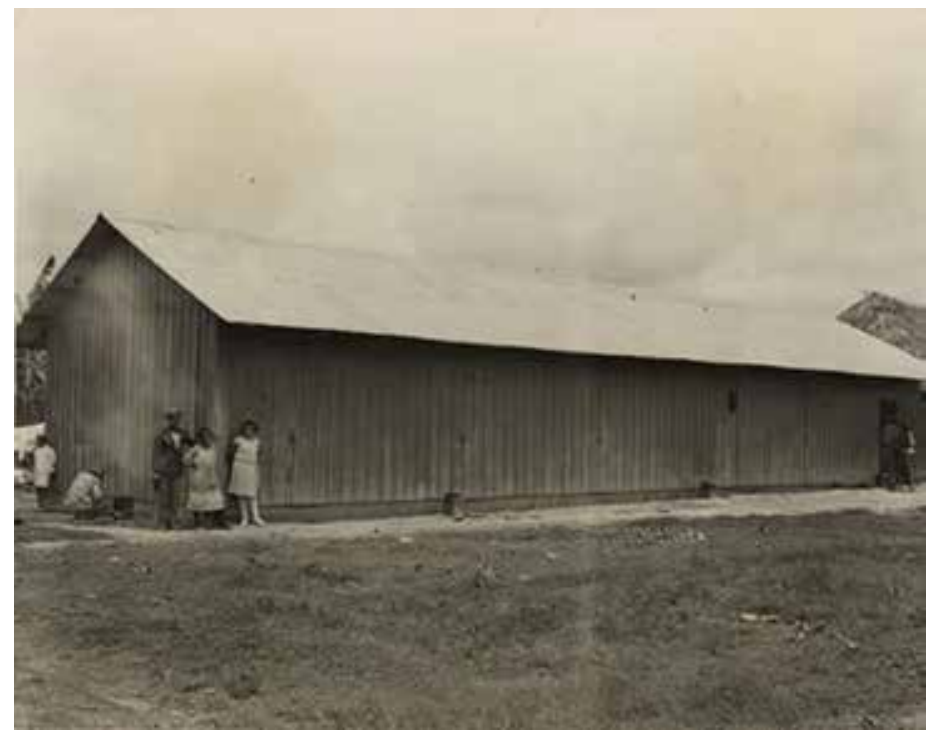

Figura 3. Fotógrafo anónimo, 1928, “12 room laborers' camp, Indiana, Colombia, Oct. 10, 1928” (descripción al dorso: “no. 600”, gelatina de plata en papel, $8 \times 10$ pulgadas, United Fruit Company Photograph Collection, Baker Library, Harvard Business School, olvwork719282).

Entre otros medios de comunicación, aparte de estas fotografías, existen informes escritos enviados por los representantes diplomáticos a las autoridades de Estados Unidos, que describían la organización de la división colombiana de la United Fruit Company. Estos contienen informaciones económicas cruciales - y, por lo tanto, políticas-, con las que parecen corresponderse las fotografías, en el sentido de que "documentan" visualmente la organización interna de la emergencia de un espacio moderno. Así mismo, las fotografías de la compañía encarnan dicho lenguaje burocrático moderno en cada una de sus leyendas; además, forman parte de esta cultura y este orden burocráticos, que definen su significado y su estatus como documentos frente a otros testimonios. Es importante destacar que la comunicación diplomática entre Colombia y Estados Unidos trata explícitamente las huelgas como agitaciones sociopolíticas, las cuales se vigilaban de cerca, como observamos, por ejemplo, en los numerosos informes del Foreign Agricultural Service. ${ }^{46}$ Las fotografías de los álbumes de la compañía adquieren el significado

46 Encontramos estos informes en los Narrative Reports del Foreign Agricultural Service del us Department of Agriculture (por ejemplo, Records of the Office of Foreign Agricultural Relations and its Predecessors, Correspondence and Narrative Reports, 1901-1958). 
de documentos y expedientes, porque, al parecer, se incluyeron en estos informes y porque contenían un mensaje político. Aunque se recopilaron al azar para los álbumes, el significado de las fotografías permanecía incompleto y, a primera vista, despojado de cualquier connotación política. No obstante, en esta serie concreta de fotografías la ruptura epistémica de la huelga que devino en la infame Masacre de las Bananeras exige nada menos que una ética de la visión.

Veamos las fotografías incluidas en el álbum y tomadas por la United Fruit Company para documentar la revolución, término usado por la compañía para describir la destrucción causada por los huelguistas en la zona bananera. Se trata de imágenes de sabotaje que conforman el argumento visual principal. La serie de fotografías data del 10 de diciembre de 1928 y muestra la infraestructura, los edificios y otras instalaciones, así como los comisariatos y las líneas ferroviarias que facilitaban las operaciones de la compañía. Es importante destacar que estas imágenes aluden a la supresión de la violencia militar contra los huelguistas, ya que muestran solo los daños que sufrieron las instalaciones de la compañía (figura 4).

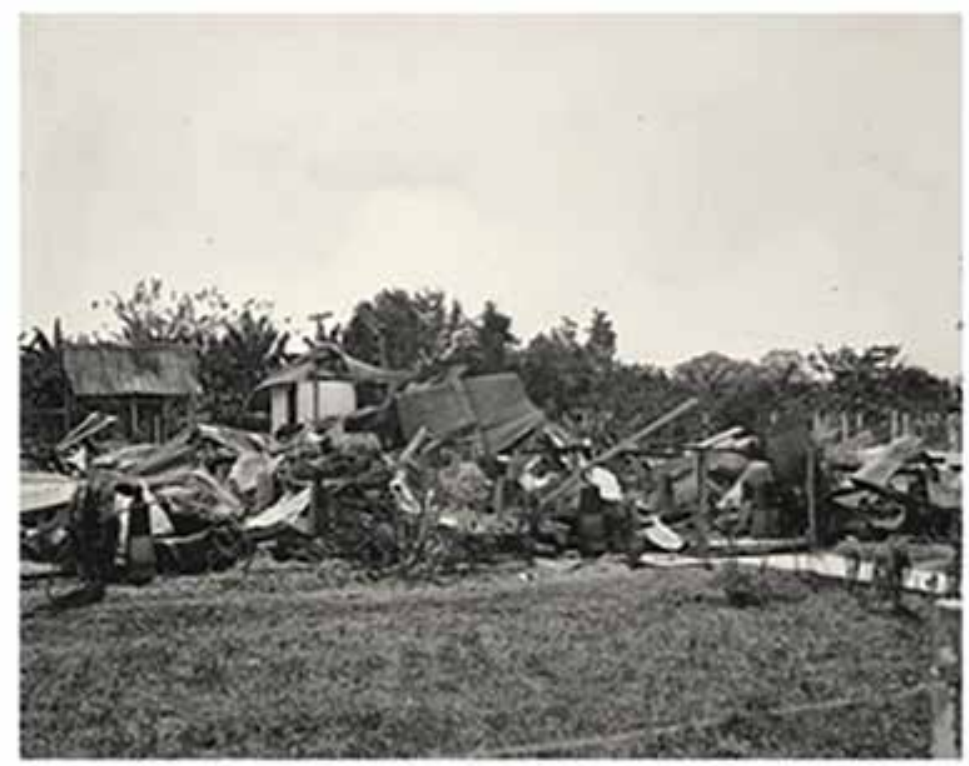

Figura 4. Fotógrafo anónimo, 1928, “no. 620. Ruins of Engineers quarters and mess-Sevilla-after revolution. Colombia. Dec. 10, 1928” (gelatina de plata en papel, $8 \times 10$ pulgadas, United Fruit Company Photograph Collection, Baker Library, Harvard Business School, olvwork719212). 
Estas fotografías no muestran en lo absoluto la masacre descrita en la novela de García Márquez; solo vemos un comisariato destruido, las ruinas de los alojamientos de los ingenieros o las líneas telefónicas tumbadas a lo largo de las vías ferroviarias que transportaban los vagones cargados de banano. Todas ellas representan actos de violencia contra la compañía y puede que hayan sido usadas como inventario legal de los daños sufridos. Algunas de estas fotografías tomadas empezaron a circular fuera del archivo fotográfico de la United Fruit Company hasta mucho después, ya que se usaron en otros estudios históricos sobre el Caribe colombiano, los cuales buscaban ilustrar la infame masacre y el conflicto social entre los trabajadores y la corporación transnacional extranjera, en el periodo después de la publicación de la novela, en 1967, cuando comenzaba un tímido proceso de reconstrucción histórica. ${ }^{47}$ Por ejemplo, las fotografías del comisariato y la oficina de los despachadores destruidos, así como las ruinas de los alojamientos de los ingenieros, se publicaron más tarde en Los sucesos de las bananeras, del general Carlos Cortés Vargas. Sin embargo, nunca se reflexionó sobre ellas como imágenes, sino que se utilizaron solo como ilustraciones y se omitieron como fuentes históricas en sí mismas. Frente a esto, la pregunta es: ¿qué tipo de violencia debían mostrar estas fotografías? ¿Su objetivo era legitimar la intervención violenta del ejército, que protegía a la United Fruit Company? O, incluso, ¿contribuyeron a reimaginar la huelga como una masacre?

Cabe aclarar que estas imágenes se recontextualizaron dentro del archivo fotográfico de la compañía; por esta razón, deben leerse junto a sus leyendas como una fuente escrita, como un intento de ilustración de la compañía y como el significado archivístico póstumo de las imágenes. No obstante, las leyendas del álbum pueden contar un relato diferente del incidente histórico; así, ellas se refieren al incidente no como una masacre, sino como la ausencia de una masacre. En la fotografía de la figura 5, la número 621, "View of cut and wrecked telephone lines like many others after the revolution, Colombia, Dec. 10, 1928”, se observa a una persona al fondo con un arma, en pose de vigilante: este es el único posible indicio de un incidente violento captado por la fotografía. Por lo demás, la imagen tiene un aire bastante técnico y parece que pretende registrar "objetivamente" la escena, ya que,

47 Judith White, Historia de una ignominia: la United Fruit Co. en Colombia (Bogotá: Presencia, 1978); Eduardo Posada Carbó, "The Bananeras and Gabriel García Márquez. One Hundred Years of Solicitude", Journal of Latin American Studies 30, n. 2 (1988): 395-414; Catherine LeGrand, "El conflicto de las bananeras", en Nueva historia de Colombia, vol. 3 (Bogotá: Planeta, 1989), 183-218. 
ante todo, "documenta" los daños supuestamente causados por actos de sabotaje de los trabajadores. Como imágenes de sabotaje, las fotografías revelan una ausencia orquestada de la masacre, con lo que evidentemente la ocultan.

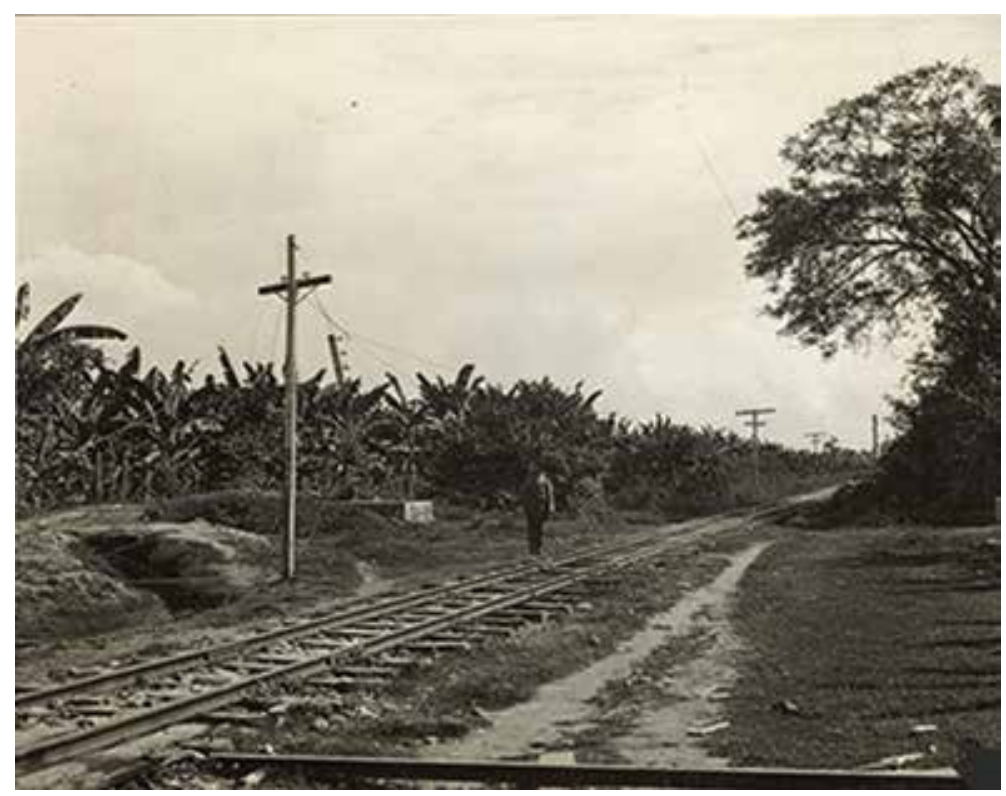

Figura 5. Fotógrafo anónimo, 1928, "View of cut and wrecked telephone lines like many others after the revolution, Colombia, Dec. 10, 1928” (descripción al dorso: "no. 621", gelatina de plata en papel, $8 \times 10$ pulgadas, United Fruit Company Photograph Collection, Baker Library, Harvard Business School, olvwork719209).

Hasta ahora, he asumido la noción de lo visible como lo opuesto al concepto de lo visual o al régimen de percepción. De hecho, la cuestión de la visibilidad concierne al conocimiento y al hecho de saber sobre la existencia del suceso. Como tal, esto parece ser esencial a la hora de discutir sobre la materialidad de la imagen: en efecto, una imagen se "[...] vuelve visible $[. .$.$] porque algo en ella ha logrado evo-$ carnos o 'traducirnos' unidades, 'temas' o 'conceptos' más complejos [...] historias o alegorías: unidades de conocimiento". ${ }^{8}$ Esta unidad de conocimiento puede ser la masacre como un topos del emergente espacio político moderno que reconocemos en estas imágenes. Además, es la novela de García Márquez la que reimagina la represión de la huelga, la masacre, la cual solo desde entonces se vuelve visible y

48 Didi-Huberman, Images in Spite of All, 13 (traducción de la autora). 
legible. Dicho de otra manera, estas unidades de conocimiento exigen una ética de la visión en la medida en que:

[la estética] no implica que [la fotografía] "salva a aquellos a los que muestra" [...]: no se trata de exculpar a los actores de la historia [...] sino, más bien, de abrir un espacio para que emerja el conocimiento y una orientación para una elección ética. ${ }^{49}$

Consecuentemente, Georges Didi-Huberman propone una distinción muy interesante con respecto a lo visible, cuando afirma que:

[...] si queremos comprender esta expresión — "la inconsciencia de lo visible"no debemos recurrir a su opuesto, lo invisible, sino a una fenomenología más complicada, más contradictoria, más intensa, es decir, más "encarnada”. Esto es lo que el suceso visual, el síntoma visual, trata de designar..$^{50}$

Entonces, nos preguntamos: ¿qué es lo que esta serie de imágenes quiere hacer visible? ¿Qué nos dicen las fotografías acerca del conocimiento que tenía la United Fruit Company sobre el suceso ¿ ¿Hasta qué punto tenemos que usar nuestra imaginación para hacer hablar a estas imágenes? Didi-Huberman tiene toda la razón, al afirmar que: "La imagen de archivo es solo un objeto [...], una impresión fotográfica indescifrable e insignificante mientras no hayamos establecido la relación -la relación imaginativa y especulativa - entre lo que estoy viendo y lo que sé de antemano".51 Por otra parte, como algunas de las fotografías del archivo de la compañía se enviaron a Colombia para que las familias de los antiguos trabajadores las apreciaran, estas formarían parte de una economía visual pública que contribuiría a descifrar el significado de las imágenes hoy en día y permitir el empoderamiento del "otro" fotografiado.

Si miramos bien estas fotografías, podríamos imaginar que es posible que eliminaran algunas del archivo o que nunca las incluyeran. Esto bien podría haber sido así, especialmente si tenemos en cuenta que la compañía las usó, con el fin de

49 Ibid., 178-179 (traducción de la autora).

50 Georges Didi-Huberman, Confronting Images: Questioning the Ends of a Certain History of Art (University Park: Pennsylvania State University Press, 2005), 29 (traducción de la autora).

51 Didi-Huberman, Confronting Images, 112 (traducción de la autora). 
presentar una imagen positiva de sus actividades en el extranjero y legitimarlas. Obviamente no encontraremos aquí ninguna fotografía que muestre el violento incidente de la huelga y que pudiera hacer emerger el concepto de masacre. No obstante, es posible hacer otra lectura: en el informe de Gaitán se afirma que los telegramas y los testimonios de los testigos oculares indicaban que la actitud de los huelguistas era pacífica y permitían establecer la hipótesis de que los actos de sabotaje contra las instalaciones de la compañía fueron organizados y ejecutados por la misma United Fruit Company o terceros relacionados con ella, con el objetivo de legitimar la intervención militar. "Sabotear el sabotaje", como reimagina la ficción de García Márquez: la serie de fotografías muestra los sabotajes para documentar los daños que sufrió la empresa. ${ }^{52}$ Naturalmente, ellas no develan quién destruyó las instalaciones, sino que son intencionalmente nebulosas al respecto. Tampoco queda claro por qué las fotografías de los sabotajes se tomaron el 10 de diciembre de 1928, a pesar de que el incidente ocurrió el 6 de diciembre. A partir de esto, se infiere que las imágenes no documentan en lo absoluto el incidente; por el contrario, parece que pretenden ilustrar el otro relato de los sabotajes contra la compañía. En este sentido, son imágenes de sabotaje que forman parte de la compañía y su discurso oficial. Mientras que la ficción de García Márquez reimagina y hace visible los numerosos cadáveres que se transportaron en tren para arrojarlos al mar como banano de rechazo, con un José Arcadio Buendía como único sobreviviente y testigo ocular de la masacre, las fotografías de la United Fruit Company ocultan intencionalmente el concepto de cadáver. En este punto, ambos archivos difieren considerablemente, pero, a su vez, rebaten el significado de las imágenes de la United Fruit Company, cuando se superponen uno con otro y con otros materiales históricos. Para ello, es importante recordar que “[...] las fotografías son extremadamente perturbadoras porque exigen ser vistas como una secuencia, por lo que retienen la crudeza de cada momento captado, en vez de condensarlo en una sola imagen icónica". ${ }^{53}$ Además, esta secuencia exige que leamos las fotografías en relación con la Masacre de las Bananeras y que las usemos con una ética de la visión, porque la forma en que la compañía usó estas imágenes de sabotaje representó un "acto de apropiación política".54

52 García Márquez, One Hundred Years, 308.

53 Newburry, "Picturing an 'Ordinary Atrocity”, 219 (traducción de la autora).

54 Ibid., 222 (traducción de la autora). 
Sin embargo, la cuestión más crucial, las pérdidas y las víctimas de la Masacre de las Bananeras, permanece sin respuesta y pide a gritos su reivindicación política. Ya hemos destacado que las fotografías del archivo fotográfico de la compañía tienen un patrón común: no representan ningún tipo de violencia o atrocidad. Con respecto al testimonio y la evidencia histórica, la discusión acerca de cómo las imágenes fotográficas trabajan cuando se trata de violencia o, incluso, genocidio es bastante amplia. Por ejemplo, se concibe la fotografía como un instrumento eficiente para ocultar o borrar por completo las atrocidades cometidas por un Estado, al emplear una "visualidad civilizada", como esbozó Jens Andermann, a modo de historia de la violencia durante la constitución de la nación en la Argentina del siglo XIX. Él demuestra con qué eficiencia lo visual hace invisible la violencia y el genocidio, al hacer "desaparecer los actos". ${ }^{55}$ No obstante, la fotografía parece dar testimonio de algunos elementos particulares de la historia, como los gestos, una expresión facial, una actitud o una tensión, los cuales de otra manera no se habrían podido registrar. Sin embargo, la no convergencia de la fotografía y la historia ha sido discutida solo recientemente, bajo el concepto de la invisibilidad de lo visible en el discurso de la historia. ${ }^{56}$ Tal como la historia de la fotografía está floreciendo, la historia a través de la fotografía parece que ha sido poco estudiada. Por eso, tenemos que leer la serie de imágenes del archivo de la United Fruit Company a la luz de esta compleja relación entre la fotografía y la historiografía.

55 Jens Andermann, The Optic of the State: Visuality and Power in Argentina and Brazil (Pittsburgh: University of Pittsburgh Press, 2007).

56 Chéroux y About, Fotografie und Geschichte, 97. 


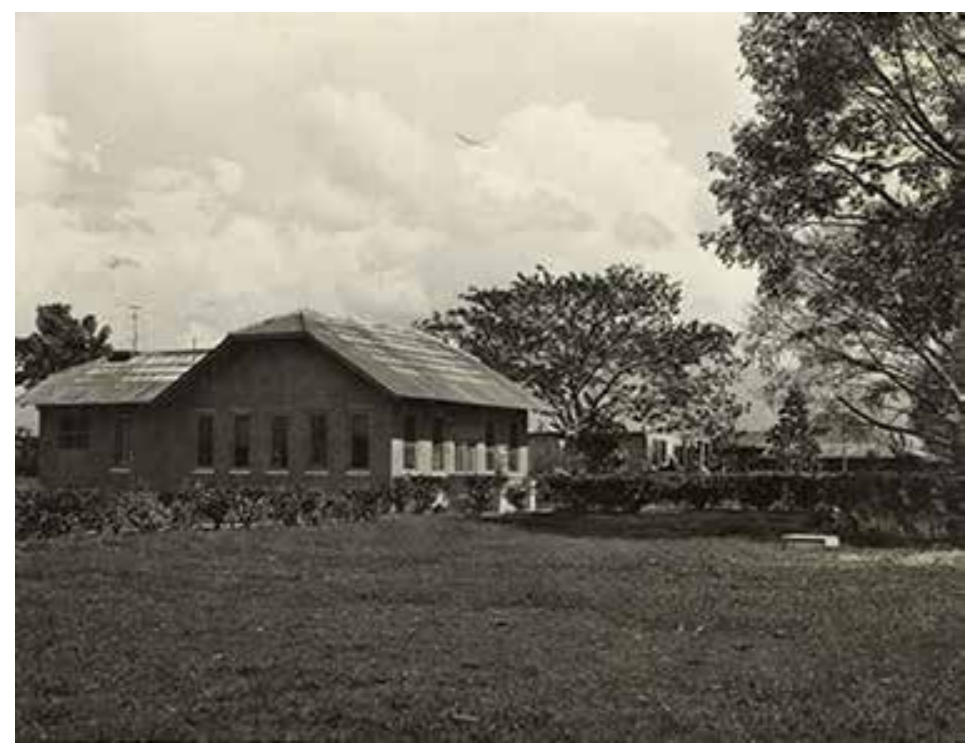

Figura 6. Fotógrafo anónimo, s. f., "View of Engineering Office-Asst. Div. Engrs' residence in background. Erasmos Coronel's grave right foreground-hat on top" (descripción al dorso: "no. 621", gelatina de plata en papel, $8 \times 10$ pulgadas, United Fruit Company Photograph Collection, Baker Library, Harvard Business School, olvwork719214).

Fotografías como la de la figura 6 acompañaban los informes internos de la compañía, como medio de comunicación de información visual sobre determinados sucesos políticos. ${ }^{57} \mathrm{~A}$ través de la leyenda "View of Engineering Office-Asst. Div. Engrs' residence in background. Erasmos Coronel's grave right foreground-hat

57 Con respecto a la Masacre de las Bananeras, Philippe Bourgois publicó una nota muy interesante: "March 8, 1929: The attached photograph shows the five of the principal leaders in the recent disturbances in the Colombian Division. Their names are as follows: [Check mark] No.1 Bernardino Guerrero. No. 2 Nicanor Serrano. No. 3 P.M. del Rio. No. 4 Raúl Eduardo Mahecha. [Check mark] No. 5 Erasmo Coronel [...]. No. 1 was secretary to Mahecha, the leader, and is now serving a term of fourteen years, seven months in the federal penitentiary in Tunga. No. 5 was killed in the fighting at Sevilla. Nos. 2 and 3 were simple laborers and were practically only figureheads in the organization. No. 4 Mahecha, was the brains of the entire outfit and is one of the most dangerous communist leaders in this country. He fomented the oil field strike in 1924 and last year was the leader of a bad strike in the coffee region in the interior. He came to Ciénaga about August of 1928 and immediately started fomenting the movement which culminated in the disturbance of December 6th. He is an ex-army captain, has a remarkable personality and undoubted genius for organization. At the time the strikers were fired on in Ciénaga he fled and it is known that he was wounded in one leg. Since then he has disappeared completely and it is now reported in the press that he has escaped to Costa Rica”. Véase Philippe Bourgois, “One Hundred Years of United Fruit Company Letters”, en Banana 
on top", se pone de manifiesto el interés de la compañía en el incidente, incluso, al mencionar a Erasmos Coronel, un supuesto agitador político. Con las indicaciones de la leyenda, se reimaginan en esta fotografía, al menos, los rastros de un cadáver, a saber, el de uno de los líderes de la huelga. Esta fotografía tiene un aire heroico y sensacionalista, es decir, el de la mirada ansiosa a la historia registrada sobre el papel. El significado de esta imagen se esboza en la relación entre la fotografía y su leyenda.

Si analizamos la relación entre la leyenda y la fotografía, notamos que la violencia se ocultó en la imagen como tal, pero se reimaginó en la anotación de la compañía. En particular, estas fotografías sobre la destrucción de las instalaciones de la compañía, que imaginan los daños causados por los sabotajes de la huelga de 1928 , fungen como documento a favor de controlar la huelga por todos los medios y como legitimización a posteriori de la "corrección" de la huelga (figura 7). Las imágenes, y aún más, el archivo fotográfico de la compañía, pretenden reproducir su poder hegemónico. Hasta cierto punto, podría resultar obvio calificar las prácticas fotográficas de la compañía como una instrumentalización de las imágenes,

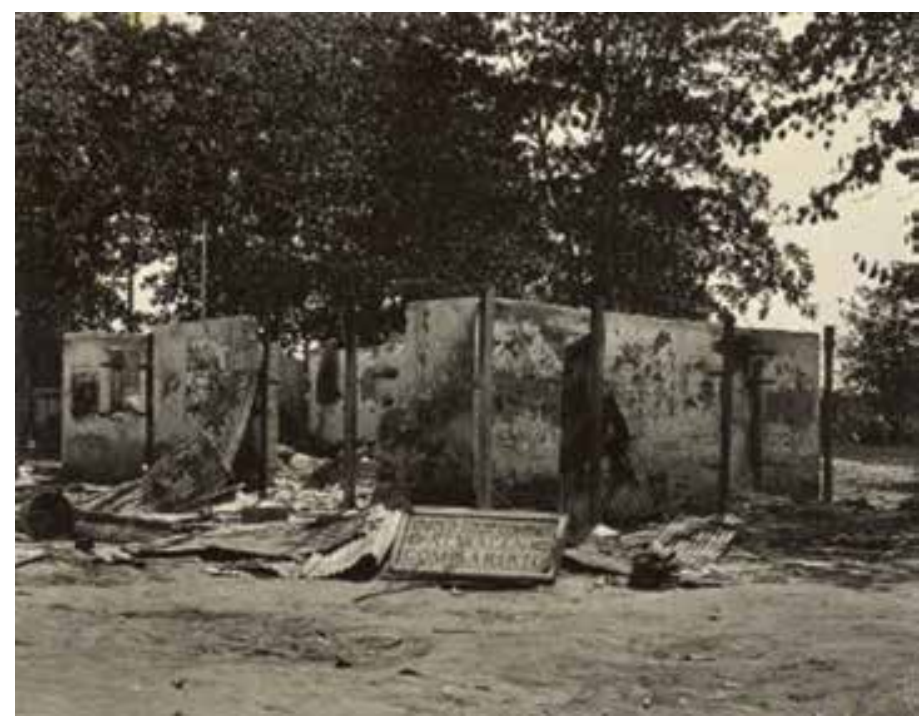

Figura 7. Fotógrafo anónimo, 1928, "Ruins of M \& S bodega and Residence for Mdse. Employees after revolution.

Colombia, Dec. 10, 1928” (descripción al dorso: "no. 614", gelatina de plata en papel, $8 \times 10$ pulgadas,

United Fruit Company Photograph Collection, Baker Library, Harvard Business School, olvwork719215).

Wars: Power, Production, and History in the Americas, ed. por Steve Striffler y Mark Moberg(Durham:

Duke University Press, 2003), 136-138. 
pero aquí también hay una comprensión más encubierta de estas que nos remite de vuelta a la cuestión inicial de este análisis, la materialidad, que pone en duda la idea de representación, la cual gobierna el “orden letrado” de la historiografía. Así, la fotografía cuestiona este orden. Veamos esta idea un poco más detalladamente: al parecer, la imagen fotográfica refleja la materialidad como la "copia y el contacto" entre el observador y lo fotografiado. ${ }^{58}$ Según esto, los términos identificación, representación y expresión se adscriben demasiado fácilmente a la fotografía: podemos descifrar su significado como la copia y el contacto en lo "poderoso y oscuro en la red de asociaciones", entre el observador, el fotógrafo y el otro fotografiado. ${ }^{59}$ Sin embargo, esta relación de la copia y el contacto permanece abierta y se vuelve inteligible y legible en un momento de peligro y de memoria. Al fin y al cabo, la fotografía revela que el ojo y el sentido de la visión son dispositivos del conocimiento. Esta nos habla de los modos y los medios de la percepción, así como de la participación del cuerpo en este contacto, articulados por las fotografías de la compañía con respecto a un nuevo orden basado en los sentidos. Por consiguiente, las supuestas máquinas miméticas, como las cámaras fotográficas, no solo cuestionan la práctica social de la fotografía, sino también la concepción de la fotografía como un "registro de la realidad" y la noción de toda tradición documental inherente a la fotografía. ${ }^{60}$

En general, el empoderamiento de la visión antecede a la fotografía. El mundo visual se ha engranado ya profundamente en la cultura occidental a través de otras técnicas y aparatos de captura de imágenes, de los que la fotografía deviene una suerte de transcripción automática. No obstante, el amplio uso de cámaras determina el rol crucial de la fotografía en la creación de un conocimiento imperial y contribuye a configurar la expansión económica de la United Fruit Company, que usó la cualidad afirmativa y la indexicalidad de la fotografía para sus fines. En este sentido, al menos con respecto a la serie de imágenes del archivo de la compañía, las fotografías se despliegan en el álbum a manera de evidencia y de prueba. Por consiguiente, la visión no solo informa sobre la expansión económica de la United Fruit Company, sino que esta modalidad sensorial también se convierte en un medio de control de los disturbios laborales que surgen como respuesta sociopolítica a la

Michael Taussig, Mimesis and Alterity: A Particular History of the Senses (London: Routledge, 1993), 21.

Ibid., 21 (traducción de la autora).

60

John Tagg, The Burden of Representation: Essays on Photographies and Histories (Minneapolis: University of Minnesota Press, 1993). 
modernización. Desplegadas de esta manera, es decir, aparentemente como herramienta de documentación objetiva, las fotografías se constituyen en una forma de conocimiento adquirido a través del relato y, por lo tanto, un medio de manipulación. Esto se hace evidente con la serie de imágenes del archivo fotográfico de la compañía, la cual presenta la huelga dentro de un discurso de sabotaje y de violencia contra esta, lo que permite ocultar el incidente como masacre.

Obviamente, en nuestro caso tanto la fotografía como la ficción son recursos que sirven para cuestionar el concepto de conocimiento. En general, los historiadores hoy en día casi siempre trabajan las fotografías de la United Fruit Company con el propósito de ilustrar la historia de la compañía; de esta manera, les otorgan implícitamente el estatus de un tipo de documentación objetiva sobre los sucesos que representan. Sin embargo, sorprendentemente parece que incluso los historiadores recurren a la ficción de García Márquez para "descubrir” detalles desconocidos o pasados por alto en relación con la Masacre de las Bananeras y sus víctimas (uno de los muchos detalles nebulosos es el número exacto de muertos, ya que los testigos oculares, los testimonios y los documentos históricos difieren entre sí). Naturalmente, las fotografías de la compañía callan al respecto, ya que su objetivo es ocultarlo; no obstante, aquí la literatura cumple su rol social al crear un archivo ficticio: la narración de García Márquez reimagina ese número de muertos que oscila entre la política del olvido y la memoria, lo que ofrece margen para un trabajo crítico de memoria. Al respecto, en la escena clave de la novela, el autor narra:

—Debían ser como tres mil —murmuró.

-¿Qué?

- Los muertos - aclaró él-. Debían ser todos los que estaban en la estación. La mujer lo midió con una mirada de lástima. "Aquí no había muertos", dijo. "Desde los tiempos de tu tío, el coronel, no ha pasado nada en Macondo". En tres cocinas donde se detuvo José Arcadio Segundo antes de llegar a la casa le dijeron lo mismo: "No hubo muertos". Pasó por la plazoleta de la estación, y vio las mesas de fritangas amontonadas una encima de otra, y tampoco allí encontró rastro alguno de la masacre. ${ }^{61}$

61 García Márquez, Cien años, 301. 
A través de Cien años de soledad, García Márquez reimaginó el incidente histórico de la huelga bananera como una masacre y cuestionó la historia oficial colombiana de ese momento, al rescatar aquel acontecimiento del silencio y de la metafórica peste del insomnio. Por lo tanto, en este caso, la literatura se convierte en un controvertido lugar de testimonio que cuestiona el voluble estatus de la evidencia y la verdad, mediante un proceso de epistemología social que involucra a un lector que participe en la producción de su significado. Con ayuda de varios andamios mágico-realistas en la historia de la familia Buendía, García Márquez construye un archivo ficticio que va más allá del orden letrado de la historiografía, al usar la literatura como una semántica contraria a la noción de la fotografía como registro de la realidad. Así, al nivel de la metaficción, la novela cuestiona tanto el concepto de archivo como el de memoria. A pesar de que las fotografías de la United Fruit Company esbozan en su oscuro interior un lugar de memoria que podría trascender su propio discurso de ocultación y supresión de la violencia, en los intersticios de ambos archivos se rebate y se amplifica el significado de las fotografías. Hoy, mediante la más bien silenciosa reapropiación de algunas de las imágenes del archivo fotográfico de la compañía (que empezaron a circular desde hace poco entre antiguos trabajadores y sus familias), la experiencia receptiva de los lectores ayudará a que se reconozca y se reapropie el significado de estas fotografías como un acto político de memoria y revisión.

Permítanme entonces concluir esta lectura de las fotografías, al abordar la cuestión de la ética de la visión, ya que esta serie de fotografías ocupa un lugar especial en el archivo fotográfico de la compañía. La primera vez que vi la serie de fotografías relacionadas con la huelga y, por ende, con la Masacre de las Bananeras, en los álbumes fotográficos de la United Fruit Company, me pareció sospechosa su narrativa visual, ya que dichas imágenes parecían contornear lo "inconsciente de lo visible" como algo desplazado y ocultado. Ellas parecían articular algo que aún no había sido articulado, es decir, se percibía un síntoma que había devenido en una expresión de algo desplazado. De este modo, me resultó evidente que la memoria y la conmemoración no son para nada procesos estables; así mismo, que ambos archivos, el fotográfico y el ficticio de Cien años de soledad, articulan este límite inestable entre lo privado y lo público, negociado en el acto del desplazamiento. La imaginación literaria materializó las dudas acerca de esta versión oficial de la Masacre de las Bananeras, que había hecho que el suceso histórico se convirtiera en un punto ciego en la misma historia colombiana durante mucho tiempo. Sin embargo, a partir del significado que surgió entre los dos archivos, sobre todo con 
respecto al silencio acerca de la masacre y las investigaciones secretas que hizo García Márquez de los documentos históricos, me resultó evidente que las fotografías de la United Fruit Company que se solapan con la ficción literaria se deben leer como un modelo de reflexión histórica que cuestiona el orden letrado de la historiografía. Por lo tanto, lo que propone Didi-Huberman adquiere importancia de nuevo: "Lo que deberíamos aprender [...] es a manejar el mecanismo de las imágenes de manera que sepamos qué hacer con nuestra visión y con nuestra memoria”. Además, enfatiza que:

La dimensión ética no desaparece en las imágenes [...]. Por lo que es cuestión de elegir: tenemos que elegir si, o cómo hacer participar la imagen en nuestro conocimiento y en nuestra acción. Podemos aceptar o rechazar una u otra imagen; tomarla como fuente de consuelo o de preocupación; hacerla formular preguntas o usarla como una respuesta preconcebida. ${ }^{62}$

De acuerdo con esto, resulta cierto que "Solo en este coraje [...] radica la capacidad de la imagen de librar lo real de su manto de invisibilidad. [...] el coraje de saber se convierte en una fuente de acción". ${ }^{63}$ Quiero concluir afirmando que la dimensión crucial de las imágenes, que sigue abierta y que hay que impugnar, es la materialidad de la imagen dentro de una epistemología social. Por consiguiente, estas imágenes de archivo exigen una ética de la visión y el uso de nuestro conocimiento para emprender una acción: esta podría reclamar la circulación de las demás fotografías fuera del archivo fotográfico de la compañía, así como su regreso a las comunidades en Colombia, de manera que podamos aprender a ver y recordar atrocidades contra la humanidad y el medio ambiente, como las que se cometieron durante la fiebre del banano y se manifestaron como la peste del insomnio, para ver y recordar la humanidad de las víctimas.

62 Didi-Huberman, Images in Spite of All, 180 (traducción de la autora).

63 Ibid., 178 (traducción de la autora). 


\section{Bibliografía}

\section{Fuentes primarias}

\section{Imágenes}

Photograph Albums, Boxes30/31. United Fruit Company Photograph Collection, Baker Library, Harvard Business School.

\section{Libros}

Gaitán, Jorge Eliécer. El debate sobre las bananeras. Bogotá: Centro Gaitán, 1988. García Márquez, Gabriel. One Hundred Years of Solitude. London: Viking, 2007. García Márquez, Gabriel. Cien años de soledad. Bogotá: Norma, 1997.

\section{Fuentes secundarias}

Albers, Irene y Bernd Busch. "Fotografie/fotografisch”. En Ästhetische Grundbegriffe, editado por Karlheinz Barck, 494-550. Stuttgart: Metzler, 2001.

Andermann, Jens. The Optic of the State: Visuality and Power in Argentina and Brazil. Pittsburgh: University of Pittsburgh Press, 2007.

Bell-Villada, Gene H. "Banana Strike and Military Massacre. One Hundred Years of Solitude and What Happened in 1928”. En García Márquez's One Hundred Years of Solitude, editado por Gene H. Bell-Villada, 127-138. Oxford: Oxford University Press, 2002.

Benjamin, Walter. “Theses on the Philosophy of History”. En Illuminations, 253-264. New York: Schocken Books, 1969.

Bourgois, Philippe. “One Hundred Years of United Fruit Company Letters”. En Banana Wars: Power, Production, and History in the Americas, editado por Steve Striffler y Mark Moberg, 103-144. Durham: Duke University Press, 2003.

Chéroux, Clément e Ilsen About. Fotografie und Geschichte: Vortrag an der Hochschule für Grafik und Buchkunst Leipzig. Leipzig: Institut für Buchkunst, 2004.

Chomsky, Aviva. "Repatriating Photographs". ReVista: Harvard Review of Latin America 8, n. $^{\circ} 26$ (2009): 64 .

Derrida, Jacques. “Archive Fever: A Freudian Impression”. Diacritics 25, n. 2 (1995): 9-63.

Didi-Huberman, Georges. Images in Spite of All. Chicago: University of Chicago Press, 2008. 
Didi-Huberman, Georges. Confronting Images: Questioning the Ends of a Certain History of Art. University Park: Pennsylvania State University Press, 2005.

LeGrand, Catherine. "El conflicto de las bananeras". En Nueva historia de Colombia, vol. 3, 183-218. Bogotá: Planeta, 1989.

Mena, Lucila. "La huelga de la compañía bananera como expresión de lo 'real maravilloso' americano en Cien Años de Soledad”. Bulletin Hispanique 74, n 3-4 (1972): 379-405.

Newbury, Darren. "Picturing an 'Ordinary Atrocity': The Sharpeville Massacre”. En Picturing Atrocity: Photography in Crisis, editado por G. Batchen, 209-223. London: Reaktion Books, 2012.

Pfeiffer, K. Ludwig. “Materialität der Literatur?”. En Materialität der Kommunikation, editado por Hans U. Gumbrecht y Karl L. Pfeiffer, 15-28. Frankfurt am Main: Suhrkamp, 1988.

Posada Carbó, Eduardo. “The Bananeras and Gabriel García Márquez”: One Hundred Years of Solitude". Journal of Latin American Studies 30, n. 2 (1988): 395-414.

Rincón, Carlos. "Las artes de la memoria en la plague of insomnia de Cien años de soledad". Literatura y Filosofía 1, n. ${ }^{\circ} 1$ (2003): 3-36.

Ríos, Valeria de los. Espectros de luz. Santiago de Chile: Cuarto Propio, 2011.

Rushdie, Salman. Imaginary Homelands: Essays and Criticism, 1981-1991. London: Penguin, 1991.

Schlie, Heike. "Bemerkungen zur juridischen, epistemologischen und medialen Wertigkeit des Zeugnisses". En Zeugnis und Zeugenschaft: Perspektiven aus der Vormoderne, editado por Heike Schlie y Wolfram Drews, 23-29. München: Wilhelm Fink, 2011.

Scholz, Oliver. "Das Zeugnis anderer-Prolegomena zu einer sozialen Erkenntnistheorie". En Positionen zwischen Tradition und Gegenwart, editado por T. Grundmann, 354-375. Paderborn: Mentis, 2001.

Tagg, John. The Burden of Representation: Essays on Photographies and Histories. Minneapolis: University of Minnesota Press, 1993.

Taussig, Michael. Mimesis and Alterity: A Particular History of the Senses. London: Routledge, 1993.

Walter, Monika. “Material”. En Ästhetische Grundbegriffe, editado por Karlheinz Barck, 866-882. Stuttgart: Metzler, 2001.

White, Judith. Historia de una ignominia: La United Fruit Co. en Colombia. Bogotá: Presencia, 1978. 


\title{
Entre blanqueamiento y paraiso racial: el Imperio de Brasil y la legitimación visual de la esclavitud en las exposiciones universales*
}

\author{
SVEN SCHUSTER \\ Alejandra Buenaventura
}

Entre 1862 y 1889, el Imperio de Brasil, bajo el Gobierno de don Pedro II, participó en las exposiciones universales más relevantes, con la intención de poner en escena la imagen idealizada de una "nación moderna". Si bien estos eventos se enfocaban en mostrar tanto los recursos naturales como el desarrollo económico de los países participantes, en el caso brasileño las élites aprovecharon esta plataforma para promover un país "tropical pero progresivo"; ${ }^{1}$ a la par, los rivales argentinos y mexicanos presentaron en estos eventos sus graduales procesos económicos y sociales, con el fin de atraer mano de obra extranjera, tecnología y capital; sin embargo, no lograron igualar los espectáculos montados por Brasil, cuya primera participación fue en la Gran Exposición de Londres en 1862.

Para Brasil, el punto más alto de su historial de participaciones en estos encuentros fue la Exposición Universal de París en 1889. Esta se desarrolló en conmemoración del centenario de la Revolución Francesa y de sus ideales republicanos, por lo que la monarquía brasileña no estuvo oficialmente representada. Pese

* Este capítulo es una versión ampliada y mejorada del artículo: Sven Schuster, "Envisioning a 'Whitened Brazil': Photography and Slavery at the World's Fairs, 1862-1889”, Estudios Interdisciplinarios de América Latina y el Caribe (ELAL) 26, n. 2 (2015): 17-41. Muchos de los cambios efectuados aquí son el resultado de la revisión meticulosa de Alejandra Buenaventura, por lo cual firma como coautora. Agradecemos a los editores de EIAL por el permiso de reproducir partes de este artículo.

1 Francisco Ignacio de Carvalho Moreira, Relatorio sobre a Exposição Internacional de 1862 (London: Thomas Brettell, 1863), 2. 
a esto, y en actuación del emperador como patrocinador, el denominado Sindicato Franco-Brasileño ${ }^{2}$ organizó una imponente presentación, la cual culminó con la construcción del pabellón nacional de Brasil, a pocos metros del nuevo símbolo de la modernidad: la Torre Eiffel. ${ }^{3}$

Irónicamente, el mejor momento del Imperio en términos de autorrepresentación fue también su último éxito: el 15 de noviembre de 1889 , solo dos semanas después de la clausura de la exhibición de París, el emperador fue derrocado mediante un golpe militar y Brasil se convirtió en una república federal. A diferencia de su antecesor monárquico, los recién formados Estados Unidos de Brasil mostraron poco interés en las "ferias internacionales del progreso" ${ }^{4}$ Con notables excepciones, las cuales se reflejan en la participación del país en las exposiciones internacionales de Chicago (1893), St. Louis (1904) y Sevilla (1929), el Brasil republicano se abstuvo de la participación en las ferias internacionales más importantes de la época. Incluso, durante la Exposición Universal de París en 1900, que contó con una asistencia superior a los 50 millones de visitantes, Brasil ni siquiera estuvo representado, debido a problemas de conmoción interna. En general, la "fiebre" de las exposiciones universales, que había comenzado en 1851 con la apertura del Palacio de Cristal en Londres y culminó en la exposición parisina de 1900, se redujo considerablemente después de esa fecha. En el mundo, la participación en exposiciones universales solo tendría un nuevo auge a partir de los años treinta del siglo XX.

2 Debido a la negativa del emperador para participar oficialmente en la exposición de 1889, comerciantes y políticos de Brasil y Francia fundaron esta asociación privada, la cual contó tanto con capital privado como con el patrocinio del Gobierno imperial brasileño y la Cámara de Comercio de París.

3 Sobre la participación del Imperio de Brasil en las exposiciones universales, véase: Margarida de Souza Neves, "Los escaparates del progreso: Brasil en las exposiciones internacionales del siglo XIX", en $\mathrm{La}$ nación expuesta: cultura visual y procesos de formación de la nación en América Latina, ed. por Sven Schuster (Bogotá: Universidad del Rosario, 2014), 83-100; José Luiz Werneck, "As arenas pacíficas do progresso" (tesis de doctorado, Universidade Federal Fluminense, Niterói, 1992); Lilia Moritz Schwarcz, "Os trópicos como espetáculo: a participação brasileira nas exposições universais de finais do século XIX”, en Galerías del progreso: museos, exposiciones y cultura visual en América Latina, ed. por Beatriz González-Stephan y Jens Andermann (Rosario: Viterbo, 2006), 195-219; Jens Andermann, "Tournaments of Value: Argentina and Brazil in the Age of Exhibitions", Journal of Material Culture 14, n. 3 (2009): 333-363; Lívia Lazzaro Rezende, "The Raw and the Manufactured: Brazilian Modernity and National Identity as Projected in International Exhibitions (1862-1922)" (tesis de doctorado, Royal College of Art, London, 2010); Sandra Jatahy Pesavento, Exposiçōes universais: espetáculos da modernidade do século XIX (São Paulo: Hucitec, 1997); Maria Inez Turazzi, Poses e trejeitos: a fotografia e as exposições na era do espetáculo (Rio de Janeiro: Funarte/Rocco, 1995).

4 Eric Hobsbawm, Das imperiale Zeitalter, 1875-1914 (Frankfurt am Main: Campus, 1989), 48. 
El impacto mediático y global de las exposiciones no tuvo comparación en la época, ya que, incluso, capturaron la atención de sectores de la clase trabajadora y de la media baja. Ningún evento masivo de la época representaba mejor el universalismo hegemónico del mundo occidental, como señala Jürgen Osterhammel. ${ }^{5}$ Aunque la mayoría de los países latinoamericanos vieron en las exposiciones de Londres (1862), París (1867 y 1889), Viena (1873) y Filadelfia (1876) la oportunidad de obtener mayor reconocimiento ante los ojos de los países líderes del mundo, al igual que la plataforma para definirse como naciones verdaderamente "modernas", el Imperio de Brasil se encontraba en desventaja respecto a sus competidores. Generalmente, los países latinoamericanos que participaron en las exposiciones universales buscaron presentar su progreso material, emulando los patrones europeos de desarrollo enfocándose en máquinas, productos agrícolas y materias primas. Lo que hizo de Brasil un caso diferente o, de cierto modo "delicado", fue el hecho de que muchos de los productos exhibidos procedían de mano de obra esclava.

Desde que Brasil abolió la esclavitud el 13 de mayo de 1888 (un año antes de la inauguración de la Exposición Universal de París), la élite imperial enfrentó un gran inconveniente: ¿cómo "vender" la continua existencia de la institución ante un público internacional? Esto ya había sido un problema durante la Gran Exposición de Londres, en 1862, debido a la fuerte presión que Gran Bretaña ejerció desde 1830, la cual poco después llevaría al abandono temporal de las relaciones diplomáticas entre los dos Estados. ${ }^{6}$ Como los esclavos representaron una parte considerable de la fuerza de trabajo brasileña durante la mayor parte de la época imperial, inicialmente los promotores de la exposición intentaron esconder este aspecto "desagradable" de la realidad social.

A pesar de esto, varios miembros de la élite progresista encargados de la participación de Brasil en las exposiciones universales también eran esclavistas. Como lo han afirmado José Luiz Werneck, la mayoría de los afiliados al Museo Nacional de Río de Janeiro, la Academia Imperial de Bellas Artes (AIBA), el Instituto de Historia y Geografía de Brasil (IHGB), la Sociedad de Apoyo a la Industria

5 Jürgen Osterhammel, Die Verwandlung der Welt: Eine Geschichte des 19. Jahrbunderts (München: C. H. Beck, 2010), 2.

6 Lilia Moritz Schwarcz, As barbas do imperador: D. Pedro II, um monarca nos trópicos (São Paulo: Companhia das Letras, 2010), 296-300. 
Nacional (SAIN) y el Instituto Imperial de Agricultura (IIFA).7 Aunque muchos de ellos dependían del trabajo de los esclavos para poder financiar su estilo de vida, optaron por una emancipación gradual, ya que, desde su perspectiva, un país que deseaba ser "civilizado y progresivo" no podía presentarse a sí mismo como una sociedad esclavista ante los ojos del mundo, así que trataron de evadir el tema en el contexto de la exposición de 1862.

Para la Exposición Universal de París en 1867, esta postura resultó inviable, tras la derrota de los Estados Confederados de América -el más fuerte bastión de la esclavitud en el mundo - en la guerra civil norteamericana, dos años atrás. Así mismo, la creciente crítica de los abolicionistas norteamericanos y franceses se erigió como un factor deslegitimador de la esclavitud, lo que llevó a los organizadores a enfrentar el tema públicamente. Así, en las exposiciones de 1867 y 1873 se presentaron imágenes y descripciones textuales de la esclavitud, probablemente para justificarla al mostrar a Brasil como un paraíso racial. ${ }^{8}$

Desde esta perspectiva, la esclavitud brasileña era "diferente" y no tenía nada en común con los relatos de horror que llegaron de las plantaciones de Cuba o Norteamérica; más bien, era un "proyecto de civilización" paternalista que algún día transformaría a los esclavos en ciudadanos. De acuerdo con la promulgación de las leyes para la gradual libertad de los esclavos, las imágenes de los puestos y pabellones brasileños durante las exposiciones universales entre 1873 y 1889 presentaban tableros y guías de exhibición que mostraban el trato particularmente "humano" hacia los esclavos. Con la excepción del esfuerzo organizado en privado en 1889, todas las participaciones de Brasil en las exposiciones eran asuntos oficiales, cuyo objetivo era demostrar el progreso humano y material del Imperio de forma condensada. No obstante, detrás de las pomposas ceremonias y las fachadas monumentales de los palacios de exhibición, en Brasil se daban fuertes debates dentro de la élite imperial sobre qué se debía mostrar y cómo se debía presentar de “manera correcta”. La prensa nacional e internacional, así como los registros y los catálogos de la exposición, mostraban un amplio rango de opiniones sobre cómo

7 José Luiz Werneck, "Isto é o que me parece: A Sociedade Auxiliadora Nacional (1827-1904) na formação social brasileira. A conjuntura de 1871 até 1877”, vol. 2 (tesis de maestría, Universidade Federal Fluminense, 1979), 64-65.

8 Célia Marinho de Azevedo, Abolicionismo: Estados Unidos e Brasil, uma história comparada, século XIX (São Paulo: Annablume, 2003), 159-161. 
combinar las visiones de la modernidad con imágenes exóticas de culturas indígenas y de la esclavitud, como lo exigían los países anfitriones.

A pesar de la celebración universal de "paz y civilización” en los terrenos de la exposición, Europa y Norteamérica se percataron de que estos eventos servían como campos para extender su lucha sobre la distribución geopolítica del poder en forma simbólica y performativa, al crear una especie de "globo en miniatura", dividido en centros, periferias y colonias. ${ }^{9}$ De esta manera, Brasil, un país oficialmente independiente, pero aún dependiente en lo económico y lo político, tuvo que “jugar según las reglas”: presentó materias primas e “imágenes exóticas” de esclavos e indígenas junto a las exposiciones tecnológicas de países más desarrollados. Pese a esto, el futuro de Brasil sería brillante si las élites tomaban el camino teleológico del desarrollo mostrado por sus "mentores" europeos y norteamericanos.

En este contexto, la aparición de la fotografía como nuevo medio visual fue especialmente relevante, ya que fue una de las pocas tecnologías a través de las cuales un país periférico como Brasil pudo demostrar sus avances técnicos y evidenciar con éxito su despliegue; incluso, la figura entusiasta de don Pedro II, primer fotógrafo amateur de su país, permitió que la élites brasileñas se asociaran con la modernidad y se contemplara esta técnica como una forma "objetiva" para representar la naturaleza. ${ }^{10}$ Las cámaras fotográficas y las fotografías se elevaron al mismo rango de los instrumentos astronómicos y las máquinas exhibidas en las exposiciones universales, como Maria Inez Turazzi ha demostrado. ${ }^{11}$ Así, mediante la repetición de las mismas imágenes en varias exposiciones nacionales e internacionales, pero siempre adaptadas a contextos históricos específicos, estas resultaron ser más contundentes con el paso del tiempo.

A partir de esto, en lo que resta del texto interpretamos, a través de la fotografía, distintos componentes visuales de discursos complejos sobre raza y esclavitud. Si bien muchos académicos han analizado la iconografía de las exposiciones universales en las numerosas referencias bibliográficas, el asunto de las representaciones visuales de la esclavitud en aquellas exhibiciones aún es un tema poco explorado. De acuerdo con las estrategias discursivas relacionadas con el "problema" de cómo se debe presentar la esclavitud frente a una audiencia sumamente crítica, este texto

9 Timothy Mitchell, “The World as Exhibition", Comparative Studies in Society and History 3, n. 2 (1989):217-236.

10 Schwarcz, As barbas do imperador, 330.

11 Turazzi, Poses e trejeitos, 114. 
se divide en dos partes temáticas: en la primera se pretende mostrar las estrategias desarrolladas para evadir el tema de la esclavitud y, en su lugar, promover el proceso gradual del "blanqueamiento de la nación", siguiendo la declaración de la ley de la libertad de vientres, en 1871; la segunda parte se centra en la construcción del llamado paraíso racialy su función sociopolítica dentro del alcance de las exposiciones.

\section{"Blanquear la nación"}

Durante la segunda mitad de siglo xIx, el Imperio de Brasil evitó difundir una imagen específica de su población, por lo que las piezas en la exposición de Londres fueron escasas; de hecho, las pocas fotografías y pinturas incluidas en la colección no daban ninguna impresión de la composición efectiva de la población del país sudamericano, ya que solo representaban los miembros de la familia imperial, así como una serie de "ilustres personalidades" (figura 1). ${ }^{12}$ En la opinión de los organizadores de la exposición internacional de 1862, en Londres, Brasil no solo debía enfocarse en productos de agricultura, sino también en la presentación de maquinaria moderna, para evitar dar la impresión en el extranjero de ser un país excesivamente subdesarrollado. No obstante, ante la dificultad para transportar grandes máquinas hacia Londres, prefirieron exponer reproducciones fotográficas de estos objetos. ${ }^{13}$ Dado que las exposiciones debían promover la modernización, la persistencia de la esclavitud no se adaptaba a la celebración del lema de la primera Exhibición Nacional, “orden, libertad y progreso”, realizada en Río de Janeiro en 1861, como preparación para la Exposición Universal. ${ }^{14}$

Entre tanto, la exclusión visual de negros libres y esclavos, que en realidad representaban una significativa proporción de la mano de obra brasileña para la década de 1860, no causó ningún debate dentro del comité de la exposición; tampoco una provocación en materia de comentarios críticos de la prensa semioficial de Río de Janeiro; sin embargo, algunas revistas humorísticas independientes reaccionaron de manera distinta. Así, en su habitual tono sarcástico, la revista Bazar Volante de Río de Janeiro publicó una serie de caricaturas para burlarse de lo que el Imperio proponía: representarse a sí mismo como un país abrumadoramente "blanco", para alejarse de las “desagradables realidades” de la esclavitud y el mestizaje. En esta

12 Commissão Diretora da Exposição Nacional, Catalogo dos productos naturaes e industriaes remettidos para a Exposição Universal em Londres (London: Typographia de C. Whiting, 1862), 105-106.

13 Ibid., 57-75.

14 Werneck, As arenas pacificas, vol. 2, 222-224. 


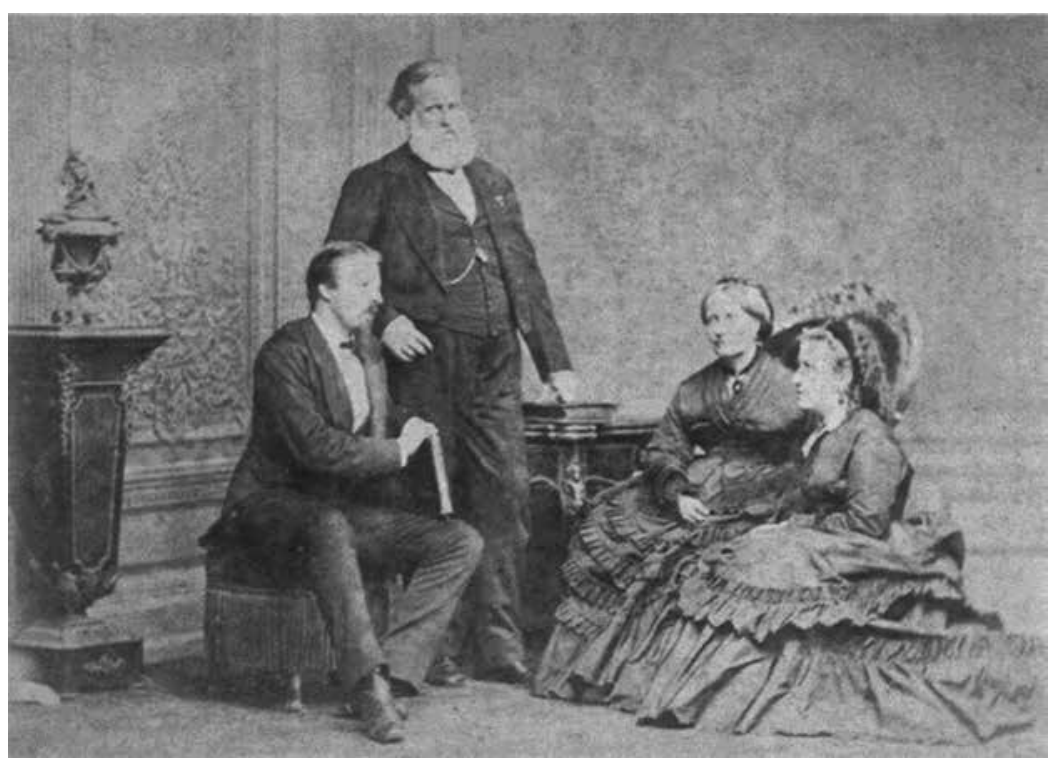

Figura 1. Albert Henschel, alrededor de 1873, "D. Pedro II, a imperatriz Thereza Christina Maria, a princesa Isabel e o conde d'Eu" (albúmina, $10 \times 13,9$ cm, Coleção Waldyr da Fontoura Cordovil Pires, Rio de Janeiro).

edición, Bazar Volante presentó dos visitantes ficticios en la exposición de ascendencia africana, quienes observan una de las pinturas expuestas por la AIBA en el edificio de la Escola Central, donde tuvo lugar la primera Exposición Nacional. En un lenguaje coloquial y gramáticamente incorrecto, los dos intentaron medir el "valor artístico" de las pinturas sin mostrar ninguna comprensión de la estética europea. Finalmente, se preguntaron si un "hombre blanco" habría interpretado la pintura en la forma en que ellos lo hicieron (figura 2). ${ }^{15}$

15 “Raridades da Exposição”, Bazar Volante, 4 de noviembre de 1866. 


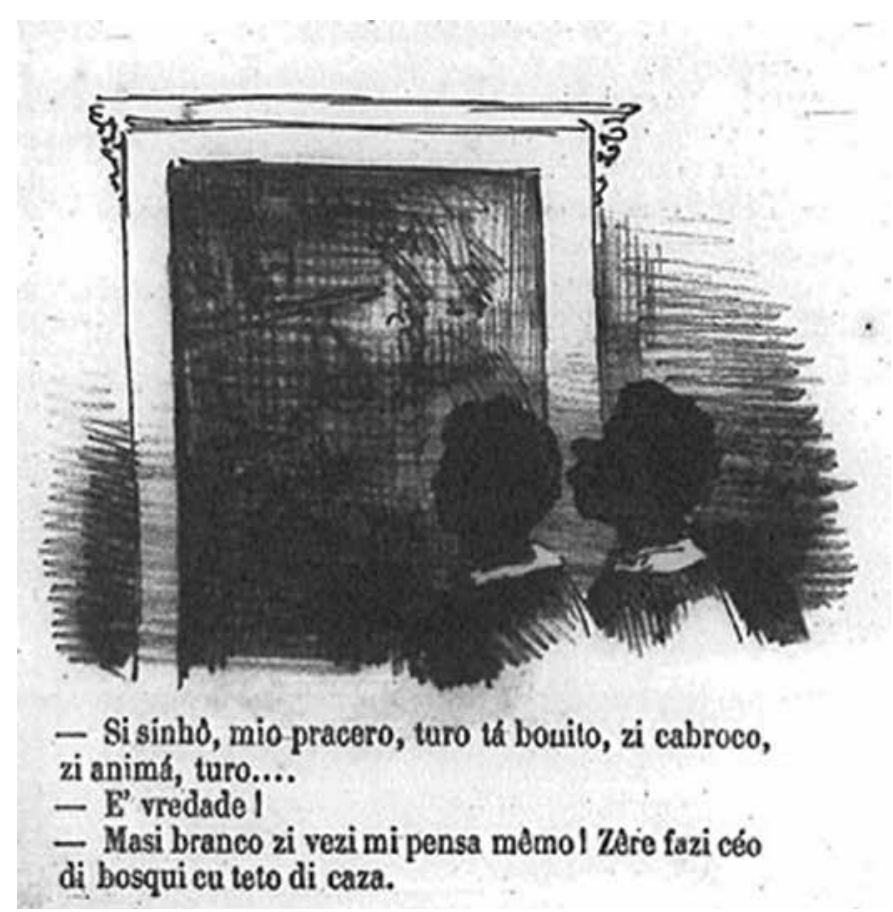

Figura 2. Bazar Volante, 4 de noviembre de 1866.

Con caricaturas racializadas como esta, Bazar Volante y otras revistas resaltaron las grandes contradicciones entre una economía dependiente de esclavos y la celebración, un tanto fuera de lugar del progreso demostrado en estas exhibiciones. Para ellos, la presentación de los trabajos de los artistas de la AIBA, que generalmente recibían parte de su educación en Francia o Italia, era una prueba del fracaso del Imperio en reconocer los verdaderos problemas de la nación, en una suerte de competencia con la cultura europea, ya que el tipo de "alta cultura" presentada en los pasillos de la exposición que reclamaba el país sudamericano ni siquiera pudo ser interpretada por los brasileños "no civilizados". En otra observación crítica sobre la Exposición Nacional, la revista humorística Semana Illustrada insinuó que las élites de Río de Janeiro solo visitaron la exposición para "ser vistos pero no para ver". Respecto a las clases altas de la capital imperial, el periódico sostuvo que las exposiciones trataban de distinciones sociales y no tenían nada que ver con la supuesta "educación popular" promovida por el emperador. ${ }^{16}$

16 “Contos do Rio de Janeiro", Semana Illustrada, 12 de enero de 1862. 
Como era de esperarse, la participación de Brasil en Londres generó duras críticas, ${ }^{17}$ las cuales se hicieron públicas a través de los comentarios de la prensa - muy comunes durante la época imperial — y, en particular, las revistas satíricas de Río de Janeiro, que disfrutaron de un sorprendente grado de libertad, mucho más en comparación con el periodo republicano entre 1889 y $1930 .{ }^{18}$ Los organizadores de la exposición vieron en la preparación de esta una oportunidad para educar a la población general acerca de los beneficios de una economía de libre mercado; así, su postura respecto al tema de la abolición resultaba ser algo ambivalente, ya que evitar acercarse al "problema de la esclavitud" en Londres fue una consecuencia de la guerra civil norteamericana y la incertidumbre de su resultado. Hubo temores extendidos sobre una posible revuelta por parte de los esclavos, como ya había sucedido en Haití, o sobre otras formas violentas de rebelión dentro del país. Así mismo, la presión por parte de los abolicionistas británicos y franceses fue considerable; esta se evidenció en la renuencia a exhibir cualquier aspecto de la esclavitud en Londres, como sucedió con las imágenes de los esclavos tomadas por el fotógrafo francés Victor Frond en plantaciones brasileñas durante los años cincuenta del siglo XIX.

Frond, quien dirigió un estudio fotográfico en Río de Janeiro entre 1858 y 1862 , fue realmente el primero en tomar fotografías de esclavos brasileños. Su reputación como fotógrafo se fundamentó en sus detalladas vistas panorámicas de Río. En particular, sus imágenes del pan de azúcar y del acueducto de Lapa se transformaron en íconos visuales, como ha señalado Margrit Prussat. ${ }^{19}$ Sus imágenes de esclavos se incorporaron dentro del álbum litográfico Brazil Pittoresco, junto a varios paisajes espectaculares y vistas urbanas. El libro, pionero en este tipo de publicaciones en América Latina, se editó por primera vez en 1859 en Río de Janeiro; en este se combinaron litografías hechas por Phillipe Benoist, basadas en las fotos tomadas por Frond, con textos del periodista francés Charles de Ribeyrolles. Una segunda edición mejorada fue publicada dos años después, por la prestigiosa

17 “The International Exhibition", The Times, 17 de noviembre de 1862; "Exposição Nacional”, Diario do Rio de Janeiro, 10 de diciembre de 1861; "O Catalogo Brasileiro na Exposição Universal de Paris em 1867”, Diario do Rio de Janeiro, 29 de diciembre de 1867. Este último artículo comenta la participación brasileña en Londres, en retrospectiva, y la describe como "exótica" y "microscópica".

18 Ana Luiza Martins, “Imprensa em tempos de império”, en História da imprensa no Brasil, ed. por Ana Luiza Martins y Tania Regina de Luca (São Paulo: Contexto, 2008), 67.

19 Margrit Prussat, Bilder der Sklaverei: Fotografien der afrikanischen Diaspora in Brasilien, 1860-1920. (Berlin: Reimer, 2008), 63. 
editorial francesa Lemercier, debido a la mala calidad que tenía el papel de su primera edición.

De acuerdo con Prussat, las litografías de Brazil Pittoresco fueron un éxito inmediato. Aunque su alto precio significaba que solo unos cuantos miembros de las élites podían adquirir el libro, la rápida difusión de las imágenes de Frond —-debido a su reproducción en otros medios - incrementó su circulación en las décadas posteriores. ${ }^{20}$ Según el historiador de la fotografía Boris Kossoy, podemos asumir que las imágenes de Frond tuvieron un impacto significativo en comparación con el trabajo de otros fotógrafos contemporáneos. ${ }^{21}$ El texto complementario, escrito por Charles de Ribeyrolles, tuvo un impacto limitado; mientras que las imágenes de Frond circularon cada vez más en contextos completamente independientes de la publicación original. ${ }^{22}$ Así, gracias al gran éxito de Brazil Pittoresco y sus retratos de "ilustres personalidades", hechos para don Pedro II, Frond fue uno de los más populares fotógrafos en el Brasil de los años cincuenta y sesenta del siglo XIX. ${ }^{23}$

Frond quería mostrar desde el inicio su "álbum pintoresco" a un público internacional, probablemente en Londres. ${ }^{24}$ Después de todo, la comunidad artística de Brasil, por lo general, estuvo de acuerdo en reconocer estas fotografías como obras maestras y el mismo Frond estaba ansioso de participar en la exposición, como lo había declarado en varias ocasiones, pero al final ninguna de sus imágenes se exhibió en la Exposición Nacional ni en la Exposición Universal. ${ }^{25}$ Aunque el álbum de Frond había sido presentado a tiempo para considerarlo una muestra oficial, el comité de jurados no lo aceptó. La decisión de rechazar una obra maestra de esta calidad parece estar relacionada con las diversas imágenes de esclavos y negros libres que aparecían en el libro; sin embargo, la negativa hacia la presentación del álbum se justificó al alegar que solo productos "nacionales" podían mostrarse, de acuerdo con las regulaciones del evento. Desde que la segunda edición de Brazil Pittoresco se imprimió sobre papel de buena calidad en París, el libro se clasificó como un

Brasil Pitoresco, de Victor Frond e Charles Ribeyrolles (1859-1861)” (tesis de doctorado, Universi-
dade Estadual de Campinas, 2011), 80-81. 
"producto extranjero" y, por ello, se excluyó de la exposición. ${ }^{26}$ En un intento por compensar a Frond, los organizadores del evento lo designaron presidente de la sección de bellas artes, con el fin de que fuese jurado en la selección de las piezas que formarían parte de las muestras fotográficas. ${ }^{27}$

Es muy probable que el fallo por parte de la comisión que excluyó a Brazil Pittoresco de la exposición estuviera influenciado por el temor de que la población brasileña pareciera demasiado "africana”, en contraste con las máquinas y los instrumentos científicos presentados en esta exhibición. De hecho, algunos componentes de esta maquinaria habían llegado originariamente de Alemania, Francia o Inglaterra y solo fueron ensamblados por compañías brasileñas. No obstante, en estos casos, los jurados de la exposición no mostraron ninguna oposición en absoluto. ${ }^{28}$ Finalmente, se presentó el álbum en la Exposición Nacional de 1861, pero solo como un libro cerrado: en vez de las fotografías de Frond, el magnífico cuero de la portada del álbum producido por la Casa Lombaerts se registró como pieza de la exposición oficial. ${ }^{29}$

Aunque las muestras y las guías de la exposición incluían descripciones gráficas y textuales de la supuesta "naturaleza benévola" de la esclavitud, la invisibilización de los elementos africanos se mantuvo. Así, en pinturas como Batalha de Campo Grande (1871) y Combate Naval do Riachuelo (1872) — ambas realizadas por Victor Meirelles y expuestas en Viena y Filadelfia, respectivamente, en las que se representaban las hazañas del ejército imperial durante la Guerra de Paraguay (1865-1870) - se minimizó sistemáticamente el papel de los soldados afrodescendientes, con el propósito de ensalzar la "gloriosa victoria" de Brasil sobre las "hordas bárbaras paraguayas", un memorable "triunfo blanco" en su historiografía e iconografía oficiales. ${ }^{30}$

Desde la aprobación de la ley de la libertad de vientres, en 1871, el blanqueamiento se concibió como una forma de ocultar el "vergonzoso" fenómeno de la esclavitud ante el público extranjero; incluso como herramienta política, pretendió

26 Turazzi, Poses e trejeitos, 120-121.

27 Antonio Luiz Fernandes da Cunha, Documentos officiaes relativos à Exposição Nacional de 1861 (Rio de Janeiro: Typographia do Diario do Rio de Janeiro, 1861), 97-98.

28 Couto da Silva, Um monumento ao Brasil, 216.

29 Ibid., 212.

30 Sven Schuster, "A visão dos vencedores: O Brasil e a glorificação da Guerra do Paraguai nas exposições universais do século XIX”, Iberoamericana 17, n. ${ }^{\circ} 64$ (2017): 147-174. 
alterar la "base biológica" de la nación, al promover la inmigración europea. Como lo había señalado Jeffrey Lesser, la mayoría de los intelectuales brasileños eran monogenistas: creían que la humanidad compartía un origen en común; pero, debido a ciertas influencias biológicas y ambientales, varias razas se habían desarrollado con el tiempo. ${ }^{31}$ Aunque no se cuestionaban la existencia de jerarquías raciales -en las cuales los descendientes de africanos usualmente ocupaban el lugar más bajo de la escala; mientras que los europeos ocupaban el puesto más alto-, estaban convencidos de que estas "realidades" no eran estáticas y podían ser cambiadas a través de medidas demográficas inteligentes, como el fomento de la inmigración europea. ${ }^{32}$

Algunos intelectuales se opusieron fuertemente a las teorías populares de la “degeneración”, propuestas por pensadores como el Conde de Gobineau, quien fue un fuerte crítico de cualquier tipo de mezcla racial. ${ }^{33}$ Muchos de los organizadores de la exposición pensaron el blanqueamiento, que para ellos representaba una forma de esparcimiento de las "razas inferiores", como la única opción de Brasil si pretendía convertirse en país "civilizado y progresivo"; ${ }^{34}$ así, los intelectuales aprovecharon la gradual liberación de esclavos y consideraron la ley de la libertad de vientres como el primer paso para "desafricanizar" el país. ${ }^{35}$

Un folleto didáctico redactado por Francisco Ignacio de Carvalho Moreira, el barón de Penedo, acerca de la nuevamente establecida colonia agrícola de Blumenau, resultó ser paradigmático al respecto. Para Penedo, la colonia fundada por pobladores alemanes en el sur de Brasil demostraba que un país verdaderamente "civilizado" solo era viable con inmigrantes europeos, en especial si eran de países de lengua alemana. La presentación de la colonia, que ganó una "mención honorable" en la Exposición Universal de París en 1867, fue una forma para atraer inmigrantes con la que, de paso, se presentaba de manera irrelevante el tema de la esclavitud, mientras se daba preferencia al clima casi “europeo" y a los paisajes de las regiones del sur de Brasil. No obstante, lo más importante era dejarles claro a los potenciales

31 Jeffrey Lesser, Negotiating National Identity: Immigrants, Minorities, and the Struggle for Ethnicity in Brazil (Durham: Duke University Press, 1999), 6-7.

32 Lesser, Negotiating National Identity, 7.

33 Helga Gahyva, “Brasil, o país do futuro: uma aposta de Arthur de Gobineau?", ALCEU 7, n. ${ }^{\circ} 14$ (2007): 152-159.

34 I. C. Galvão, Discurso (Rio de Janeiro: Typographia Universal de Laemmert, 1870), 7-13 y 65-66.

35 Thomas Skidmore, Preto no branco-raça e nacionalidade no pensamento brasileiro (Rio de Janeiro: Paz e Terra, 1976), 154-162. 
inmigrantes que no debían temer ser tratados como esclavos, como muchos opositores de la emigración masiva en Europa advertían en esa época. Por estas razones, Penedo prometía que el Gobierno brasileño adoptaría medidas para poner fin a la esclavitud, "reduciendo" gradualmente a las personas de ascendencia africana, ya que ellos representaban un "obstáculo para el desarrollo".36

Este punto de vista lo compartían muchos abolicionistas, como Joaquim de Nabuco. ${ }^{37}$ Otros textos escritos para la exposición brasileña en París rechazaron la visión de Brasil como un país "africano", al describir la esclavitud como una reliquia del pasado y la inmigración como el camino hacia una sociedad "racialmente regenerada”. En estos libros y panfletos, los organizadores de la exposición de París separaron artificialmente muchos productos agrícolas de la exposición en los puestos y los pabellones de sus productores, los esclavos, ya que, como lo había reseñado una guía oficial de Brasil, los productos provenientes de las actividades agropecuarias, como el azúcar y el café, eran producidos por "ciudadanos libres". ${ }^{38}$

Un tema más significativo que el de las descripciones apologéticas de la esclavitud en los reportes y catálogos de la exposición fue el de las fotografías de los "tipos de negros", tomadas por el fotógrafo italiano Auguste Stahl y presentadas en la Segunda Exposición Nacional en 1866. Claramente, estas imágenes fueron influenciadas por la fotografía antropométrica, una técnica popular de la época, con la que se ilustraban las teorías raciales contemporáneas que enmarcaron las políticas del blanqueamiento. A través de este tipo de fotografía, fue posible visualizar ciertas propiedades fenotípicas que describían las "razas", mediante una serie de imágenes de cuerpos desnudos o semidesnudos en posiciones inmutables, con las cuales se pretendía deducir las supuestas propiedades consistentes de una cierta "familia racial". Adhiriéndose a una concepción positivista de la fotografía, muchos vieron en este nuevo medio la mejor forma para describir la naturaleza —incluido el cuerpo humano - de manera empírica y objetiva, pues, para ellos, la fotografía era "el lápiz de la naturaleza”.39

36 Francisco Ignacio de Carvalho Moreira, A colonia Blumenau, CLXx.

37 Azevedo, Abolicionismo, 85-87.

38 François Ducuing, L'Exposition Universelle de 1867 illustrée, vol. 2. (Paris: Bureaux d'abonnements, 1867), 393.

39 Mauricio Tenorio Trillo, Mexico at the World's Fairs: Crafting a Modern Nation (Berkeley: University of California Press, 1996), 118; Nancy Stepan, Picturing Tropical Nature (Ithaca: Cornell University Press, 2001), 88; Schwarcz, As barbas do imperador, 326-347. La expresión lápiz de la naturaleza deriva 
Las fotografías de Stahl, presentadas en la Exposición Nacional de 1866, coincidieron toscamente con la creciente propagación de teorías biológicas raciales en Brasil, aunque no estuvieran del todo aceptadas. ${ }^{40}$ Como una representación de los "tipos raciales" que podían medirse y clasificarse, las fotografías del estudio de Stahl en el formato de carte de visite carecían de información contextual, sin tener siquiera el nombre de la persona fotografiada. En vez de ello, la información mencionaba las diferentes "naciones" a los que los sujetos supuestamente pertenecían, como era el caso del "esclavo Mina Mondrí" (figura 3). ${ }^{41}$ Las visibles cicatrices tribales de los sujetos indicaban que ellos no habían nacido en esclavitud, pero probablemente eran boçais traídos de África. Las cartes de visites de este tipo circularon ampliamente en Brasil entre 1860 y 1880 y es posible que desempeñaran una función social similar a la de las famosas pinturas de castas de finales del siglo XviII en la América española. ${ }^{42}$ En el Brasil imperial, ciertas "fotografías de tipos" se distribuyeron como "archivos visuales", con los cuales la emergente burguesía pretendía establecer una diferenciación visual entre ellos y las bajas "castas" en los inicios de la abolición, como afirma Jens Andermann. ${ }^{43}$ Con esto, tales imágenes de la otredad basada en una "verdad científica" fueron en extremo útiles en términos de mantener un control social, en un tiempo en el que la establecida jerarquía racial estaba amenazada.

A pesar de su gran calidad, los "tipos de negros" de Stahl solamente fueron exhibidos en la Exposición Nacional; mientras que él y su compañero de negocios, Germano Wahnschaffe, presentaron nada más que unos "inofensivos" paisajes fotográficos en la Exposición Universal de París. En cuanto a la exclusión de las fotografías de Victor Frond de la Exposición Universal de Londres en 1862, no existía una probable coincidencia. En este contexto, Nancy Stepan ha argumentado que la comisión de la segunda Exposición Nacional fue renuente a exhibir las imágenes de afrobrasileños en Europa, lo que provocó su descalificación antes de

del famoso álbum ilustrado The Pencil of Nature (1844) del científico y fotógrafo pionero Henry Fox Talbot. Stepan, Picturing Tropical Nature, 85-148.

41 En este contexto, el término mina se refiere a los esclavos provenientes del puerto de Elmina, en la Costa de Oro (oeste de África, hoy Ghana). Se trataba del principal puerto del comercio de esclavos en la región.

42 George Reid Andrews, Afro-Latin America, 1800-2000 (New York: Oxford University Press, 2004), 44-47.

43 Jens Andermann, The Optic of the State: Visuality and Power in Argentina and Brazil (Pittsburgh: Pittsburgh University Press, 2007), 186-187. 


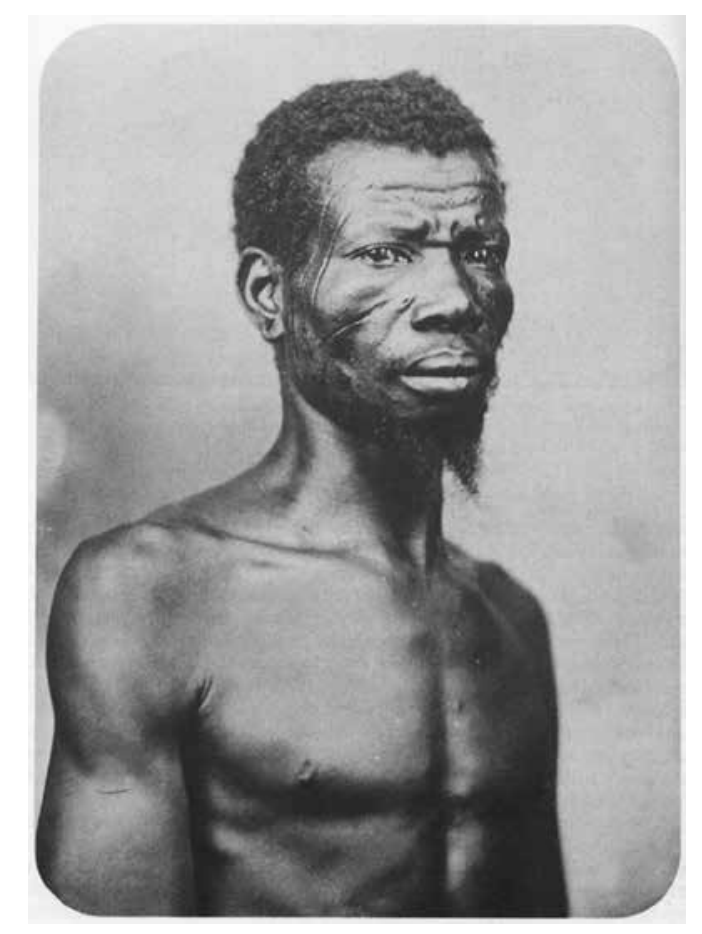

Figura 3. Augusto Stahl, alrededor de 1865, "Escravo Mina Mondri" (albúmina, $15 \times 12 \mathrm{~cm}$, Peabody Museum, Cambridge, MA).

que llegaran a París. Mientras Stepan crea su punto de vista al citar el ejemplo del fotógrafo Cristiano Júnior y sus igualmente famosos retratos de esclavos, es más probable que esto le haya sucedido a Stahl en vez de a su competidor. ${ }^{44}$ De hecho, Cristiano Júnior nunca presentó alguno de sus retratos de esclavos; en cuanto a la segunda Exposición Nacional, él solamente exhibió una selección de reproducciones fotográficas del libro titulado Os Lusíadas. ${ }^{45}$

Las fotografías de Stahl recibieron varios comentarios positivos dentro del contexto de la Exposición Nacional; incluso, el artista de mayor renombre en el Imperio, Victor Meirelles, alabó su "excepcional calidad”. Aunque Meirelles,

44 Stepan, Picturing Tropical Nature, 262.

45 Maurício Lissovsky y Beatriz Jaguaribe, $O$ choque do real: estética, mídia e cultura (Rio de Janeiro: Rocco, 2007), 54-56; Victor Meirelles, "28a. Classe. Photografia, 20 de Novembro de 1866”, en Relatorio da $2^{a}$. Exposição de 1866, vol. 2, ed. por Antonio José de Souza Rego (Rio de Janeiro: Typographia Nacional, 1869), 164-165. 
miembro de la AIBA, declaró que el "novedoso medio de la fotografía” no podía considerarse una forma de arte en comparación con la pintura o la escultura, hablaba bien de las fotografías de Stahl y elogiaba especialmente las imágenes de "diversos tipos de raza africana”. De acuerdo con Meirelles, estas combinaban las propiedades esenciales que equivalían a una "fotografía perfecta". ${ }^{6}$ A pesar de su descalificación oficial, algunos de los "tipos raciales" de Stahl se presentaron de manera indirecta en las siguientes exposiciones universales: después de haber sido incluidas como ilustraciones en el famoso diario de viaje A Journey in Brazil (1868), escrito por el naturalista suizo-americano Louis Agassiz y su esposa Elizabeth Cary Agassiz, estas imágenes circularon en la Exposición Universal de Viena, en 1873, así como en la Exposición del Centenario de Filadelfia, tres años después. ${ }^{47}$

La estrategia de presentar imágenes de afrobrasileños en las exposiciones nacionales, mas no fuera del país, fue una constante durante la época imperial. Mientras la figura del indígena brasileño idealizado y romantizado —en la forma heroica del ya desaparecido "salvaje noble" - resultó ser la alegoría oficial del Imperio de Brasil, tanto dentro del país como en el extranjero, las imágenes de negros libres y esclavos eran sumamente raras en el contexto de las exposiciones universales. ${ }^{48}$ En el ámbito visual, los organizadores de la exposición siempre buscaron hacer hincapié en el proceso gradual de blanqueamiento como resultado de la inmigración europea. De este modo, durante la Exposición Universal de Viena, en 1873, la Semana Ilustrada declaró orgullosamente que, aunque las muestras de maquinaria habían sido bastante decepcionantes, el público internacional habría al menos reconocido que "no todos los brasileños eran negros o mulatos". ${ }^{49}$

Finalmente, durante la última participación del Imperio en una exposición universal, en 1889, el objetivo fue, una vez más, presentar a un Brasil “europeizado”, aunque la esclavitud había sido abolida un año antes. En los pasillos del monumental pabellón brasileño, así como en las páginas del álbum ilustrado Vues du Brésil, editado por el barón de Rio Branco en exclusiva para la exposición de París, había muchas fotografías y litografías que representaban las condiciones de trabajo y

46 Meirelles, "28ª Classe. Photografia”, 164.

47 Louis Agassiz, A Journey in Brazil (Boston: Ticknor and Fields, 1868).

48 Lilia Moritz Schwarcz, "A Mestizo and Tropical Country: The Creation of the Official Image of Independent Brazil”, Revista Europea de Estudios Latinoamericanos y del Caribe, n. 80 (2006): 25-42.

49 "Publicações", Semana Illustrada, 21 de septiembre de 1873. 
de vida de inmigrantes europeos en las plantaciones de café de São Paulo. ${ }^{50}$ Estas imágenes caracterizaban el trabajo en las plantaciones como una actividad ordenada y armoniosa, sin reconocer que los afrobrasileños todavía formaban parte de la mano de obra agrícola. En la figura 4 se observa una litografía de una plantación en São Paulo: el trasfondo se destaca, en especial, por un campo sin límites, donde las plantas de café empiezan a fusionarse con el horizonte. La presencia de unos cuantos ociosos inmigrantes que trabajan sobre la tierra y las filas interminables de árboles bien plantados ilustran perfectamente el propósito de la campaña brasileña: promover una riqueza natural ilimitada y un gran potencial agrícola, así como unas condiciones de trabajo humanas y organizadas. De esta forma, los organizadores de la exposición restaron atención a la continua importancia de los trabajadores negros dentro de la economía del Brasil postabolicionista.

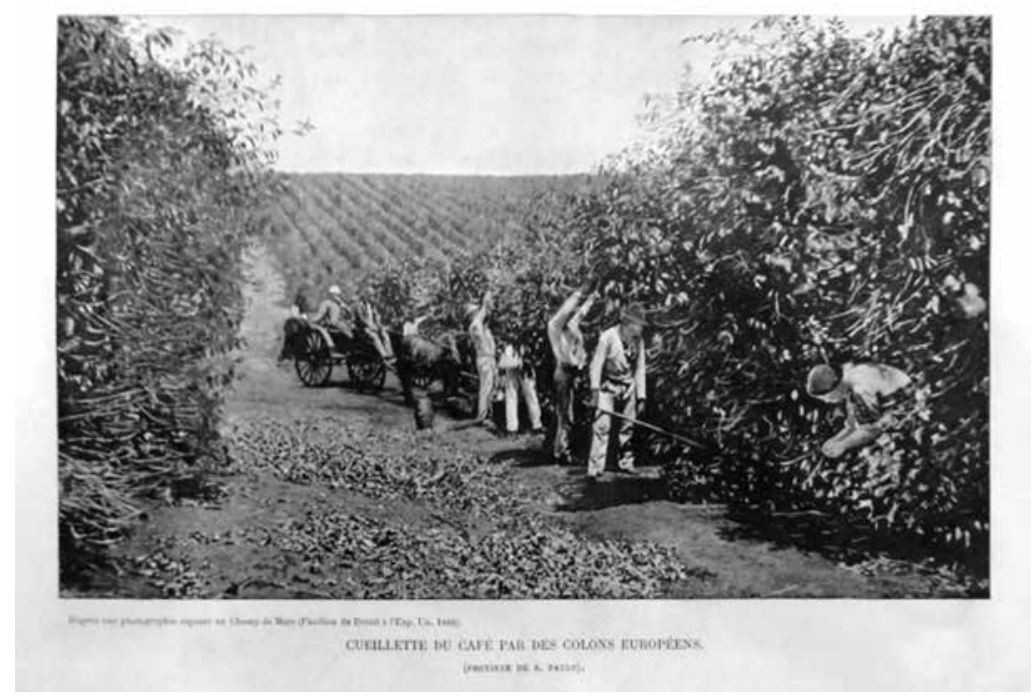

Figura 4. Rougeron, Vignerot \& Cie., 1889, “Cueillette du café par des colons européens” (litografía, en: Paranhos, J. M. da Silva [barón de Rio Branco], Album de vues du Brésil [Paris: Imprimerie A. Lahure, 1889], s. p.). 50 J. M. da Silva Paranhos (barón de Rio Branco), Album de vues du Brésil (Paris: Imprimerie A. Lahure,
1889). 


\section{El "paraíso racial”}

Mientras esclavos y negros libres eran, por lo común, invisibles o representados como si desaparecieran, debido a una "inteligente mezcla racial", se estaba elaborando otra estrategia discursiva en las exposiciones de 1867 a 1889. Desde esta perspectiva, los organizadores de las exposiciones reconocieron la existencia de una gran población afrobrasileña, así como la persistencia temporal de la esclavitud, pero la presentaron como un tipo de "proyecto educacional". En la Exposición Universal de París de 1867, por ejemplo, los brasileños ratificaron su práctica esclavista como la contraparte más humana de la infame "institución peculiar" de Norteamérica, con tal de combatir el creciente criticismo de los abolicionistas franceses y británicos. De este modo, los organizadores de la exposición decidieron reducir el papel de la esclavitud y promover el blanqueamiento, así como buscar la creación de una contundente contraimagen.

La imagen del "paraíso racial" resultó ser especialmente popular en los años poco antes y después de la declaración de la ley de libertad de vientres, como se apreció en las exposiciones internacionales de París (1867) y Viena (1873). Mientras se celebraban las buenas condiciones de vida de los esclavos, la benévola y tolerante naturaleza de la población brasileña y el aspecto educacional del trabajo forzado, los organizadores de la exposición manejaron la construcción de esta imagen con sumo cuidado. Debido a la preeminencia del discurso del blanqueamiento, no existían muchas representaciones de negros libres y esclavos en las exposiciones universales; sin embargo, las pocas fotografías presentadas se diseñaron para convencer a un público internacional de que la esclavitud se encontraba en decadencia en Brasil. En el futuro no habría más esclavos y, quién sabe, quizás ya no habría siquiera "personas de sangre africana”. ${ }^{51}$ Entre tanto, el público europeo que asistió a las presentaciones de Brasil en París, Viena y Filadelfia podía observar que la esclavitud a la brasileña fue, de hecho, una "institución benigna":

Los esclavos eran tratados con humanidad y por lo general contaban con una buena alimentación y vivienda. En gran parte de las plantaciones, se les permitía cultivar porciones de tierra para sus propios fines y para disponer de sus cosechas con total libertad.

51 E. da Silva Prado, “Immigration", en Le Brésilen 1889, ed. por M. F.-J. Santa-Anna Nery (Paris: Libraire Charles Delagrave, 1889), 481. 
Hoy en día su labor es moderada y usualmente sus jornadas duran hasta cuando se pone el sol; sus noches las pasan en reposo, practicando su religión o pasando su tiempo en diversiones varias.

La institución fue impuesta en Brasil por la fuerza de circunstancias particulares que datan desde los primeros años de su descubrimiento. Las preguntas, de las que depende su total represión, atraen la más seria atención por parte del Gobierno; el sentimiento de este cuerpo sobre la materia ha sido recientemente manifestado en la respuesta remitida a la dirección de la Sociedad Francesa Abolicionista. ${ }^{52}$

En estos textos, la esclavitud se describió como una situación casi idílica, una decente "forma de vida", lo cual contrastaba con las horrendas condiciones de trabajo que algunos comentadores europeos se imaginaron. No obstante, estas descripciones estaban alejadas de la realidad, como lo han demostrado los innumerables estudios históricos sobre la esclavitud en Brasil. Así, los organizadores de la exhibición excluyeron deliberadamente cualquier referencia de las espantosas prácticas de tráfico interno de esclavos, que se había intensificado desde 1850 como resultado del fin del tráfico negrero transatlántico, forzado principalmente por la armada británica. En el curso de este tráfico interno, un creciente número de esclavos llegaba de las cada vez más empobrecidas regiones del noreste a las minas y las plantaciones de Río de Janeiro, São Paulo y Minas Gerais, lo que generó la separación de familias enteras y costó la vida de miles de personas. ${ }^{53}$ No obstante, en las exposiciones universales, el Imperio escogía presentar una imagen apologética de la forma paternalista y, aparentemente, "humana" de la esclavitud brasileña, que de cierto modo recuerda la imagen de la democracia racial, la cual Gilberto Freyre formuló setenta años después.

Esta visión creada por los curadores de la exposición también se consideró un paraíso racial, concepto cuyas raíces se remontan a la primera mitad del siglo XIX; en efecto, los abolicionistas norteamericanos emplearon este término para contrastar las duras condiciones de la esclavitud de su propio país con una supuesta

52 Commissão Brazileira na Exposição Universal de Paris, The Empire of Brazil at the Paris Universal Exhibition of 1867 (Rio de Janeiro: Laemmert, 1867), 30-31 (traducción de los autores). Textos similares que también hacen referencia a la ley de libertad de vientres se presentaron en las exposiciones de Viena y Filadelfia.

53 Para una historia sinóptica de la esclavitud en Brasil, véase: Herbert Klein y Francisco Vidal Luna, Slavery in Brazil (Cambridge: Cambridge University Press, 2009). 
forma "más suave" de la esclavitud encontrada en Brasil. Sin embargo, los dueños de las plantaciones brasileñas pronto adoptaron este provechoso concepto, como lo afirma Célia Marinho de Azevedo. ${ }^{54}$ La referencia sobre los supuestos paraísos raciales de América del Sur desempeñó un importante papel en la lucha de los abolicionistas de Estados Unidos, ya que, incluso, existían planes para reubicar personas negras en Brasil después de la guerra civil. De acuerdo con esta narrativa, el racismo no era un asunto demasiado serio en Brasil, país supuestamente caracterizado por la tolerancia y la armonía. ${ }^{55}$ No obstante, como la historiografía contemporánea ha demostrado, ambas sociedades esclavistas podían compararse en términos de tratamientos crueles hacia los esclavos y de los regímenes de control social que establecían, incluido el discurso del racismo cientifico. Como se observa en la cita anterior, la amena descripción del paraíso racial — un lugar donde los esclavos podían vivir en condiciones similares a las de su África natal y, adicionalmente, se les ofrecía una educación, para que algún día se volvieran "civilizados”-, también significó una respuesta directa a las quejas de la Sociedad Abolicionista Francesa. ${ }^{56}$

Como componente visual del discurso del paraíso racial, el álbum Brazil Pittoresco finalmente obtuvo algo de reconocimiento en la Exposición Universal de París, en 1867. Mientras que las fotografías de Victor Frond habían sido descalificadas cuatro años antes, debido a su “origen extranjero", su "magnífico álbum pintoresco", como fue descrito en un informe austríaco de la exposición, finalmente se exhibió a un público internacional. ${ }^{57}$ Aparentemente, el álbum encajó en la nueva estrategia visual de promocionar a Brasil como paraíso racial, así como Frond había representado la mayoría de los esclavos negros en ambientes pacíficos y apacibles. La mayoría de las litografías de esclavos de Brazil Pittoresco mostraba grandes grupos de trabajadores de campos o esclavos en sus labores cotidianas, con tomas de ángulo ancho que dominaban el escenario. De acuerdo con Margrit Prussat, las imágenes de Frond parecían estar inspiradas en un estilo bucólico y pintoresco de las pinturas

54 Azevedo, Abolicionismo, 159-161.

Ibid., 159-161.

56 En respuesta a la petición formulada en 1866 por numerosos intelectuales franceses, dirigidos hacia el Gobierno imperial, don Pedro II respondió inmediatamente. Prometió emprender una iniciativa para acabar con la esclavitud después de la "victoria inminente” sobre Paraguay. Véase: Schwarcz, As barbas do imperador, 135.

57 K. K. Österreichisches Central-Comité, Officieller Ausstellungs-Bericht über die Welt-Ausstellungzu Paris im Jahre 1867, vol. 6 (Wien: Wilhelm Braumüller, 1868), 67. 
europeas, los cuales habían servido también como modelos para muchos artistas de la AIBA en aquella época. ${ }^{58}$

Por otro lado, el texto adjunto de Charles de Ribeyrolles hizo eco en la larga tradición de la literatura de viajes europea en Latinoamérica desde el siglo XVIII. Por lo tanto, el resultado no fue una representación realista o crítica de la esclavitud en Brasil, sino una combinación de imágenes y textos que pretendían legitimar el ideal prevalente del paraíso racial como una realidad benévola y paternalista. En cuanto a la sugerencia de otros textos oficiales de la sección de Brasil en Francia, estos afirmaban que los esclavos traídos hasta Brasil se consideraban "de alguna forma más cómodos dentro del Nuevo Mundo" que en las "regiones bárbaras" del África. 59

Brazil Pittoresco era una declaración sobre los aspectos beneficiosos de la vida social dentro de las poblaciones esclavas y la buena voluntad de sus amos, en términos de aceptar la "carga" de la formación de buenos ciudadanos. ${ }^{60}$ De acuerdo con Prussat, la composición pictórica de la mayoría de las litografías incluidas en el álbum siguió principios distintivamente armónicos, como se muestra en la balanceada estructura del primer plano, el centro y el fondo, así como la tendencia a evadir las líneas convergentes. De alguna forma, el resultado fue un efecto de "tarima", parecido al de una obra teatral. ${ }^{61}$ Sin embargo, este tipo de composición se parecía bastante a la de los retratos fotográficos y los paisajes del siglo XIX. Muchos álbumes similares y guías turísticas ilustradas, escritas para lectores europeos interesados en "temas exóticos", buscaron narrar una historia coherente en relación con las expectativas prefabricadas de lo otro, al describir escenas de la "vida cotidiana" de una manera altamente estilizada y romántica. ${ }^{62}$ De esta forma, con tal de invalidar las percepciones europeas, como las precarias condiciones higiénicas de las cabañas para los esclavos, la realidad del mercado esclavista o el régimen de castigos crueles, Brazil Pittoresco resultó ser un vehículo de propaganda ideal.

Al mostrar a los esclavos rodeados de idílicos paisajes urbanos y naturales, se presentaban como elementos decorativos que se acomodaban bastante bien en la

\footnotetext{
58 Prussat, Bilder der Sklaverei, 66.

59 José Maria dos Reis, Catalogo dos Instrumentos de Optica e Scientificos apresentados à Exposição Nacional Brasileira pelo establecimento de José Maria dos Reis (Rio de Janeiro: Typographia do Commercio de Pereira Braga, 1866), 6.

60 Prussat, Bilder der Sklaverei, 66.

61 Ibid., 66.

62 Kossoy, Dicionário histórico, 152.
} 
imagen del paraíso racial. El texto complementario de Ribeyrolles contribuyó al proceso de descontextualización, al subrayar la "diferente" naturaleza de la esclavitud del Brasil. Así, por ejemplo, Ribeyrolles mencionó la "posibilidad natural de un ascenso social de los negros libres o libertos" en Brasil, como si esto fuera un fenómeno comúnmente observado. ${ }^{63}$ Esta posibilidad existía, pero la sociedad brasileña no contaba con mucha movilidad social, con excepción de algunos mulatos miembros de las élites brasileñas, un hecho que perturbó considerablemente al padre del racismo científico, el conde de Gobineau, durante su estadía en Brasil entre abril de 1869 y mayo de 1870. Así mismo, era posible para los esclavos "comprarse la libertad" (alforria), pero ambas situaciones no eran la regla, como Ribeyrolles sugirió falsamente. ${ }^{64}$

En las litografías, los esclavos siempre se representaban con ropa limpia y con la apariencia de estar bien alimentados y, por lo tanto, "civilizados", en el sentido moderno de la palabra. Al eliminar las costumbres africanas, la joyería tradicional o las cicatrices tribales, elementos que habían aparecido en algunas fotografías de 1870 y 1880 que intentaban describir una realidad afrobrasileña mucho más exótica y que podía venderse como "recuerdos de Brasil", las imágenes de Frond resaltaban el éxito del "proceso civilizatorio". Un impresionante ejemplo del estereotipo del paraíso racial brasileño es la litografía Escravos cozinhando na roça, que muestra a un grupo de esclavos durante un receso del trabajo (figura 5). Actualmente es una de las imágenes más reproducidas de Brazil Pittoresco. Allí aparecen cuatro mujeres preparando una comida a campo abierto, mientras una de ellas carga a un niño en su pecho. Aunque el texto de Ribeyrolles expresa cierto remordimiento por mencionar el triste destino del recién nacido en condiciones de esclavitud, el autor se empeña en describir las condiciones especialmente "humanas": supuestamente asegura que todos los esclavos de Brasil tendrán algún día la oportunidad de hacer "parte de la civilización". ${ }^{65}$ En general, se puede constatar que Frond logró una composición casi que tomada de un cuadro de costumbres, en la que el plano abierto intenta mostrar a las mujeres en su espacio "natural", tal como si hiciesen parte de la naturaleza, como si estuvieran sentadas desde siempre a la espera de ese

63

Charles de Ribeyrolles, Brasil pitoresco: história-descrições-viagens-colonização-instituições. Ilustrado com gravuras de vistas, panoramas, paisagens, costumes, etc. por Victor Frond (São Paulo: Martins, 1941), 207.

64 Ibid., 207.

65 Ibid., 207. 
instante en el que el fotógrafo conectó a la tierra y al cielo en medio de la naturaleza agreste y paradisiaca.

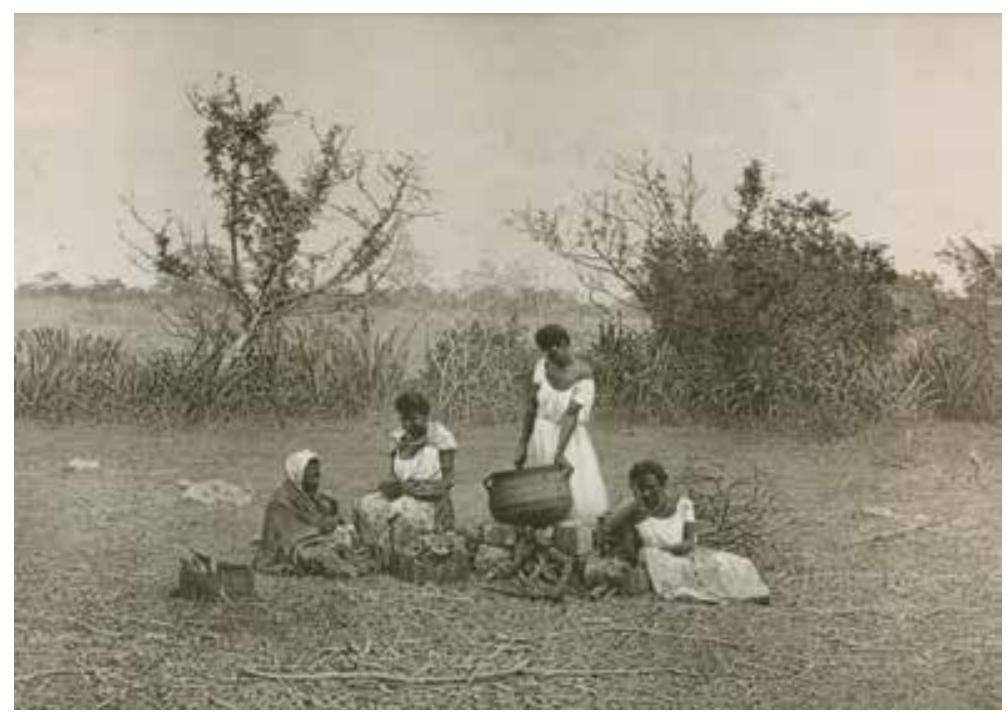

Figura 5. Ph. Benoist, 1858, "Escravos cozinhando na roça” (litografía basada en una fotografía original de Victor Frond, $25 \times 32$ cm, Fundação Biblioteca Nacional, Rio de Janeiro).

En la Exposición Universal de Viena, el discurso del paraíso racial se manifestó de nuevo, esta vez gracias a Albert Henschel, fotógrafo alemán. Sus obras se exhibieron durante las secuelas de la ley de libertad de vientres, en las que finalmente fue posible confirmar el proceso gradual de liberación, puesto en marcha a partir de 1871. Los organizadores de la exhibición asumieron correctamente que nadie cuestionaría la efectividad de la ley, lo cual no sirvió de mucho, ya que la esclavitud duraría por unos diecisiete años más. ${ }^{66}$ De este modo, al destacar la transición "armoniosa" de una sociedad esclavista a una sociedad de ciudadanos libres, el público internacional en Viena debía ver la "forma brasileña de la abolición” como la mejor solución para un país todavía muy dependiente del trabajo manual agrícola. Como se indica en las guías oficiales de Brasil, publicadas especialmente para la exposición en alemán, inglés, francés y portugués, no era necesario temer una violenta revuelta por parte de los esclavos, como si la sociedad se caracterizara por la

66 Andrews, Afro-Latin America, 82-83. 
tolerancia, la armonía, el pacifismo y la franqueza hacia el mundo, así como por un deseo general para el "progreso".67

En este contexto, la Baiana Quitandeira, de Henschel, fue seguramente la representación visual más memorable de afrobrasileños en las exposiciones universales del siglo XIX (figura 6). Aunque el catálogo oficial no permitía ningún tipo de conclusión acerca del contenido de las fotografías de Henschel, el 10 de abril de 1873, el Diario de Pernambuco comentó acerca de ellas durante la tercera Exposición Nacional. ${ }^{68}$ Además de la emblemática vendedora de frutas, posiblemente una escrava de ganho - una forma de esclavitud urbana que permitía a los esclavos hacer negocios, pero luego los obligaban a entregar a sus amos lo que habían obtenido-, Henschel y su compañero Francisco Benque enviaron un retrato semioficial de la familia imperial a Viena. La descripción del periódico sobre las fotografías no hizo referencia al contenido; solamente se mencionaba su perfecta ejecución técnica y su sobresaliente calidad artística.

Como la audiencia internacional en la Exposición Universal de Viena probablemente no era consciente de la existencia de los escravos de ganho, pudieron interpretar la fotografía de Henschel como una evidencia de que los negros brasileños hacían negocios de manera aparentemente "libre" e independiente. Las imágenes de Henschel, tomadas entre 1866 y 1872 en Recife, Salvador da Bahia y Río de Janeiro, diferían de los retratos de esclavos más comunes, tomados por fotógrafos como Auguste Stahl y Christiano Júnior. Aunque Henschel retrató personas negras y esclavos en frente de frutas tropicales o delante de selectos fondos "exóticos", así como usó algunos trajes como atuendos ficticios "africanos", con tal de apelar a los gustos de una audiencia europea interesada en el "exoticismo", él nunca redujo a sus modelos a meros objetos. En contraste con las imágenes comunes de "tipos de africanos", las cuales estaban fuertemente influenciadas por la fotografía antropométrica, Henschel respetó la individualidad de sus modelos. ${ }^{69}$

67 Commissão Brazileira na Exposição Universal de Vienna, Das Kaiserthum Brasilien im Jahre 1873: Ein kurzgefaßter Überblick der vorwärtsschreitenden Entwicklung Brasiliens (Rio de Janeiro: J. Paul Hildebrandt, 1874), 16.

68 "Photographia", Diario de Pernambuco, 10 de abril de 1873; Commissão Brazileira na Exposição Universal de Vienna, Resume du catalogue de la Section Brésilienne a l'Exposition Internationale à Vienne en 1873 (Vienne: Edition de la Section Brésilienne, 1873), 27.

69 Para mayor información sobre Albert Henschel y su obra, véase: Itaú Cultural, Enciclopédia (São Paulo: Itaú Cultural, 2017). 


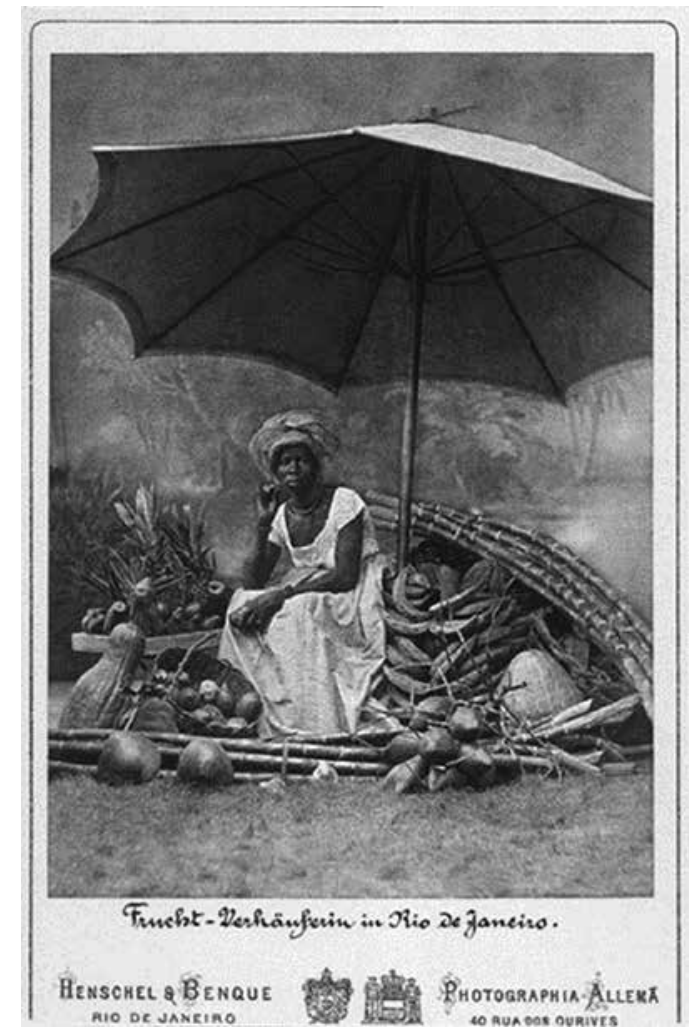

Figura 6. Albert Henschel, alrededor de 1869, "Frucht-Verkäuferin in Rio de Janeiro" (albúmina, 13,2 × 9,6 cm, Leibniz-Institut für Länderkunde, Leipzig).

Por ello, la Baiana Quintadeira se presenta en una posición relativamente "natural", mientras fuma una pipa. Esta escenificación de la vida diaria y la referencia de la personalidad del sujeto distaban mucho de los infames retratos de esclavos de Christiano Júnior y Auguste Stahl, quienes se enfocaron en la supuesta etnicidad y las características físicas de las "razas inferiores". A pesar de esto, las posiciones de la gente negra fotografiada por Henschel no eran tan diferentes de aquellas encontradas en las contemporáneas cartes de visites, frecuentemente ordenadas por familias ricas en el estudio del fotógrafo. Sin embargo, estas representaciones, que describían a los exesclavos como amos de su propio destino - por ejemplo, como vendedores o asalariados-, aparecían raras veces en las exposiciones. En el contexto de la promoción de la ley de libertad de vientres, probablemente parecería apropiado visualizar la "liberación gradual" de los esclavos, con tal de convencer al público internacional de las intenciones humanitarias de Brasil. 
Después de la Exposición Universal en Viena, la imagen del paraíso racial fue conscientemente evadida en la Exposición del Centenario en Filadelfia, en 1876. Como la prensa brasileña señaló en ese entonces, esto estaba relacionado con el cambio en el significado de la esclavitud en un país que todavía luchaba con las consecuencias de su desastrosa guerra civil. ${ }^{70}$ Finalmente, para la época de la Exposición Universal de París en 1889 ya no había necesidad de celebrar el proceso de la gradual emancipación o de las buenas condiciones de vida de los esclavos, ya que la institución había sido abolida el 13 de mayo de 1888. De esta forma, pinturas monumentales como A abolição da escravatura (1889), de Daniel Bérard, conmemoraron la paternalista "ley dorada", que otorgaba libertad a todos los esclavos brasileños; mientras las guías de la exhibición celebraban el "maniático entusiasmo" mostrado por el pueblo brasileño, así como la nueva época de "progreso y prosperidad”. ${ }^{11}$ En este contexto, la imagen de un paraíso racial se evocó una última vez, justo a unas semanas de la caída del Imperio.

Como las imágenes de Henschel dieciséis años antes en Viena, los fotógrafos Marc Ferrez y Rodolpho Lindemann también mostraron escenas del noreste de Brasil en París: principalmente, se centraron en la abundancia de productos agrícolas y en las muestras de infraestructura moderna; así mismo, ambos presentaron imágenes altamente exóticas de afrobrasileños del noreste. ${ }^{72}$ Los Tableaux photographiques de Bahia et Pernambuco se exhibieron en el pabellón de Brasil y fueron alabados, incluso, en guías internacionales. ${ }^{73}$ Entre estas imágenes aparecía nuevamente una vendedora de frutas, similar a la de la fotografía Baiana Quintadeira de Henschel, pero más "exótica” (figura 7). Así, la imagen también formaba parte de una guía turística de Brasil, junto con la descripción pintoresca de naranjas, bananos, mangos y piñas. En el texto en francés se hacía referencia únicamente a una aparente "vendedora de bananas", así como a su color de piel, como si ella fuera otro "recuerdo de Brasil".74

\footnotetext{
70 "Estados Unidos", Provincia de São Paulo, 13 de junio de 1876.

71 Francisco Ervy, "Brasil", en Revista de la Exposición Universal de Paris en 1889, ed. por F. G. Dumas y L. de Foucard (Barcelona: Montaner y Simón, 1889), 522; A. Loiseau-Bourcier, Guide International d'Europe au Brésil \& a La Plata (Paris: A. Loiseau-Bourcier, 1889), 220.

72 Loiseau-Bourcier, Guide International, 223-224.

73 Ibid., 223-224.

$74 \quad$ Ibid., 266-267.
} 


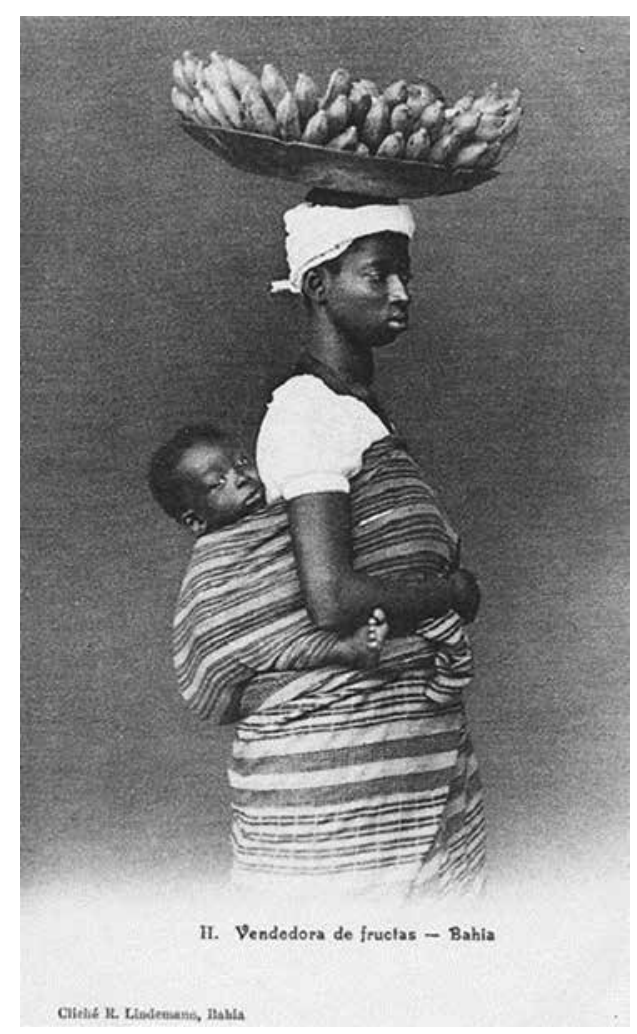

Figura 7. Rodolpho Lindemann, s. f., "Vendedora de fructas-Bahia" (tarjeta postal, Oliveira Lima Library, Washington, D. C.).

Es probable que, dada la reproductibilidad de la imagen y su uso como tarjeta postal, la intención fuera condensar un plano en el que se comunicara rápidamente que el país aún conservaba una inclinación por las actividades agrícolas, pero no exclusivamente a través del cultivo, sino de la comercialización, ahora por parte de las personas "antes esclavizadas". Así, "la fotografía repite mecánicamente lo que nunca más podrá repetirse existencialmente”; en este caso, también se convirtió en un medio de trasladar esclavos, ya no apilados en galeras, sino apresados anónimamente en imágenes con una suerte de contenido servil, las cuales serían apreciadas de manera exótica por sujetos blancos. ${ }^{75}$

75 Roland Barthes, La cámara lúcida: nota sobre la fotografía (Barcelona: Paidós, 1990), 31. 


\section{Conclusión}

Los organizadores de la exposición fueron verdaderamente exitosos al proyectary difundir la imagen de una "nación moderna" en el extranjero. Para un país periférico como Brasil, no fue una tarea fácil combinar las imágenes de la "modernidad", asociadas con el progreso tecnológico y la "alta cultura", con la triste realidad de una monarquía esclavista, cuya población era abrumadoramente pobre, analfabeta y "racialmente mezclada”. Desde este punto de vista, el tema de la esclavitud fue problemático desde sus inicios, a partir del estallido de la guerra civil norteamericana, justo un año antes de que el Imperio participara por primera vez en una exposición universal. Debido a la presión diplomática ejercida por Gran Bretaña y Francia sobre el asunto de la abolición, evitar esta temática del todo resultaba ser una decisión inteligente. No obstante, después de la derrota de los Estados Confederados de América, esta postura ya no fue viable.

Mientras los esclavos y los negros libertos eran "invisibilizados" en la Gran Exposición de Londres, los organizadores brasileños decidieron irse a la ofensiva en la Exposición Universal de París de 1867, al presentar fotografías de la esclavitud ante un público internacional. Estas imágenes proyectaron la esclavitud como un tipo de "proyecto educacional", con el aparente objetivo de formar "ciudadanos libres". En las mentes de los organizadores, la fotografía era la técnica apropiada para convencer a la opinión pública de la naturaleza "humana" de la esclavitud en Brasil, dado que este medio era generalmente asociado con la "objetividad" y, por lo tanto, adecuado para crear un "efecto de la realidad". Aunque había pocas fotografías en las exposiciones universales que mostraban la esclavitud de Brasil, estas imágenes fueron importantes en términos de la defensa del Imperio contra la creciente crítica internacional de los abolicionistas.

Con esto, las imágenes podían exhibirse en el exterior, si es que se consideraban apropiadas para afirmar el ideal del paraíso racial, pero si las fotografías eran calificadas "peligrosas", como fue el caso de las imágenes presentadas por Victor Frond y Auguste Stahl, debían "quedarse en casa”. En las exposiciones nacionales, las fotografías antropométricas servían para legitimar el control social sobre una "base científica"; sin embargo, el discurso predominante en todas las exhibiciones era el del blanqueamiento. Por esta razón, y muy al estilo del indigenismo hispanoamericano, el Imperio de Brasil celebraba la figura del noble y heroico pero ya "muerto" indígena, mientras la relevancia social y económica de los afrobrasileños se desvaneció. Por el contrario, las exposiciones fueron hechas para estimular la 
futura inmigración europea, con el fin de "mejorar la raza". A pesar de ello, ambos discursos eran altamente ambivalentes en la manera como descuidaron no solo las realidades sociales, sino también las emergentes tensiones políticas dentro del Imperio, sin mencionar el hecho de que muchos de los organizadores de las exposiciones eran esclavistas.

\section{Bibliografía}

\section{Fuentes primarias}

\section{Imágenes}

Coleção Waldyr da Fontoura Cordovil Pires, Rio de Janeiro.

Fundação Biblioteca Nacional, Acervo Iconográfico, Rio de Janeiro.

Leibniz-Institut für Länderkunde, Leipzig.

Oliveira Lima Library, Washington, D.C.

Peabody Museum of Archeology \& Ethnology at Harvard University, Cambridge, MA.

\section{Publicaciones periódicas}

Bazar Volante. Rio de Janeiro, 1866.

Diario do Rio de Janeiro. 1861 y 1867.

Diario de Pernambuco. Recife, 1873.

Provincia de São Paulo. 1876.

Semana Illustrada. Rio de Janeiro, 1862 y 1873.

The Times. Londres, 1862.

\section{Libros, catálogos e informes}

Agassiz, Louis. A Journey in Brazil. Boston: Ticknor and Fields, 1868.

Commissão Brazileira na Exposição Universal de Paris. The Empire of Brazil at the Paris Universal Exhibition of 1867. Rio de Janeiro: Laemmert, 1867.

Commissão Brazileira na Exposição Universal de Vienna. Resume du catalogue de la Section Brésilienne a l'Exposition Internationale à Vienne en 1873. Vienne: Edition de la Section brésilienne, 1873.

Commissão Brazileira na Exposição Universal de Vienna. Das Kaiserthum Brasilien im Jahre 1873. Ein kurzgefaßter Überblick der vorwärtsschreitenden Entwicklung Brasiliens. Rio de Janeiro: J. Paul Hildebrandt, 1874. 
Commissão Diretora da Exposição Nacional. Catalogo dos productos naturaes e industriaes remettidos para a Exposição Universal em Londres. Londres: Typographia C. Whiting, 1862.

Cunha, Antonio Luiz Fernandes da. Documentos officiaes relativos à Exposição Nacional de 1861. Rio de Janeiro: Typographia do Diario do Rio de Janeiro, 1861.

Ducuing, François. L'Exposition Universelle de 1867 illustrée. 2 vols. Paris: Bureaux d'abonnements, 1867.

Ervy, Francisco. "Brasil". Revista de la Exposición Universal de París en 1889, editado por F. G. Dumas y L. de Foucard, 522. Barcelona: Montaner y Simón, 1889.

Galvão, I. C. Discurso. Rio de Janeiro: Typographia Universal de Laemmert, 1870.

K. K. Österreichisches Central-Comité. Officieller Ausstellungs-Bericht über die Welt-Ausstellungzu Paris im Jahre 1867. Wien: Wilhelm Braumüller, 1868.

Loiseau-Bourcier, A. Guide International d'Europe au Brésil \& a La Plata. Paris: A. Loiseau-Bourcier, 1889.

Meirelles, Victor. “28a. Classe. Photografia, 20 de Novembro de 1866”. En Relatorio da $2^{a}$. Exposição de 1866. Vol. II, editado por Antonio José de Souza Rego, 158-170. Rio de Janeiro: Typographia Nacional, 1869.

Moreira, Francisco Ignacio de Carvalho de. "A colonia Blumenau”. En Relatorio sobre a Exposição Universal de 1867. Redigido pelo secretario da Commissão Brazileira Julio Constancio de Villeneuve e apresentado a Sua Magestade o Imperador pelo presidente da mesma commissão Marcos Antonio de Araujo. Vol. I, editado por Julio de Villenueve, CLIV-CLXI. Paris: Typographia de Julio Claye, 1868.

Moreira, Francisco Ignacio de Carvalho de. Relatorio sobre a Exposição Internacional de 1862. London: Thomas Brettell, 1863.

Paranhos, J. M. da Silva (barón de Rio Branco). Album de vues du Brésil. Paris: Imprimerie A. Lahure, 1889.

Prado, E. da Silva. “Immigration”. En Le Brésilen 1889, editado por M. F. J. Santa-Anna Nery, 473-507. Paris: Libraire Charles Delagrave, 1889.

Reis, José Maria dos. Catalogo dos Instrumentos de Optica e Scientificos apresentados à Exposição Nacional Brasileira pelo establecimento de José Maria dos Reis. Rio de Janeiro: Typographia do Commercio de Pereira Braga, 1866.

Ribeyrolles, Charles de. Brazil Pittoresco: viagens, historia, descripções, Instituições, colonização. Acompanhado de album de visitas, panoramas, paisagens, costumes, etc. por Victor Frond. 3 vols. Rio de Janeiro: Typographia Nacional, 1859. 
Ribeyrolles, Charles de. Brasil pitoresco: história-descrições-viagens-colonização-instituições. Ilustrado com gravuras de vistas, panoramas, paisagens, costumes, etc. por Victor Frond. São Paulo: Martins, 1941.

\section{Fuentes secundarias}

Andermann, Jens. "Tournaments of Value: Argentina and Brazil in the Age of Exhibitions". Journal of Material Culture 14, n. 3 (2009): 333-363.

Andermann, Jens. The Optic of the State: Visuality and Power in Argentina and Brazil. Pittsburgh: Pittsburgh University Press, 2007.

Andrews, George Reid. Afro-Latin America, 1800-2000. New York: Oxford University Press, 2004.

Azevedo, Célia Marinho de. Abolicionismo: Estados Unidos e Brasil, uma história comparada, século XIX. São Paulo: Annablume, 2003.

Barthes, Roland. La cámara lúcida: nota sobre la fotografía. Barcelona: Paidós, 1990.

Gahyva, Helga. "Brasil, o país do futuro: uma aposta de Arthur de Gobineau?” ALCEU 7, n. ${ }^{\circ} 14$ (2007): 152-159.

Hobsbawm, Eric. Das imperiale Zeitalter, 1875-1914. Frankfurt am Main: Campus, 1989.

Itaú Cultural. Enciclopédia. São Paulo: Itaú Cultural, 2017. http://www.itaucultural. org.br/aplicexternas/enciclopedia_ic/index.cfm

Kossoy, Boris. Dicionário histórico fotográfico brasileiro. São Paulo: Instituto Moreira Salles, 2002.

Lesser, Jeffrey. Negotiating National Identity: Immigrants, Minorities, and the Struggle for Ethnicity in Brazil. Durham: Duke University Press, 1999.

Lissovsky, Maurício y Beatriz Jaguaribe. O choque do real: estética, mídia e cultura. Rio de Janeiro: Rocco, 2007.

Martins, Ana Luiza. “Imprensa em tempos de império”. En História da imprensa no Brasil, editado por Ana Luiza Martins y Tania Regina de Luca, 44-80. São Paulo: Contexto, 2008.

Mitchell, Timothy. "The World as Exhibition”. Comparative Studies in Society and History 31, n. 2 (1989): 217-236.

Neves, Margarida de Souza, "Los escaparates del progreso: Brasil en las exposiciones internacionales del siglo XIX”. En La nación expuesta: cultura visual y procesos de formación de la nación en América Latina, editado por Sven Schuster, 83-100. Bogotá: Universidad del Rosario, 2014. 
Osterhammel, Jürgen. Die Verwandlungder Welt: Eine Geschichte des 19. Jahrhunderts. München: C. H. Beck, 2010.

Pesavento, Sandra Jatahy. Exposições universais: espetáculos da modernidade do século XIX. São Paulo: Hucitec, 1997.

Prussat, Margrit. Bilder der Sklaverei: Fotografien der afrikanischen Diaspora in Brasilien, 1860-1920. Berlin: Reimer, 2008.

Rezende, Lívia Lazzaro. “The Raw and the Manufactured: Brazilian Modernity and National Identity as Projected in International Exhibitions (1862-1922)”. Tesis de doctorado, Royal College of Art, London, 2010.

Schuster, Sven. "A visão dos vencedores: O Brasil e a glorificação da Guerra do Paraguai nas exposições universais do século XIX”. Iberoamericana 17, n. 64 (2017), 147-174.

Schuster, Sven. "Envisioning a 'Whitened Brazil': Photography and Slavery at the World's Fairs, 1862-1889”. Estudios Interdisciplinarios de América Latina y el Caribe (ELAL) 26, n. 2 (2015): 17-41.

Schwarcz, Lilia Moritz. "A Mestizo and Tropical Country: The Creation of the Official Image of Independent Brazil". Revista Europea de Estudios Latinoamericanos y del Caribe, n. ${ }^{\circ} 80$ (2006): 25-42.

Schwarcz, Lilia Moritz. As barbas do imperador: D. Pedro II, um monarca nos trópicos. São Paulo: Companhia das Letras, 2010.

Schwarcz, Lilia Moritz. "Os trópicos como espetáculo: a participação brasileira nas exposições universais de finais do século xıx”. En Galerías del progreso: museos, exposiciones y cultura visual en América Latina, editado por Beatriz González-Stephan y Jens Andermann, 195-219. Rosario: Viterbo, 2006.

Silva, Maria Antonia Couto da. "Um monumento ao Brasil: considerações acerca da recepção do livro Brasil Pitoresco, de Victor Frond e Charles Ribeyrolles (1859-1861)”. Tesis de doctorado. Universidade Estadual de Campinas, 2011.

Skidmore, Thomas. Preto no branco-raça e nacionalidade nopensamento brasileiro. Rio de Janeiro: Paz e Terra, 1976.

Stepan, Nancy. Picturing Tropical Nature. Ithaca: Cornell University Press, 2001.

Tenorio Trillo, Mauricio. Mexico at the World's Fairs: Crafting a Modern Nation. Berkeley: University of California Press, 1996.

Turazzi, Maria Inez. Poses e trejeitos: a fotografia e as exposições na era do espetáculo. Rio de Janeiro: Funarte/Rocco, 1995. 
Werneck, José Luiz. "Isto é o que me parece: A Sociedade Auxiliadora Nacional (18271904) na formação social brasileira. A conjuntura de 1871 até 1877 ”. 2 vols. Tesis de maestría. Universidade Federal Fluminense, 1979.

Werneck, José Luiz. “As arenas pacíficas do progresso”. 2 vols. Tesis de doctorado. Universidade Federal Fluminense, 1992. 


\title{
Sobre máquinas y titanes: la autorrepresentación fotográfica del gremio industrial colombiano (1945-1960)
}

\author{
Óscar Daniel Hernández Quiñones
}

Un gran ideal cultural y espiritual se funde en una realidad material y social emergente. La búsqueda romántica del autodesarrollo, que ha llevado tan lejos a Fausto, se está abriendo paso a través de una nueva forma de romance, a través del trabajo titánico del desarrollo económico. Fausto se está transformando en una nueva clase de hombre, para adaptarse a una nueva ocupación. En su nuevo trabajo, sacará a la luz algunas de las potencialidades más creativas y más destructivas de la vida moderna; será un demoledor y creador consumado, la figura oscura y profundamente ambigua que nuestra era ha llamado el "Desarrollista"

Marshall Berman ${ }^{1}$

Me interesa analizar en este escrito cómo el empresariado industrial colombiano empleó la fotografía documental para autorrepresentarse y ensamblar una identidad gremial entre 1945 y 1960. Como han señalado los estudios críticos del desarrollo en América Latina, finalizada la Segunda Guerra Mundial, la modernización tecnológica y productiva del continente se convirtió en la prioridad de las ahora denominadas economías tercermundistas. Frente al temor de una repentina invasión de artículos importados, estas economías buscaron reducir su dependencia comercial

\footnotetext{
1 Marshall Berman, Todo lo sólido se desvanece en el aire: la experiencia de la modernidad (Buenos Aires: Siglo XXI, 1989), 55.
} 
respecto a la política exterior de Estados Unidos, al ofrecer garantías para la industrialización de mercados locales (desarrollo hacia adentro) que demandaban mayor complejidad en materia de técnica y organización. No lo hicieron solas o de forma desarticulada, ya que estuvieron respaldadas por proyectos intelectuales como la Comisión Económica para América Latina y el Caribe (Cepal) y su consigna de conceptualizar las estructuras del atraso regional para formular políticas asistenciales. $^{2}$

El panorama de la economía colombiana no fue una excepción aislada de dicha tendencia modernizadora. A pesar de que el apoyo estatal se debatió de manera intermitente entre favorecer los intereses de la ya posicionada burguesía cafetera o las agendas industriales, la ampliación del sector manufacturero fue exponencial desde 1945, tanto así que alcanzó un crecimiento anual promedio del $7 \%$ en su valor agregado. ${ }^{3}$ Posterior a este éxito circunstancial —influenciado en buena medida por las secuelas indirectas de la posguerra-, las expectativas de mayor dinamismo para la industria nacional presionaron a sus representantes a pensarse a sí mismos como gremio y elaborar una imagen armónica, capaz de unificarlos bajo su nueva condición de grupo. Con esta cohesión artificialmente lograda, sería factible desplegar simultáneamente todo tipo de campañas propagandísticas que legitimaran su incipiente ascenso. Una de las acciones persuasivas para inculcar entre los productores manufactureros un ambiente de afinidad fue la difusión de fotografías asociadas a la industria y su promesa de mejoramiento colectivo. A través de revistas empresariales y boletines de cobertura limitada, industriales de varios ramos productivos apostaron por enaltecer visualmente el novedoso mundo de la técnica, la producción en serie y los "paisajes fabriles", ${ }^{4}$ al fijar desde la fotografía - e incluso otro tipo de ilustraciones señaladas más adelante- un conjunto de referentes simbólicos relacionados con su agrupación gremial y la esperanza de cambio que esta empezaba a encarnar. Si bien me interesa resaltar algunos casos que dan cuenta de la circulación y recepción de dichas imágenes, el objetivo principal de este texto es indagar cómo y bajo qué pautas fotográficas la comunidad

2 Sobre estudios críticos del desarrollo, véase: Wolfgang Sachs, The Development Dictionary: A Guide to Knowledge as Power (New York: Zed Books, 2010).

3 Carlos Brando, "La industrialización a medias", en Nueva historia económica de Colombia, ed. por Salomón Kalmanovitz (Bogotá: Taurus y Universidad Jorge Tadeo Lozano, 2010), 207.

4 Tomás Cornejo, "Fotografía como factor de modernidad: territorio, trabajo y trabajadores en el cambio de siglo", Historia 45, n. ${ }^{\circ} 1$ (2012): 17. 
industrial se proyectó durante un periodo específico, en el que su fortalecimiento exigía una mayor visibilidad tanto en sus propios espacios de comunicación como en grandes audiencias políticas y civiles.

En este sentido, sostengo que el uso deliberado de fotografías alusivas a la industria colombiana rebasó sus funciones técnicas o documentales: operó como un mecanismo con el que el empresariado fabril configuró una identidad de gremio, al plasmar mediante imágenes aquellos elementos que lo diferenciaran de otros sectores económicos. Esto indica que, además de socializar aspectos compartidos por la élite manufacturera, como la clase social de rasgos urbanos, los industriales fundamentaron su identidad en la representación idealizada de sus oficios y procedimientos mecánicos para generar valor, así como en la asociación directa que se designó a estos últimos con el progreso, la civilización y la transformación del mundo material en provecho del hombre. Así, los integrantes del gremio colocaron el acento de su identidad en el discurso moderno que evocaba su ocupación y proyectaron los saberes técnicos como la "única” solución para superar el pasado precario y pastoril de la economía nacional: la industrialización se imaginó como necesaria frente a las contingencias de la posguerra.

Para el primer apartado, se advierten los principales criterios teórico-metodológicos que nutren la perspectiva de este ensayo y se sugieren algunas herramientas para analizar un fenómeno económico como la industria desde la fotografía. En un segundo momento, se realiza una breve caracterización del periodo seleccionado, destacando dos procesos cruciales que confluyeron en el uso de la fotografía documental como tecnología idónea para representar lo fabril: 1) la diversificación y masificación de los medios de comunicación en Colombia desde los años treinta y 2) la institucionalización del empresariado industrial como gremio en 1944. En el tercer apartado se señalan las principales tendencias y estilos fotográficos mediante los cuales los industriales se visibilizaron; de igual manera, en un último momento, se vinculará el análisis de dichas fuentes con la recepción que tuvieron, así como con los soportes materiales en los que estas circularon. Para finalizar, se recogen los resultados de la investigación en una sección de conclusiones y reflexiones abiertas al debate.

\section{Consideraciones previas y niveles de análisis}

$\mathrm{Al}$ acercarnos desde fuentes iconográficas a fenómenos como la industrialización nacional, resulta necesario aclarar ciertas premisas respecto al accionar persuasivo de los gremios económicos como agentes históricos. Además de desempeñar funciones 
determinantes en los ritmos financieros de un país, estos deben concebirse como productores y consumidores de significados sobre sus respectivas ocupaciones. Sus itinerarios se fundamentan en narrativas de pertenencia hacia sus prácticas comerciales o productivas, alimentadas a su vez por mecanismos simbólicos de distinción que separan sus necesidades y experiencias de otras agremiaciones. Lo anterior hace imposible desligar la conducta exclusivamente económica de los industriales de aquellas estrategias retóricas con las cuales estos materializan su pertenencia a una colectividad, edificada por ellos mismos a través de textos, imágenes y apariciones en la vida pública. ${ }^{5}$

Bajo premisas afines, campos de estudio como la renovada historia empresarial -entrepreneurial and business history, ${ }^{6}$ influida recientemente por los aportes del giro lingüístico y perspectivas teóricas como el construccionismo- han explorado miradas alternativas a la historia económica, al analizar al empresario a partir de sus prácticas sociales, sus relaciones con el Estado, sus avatares en los negocios o los círculos socioculturales en los que se desenvuelve. Igualmente, estas mismas líneas de investigación han complementado el limitado interés biográfico, el cual buscaba, en un principio, establecer grandes conclusiones sobre la trayectoria individual del capitalista, para dar paso a nuevas preguntas que indaguen su relación con el ejercicio del poder, con los impactos culturales sobre las regiones donde opera y con las nociones de emprendimiento que imprime en su cotidianidad. ${ }^{7}$ Por otro lado, autores cercanos a la teoría organizacional, como Lene Foss, proponen pensar al empresariado como un grupo social marcado por la constante necesidad de buscar las raíces temporales y espaciales que justifiquen su relevancia en contextos específicos. En esta búsqueda, los gremios económicos se valen de aquellos recur-

5 Álvaro Tirado, “Teorías y conceptos para analizar las organizaciones gremiales de empresarios”, Revista Mexicana de Sociologia 77, n. 3 (2015): 469.

6 Algunos textos ilustrativos que hacen hincapié en la relación entre empresariado y cultura son: Monica Lindgren y Johann Packendorff, "Social constructionism and entrepreneurship: Basic assumptions and consequences for theory and research", International Journal of Entrepreneurial Behavior \& Research 15, n. 1 (2009): 25-47; Daniel Hjorth y Chris Steyaert, eds., Narrative and Discursive Approaches in Entrepreneurship (Cheltenham: Edward Elgar, 2004).

7 Luis Rubén Pérez Pinzón, "Perspectivas historiográficas sobre la historia empresarial del nororiente de Colombia” (ponencia, Universidad de los Andes, Bogotá, Colombia, febrero de 2015). 
sos persuasivos con el potencial de construirlos y definirlos como fuerzas sociales creativas y transformadoras. ${ }^{8}$

Así, el elemento fotográfico se presenta como una tecnología eficiente para caracterizar la identidad del gremio industrial colombiano. Interpretar la fotografía en calidad de fuente para la historia requiere pensarla como una "estructura incompleta", capaz de administrar o jerarquizar las posiciones de los sujetos y objetos presentes en la imagen. La fotografía visibiliza e invisibiliza elementos conforme a criterios específicos, establece relaciones y es dotada de sentido desde su producción hasta su recepción. Esto logra darse gracias a su lenguaje ostensivo, ${ }^{10}$ el cual permite un consumo instantáneo por parte del espectador, a diferencia del lenguaje escrito. De este modo, parecería poco prudente asumir el ensamblaje de una identidad gremial por fuera de aquello que la fotografía enaltece, oculta o manipula; principalmente, si se tiene en cuenta que la identidad requiere ejercicios permanentes de representación, los cuales afianzan la solidaridad entre los miembros de una colectividad, así como el reconocimiento (identificación) ${ }^{11}$ de ciertos orígenes o características compartidas entre estos. Por ejemplo, no es fortuito que para las primeras décadas del siglo xx las mejoras materiales que pretendían modernizar los lugares de producción y consumo o la infraestructura del transporte, en

8 Lene Foss, “Going against the grain... Construction of entrepreneurial identity through narratives", en Narrative and Discursive Approaches in Entrepreneurship, ed. por Daniel Hjorth y Chris Steyaert (Cheltenham: Edward Elgar, 2004), 80-104.

9 Beatriz González Stephan, "Las tarjetas de visita: racialidad y disciplinamiento de ciudadanías blanqueadas en la pardocracia venezolana”, en La nación expuesta: cultura visual y procesos de formación de la nación en América Latina, ed. por Sven Schuster (Bogotá: Universidad del Rosario, 2014), 124-125.

10 Antonio Pantoja, "La imagen como escritura: el discurso visual para la historia", Norba. Revista de Historia, n. 20 (2007): 192.

11 Para autores como Stuart Hall o Peter Wade, la identidad necesita pensarse como un concepto en constante construcción. No es estática y tampoco obedece a una "esencia" fija del individuo o el grupo social que la busca. Así, la identidad necesita de la representación y de aquellas contingencias externas en las cuales adquiere visibilidad. Con el ánimo de aplicar el concepto de forma más dinámica y menos "esencialista", Hall apuesta por hablar de identificación, la cual sugiere un proceso variable y “[...] nunca terminado". Véase: Stuart Hall, Introducción a Cuestiones de identidad cultural, comp. por Stuart Hall y Paul du Gay (Buenos Aires: Amorrortu, 2003), 15-16; Peter Wade, "Identidad", en Palabras para desarmar, ed. por Margarita Serge, María Cristina Suaza y Roberto Pineda (Bogotá: Ministerio de Cultura e Instituto Colombiano de Antropología e Historia [ICANH], 2002), 255-264. 
ciudades como Bogotá y Medellín, ya se asociaran con las clases altas simpatizantes de la industrialización en la práctica temprana de la publicidad. ${ }^{12}$

En primera instancia, puede plantearse que los discursos alrededor de la incipiente industria en el país engrandecieron la idea de un modelo económico en permanente ascenso. No obstante, resulta polémico, en términos objetivos, afirmar la existencia de un sector industrial colombiano históricamente progresivo. Sus ritmos de crecimiento se han caracterizado más por la discontinuidad que por verdaderos periodos de estabilidad; incluso, se ha experimentado una desaceleración vigente desde la apertura gradual implementada por la administración de Alfonso López Michelsen (1974-1978). ${ }^{13}$ A pesar de estos altibajos, la producción textual e iconográfica utilizada por los grupos dedicados a las manufacturas para autorrepresentarse sí ha sido una constante, especialmente tras la fundación de la Asociación Nacional de Industriales (ANDI), en Medellín (1944), momento en el que ya había un posicionamiento emergente de la industrialización como proyecto ideológico, así como una mayor influencia de este frente a organismos oficiales clave para la elaboración de políticas económicas. ${ }^{14}$

La conformación de este gremio formalizó y ofreció un marco institucional a las demandas de la naciente "burguesía industrial" 15 ante el Estado, la población e, incluso, la comunidad internacional. ${ }^{16}$ Autores como Eduardo Sáenz Rovner sostienen que por medio de campañas propagandísticas en los periódicos con mayor divulgación del país, como El Tiempo, El Colombiano y El Siglo, los voceros de la ANDI en sus oficinas principales buscaron "equiparar sus intereses particulares con los de la nación", ${ }^{17}$ aunque tal iniciativa implicara sacrificar el apoyo a pequeñas fábricas y atacar al predominante ramo cafetero.

12 Santiago Castro Gómez, Tejidos oniricos: movilidad, capitalismo y biopolitica en Bogotá (1910-1930) (Bogotá: Pontificia Universidad Javeriana, 2009), 194-195.

13 Alexander Alfonso Maldonado, "La evolución del crecimiento industrial y transformación productiva en Colombia, 1970-2005: patrones y determinantes" (tesis de maestría, Universidad Nacional de Colombia, 2010), 31.

14 Eduardo Sáenz Rovner, La ofensiva empresarial: industriales, politicos y violencia en los años 40 en Colombia, 2a ed. (Bogotá: Universidad Nacional de Colombia, 2007), 19.

Ibid., 39.

16 Paulo César León, "La literatura sobre la industrialización colombiana: balance y perspectivas", Innovar, n. 23 (2004): 184.

17 Sáenz Rovner, La ofensiva empresarial, 71-72. 
Con los anteriores puntos trazados, presento brevemente algunos elementos que, en la primera mitad del siglo pasado, sirvieron de antesala para la elaboración de estrategias visuales por parte del empresariado industrial. Concretamente, por un lado, me refiero a la institucionalización de este último a través de diferentes entidades y, por otro, a la diversificación previa de medios comunicativos que tocó a las ciudades colombianas más desarrolladas en términos económicos. Este último proceso aumentó considerablemente la creación y el consumo de imágenes reproducidas masivamente, así como la especialización de ciertas técnicas, como la fotografía documental y su presencia en varios soportes materiales.

\section{Rumbo al gremio industrial: condiciones para legitimar un nosotros}

La meta de abrazar el capitalismo fabril se tornaba distante en Colombia durante las dos primeras décadas del siglo Xx. Con la excepción de escasos mercados cautivos, dedicados a la producción de bebidas, alimentos, lozas y textiles, el país solo logró perfeccionar sus fábricas de tecnología liviana hasta los años treinta, cuando el flujo de capitales extranjeros y el crecimiento de la economía cafetera (la danza de los millones) estimularon un aumento del gasto público en infraestructura nacional y en el mejoramiento de técnicas productivas artesanales. De la mano de estas mejoras, algunos retos esbozados por las élites precursoras de la modernización económica consistieron en racionalizar el incipiente espacio urbano, establecer rutinas industriales de manufacturación y remplazar costumbres populares arraigadas en la colonia por "civilizados" hábitos de consumo; ${ }^{18}$ estas eran todas condiciones de posibilidad para impulsar una sociedad de clases fundamentada en la diferenciación salarial, la mecanización del trabajo y un culto ascendente a la realización personal mediante la adquisición de artículos que satisficieran los deseos y las necesidades de los nuevos modos de vida.

De forma simultánea, la primera mitad de siglo se caracterizó por nuevas simbolizaciones de dicho capitalismo fabril en los medios masivos de comunicación, asunto en el que la radio, la fotografía y el cine comenzaron a ganarle audiencias y escenarios de recepción a la tradición escrita. Tras la pausa involuntaria de la

18 Sobre producción y consumo modernos en la primera mitad del siglo xx colombiano, véase María del Pilar López Uribe, Salarios, vida cotidiana y condiciones de vida en Bogotá durante la primera mitad del siglo XX (Bogotá: Universidad de los Andes, 2011), 209; Juan Esteban Posada, "La promesa del capitalismo en Medellín (Colombia, 1939-1962)”, Historia Crítica, n. ${ }^{\circ} 57$ (2015): 141-160. 
producción cultural europea causada por la Segunda Guerra Mundial, Estados Unidos se convirtió en el referente de una nueva estética, importada por familias nacionales prestantes. Películas, revistas y pautas publicitarias serían objeto de una americanización avasalladora, al introducir en la vida diaria elementos iconográficos de una nueva cultura popular, un panorama de ensueño en el que el trabajo moderno se complementaba con el consumo moderno. ${ }^{19}$ Publicaciones innovadoras como El Gráfico o Cromos comenzaron a dar preeminencia al material fotográfico sobre el textual, no solo al emular en sus páginas las temáticas de revistas estadounidenses (ocio, celebridades, eventos sociales, etc.), sino también al aplicar técnicas vanguardistas como la fotografía documental, la cual explico más adelante. Como resultado, los atributos culturales de la promesa industrial — ahora situada en la nueva potencia del llamado mundo occidental - se incorporaban tanto en medios de mayor alcance como en tecnologías comunicativas más sofisticadas. Públicos letrados y analfabetas naturalizaron el consumo de imágenes para entender y recrear su cotidianidad, y ello ocasionó, por ejemplo, que hacia 1949, Bogotá contara con 41 salas de cine y que la prensa nacional comenzara a hacer sistemático el uso del fotoperiodismo para documentar acontecimientos cada vez más visuales y, por ende, más “reales” según las nociones de objetividad del momento.

Esta expansión de tecnologías informativas acompañó el crecimiento de la industrialización colombiana hacia mediados de siglo. A pesar de la intensa violencia política que movilizaba las decisiones macroeconómicas en función de intereses partidistas, los años de posguerra constituyeron un momento de reflexión para diagnosticar los problemas derivados del atraso tecnológico e institucionalizar las actividades fabriles en favor del progreso nacional. ${ }^{20}$ Proyectos como la creación del Instituto de Fomento Industrial (IFI), en 1940; la fundación de la ANDI, en 1944; la realización del Primer Censo Industrial, en 1945; ${ }^{21}$ y la formalización de las firmas Ecopetrol, en 1950, y Paz de Río, en 1954, son algunos ejemplos que dan cuenta de

19 Victoria Peralta, Distinciones y exclusiones: en busca de cambios culturales en Bogotá durante las repúblicas liberales. Una historia cultural de Bogotá (1930-1946) (Bogotá: Academia Colombiana de Historia, 2013), 60-61 y 105-108.

20 León, "La literatura sobre la industrialización", 186.

21 El Primer Censo Industrial se diseñó para cuantificar los crecientes procesos de industrialización en las principales zonas fabriles colombianas. La recolección de datos se llevó a cabo desde el 1 de julio de 1944 hasta el 30 de junio de 1945 y los resultados se publicaron en agosto de 1947. Véase: Dirección Nacional de Estadística, Primer Censo Industrial de Colombia: 1945 (Bogotá: Imprenta Nacional, 1947). 
las funciones extendidas del Estado en la economía, así como de la consolidación de una fuerza gremial que comenzaba a legitimarse oficial y popularmente. Para el periodo analizado, el volumen de los capitales industriales no era despreciable. En 1945, la Contraloría General de la República tenía contabilizados 7853 establecimientos manufactureros en el país, los cuales pertenecían a campos como el textil, el metalúrgico, el químico, el tabacalero, el alimenticio, etc. Así, la política de sustitución de importaciones había alcanzado un margen significativo de éxito en relación con los bienes de primera necesidad;22 sin embargo, los industriales buscaron que su legitimidad fuera más allá de la coyuntura. En efecto, pretendían dar a conocer sus ventajas a la sociedad colombiana, pero, para lograrlo, tuvieron que elaborar primero una representación adecuada de sí mismos en calidad de gremio.

Como ya se mencionó, los diarios de amplia difusión, incluso la radio, tuvieron espacios patrocinados por los industriales para obtener el respaldo de la opinión pública, según ya lo ha señalado Sáenz Rovner. No obstante, también fue común la impresión periódica de revistas especializadas en contenidos de técnica e industria, donde gerentes, ingenieros e inversionistas expresaron sus críticas y opiniones con menos mesura. Para este trabajo me he centrado en dichas revistas, ya que fueron dispositivos de circulación limitada y, por lo tanto, más “íntimos”, producidos por los mismos portavoces y practicantes de la industria, con el fin de introducir elementos de identificación con el gremio. Debe advertirse que el ensamblaje de la identidad sugerida aquí no puede pensarse únicamente desde los canales masivos de comunicación, en los que el mensaje original solía distorsionarse por moderación de actores externos o por discreción de los mismos industriales. Sin obviar estos medios, indispensables para negociar la identidad entre el "adentro" y el "afuera" del gremio, ahondaré en los procesos internos de imaginación y representación dentro de los que la comunidad manufacturera fijó con mayor confianza o margen de maniobra definiciones parciales sobre su rol en la economía y en la sociedad colombiana. A través de textos e imágenes cada vez más protagónicas, las revistas en cuestión, en su mayoría de suscripción privada, ofrecieron a sus selectos lectores la idea de una colectividad o un nosotros, que pasaba por su edad de oro y compartía la responsabilidad de transformar las realidades materiales del país.

$\mathrm{Al}$ simular la estructura narrativa y editorial de grandes revistas de interés general, las publicaciones de los industriales realizaron reportajes periodísticos

22 Jesús Antonio Bejarano, “Industrialización y política económica (1950-1976)”, en Colombia hoy, $9^{a}$ ed., ed. por Mario Arrubla (Bogotá: Siglo XXI, 1985), 221-222. 
en fábricas representativas y notas biográficas sobre empresarios ejemplares, así como llevaron a cabo el cubrimiento de exposiciones internacionales, entre otras actividades. De igual manera, informaron sobre la actualidad financiera, instruyeron a gerentes y directores en el manejo del personal obrero y, principalmente, promovieron fuertes discusiones políticas respecto a la protección que, a juicio del gremio, el Estado debía garantizar a la incipiente industria.

Todo tipo de campos fabriles y regiones en proceso de tecnificación encontraron en las revistas una tribuna donde socializar sus alcances frente a otros pares. A pesar de editarse en núcleos urbanos con una industrialización más pronunciada, como Bogotá o Medellín, los directores de las distintas publicaciones procuraron condensar varios proyectos regionales, aparentemente aislados, en un discurso nacional homogéneo. De esta manera, los avances particulares se articularon con productos impresos con cierta coherencia, en los que empezaron a resaltarse las características “comunes” de una burguesía fabril recién organizada, identificada con "lo industrial" y separada intencionalmente de otros sectores económicos.

Un caso representativo fue el de la publicación mensual Industria Colombiana, una de las revistas más citadas en este artículo por la importante difusión que llegó a tener y por su uso sistemático de la fotografía. Editada en Bogotá y registrada ante el Ministerio de Fomento, funcionó desde 1954 hasta 1960, periodo en el que llegó a lanzar ejemplares con índices de contenido en inglés, francés y alemán. La publicación empezó bajo la dirección de Eduardo Cuéllar, gerente de la seccional bogotana de la ANDI y anterior presidente de la Empresa de Energía Eléctrica en la misma ciudad, ${ }^{23}$ asuntos nada desdeñables que ya evidenciaban la incidencia del gremio industrial y algunos de sus delegados en los nuevos lugares textuales de opinión. En la nota editorial de su primer número, la revista señaló:

Si no existiera industria en Colombia, el país estaría sometido a una economía agropecuaria en la cual la enorme masa de la población desempeñaría meras labores de peón o de vaquero. Unos pocos llegarían a la categoría de mayordomos y otro grupo reducido serían los comerciantes de las ciudades que venderían herramientas y abonos a las gentes del campo o actuarían como intermediaros para la compra y reventa de los productos del campo. ${ }^{24}$

23 Juan Camilo Rodríguez, Historia de la Empresa de Energía de Bogotá (Bogotá: Universidad Externado de Colombia, 2000), 16.

24 “Aspectos sociales de la industrialización en Colombia", Industria Colombiana, enero de 1954, s. p. 
Esta cita introduce la relación industria-civilización, al referirse a la economía rural como un proyecto de pocas posibilidades para la movilidad social de sus trabajadores. La hacienda agropecuaria, concebida tradicionalmente como una de las mayores unidades generadoras de valor desde el periodo colonial, de acuerdo con el razonamiento de los editores, quedaba relegada a un plano de rechazo si no se articulaba con actividades prósperas y dinámicas, capaces de afectar positivamente el mundo del trabajo.

Como elemento esencial de estas discusiones, la fotografía documental constituyó un dispositivo eficaz para exaltar la crítica esgrimida por el gremio industrial a la condición económica colombiana. Para el siguiente apartado, a partir de algunos ejemplos y modalidades, explico cómo el recurso fotográfico llegó a idealizar diferentes dimensiones (lugares, personajes, eventos, procesos productivos, entre otros) de la comunidad industrial, con el objetivo de modelar su identidad. El uso de distintas retóricas que representaban "lo propio y lo ajeno" de la agremiación exigía una cuidadosa selección visual de características comunes; en otras palabras, se requería la elaboración de una oferta gráfica y textual que permitiera fortalecer tanto la pertenencia hacia lo industrial como la diferenciación de otros rubros. El análisis plantea una lectura de las fuentes en sí - para el cual la historia de la fotografía es un sustento teórico importante- y de las redes de producción y circulación que las atravesaron. Con esto último, la investigación sugiere salir de la contemplación inocente de las imágenes para pensarlas en un nuevo registro: como producciones deliberadas con incidencia en los procesos históricos.

\section{La industria nacional en clave fotográfica}

En teoría, el estilo documental - consolidado en Estados Unidos durante el periodo de entreguerras y practicado en América Latina desde los años treintase empeñaba en distanciarse del margen creador del fotógrafo para obtener tomas de naturaleza mecánica. ${ }^{25}$ Sus procedimientos de captura prometían realizar un reportaje social de la cotidianidad, ya que ofrecía una noción de objetividad en la composición de la imagen que, al producirse supuestamente sin maquillaje o manipulación alguna, reforzaba su condición de documento o testimonio. Las temáticas privilegiadas de esta técnica fueron escenas comunes de un paisaje primordialmente urbano, caracterizado en el caso estadounidense por la estética decadente de la Gran

25 Olivier Lugon, El estilo documental: de August Sander a Walker Evans (1920-1945) (Salamanca: Universidad de Salamanca, 2010), 123. 
Crisis de 1929 y en el caso latinoamericano por procesos de migración rural hacia ciudades en expansión. Para mediados de siglo, la fotografía documental había sido incorporada culturalmente como una de las “evidencias" más adecuadas para la crítica social, el ejercicio del periodismo, la justificación de políticas estatales y, principalmente, la movilización de diversos grupos poblacionales en función de intereses particulares.

En Colombia, la fuerza ascendente de diferentes élites económicas permitió que su accionar político integrara herramientas gráficas para la defensa de sus mercados y beneficios. En el caso de los industriales, estos recurrieron a todo tipo de estrategias elocuentes para inclinar los planes fiscales del Estado a su favor. Además de librar intensos debates en el Congreso con dependencias como la Junta Nacional de Aduanas, ${ }^{26}$ el gremio fabril extendió su presión por un proteccionismo total a otros ámbitos comunicativos, entre ellos el fotográfico. Una de las tendencias más utilizadas en este ámbito fue la de comparar escenarios precarios asociados a la "barbarie" de lo rural con escenarios vinculados a la promesa digna y progresiva del capitalismo industrial (figura 1). Al postular a este último como el único camino capaz de generar riqueza para todos, la fotografía documental abandonaba su propósito objetivo e "imparcial"; ahora, tomaba parte, juzgaba, adaptaba sus procedimientos a una intencionalidad y, finalmente, sugería. Dicho de otra forma, cambió su pretensión de neutralidad y adquirió un rol activo, al negar la continuidad de una sociedad "tradicional" y fomentar imperativamente el siguiente paso hacia la civilización.

La figura 1 alude al impacto positivo que trajo la acería Paz de Río (Boyacá) a las condiciones de vida de la región. El contraste radical y selectivo entre una vivienda campesina aparentemente inestable y un conjunto de casas distribuidas a manera de vecindario más citadino se traduce en un intento por representar la llegada del complejo siderúrgico como una ruptura temporal y cualitativa. Paz de Río define, tanto en la foto como en otros mensajes o descripciones, un antes y un después; así, se inserta en una narración evolutiva del desarrollo nacional. En principio, la firma fue patrocinada por el Gobierno de Mariano Ospina Pérez (1946-1950);

26 La Junta Nacional de Aduanas se creó a través del Decreto extraordinario 2902 de 1944, con el ánimo de "[...] aumentar los ingresos por concepto de impuestos aduaneros a las importaciones". Los industriales de sectores como el tabacalero y textil hallaron en esta medida una oportunidad para satisfacer sus intereses, al presionar al Gobierno de fijar altos impuestos de venta a los artículos de fábricas extranjeras, pero, a su vez, al insistir en la protección y los bajos aranceles a los insumos que importaran para la producción local. Véase: Sáenz Rovner, La ofensiva empresarial, 135. 


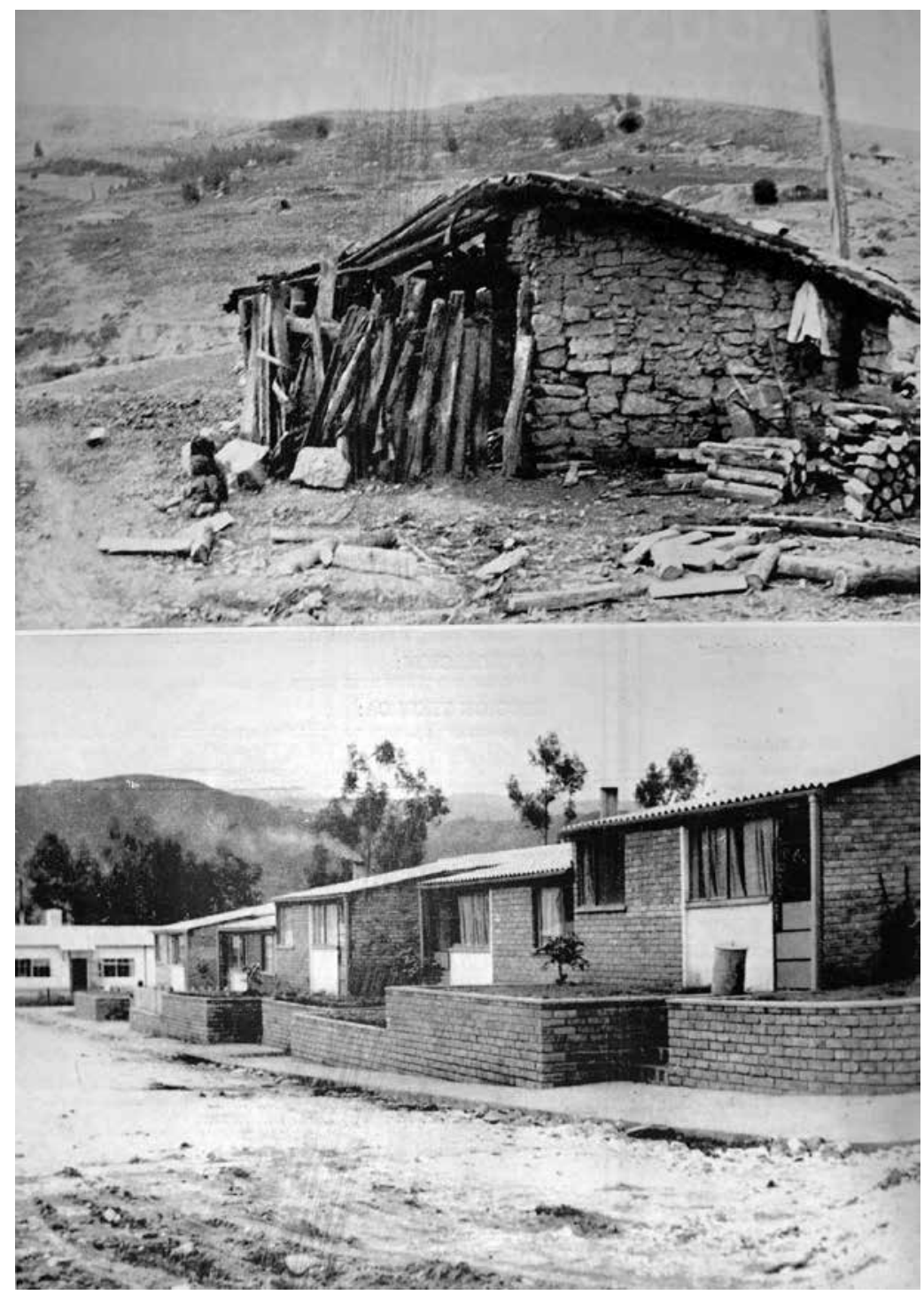

Figura 1. Anónimo, agosto de 1954, “Antes de Paz de Río-Después de Paz de Río” (fotografía, revista Industria Colombiana, Biblioteca Nacional de Colombia, Hemeroteca Manuel del Socorro Rodríguez, Bogotá, 8).

posteriormente, fue fundada en 1954 por el general Gustavo Rojas Pinilla, con la intención de llevar la industria intermedia a un nuevo estadio de industria pesada, preparada para trabajar el acero. En sus primeros años fue administrada por el ingeniero Roberto Jaramillo Ferro, quien llegó a colaborar con Industria Colombiana para la realización de reportajes dentro de las instalaciones de la empresa 
— consideradas un estandarte casi patriótico de la producción nacional, según el consenso de ingenieros, técnicos, políticos y periodistas- ${ }^{27}$

$\mathrm{Al}$ regresar a la comparación visual de ambas viviendas, cabe resaltar que la imagen de cada una conserva diferentes pautas de encuadre; para dicha interpretación, me baso en las clasificaciones hechas por el historiador de la fotografía Olivier Lugon. Mientras que la foto superior (la casa campesina) utiliza la "visión frontal" y tonalidades opacas frente a su objeto, la pieza inferior (las casas nuevas) apela a la claridad lumínica del documento, al destacar de forma simultánea la escala y la repetición en serie de las fachadas exhibidas. ${ }^{28}$ Una de las convenciones más comunes en la práctica de la fotografía arquitectónica en Colombia consistía en maximizar los exteriores de las estructuras para potencializar sus proporciones dentro del entorno en que se localizaban. Lo mismo sucedía con los espacios interiores, solo que en estos el atractivo de la fotografía no era la escala, sino la profundidad. ${ }^{29} \mathrm{De}$ esta manera, la oscuridad y la captura plana de la figura superior, alusiva al atraso de la región "antes del acero", no ofrece posibilidades para resaltar dimensiones espaciales, como sí lo hace la segunda foto dotada de ángulos y tonos más elaborados.

La carga de nociones críticas hacia el subdesarrollo a través del ejercicio fotográfico hizo evidente la pregunta por la industrialización nacional como una materia de preocupación social. La complementariedad entre texto e imagen de las revistas citadas abogaba vehementemente por una transformación estructural, que supliera “anticuados” elementos periféricos o rústicos a cambio de nuevas expectativas de modernidad que los industriales supieron escenificar con destreza. En efecto, tecnificar la producción local pasó de ser un deseo lejano a ocupar un lugar protagónico en imágenes con un halo de realidad (figura 2).

Las técnicas de encuadre usadas en las piezas anteriores cumplían, con escasas diferencias de estilo, los parámetros básicos del documentalismo fotográfico estadounidense fijados en los años veinte, entre otros: el carácter noticioso de los artículos; el anonimato del fotógrafo, cuya identidad rara vez figuraba en la des-

27 En 1959, año del fallecimiento de Roberto Jaramillo Ferro, El Tiempo citó en su homenaje al ingeniero la expresión de Alberto Lleras, quien decía “[...] que si Boyacá había dado la batalla decisiva para la libertad de la Gran Colombia, Paz del Río estaba dando la batalla para la libertad económica de Colombia". Además, se calificó a Ferro como un verdadero "soldado del progreso" en el campo de la metalurgia, al que había dedicado toda su vida. Véase: "Roberto Jaramillo Ferro", El Tiempo, 3 de noviembre de 1959, 17.

Eduardo Serrano, Historia de la fotografía en Colombia (1950-2000) (Bogotá: Planeta, 2006), 140. 


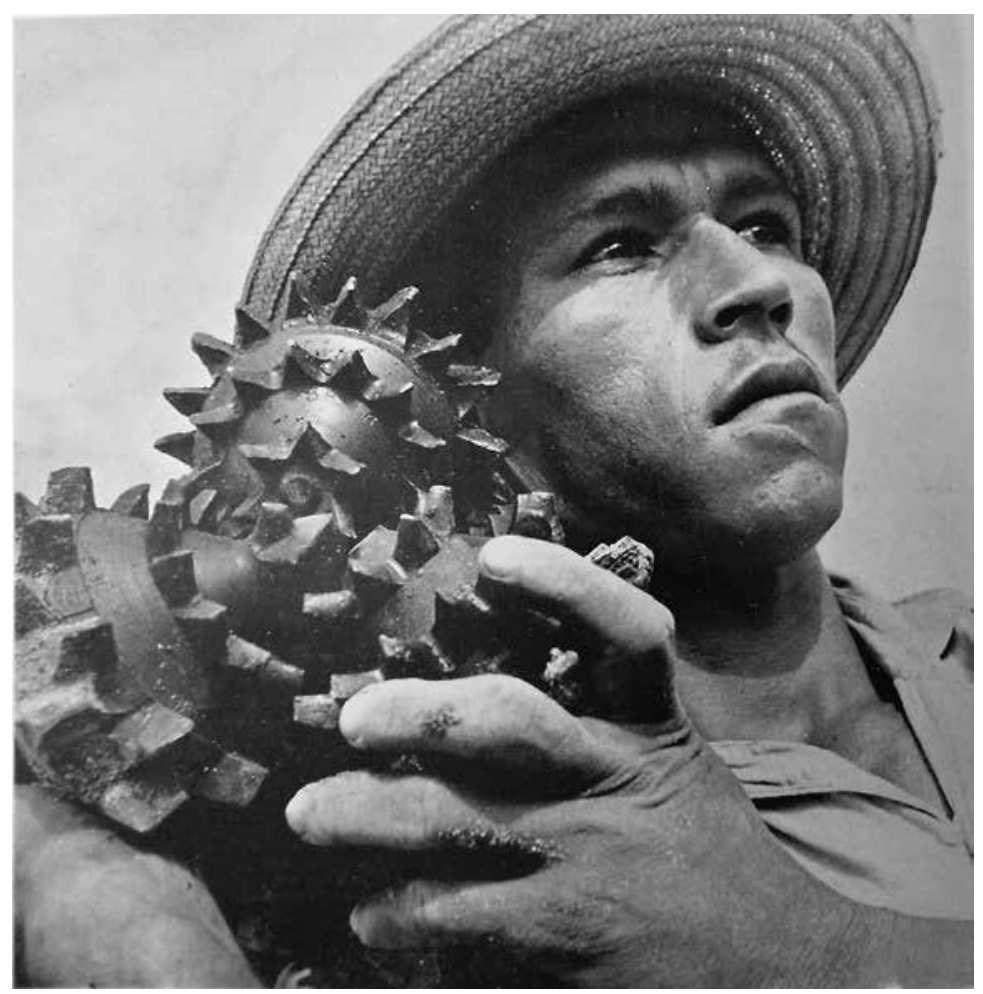

Figura 2. Leo Matiz, c. a. 1954, "Hombre del petróleo" (@Alejandra Matiz, Acervo de la Fundación Leo Matiz [c. a. FLM-066096], Colombia).

cripción de las imágenes; la impresión de objetividad y, consecuentemente, aquello que Margarita Ledo ha llamado un "efecto verdad" o "reflejo del mundo". ${ }^{30}$ Sumado a esto, el hecho de que las fotografías fueran a blanco y negro implicaba mayores posibilidades de abstracción para la idea representada, así como un aire de omnisciencia atribuido al autor de la toma, lo que provocaba que su rol se asociara con el de un narrador presente en el momento exacto, con la facultad de resumir cada situación dentro del reportaje. ${ }^{31}$

La figura 2 se presenta de forma más personalizada, tanto por su referente humano como por su autoría, a cargo del reconocido fotógrafo Leo Matiz. Allí, volvemos a apreciar las tonalidades claras en el rostro del individuo retratado, quien fija su mirada en el horizonte, mientras sostiene un par de brocas perforadoras

\footnotetext{
30 Margarita Ledo, Documentalismo fotográfico: éxodos e identidad (Madrid: Cátedra, 1998), 65.

31 Ibid., 18.
} 
empleadas en el sector petrolero. La coexistencia de hombre y máquina dentro de la imagen se evidencia en las proporciones relativamente iguales que ocupa cada uno, de manera que los instrumentos usados para extraer el crudo y las características del sujeto que los levanta, como el sombrero, la indumentaria campesina, la luz del sol en su rostro y las manos llenas de arena, se complementan en un equilibrio mistificado de trabajo humano y trabajo mecánico. La foto formaba parte de una nota periodística realizada por Industria Colombiana a la firma Ecopetrol; Matiz fue el artífice a cargo de la cámara durante todo el cubrimiento. En la descripción de algunas de las fotografías se destaca precisamente la combinación de "mente y esfuerzo" requerida para la búsqueda del "codiciado petróleo",32 además de la unión sincronizada entre los ritmos de trabajo obrero y los ritmos de las máquinas a campo abierto.

Trayectorias como la de Matiz en medios de prensa local e internacional daban cuenta de un fotoperiodismo que, a pesar de conservar su propósito documental, agregaba propiedades estilísticas que desvanecían la distancia despersonalizada entre fotógrafo y objeto. Al mismo tiempo, esto permitía que la toma se independizara de su estricta función de registro y se hiciera susceptible de crítica artística. Algunas colaboraciones en publicaciones extranjeras, como Life, Reader's Digest y Harper's Magazine, ofrecieron a fotógrafos como Matiz la posibilidad de aplicar vanguardias en diferentes campos temáticos, incluido el de una atractiva industrialización que apresuraba su marcha en América Latina.

Otro fotógrafo identificado en las fuentes de este tipo es el antioqueño autodidacta Gabriel Carvajal, quien también llegó a compartir su trabajo en publicaciones internacionales, así como en los diarios colombianos El Espectador y El Tiempo o en las revistas Cromos y Semana. Sus tomas aéreas de plantas textiles de Medellín, como Coltejer o Fabricato, exaltaban desde amplios planos rurales y urbanos el papel de centralidad ocupado por la fábrica, la cual se ubicaba, a su vez, en entornos sociales que se expandían a su ritmo. Lo interesante es que este tipo de lugares enfocados por Carvajal, y solo mencionados a manera de ejemplo, coincidieran con un estilo particular del cual quisiera ocuparme a continuación.

32 Fernando Caycedo, “Tributación del petróleo en Colombia”, Industria Colombiana, abril-mayo de 1954, 32. 


\section{La fotografía industrial como modalidad y mensaje}

Sehan enunciado los principales usos que tuvo la fotografía documental en revistas producidas bajo la dirección de algunos industriales colombianos; sin embargo, los ejemplos anteriores, aunque comparten una promesa de prosperidad, aún no dan cuenta de un ejercicio de autorrepresentación que ilustre elementos distintivos y específicos del gremio manufacturero. De hecho, tales ejemplos (figuras 1 y 2) muestran un estilo genérico de tipo social o documental en un sentido vago, de manera que la industria no ocupa el contenido principal de las piezas. Para este subapartado, me propongo explicar cómo la estrategia visual de elaborar una impresión positiva de la industria privilegió una modalidad fotográfica concreta: la fotografía industrial, cuya temática primordial fue la exposición del espacio fabril, entendido en este estudio como un referente de identidad que localizaba el discurso progresivo en recintos técnicos con características especiales.

El paisaje industrial reúne en su composición artefactos como motores, calderas y chimeneas que, en medio de su carácter funcional, simbolizan igualmente los cambios materiales de la producción mecanizada. En Colombia, fotografiar escenarios con estas características se hizo común desde los años cincuenta, al proyectar a la fábrica como ese novedoso organismo maquinal donde la producción de mercancías alcanzaba su nivel más avanzado. Aquellas utopías que a comienzos del siglo Xx planteaban la posibilidad de tener capitales tecnológicos importantes, ahora gozaban de algunos puntos de contacto con la realidad empírica. Así, las expectativas de una modernidad industrial hallaron en la fotografía un soporte con estatus de verdad, que ahora materializaba el imaginario del progreso en nuevas espacialidades y paisajes económicos.

La fotografía industrial aparece como un subconjunto derivado del estilo documental. Su interés se ubica en complejos fabriles, rutinas de producción en serie, bienes de capital y toda clase de objetos que conserven una relación metafórica con la economía desarrollada. ${ }^{33} \mathrm{~A}$ su vez, busca maximizar las proporciones de los paisajes industriales con orientaciones diagonales de 45 grados sobre las estructuras retratadas, ambientes luminosos escogidos al amanecer o en horas avanzadas de la tarde, sombras fuertes que enfatizan volúmenes y, en particular, ausencia de

33 Geraldine Wojno Kiefer, “Industrial Photography”, en Encyclopedia of Twentieth-Century Photography, ed. por Lynne Warren (New York: Taylor \& Francis, 2006), 781-782. 
personas (figura 3). ${ }^{34}$ La potencia creativa de la máquina gana predominio en esta modalidad, se opone al procedimiento artesanal considerado dispendioso desde el "credo mecánico" 35 y oculta con su imponencia ingenieril los rastros del trabajo humano. Fábricas vacías dotadas de aparatos en funcionamiento hacían que la fotografía industrial concediera a la imagen una atmósfera de productividad, una noción fetichizada de espacios tecnológicos en los que el movimiento y el estruendo aparentaban generarse por sí solos. En muchos casos, la presencia humana quedó reducida a una simple comparación de escalas, en las que un operario a cargo posaba al lado de máquinas con amplias dimensiones que opacaban cualquier figura ajena al paisaje descrito (figura 4). Así, el lugar de producción pasaría a ser un campo fotográfico favorecido en las producciones editoriales de los industriales, quienes apostaron por convertir en emblemas de su ocupación las nuevas instalaciones de la técnica, presentes en cementeras, cervecerías, refinadoras de petróleo, fábricas de tejidos, laboratorios, etc.

Parece contradictorio que la gran consigna de presentar la industria como fuente inagotable de trabajo compaginara con el énfasis fotográfico puesto en factorías que parecían prescindir de la fuerza humana. No obstante, es necesario insistir en que la identidad modelada por los industriales operaba en un ámbito público, de tono inclusivo, y en otro privado, en el que sus intereses y referentes puntuales como élite llegaron a diferir en algunos detalles de la narrativa generosa de difusión nacional. Aunque en los dos ámbitos existió un esfuerzo por documentar los avances de la técnica moderna y sus impactos sociales, las revistas especializadas en asuntos fabriles intensificaron entre sus lectores la socialización de imágenes, noticias y saberes sobre aquellos espacios regionales donde comenzaba a insertarse la máquina. Este es el caso de publicaciones como Quimica e Industria (1949), fundada por la Sociedad Colombiana de Químicos, y la Revista Colombiana del Trabajo (1939), cuyo nombre fue remplazado por Industrias Colombianas (diferente a Industria Colombiana) en 1953, a raíz de las transformaciones estructurales presenciadas en compañías nacionales a mediados de siglo. ${ }^{36}$

34 Rolf Sachse, "Architectural Photography", en Encyclopedia of Twentieth-Century Photography, ed. por Lynne Warren (New York: Taylor \& Francis, 2006), 59.

35 Lewis Mumford, Técnica y civilización (Madrid: Alianza, 1971), 309.

36 “Explicación”, Industrias Colombianas: Transportes, Comercio, Trabajo, n. 135 (1953): 5. 
Sobre máquinas y titanes: la autorrepresentación fotográfica del gremio industrial colombiano (1945-1960)

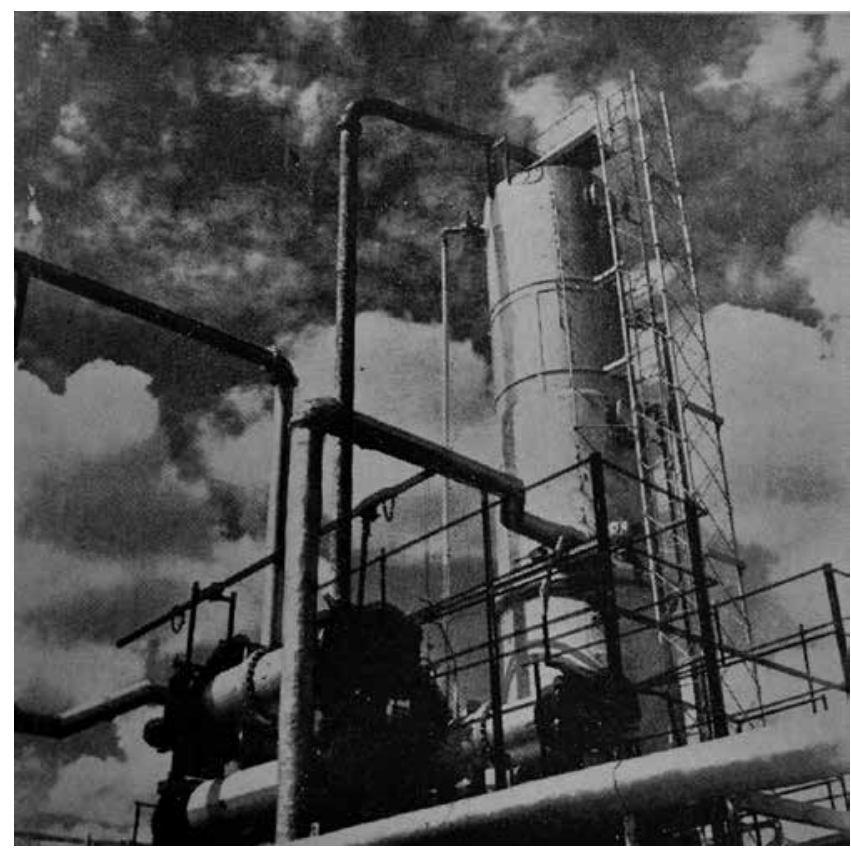

Figura 3. Leo Matiz, edición de abril y mayo de 1954, sin título (fotografía en la revista Industria Colombiana, Biblioteca Nacional de Colombia, Bogotá, 17).

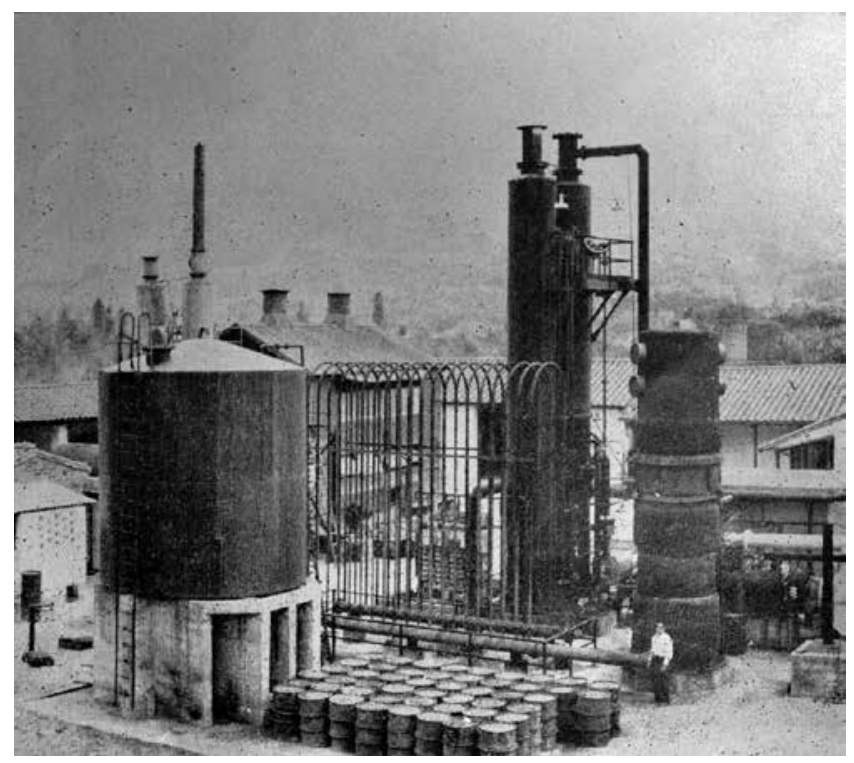

Figura 4. Anónimo, enero de 1951, "Vistas parciales de la planta de ácido sulfúrico" (fotografía en la revista Química e Industria, Biblioteca Nacional de Colombia, Hemeroteca Manuel del Socorro Rodríguez, Bogotá, 32). 
Al hablar de una eventual “escenificación” fotográfica de los complejos industriales, no pretendo afirmar que estos fueran objeto de montajes — al menos desde un primer acercamiento-; más bien, me refiero a la elaboración poco espontánea y la edición minuciosa de imágenes sobre fábricas que efectivamente habrían comenzado a multiplicarse desde los años cuarenta; de hecho, acapararon la atención de medios, fotógrafos independientes y, por supuesto, empresarios con ansias de conocer e invertir en nuevos mercados.

La expansión tecnológica era un hecho ineludible; como prueba de ello, en 1945, el Estado ordenó aplicar el Primer Censo Industrial para cuantificar los establecimientos manufactureros distribuidos en ciudades y pequeños municipios con adelantos progresivos (figura 5). Los resultados de dicha encuesta postulaban a Antioquia como el departamento de mayor producción fabril, con anteriores capitales mineros, cafeteros y comerciales canalizados hacia una industria sólida de textiles y minerales no metálicos. ${ }^{37}$ Cundinamarca, por su parte, figuraba como la “industria más numerosa", ya que en un lapso de 15 años su cantidad de fábricas con producción mayor a 6000 pesos casi se había cuadruplicado: pasó de 400 a 1569. 38

Ciertamente, el acompañamiento fotográfico de estos procesos permitió ofrecer un relato coherente, según el cual la nación pasaba por una transformación generalizada que motivaba a los delegados de la industria a no bajar la guardia y defender colectivamente la institucionalización de sus intereses, distribuidos para ese entonces en una nueva geografía económica.

Tanto la forma como el contenido de la fotografía industrial tuvieron apropiaciones locales que hacen difícil pensar en una técnica universal sin variaciones. En América Latina, la práctica profesional de este estilo adquirió en el tránsito del siglo XIX al XX nociones como la exposición del territorio natural y sus componentes en amplios planos panorámicos. Ningún elemento de los paisajes intervenidos mecánicamente sobraba en la imagen premeditada de una industrialización extractiva (figuras 6 y 7), la cual, además de reconciliar a través de la cámara la relación campo-tecnología, daba a conocer al empresariado nacional y foráneo las ventajas de invertir en sitios poco explorados. Dicho esto, la pregunta por los ambientes

37 Sobre la evolución empresarial antioqueña, véase: Carlos Dávila, Empresariado en Colombia:perspectiva histórica y regional (Bogotá: Universidad de los Andes, 2012), 138-141; Ann Farnsworth-Alvear, Dulcinea in the Factory: Myths, Morals, Men, and Women in Colombia's Industrial Experiment, 19051960 (Durham: Duke University Press, 2000), 45-46.

Dirección Nacional de Estadística, Primer Censo Industrial, 3-12. 


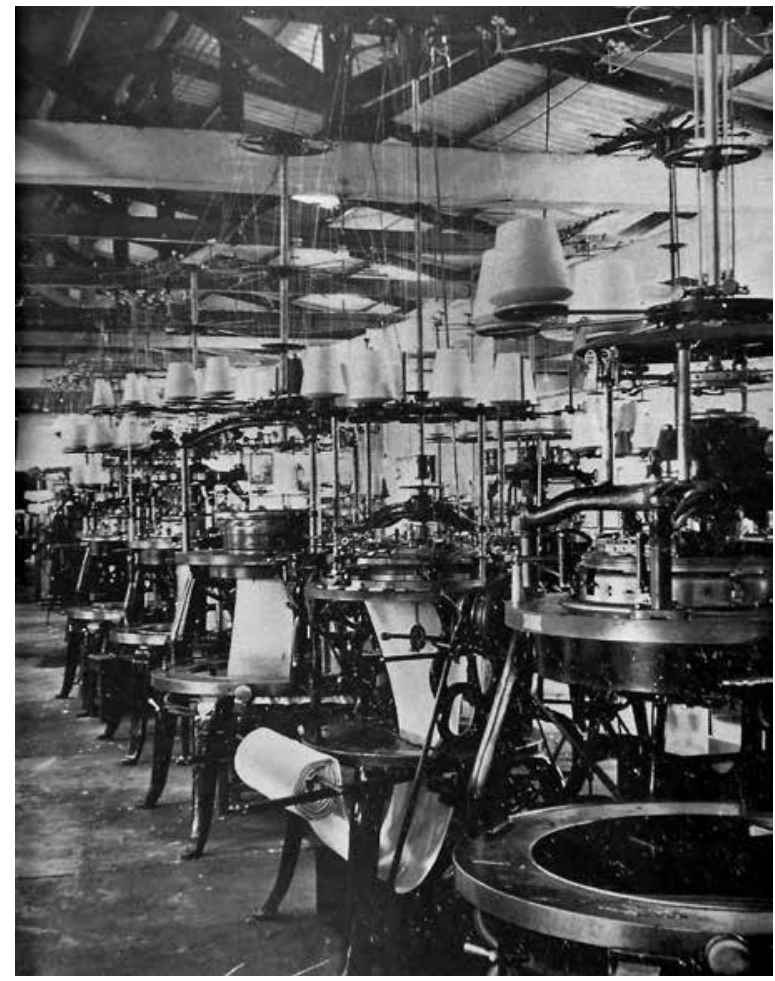

Figura 5. Anónimo, marzo de 1954, "Fábrica de tejidos Santa Ana (Zipaquirá)" (fotografía en Industria Colombiana, Biblioteca Nacional de Colombia, Bogotá, 45).

fabriles fotografiados no debe limitarse a sus posibles significados estéticos; también debe encaminarse hacia sus efectos prácticos. Al ser un soporte documental con la capacidad de inspirar nuevos proyectos capitalistas, la fotografía ejerce una función performativa, es decir, sus códigos inciden en la toma de acciones u opiniones de aquellos actores individuales o grupales entre los que circula.

En relación con lo anterior, trabajos como el de W. J. T. Mitchell, en diálogo con autores de la teoría pictórica y literaria, comprenden el paisaje (rural o urbano) como un cuerpo de signos determinados que instrumentalizan el espacio para alegorizar y naturalizar nociones ideológicas o culturales. ${ }^{39}$ Así, Mitchell sugiere no concebir el paisaje como sustantivo, sino como verbo y acto de poder (from a noun to a verb): una representación artificial del entorno que posibilita la apropiación visual del territorio, así como la creación de subjetividades contenidas en este.

39 W. J. T. Mitchell, Landscape and Power (Chicago: The University of Chicago Press, 2002), 1-2. 


\section{PETROLEO EN EL TOLIMA}

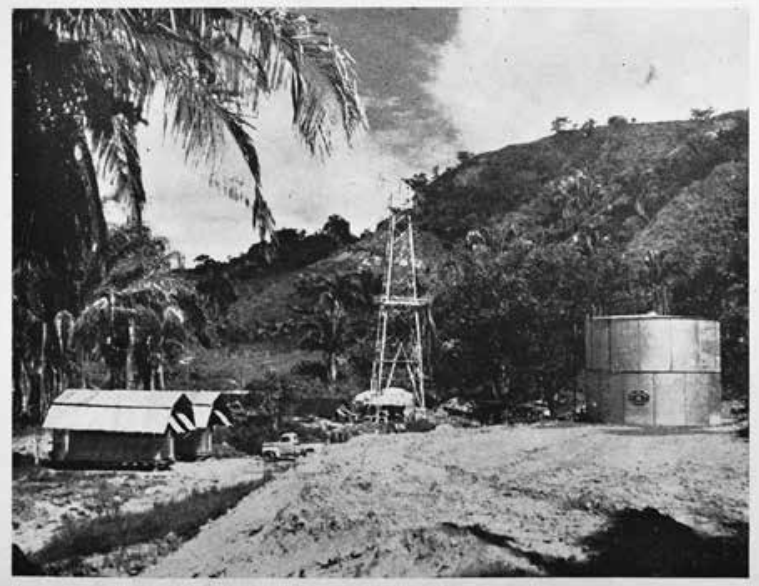

Lo Texas Petroleum Company adelanta actividades de perforación en el Municipio de Ortego (Tolima).- Visto de un poxo petrolero. (Cortesia de la Texas Petroleum Co.).

Figura 6. Texas Petroleum Company, 1950, "Petróleo en el Tolima” (fotografía publicada en la Revista del Petróleo, Biblioteca Nacional de Colombia, Bogotá).

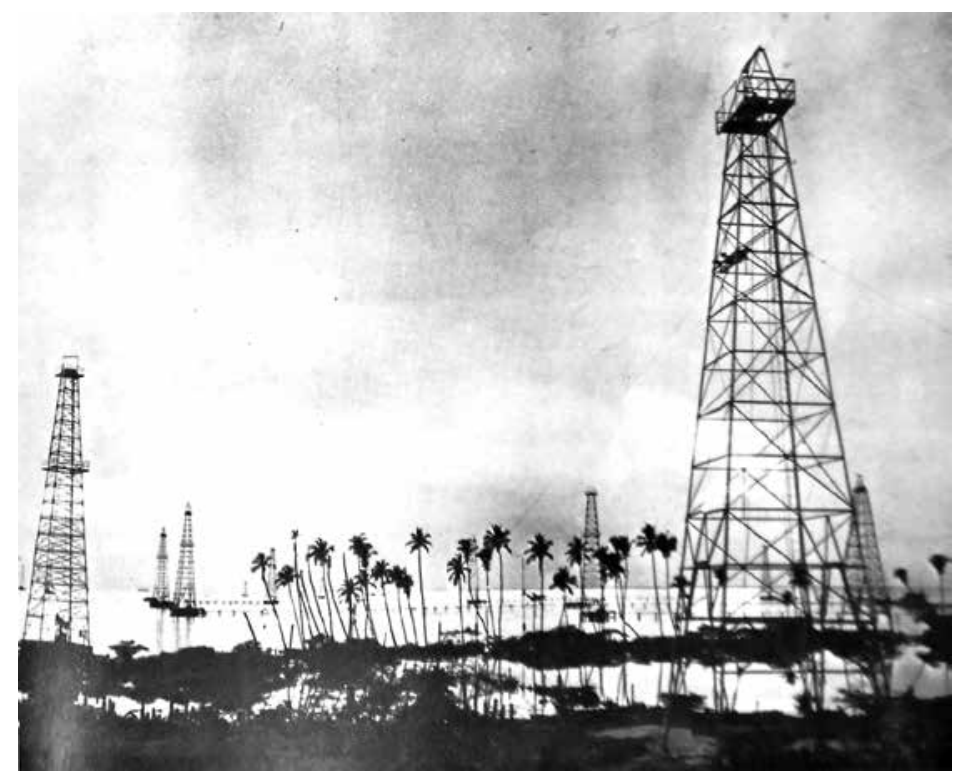

Figura 7. Leo Matiz, 1954, “Torres petroleras en Coveñas (Córdoba)” (fotografía publicada en Industria Colombiana, Biblioteca Nacional de Colombia, Bogotá). 
El hecho de que los industriales difundieran sus revistas e imágenes preferiblemente entre colegas no impidió que algunas tuvieran una repercusión conveniente en amplias tribunas de la opinión pública. Hacia 1950, boletines independientes como la Revista del Petróleo recibían felicitaciones de los diarios El Tiempo, La Nación, El Liberal y El Siglo, además de críticas favorables por parte de publicaciones internacionales como la Colombian Oil New Digest..$^{40}$ La Revista del Petróleo, también comprometida con el fortalecimiento de la industria, manifestaba criterios y expectativas similares a los de la ANDI, al velar por un proteccionismo total, pero sin oponerse a que la intensificación interna de lo fabril se valiera de impulsos procedentes de potencias extranjeras. Fotográficamente, esta permisividad queda plasmada en ejemplos como el de la figura 6: las perforaciones de la Texas Petroleum Company en el departamento del Tolima evidencian lo habitual que resultaba introducir imágenes o noticias de conglomerados foráneos en revistas nacionales, donde el entorno representado como inhóspito o agreste se ve alterado por el avance tecnológico de la firma estadounidense.

Ahora, no toda la discusión sobre lo propio o lo externo de estas imágenes se agota en el análisis iconográfico. En efecto, había fenómenos de corte macroeconómico que explicaban la coexistencia de discursos industrialistas locales y globales en una misma publicación. A diferencia de países como Chile, Argentina, Brasil o México, que durante los años de posguerra basaron sus modelos económicos en las tesis estructuralistas de la Cepal y, más tarde, en la teoría de la dependencia, Colombia trazó un curso opuesto: las clases dirigentes prefirieron apoyar el modelo liberal de desarrollo coordinado por Estados Unidos, elección que implicó aceptar la mediación de organismos de crédito multilaterales como el Fondo Monetario Internacional o el Banco Mundial y, consecuentemente, distanciarse de la crítica cepalina al sistema internacional de centro-periferia. ${ }^{41} \mathrm{Si}$ algo distinguió la batalla mediática de los industriales en distintos sectores fue su habilidad retórica de transitar, de acuerdo con cada coyuntura, entre la defensa del proteccionismo y su respaldo a la libre empresa. De esta manera, no sería tan descabellado que el accionar político de estos o sus medios visuales de promoción fueran flexibles, al punto de vincular en su mensaje una disposición amable hacia las compañías norteamericanas. En su primer volumen de 1950, la Revista del Petróleo manifestó:

40 "La prensa de Bogotá y la Revista del Petróleo", Revista del Petróleo, 1950, 30-31.

41 Juan Carlos Villamizar, Pensamiento económico en Colombia: construcción de un saber (1948-1970) (Bogotá: Universidad del Rosario, 2013), 36 y 79-80. 
Siguiendo este orden de ideas se reafirma el concepto de la Asociación Nacional de Industriales de que es conveniente que se adopten medidas legislativas y administrativas que den estímulo a la venida de capitales extranjeros para la explotación de los recursos naturales de la Nación y para acelerar el desarrollo económico. ${ }^{42}$

Cerraré este punto retomando uno de mis argumentos centrales, según el cual la aceptación poco crítica de propaganda e, incluso, tendencias fotográficas extranjeras dificultan asimilar el discurso nacionalista y “autóctono” de los industriales como un fundamento base de su comunión gremial. Expresiones como patriotismo o deber patriótico, tan usuales en textos y proclamas de la ANDI, eran simples eufemismos que invitaban a voceros del rubro fabril a conservar su unidad, reclamando apoyo del Estado, pero, evitando al mismo tiempo su agencia reguladora. ${ }^{43}$ La identidad de los manufactureros descansaba, más bien, en la autorrepresentación casi apologética de su ocupación. Como se explicará en el próximo subapartado, estos eran abanderados de una modernidad cosmopolita, sin fuertes arraigos a las fronteras locales o al sentimiento patrio. Sin embargo, no se trataba de una simple modernidad productiva; la industrialización era el paso previo para la sociedad de consumidores, para una adaptación a la lógica de la mercancía y a la vida metropolitana, ${ }^{44}$ tal como anotaba Mariano Ospina Hernández, hijo del entonces expresidente Mariano Ospina Pérez y director de Industria Colombiana, luego de la corta gestión de Eduardo Cuéllar. En una de sus notas editoriales, Ospina apeló al tono inclusivo con el siguiente cuestionamiento:

Ahora bien, ¿a quién han beneficiado los grandes adelantos de la técnica sino a las mismas masas trabajadoras en los Estados Unidos? Los millones de automóviles, radios, neveras, cámaras fotográficas, aparatos de televisión, plásticos, etc., que aquel país produce anualmente no pueden ser para unos pocos "capitalistas" que acumulen en sus casas todos esos artefactos, ni siquiera para la exportación, ya que esta no alcanza a copar más del $10 \%$ de la producción norteamericana. Esas comodidades y adelantos son para los millones de trabajadores, de la ciudad y del campo, que con sus esfuerzos han hecho posible no solo una gran

42 "Sin título", Revista del Petróleo, marzo, 1950, 13.

43 Sáenz Rovner, La ofensiva empresarial, 136.

44 Posada, La promesa del capitalismo, 142. 
conquista material, sino también un progreso cultural sin precedente, como lo atestiguan museos, universidades, orquestas sinfónicas, y en fin toda clase de instituciones culturales de un nivel que ni siquiera sospechamos en nuestros países; porque en síntesis, la industria enriquece a todos por igual, sin distinción de clase social alguna. ${ }^{45}$

\section{"Capitanes de la industria": patrones e ingenieros a través de las lentes}

Según indicaba, la presencia de fuerza laboral en la fotografía industrial escaseaba frente al predominio de la máquina; sin embargo, las contadas excepciones en las que el elemento humano sobresalió mostraban otra tendencia u objeto privilegiado por la cámara: el capitalista y el ingeniero. Con presencia en portadas, secciones biográficas y reportajes, el propietario o técnico al mando de la producción suplía la carencia de personas en el repertorio iconográfico de las revistas. De acuerdo con Carlos Dávila, este era la "mano visible del mercado", ${ }^{46}$ el rostro carismático y autorizado que personalizaba la documentación de un proceso económico complejo. Las páginas que protagoniza pretenden exaltar su "titánica" labor en ejecución, así como su capacidad para dominar las fuerzas naturales en busca de la máxima utilidad, como se observa en la figura 8. En este caso, se descarta, igual que con las imágenes de fábricas, que la aparición de ingenieros y directores fuera casual o espontánea. Por el contrario, el rol que desempeñaban en la imagen era preconcebido y acoplado artificiosamente con su ambiente de trabajo. Aunque se les mostrara como personajes de élite, estos se insertaban en los mismos escenarios de la rutina obrera. Su formación profesional de signo pragmático los definía como un compañero más que, a pesar de trabajar "hombro a hombro" con su nómina, se distinguía por sus virtudes pedagógicas y conocimientos científicos importados de academias estadounidenses, inglesas o francesas. ${ }^{47}$

\footnotetext{
45 Mariano Ospina Hernández, "Industrialización y proletariado", Industria Colombiana, agosto de 1954, 9.

46 Dávila, Empresariado en Colombia, 13.

47 Alberto Mayor Mora, Ética, trabajo y productividad en Antioquia (Bogotá: Tercer Mundo, 1989), 270-271.
} 


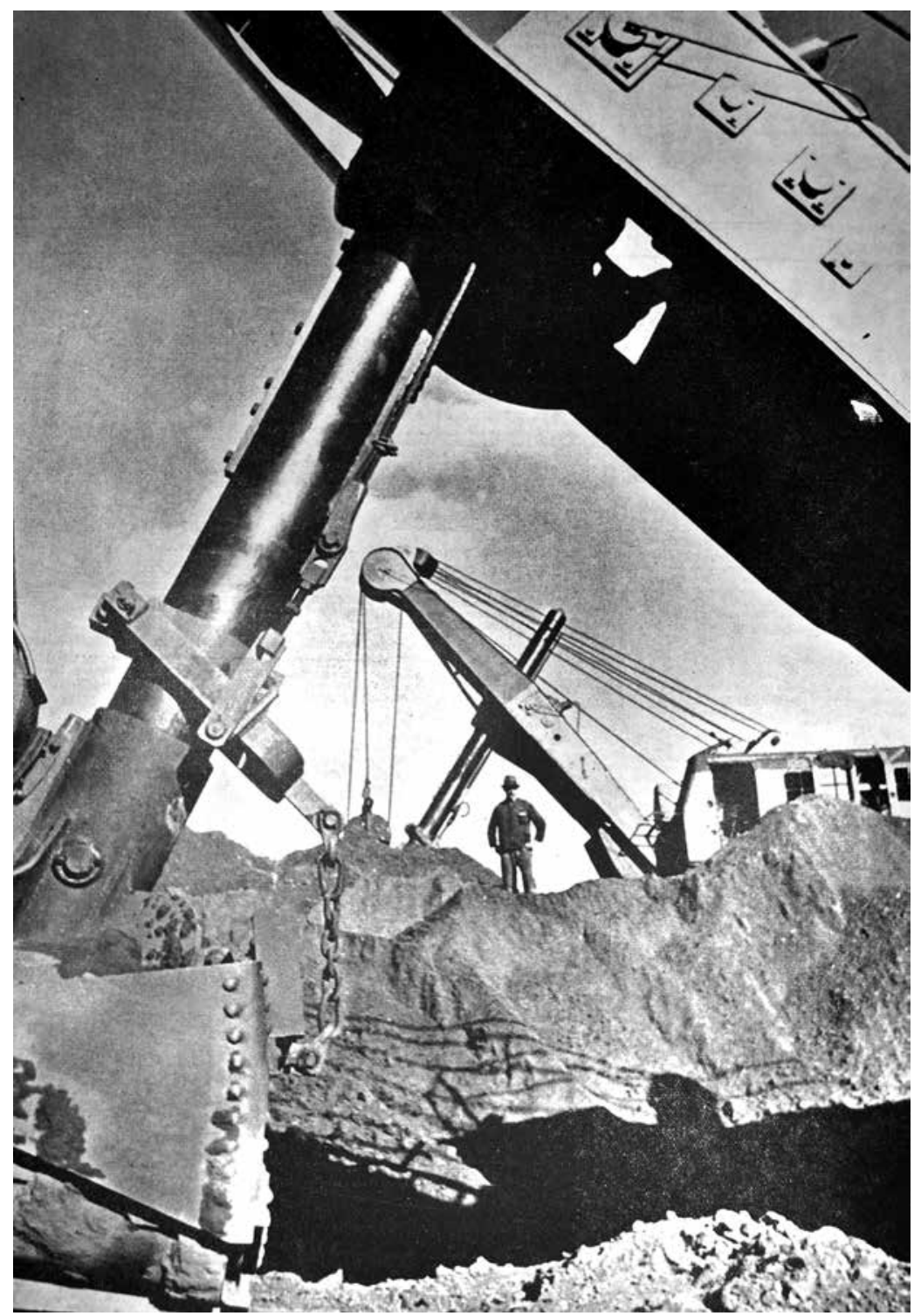

Figura 8. Anónimo, marzo de 1955, "La industria de la construcción" (fotografía, Industria Colombiana, Biblioteca Nacional de Colombia, Bogotá, Hemeroteca Manuel del Socorro Rodríguez Bogotá, s. p.).

Cumplir funciones publicitarias parecía ser una finalidad de las fotografías en cuestión; otra, menos evidente, fue sintetizar la subjetividad y el ethos del industrial: un personaje educado, de rasgos urbanos y dotado con una inteligencia práctica, característica que se convierte — durante el panorama de una transformación eco- 
nómica nacional - en su principal atributo de estatus social e, incluso político. Bajo esta interpretación, el retrato del empresario fabril generaliza su apariencia, la reifica y le asigna un sentido, una "forma de verse" ligada a su "forma de actuar". Por otro lado, distintos tipos de ilustraciones como la caricatura reforzaron, mediante una oferta visual más sencilla, esta configuración escénica del patrono industrial: su posición acomodada (figura 9) y su jerarquía en la organización del trabajo (figura 10) no pasaron desapercibidas en los dibujos que ornamentaban las secciones informativas de las publicaciones del gremio. ${ }^{48}$

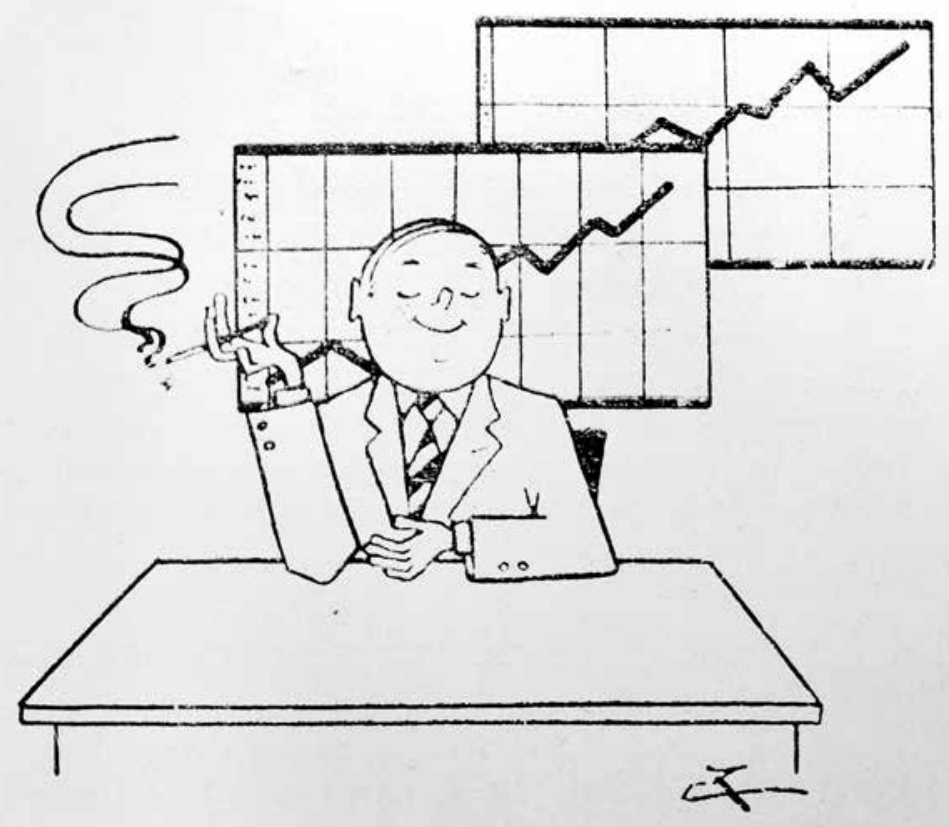

Figura 9. Anónimo, agosto de 1956, “Sección de economía y finanzas” (caricatura en Industria Colombiana, Biblioteca Nacional de Colombia, Bogotá, 21).

48 La industria no fue una temática muy trabajada por caricaturistas con intereses en fenómenos económicos; al menos, no lo sería en medios masivos donde el sector cafetero o el bancario sí fueron objeto constante de sátira. En el caso de las figuras 8 y 9, en lugar de una sátira, se reitera la idealización del jefe fabril, así como su distinción social autorrepresentada. Sobre caricatura económica, véase: Juanita Villaveces, Caricatura económica en Colombia 1880-2008 (Bogotá: Universidad del Rosario, 2010), 17-18. 


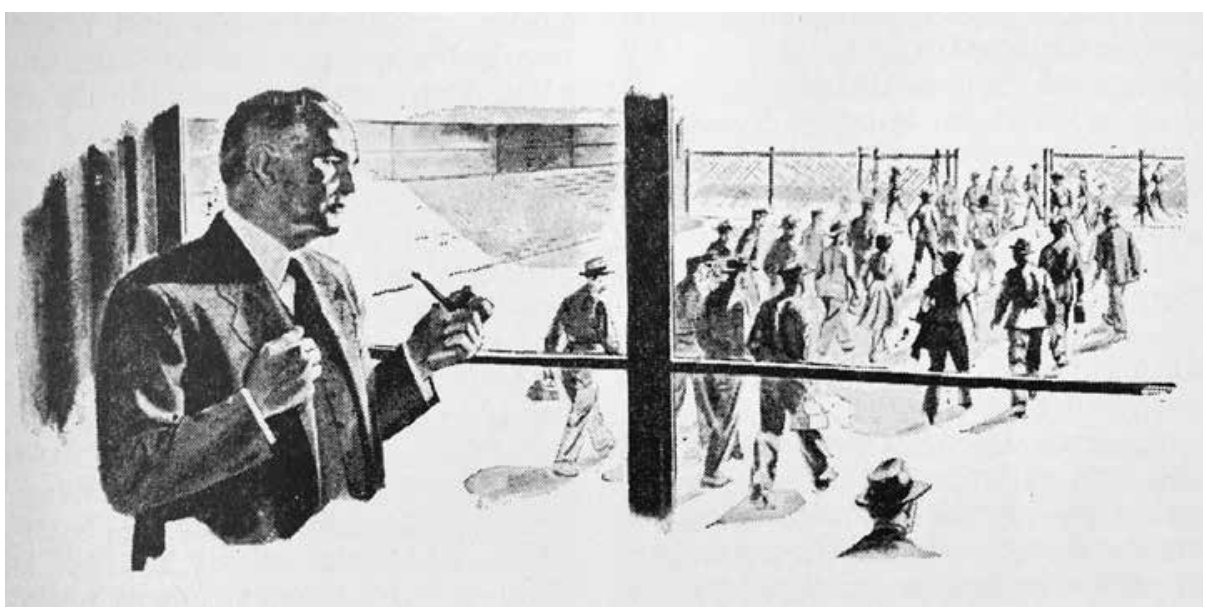

Figura 10. Anónimo, 1954, "Sección legal" (caricatura en Industria Colombiana, Biblioteca Nacional de Colombia, Bogotá, s. p.).

La socialización de esta estética en soportes editoriales familiarizó tanto a lectores ocasionales como a suscriptores permanentes con un conjunto de alegorías sobre sus oficios, colegas y trayectorias. No era coincidencia que la reputación del industrial en cargos económicos o políticos fuera constantemente asociada con la de un visionario. Conceptos tan abstractos como ingenio o experticia lograron atribuirse a través de la cámara fotográfica a personajes puntuales, entrevistados por los mismos corresponsales de las revistas. Un ejemplo de ello es la figura 11: una portada de la Revista del Petróleo, en la que Pedro Nel Rueda Uribe, ministro de Minas en 1953, sostiene sus anteojos con firmeza, mientras fija una mirada inalterable hacia el frente, en señal de tenacidad.

A partir de lo dicho, podría afirmarse que el dispositivo de la fotografía, desde su propia materialidad, transportaba el ethos pragmático ya mencionado. Imágenes como las anteriores, además de su función técnica o alcance propagandístico, vehiculizaron referentes y códigos en los cuales la agremiación industrial pudo (re)conocerse e identificarse con sus propios valores de élite productiva. Algunos boletines periódicos, como Integral Industrial, dirigido por la Sociedad de Ingenieros Químicos de la Pontificia Universidad Bolivariana de Medellín, fomentaron secciones relacionadas con estos valores o cualidades ejemplares que, según sus editores, debería reunir cualquier líder fabril. Columnistas internacionales como Neil Gilchrist hicieron aportes a esta reflexión inacabada, al resumir las habilidades del buen industrial en don de mando, discernimiento, honradez intelectual y 


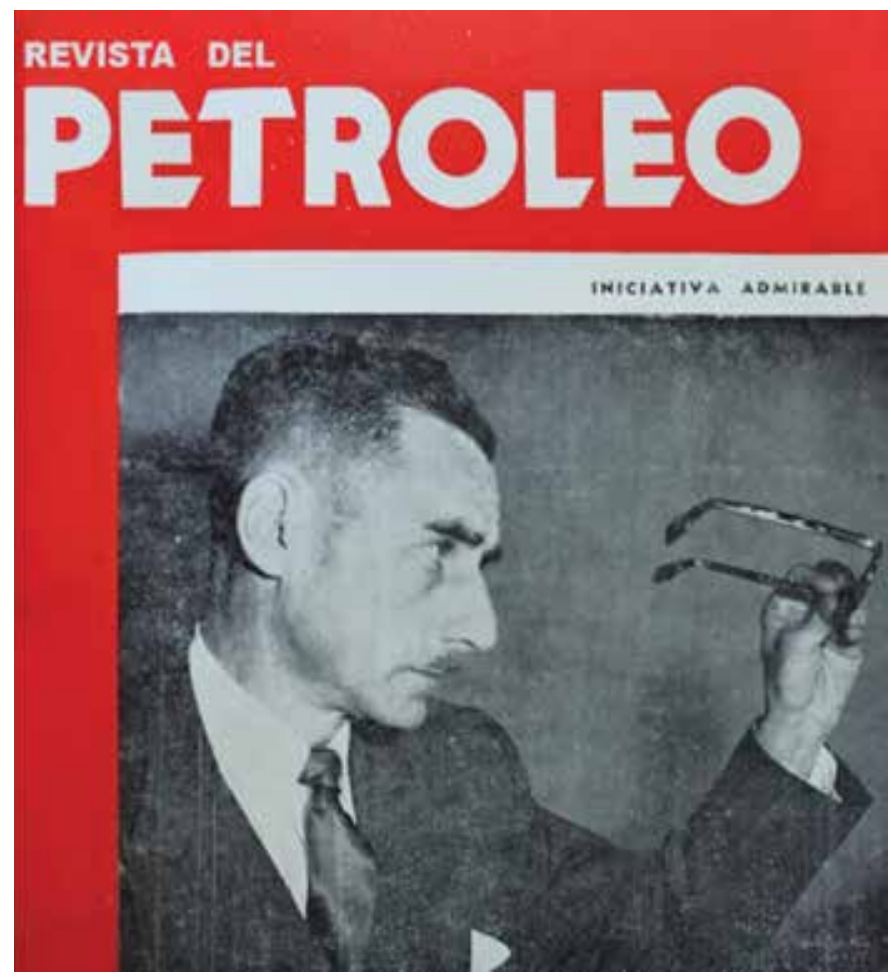

Figura 11. Anónimo, 1953, "Pedro Nel Rueda Uribe, ministro de Minas y Petróleos” (fotografía en la portada de la Revista del Petróleo, Biblioteca Nacional de Colombia, Hemeroteca Manuel del Socorro Rodríguez Bogotá).

sentimientos de sociabilidad; ${ }^{49}$ aspectos que, en mayor o menor medida, se abreviaron exitosamente a través de producciones con materiales gráficos y discursos elocuentes de unidad gremial.

\section{El eco de la identidad: circulación y recepción de lo ensamblado}

Una vez abordado el eje principal sobre los modos y estilos que caracterizaron el proyecto fotográfico de los industriales, me parece pertinente desplazar el análisis hacia la movilización y acogida que este tuvo en audiencias particulares; esto con la intención de situar las fuentes señaladas en aquellos escenarios donde se recibieron y resignificaron, lo que complementa el enfoque principal puesto en la producción e interpretación de las imágenes. Para este cambio de perspectiva se presentan algunos casos relevantes que dan cuenta, por un lado, de los alcances

49 Neil Gilchrist, "La personalidad administrativa”, Integral Industrial, mayo de 1958, 7-18. 
transnacionales experimentados por ciertas revistas y, por otro, de las opiniones cruzadas entre los lectores y las directivas de estas. Sobre este último punto, cabe agregar que la correspondencia publicada por las mismas revistas entre suscriptores y editores se presenta como uno de los indicios más estimulantes ante la investigación; al entender las revistas empresariales como productos diseñados para la sociabilidad de su público selecto, resulta indispensable explorar la apropiación y negociación de los rasgos identitarios promulgados por algunos industriales a la cabeza de producciones escritas.

Como se mencionó, por ejemplo, Industria Colombiana llegó a lanzar los índices temáticos de sus volúmenes en alemán, inglés y francés, específicamente después de su primer año de circulación. En esta proyección internacional el ensamblaje de la identidad gremial abandonó su dimensión puramente interna para convertirse en objeto de una discusión más abierta, en la que no se hicieron esperar comentarios y sugerencias. Carlos A. León — negociante colombiano que vivía en Long Island (Nueva York) - escribió en 1955 a Gabriel Baraya, gerente de Industria Colombiana, las siguientes líneas, igualmente publicadas en la revista:

He leído su revista de mayo del 55 y encontré todos sus artículos de mucho interés. Las gráficas que aparecen en las páginas 32 y 33 darían un gran resultado si fueran publicadas en una revista norteamericana (Life por ejemplo)... pues francamente señor gerente... eso de rascarnos la barriga nosotros mismos en Colombia... no vamos a ningún Pereira. ${ }^{50}$

El anhelo era claro: alcanzar una repercusión que superara la limitada difusión local; sin embargo, no se trataba de un consenso. El debate por una visibilidad global o por una solidaridad más latinoamericana era un asunto de permanentes afinidades y desencuentros. Contario al concepto emitido por León, otras voces manifestaron su reserva con la excesiva fijación en referencias ajenas, invitando a las iniciativas editoriales del gremio a profundizar en las relaciones profesionales de la región y robustecer los vínculos de los industriales con las naciones y los procesos de los que formaban parte. En 1958, el químico mexicano Hugo Ortiz se dirigió por escrito a Integral Industrial (Medellín) para destacar la calidad del material impreso, pero, al mismo tiempo, para hacer el siguiente llamado de atención:

50 Carlos A. León, “Cartas a la gerencia”, Industria Colombiana, agosto-septiembre de 1955, 46. 
Yo pienso que es necesario inculcar entre nuestros compañeros más sentido de patria. No solo sentimentalismo sino orgullo industrial y moral. Y ustedes pueden hacer mucho desde esa tribuna. Pueden por ejemplo incluir artículos en que se hable de nuestros adelantos, nuestros problemas, nuestros triunfos y aspiraciones. Pero poner siempre a la cabeza, aun cuando en un solo artículo por entrega, un título similar a estos: "PROGRESO INDUSTRIAL DE COLOMBIA" o "COLOMBIA PUERTA INDUSTRIAL SUDAMERICANA". 51

En su concepto, Ortiz echaba de menos una reflexión más crítica de la realidad económica cercana. Al igual que Industria Colombiana o la Revista del Petróleo, Integral Industrial presentaba una constante documentación de avances extranjeros (particularmente en el campo de la química); así, varias de sus notas editoriales o reportajes tuvieron como centro de discusión los casos de laboratorios canadienses, alemanes o suecos que, además de ser novedades científicas, buscaban cumplir una función pedagógica que permitiera aplicar tales invenciones en fábricas nacionales. En este sentido, es comprensible que la opinión de Ortiz, al enunciarse desde un país simpatizante de las políticas cepalinas como México, aconsejara un sentido de pertenencia más fuerte hacia “lo propio". Del mismo modo, también es comprensible la poca sorpresa suscitada por revistas como Integral Industrial y su preferencia por el componente tecnológico del "primer mundo". Aquí, insisto en la dificultad que implica comprender la formación del gremio industrial colombiano al margen de la referencia norteamericana o europea y su propósito instructivo. De hecho, no era una materia exclusiva de revistas, ya que llamó la atención de empresarios a cargo de lugares más prácticos para el aprendizaje. Así lo prueban los varios eventos en universidades, el patrocinio de la ANDI a estudiantes de ingeniería en el exterior y la creación del Instituto de Experimentación Industrial, en 1955, el cual, además de invitar técnicos de compañías internacionales, fundó bibliotecas con literatura científica actualizada por las mismas comunidades fabriles emuladas localmente.

Ahora, si hubo un conjunto de escenarios en los que el alcance de fotografías y revistas industriales fuera realmente provechoso, sin duda alguna fueron las exposiciones y ferias internacionales. Para Colombia, la década de los cincuenta estuvo marcada por numerosas participaciones en certámenes universales del desarrollo: verdaderas "vitrinas" del progreso que, al contar con la asistencia masiva de autoridades económicas y políticas, se transformaron paulatinamente en otro tema digno

51 Hugo Ortiz, “Carta a la dirección”, Integral Industrial, 7 de marzo de 1958, 58. 
de fotografiarse. Revisemos cronológicamente algunos casos: en 1953, el ministro de minas y petróleos, Pedro Nel Rueda Uribe, convocó el Congreso de Geólogos e Ingenieros, seguido de la Exposición Francesa, realizada en el Museo Nacional de Bogotá hacia 1954; en marzo de 1955, varias publicaciones informaron los requisitos para acudir a la XxxIII Feria Muestrario Internacional de Valencia; al año siguiente (1956), el Comité Intergubernamental para las Migraciones Europeas (CIME) preparó en Ginebra una exhibición especial sobre Colombia e invitó a revistas como Industria Colombiana a enviar algunos ejemplares para el conocimiento de los delegados. ${ }^{52}$ Por último, ese mismo año, la firma alemana Riensch \& Held coordinó, desde su sucursal en Bogotá, las contribuciones nacionales para presentarse en la Feria Industrial de Hannover.

De todos estos proyectos globales, el más ambicioso para los industriales colombianos fue la Feria Exposición Internacional (figura 12), evento financiado por la Asociación Colombiana de Medianas y Pequeñas Industrias (Acopi) y el Banco Popular, para el cual se levantó el Centro de Negocios y Exposiciones (actual Corferias). Sus dos primeras versiones (1954 y 1955) contaron con la asistencia de 25 naciones, 100.000 visitantes y 1127 stands, con adelantos de todas las regiones y sectores manufactureros. ${ }^{53} \mathrm{La}$ feria deslumbró al público con sus cifras - incluso al presidente Gustavo Rojas Pinilla y parte de su gabinete (figura 13) —, pero también con su organización logística; de esta manera, se convirtió en un certamen que, según analistas, arquitectos y decoradores, muy poco debía envidiar a los pabellones de Europa y Estados Unidos con respecto a sus estructuras, iluminación y variedad.

A manera de cierre para este breve y último apartado, las exposiciones pueden entenderse como espacios donde llegó a desdibujarse la frontera entre los niveles internos y externos de la representación gremial. El proyecto de la industrialización nacional encontró en estas una serie de plataformas legítimas y ostentosas para mostrar la identidad en construcción a públicos amplios que, en calidad de testigos, formularon opiniones cada vez más constantes sobre un grupo económico que, pocos años atrás, resultaba relativamente marginal ante los intereses del Estado y que ahora negociaba espacios de poder desde diferentes ámbitos.

52 Raymond Y. Rodié, "La revista Industria Colombiana invitada a una exposición internacional”, Industria Colombiana, 1 de febrero de 1956.

53 Fabio Malagón Londoño, “Segunda Feria Exposición Internacional”, Industria Colombiana, noviembre de 1955, 11. 


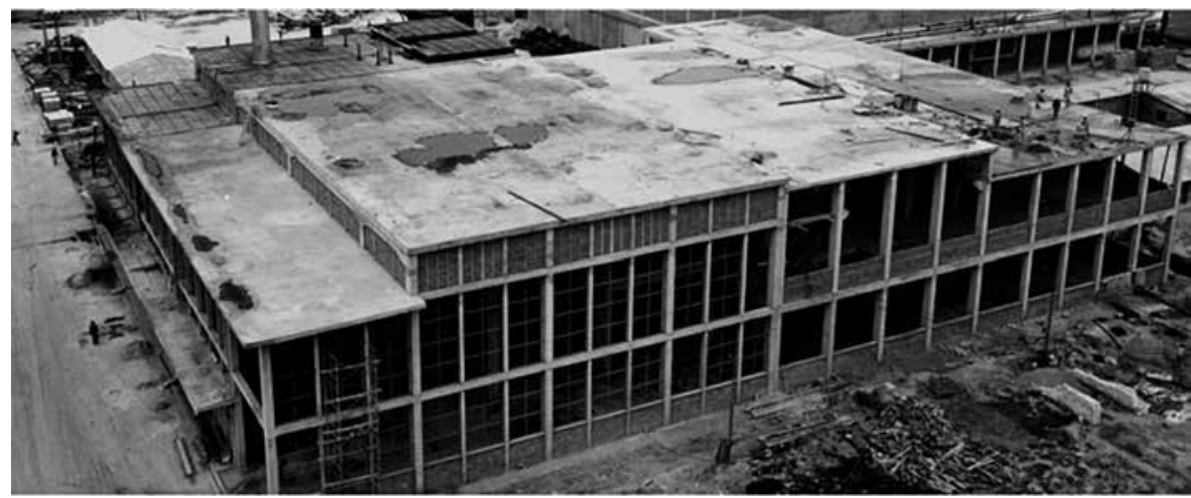

Figura 12. Anónimo, 1954, "Construcción del Centro de Negocios y Exposiciones (actual Corferias) para Primera Feria Exposición Internacional” (fotografía en la página web de Corferias, http://corferias.com/).

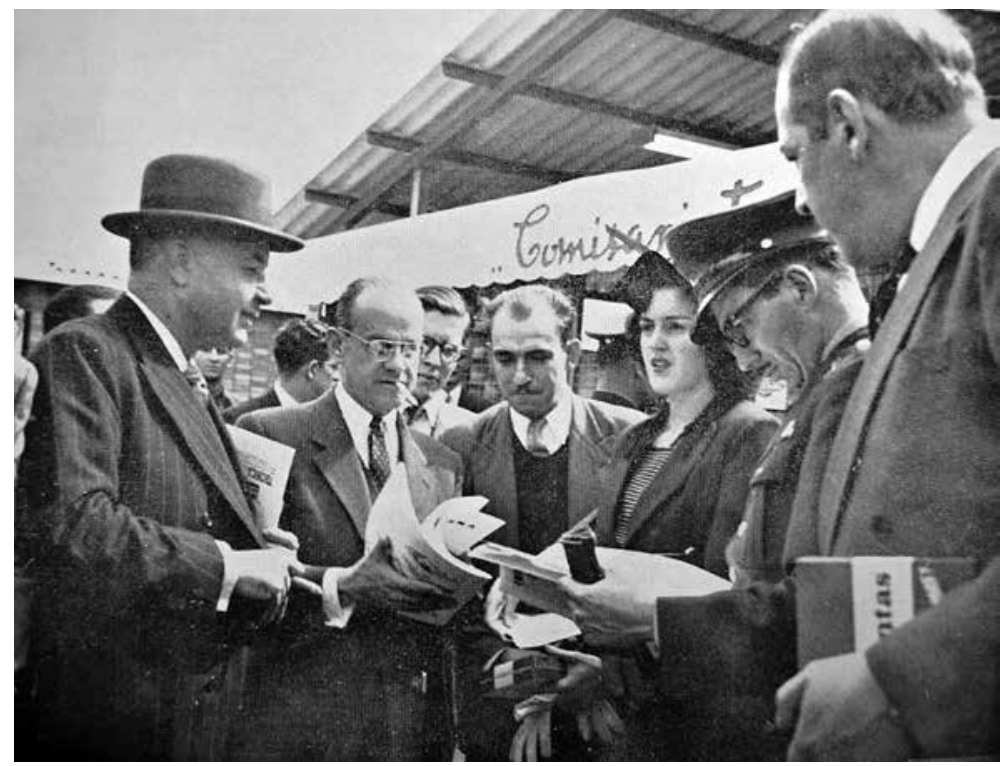

Figura 13. Fotopress Bogotá, 1954, "El canciller Evaristo Sourdis; el ministro de Hacienda, Carlos Villaveces; Gabriel Baraya, gerente de Industria Colombiana; Agustín Gastaminza, redactor jefe de Industria Colombiana; María Eugenia Rojas Correa; coronel Ruiz Novoa, contralor general de la República, y Luis Caro Escallón, ministro de Justicia, comentan en amigable charla el último número de la mencionada revista Industria Colombiana, durante la reciente visita de Su Excelencia, el Presidente de la República, a la Primera Feria Exposición Internacional de Bogotá” (fotografía, Biblioteca Nacional de Colombia, Hemeroteca Manuel del Socorro Rodríguez Bogotá). 


\section{Consideraciones finales}

A mediados del siglo $\mathrm{xx}$, las élites industriales colombianas pasaron de ser un grupo disperso de familias con leves inversiones en las manufacturas a ser un gremio institucionalizado. En buena medida, su posicionamiento puede explicarse por impulsos externos, como la segunda bonanza cafetera (1950-1954) o la inclinación generalizada de las naciones latinoamericanas por modernizar sus economías en el marco de la posguerra. ${ }^{54}$ Sin embargo, aún reciben poca atención historiográfica las estrategias internas mediante las cuales la incipiente comunidad fabril buscó unificar sus agendas para llevar su fortalecimiento más allá de una coyuntura geopolítica. Aparte del cabildeo o la propaganda masiva, elementos mencionados en la literatura disponible, aún falta un rastreo más extenso de aquellos mecanismos íntimos utilizados por los mismos industriales para designar un sentido a su agremiación y su propuesta de desarrollo; solo al definir dicho sentido y articular sus intereses bajo una imagen sólida de grupo, estos podrían proyectarse exitosamente ante la opinión pública y la escena política.

Aunque fueron varios los recursos empleados para afianzar la identificación de los empresarios manufactureros con su colectividad, me interesaban las posibilidades técnicas que ofreció la fotografía para personalizar y significar la emergente industrialización nacional y, así, sustentar un proyecto de representación gremial. Considero que tal proyecto fue deliberado, ya que, detrás del estilo documental utilizado en las publicaciones del sector fabril, hubo un ejercicio sistemático de producción, selección y reproducción de imágenes con pautas particulares. En este orden, la fotografía logró condensar ciertas nociones o referencias visuales asociadas a la industria, al fijarlas como elementos de reconocimiento y, al mismo tiempo, de distinción. De reconocimiento, en la medida que exaltó las rutinas, espacios y conquistas de un proceso asimilado por sus artífices como "propio" o "compartido". De distinción, por su parte, en cuanto privilegió una estética cercana a las dinámicas industriales, así como contrapuesta a otros rubros productivos, como el agro. Destacar la similitud y valerse de la diferencia; ambos fueron procedimientos para escenificar un adentro y un afuera del gremio: crear, en términos de Stuart Hall, un "efecto de frontera", indispensable para legitimar la identidad.5

54 Carlos Caballero Argáez, "Café, industria y política económica: ¿quién manejó la economía colombiana entre 1930 y 1990?” (ponencia, Universidad de los Andes, 13 de noviembre de 2015). 
Una vez más, cabe advertir que la lectura de las fuentes estudiadas no estaría completa sin la inclusión de los soportes materiales en las que se publicaron, es decir, revistas y boletines (algunas más cercanas a la ANDI que otras), los cuales operaron como espacios de sociabilidad y de alfabetización técnica entre colegas. Esto vuelve esencial el concepto de ensamblaje para pensar la identidad en cuestión, ya que denota un proceso de intercambios, ajustes y contribuciones a la autorrepresentación ejercida por empresarios de distintos campos y criterios.

Así, pareciera presentarse una doble reflexión. La primera invita a complejizar la mirada histórica de agentes económicos como los gremios, al abrir la posibilidad de verlos también como productores de significados y nociones de su sociedad. La segunda, de corte más metodológico, sugiere una disposición diferente frente a la fotografía, la cual, en lugar de "ilustrar" el pasado, motiva a indagar innumerables operaciones codificadas bajo un imaginario de transparencia documental.

\section{Bibliografía}

\section{Fuentes primarias}

\section{Imágenes}

Biblioteca Luis Ángel Arango, Bogotá.

Biblioteca Nacional de Colombia, Bogotá.

“Corferias", Corferias Bogotá-Centro Internacional de Negocios. http://corferias. $\mathrm{com} /$.

\section{Libros}

Departamento Nacional de Estadística. Primer Censo Industrial de Colombia: 1945. Bogotá: Imprenta Nacional, 1947.

\section{Publicaciones periódicas}

El Tiempo. Bogotá, 1959.

Industria Colombiana. Bogotá, 1954-1960.

Industrias Colombianas: transportes, comercio, trabajo. Bogotá, 1953-1954.

Integral Industrial. Medellín, 1956-1960.

Quimica e Industria. Bogotá, 1949-1951.

Revista del Petróleo. Bogotá, 1950-1955. 


\section{Fuentes secundarias}

Brando, Carlos. "La industrialización a medias”. En Nueva historia económica de Colombia, editado por Salomón Kalmanovitz, 197-213. Bogotá: Taurus; Universidad Jorge Tadeo Lozano, 2010.

Bejarano, Jesús Antonio. “Industrialización y política económica (1950-1976)”. En Colombia hoy, editado por Mario Arrubla, 221-270. Bogotá: Siglo XXI, 1985.

Berman, Marshall. Todo lo sólido se desvanece en el aire: la experiencia de la modernidad. Buenos Aires: Siglo XXI, 1989.

Caballero, Carlos. "Café, industria y política económica: ¿Quién manejó la economía colombiana entre 1930 y 1990 ?". Ponencia presentada en el Seminario de Historia Empresarial y Económica dirigido por el Grupo de Historia y Empresariado de la Universidad de los Andes, Bogotá, Colombia, 13 de noviembre de 2015.

Castro Gómez, Santiago. Tejidos oníricos: movilidad, capitalismo y biopolitica en Bogotá (1910-1930). Bogotá: Pontificia Universidad Javeriana, 2009.

Cornejo, Tomás. "Fotografía como factor de modernidad: territorio, trabajo y trabajadores en el cambio de siglo". Historia, n. 45 (2012): 5-48.

Dávila, Carlos. Empresariado en Colombia: perspectiva histórica y regional. Bogotá: Universidad de los Andes, 2012.

Farnsworth-Alvear, Ann. Dulcinea in the Factory: Myths, Morals, Men, and Women in Colombia's Industrial Experiment, 1905-1960. Durham: Duke University Press, 2000.

Foss, Lene. "Going against the Grain... Construction of Entrepreneurial Identity through Narratives". En Narrative and Discursive Approaches in Entrepreneurship, editado por Daniel Hjorth y Chris Steyaert, 80-104. Cheltenham: Edward Elgar, 2004.

González Stephan, Beatriz. "Las tarjetas de visita: racialidad y disciplinamiento de ciudadanías blanqueadas en la pardocracia venezolana”. En La nación expuesta: cultura visual y procesos de formación de la nación en América Latina, editado por Sven Schuster, 123-151. Bogotá: Universidad del Rosario, 2014.

Hall, Stuart y Paul du Gay. Cuestiones de identidad cultural. Buenos Aires: Amorrortu, 2003.

Hjorth, Daniel y Chris Steyaert, eds. Narrative and Discursive Approaches in Entrepreneurship. Cheltenham: Edward Elgar, 2004. 
Ledo, Margarita. Documentalismo fotográfico: éxodos e identidad. Madrid: Cátedra, 1998.

León, Paulo César. "La literatura sobre la industrialización colombiana: balance y perspectivas”. Innovar, n. 23 (2004): 182-207.

Lindgren, Monica y Johann Packendorff. "Social constructionism and entrepreneurship: Basic assumptions and consequences for theory and research". International Journal of Entrepreneurial Behavior \& Research 15, n. 1 (2009): $25-47$.

López Uribe, María del Pilar. Salarios, vida cotidiana y condiciones de vida en Bogotá durante la primera mitad del siglo XX. Bogotá: Universidad de los Andes, 2011.

Lugon, Olivier. El estilo documental: de August Sander a Walker Evans (1920-1945). Salamanca: Universidad de Salamanca, 2010.

Maldonado, Alexander. "La evolución del crecimiento industrial y transformación productiva en Colombia 1970-2005: patrones y determinantes". Tesis de Maestría en Economía. Universidad Nacional de Colombia, Bogotá, 2010.

Mayor Mora, Alberto. Ética, trabajo y productividad en Antioquia: una interpretación sociológica sobre la influencia de la Escuela Nacional de Minas en la vida, costumbres e industrialización regionales. Bogotá: Tercer Mundo, 1989.

Mitchell, W. J. T. Landscape and Power. Chicago: The University of Chicago Press, 2002.

Mumford, Lewis. Técnica y civilización. Madrid: Alianza, 1971.

Pantoja, Antonio. "La imagen como escritura: el discurso visual para la historia". Norba. Revista de Historia n. $^{\circ} 20$ (2007): 185-208.

Peralta, Victoria. Distinciones y exclusiones: en busca de cambios culturales en Bogotá durante las repúblicas liberales: una historia cultural de Bogotá (1930-1946). Bogotá: Academia Colombiana de Historia, 2013.

Pérez Pinzón, Luis Rubén. "Perspectivas historiográficas sobre la historia empresarial del nororiente de Colombia”. Ponencia presentada en el Seminario de Historia Empresarial y Económica dirigido por el Grupo de Historia y Empresariado de la Universidad de los Andes, Bogotá, Colombia, 27 de febrero de 2015.

Posada, Juan Esteban. "La promesa del capitalismo en Medellín (Colombia, 19391962)”. Historia Critica, n. ${ }^{\circ} 57$ (2015): 141-160.

Rodríguez, Juan Camilo. Historia de la Empresa de Energía de Bogotá. Bogotá: Universidad Externado de Colombia, 2000. 
Sachs, Wolfgang, ed. The Development Dictionary: A Guide to Knowledge as Power. New York: Zed Books, 2010.

Sachse, Rolf. "Architectural Photography”. En Encyclopedia of Twentieth-Century Photography, editado por Lynne Warren, 56-63. New York: Taylor \& Francis, 2006, 56-63.

Sáenz Rovner, Eduardo. La ofensiva empresarial: industriales, politicos y violencia en los años 40 en Colombia, 2a ed. Bogotá: Universidad Nacional de Colombia, 2007.

Serrano, Eduardo. Historia de la fotografía en Colombia (1950-2000). Bogotá: Planeta, 2006.

Tirado, Álvaro. “Teorías y conceptos para analizar las organizaciones gremiales de empresarios". Revista Mexicana de Sociología 77, n. 3 (2015): 467-495.

Villamizar, Juan Carlos. Pensamiento económico en Colombia: construcción de un saber (1948-1970). Bogotá: Universidad del Rosario, 2013.

Villaveces, Juanita. Caricatura económica en Colombia 1880-2008. Bogotá: Universidad del Rosario, 2010.

Wade, Peter. "Identidad”. En Palabras para desarmar, editado por Margarita Serge, María Cristina Suaza y Roberto Pineda, 255-264. Bogotá: Ministerio de Cultura e Instituto Colombiano de Antropología e Historia (ICANH), 2002, 255-264.

Wojno Kiefer, Geraldine. "Industrial Photography”. En Encyclopedia of TwentiethCentury Photography, editado por Lynne Warren, 781-786. New York: Taylor \& Francis, 2006. 


\section{Imágenes para la nación}




\title{
La Pola, alegoría de la nación: memorias y silencios en las representaciones de Policarpa Salavarrieta
}

\author{
DANiEla Prada
}

Recientemente en Colombia, la televisión nacional se ha convertido en el medio más exitoso para retratar o, quizá, caricaturizar la historia convulsionada del país. Ejemplos hay muchos, pero pocos tan notorios como el surgido en el 2010, cuando con motivo del bicentenario de la Independencia nacional, la telenovela La Pola, amar la hizo libre, dirigida por Sergio Cabrera y proyectada por la cadena de televisión RCN, salió al aire. En esta, la vida de Policarpa Salavarrieta fue presentada de forma lineal desde su adolescencia hasta su muerte. La telenovela transcurría durante el proceso de Independencia, los primeros veinte años del siglo XIX; allíse mostraba cómo ser patriota o realista definiría el destino de los personajes durante la trama. Aunque la producción deseaba rescatar los aspectos políticos del proceso, el verdadero enfoque estaba en la vida privada y amorosa de dichos personajes. La narrativa estaba influenciada por una idea romántica de la Independencia atada a los ideales de libertad e igualdad; las pasiones de los protagonistas los llevarían hasta las últimas consecuencias. En este contexto, morir por la causa patriota era el más grande honor y una verdadera manifestación de libertad. Policarpa era representada como la heroína más grande de la lucha anticolonial, una mujer audaz y sensual que lograba desarrollar su función de espía y colaboradora de los ejércitos patriotas gracias a su inteligencia y belleza. Caracterizada por su romanticismo, Salavarrieta aparece en la telenovela como aquella quien, como sujeto político, decide ser fusilada por sus ideales, y como mujer, decide morir por su verdadero amor, Alejo Savaraín. Bajo esta descripción, se muestra a una Pola que sobrepasa los límites sociales y políticos designados a su género en la época y persigue los principios de su causa: es amiga de los marginados y está dispuesta a morir por lo que cree y ama. 
Ese mismo año, la revista colombiana Soho (Solo Hombres) decidió conmemorar en su portada de octubre a la prócer de la Independencia, a través de una exposición fotográfica que evocara su heroísmo y belleza. La Pola erótica se llamó el conjunto de fotografías en el que la modelo Eliana Franco representó los episodios más emblemáticos del personaje histórico, a través de la desnudez y la sensualidad. En el momento de ser fusilada, esta Pola aparece desnuda, atada y con un rostro extasiado por alcanzar el más grande honor: morir por el nacimiento de la patria anhelada.

Cien años atrás, en 1910, Bavaria puso en circulación la edición conmemorativa del centenario de la Independencia. En la publicidad de la cerveza se mostraba a Policarpa envuelta en la bandera tricolor, con la mano izquierda en alto y con la derecha en el corazón. La bandera aparece clavada en la tierra, junto a las monedas de oro que tienen grabados símbolos nacionales como el escudo y el gorro frigio. Sin duda, dicha publicidad es una fiel alegoría de la República; Policarpa representa a Colombia, una mujer espigada de vestido largo, con una mano en la bandera (la misma en la que se envuelve) y la otra mano dirigida hacia el cielo (figura 1): es la Marianne colombiana. Las hojas de laurel simbolizan la victoria, y el gorro frigio, la libertad, la razón y el republicanismo. Cabe recordar que poco tiempo antes (18781904), Rafael Núñez y Miguel Antonio Caro habían buscado la consolidación de la nación mediante la unificación de las regiones bajo símbolos comunes, lo que llevó a establecer una bandera, un himno, una sola moneda y la creación del Banco Nacional. Igualmente, Caro impulsó durante su administración la nacionalización de licores. Esto hizo que la industria cervecera se consolidara a finales del siglo XIX y comienzos del xx, remplazara bebidas alcohólicas tradicionales como la chichay el guarapo - criminalizadas posteriormente - y se convirtiera en parte importante del proyecto modernizador de la nación. ${ }^{1}$ Así, para 1910, la cerveza La Pola no solo representaba la imagen de una república sólida, sino la transformación "radical" de Colombia en diferentes ámbitos: las instituciones fuertes, la industrialización de la economía y un prospecto novedoso de ciudadanos conformaron el emergente imaginario de la nación moderna.

1 Para profundizar en este argumento véase: Mauricio Archila, Cultura e identidad obrera: Colombia 1910-1945 (Bogotá: Cinep, 1992); William Ramírez, "La crónica roja en Bogotá, Historia Crítica, n. ${ }^{\circ} 21$ (2001): 111-126. 


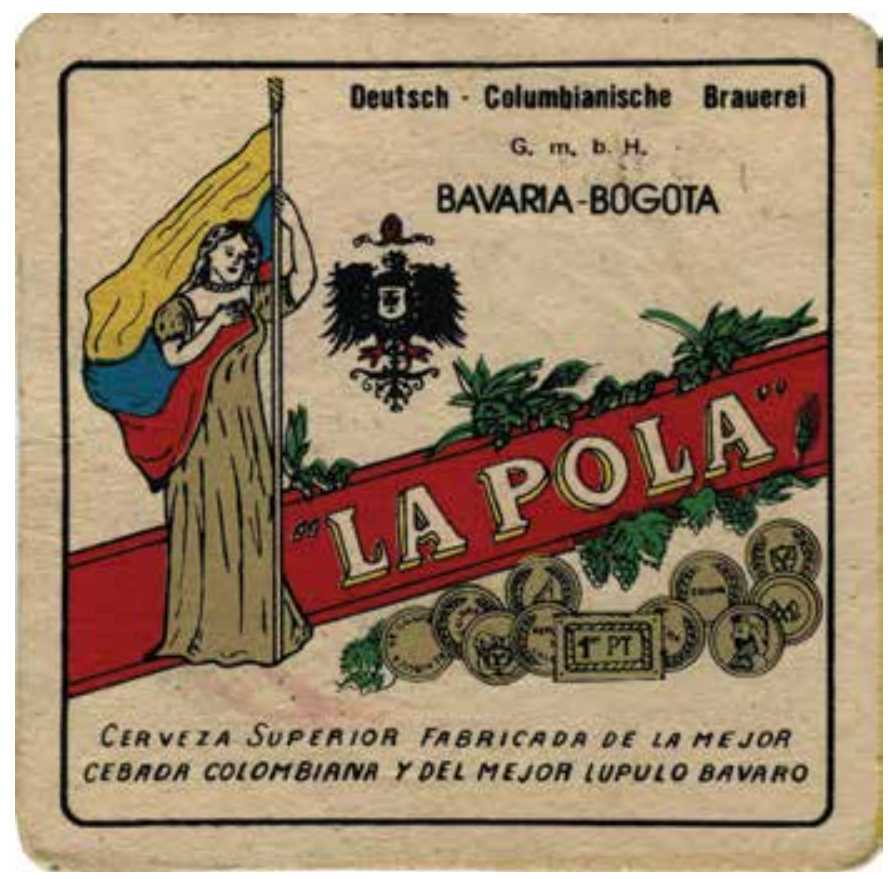

Figura 1. Deutsch Kolumbianische Brauerei G. m.b.H/Bavaria-Bogotá, 1910, "Portavaso publicitario de Cerveza La Pola" (tinta de impresión/cartón, $9 \times 9 \mathrm{~cm}$, Museo Nacional de Colombia, Bogotá, número de registro: 6595).

Como relata Germán Arciniegas, todo en Colombia se movía, a fin de buscarle nuevos rumbos al Estado. En 1910 se dejaba el enfrentamiento feroz que había puesto a caminar a los colombianos con la sangre a los tobillos. Se tenía la sensación de una nueva América, cosa común a casi todo un continente cansado ya de la barbarie del XIX. ${ }^{2}$ Ciertamente, la conmemoración del centenario se presentaba como la oportunidad de rehacer los fundamentos de la patria, de fortalecer los lazos de unidad nacional y de dejar atrás el horror de la guerra civil, la miseria en el campo y las ciudades, y las radicalidades de los odios políticos. El centenario era el escenario que el país necesitaba para refundirse y presentarse como una comunidad política sólida y con un porvenir prometedor. En este contexto, la participación activa de las academias profesionales y de las facultades universitarias les dio a las conmemoraciones una dimensión pedagógica en aras de enseñar e instruir a los nuevos ciudadanos. En unas y otras se escucharon conferencias magistrales sobre los temas asociados con la Independencia. Además, se organizaron concursos para la

2 Germán Arciniegas, “1910”, El Tiempo, Bogotá, 15 de agosto de 1996. 
publicación de libros oficiales sobre geografía, medicina, jurisprudencia e historia; este último, ganado por José María Henao y Gerardo Arrubla, autores del Manual de historia de Colombia, que desde entonces se convirtió en el texto clásico bajo el cual se educaron varias generaciones en las décadas subsiguientes. ${ }^{3}$

Se entendía que uno de los elementos esenciales para contribuir a la construcción de la nacionalidad era la enseñanza de la historia. Este fue el momento de Henao y Arrubla. No solo el jurado calificador, sino también la recién creada Academia Colombiana de Historia y el mismo Gobierno destacaron desde un comienzo las virtudes pedagógicas de la obra, aduciendo, entre otros aspectos, la "claridad y método" de la exposición, el respeto a la "verdad histórica”, la "imparcialidad" en relación con las agrupaciones partidistas y "el santo amor a la Patria" que buscaba inculcar. ${ }^{4}$ En el Manual se dedicaron tres páginas al relato sobre Policarpa; estas hojas la inmortalizaron como la heroína de la patria: "Esta heroína de carácter altivo, de buena inteligencia, [que] conspiraba en Santa Fe contra el régimen español". La misma a la que "las cajas de guerra [le] apagaron su voz, seis balazos [le] arrancaron la vida y eternizaron [su] memoria". ${ }^{5}$ Es interesante ver cómo, aunque la patria hace referencia a los 'padres' que han surgido de ella y que, de alguna forma, la han cimentado y dotado de sentido, en la conmemoración hay espacio para una 'madre', para la figura femenina de la mártir, pero sobre todo de la prócer. Morir por la patria no es un sacrificio, sino el más solemne de los deberes. En el Manual y en la conmemoración Policarpa tiene el mismo estatus que Bolívar o Santander, es su par y compatriota de digno reconocimiento.

Curiosamente, hacia 1810 no existía representación alguna de la Pola, ya que no se le realizaron imágenes mientras estuvo viva. Solo hasta 1857 se conoce un conjunto de pinturas que José María Espinosa elaboró de la mujer. Espinosa es el pintor clave de Policarpa, al crear un grupo de obras inéditas que fueron retomadas por los artistas venideros, entre ellos, Epifanio Garay. De modo que la iconografía de la prócer es un objeto de estudio histórico sugerente, sobre todo porque su imagen ha trascendido la fuente originaria. En otras palabras, sus representaciones visuales

3 Eduardo Posada Carbó, “1910: la celebración del primer centenario en Colombia”, Revista de Indias 73, n. ${ }^{\circ} 258$ (2013): 582.

4 Bernardo Tovar, "Jesús María Henao y Gerardo Arrubla: nueva lectura de una vieja Historia de Colombia”, Revista Credencial Historia, n. ${ }^{\circ} 115$ (1999): 3 .

5 Jesús María Henao y Gerardo Arrubla, Historia de Colombia para la enseñanza secundaria, 2 vols. (Bogotá: Escuela Tipográfica Salesiana, 1911), 356. 
han encontrado significaciones que no se agotan en la referencia textual presente en la imagen. ${ }^{6}$ Por el contrario, estas se extienden a un ámbito interpretativo, que obliga al investigador a preguntarse por su historia, por el contexto de origen y sus implicaciones prácticas. Adicionalmente, las representaciones de la Pola no solo datan de finales del siglo XIX, sino que se han actualizado a lo largo del proceso de construcción de la nación colombiana; incluso han llegado hasta la actualidad a través de telenovelas, propagandas de cervezas, loterías, medallas, recordatorios, literatura, pinturas, grabados, entre otros. ${ }^{7}$

El concepto de representación en los estudios históricos ha sido objeto de debate desde el siglo XIX. Sin embargo, en los años noventa, con el fortalecimiento de la llamada historia cultural, Roger Chartier ofreció una compilación de ensayos que pretendían recoger las consideraciones más importantes sobre el término. Chartier empezó por definir la historia cultural como una aproximación a las complejas construcciones del significado; como un acercamiento teórico-metodológico que recoge la historia de las representaciones y las prácticas, la historia de las formas y los mecanismos simbólicos mediante los cuales las comunidades perciben y comprenden tanto su sociedad como su historia. En resumen, se trata de ver la historia como "los modos de articulación entre las obras o las prácticas y el mundo social, sensibles a la vez a la pluralidad de divergencias que atraviesa una sociedad y a la diversidad de empleo de materiales o códigos compartidos". ${ }^{8}$ Las representaciones son, recogiendo los aportes del renombrado historiador, gobiernos de interpretación que condicionan la relación con el mundo, con los otros, que orientan y regulan las conductas. Son, por lo tanto, formas de conocimiento y comprensión basadas en la percepción de fenómenos a partir de las interacciones sociales. Cabe anotar que, según Chartier, existen dos vías para entender las representaciones colectivas: una piensa la construcción de las identidades sociales como resultantes de una relación forzada entre las representaciones hegemónicas (impuestas por los agentes o instituciones con el poder de designar la definición

6 Huber Damisch, “Semiotics and Iconography”, en The Art of Art History: A Critical Anthology, ed. por Donald Preziosi (New York: Oxford University Press, 2009), 237.

7 Para consultar la catalogación de representaciones de Policarpa, véase Museo Nacional de Colombia, Policarpa 200. Exposición Conmemorativa del Bicentenario del Nacimiento de Policarpa Salavarrieta, serie Cuadernos Iconográficos del Museo Nacional, n. ${ }^{\circ} 1$ (Bogotá: Museo Nacional de Colombia, 1996).

8 Roger Chartier, Elmundo como representación. Historia cultural: entre práctica y representación (Barcelona: Gedisa, 1992), 50. 
sobre algo o alguien); la otra considera la representación que un grupo hace de sí mismo, es decir, el reconocimiento de su existencia como comunidad a partir de una exhibición de este como unidad homogénea. ${ }^{9}$ Un ejemplo de lo último es la construcción discursiva de "lo colombiano" (la colombianidad), lo cual también articula prácticas alrededor de este presupuesto.

Construir la noción de representación como el instrumento esencial del análisis cultural, implica otorgarle una pertinencia operatoria; también implica explorar de qué modo ciertas concepciones del pasado elaboran significados sobre este, muchas veces, con base en las demandas del presente. Para Chartier, el concepto de representación se distingue por dos sentidos aparentemente contradictorios: por un lado, este siempre contiene una ausencia, es decir, un vacío entre aquello que se representa (el “original”) y lo que es representado. Por otro, la representación es la exhibición de una presencia, la exposición pública de una cosa o una persona. Estos dos sentidos se encuentran de la siguiente forma: 1) la representación como categoría de análisis se convierte en el instrumento de un conocimiento que hace ver un objeto ausente y lo sustituye por una imagen capaz de volverlo a la memoria y de mostrarlo "tal cual es". Un ejemplo de esto es el propósito de la mencionada telenovela La Pola de RCN, la cual buscaba presentar a los colombianos quién era Policarpa, cómo lucía, qué hacía y cuáles episodios de su vida merecían ser recordados. La producción televisiva intentaba retratar a la Pola y a su época a través de una trama rápida y un argumento con el cual familiarizar a la audiencia. Ciertamente, la distinción entre lo que esta representa y lo que es representado no solo se manifiesta en la diferencia temporal que existe entre el hecho histórico y los doscientos años que lo separan de la telenovela, sino en la escogencia misma de las narrativas por parte de los libretistas para traer a la memoria cierta imagen de Policarpa. 2) La segunda vía, en la que se encuentran los dos sentidos mencionados, tiene que ver con la forma en que las imágenes representadas establecen relaciones simbólicas. En efecto, se presenta la desaparición de la violencia inmediata, ${ }^{10}$ remplazada por otro tipo de violencias "menos evidentes". Para Chartier, en este proceso de larga duración - el de la erradicación de la violencia convertida en monopolio del Estado- debemos inscribir la importancia creciente de las luchas de representación, cuyo propósito es el ordenamiento, la alineación y, por tanto, la jerarquización de la estructura social en sí. Esto implica que hoy, en algunos ejercicios de memoria

\footnotetext{
$9 \quad$ Ibid., 53.

10 Ibid., 54.
} 
histórica, se asuman como "historia nacional" ciertas narraciones exclusivas del pasado, que no solo esconden la responsabilidad y las violencias ejercidas por distintos sectores de la sociedad, sino que además buscan rememorar las necesidades e intereses del Estado, el sector privado y las élites.

Desde estos ordenamientos, la figura del héroe republicano se ha cimentado a lo largo de la historia de Colombia, mediante diversos registros de violencia. Me atrevo a enunciar los siguientes: 1) la violencia por la imposición de las instituciones a rememorar ciertos personajes y ciertos episodios de la Independencia; 2) la violencia de género por masculinizar el proceso independentista y la construcción de la nación; 3) la violencia por olvidar, relegar y silenciar actores sociales no considerados protagonistas de la historia. Para la mayor parte de la historiografía colombiana del siglo xx, la representación heroica ha estado revestida de pantalones, galardones militares y un lugar social distinguido. El héroe de la Independencia, generalmente, ha sido representado como un hombre-militar-oligarca. Tal comolo señala Beatriz González, la iconografía procera fue creada por quienes tuvieron la voluntad de difundir ciertas imágenes y, por medio de ellas, guardar memoria. Lo que hicieron los pintores e historiadores del siglo XIX se inscribe así en un programa de memoria y un estado de memoria. ${ }^{11}$ Se trata, por consiguiente, de un discurso inherentemente hegemónico, que incluye y excluye, que edifica sobre la base de la integración, supresión y jerarquización de las diferencias sociales, políticas, étnicas, entre otras. ${ }^{12}$ Estos discursos no solo se difunden por parte del Estado, sino por otros sectores influyentes en la sociedad como la misma academia. Jacques Le Goff decía que la memoria no solo era una conquista, sino un instrumento y una mira de poder. ${ }^{13}$ Precisamente, los estados de memoria conservan, actualizan y vinculan representaciones, significaciones y resignificaciones de visiones del pasado que han sido reorganizadas y proyectadas en la teleología nacional. Por ejemplo, para Henao y Arrubla, en la conmemoración del centenario "se ha[bía] querido resucitar a los hombres y a las sociedades que fueron [...], para presentar, en lo posible,

11 Beatriz González y Verónica Hanabergh, Manual de arte del siglo XIX en Colombia (Bogotá: Universidad de los Andes, 2013), 60.

12 Gonzalo Sánchez, "Introducción”, en Museo, memoria y nación: misión de los museos nacionales para los ciudadanos del futuro, ed. por Gonzalo Sánchez y María Emma Wills (Bogotá: Ministerio de Cultura; Museo Nacional de Colombia; PNUD; IEPRI; ICANH, 2000), 28.

13 Jacques Le Goff, El orden de la memoria (Barcelona: Paidós, 1997), 181. 
el pasado en sus diversas fases, y dar así vida a lo que debe imitarse, a los rasgos de virtud y heroísmo". ${ }^{14}$

El recuerdo de Policarpa Salavarrieta como heroína de las guerras de independencia ganó importancia a finales del siglo XIX e inicios del XX, especialmente con los trabajos de investigación de la Academia Colombiana de Historia, publicados en el Boletín de Historia y Antigüedades, ${ }^{15}$ una revista que, junto a diferentes conmemoraciones y actos alegóricos, reforzó el culto al personaje. En el arte, aquel tránsito entre siglos significó el remplazo de las figuras religiosas por aquellas de próceres y héroes de las luchas independentistas. En estas condiciones se inscribe la representación de Policarpa Salavarrieta, cuya presencia se opone a la tradicional configuración hegemónica del héroe, al figurar como una personificación femenina de libertad, igualdad y valentía. ${ }^{16}$ En este caso, resulta pertinente preguntarse por las modalidades de memoria que se han usado para representar a la Pola. Así, las preguntas que guían este capítulo tienen como fin responder cuáles han sido los criterios a lo largo de casi dos siglos para representar a Policarpa Salavarrieta y qué función han cumplido estas imágenes en el proceso de la formación nacional colombiana.

El texto se construyó a partir de tres grupos de fuentes primarias escogidas según la relevancia histórica que han tenido en los estudios iconográficos realizados sobre la Pola. El primero utiliza tres pinturas y una litografía; dos de las pinturas hacen parte del conjunto de retratos de José María Espinosa y la tercera es una reproducción de Epifanio Garay. La litografía hace parte de la colección de Celestino Martínez. El segundo grupo reúne billetes, monedas y estampillas de correo. El último se enfoca en las estatuas de Dionisio Cortés y Silvano Cuéllar, la primera antiguamente ubicada en la plaza de Las Aguas, en el centro de Bogotá, y la segunda ubicada en la plaza principal de Guaduas, Cundinamarca. A partir de estos conjuntos de fuentes, el objetivo fue analizar cómo se han entendido las representaciones de Policarpa y de qué forma se han utilizado para legitimar

\footnotetext{
14 Henao y Arrubla, Historia de Colombia, 3.

15 Algunas de estas investigaciones se encuentran en María Restrepo y Enrique Ortega, La Pola yacepara salvar la patria (Bogotá: Archivo Nacional, 1949); E. de Saldanha, "Detalles desconocidos sobre la Pola”, Boletín de Historia y Antigüedades 12, n. 133 (1918): 13-23.

16 Carolina Vanegas, Disputas simbólicas en la celebración del centenario de la Independencia de Colombia en Bogotá (Bogotá: Ministerio de Cultura, 2011), 87.
} 
memorias hegemónicas sobre la Independencia y los imaginarios de construcción del Estado-nación colombiano.

\section{Las primeras pinceladas}

José María Espinosa (1796-1883), quien también hacía parte de las guerrillas patriotas, ${ }^{17}$ fue el primer pintor — según la documentación- que representó a la Pola. Beatriz González, en Policarpa 200, hace un recuento detallado de las posibles fuentes escritas en las que Espinosa podría haberse basado para pintar a la mujer. Entre ellas se encuentran las Memorias de José Hilario López (1798-1869) y los relatos literarios de José María Caballero (1802-1819). Los elementos distintivos de estos testimonios enunciaban a una Policarpa con tez blanca, buenamoza, vestida de traje azul, con un mantón blanco y un sombrero de mimbre estilo cubano. Desde el punto de vista iconográfico, según González, en las pinturas sobre Salavarrieta hay dos estilos: el neoclásico y el romántico. El primero representa a una mujer serena, cercana a la muerte. El segundo enseña la valentía y el ánimo subversivo. En las obras de Espinosa predominó el tema de la heroína en prisión. Por ejemplo, en "La Pola en capilla" (figura 2), Espinosa decide representarla con el traje azul que mencionaba Caballero, el plan revolucionario sostenido en su mano derecha, un mantón blanco en la mano izquierda, el escapulario mariano, y al fondo, un guardia, quien, según las Memorias de López, es el mismo que custodia a la Pola y debe presenciar su trágico destino.

17 He decidido omitir la historia de Policarpa Salavarrieta, dada la especificidad del presente artículo. Sin embargo, para saldar las inquietudes del lector comentaré que la Pola nació en 1796 en Guaduas, aunque hay dudas sobre la exactitud de la fecha; la poca documentación disponible lo demuestra así. Durante la época de la llamada Reconquista española (1815-1819), la Pola sirvió como enlace de las guerrillas patriotas. A la edad de 21 años, en 1817, fue fusilada en el claustro del Colegio Mayor de Nuestra Señora del Rosario por el Real gobierno. 


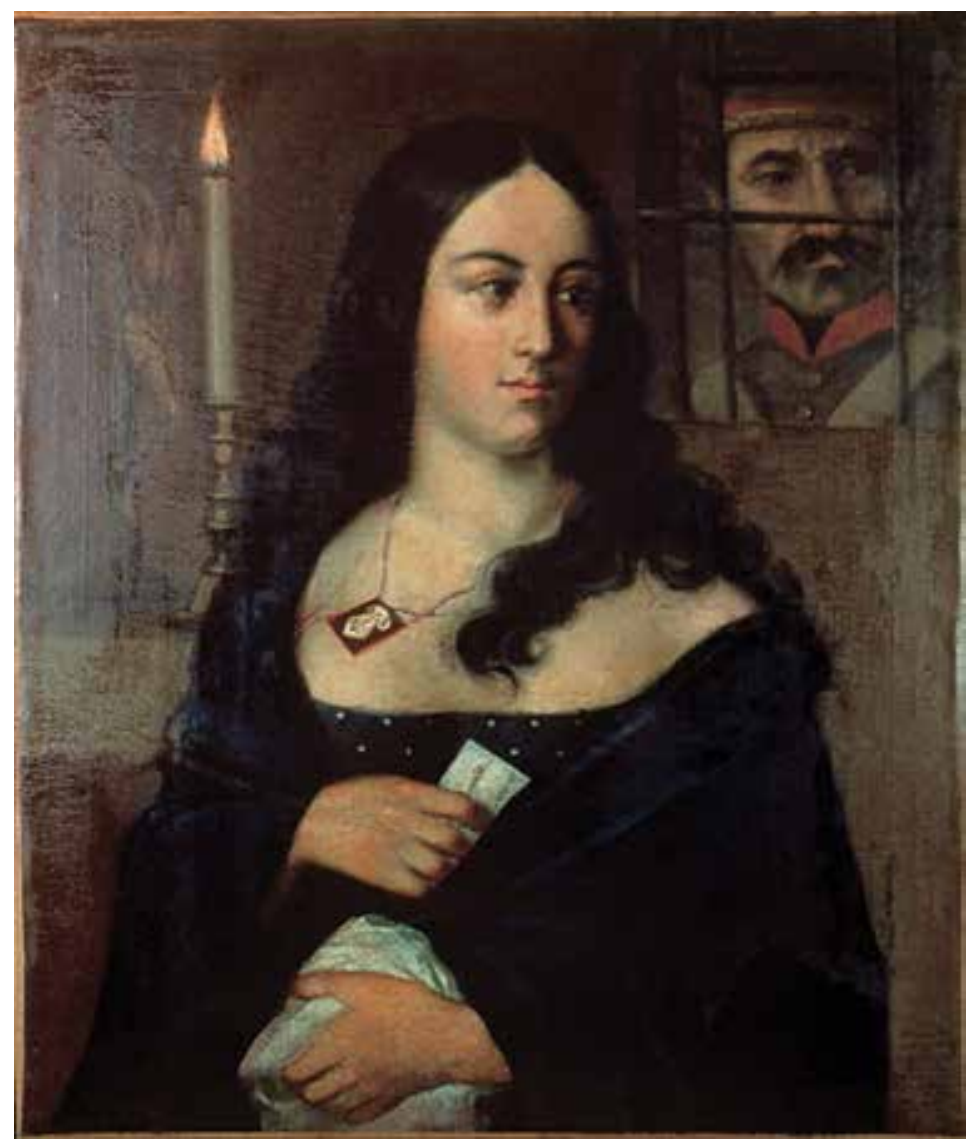

Figura 2. José María Espinosa, 1857, "La Pola en capilla” (óleo sobre tela, $80 \times 70 \mathrm{~cm}$, Museo Nacional de Colombia, Bogotá, número de registro: 233).

La segunda pintura más reseñada de Policarpa — también hecha por Espinosa - ha sido el retrato de busto donde se presenta a una mujer muy joven, con una belleza evidente, de tez blanca perlada y pómulos rosa. Titulada "Policarpa Salavarrieta" (figura 3), esta pintura traza el rostro del personaje muy sereno, despejado, casi estático. Con el tiempo, la imagen fue utilizada por el Banco de la República para la elaboración del actual billete de 10.000 pesos. Esta pintura es de las pocas que retrata a la Pola en un ambiente distinto a su encarcelamiento o fusilamiento. Aquí también desaparecen elementos como el escapulario, el plan de guerrillas, el guardia, etc. 


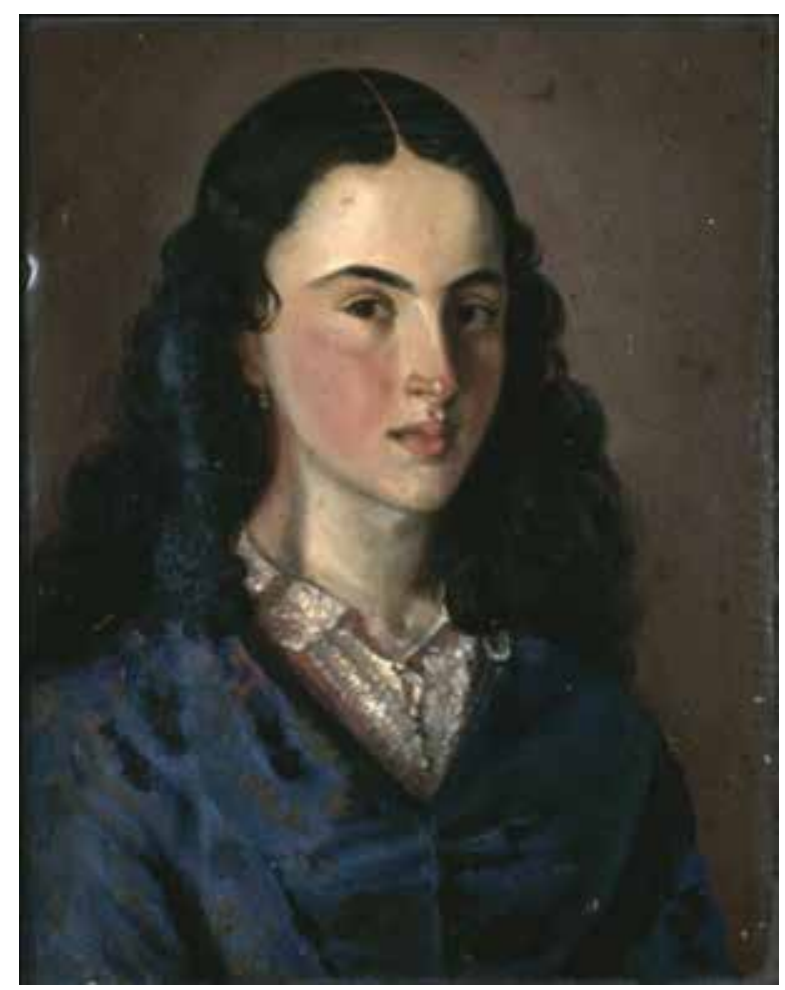

Figura 3. José María Espinosa, 1857, "Policarpa Salavarrieta” (óleo sobre tela, $34 \times 24,3 \mathrm{~cm}$, Museo Nacional de Colombia, Bogotá, número de registro: 2094).

Pasando a la representación de Epifanio Garay (1849-1903), debe señalarse que esta se basa en la que habría hecho su padre Narciso Garay, inspirada a su vez en "La Pola en capilla" de Espinosa (figura 4). En esta pintura hay algunas variaciones como el guardia, quien ahora aparece de cuerpo completo; la mesa que sostenía la vela en la pintura de Espinosa se trasforma en un altar; en la pared aparece un crucifijo y, además — como un elemento sugerente—, Policarpa deja de tener en la mano derecha el plan de las guerrillas para sostener una carta de amor de Alejo Savaraín. Con este elemento tan particular, la representación de Garay muestra a una Pola romántica, tranquila y conforme con su destino. Según González: “nada parece inquietar a esta mujer". 18

18 Beatriz González, "La iconografía de Policarpa Salavarrieta", en Policarpa 200: Exposición conmemorativa del bicentenario del nacimiento de Policarpa Salavarrieta, ed. por Martha Segura (Bogotá: Museo Nacional de Colombia, 1996), 32. 


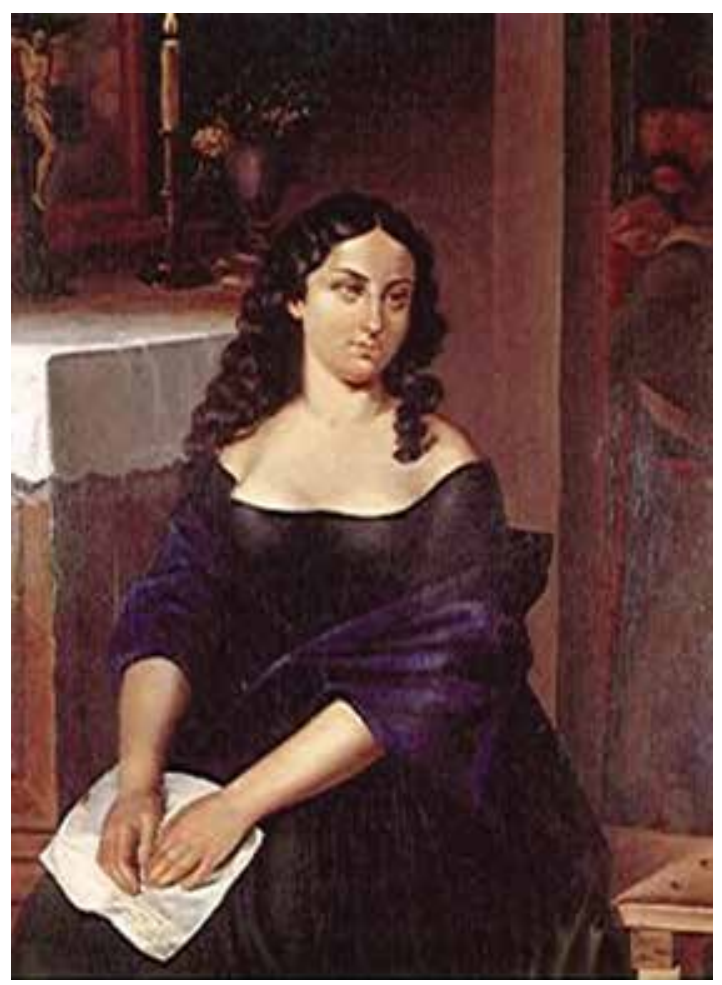

Figura 4. Epifanio Garay, 1890, "La Pola en capilla” (óleo sobre tela, $129 \times 93,5$ cm, Museo Nacional de Colombia, Bogotá, número de registro: 355$)$.

La última imagen que hace parte de esta selección es un dibujo litográfico procedente de la colección de Celestino Martínez (1820-1885). En este se presenta un retrato de medio cuerpo de la Pola, donde los atributos físicos son notablemente diferentes de los que escoge Espinosa (figura 5). En lugar del escapulario mariano hay un camafeo, su rostro está inclinado, su mirada es adusta y el ceño está fruncido. Los gestos faciales se distancian considerablemente de las pinturas anteriores. Adicionalmente, el vestido se bogotaniza; a pesar de que Policarpa fuera de Guaduas, la obra de Martínez añade a su indumentaria el cuello tipo "bandeja”, de uso más frecuente en las mujeres capitalinas. De esta manera, Salavarrieta aparece mucho más cubierta y con un rostro más expresivo. A diferencia de las piezas anteriores, la litografía proyecta una disposición diferente de la Pola, quien porta un escapulario o medallón en su cuello y manifiesta cierta actitud de resignación, presente tanto en su expresión como en su misma postura. 


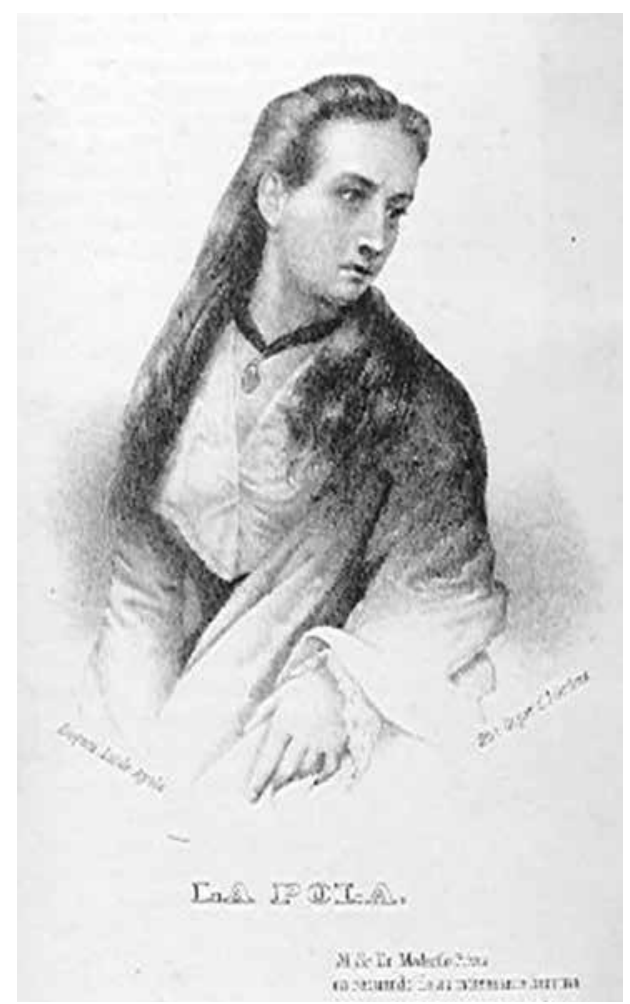

Figura 5. Celestino Martínez, 1850, "La Pola" (litografía, $26 \times 16 \mathrm{~cm}$, impreso en Medardo Rivas, La Pola. Drama histórico en cinco actos. A la memoria de los próceres de la Independencia [Bogotá, Imprenta y Estereotipia de Medardo Rivas, 1871], s. p.).

Hasta aquí la lectura se ha concentrado en la variación de los elementos iconográficos dentro de las pinturas que perfilan y conforman la figura de la Pola. No obstante, aún no nos hemos aproximado a la compresión de las representaciones de Policarpa en su pasado mismo. ${ }^{19}$ Gran parte de los estudios de la artista e historiadora Beatriz González sobre este tema se han concentrado en inventariar las obras donde figura el personaje en cuestión y, en buena medida, en rastrear las formas estilísticas de cada representación, prestándole mucha atención a los elementos que se mantienen y a los que dejan de utilizarse. Sin embargo, más allá de la aplicación de un método iconológico e incluso reconstructivo por parte de González, pocos

19 Georges Didi-Huberman, Ante el tiempo: historia del arte y anacronismo de las imágenes (Buenos Aires: Adriana Hidalgo, 2006), 36. 
han sido los aportes investigativos sobre la función social de las imágenes y representaciones de la Pola inscritas en soportes como pinturas o grabados.

Gran parte de la historiografía sobre el arte en la Colonia y el periodo republicano ha desdeñado las desviaciones, paradojas y contradicciones en la representación de ciertas figuras, personajes o símbolos que adquieren un sentido especial en la constitución de la historia oficial colombiana. ${ }^{20}$ Las narrativas independentistas tradicionales continúan, de una u otra forma, obstruyendo las lecturas críticas sobre las significaciones que han adquirido figuras como Policarpa Salavarrieta o Simón Bolívar, por nombrar algunas. Por el contrario, siguiendo a Georges Didi-Huberman, reducir las imágenes a la apreciación de nociones como estilo y época, limita la historia y las disputas por las representaciones a una cuestión de plástica. ${ }^{21}$ En cambio, hay que analizar cómo alrededor de las expresiones simbólicas o gráficas se abre un abanico de tiempo; un espectro de diferentes temporalidades superpuestas que configuran sentidos determinados. Estas temporalidades distintas enuncian el contexto de creación de la imagen, su contenido, la representación sobre esta, la interpretación de la representación, entre tantas otras, en un movimiento infinito donde una temporalidad se solapa sobre la otra. Esto conlleva reconocer el principio funcional de cierta dinámica de la memoria. ${ }^{22}$ Como menciona Didi-Huberman, las imágenes han tenido, llevado y producido la memoria. Así es como las evocaciones traídas al presente se desplazan y se reubican en todos los cuadros del tiempo.

Los primeros retratos de la Pola intentaban mostrar a una mujer blanqueada que encarnaba un tipo de heroína capaz de ser comparada con Juana de Arco. ${ }^{23}$ Estas representaciones respondían a la necesidad de dar legitimidad a la República, de construir las primeras memorias sobre los tempranos años independentistas narrados con toda la épica y el coraje que se debía tener para declararse antirrealista. El orgullo republicano, nacido de la Independencia, desempeñó un papel primordial en estos esbozos de definición nacional. Pertenecer a un país de insti-

20 Se recomienda la investigación de Diana Luz Ceballos, "Iconografía y guerras civiles en la Colombia del siglo XIX: una mirada a la representación”, en Ganarse el cielo defendiendo la religión: guerras civiles en Colombia, 1840-1902, ed. por Luis Ortiz Mesa (Medellín: Universidad Nacional de Colombia, 2005), 62-95.

21 Didi-Huberman, Ante el tiempo, 104.

22 Ibid., 42.

23 Para ampliar este punto, véase: Vanegas, Disputas simbólicas; Rafael Álvarez, Policarpa, ¿ una heroina... Genio? (Bogotá: Editorial de Cundinamarca Antonio Nariño, 1995). 
tuciones modernas era el elemento más tangible de orgullo patriótico. ${ }^{24}$ La España monárquica era vieja y despótica; mientras que Colombia era nueva, libre y llena de potencialidades. Por lo tanto, estas representaciones no podían materializar la idea de una Pola martirizada, débil y fusilada. La memoria que debía construirse tenía que ser heroica; una Policarpa erguida, blanca, de piel tersa y semblante firme definiría el criterio de su representación póstuma. La creación de las primeras alegorías no solo buscaba generar memoria al reconstruir un episodio de martirio, sino también difundir la fama del héroe. En tal caso, podría decirse que existía un interés pedagógico — heredado de las prácticas coloniales— apoyado en la imagen, pues la pintura acarreaba la función de enseñar las virtudes del héroe para aquellos que la observaran; presentaba al personaje ejemplar que debía ser imitado. ${ }^{25}$

Didi-Huberman señala que las imágenes tienen distintas temporalidades y que resulta pertinente cuestionar la historicidad misma de estas para ir más allá del paradigma textualista de la interpretación visual. Esto, en últimas, conduce a develar la compleja temporalidad de las imágenes, las memorias tanto enterradas como las surgidas, las distancias entre lo que se representa y lo representado y las luchas simbólicas alrededor de la memoria. ${ }^{26}$ Como menciona Eduardo Posada Carbó: "en el arte de la Independencia se encuentran rupturas y continuidades. Rupturas como el cambio de modelos: a las gentes del pueblo, que demostraron su valor en

24 Frédéric Martínez, El nacionalismo cosmopolita: la referencia europea en la construcción nacional de Colombia, 1845-1900 (Bogotá: Banco de la República; Instituto Francés de Estudios Andinos, 2001), 251.

25 Yobenj Chicangana, La Independencia en el arte y el arte en la Independencia (Bogotá: Ministerio de Educación Nacional de Colombia, 2009), 101.

Un autor que ahonda en el concepto de historicidad es François Hartog, quien desarrolla la noción de regimenes de historicidad con la intención de que el historiador ponga el presente en perspectiva y haga un ejercicio crítico de la historia. Este concepto es una manera de interrogar las diversas experiencias del tiempo o "crisis del tiempo", es decir, el momento en el que el pasado, el presente y el futuro se articulan y pierden su evidencia. Con el régimen de historicidad se pueden hacer inteligibles las experiencias del tiempo; permite la realización de ejercicios comparativos de diversas experiencias del tiempo, de tal forma que se puede reflexionar sobre la manera en que el presente actual difiere de otros presentes del pasado, con lo que el historiador se vuelve contemporáneo de lo contemporáneo. El régimen de historicidad no solo es una manera de articular pasado, presente y futuro, sino que permite aprehenderlo, decirlo, ordenarlo y darle sentido. Hartog advierte que el régimen de historicidad no es una realidad dada o directamente observable, sino que es construido por el historiador, motivo por el que es necesario reflexionar sobre sus implicaciones pues los investigadores, por lo regular, lo "naturalizan" o "instrumentalizan". Véase François Hartog, Regimenes de historicidad: presentismo y experiencias del tiempo (México: Universidad Iberoamericana, 2007), 243. 
las luchas por la Independencia, se las retrató como héroes". ${ }^{27}$ Algunos interrogantes resultan de lo anterior: ¿ por qué conviene representar a Policarpa Salavarrieta como una heroína nacional?, ¿a qué retórica política responde la construcción de estas representaciones y por quiénes son integradas al discurso nacionalista?

Las representaciones que se construyen de los símbolos patrios, como señalaba Chartier, tienen una pertinencia operatoria, según señalé antes. Por un lado, vuelven una imagen a la memoria y la socializan "tal cual era" o, más bien, como "debía serlo". Por otro lado, se convierten en un referente simbólico del cual desaparecen algunas violencias mientras se imponen otras. En la construcción de la historia nacional, a través de los estados de memoria, las representaciones de los acontecimientos independentistas a lo largo del tiempo han erradicado la violencia misma de los hechos históricos y asignado otro tipo de violencias más relacionadas con los silencios, las omisiones y las ausencias de personajes o episodios. Un estudio de caso de la Pola permite develar las luchas de representación que construyen los imaginarios nacionales.

El manual de Henao y Arrubla retoma las descripciones de 'testigos oculares' como José María Caballero y José Hilario López, sobre la representación inmediata de Policarpa años después de su fusilamiento. Relatan cómo "Presa la Pola y reducida a un calabozo en el Colegio del Rosario, presentóse ante aquél en medio de los demás presos, vestida con camisón de zaraza azul, mantilla de paño azul y sombrero cubano; era muchacha muy despercudida, arrogante, buena moza y de buenas prendas". La energía de ánimo de la heroína en la capilla fue admirable; al decir de un testigo ocular, la joven mártir, poseída de gran excitación en los momentos en que iba a arreglar su conciencia, lanzaba estas palabras contra su verdugo: "Generoso Sámano y compasivo ¡qué error! ¿Pero ustedes conciben que yo desearía conservar la vida a cambio de implorar clemencia? No, señores, no pretenderé nunca semejante cosa, ni deseo nunca que se me perdone, porque el cautiverio es todavía peor que la misma muerte". ${ }^{28}$ Más adelante, en el relato de su muerte, describen cómo "en medio de un redoble general de las cajas de guerra que apagaron su voz, seis balazos arrancaron la vida y eternizaron la memoria de Policarpa Salavarrieta". ${ }^{29}$ En estas breves descripciones, por un lado, se originan todas las referencias iconográficas que darían cuerpo al retrato de la Pola; por otro, se alegoriza la representación de

27 González y Hanaberg, Manual de arte del siglo XIX, 43.

28 Henao y Arrubla, Historia de Colombia, 355.

29 Ibid., 356. 
esta: se dota de significado su trayectoria individual en el escenario público, se le significa no solo como la joven de Guaduas informante de los patriotas, sino que se le resignifica como mártir y heroína del proceso independentista. Se exaltan sus virtudes y se presenta como quien "amó la libertad de la patria con delirio" $30 \mathrm{Se}$ conmemora no su nacimiento, ni su desplazamiento de Guaduas a la capital, sino su muerte, pues es este episodio el que la inmortaliza en la memoria nacional. Escriben Henao y Arrubla en su introducción que estudiar la historia de Colombia sería, sin lugar a dudas, la verdadera escuela del patriotismo, porque esto hace conocer y admirar la patria desde su cuna, amarla y servirla con desinterés, y asegura su porvenir manteniendo la integridad del carácter nacional. ${ }^{31}$ Ciertamente, la iconografía procera iba de la mano con la empresa de consolidar una sola historia nacional, recuperar la memoria de la patria y conmemorar a aquellos "hombres", para dar vida así a "lo que debe imitarse", a "los rasgos de virtud y heroísmo". Esta empresa tenía el interés político de "escolarizar", aleccionar, instruir a los ciudadanos de la nación centenaria sobre la moral que la patria necesitaba para asegurar su porvenir y fortalecerse en la posteridad.

\section{Síntomas de memoria: conmemoraciones y memorias institucionales}

La función de algunas imágenes en la primera fase de construcción de las naciones latinoamericanas es fundamental. Las imágenes son productos de opiniones particulares, muchas veces promovidas por los grupos políticos dominantes, debido a su capacidad para crear representaciones y transmitir imaginarios que adquieren funciones en situaciones sociales. ${ }^{32}$ Como lo menciona Hans-Joachim König, los políticos de los Estados crean una conciencia nacional y para ello se sirven de una serie de símbolos y retóricas manifiestas en imágenes materiales, virtuales o, incluso, mentales. Las representaciones de la Pola se convierten en una figura para los discursos nacionalistas, ya sea dentro de exposiciones, museos, en la prensa, el arte, la televisión y en monumentos para cumplir con su rol de "imagen pública”.

\footnotetext{
Ibid., 356.

Ibid., 3.

32 Hans-Joachim König, "La función de las imágenes en el proceso de la construcción de las naciones latinoamericanas", en La nación expuesta: cultura visual y procesos de formación de la nación en América Latina, ed. por Sven Schuster (Bogotá: Universidad del Rosario, 2014), 2.
} 
Para la conmemoración del centenario de la Independencia, la empresa de Correos de Colombia encomendó a la American Bank Note Co., con sede en Nueva York, la realización de tres millones de estampillas con diez motivos diferentes. Los sellos se grabaron en planchas de acero; a Nueva York se enviaron retratos tamaño postal en blanco y negro basados en óleos y estatuas. ${ }^{33}$ En los diez sellos diseñados se ilustraban ocho personajes. De estos, tres fueron actores principales en el grito de independencia del 20 de julio: Camilo Torres, Francisco José de Caldas y Antonio Nariño. Por otra parte, también se encontraban tres personajes emblemáticos en las guerras de independencia: Policarpa Salavarrieta, Simón Bolívar y Francisco de Paula Santander. Además, una de las estampillas reproduce el desfile de patriotas al patíbulo donde fueron fusilados por orden de Pablo Morillo, en Cartagena, en 1816 (figura 6).

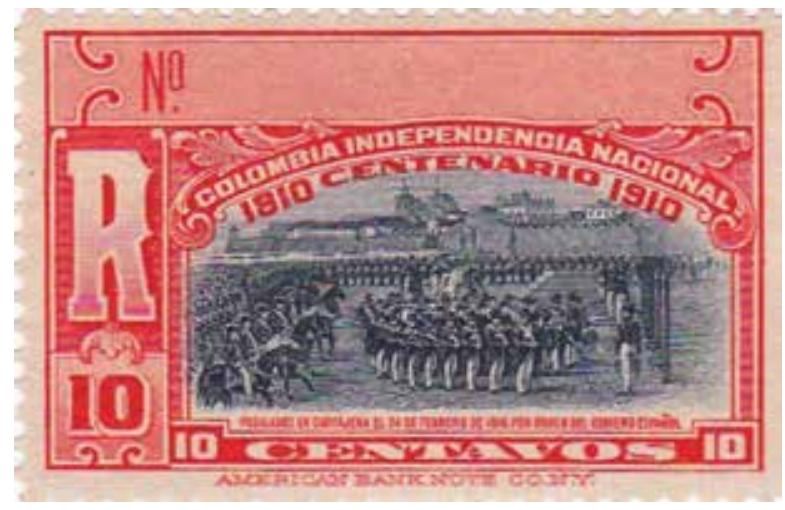

Figura 6. American Bank Note Co., 1910, "Fusilados en Cartagena el 24 de febrero de 1816 por orden del Gobierno español" (sello postal para Servicio Recomendado, impreso en color rojo, valor facial 10 centavos, conmemorativo del Centenario de la Independencia Nacional, colección Administración Postal Nacional, Bogotá).

Según el historiador Luis Horacio López, el Gobierno español envió una reclamación por motivos de la circulación del sello que representaba crudamente la masacre de Morillo a los patriotas. Coleccionistas de la época señalan que se trató de un caso de "autocensura" por parte del Gobierno de ese entonces, ${ }^{34}$ puesto que del sello fueron emitidas ocho mil unidades retiradas el mismo año de su lanzamiento.

33 Luis Horacio López, "Los sellos postales y las conmemoraciones de la independencia”, Revista Credencial Historia, n. ${ }^{\circ} 251$ (2010): 10-14.

34 Ibid., 11. 
Luego fue restituido para servicio interno y así salió por completo de la circulación internacional. Por decreto del 30 de diciembre de 1911, se ordenó la incineración de las unidades aún disponibles.

Policarpa Salavarrieta fue la primera mujer en aparecer en los sellos de correo de Colombia. De su estampilla circularon alrededor de seiscientas mil unidades en verde y negro. No se conoce explícitamente quién fue su autor, aunque las anotaciones de López sobre el trabajo de la American Bank Note Co. sugieren que los grabadores trabajaron con distintos referentes. Así, puede pensarse que la representación del sello podría ser un híbrido entre el retrato de Garay y el de Espinosa (figura 7).

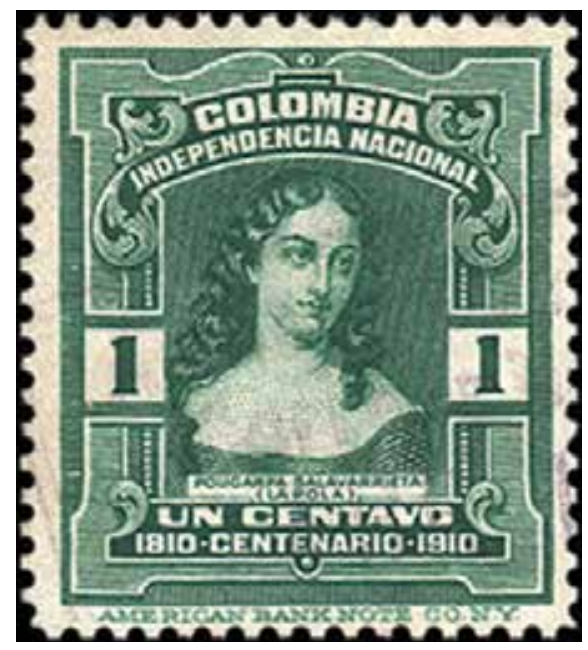

Figura 7. American Bank Note Co., 1910, "Policarpa Salavarrieta (La Pola)" (sello postal, impreso en color verde, perforación 12 , valor facial 1 centavo, pliego de 100 estampillas, conmemorativo del Centenario de la Independencia Nacional, ilustración a partir de un cuadro de Epifanio Garay, colección Administración Postal Nacional, Bogotá).

Es importante mencionar que para 1910, el Estado colombiano ya designaba algún tipo de reconocimiento a Policarpa y, con este, un manejo institucional pionero, al ser la única heroína de las guerras anticoloniales. A finales del siglo xix y durante las primeras décadas del $\mathrm{xx}$, las representaciones de la Pola aumentaron considerablemente; en especial con esta ocasión del primer centenario, su figura se volvió protagónica para ser integrada en el proyecto de nación..$^{35}$ No obstante,

35 Sin embargo, algunos años antes, con motivo del centenario del natalicio de Salavarrieta, la Ley del Congreso 15 de 1894, dispuso levantarle un monumento en Guaduas, mientras que la Ordenanza 31 
en medio de este reconocimiento creciente, un asunto revelador surge con el caso de la estampilla de "Fusilados en Cartagena" y su veto por parte del Gobierno colombiano tras la presión española para eliminar la pieza. Existe, en este caso, otro estado de memoria: una política que llevaría a pensar que, de ser representada en el momento de su fusilamiento, la estampilla de la Pola también hubiese sido vetada.

Un aspecto interesante que recoge Posada Carbó explora cómo la primera parte de las celebraciones del Centenario estuvo precedida por varios discursos que reivindicaban la obra de España y su legado en América. Cita este autor el discurso de Antonio Gómez Recuero, en nombre de la Comisión del Centenario: "la admiración por los hombres de la República no nos impide reconocer los altos méritos de los buenos mandatarios españoles, [...] la guerra de independencia había tenido muchas de las características de una contienda entre miembros de una misma familia”. Para Gómez, este era un mensaje de hospitalidad, pues "España tenía un hogar propio en cada una de las naciones que brotaron de su seno”. Posada Carbó también recoge el discurso de Rafael María Carrasquilla, donde se expresa que "deudores somos de nuestra civilización a la madre España" ${ }^{36}$

Aunque ambas intervenciones confluyeran en un mensaje de conciliación con el pasado colonial, este era marginal frente a los valores de libertad e igualdad que quisieron resaltarse en los festejos conmemorativos de la independencia. Según Posada, fueron más protagónicos los anhelos de progreso, bienestar “y la urgente necesidad de consolidar la paz",37 dado que el país recién salía de una de las guerras más sangrientas de finales del siglo XIX. Sin embargo, valdría la pena preguntarse ¿qué tan marginales fueron los reconocimientos públicos del favor de España hacia la patria en la construcción de la narrativa nacional? Pues con la estampilla de los fusilados y con la representación de la Pola a partir de su busto y no de su fusilamiento (nos detendremos en este aspecto más adelante) se estaba desplazando la

del mismo año del Departamento de Cundinamarca contribuyó con la respectiva disposición legislativa. El 26 de enero de 1895, día del centenario, se erigió en la plaza principal de Guaduas una columna de piedra con inscripciones alusivas a la prócer. Bajo la misma legislación, en la capital también se realizó un monumento en su memoria, siendo el Consejo Municipal de Bogotá el que dio el nombre de la mártir a la plazuela de Las Aguas, donde se inmortalizó el famoso anagrama "yace por salvar la patria”, que formó del nombre de Policarpa Salavarrieta el poeta bogotano, su contemporáneo, Joaquín Monsalve. En 1910 se levanta la estatua de Policarpa en la plaza de su nombre en Bogotá, y al año siguiente se erige otra en Guaduas.

36 Posada Carbó, “1910: la celebración del primer centenario”, 580.

37 Ibid., 581 . 
figura de mártir por la de héroe, se estaba escondiendo el pasado violento y hostil que vivieron aquellos idealistas de la patria por figuras erguidas, que se mostraban poderosas y arrogantes. En este sentido, hubo una transformación del relato victimizado al relato virtuoso que llegó a incrustarse en la teleología nacional. La escogencia en la representación iconográfica para el centenario de los próceres dejó a un lado los símbolos de fusilamiento, encarcelamiento, exilio y, por supuesto, de los ciclos de violencia que antecedieron y sucedieron a las guerras anticoloniales: la Comisión del Centenario y los gobiernos de turno decidieron recoger aquello que simbolizara virtudes, valores, lo heroico y ejemplar.

Gonzalo Sánchez señala que la memoria es un terreno de disputa, donde evocar y silenciar son actos de poder. ${ }^{38}$ Para Sánchez, existe una memoria que celebra y exalta el pasado, sus héroes y aquellos acontecimientos que se reconocen como "históricos". Esta es la memoria épica, perteneciente al mundo institucionalizado. Otra muy diferente es la memoria traumática, relacionada con lo psicosocial, con los duelos de los marginados, de las víctimas, atañida al dolor y al olvido. Esta es en especial una memoria de ausencias y vacíos, pues busca justicia, reparación y responsabilidades históricas. Considero que ambas memorias no son necesariamente excluyentes y que, en algunos casos, una puede contener a la otra o relacionarse de alguna forma. En el proceso de construcción de la nación y con las representaciones proceras y republicanas de los personajes independentistas, afirmo que esta memoria épica también está llena de impunidad y silencios: es una memoria que esconde lo infame.

Aunque en el segundo tipo de memoria (traumática) Sánchez se refiere particularmente a los contextos de posguerra del siglo $\mathrm{xx}$, es válido desplazar parte de esa caracterización a la producción de representaciones nacionales que vienen desde el siglo XIx. Lo anterior se debe a que las guerras anticoloniales fueron violentas en muchos sentidos; miles murieron sin conseguir ver la libertad o la independencia total de sus territorios. En efecto, la campaña de Morillo cobró la vida de cientos de patriotas, y las políticas represivas españolas, como los fusilamientos y el destierro, hicieron parte de un contexto violento y doloroso, donde incluso ser exiliado político o estar preso en Cádiz durante años se convirtió en una represalia naturalizada. ${ }^{39}$ Con base en la eliminación de los sellos postales a raíz del reclamo

38 Sánchez, "Introducción", 21.

39 Para profundizar sobre la experiencia del encarcelamiento y el exilio, véase José Antonio Amaya, Enrique Umaña Barragán: ciencia y politica en la Nueva Granada (Bogotá: Maremágnum, 2014); Iván Jaksic, Andrés Bello: la pasión por el orden (Santiago de Chile: Editorial Universitaria, 2001). 
español, parecería ser que la defensa de las representaciones de la violencia y los hostigamientos, tanto de patriotas como de realistas en el proceso independentista, no estaba en la agenda política para 1910. A propósito, Rebecca Earle expone cómo las festividades del Centenario se aseguraron de no incluir referencias a las atrocidades de las guerras reales. La historiadora estadounidense expone, precisamente, el caso de la estampilla conmemorativa que muestra a los patriotas siendo ejecutados por los españoles en 1816 y que fue retirada para no ofender a España. Igualmente, Earle explora cómo los discursos de quienes hacían la apertura de la conmemoración estuvieron adscritos al "elemento ibérico" ${ }^{40}$ Esto era, de hecho, una actitud común en el continente hispanoamericano: en diferentes países se erigieron estatuas con referencias a España, se instalaron placas conmemorativas en edificios coloniales y se renombraron calles en honor a la "madre patria". Tales actos tenían la intención de conmemorar los orígenes que "hoy en día existen entre la noble España y la gente de las Américas”. ${ }^{41}$ Parafraseando el imaginario de aquel entonces, la historiadora comenta que el periodo colonial no era más un tiempo oscuro, sino aclamado como la "indestructible fundación de nuestra existencia colectiva”, la fuente de la civilización. ${ }^{42}$

Aquí es donde cobra sentido la transformación de las representaciones proceras de comienzos de siglo. Este aspecto es retomado por Posada Carbó, mediante el discurso del presidente de la Academia Colombiana de Historia de ese momento (1909-1910), Adolfo León Gómez:

Estas [las conmemoraciones del Centenario] no eran "una mera fiesta para rendir homenaje a los héroes y a los mártires y para exhibir plausibles adelantos materiales, se trataba de algo muy trascendental": "cumplir el deber de asegurar las redenciones del futuro". Esta era, para Gómez, una "fiesta de paz, de civilización y progreso" que tomaba lecciones del pasado. La independencia de 1810 había sido el "mandato de otra nueva y más indispensable independencia”, una que debía acabar con el "yugo aún más odioso de la pasión política, de la preocupación y la ignorancia y de las dictaduras feroces de partido". 43

\footnotetext{
40 Rebecca Earle, "Padres de la patria' and the Ancestral Past: Commemorations of Independence in Nineteenth-Century Spanish America, Journal of Latin American Studies 34, n. ${ }^{\circ}$ (2002): 802.

$41 \quad$ Ibid., 802.

42 Ibid., 802.

43 Posada Carbó, “1910: la celebración del primer centenario”, 586.
} 
Los homenajes a los héroes no solo buscaban trasformar e inmortalizar un pasado glorioso, sino transformar lo catastrófico de las guerras del XIX y resignificarlo alrededor de la agenda política de comienzos del siglo Xx. No se podía construir una representación de la nación doliente y accidentada, sino que se debían rescatar las "virtudes del pasado", el amor por la patria, el carácter nacional. El proceso de construcción de la nación aún estaba por acontecer y era fundamental asegurar su porvenir.

Hacia la segunda mitad del siglo xx, en 1972, el Banco de la República imprimió el billete de dos pesos oro con la imagen de Policarpa y sobre el cual no se tiene mucha información. Sin embargo, se puede notar que la representación de la Pola en la pieza es la de Epifanio Garay, donde su figura se vislumbra con el cuello y pecho descubiertos. En el reverso de este billete se encuentra grabada la Balsa muisca del Museo del Oro y encima de esta — ocupando un tamaño significativo - aparece el símbolo del Banco: la figura de Marianne, que además de ser alegoría de la República francesa, encarna valores patrióticos atados al pasado decimonónico de luchas antirrealistas. Con todo esto, para los años setenta, la representación de Policarpa se ratificaba como la imagen femenina de la nación colombiana. El billete de dos pesos oro exaltaba entonces virtudes republicanas, por un lado, y los recursos naturales y riquezas de la nación, como el oro nativo del territorio, por otro (figura 8).

En la década de los ochenta, circula también la moneda de cinco pesos con la figura grabada de Policarpa Salavarrieta. En el anverso aparecía con las manos atadas, mirando a la derecha mientras espera el fusilamiento. Por primera vez, después de los óleos del siglo xix y algunos del xx, la Pola, en su función institucional de imagen pública, es ilustrada en el momento previo a su muerte. En el reverso se mostraba la denominación y un grabado panorámico alusivo a la industria nacional (figura 9). Es muy probable que la ilustración de Salavarrieta haya estado basada en la estatua de Dionisio Cortés, que analizo en el siguiente apartado. Posiblemente en el periodo de Virgilio Barco (1986-1990) ya no era importante reedificar una imagen nacional frente a las guerras del xix. La agenda ya habría cambiado, y la anhelada pacificación de comienzos de siglo nunca habría llegado. A la orden del día estaba el asesinato sistemático de casi todos los miembros de la Unión Patriótica, la desmovilización de la guerrilla urbana Movimiento 19 de Abril, el asesinato de diferentes líderes políticos y periodistas, la guerra contra el narcotráfico, entre otros. 

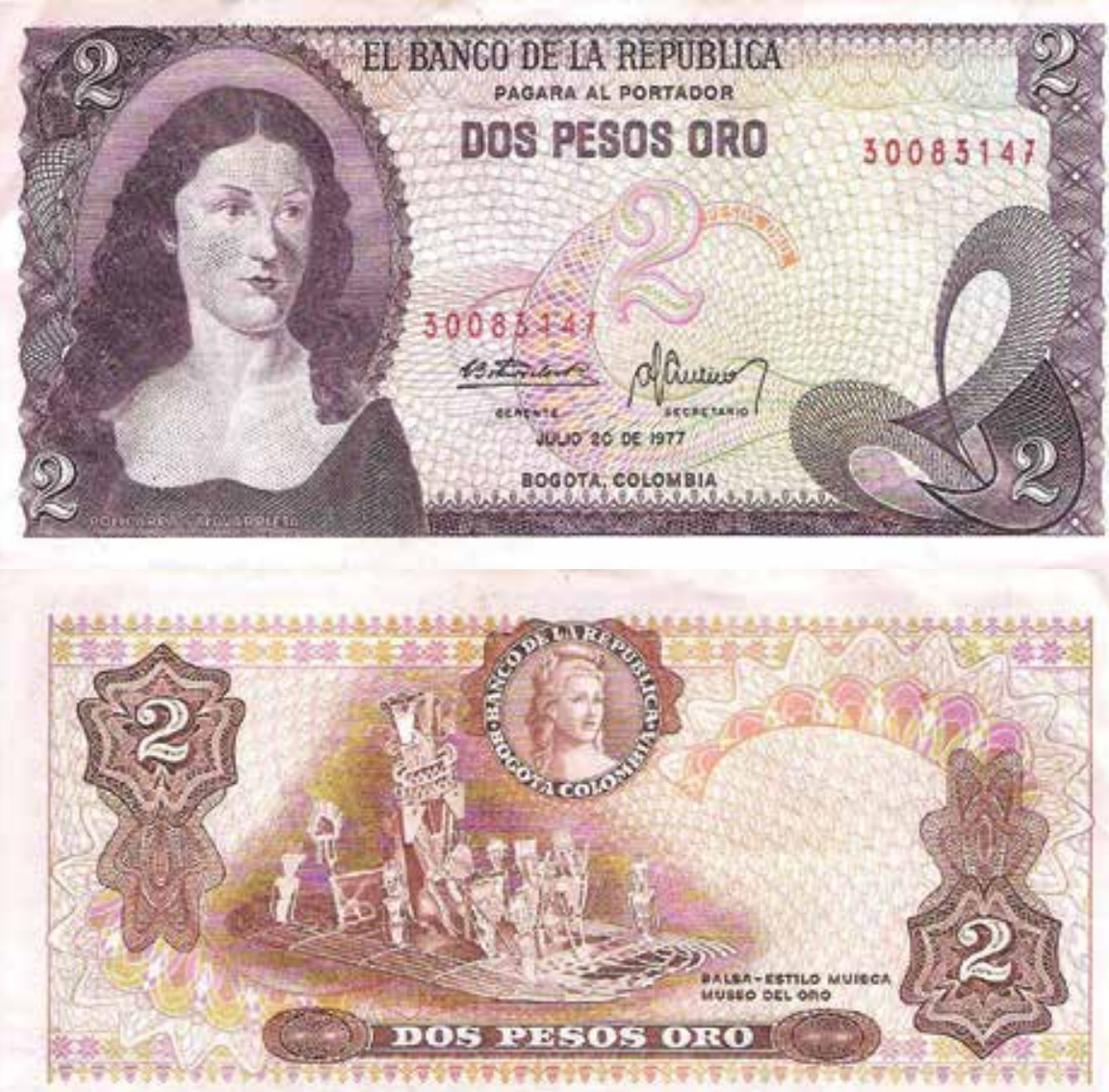

Figura 8. American Bank Note Co., 1972, "Billete de dos pesos oro: Policarpa Salavarrieta" (emisiones entre 1972 y 1976, Banco de la República, Bogotá).

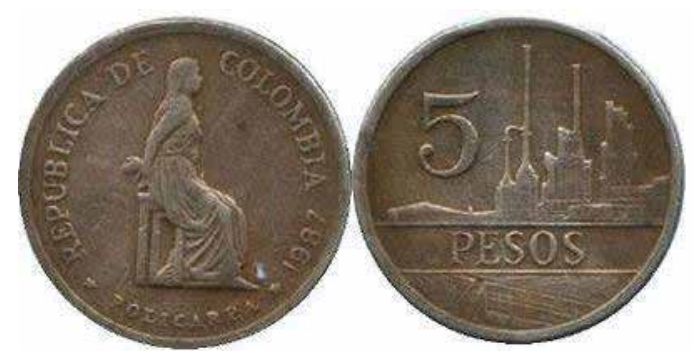

Figura 9. Banco de la República, 1988, "Moneda de cinco pesos" (aleación metálica, 2,6 cm, anverso a partir de escultura de Dionisio Cortés, Casa de la Moneda, Bogotá). 
Posteriormente, en 1995, para conmemorar el bicentenario del nacimiento de Policarpa, se imprimió el billete de diez mil pesos (figura 10). Aquí se presenta el personaje con base en el retrato de busto de Espinosa. Esta imagen - aún presente en la circulación monetaria actual- muestra a una Policarpa joven, bella y con cierto aire de templanza. En el reverso del billete se incluye el fragmento de una acuarela panorámica de la plaza de Guaduas. Esta segunda obra fue elaborada por el diplomático inglés Edward Walhouse Mark, quien vivió durante trece años en la región (1843-1856) y pintó en acuarela los diversos lugares que visitaba, en versiones costumbristas propias de la época, similares a la que se aprecia en el billete. ${ }^{44} \mathrm{~A}$ diferencia de los óleos, en esta ilustración Policarpa figura mirando hacia la derecha y su cabeza ya no está inclinada hacia abajo, sino dirigida fijamente hacia el espectador. Nuevamente, no es la representación de una mártir de la Independencia, sino de una prócer: serena, digna, heroica y victoriosa.

Si bien el análisis de sellos y numismática ilustra algunas de estas tensiones sobre los tipos de memoria que han acompañado la figura de Policarpa Salavarrieta, existen otras fuentes de conocimiento público como la estatuaria, que permiten ejemplificar las luchas que he venido mencionando (entre exaltar o silenciar el pasado violento). Por esta razón, cobran importancia monumentos como la estatua de la plaza de Las Aguas de Dionisio Cortés, quien para 1910 ya había construido una pieza de yeso que representaba a la Pola sentada con las manos atadas, esperando a ser fusilada.

44 Banco de la República, "Policarpa: billete de diez mil”, http://www.banrepcultural.org/visitastematicas/numismatica/policarpa-billete-diez-mil (31/03/2017). 


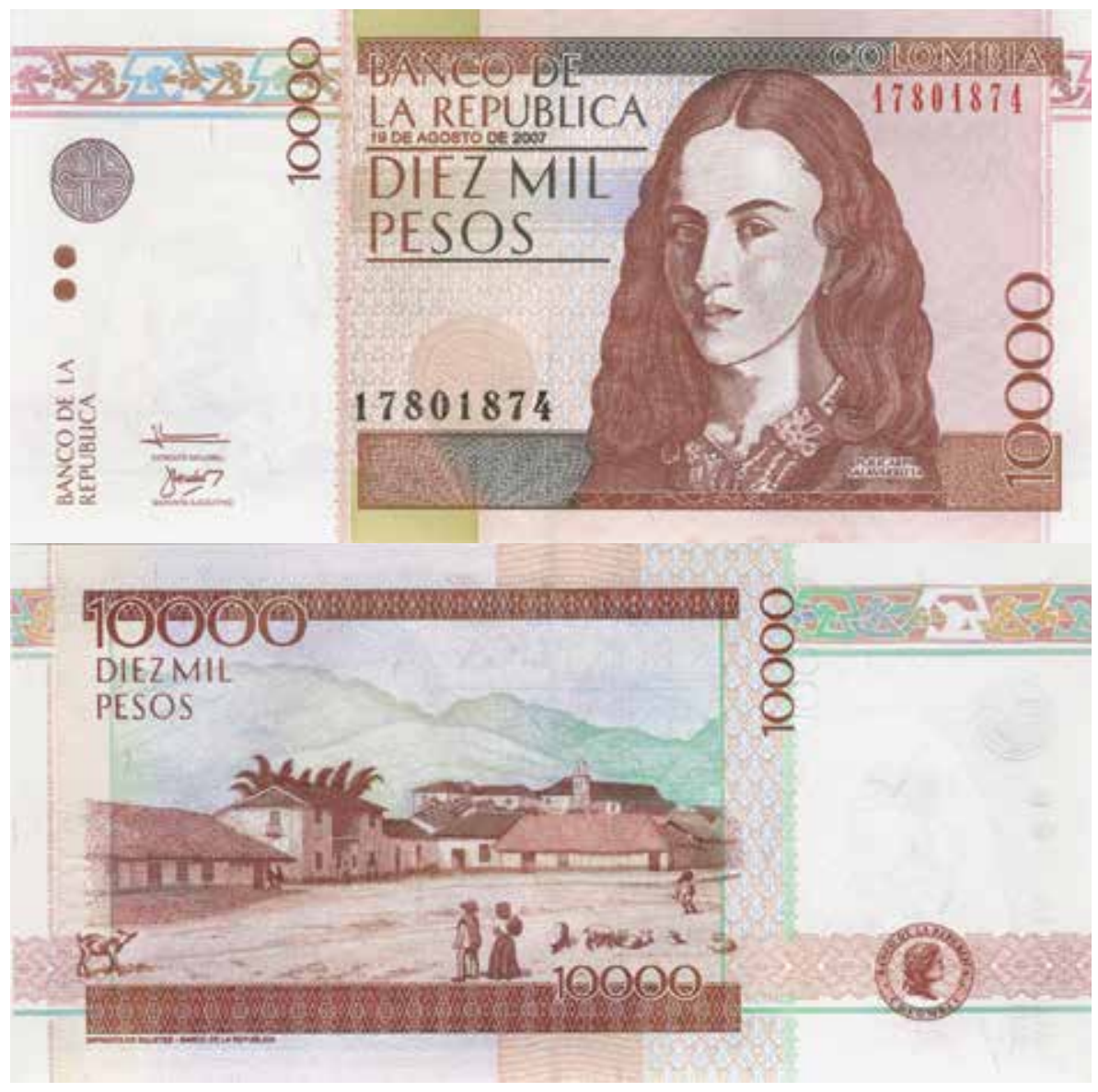

Figura 10. Banco de la República, 1995, "Billete de diez mil pesos. Homenaje a Policarpa Salavarrieta" (grabado sobre papel, $7 \times 14 \mathrm{~cm}$, ilustración a partir de cuadros de José María Espinosa y Edward Walhouse Mark, Banco de la República, Bogotá). 


\section{Silencios sobre la Pola de Las Aguas}

Germán Rubiano incluyó en su libro de Escultura colombiana del siglo XX una anotación sobre el escultor Dionisio Cortés, donde señalaba que la estatua de Policarpa Salavarrieta era una figura muy pobre tanto expresiva como escultóricamente, y que podría tratarse de uno de los primeros casos en que un monumento público carecía de interés artístico. ${ }^{45} \mathrm{El}$ comentario de Rubiano se dirigía realmente a la actual estatua de la Pola, la cual remplazó en 1968 a la original, por encontrarse en muy mal estado (figura 11). Por decisión del Gobierno, la Academia Colombiana de Historia le encargó a Gerardo Benítez, artista peruano, la ejecución de la obra actual. Sin embargo, en este proceso se perdió la estatua original elaborada por Cortés. Años después, el Fondo Cultural Cafetero realizó una investigación que encontró una fotografía inédita de la obra de Cortés que cedió al Museo Nacional para una exposición iconográfica de Policarpa Salavarrieta (figura 12). Esta exposición recoge también todas las fuentes primarias que utilizó Beatriz González en Policarpa 200. No obstante, al referenciar la fotografía, González citó el comentario de Rubiano, como si este hablara de la estatua de 1910 y no de la de 1968, lo cual es cierto de alguna forma, pues Rubiano escribió Escultura colombiana sin tener información de la existencia de la fotografía que probaba la escultura original, la de Cortés. Sin embargo, el problema surge cuando González, luego de conocer la fotografía, comete la misma equivocación de Rubiano. Esto ha generado que algunos documentos institucionales como es el caso de la Colección del Bicentenario La Independencia en el arte y el arte en la Independencia, elaborado por el Ministerio de Educación Nacional en el 2009, siga corroborando que la actual estatua de la Pola en Las Aguas es la inaugurada en 1910, elaborada por Dionisio Cortés, en lugar de aclarar que se trata de la obra del peruano Gerardo Benítez.

45 German Rubiano, Escultura colombiana del siglo XX (Bogotá: Ediciones Fondo de Cultura Cafetero, 1983), 17. 


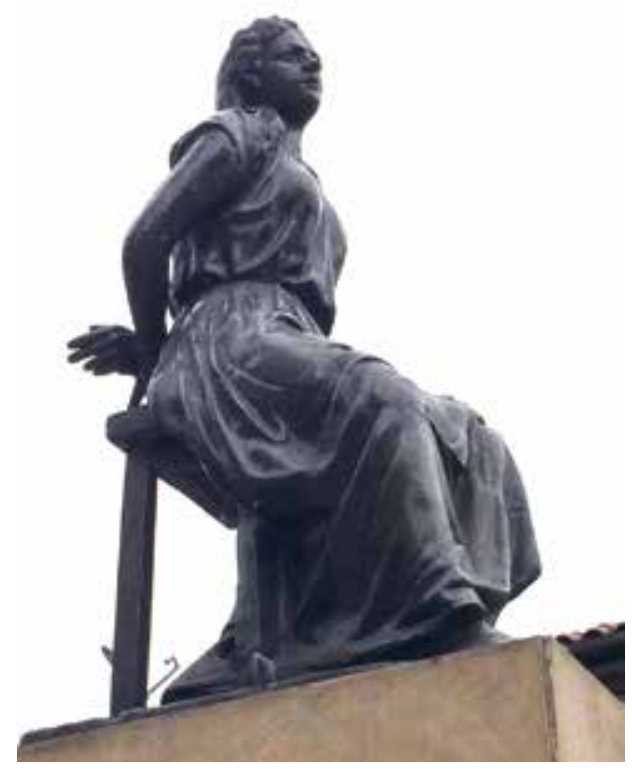

Figura 11. Simón Díez, 2016, “Estatua de la Pola elaborada por Gerardo Benítez en 1968” (fotografía, Bogotá).

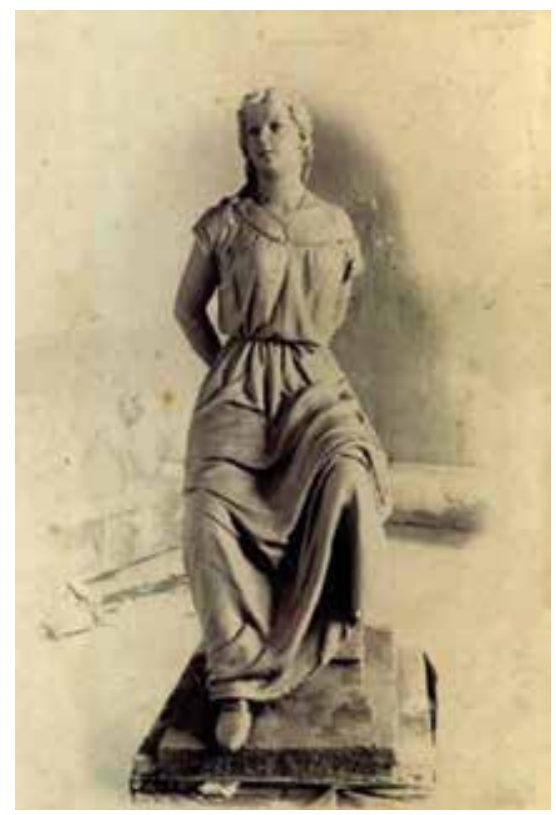

Figura 12. Lino Lara, "Modelo para escultura de Policarpa Salavarrieta realizada por Dionisio Cortés en Las Aguas" (fotografía, gelatina sobre plata, $22 \times 18,9 \mathrm{~cm}$, Museo Nacional de Colombia, Bogotá, número de registro: 3718 ). 
Este asunto permitió que la obra de Cortés se considerara "menor" y quedara en un lugar marginal de la historia del arte colombiano. ${ }^{46} \mathrm{La}$ estatua llegó a ser clasificada como "iconografía sin referentes" en el estudio de González. Por su parte, Carolina Vanegas hace una detallada descripción de la obra de Cortés, y muestra que el artista esculpió y modeló una estatua en yeso alusiva al momento en que la Pola está en el banquillo antes de ser fusilada (figura 12). Su cabeza mira hacia la derecha con un gesto grave hacia arriba; su cuello está rodeado por una cinta de la que pende un crucifijo; su vestido es cuello tipo bandeja como en la representación de Garay, sus brazos están atados hacia atrás, su pierna derecha sobresale y en el pedestal se encuentra la inscripción "yace por salvar la patria". Los elementos que se destacan en esta representación son, por un lado, la posición de la cabeza hacia la derecha y la mirada alta, referentes que van en contra de la iconografía canónica del siglo XIX que retrata a Policarpa. Por otro lado, la elección del momento de la representación está ligada al fusilamiento. Vanegas referencia una nota de prensa en la cual se comentaba la obra: "Sentada con altivez en el banquillo, las manos atadas hacia atrás, dirige con arrogancia la hermosa cabeza hacia las fuerzas españolas, que estaban formadas en su mayor parte, de americanos, y con ceñudo semblante y mirada retadora parece decirles: $¡$ Viles americanos, volved esas armas sobre los opresores de vuestra patria!". ${ }^{4}$

La nota anterior destaca la representación de Cortés y reafirma la centralidad de Policarpa como un referente fundamental del mito patriótico. En 1894, el Congreso de la República emitió la Ley 15, en la cual se asignaban dineros para conmemorar el centenario del nacimiento de la Pola. Las municipalidades de Bogotá y Villa de Guaduas se comprometieron a ejecutar conmemoraciones sobre la heroína. La obra de Cortés participó ante el Ministerio de Instrucción Pública para ser elegida como uno de los monumentos que se expondrían en el municipio de Bogotá. Sin embargo, por cuestiones procedimentales, su obra no ganó. ${ }^{48}$ El escultor volvió a presentarse en 1899 en la Exposición de Bellas Artes, pero el jurado no lo favoreció, a pesar de la buena recepción que la obra tuvo en la prensa. ${ }^{49}$

Frente a todo pronóstico, Cortés logró que la Asociación de Vecinos de Las Aguas pusiera su estatua en la plaza, a una cuadra de la iglesia. Para Vanegas, este es

\footnotetext{
46 Vanegas, Disputas simbólicas, 86.

47 El Heraldo, 17 y 22 de agosto de 1899, citado en Vanegas, Disputas simbólicas, 96.

48 González, "La iconografía de Policarpa Salavarrieta", 32.

49 Vanegas, Disputas simbólicas, 97.
} 
el primer caso en que la plaza republicana no se estableció sobre la plaza colonial, sino que se le designó un nuevo lugar y contribuyó a que el símbolo republicano se insertara más fácil en el imaginario ciudadano. ${ }^{50} \mathrm{El}$ caso de Cortés sobresale por ejemplificar las luchas de representaciones que encarnan las memorias del pasado. Vanegas explica en su investigación que la estatuaria decimonónica buscaba rodear al personaje de un halo de inmortalidad y dejar a un lado su contingencia humana. Para ilustrar este punto señala las diferentes representaciones de Juana de Arco en Francia, donde se la muestra vigorosa, victoriosa y fuerte. Sin embargo, las elecciones de Cortés en la estatua de la Pola escaparon a este canon, pues el escultor prefirió hacer hincapié en un momento que remite a su figura de mártir, en que denuncia a sus verdugos y la impunidad histórica sobre su vida y memoria. La representación de Cortés mostraba claramente un momento trágico en la historia nacional, visibilizaba la tortura y la violencia de una época convulsionada antes de la República soñada.

Por otra parte, la estatua de Silvano Cuéllar (figura 13), inaugurada en Guaduas, un año después de la de Cortés, representa a Policarpa en postura arrogante que, como señala Pedro María Ibáñez, "supo interpretar con gentileza la virgen calentana [...] recordando las estatuas levantadas en Francia en honor de Juana de Arco. ${ }^{51}$ Para la época, la representación de Cuéllar encaja en los cánones academicistas de la estatuaria y permite ilustrar a la Pola triunfante y vigorosa. El canon estatuario del siglo Xix les exigía a los escultores modelar piezas elocuentes de la nacionalidad y la república. ${ }^{52}$ Aunque la obra de Cortés no coincidía con esta normativa, la obra de Cuéllar sí resultaba modélica. Este último contó con el apoyo formal de los dirigentes de la época. La obra fue tallada en bronce; mientras que la de Cortés estaba hecha en yeso y solo fue instalada gracias al apoyo popular. Como relata Vanegas, la celebración de la inauguración en Las Aguas no tuvo la misma legitimidad política que la de Guaduas; además, pocas personas del Gobierno asistieron a la primera y el apoyo considerable sería el de los miembros del barrio y demás habitantes del centro.

$50 \quad$ Ibid., 100.

51 Pedro María Ibáñez, Crónicas de Bogotá (Bogotá: Imprenta Nacional, 1917), 381.

52 González y Hanabergh, Manual de arte del siglo XIX, 60. 


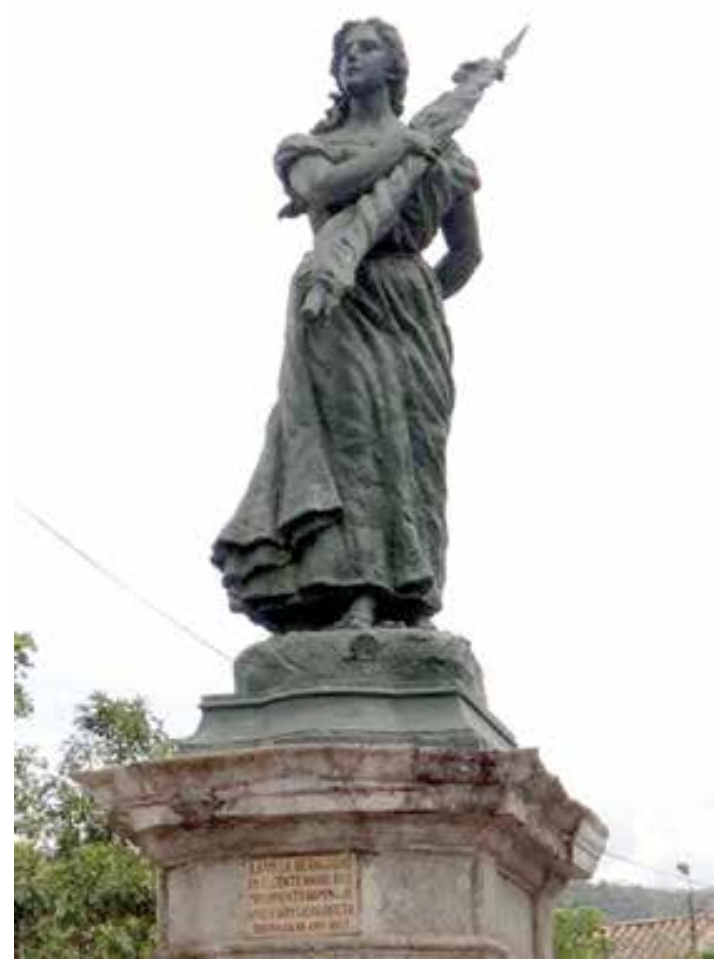

Figura 13. Lery Munar, 2015, "La Pola: estatua elaborada por Silvano Cuéllar e inaugurada en 1911" (fotografía, Guaduas, Cundinamarca).

Las celebraciones de la Independencia habían suspendido de la memoria los hechos brutales ocurridos durante el Régimen del Terror. Las ejecuciones de patriotas y defensores de un eventual orden republicano habían quedado relegadas en los confines del antihispanismo. En algún sentido, la memoria histórica de 1910 se construía con un rechazo profundo hacia el pasado violento. En las representaciones que subsistían de la Pola debían primar las cualidades homéricas y memorables. La figura de Policarpa no debía evocar un momento de martirio, sino presentar a la heroína de una forma general, exaltada y gloriosa, sin señalar a sus ejecutores; debía representarse con un manto de victoria, pues la República había triunfado. Las políticas de memoria de los gobiernos colombianos a inicios del siglo xx proyectaban al país como una democracia triunfante, abierta a la inversión extranjera y en proceso de industrializar sus recursos y su economía. Bavaria S. A. se había consolidado en el país y aprovechaba el "espíritu nacional" para ratificar la cerveza como la bebida moderna que había remplazado a la primitiva chicha. 
La Pola era la bebida de colombianos, la Pola era la representación femenina de la novísima Colombia.

Mientras en el siglo XIX las representaciones de la Pola permanecieron cercanas a los poetas y artistas, en los proyectos institucionales de cara al siglo $\mathrm{xx}$, la Pola se vuelve la primera figura femenina fundacional que ilustra las leyendas más audaces de los tiempos independentistas y representa la nueva nación. El Gobierno y el sector privado posibilitan que la heroína y emblema de la independencia se convierta en objeto de publicidad. En la estatuaria de la Pola se construye un doble movimiento en la representación histórica: por un lado, el espectador de las obras de Cuéllar y Cortés puede pensar que la obra del primero retrata una figura heroica, legendaria y emblemática de Policarpa; mientras que la obra de Cortés la representa pasiva, mártir y doliente. Por otro lado, mientras la obra del último discute con los estereotipos estilísticos de su época para retratar la historia de un pasado violento e injusto, la pieza de Cuéllar deja de lado el sufrimiento y se concentra en mostrar a una Policarpa victoriosa e indolente, una representación que necesitaba la política gubernamental de 1910 para sanar los horrores de la guerra y para fortalecer la esperanza en el nuevo porvenir aún por construir.

\section{Conclusiones}

El caso de las estatuas y de las imágenes institucionales de la Pola son algunos ejemplos de los diferentes regímenes temporales que ejercen control sobre las representaciones del pasado. Pueden entenderse también como procesos que dotan de nuevos significados, valores y prácticas a objetos, personajes y episodios de la historia nacional, que a su vez construyen múltiples relaciones con el pasado y la memoria. Estas nuevas articulaciones, generalmente, están impulsadas por lugares hegemónicos de producción que excluyen, incluyen, integran y ocultan diferencias sociales, políticas, raciales o económicas. Los documentos, los monumentos y los objetos históricos están completamente atravesados por la intencionalidad, el contexto y los intérpretes. Se vuelven instrumentos de memoria sujetos a la manipulación, a la desaparición, a la dialéctica del recuerdo y la amnesia. ${ }^{53}$ Así, las guerras de representaciones sustituyen una fracción del pasado por una imagen que aparentemente es capaz de traer aquello a la memoria y mostrarlo como si así fuese; como si la Policarpa que vemos victoriosa representara a la que fue fusilada por la causa patriótica. Las representaciones de la Pola también se construyen sobre

53 Sánchez, "Introducción”, 26. 
ausencias y desapariciones que remiten, generalmente, a violencias que por coyunturas políticas deben mantenerse ocultas. Estas hacen parte de los silenciamientos de la historia que, a su vez, enuncian las diferentes temporalidades y versiones de esta, solapadas sobre un mismo acontecimiento. Las alegorías visuales de la Pola dan cuenta de una creación continua del pasado que involucra una multiplicidad de actores más allá de la academia misma (Gobierno, privados, industria del entretenimiento, historiadores aficionados, tradiciones artísticas, etc.). Los silencios en las representaciones de Policarpa no son producidos por la ausencia de hechos o interpretaciones, sino por las apropiaciones mismas de la persona de la Pola, de su imagen pública. Lo que encierra este asunto es cómo el presunto consenso sobre la imagen del emblemático personaje enmascara una historia de conflictos, cómo se producen los silencios de una representación a otra y qué propósito tienen.

Estas temporalidades testifican las decisiones sobre la historia que toman, generalmente, los grupos dominantes. Como lo han señalado muchos académicos, el poder es constitutivo de la historia. Rastrearlo a través de varios momentos ayuda a recalcar el carácter procesal de la producción histórica para darles forma a las historias que importan, mientras se relega un espectro muy amplio de la experiencia histórica. El poder trabaja en conjunto con la historia, proviene de diferentes ángulos, precede a la propia narrativa y contribuye a su creación e interpretación. ${ }^{54}$ En este caso, el tiempo histórico que ciñe las representaciones de Salavarrieta se compone por los cánones vigentes en la estatuaria a finales del XIX, por las presiones por parte de los gobiernos sobre la difusión de estampillas que testifican violencias de las primeras décadas del mismo siglo xx y del amplio pasado colonial. Se compone también por las interpretaciones que han hecho los estudiosos del arte colombiano sobre el periodo republicano, en que omiten obras y marginan artistas de la historia nacional. Así, la estatuaria, los usos institucionales y las representaciones pictóricas se ajustan en una dinámica de memoria que cuenta muchas narrativas del pasado; pero que, sobre todo, enuncia los poderes discursivos que entran en la pugna por el control de la verdad del pasado y de una única forma de aprehender el proceso de construcción de la tan anhelada nación. Si el análisis histórico renovado no inscribe la importancia de las luchas de representación frente al poder de los discursos históricos, donde el ordenamiento y la alienación por parte de las políticas del Estado manipula, silencia, caricaturiza episodios de la historia que esconden

54 Michel-Rolph Trouillot, Silencing the Past: Power and Production of History (Boston: Beacon Press, 1995), 27. 
las responsabilidades políticas y las reflexiones sobre el pasado mismo, la importancia de estudiarlo y su historicidad propia quedarían sumidas en la inutilidad memorial de la recordación de fechas y personajes, inscritos en una narrativa lineal e institucionalizada, que cuenta las anécdotas del arduo camino del progreso y la consolidación de la nación.

Vale la pena resaltar cómo las representaciones contemporáneas de la Pola, a través de los medios de comunicación y productos culturales como telenovelas no solo refuerzan una perspectiva romántica de la vida de la prócer, sino que la sexualizan y erotizan. Resulta interesante preguntarse por qué aún no hemos visto representaciones sexuales de Bolívar o de Santander, y por qué sí de Policarpa. Se puede decir que, en términos cuantitativos, Policarpa es la única mujer representativa del proceso independentista, ¿por qué sexualizarla? ¿Por su condición de mujer? Otro aspecto llamativo tiene que ver con la forma en que la historia oficial posiciona la figura de Policarpa. Para la narrativa nacional, esta es tildada de heroína y de prócer del mismo modo que otros hombres destacables de la esfera política del siglo XIX. Es clave ver cómo para la época, a pesar de su condición de mujer y de la forma en que se representa a la patria y a sus "padres", en la conmemoración hay un espacio para una madre, para la figura femenina de la heroína, de la prócer. En la representación que hace de ella la cervecería Bavaria, Policarpa es mostrada como la República gloriosa: una mujer espigada con un vestido largo, con una mano en la bandera y con otra mano dirigida hacia el cielo. Ciertamente, resulta sugerente cómo la representación procera de Policarpa negó, hasta casi finales del siglo xx, el momento mártir de la heroína; cómo, mediante un estado de memoria, se concilió la violencia colonial y patriota eliminando por completo las referencias al sufrimiento y al aniquilamiento de quienes murieron por una causa o la otra. A comienzos del siglo xx, la política de memoria obligaba a darle un lugar importante a la madre patria justificando su labor civilizatoria con sus hijas patrias. Además, la conmemoración del centenario sirvió como escenario para dejar atrás los dolores de la guerra y los odios políticos. Era el momento de refundar y recalcar los valores de la patria y su prometedor porvenir, incluso si esto costaba tergiversar trágicos episodios nacionales y transformarlos en grandes narraciones épicas.

Este capítulo no pretendía ceñirse a una lectura estilística de las obras que representaron a la Pola en un momento dado. Más bien se encuentra cerca de un análisis histórico, próximo a la historia cultural, donde las fuentes primarias empleadas fueran más allá de un estudio detallado desde la historia del arte. Como señaló James Elkins: "Quiero que sea más difícil mirar y describir las pinturas de modo que 
no podamos ir tan rápido del estiércol de las marcas al ordenado sentido histórico".55 Hay que desconfiar de lo que se presenta como dado. El reconocimiento y poder otorgado a personajes, eventos y símbolos no es inocente; está destinado a crear narrativas e imaginarios que construyan las representaciones que se quieren de la nación y de su historia. Así como no es inocente que Bavaria, la compañía cervecera más grande del país, haya conmemorado la Independencia con su representación alegórica de la Pola y que esto haya coincidido con la expansión de su industria y las políticas nacionales que facilitaban el consumo de la cerveza, tampoco es inocente que la única mujer reconocida del proceso republicano sea Policarpa — destacada por su belleza, tez blanca, astucia e incluso por su sensualidad- y no a las esclavas, mulatas y criollas que colaboraron como espías, correos, en hospitales y campamentos de los ejércitos patriotas. Por último, tampoco es inocente que se haya intentado olvidar e invertir la imagen de los fusilados y derrotados de la independencia por aquellos heroicos próceres, rodeados por un halo de inmortalidad, petrificados en estatuas que olvidan retratar su humanidad y fragilidad. Contra todo testimonio, contra toda historia, intentamos contar la historia heroica y civilizada de la patria en lugar de la convulsionada, fraccionada y triste.

Aunque esta reflexión partió de un inventario iconográfico, intentó en lo posible no limitarse a este, buscando armarse de una interpretación útil para el estudio histórico sobre los tiempos, las narraciones y las justificaciones que le dan forma al pasado que hoy conocemos. Según menciona Peter Burke, las imágenes son un documento esencial para el estudio histórico, porque estas nos informan de lo vencido; las imágenes constituyen un testimonio de ordenamiento social del pasado y, sobre todo, de las formas de pensar y de ver en tiempos pretéritos. ${ }^{56}$

\section{Bibliografía}

\section{Fuentes primarias: imágenes}

Banco de la República, Casa de la Moneda, Bogotá.

Colección Administración Postal Nacional, Bogotá.

Colección privada (Lery Munar y Simón Díez), Bogotá.

\footnotetext{
55 James Elkins, "Marks, Traces, Traits, Contours, 'Orli', and 'Splendores': Nonsemiotic Elements in Pictures", Critical Inquiry, n. 4 (1995): 824.

56 Peter Burke, Visto y no visto: el uso de la imagen como documento histórico (Barcelona: Crítica, 2001), 236.
} 
Medardo Rivas, Celestino. La Pola: drama histórico en cinco actos. A la memoria de los próceres de la Independencia. Bogotá: Imprenta y Estereotipia de Medardo Rivas, 1871.

Museo Nacional de Colombia, Bogotá.

\section{Fuentes secundarias}

Amaya, José A. y Enrique Umaña. Ciencia y politica en la Nueva Granada. Bogotá: Maremágnum, 2014.

Archila, Mauricio. Cultura e identidadobrera: Colombia 1910-1945. Bogotá: Cinep, 1992.

Banco de la República. "Policarpa: billete de diez mil”, http://www.banrepcultural.org/ visitas-tematicas/numismatica/policarpa-billete-diez-mil (31/03/2017).

Burke, Peter. Visto y no visto: el uso de la imagen como documento histórico. Barcelona: Crítica, 2001.

Chartier, Roger. Elmundo como representación. Historia cultural: entre práctica y representación. Barcelona: Gedisa, 1992.

Chicangana, Yobenj. La Independencia en el arte y el arte en la Independencia. Bogotá: Ministerio de Educación Nacional de Colombia, 2009.

Damisch, Huber. "Semiotics and Iconography”. En The Art of Art History: A Critical Anthology, editado por Donald Preziosi, 236-242. New York: Oxford University Press, 2009.

Didi-Huberman, Georges. Ante el tiempo: historia del arte y anacronismo de las imágenes. Buenos Aires: Adriana Hidalgo, 2006.

Earle, Rebecca. "Padres de la patria' and the Ancestral Past: Commemorations of Independence in Nineteenth-Century Spanish America”. Journal of Latin American Studies 34, n. ${ }^{\circ} 4$ (2002): 775-805.

Elkins, James. “Marks, Traces, Traits, Contours, 'Orli', and 'Splendores': Nonsemiotic Elements in Pictures". Critical Inquiry, n. 4 (1995): 822-860.

González, Beatriz. "La iconografía de Policarpa Salavarrieta”. En Policarpa 200: Exposición Conmemorativa del Bicentenario del Nacimiento de Policarpa Salavarrieta, 14-23, serie Cuadernos Iconográficos del Museo Nacional, n. ${ }^{\circ} 1$. Bogotá: Museo Nacional de Colombia, 1996.

González, Beatriz. Manual de arte del siglo XIX en Colombia. Bogotá: Ediciones Uniandes, 2013.

Henao, Jesús María y Gerardo Arrubla. Historia de Colombia para la enseñanza secundaria, 2 vols. Bogotá: Escuela Tipográfica Salesiana, 1911. 
Ibáñez, Pedro María. Crónicas de Bogotá. Bogotá: Imprenta Nacional, 1917.

Jaksic, Iván. Andrés Bello: la pasión por el orden. Santiago de Chile: Editorial Universitaria, 2001.

König, Hans-Joachim. "La función de las imágenes en el proceso de la construcción de las naciones latinoamericanas". En La nación expuesta: cultura visual y procesos de formación de la nación en América Latina, editado por Sven Schuster, 1-28. Bogotá: Universidad del Rosario, 2014.

Le Goff, Jacques. El orden de la memoria. Barcelona: Paidós, 1997.

López, Luis Horacio. "Los sellos postales y las conmemoraciones de la independencia”. Revista Credencial Historia, n. 251 (2010): 10-14.

Martínez, Frédéric. El nacionalismo cosmopolita: la referencia europea en la construcción nacional de Colombia, 1845-1900. Bogotá: Banco de la República; Instituto Francés de Estudios Andinos, 2001.

Posada Carbó, Eduardo. "1910: la celebración del primer centenario en Colombia”. Revista de Indias 73, n. ${ }^{\circ} 258$ (2013): 579-590.

Ramírez, William. "La crónica roja en Bogotá". Historia Critica, n. ${ }^{\circ} 21$ (2001): 111-126.

Restrepo, María y Enrique Ortega. La Pola yace para salvar la patria. Bogotá: Archivo Nacional, 1949.

Rubiano, Germán. Escultura colombiana del siglo XX. Bogotá: Ediciones Fondo de Cultura Cafetero, 1983.

Saldanha, E. de. "Detalles desconocidos sobre la Pola". Boletín de Historia y Antigüedades 12, n. ${ }^{\circ} 133$ (1918): 13-23.

Sánchez, Gonzalo. “Introducción”. En Museo, memoria y nación: misión de los museos nacionales para los ciudadanos del futuro, editado por Gonzalo Sánchez y María Emma Wills, 19-31. Bogotá: Ministerio de Cultura; Museo Nacional de Colombia; PNUD; IEPRI; ICANH, 2000.

Tovar, Bernardo. “Jesús María Henao y Gerardo Arrubla: nueva lectura de una vieja Historia de Colombia”. Revista Credencial Historia, n. ${ }^{\circ} 115$ (1999): 3.

Vanegas, Carolina. Disputas simbólicas en la celebración del centenario de la Independencia de Colombia en Bogotá. Bogotá: Ministerio de Cultura, 2011. 


\title{
Fragmentando la unidad: análisis de la representación territorial chilena en el atlas de 1854
}

\author{
Camila Ramírez Maldonado
}

En la organización política y administrativa de los nacientes Estados latinoamericanos en el siglo XIX, la geografía, como medio científico, pero también como herramienta práctica y táctica, fue fundamental para conocer y reconocer el territorio que se debía organizar y gobernar exitosamente. Así mismo, la cartografía fue relevante, en la medida en que permitió visualizar el territorio nacional y, en cierto sentido, hacerlo tangible. Dentro de sus amplios estudios, la geografía histórica se interesa por los cambios en las fronteras políticas, la variación de la extensión en un territorio determinado, un estado, una región o una provincia. Para ello se vale del estudio de la geografía del pasado y se concentra en analizar y comprender cómo un lugar o una región cambia y se construye en el tiempo. Una de las fuentes que usa la geografía histórica para dar cuenta de este fenómeno son los mapas. Su relevancia está en la capacidad que tienen de sintetizar el tiempo y el espacio en una representación de la tierra que la simula y la hace manipulable y legible fácilmente. "Por medio de la cartografía el espacio se transforma en un dispositivo móvil que hace posible proclamar el conocimiento y el dominio de vastos territorios, incluso a grandes distancias". ${ }^{1}$

En la cartografía también está presente una narrativa continua entre el pasado y el futuro de la nación, así como la conformación de sujetos políticos nacionales. Esta disciplina es un medio de difusión que da a conocer la existencia de los rasgos

1 Sebastián Díaz, Santiago Muñoz y Mauricio Nieto, "Desensamblando la nación: el caso del Atlas geográfico e histórico de Colombia de 1889”, en Proyecto Ensamblado en Colombia, vol. 1., ed. por Olga Restrepo Forero (Bogotá: Universidad Nacional de Colombia, 2013), 6. 
geográficos particulares de un territorio — en este caso, la nación-, delimitados y referenciados claramente. Cuando menciono la cartografía como medio para difundir una "nación gráfica", tomo como referencia los atlas, los cuales, en el caso de América Latina, fueron parte de proyectos estatales que buscaron dar a conocer la nación a públicos amplios por medio de su uso en instituciones educativas.

Con este panorama general, el presente capítulo busca responder cómo está representado el territorio chileno en los mapas de la obra de Claudio Gay, titulada Atlas de la historia física y politica de Chile (1854). A su vez, se busca indagar en la manera en que estas representaciones unifican el territorio nacional o crean la ilusión de un territorio único y propio a cada sujeto que lo habita. Tales objetivos apuntan a hacer una crítica deconstructiva de la unidad nacional, para dar cuenta de cómo cada parte del territorio es una unidad geográfica autónoma; pero que — al ser plasmada en productos como los atlas - se pone en diálogo con aspectos simbólicos y culturales más amplios, por ejemplo, la suposición de una historia común.

El capítulo se divide en cuatro partes. Una primera versa sobre las formas y fuentes que se emplearon para legitimar la ocupación territorial por parte del Estado chileno y los usos que adquiere la cartografía en el ejercicio de soberanía. Seguido a esto, la segunda parte ahonda en la finalidad de la obra de Claudio Gay y su carácter tanto de "acto comunicativo" como de contenido simbólico. En la tercera parte se describe el atlas de Gay y se analiza el componente pedagógico y performativo de sus imágenes para la consolidación de una identidad nacional en torno al territorio y sus diversos componentes; este análisis, inicialmente de mapas, se ve acompañado de otros contenidos visuales presentes en el Atlas que potencializaron las clásicas imágenes de la geografía, que representaban la cotidianidad corográfica de Chile y, consecuentemente, hicieron más tangibles los componentes de su geografía humana. Finalmente, en la cuarta parte, se mencionan los procesos de circulación y producción de la obra y algunos de los problemas que se tuvieron en su edición.

\section{I}

Elisée Reclus ${ }^{2}$ sostenía que la geografía no es más que la historia en el espacio, el estudio de la simultaneidad del espacio-tiempo y la relación de ambos con las sociedades que los producen a través de sus concepciones del mundo, sus prácticas y saberes. Las representaciones geográficas tienen diversas formas: atlas, imágenes cartográficas y topográficas, mapas, narraciones literarias y libros escolares. Estos

2 Elisée Reclus, El hombre y la tierra (México: Fondo de Cultura Económica, 1986), 16. 
son productos intelectuales y artísticos usados por individuos o instituciones como mecanismos culturales para organizar y dar sentidos al mundo. ${ }^{3}$ Así, las representaciones geográficas y sus narraciones, es decir, la manera en la que están elaboradas, poseen una dimensión pedagógica en la medida en que muestran la nación como una "totalidad homogénea" poseedora de una identidad definida ${ }^{4} \mathrm{y}$ delimitada por medio del territorio en el que se encuentra, promoviendo un proceso de cohesión interna y de diferenciación externa. ${ }^{5}$

El Estado-nación moderno está construido por tres elementos principales: el territorio, la población y el ejercicio de poder. Una de las finalidades de esta institución es construir una comunidad nacional cohesionada en torno a un territorio particular, el cual sustenta la localización del ejercicio de poder y la soberanía. Además, el reconocimiento a profundidad de este aspecto permite que se legitime parcialmente su ocupación por un determinado grupo humano, su dominio, explotación, administración y defensa. Podría decirse, entonces, que un mapa es una representación del vínculo entre la noción de posesión y el territorio en sí mismo.

Ahora bien, Chile es un país cuyo territorio, a lo largo de los siglos XVIII y XIX, fue objeto de disputas. Inicialmente se utilizaron argumentos de tipo histórico para legitimar la ocupación de los territorios. Estos se basaban en fuentes como las bulas papales y las actas de fundación de ciudades por los primeros colonos. Luego los argumentos cambiaron y la lucha por el territorio se basó en su ocupación por tradición; sin embargo, estos no eran suficientes, así que fue necesario emplear la cartografía y la geografía como herramientas que permitieran certificar la pertenencia y la defensa de determinados espacios de la nación y el ejercicio del poder sobre estos. Por ejemplo, en 1775, España comienza a estudiar la formación del

3 Roger Chartier, El mundo como representacion. Historia cultural: entre práctica y representación (Barcelona: Gedisa, 1992), 45-62.

4 Esta "identidad definida" desde el "origen de la nación" se puede poner en duda en la medida en la que para el caso latinoamericano, en general, cada proyecto de Estado-nación según sea la filiación política propone diversos y distintos rasgos identitarios. Igualmente, esto sería presumir que la sociedad y sus particularidades son estáticas e inmutables en el tiempo o que solo hay una única manera de concebirla y hacer parte de ella. Por eso mismo, Homi Bhabha también habla de un carácter performativo que visibiliza procesos de inacabamiento y heterogeneidad. Para referencia completa, véase Homi K. Bhabha, El lugar de la cultura (Buenos Aires: Manantial, 2002).

5 Perla Zusman y Sandra Minvielle, "Sociedades geográficas y delimitación del territorio en la construcción del Estado-Nación argentino" (trabajo presentado en el V Encuentro de Geógrafos de América Latina, La Habana, Cuba, agosto, 1995), http://repositoriorecursos-download.educ.ar/repositorio/ Download/file?file_id=05573c0d-7a0b-11e1-821e-ed15e3c494af. 
Virreinato de la Plata y encarga a su cartógrafo, Juan de la Cruz Cano, el mapa de las gobernaciones de Chile y del futuro virreinato. Dicho mapa se usó para hacer un análisis comparativo de lo que fue este territorio - en lo que se convirtió con cada pérdida de este en el siglo $\mathrm{XIX}^{6}$ - al igual que para respaldar la lucha por su recuperación.

De este modo, cartografía y geografía se utilizaron con fines administrativos y diplomáticos. Su circulación no era muy amplia y se limitaba mayoritariamente a los círculos políticos e intelectuales. ${ }^{7}$ Debido a que para la primera mitad del siglo XIX, Chile tenía una gran carencia en materia de cartografía general, fue necesario iniciar un proceso intelectual riguroso que la supliera. ${ }^{8}$ Las autoridades de Gobierno visualizaron desde los albores de la República la imperiosa necesidad de disponer información territorial confiable del espacio geográfico que les correspondía administrar. De ahí su afán por contar con un inventario de los recursos disponibles en el territorio, que tuviera información sobre su extensión y distribución, la localización de la población y de sus riquezas naturales. Cada uno de estos elementos debía venir acompañado de su correspondiente representación cartográfica; es decir, de lo que actualmente se conoce como cartografía topográfica y cartografía temática. ${ }^{9}$

\section{II}

En 1829 surge la República Conservadora encabezada por Diego Portales. Este periodo político, que dura treinta años, se caracterizó por haber establecido en la nación un tiempo de relativa estabilidad interna ${ }^{10}$ mediante una política de repre-

6 Benjamín González, Historia cartográfica resumida en los límites de Chile (Santiago: Cristian Salazar, 2001-2002), 145.

7 Cristóbal García-Huidobro Becerra, reseña de Construcción de Estado en Chile (1800-1837). Democracia de los "pueblos", militarismo ciudadano, golpismo oligárquico, de Gabriel Salazar, Historia 40, n. ${ }^{\circ} 1$ (2007): 194-198.

8 Jaime Rosenblitt y Carolina Sanhueza, "Prólogo", en Cartografía histórica de Chile, ed. por Rafael Sagredo Baeza (Santiago de Chile: Pontificia Universidad Católica de Chile; Cámara Chilena de la Construcción; Biblioteca Nacional, 2010), xii.

9 Michael Biggs, "Putting the State on the Map: Cartography, Territory, and European State formation", Compartive Studies in Society and History 42, n. 2 (1999): 374-405.

10 Para profundizar en este tema, véase: Bernardino Bravo Lira, El absolutismo ilustrado en Hispanoamérica: Chile (1760-1860) de Carlos III a Portales y Montt (Santiago: Imprenta y Oficina de la Democracia, 1994). 
sión severa ${ }^{11}$ que puso fin al militarismo y a la lucha armada entre conservadores, liberales, centralistas y federalistas, creando una nueva constitución para $1833 .{ }^{12}$

Durante esos mismos años, el naturalista francés Claudio Gay (1800-1873) llegó a Chile para desempeñarse como profesor de geografía en el Colegio de Santiago. En 1830, debido a su trayectoria como científico e investigador, fue contratado por el Gobierno conservador de Portales para realizar un detallado estudio de la realidad geográfica, histórica y natural del país. La finalidad de este proyecto consistía en ejecutar una exhaustiva investigación general que tuviera como resultado una obra visual y descriptiva de Chile desde una perspectiva interdisciplinar y que posibilitara una mirada más amplia y heterogénea de la realidad nacional. ${ }^{13}$ Esta permitiría conocer la forma del país y las dimensiones del espacio geográfico heredado de la Corona española. Además, "el hecho de poder contar con tales coberturas, se consideraba fundamental para fines militares, de administración y ordenación del territorio". ${ }^{14}$

Lo anterior indica que, a pesar de que el proyecto fuera un "acto comunicativo" para dar a conocer la nación, su territorio y seres vivos que la habitaban, sus usos parecían seguir estando limitados al ejercicio del poder político y a la administración estatal. Por consiguiente, cabría preguntarse por la circulación de estas herramientas en todo el territorio. Si bien es complicado medir la difusión de los mapas en zonas periféricas de la nación para dar a conocer sus límites a sus habitantes, es interesante indagar por los posibles usos abstractos que tuvo la geografía por medio de narraciones más directas o simbólicas, a fin de buscar unificar a la gente en torno a un espacio nacional.

Por otro lado, la cartografía tiene un papel importante en la condensación, comunicación y visualización del poder y de la nación. Los mapas, más allá de su dimensión "científica” relacionada con la precisión, son producto no solo de disciplinas técnicas, sino también de las normas, los valores del orden y la tradición

11 Francisco Encina, Historia de Chile, vol. 10 (Santiago de Chile: Nascimiento, 1952), proporciona una descripción detallada de la dictadura de Portales.

12 Luis Galdames, La evolución constitucional de Chile, 1810-1825 (Santiago: Imprenta Balcells y Cía., 1926), 872.

13 Carlos Ortiz, Los atlas de historia fisica y politica de Chile por Claudio Gay (Santiago de Chile: Imprenta Universitaria, 1954), 80.

14 José González, "Primeros levantamientos cartográficos generales de Chile con base científica: los mapas de Claudio Gay y Amado Pissis”, Revista de Geografia Norte Grande, n. 38 (2007): 22. 
social. ${ }^{15}$ La cartografía se usa y se considera un cuerpo de conocimiento teórico y práctico; un modelo que muestra objetos y elementos del mundo registrados como reales, objetivos y con una existencia independiente del cartógrafo. A través de esta, la realidad puede expresarse en términos matemáticos, donde la observación y la medición sistemáticas son la única ruta a la "verdad del espacio”, y donde dicha verdad puede ser comprobada de manera independiente. Así, los mapas son tratados como fotografías simplificadas de la realidad o como una imagen analógica ${ }^{16}$ que aspira a garantizar "un fiel reflejo de la realidad descrita, así como asegurar la tarea de producir un conocimiento científicamente legitimado". ${ }^{17}$ Igualmente, se considera al "objeto plasmado como una representación figurativa, pero con carga de realidad así físicamente no corresponda a ella". ${ }^{18}$

Al analizar un mapa o un compendio cartográfico, se tiende a pasar por alto su contenido simbólico. Frente a esto cabe señalar que al ser estas imágenes representaciones visuales del territorio, están mediadas por las experiencias de sus elaboradores y, en el caso chileno, por las exigencias e intereses estatales. Este aspecto subjetivo o sesgado de los mapas es lo que amplía sus usos, pues se manifiestan como una construcción artificial que describe el mundo "en términos de relaciones y prácticas de poder, preferencias y prioridades culturales". ${ }^{19}$ Así, los mapas reflejan una "visión del mundo"; ${ }^{20}$ son una "construcción de la realidad, imágenes cargadas de intenciones y consecuencias que se pueden estudiar en las sociedades de su tiempo" (figura 1).

15 Jeremy Crampton, “Maps as Social Constructions: Power, Communication and visualization”, Progress in Human Geography, n. ${ }^{\circ} 25$ (2001): 235-252.

16 Carla Lois, "La elocuencia de los mapas: un enfoque semiológico para el análisis de cartografías", Anales de Geografia, n. 36 (2000): 93-109.

17 Gabriela Cecchetto, "Explorar, imaginar y relatar el territorio: viajes y tecnologías de poder en la producción y legitimación de saberes geográficos en la universidad nacional de Córdoba, 1876-1882" (trabajo presentado en el XIII Coloquio Internacional de Geocrítica, Barcelona, 5-10 de mayo de 2014), 7.

18 Miriam Loaiza, "Iconografía cartográfica, un método para la lectura", Memoria y Sociedad 6, n. 12 (2002): 64 .

19 John Harley, La nueva naturaleza de los mapas (México: Fondo de Cultura Económica, 2005), 59.

20 Vladimir Montoya, "El mapa de lo invisible: silencios y gramática del poder en la cartografía”, Universitas Humanistica, n. ${ }^{\circ} 63$ (2007): 161. 
Fragmentando la unidad: análisis de la representación territorial chilena en el atlas de 1854

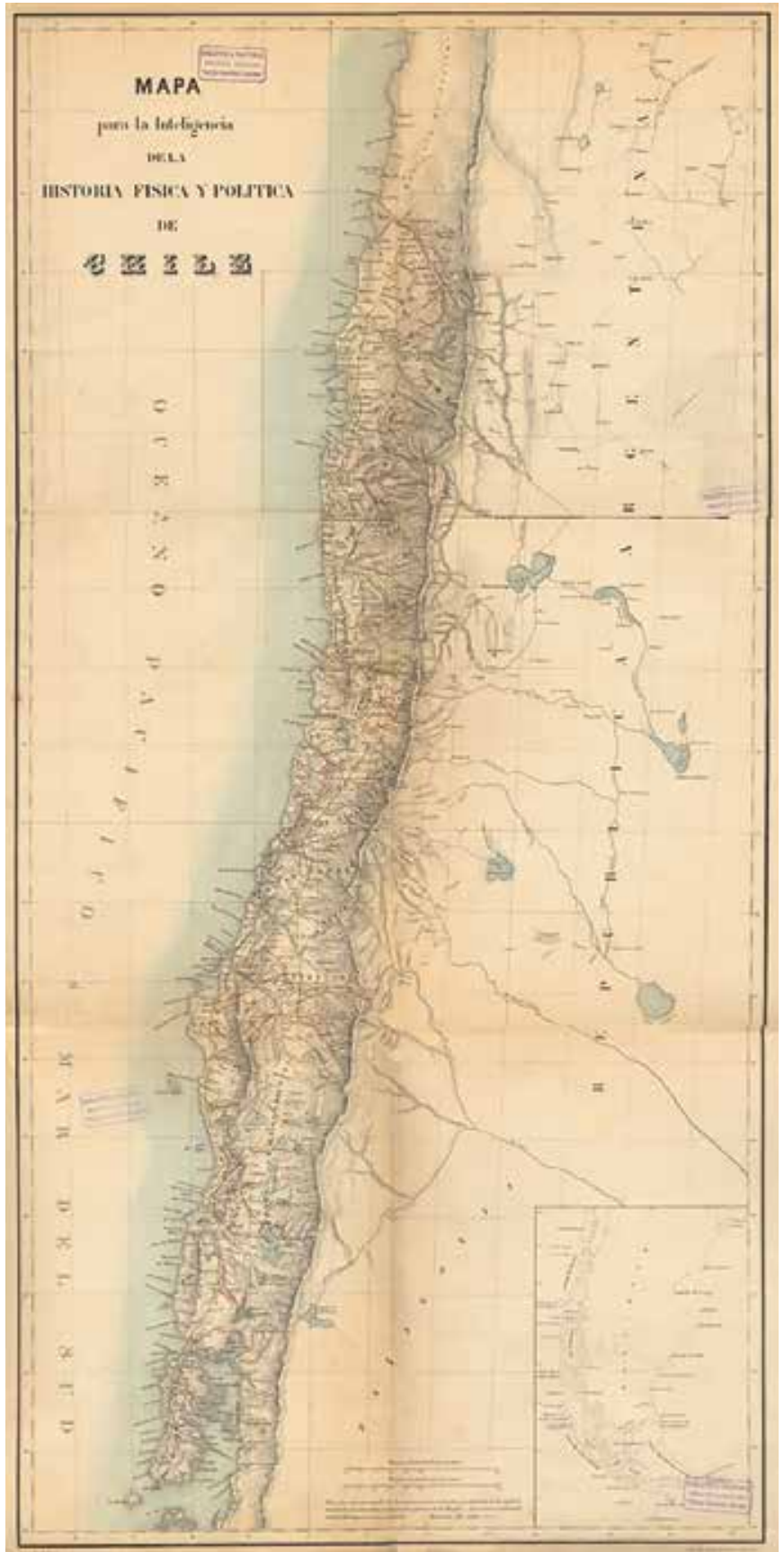

Figura 1. Claudio Gay, 1854, "Mapa para la inteligencia de la historia física y política de Chile” (lámina N. 1, grabado en acero e impresión en lámina, Atlas de la historia física y política de Chile [París: Imprenta de E. Thunot], Biblioteca Nacional, Santiago de Chile). 
Por otro lado, debe tenerse en cuenta que aquello que se representa o se busca representar depende de los intereses del viajero y de las oportunidades de su travesía. Lo anterior explica, de cierta manera, por quéla mayoría de las imágenes del atlas de Gay son representaciones de la flora, la fauna y la geografía humana propia de Chile. Así mismo, estas imágenes pueden analizarse como una mezcla de temporalidades y experiencias dispersas que se quieren unificar. A lo largo de su proceso de elaboración y reproducción, sufren cambios y transformaciones para legitimarse como representaciones "fieles" a la realidad, las cuales pueden ser idealizadas durante el proceso, en especial cuando se trata de imágenes sobre la geografía humana.

En este caso, un compendio de mapas es una forma de conocimiento y, por lo tanto, una forma de representar el poder de la nación en la medida en que estos constituyen medios de control sobre un espacio geográfico determinado. El mapa, como dispositivo, moviliza algún mensaje de manera explícita o implícita y es usado por los Estados modernos para reclamar sus dominios territoriales. De esta forma, se convierte en un "instrumento de política del Estado, así como de soberanía"21 que permite comprender cómo se configura y desarrolla un país a lo largo del tiempo, tanto en su estructura interna como en sus fronteras nacionales, a fin de generar estrategias para la construcción de una nación unificada en torno a la representación del territorio que comprende.

\section{III}

Los viajes de Claudio Gay van desde 1834 hasta 1842, año en el que regresa a su país de origen para sistematizar y organizar la información recolectada, para luego finalizar el trabajo bajo el Gobierno de Manuel Montt. Como resultado, surge en 1854 la obra llamada Historia física y politica de Chile, dos de los tomos que componen su obra de treinta volúmenes. Para ello, Gay realizó doce mapas del territorio chileno en los cuales hizo hincapié en el relieve y los detalles de la zona interna más que en el litoral, debido a que el interior era la parte menos explorada. Las otras imágenes que allí aparecen son retratos de sus habitantes, espacios urbanos, puntos ambientales estratégicos, sucesos históricos clave en el surgimiento de la nación, objetos y tradiciones culturales propias de las comunidades indígenas, así como la variedad de animales y plantas propias del territorio que, desde la perspectiva de su

21 Denis Wood y John Fels, "Designs on Signs: Myth and Meaning in Maps", Cartographica 23, n. 3 (1986): 63 . 
compilador, debían ser graficadas, representadas y difundidas con más rigurosidad, ya que estos últimos representaban la riqueza de la nación.

Estas diversas representaciones de los elementos que componen la nación se jerarquizan dentro de la obra de Gay no de manera científica o política; se organizan de forma pedagógica, a la vez que responden a las solicitudes intelectuales y estatales. Los treinta tomos de la obra completa se dividen de la siguiente manera: los ocho primeros tratan de historia política; otros dos contienen documentos históricos reunidos en diversos archivos nacionales y extranjeros; ocho tomos son sobre botánica; ocho de zoología; dos tomos forman un atlas (fuentes centrales de este texto) con grabados de las especies naturales, mapas de diversas regiones, paisajes, tipos humanos y costumbres chilenas; finalmente, dos tomos detallan un estudio sobre el estado de la agricultura chilena. Esta distribución, en términos pedagógicos, lleva al lector en un paso a paso del reconocimiento del territorio y sus partes. Primero, conocer los límites de la nación, luego sus gentes y cultura y, por último, su naturaleza. Igualmente es una manera práctica de organizar elemento por elemento la narrativa espacial de la nación.

Por otro lado, esta distribución permite que los lectores aprecien una continuidad geográfica y no cambios abruptos en los límites internos y externos de la nación. Esta es una forma eficiente de mostrar la geografía nacional como resultado de la mezcla entre el "paisaje original" y los acontecimientos significativos durante la historia del país que han sucedido en espacios geográficos determinados, delimitados y representados cartográficamente. Así mismo, cuando se analiza la obra en su totalidad, la abundancia de imágenes referentes a la naturaleza (fauna y flora) de Chile da cuenta de los intereses propios del autor, cuya formación de naturalista se evidencia claramente, además del interés estatal por tener una descripción amplia y detallada de los animales, vegetales y minerales que hacen que el territorio sea rico y llamativo.

La obra de Gay fue criticada por falta de precisión en las medidas y en la localización de algunas demarcaciones, pues el objetivo de los mapas era "producir un modelo 'correcto' del terreno". 22 A pesar de que varias técnicas usadas para el levantamiento cartográfico resultaban adelantadas y modernas, en los términos científicos de la época, también podían tener problemas de precisión; lo anterior sin contar con los errores que pudieron surgir en el proceso posterior de edición

22 Harley, La nueva naturaleza, 185. 
e impresión. ${ }^{23}$ No obstante, la obra —más allá de sus procedimientos- fue elogiada por presentar nueva información sobre las características físicas de la nación y, adicionalmente, por la representación de sus componentes culturales, naturales e históricos. Fue un importante aporte al conocimiento geográfico chileno en términos científicos y culturales, pues se trataba de un novedoso soporte gráfico e intelectual de la anhelada unidad.

Para el momento en el que Claudio Gay inicia sus viajes en Chile (1834), la división política-administrativa del país se constituía por diez provincias. Una vez vuelve a París y se encuentra realizando su trabajo de confección cartográfica, se modifica dicha división interna, debido a que en 1843 se agregó otra provincia, al igual que en $1848,{ }^{24}$ las cuales alcanzaron a ser incluidas oportunamente por Gay. La manera en la que se organiza y se presenta el territorio en los mapas de su obra buscaba abarcar la "totalidad” del país. Este se expone como una unidad sólida sin división alguna, donde los únicos aspectos dignos de ser mostrados, a través de un alto rigor científico, son sus elementos físicos (figura 2). Gay pretendió unir en el atlas elementos que parecían dispersos en la descripción del país y, a la vez, proponía una manera de entenderlo. Siguiendo la línea argumentativa de Derrida, ${ }^{25}$ esta unidad podría analizarse desde un ejercicio de deconstrucción de la totalidad nacional. Dicha apuesta conlleva una redefinición crítica de la nación y de sus características geográficas por medio de mapas e imágenes, pasando de la lectura universal del territorio a un ejercicio de interpretación más local.

Plantear esta "deconstrucción de la totalidad única" es posible en la medida en que Gay representa aspectos que él considera claves para la definición y construcción de la nación chilena. Su obra ilustra eventos, personas, objetos, animales y plantas conforme a sus enfoques particulares como científico, geólogo, historiador y estadista. ${ }^{26}$ Adicionalmente, Gay juega indirectamente con la escala geográfica, en la que se entrecruzan — para el caso de los mapas - lo local, lo regional y lo nacional, haciendo tangibles tales divisiones por medio de la representación visual de prácticas sociales, culturales y económicas propias a cada provincia. Vale la pena

23 Aclaro que en este capítulo no se profundiza sobre el carácter técnico de la producción de los mapas.

24 González, "Primeros levantamientos cartográficos", 34.

25 Jacques Derrida, La escritura y la diferencia (Barcelona: Anthropos, 1989).

26 Estas facetas alternativas se evidencian en obras como: Claudio Gay, Historia de la independencia chilena (París: Imprenta de E. Thunot, 1856); Claudio Gay, Consideraciones sobre las minas de mercurio en Andacollo e Illapel con su posición politica (París: Imprenta de E. Thunot, 1851). 


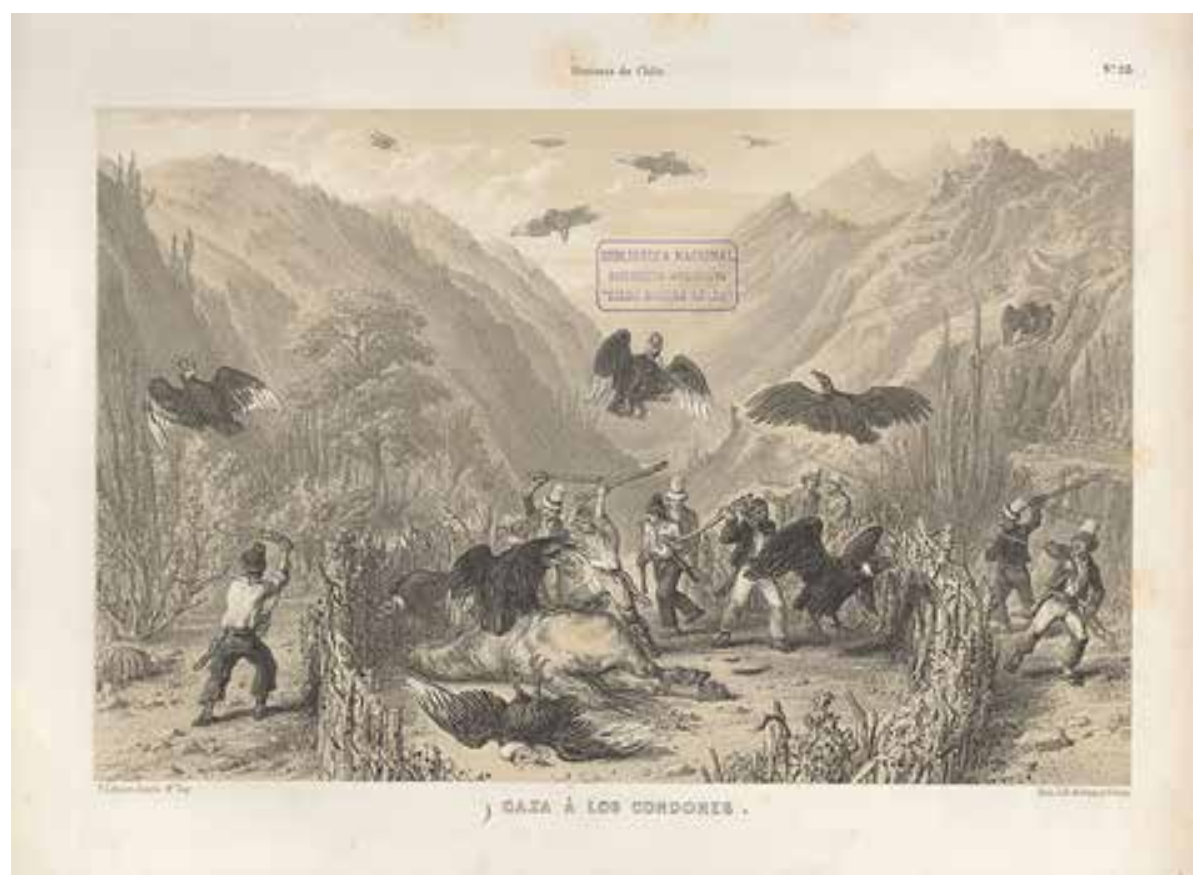

Figura 2. Claudio Gay, 1854, "Caza a los cóndores" (lámina N. 53, grabado en acero e impresión en lámina, Atlas de la historia fisica y politica de Chile [París: Imprenta de E. Thunot], Biblioteca Nacional, Santiago de Chile).

mencionar en este punto que estas imágenes también pueden entenderse como un intento por simular una continuidad cultural a lo largo de la historia; es decir, no pretenden mostrar un antes y un después radical, sino una transición lenta y constante que se refleja en lo que es hoy en día la nación. La continuidad suele ser más importante que el cambio para las comunidades, pues simbólicamente las hace pertenecer a algo más grande de manera mitificada.

Según señalaba anteriormente, a pesar de que el atlas de Claudio Gay es una herramienta política importante, también desempeña una función pedagógica y práctica. ${ }^{27}$ Dentro de su dimensión pedagógica surge la necesidad por particularizar la totalidad del territorio; los mapas del Atlas muestran cada provincia por separado e ilustran con más detalle sus características geográficas físicas. No obstante, esta particularización puede entenderse como un ejercicio simbólico donde el territorio nacional se representa como la unión de varias unidades políticas

27 Jean Marc Besse, "El nacimiento del atlas moderno", en Elmundo de los mapas, ed. por Lafreti Ortelius (Madrid: Fundación Botín, 2007), 93-139. 
autónomas, puestas en diálogo unas con otras a través de aspectos sociales, culturales, históricos e ideológicos, denominados comunes o compartidos con el fin de divulgar y dar a conocer diversas prácticas culturales que se encuentran en todo el territorio. Por ejemplo, la lámina titulada "Caza a los cóndores" (figura 2) o el "Incendio de Valparaíso" (figura 3) son imágenes de acontecimientos que ilustran costumbres y sucesos históricos. Estas —analizadas dentro de las percepciones y marcos culturales del momento - adquieren sentido al representar acciones que son o "deberían" ser relevantes para la población chilena desde la perspectiva de quien las manda a hacer, quien las realiza o, incluso, de quien las publica. En el ejercicio sugerido de deconstrucción de la unidad nacional deben tenerse en cuenta una serie de consideraciones: primero, comprender que existe una separación entre el cartógrafo como emisor y el lector como receptor; segundo, el mapa debe verse como el intermediario de la relación anterior; tercero, el mapa comunica la información seleccionada por el cartógrafo, condicionado a su vez por entidades o circunstancias exteriores; por último, hay que conocer los parámetros cognitivos del lector, sus experiencias y modos de observación. Todo esto con el fin de indagar cómo un mapa con pretensiones de totalidad puede tener una sola representación, pero múltiples definiciones. Así, se aprecia la interacción entre las ideas del cartógrafo y las del lector, mediada por la interpretación de símbolos y significados que se materializan en otras narraciones y acciones (formas de ocupar el territorio y apropiárselo) al punto de desembocar en la "construcción del todo y en la unidad de lo fragmentado".

El atlas es una abstracción de la nación, dividida estratégicamente por medio de parámetros administrativos y culturales. A primera vista, las divisiones geográficas no son tan relevantes en el caso chileno como sí lo fueron en otros países más fragmentados. Sin embargo, estas resultan evidentes cuando el atlas de Gay hace referencia a las provincias del interior y a las provincias costeras o, incluso, a las características climáticas de cada una según su ubicación espacial. Un mapa (o un conjunto de mapas) no es el territorio que representa; aun así, guarda similitud con la estructura territorial en la que se inspira su realización. Del mismo modo, un retrato no es una persona ni da fe de su cotidianidad o de los hechos históricos en los que participó; pero representa, o puede representar, esos aspectos de manera simbólica. Para el caso de la fragmentación de la nación en regiones o provincias, las fronteras elegidas para dividir el territorio son artificiales, así como lo son aquellas que se trazan en los mapas, exceptuando las de carácter natural: por ejemplo, un río que separe "inevitablemente" un territorio. La división usada por Gay, a pesar de 


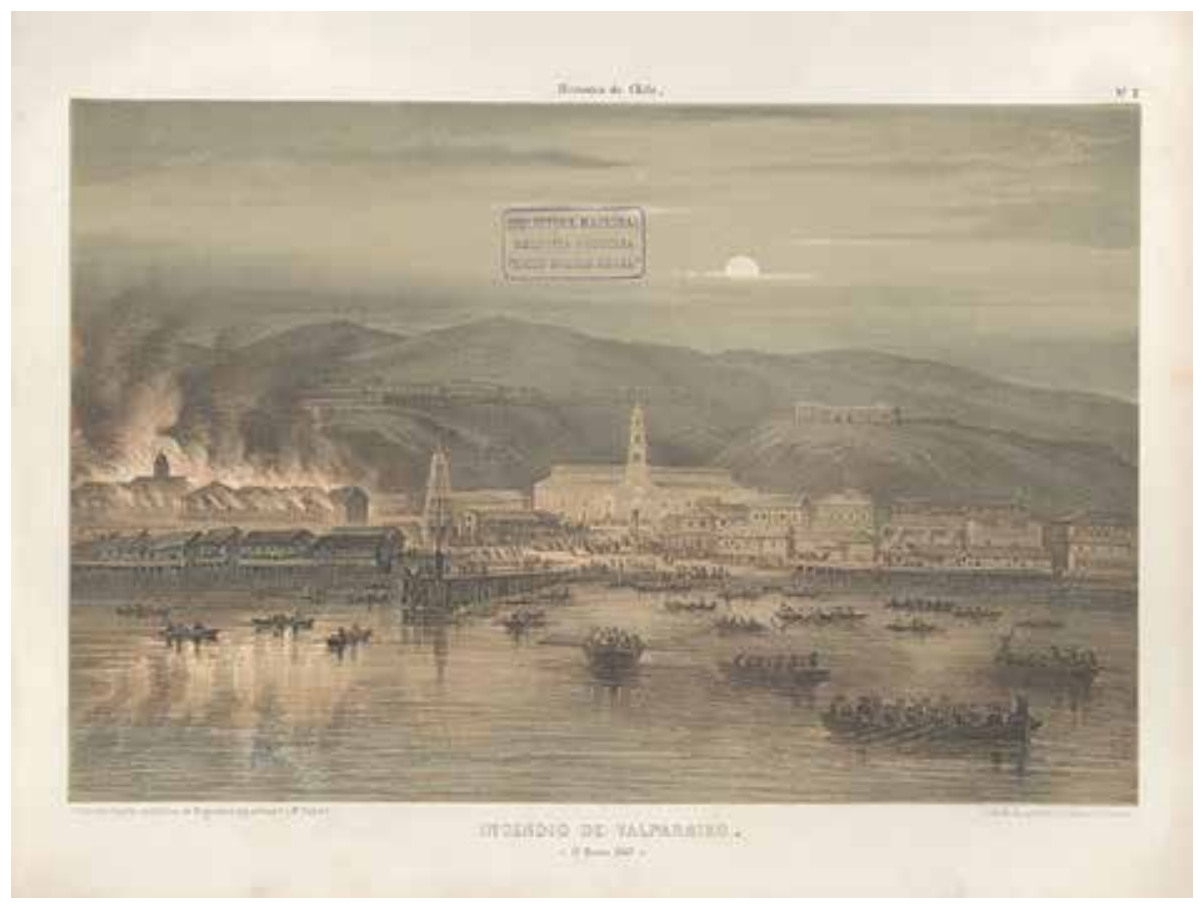

Figura 3. Claudio Gay, 1854, "Incendio de Valparaíso" (lámina N. 31, grabado en acero e impresión en lámina, Atlas de la historia fisica y politica de Chile, Biblioteca Nacional, Santiago de Chile).

coincidir con la de las provincias, responde a criterios más "científicos" que estrictamente políticos. Chile es un país poco ancho y su longitud permite una división territorial práctica que use los paralelos, tal y como puede apreciarse en las imágenes de las provincias de Valdivia (figura 4) y Concepción (figura 5), al igual que en varios mapas del Atlas. Así mismo, el hecho de hacer más “científicos" los mapas por medio de herramientas especializadas, permite que la cartografía adquiera un estatus disciplinar catalogado como objetivo y que, como resultado, produzca "conocimiento verdadero, probable, progresivo o muy confirmado", ${ }^{28}$ acorde a las nociones y parámetros de su tiempo.

28 Larry Laudam, Progress and its Problems: Toward a Theory of Scientific Growth (Berkeley: University of California Press, 1977), 2. 


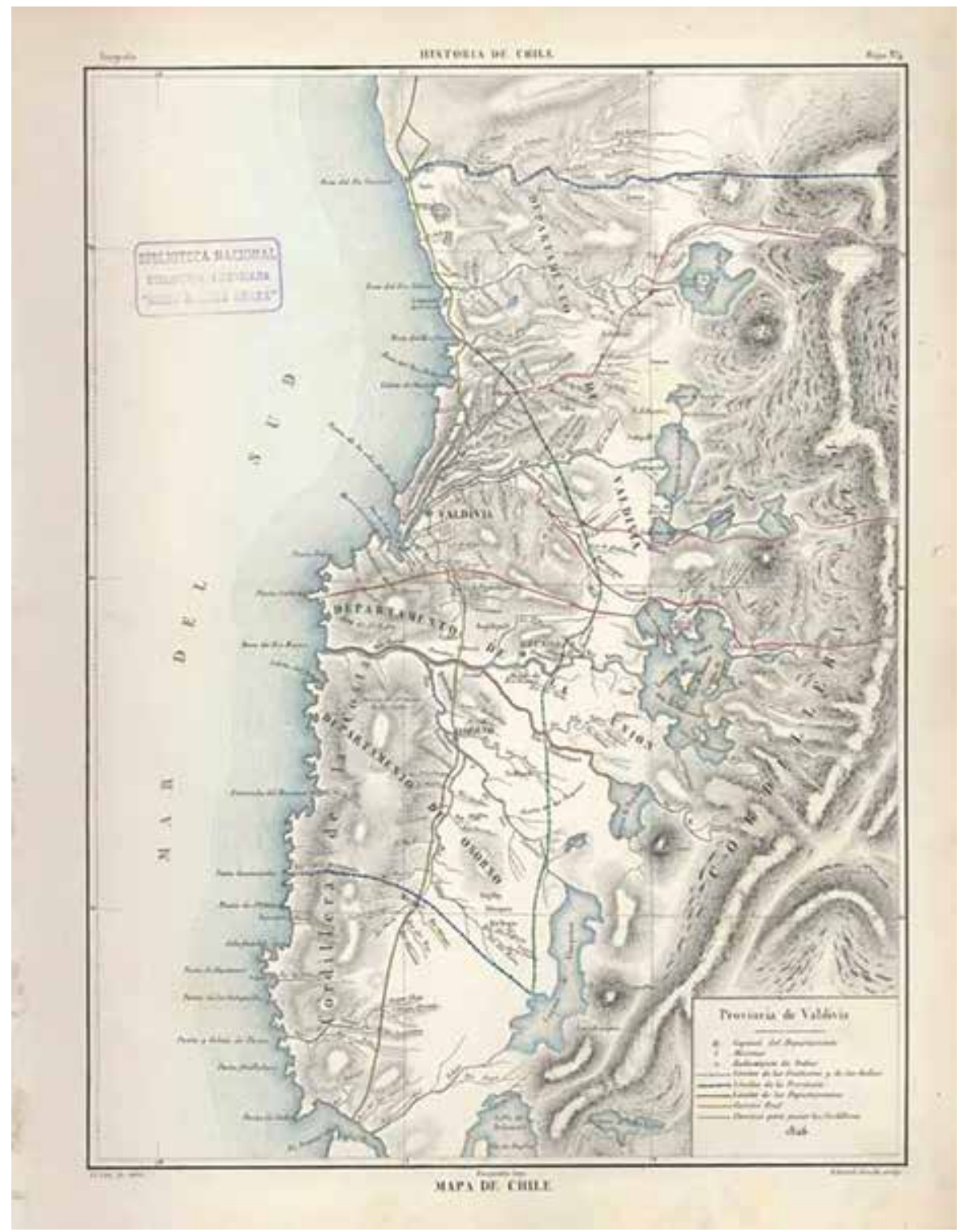

Figura 4. Claudio Gay, 1854, "Mapa de Chile, provincia de Valdivia” (lámina N. 6, grabado en acero e impresión en lámina, Atlas de la historia física y política de Chile [París: Imprenta de E. Thunot], Biblioteca Nacional, Santiago de Chile). 
Fragmentando la unidad: análisis de la representación territorial chilena en el atlas de 1854

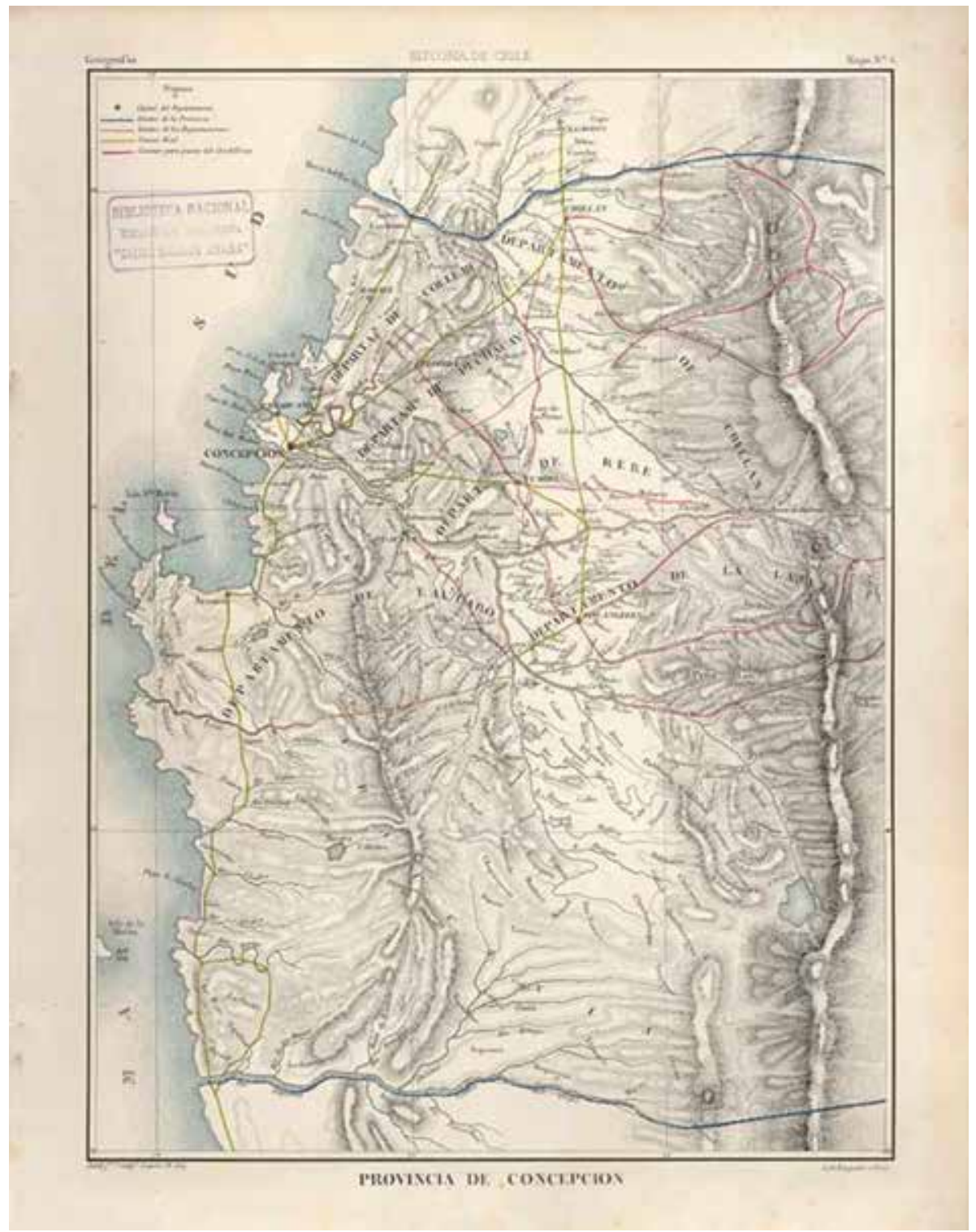

Figura 5. Claudio Gay, 1854, "Provincia de Concepción” (lámina N. 7, grabado en acero e impresión en lámina, Atlas de la historia física y politica de Chile [París: Imprenta de E. Thunot], Biblioteca Nacional, Santiago de Chile). 
Existe, según señalaba, cierta producción de subjetividades asociadas a la construcción de territorialidad en dispositivos móviles como los mapas, motivo por el cual la visualización geográfica adquiere importancia en la medida en la que hace visible las relaciones espaciales y las conexiones de los datos presentados, con el fin de crear una interacción con la fuente misma. El hecho de crear instrumentos visuales y ponerlos a circular en medios como los atlas reitera el uso y la finalidad pública de la cartografía ${ }^{29}$ - a pesar de que su distribución esté mediada por instituciones públicas o privadas-, la cual busca dar a conocer la totalidad del territorio nacional y sus bondades particulares.

Las divisiones, que pueden ser de carácter administrativo, geográfico o por unidades económicas, culturales y raciales, son indicios sobre la forma en que se concibe la geografía como disciplina y herramienta de poder, no solo para administrar los recursos de la nación, sino también a sus habitantes. Por un lado, las representaciones aisladas de cada provincia o parte de la totalidad hablan sobre la manera en la que se entienden los componentes geográficos de la nación. Por el otro, hablan sobre la manera en que la nación se jerarquiza de manera fraccionada, pensándose e idealizándose a partir de un momento originario de formación. Así mismo, esta fragmentación da bases para la formación de regiones con orientaciones políticas y sistemas económicos autónomos que se acentúan por medio de las divisiones geográficas naturales y las distancias entre las mismas regiones o nodos de poder.

En este contexto se destaca la obra de Claudio Gay, debido a su vinculación directa con una iniciativa nacional, cuyos resultados fueron los primeros mapas que representaron a la república como un espacio geográfico unitario y longitudinal, al tiempo que mostró la dimensión legítima del territorio chileno y su contenido. Gay es considerado el pionero en la creación de herramientas visuales que contribuyeron a la consolidación e, incluso, a la creación de una identidad nacional fundamentada en el aspecto espacial; así lo señalan Jaime Rosenblitt y Carolina Sanhueza, quienes

29 Es necesario tener en cuenta que obras como esta, con la finalidad de difundir conocimientos específicos, incluso en sectores populares, pudieron llegar a decepcionar a este tipo de lectores. La obra de Gay fue esperada con ansias, pues prometía ser un compendio ilustrado, informativo y entretenido sobre el país. Sin embargo, tras su lanzamiento, el público quedó parcialmente desencantado, porque algunas de sus imágenes, en especial las relacionadas con la botánica, si bien eran llamativas, resultaban a su vez muy "científicas" en cuanto a su breve descripción, lo cual hacía necesario revisar otros tomos de la obra para conocer mejor los usos de las plantas que allí aparecían. 
afirman que: ${ }^{30}$ "Al comenzar el período republicano, la cartografía contribuyó a la formación de una identidad nacional con mapas orientados verticalmente de norte [a] sur, para transmitir a sus ciudadanos una imagen del país radicalmente distinta a la del período colonial". ${ }^{1}$

Volviendo sobre los criterios de ilustración utilizados para el Atlas de Gay, a pesar de que varias provincias están bien detalladas en los mapas, y teniendo claro que el principal interés del cartógrafo era la parte interior del país, hay una ausencia de detalle en la representación de los territorios costeros. Dicho vacío arroja pistas sobre la manera en la que se habitan o no los territorios, así como el protagonismo designado a estos. Tener presente la preferencia de Gay por los territorios interiores de la nación, permite plantear un contraste entre las imágenes de la "Bahía de Talcahuano" (figura 6) y la "Bahía de Valparaíso" (figura 7), desde una perspectiva en la que el observador - a primera vista - podría pensar que la primera no resulta muy importante para las actividades económicas del país y, por consiguiente, no es un lugar apto para el establecimiento de una ciudad próspera o para figurar de manera especial en los mapas. Esto debido a los elementos que componen cada imagen: mientras en Valparaíso hay un asentamiento urbano, en Talcahuano no lo hay.

30 Debido a la carencia de prácticas o narrativas de identidad y unidad previas, los procesos de conquista estatal del espacio contribuyen a acentuar el peso del factor territorial. Para ampliar, revísese: Antônio Morães, "Notas sobre a identidade nacional e a institucionalizacão da geografia no Brasil", Estudos Históricos 4, n. ${ }^{\circ} 8$ (1991): 166-176.

31 Rosenblitt y Sanhueza, "Prólogo”, 7. 


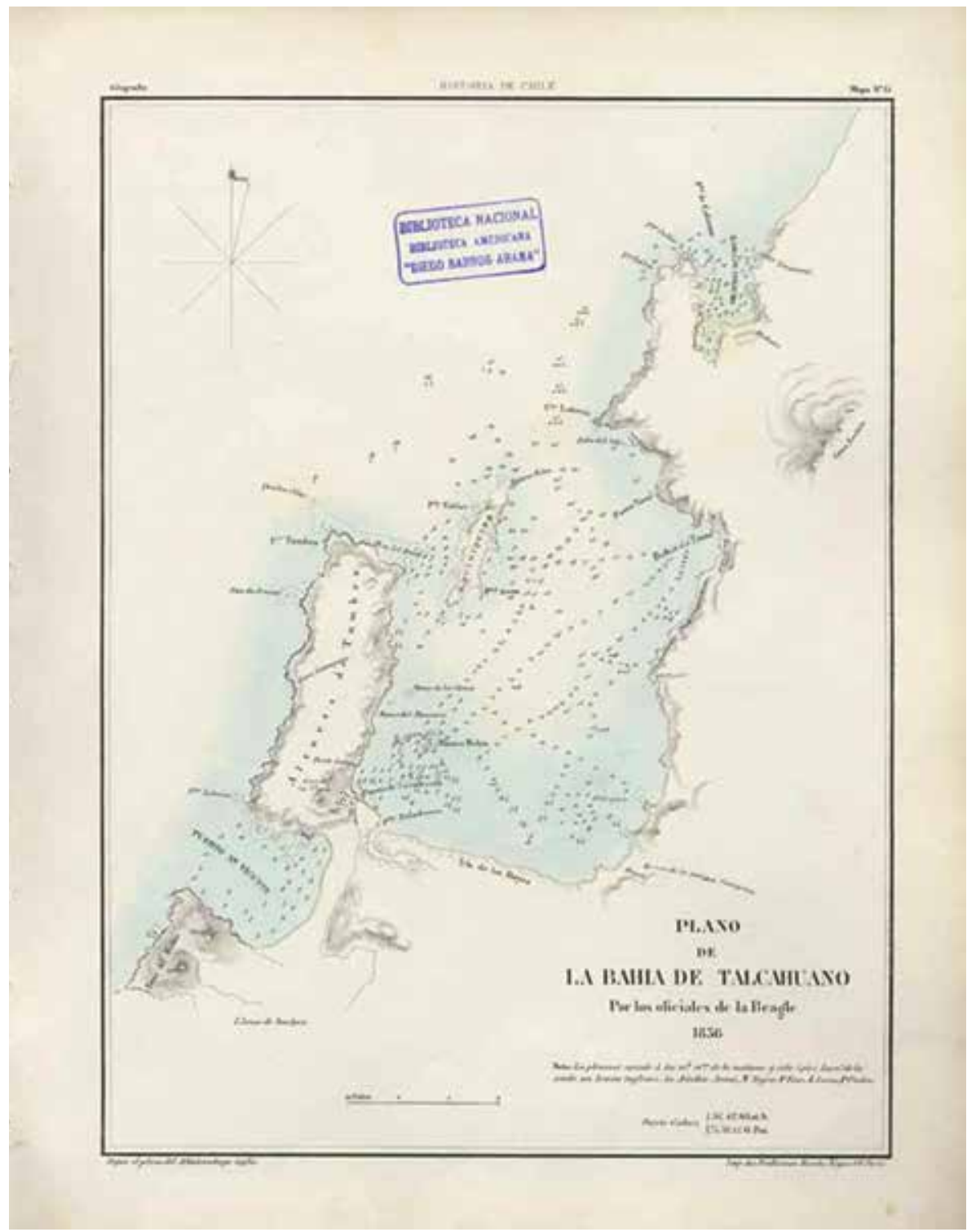

Figura 6. Claudio Gay, 1854, "Plano de la bahía de Talcahuano” (lámina N. 17, grabado en acero e impresión en lámina, Atlas de la historia física y política de Chile [París: Imprenta de E. Thunot], Biblioteca Nacional, Santiago de Chile). 


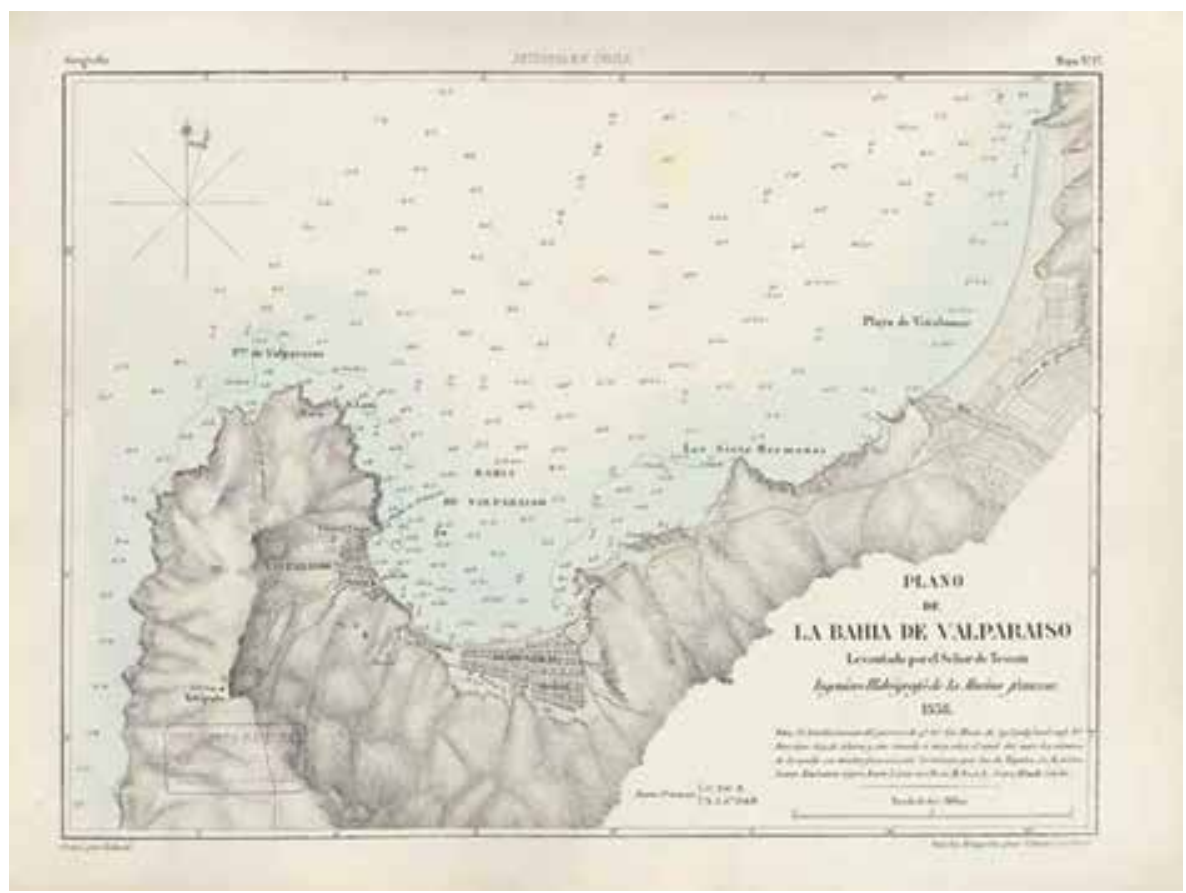

Figura 7. Claudio Gay, 1854, "Plano de la bahía de Valparaíso" (lámina N. 19, grabado en acero e impresión en lámina, Atlas de la historia física y politica de Chile [París: Imprenta de E. Thunot], Biblioteca Nacional, Santiago de Chile).

La jerarquización de las imágenes y las regiones que representan se analiza desde dos perspectivas. La primera sería de forma circunstancial, es decir, por cuestiones indefinidas, el autor pudo tener más información sobre un espacio particular o tuvo la oportunidad de estudiar con más detenimiento esa zona. La segunda interpretación sugeriría que el autor, en su tarea de representar la totalidad del territorio desde las particularidades de cada región, identificó esa zona como relevante, debido a su alta actividad económica, por lo que la representó así con mayor detalle a partir de sus vivencias y experiencias.

En el caso de la bahía de Valparaíso, esta puede ser considerada "más importante", debido a su actividad portuaria, a su infraestructura, a su conectividad (por carretera o ferrocarril), así como por su marco sociopolítico y el contexto económico en general. ${ }^{32}$ Por otro lado, a pesar de que Valparaíso fuera un punto importante de

32 Estos aspectos de clasificación se usan actualmente para la realización de los rankings locales, regionales e internacionales de los puertos. 
comercio para el siglo XIX, la cartografía del Atlas no muestra numerosos caminos que la comuniquen con el interior del país. Tal forma de representar los territorios también nos ofrece pistas sobre otros aspectos de la sociedad; en este caso, sobre la importancia de los puertos y la manera en la que se relacionan con la zona interior, y ello designa a los mapas la responsabilidad simultánea de configurar una geografía económica, de producción y comunicación regional.

Para ver la conexión de este puerto con el resto de la nación, es necesario un análisis entre escalas geográficas donde se comparen las representaciones de cada zona particular con la ilustración total del país. Las vías de comunicación que se grafican en los mapas adquieren de este modo una función política y práctica que permite ver las localizaciones de la nación unidas a la totalidad, así como la jerarquía de los territorios por separado. No es gratuito el hecho de que la bahía de Talcahuano esté desconectada del interior chileno por vía terrestre; da la impresión de que es un territorio con acceso primordialmente marítimo, lo que anuncia, a su vez, la importancia de este tipo de transporte e infraestructura para el Estado chileno decimonónico. Hablar en este caso de un "maritorio" resulta pertinente, en cuanto se hace referencia a la apropiación del territorio marino, incluyendo sus espacios costeros o insulares. ${ }^{33}$

Por otro lado, la representación de cada provincia es insuficiente usando solo un mapa. Al ser consciente de esto, Gay recurrió a otras estrategias gráficas que dieran cuenta de una unidad geográfica desde sus aspectos culturales, históricos y naturales como se ha mencionado. El Atlas tiene imágenes que abandonan su carácter "científico" para dar paso a ilustraciones con componentes simbólicos sobre la geografía física y humana; son imágenes donde figuran diversas etnias con sus vestimentas tradicionales, animales, vegetación, herramientas de uso cotidiano y otros elementos relacionados con la corografía y riqueza natural. Hay un intento por mostrar la manera en la que las actividades humanas modifican el medio ambiente y, a la vez, lo jerarquizan según la importancia o la relevancia de los sistemas de producción.

33 El territorio se entiende como ejercicio de poder, una forma en que se apropia el espacio; no solo se piensa como una noción geográfica, sino como una noción jurídico-política. Véase: Michel Foucault, "Preguntas a Michel Foucault sobre la geografia", en Estrategias de poder: obras esenciales, vol. 2, ed. por Julia Varela y Fernando Álvarez (Barcelona: Paidós, 1999), 313-326. 
Como lo menciona Beatriz Rodríguez, ${ }^{34}$ en una delimitación disciplinaria, la geografía se limita al aspecto matemático; mientras que la corografía, siendo más amplia en su contenido, es el “complemento 'artístico-social' de la geografía”. Así, en el atlas de Claudio Gay es posible encontrar imágenes cuya composición da cuenta de los aspectos que se le escapan a la geografía. De este modo, las prácticas "geográficas se enfocan en la producción de conocimiento que posibilita y garantiza la apropiación y transformación material y simbólica del territorio nacional". 35

Aunque los mapas consolidan la imagen de un territorio condensado y unificado — con sus respectivas jerarquizaciones—, las otras imágenes elaboradas por Gay dan la impresión de no buscar representar la nación como una totalidad en sí misma, sino más bien como un "bricolaje" geográfico y corográfico en el que se resaltan algunos escenarios particulares, reconocidos bien sea por sus bondades naturales (flora, fauna y recursos), por sus procesos históricos (batallas y fundaciones) o por su legado étnico-cultural (como el caso de las representaciones indígenas). Igualmente, estas representaciones sugieren varios interrogantes sobre su contenido; las más obvias son aquellas relacionadas con las gentes que allíse retratan y sus características. Para el caso chileno, la mayoría de las imágenes se encargan de mostrar a la población indígena y a los campesinos.

Sin embargo, las imágenes "Araucanos" (figura 8), “Capatazy peón” (figura 9), "Mineros" (figura 10) y "Carretero capataz" (figura 11) son las únicas que representan algunos "tipos definidos" de personas de manera detallada, en el sentido de que se trata de ilustraciones dedicadas exclusivamente a mostrar grupos humanos o sectores sociales desde sus particularidades fenotípicas, indumentaria y, en menor medida, sus oficios manuales. Se retrata a estos personajes en posiciones "no naturales", ubicados en paisajes donde seguramente sí es posible encontrarlos, a pesar de que el fondo de las imágenes no esté bien elaborado. Se podría decir que se deja la asociación del paisaje y los sujetos a la imaginación del lector; no obstante, hay pistas sobre el espacio específico en el cual se podrían o deberían hallar.

\footnotetext{
34 Beatriz Rodríguez, "El ensamblaje visual del cuerpo negro: el caso de la Comisión Corográfica de la Nueva Granada”, Tabula Rasa, n. ${ }^{\circ} 17$ (2012): 48.

35 Cecchetto, Explorar, imaginar y relatar, 4.
} 


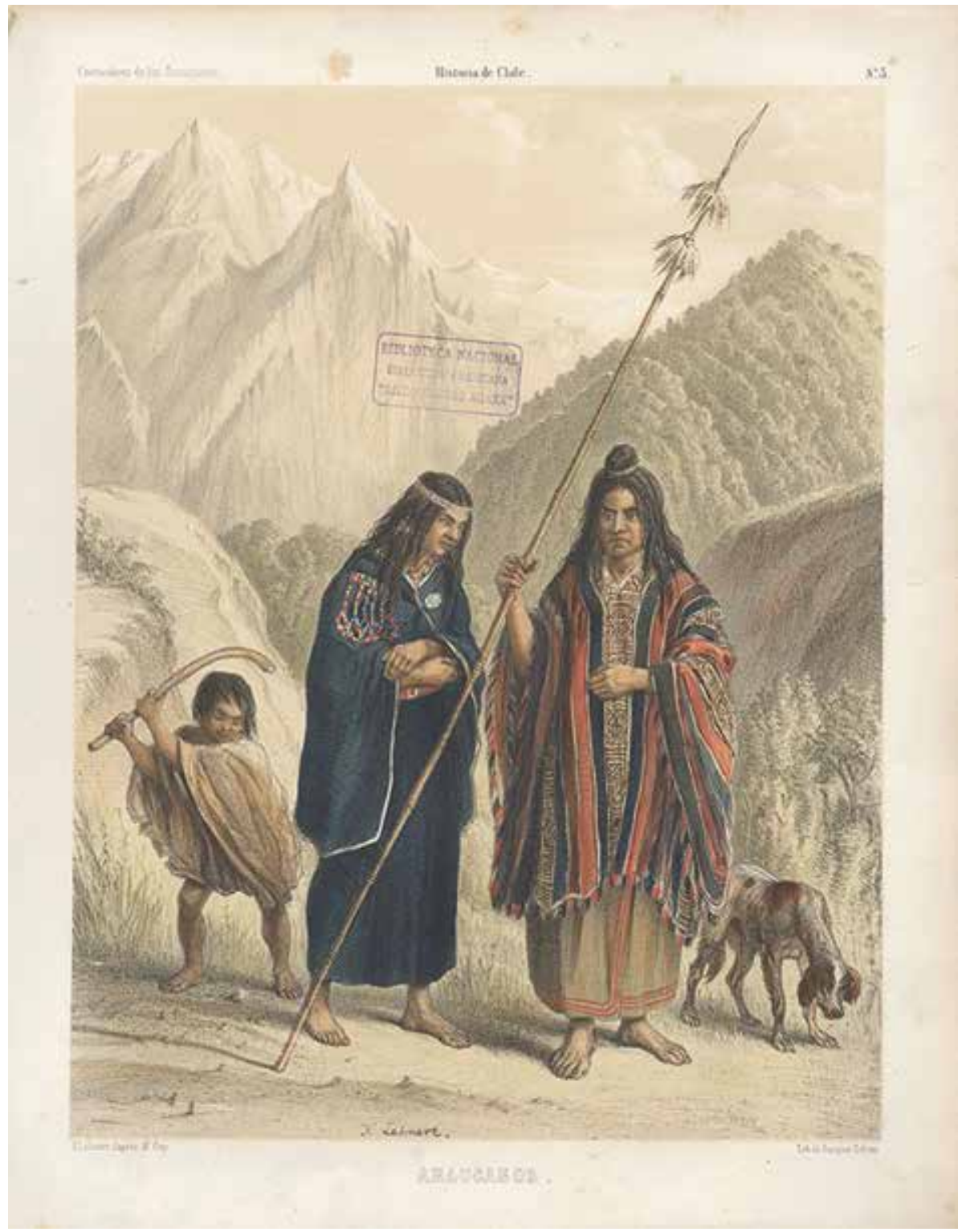

Figura 8. Claudio Gay, 1854, “Araucanos” (lámina N. 28, grabado en acero e impresión en lámina, Atlas de la historia fisica y politica de Chile [París: Imprenta de E. Thunot], Biblioteca Nacional, Santiago de Chile). 


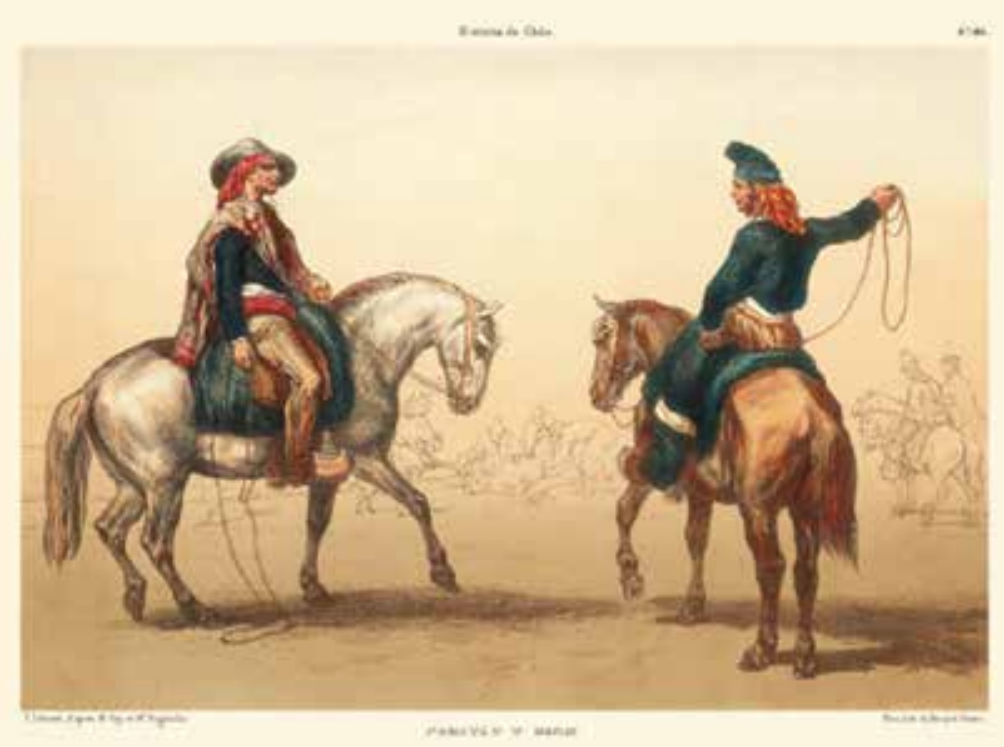

Figura 9. Claudio Gay, 1854, "Capataz y peón” (lámina N. 76, grabado en acero e impresión en lámina, Atlas de la historia fisica y politica de Chile [París: Imprenta de E. Thunot], Biblioteca Nacional, Santiago de Chile).

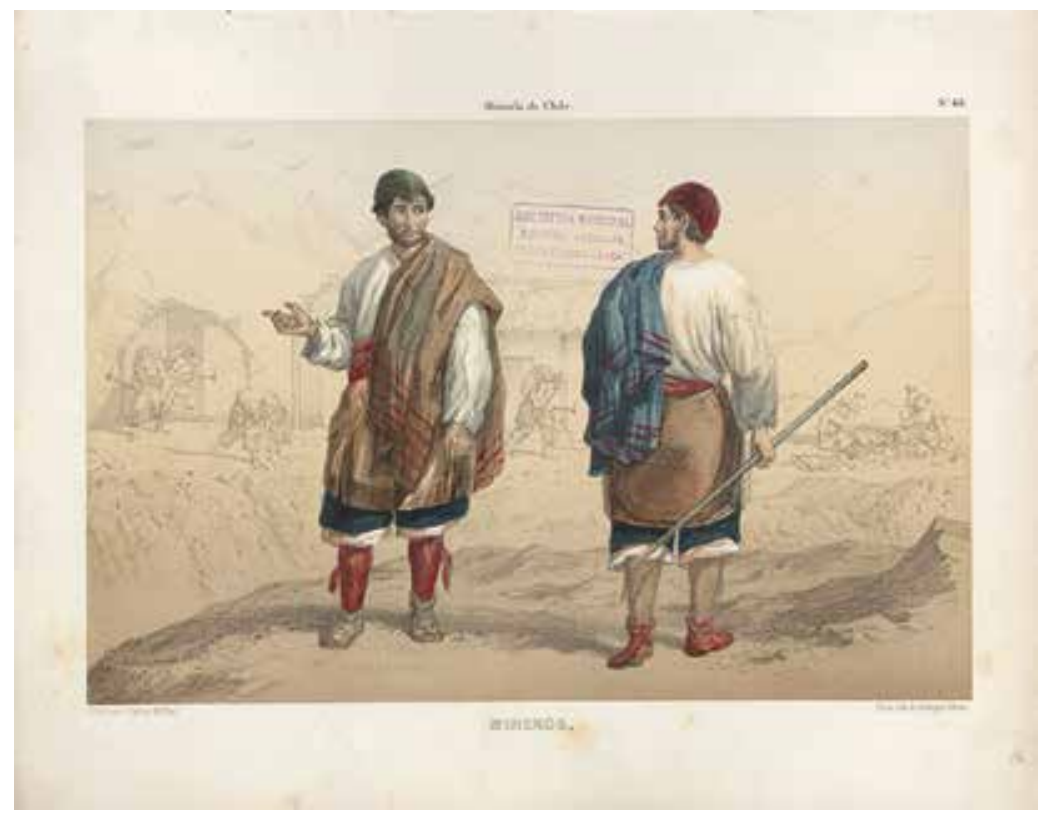

Figura 10. Claudio Gay, 1854, "Mineros" (lámina N. 52, grabado en acero e impresión en lámina, Atlas de la historia fisica y politica de Chile [París: Imprenta de E. Thunot], Biblioteca Nacional, Santiago de Chile). 


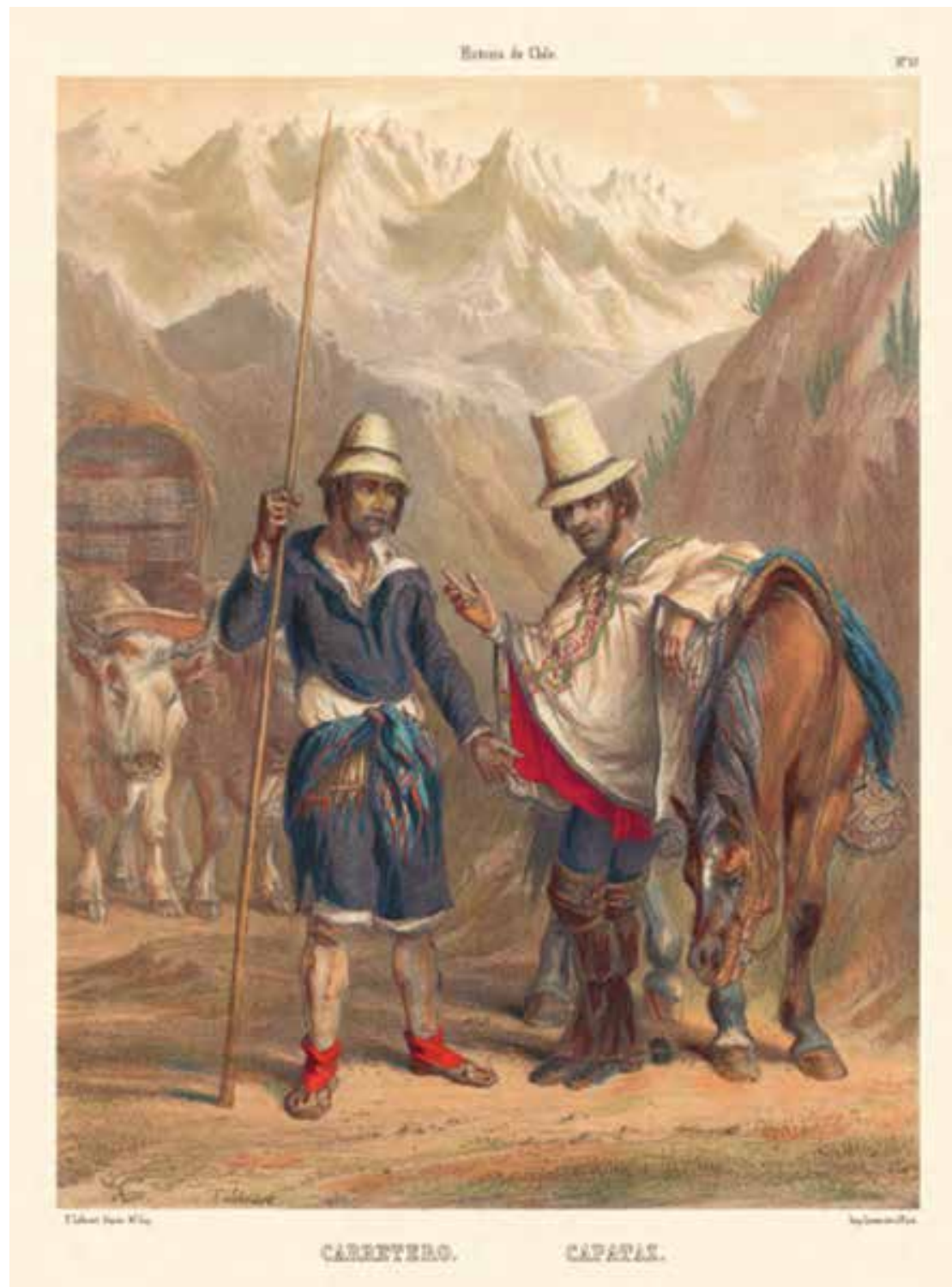

Figura 11. Claudio Gay, 1854, “Carretero y capataz” (lámina N. 48, grabado en acero e impresión en lámina, Atlas de la historia física y política de Chile [París: Imprenta de E. Thunot], Biblioteca Nacional, Santiago de Chile).

Así, los sujetos representados se encuentran en un medio geográfico particular, abstraídos de sus actividades cotidianas. Se les muestra idealizados; situados en espacios peculiares que, en muchas ocasiones, solo se reconocen por el trabajo que realizan o las costumbres que imprimen en la imagen. Podría hablarse entonces de 
una "diferencia situada", ${ }^{36}$ de tal forma que se hace tangible deducir desde dónde se enuncia la diferencia y dónde se localiza al "otro". Igualmente, se podría pensar que el público al que está dirigida la obra de Gay es una audiencia sin demasiado conocimiento del indígena o el campesino; un público al que tales descripciones gráficas deben serle presentadas mediante una oferta simbólica simple de asimilar e imaginar.

El Atlas de Gay es un intento por visibilizar no solo la desconocida geografía física del territorio, sino también su geografía humana "exótica", "diferente" y "lejana” a la realidad inmediata del lector urbano. Lo más seguro es que estos personajes también fueran ajenos a Gay, en cierta medida, y por ello fueran representados con mayor y mejor detalle que otros grupos sociales, como las mismas élites de la incipiente vida citadina. Sin duda, la obra del francés es un medio de comunicación que reconfigura e incluye la presencia del otro dentro de un mundo social ya establecido. Por medio de estas imágenes se evidencia una "geografía positivista" que ubica al otro en un lugar específico, con características sociales y culturales definidas (esencializadas), que a su vez forman parte de la nación chilena moderna. Más allá de las ilustraciones simbólicas, la geografía humana también es representada bajo parámetros "científicos", partiendo de los principios de clasificación y denominación del “otro", propios de la época. En ese sentido, tanto la expedición de Gay como su obra pueden ser consideradas "dispositivo(s) para construir la 'otredad", en cuanto posibilitan el encuentro con otros y producen un conjunto de ideas y representaciones sobre ellos y configura, a su vez, los lugares o entornos donde se materializa su presencia. ${ }^{37}$

El "grueso de la población chilena" (la clase media y la élite) también ocupó algunas ilustraciones en el Atlas. Aparentemente, este sector no merece un espacio determinado donde se representen sus particularidades físicas o de vestimenta (ya “se sabe cómo es"). Algunas imágenes, por ejemplo, la de "Andacollo" (figura 12), muestran a la gente en sus actividades "diarias" sin resaltar cuestiones fenotípicas, sino más bien prácticas culturales, al igual que en las láminas de "Una tertulia en 1840" (figura 13) o un "Juego de bola" (figura 14). La representación del "chileno corriente" abandona la minucia de sus rasgos y lo inserta en planos más amplios.

36 Néstor García Canclini, La globalización imaginada (México: Paidós, 1999).

37 Hortencia Castro, "Otras miradas, otros lugares: los relatos de viajeros en la construcción de la Puna argentina”, en Viajes y geografias, ed. por Perla Zusman, Carla Lois y Hortencia Castro (Buenos Aires: Prometeo, 2007), 94. 


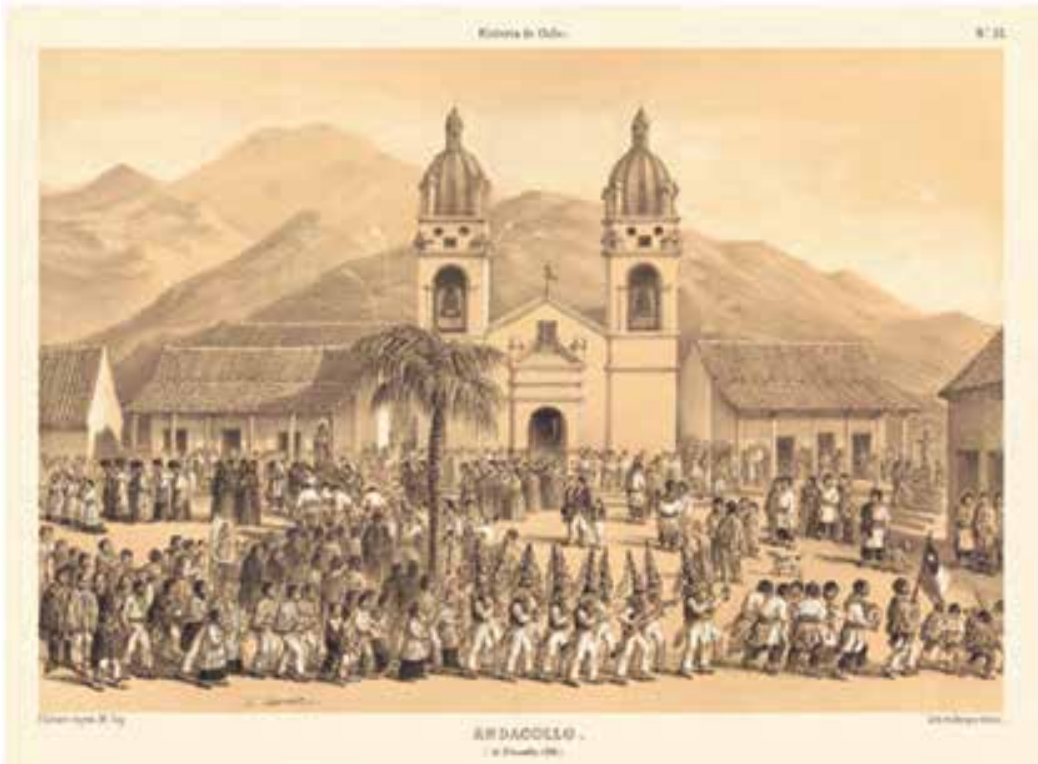

Figura 12. Claudio Gay, 1854, "Andacollo" (lámina N. 51, grabado en acero e impresión en lámina, Atlas de la historia física y politica de Chile [París: Imprenta de E. Thunot], Biblioteca Nacional, Santiago de Chile).

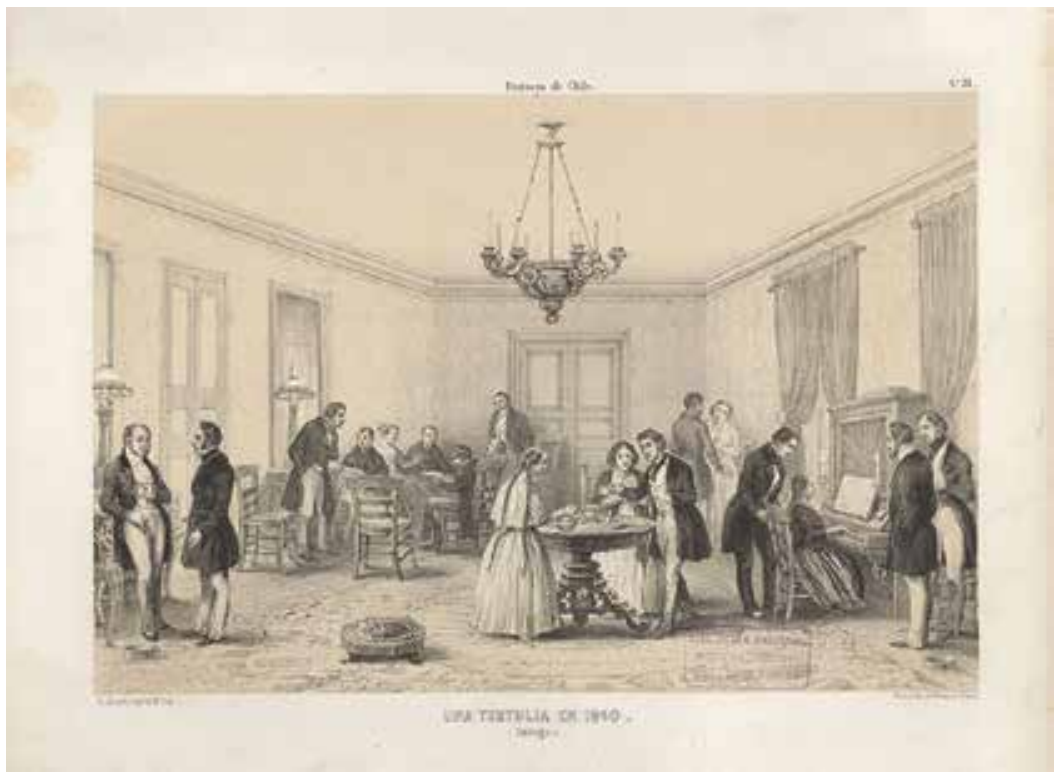

Figura 13. Claudio Gay, 1854, “Una tertulia en 1840” (lámina N. 61, grabado en acero e impresión en lámina, Atlas de la historia fisica y politica de Chile [París: Imprenta de E. Thunot], Biblioteca Nacional, Santiago de Chile). 


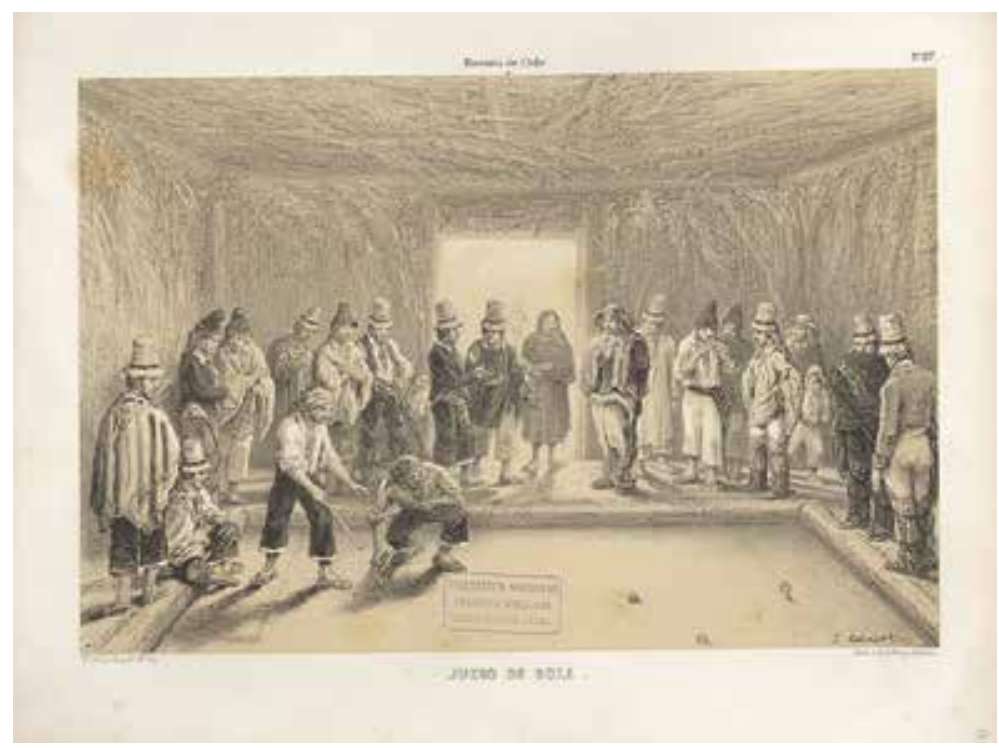

Figura 14. Claudio Gay, 1854, "Juego de bola” (lámina N. 57, grabado en acero e impresión en lámina, Atlas de la historia fisica y política de Chile [París: Imprenta de E. Thunot], Biblioteca Nacional, Santiago de Chile).

A pesar de que cambie el estilo de graficar a los sectores urbanos - en comparación con los indígenas o campesinos de zonas “exotizadas"—, cada práctica cultural tiene particularidades que iluminan la manera en que la categoría de "clase" también se hace presente en las imágenes, pues se conjuga con el aspecto geográfico bajo una dinámica similar a las anteriores. Un ejemplo de esto es la imagen titulada "Un baile en la casa del gobierno" (figura 15), en la cual se pueden apreciar sujetos con cierto estatus económico y social, manifiesto no solo en sus vestimentas, sino también en su corporalidad y en el lugar donde se lleva a cabo el evento. Las imágenes son un mecanismo por el cual se representa una marcada diferencia no solo "racial" o fenotípica, sino también de estatus social.

En este ejercicio crítico y deconstructivo de la unidad nacional podría hablarse de lo que actualmente se ha denominado un quiebre epistemológico del modelo cartográfico. ${ }^{38}$ Esto implica que la forma de interpretar productos intelectuales y sistemáticos como los atlas pasa de pensarlos como simples sistemas de comunicación que describen las características y componentes presentes en un territorio, a verlos como fuentes que ponen en evidencia las relaciones de poder entre los componentes

38 Crampton, “Maps as Social Constructions”, 235. 


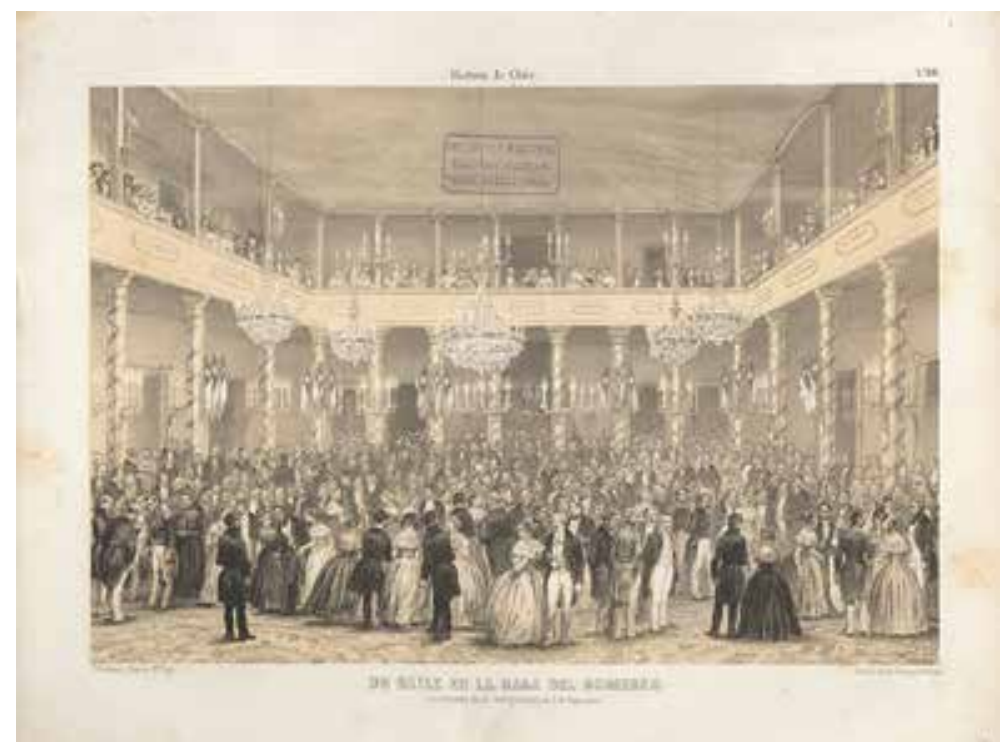

Figura 15. Claudio Gay, 1854, "Un baile en la casa del gobierno" (lámina N. 58, grabado en acero e impresión en lámina, Atlas de la historia física y política de Chile [París: Imprenta de E. Thunot], Biblioteca Nacional, Santiago de Chile).

de los mapas, la información conocida por sus autores y el nuevo conocimiento en construcción. Este cambio o ruptura puede entenderse como una oportunidad para que la cartografía "renueve" su relación con el estudio de la geografía humana, ${ }^{39}$ enriqueciendo sus análisis y potencializando sus alcances performativos y comunicativos, a pesar de tener una distribución limitada y precaria.

El atlas de Gay no tiene una gran cantidad de mapas. La mayoría de sus imágenes son acuarelas, las cuales, relacionando su contenido y finalidad con otros casos simultáneos, podrían ser el "equivalente” a las producidas por la Comisión Corográfica de la Nueva Granada hacia la segunda mitad del siglo XIX. La presencia de esta técnica en la obra señala la necesidad de usar otras estrategias narrativas y gráficas para crear una identificación territorial más sólida que unificara la nación alrededor de características culturales, físicas, sociales e históricas representadas visualmente, una narrativa que ayude a actualizar la definición de la nación y el contexto en el que se encuentra.

$39 \quad$ Ibid., 236. 
Es necesario analizar qué tipo de actividades se retratan y la manera como se hace. La imagen de "Una carrera en las lomas de Santiago" (figura 16) puede representar una actividad cotidiana medianamente conocida. También puede ser vista y tratada como una imagen idealizada de un hecho particular, del espacio donde ocurre o de la misma gente que asiste al evento. Sin embargo, "el realismo que le atribuimos al universo visual corográfico evidencia el triunfo de la ideología de la Ilustración que hace de la observación la principal actividad del ojo científico".40

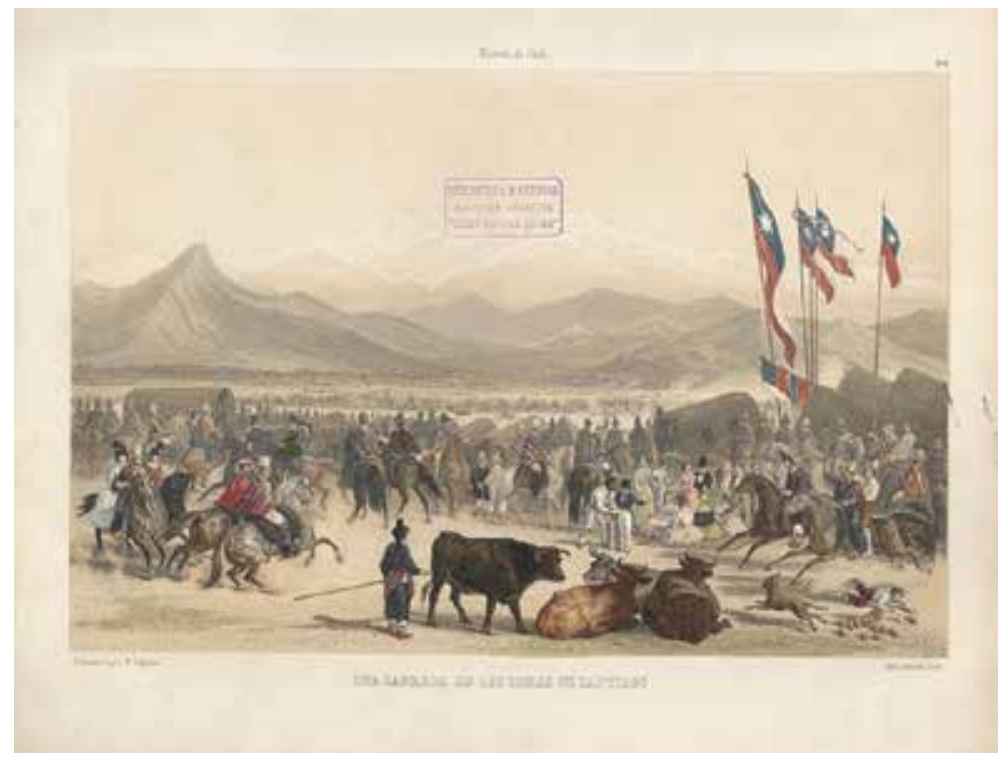

Figura 16. Claudio Gay, 1854, “Una carrera en las lomas de Santiago” (lámina N. 38, grabado en acero e impresión en lámina, Atlas de la historia física y politica de Chile [París: Imprenta de E. Thunot], Biblioteca Nacional, Santiago de Chile).

Para el naturalista, las acuarelas trascienden su importancia como simples imágenes ilustrativas, ya que se perfilan como elementos clave para la conformación de la identidad chilena ${ }^{41}$ desde lo local a lo universal. Su obra no solo contribuyó a trazar la forma del territorio, sino también a la abstracción de este como una unidad política enmarcada o ajustada a una realidad natural, histórica y social en constante redefinición. Fue esta obra la que dio a conocer a un público nacional e

40 Rodríguez, "El ensamblaje visual", 47.

41 González, Primeros levantamientos cartográficos, 21-44. 
internacional los recursos naturales y las riquezas culturales no solo por medio de su distribución, sino también de la unión de lo específico con lo universal.

Comentaba que geografía y cartografía también permitieron señalar las potencialidades de las regiones chilenas, aspecto que ya consideraba Claudio Gay al incluir imágenes relacionadas con la flora en el primer tomo y con la fauna en el segundo. Debido a su formación disciplinar, resultaba más importante resaltar las riquezas naturales del territorio que las humanas o las históricas. Así, el producto final de sus viajes corresponde al interés personal del científico por retratar y realizar un detallado registro de las especies que se pueden encontrar en el país, ya fueran conocidas o que él mismo "descubriera” para ilustrar de forma inédita.

Además de representar los recursos disponibles del territorio, existe cierto propósito por recodificar la nación y sus partes. Después de todo, en el ejercicio de la construcción geográfica del siglo XIX, incluir la composición interna de las regiones era relevante para saber qué tipo de atractivos ofrecería el país tanto en el plano interno como al mundo industrializado, cada vez más cercano de América Latina y sus economías extractivas. Por otro lado, el hecho de retratar aves, mamíferos, peces y otras especies del mundo animal, si bien no generaba gran impacto en el interés sobre la administración económica del territorio, sí lo causaba en el ámbito académico nacional e internacional. ${ }^{42}$

Las ilustraciones inscritas en los mapas se pueden ver y analizar como herramientas instructivas que complementan las clásicas imágenes de la geografía. Podríamos ubicarlas como un medio de transmisión del conocimiento espacial por medio de la "vivencia”, donde la cotidianidad geográfica y corográfica se hace más cercana y tangible, al modificar la relación espaciotemporal de quienes tienen acceso a estas imágenes con su entorno inmediato o lejano. Al integrar en un mismo compendio geográfico mapas e imágenes, se pueden activar otros mecanismos pedagógicos que realzan las imágenes en sí mismas, así como el mensaje que se quiere transmitir con ellas. El hecho de poner ilustraciones de carácter cultural a las cuales se les ha asignado un papel de "imagen icónica" junto a los mapas e imágenes de fauna y flora, conlleva una reinterpretación de la realidad, ya no de manera separada, sino en conjunto. Del mismo modo se reinterpreta su recordación, la cual puede incrementarse tras la consolidación de lugares comunes o imaginarios del territorio.

42 Una de las intenciones de Gay era publicar su obra en francés, cosa que no se pudo hacer por falta de recursos. Tampoco se divulgó mucho en el ámbito internacional, debido a que estaba en español. 
Se trata de elaboraciones que dan un sentido lógico a la secuencia de imágenes presentadas, de tal manera que se pueda crear la noción de totalidad territorial, dividirla en unidades analíticas (geográficas, sociales, políticas, económicas y culturales) más sencillas de comprender y, posteriormente, articular estas últimas para proyectar la nación unificada desde la fragmentación. Gay ilustra el uso que se les da a los objetos, a las plantas y al paisaje, clasificando lo observado durante el viaje, sometiéndolo al análisis de su disciplina, pero sin descuidar las distintas apropiaciones que el pueblo chileno ha hecho de su entorno y su naturaleza. Así, Gay logra, epistemológicamente hablando, incorporar la ciencia natural europea en un universo biológico y cultural desconocido, que emplea dichos saberes técnicos para fortalecer un conjunto de ideas y afectos nacionales.

A raíz de los altos costos de producción de la obra y su poca inversión por parte de los gobiernos chileno y francés, el Atlas no fue reproducido a gran escala y, por consiguiente, su difusión —si bien no fue limitada — fue fraccionada. En 1843, Claudio Gay escribía al presidente Manuel Montt algunas consideraciones sobre esta limitación:

Cuando en Santiago hice el presupuesto de los gastos que tenía que hacer, la falta de datos y el temor de pedir más caro de lo que debía, me atrasaron a un cálculo falso que tendré que gastar casi el doble de lo que se había pensado... ${ }^{43}$

Empero, es necesario tener en cuenta que una forma de recaudación de fondos estaba basada en un sistema de suscripciones creado por el mismo naturalista; un sistema que posibilitaba la participación del público en la realización de la obra, al basarse en pagos adelantados por quienes quisieran adquirir el trabajo. Este sería suministrado en ocho entregas, cuatro por cada tomo y cada una tendría un costo de cincuenta centavos sin láminas; un peso y veinticinco centavos con láminas y dos pesos y veinticinco centavos con láminas a color. ${ }^{44}$ Este pago se puso a discusión y en abril, en el diario Agricultor, se publicaba lo siguiente:

43 Carta del 7 de septiembre de 1843 dirigida a Manuel Montt. Citado en Guillermo Feliu, "Perfil de un sabio: Claudio Gay a través de su correspondencia”, en Vida de Claudio Gay: escritosy documentos, vol. 1, ed. por Stuardo Ortiz (Santiago de Chile: Fondo Histórico y Bibliográfico José Toribio Medina, 1973), 74-83.

44 Diego Barros, Don Claudio Gay, su vida i sus obras: estudio biográfico y critico (Santiago: Imprenta Nacional, 1876), 363-364. 
La sociedad ha examinado prolijamente los cálculos que don Claudio Gay ha tenido a la vista para fijar el precio de la obra, y creemos cumplir un deber de justicia asegurando que las condiciones de la suscripción que aquel sujeto le ha consultado, son un nuevo testimonio del generoso y noble desprendimiento... ${ }^{45}$

Los encargados de recoger este dinero eran los intendentes y gobernadores de las provincias. Sin embargo, a pesar del común acuerdo entre los suscriptores para realizar los pagos, la recaudación del dinero sufrió dificultades. El mismo naturalista francés explicaba que: "Según se me dice, no pocos no quieren recibirla (la obra) sino encuadernada y quizás no son más que pretextos para salvar toda entrega de plata” ${ }^{46}$ Adicional a los inconvenientes económicos para la producción, se suma que en 1855 el Gobierno chileno consideró por terminado su compromiso con el proyecto. ${ }^{47}$ Fue necesaria una nueva negociación de la cual surgió una respuesta favorable varios años después, que hizo posible que hasta 1862 se publicara el primer volumen.

En cuanto a las suscripciones, 605 personas pagaron por adelantado el importe de las cuatro primeras entregas. ${ }^{48}$ Infortunadamente, los retrasos de los ejemplares hicieron que cuando llegaran a Chile no todos los reclamaran. Por esta razón, para 1849 eran pocos los interesados en la obra. Como consecuencia del interés perdido para adquirir los siguientes tomos, Gay imprimió de nuevo los primeros para completar las colecciones y los vendió a un precio más bajo, con el fin de popularizar la obra, hasta terminar sus existencias en "bodega”. La desvalorización de la obra terminó destinándola para libre disposición de los ciudadanos en instituciones públicas como bibliotecas y colegios. Para su divulgación fuera de Chile, en " 1875 la casa de Trübner y Cía. de Londres vendía por 30 libras esterlinas (150 pesos) un ejemplar de la obra con su Atlas, al cual faltaban los tomos viI y viII de la historia política". ${ }^{49}$ Sin embargo, su compra no sería alta debido a que estaba publicada en español.

Con el ánimo de compensar estos pormenores, el proyecto de ley que avalaba la difusión del Atlas rezaba en el artículo tercero: "se autoriza al gobierno para que

Agricultor, abril de 1841, 48 .

Cita de Gay en Guillermo Feliu, Perfil de un sabio, 74-83.

Barros, Don Claudio Gay, 410.

Ibid., 414.

Ibid., 414. 
auxilie con la cantidad que fuere necesaria la publicación en lengua castellana de las obras relativas a la historia y geografía de Chile que han de darse a luz en Europa bajo la dirección del mencionado naturalista". 50 Así, la mayoría de las reproducciones fueron realizadas en un papel común con láminas iluminadas que se podían distribuir en bibliotecas públicas. No obstante, debido a los obstáculos económicos, los últimos dos tomos, el viI y viII, no fueron reproducidos masivamente; estos serían hechos por cuenta del autor y obsequiados a sus amigos cercanos, haciendo que su circulación fuera muy limitada en Chile.

\section{Conclusiones}

Los mapas de Gay se usaron para unificar la nación chilena de manera simbólica; encarnan una representación del poder, la cual encuentra sus limitaciones en la medida en la que ilustran grandes extensiones territoriales de manera general, pero se pierden detalles cuya representación también se hace necesaria. Para ello, es preciso recurrir a otras estrategias visuales: fraccionar el territorio para sustentar las bondades específicas de cada región, sin perder de vista la integración de tales unidades con la entidad nacional en un diálogo de mayor escala. Esta fragmentación territorial, podría decirse, cumple la función de generar un discurso lógico, hilado e incluyente sobre la nación. No obstante, la representación de la geografía nacional como un todo coherente tiene sus límites debido a que las interpretaciones y usos de esta son múltiples y varían según el contexto histórico, social, político, económico o cultural.

Las herramientas con intención de ordenar y dominar los territorios también se usaron con fines pedagógicos para dar a conocer la nación a sus habitantes por distintos medios; responden al objetivo de educar a la sociedad civil respecto a su entorno natural y social. A lo anterior se suma que el interés principal de la República Conservadora de estabilizar el país requería diversos elementos que lograran de manera práctica y eficaz unir a los bandos enfrentados (liberales, conservadores, centralistas y federalistas). En la geografía se encontró una de varias formas para difundir un sentimiento de pertenencia hacia un territorio común, independientemente de quién o quiénes estuvieran a la cabeza del Estado. No obstante, esta manera de unificar simbólica e ideológicamente el territorio abría el debate sobre cuál sería la mejor manera de gobernar la nación.

50 Manuel Montt, Búlnes, 5 de noviembre de 1841, citado en Barros, Don Claudio Gay, 366. 
Aunque la distribución del Atlas fue limitada y parcializada frente a lo que se tenía planeado en un primer momento, hay que reconocer los esfuerzos de su elaborador, Claudio Gay, para popularizar y difundir la obra, y en menor medida por el Gobierno chileno, que ya había perdido interés en el proyecto, debido a la demora en su producción a gran escala y a que era apremiante invertir el dinero en otros asuntos. Con esto, queda abierta la ventana para futuras investigaciones que ahonden en la relación existente entre lo público y lo privado respecto a la inversión de recursos para la producción y la difusión del conocimiento nacional.

Por otro lado, las imágenes que complementan la información proporcionada por los mapas son una muestra del imaginario social sobre el territorio y sus bondades (contenidos) que se quiere difundir. Es pertinente una interpretación de la iconografía del Atlas, pues esta ilustra parcialmente el intento por iniciar un proceso que, a largo plazo, junto con otros proyectos estatales de carácter educativo y político, consolidaría la identidad chilena en torno al "espacio compartido". El atlas puede considerarse un dispositivo político para ordenar y gobernar, al tiempo que se ubica dentro de un marco ideológico y cronológico postindependentista, donde se efectúa un ejercicio de autoconciencia por medio del conocimiento y de reconocimiento territorial geográfico y corográfico. Lo anterior se ha analizado desde una reflexión deconstruccionista, para entender los territorios nacionales como un constructo en constante cambio y no como algo dado e inmutable.

Los mapas son representaciones que nos hablan sobre la manera en la que las personas se apropian de su espacio, lo habitan, lo simbolizan y lo entienden, ya sea de manera cultural o científica (incluso ambas). Son un aspecto esencial para la construcción de identidades ligadas al territorio, pues crean la ilusión gráfica del todo conectado de manera armónica, a pesar de las divisiones geográficas o políticas de carácter "natural o artificial". La idea de fragmentar la totalidad responde a dinámicas políticas-administrativas específicas que, en los inicios de la república chilena, fueron claves para poder ordenar el nuevo espacio nacional. De igual forma, la fragmentación responde al interés por reconstruir y recodificar la misma república y sus partes. En este sentido, es más fácil hablar de las características propias a cada unidad política, para resaltar sus cualidades en un primer momento y luego ponerlas en diálogo con la totalidad del territorio.

El atlas de Gay — al igual que otros ejercicios de representación del territorio y sus componentes culturales - se encarga de resaltar al "otro", de presentarlo de la manera más clara posible y de sumergirlo en un espacio particular. La geografía y la corografía se unen para mostrar, señalar e imaginar a ese otro. Así, considerar las 
distintas disciplinas que enriquecen la geografía histórica, permite identificar y cuestionar enunciaciones particulares sobre la relación espacio-sociedad en contextos históricos específicos. Estas enunciaciones confluyen en producciones intelectuales y científicas como mapas o atlas, que dejan ver intereses concretos representados en soportes gráficos, alusivos — en este caso - al territorio y sus partes, en un momento cuando tales fuentes encontraron un impacto social y educativo a largo plazo.

Finalmente, esta es una forma de mostrar cómo lo particular se relaciona directamente con lo universal. Los cambios y las representaciones de la geografía, el medio ambiente y sus partes son el resultado de los procesos y acontecimientos históricos en determinado espacio y la relación del ser humano con su entorno. El mundo natural y su representación están vinculados inevitablemente con la historia política de las naciones latinoamericanas en su formación. La geografía sería, entonces, un instrumento que define la manera en que las comunidades entienden el medio ambiente y lo relacionan directa o indirectamente con un futuro próspero, con las posibilidades y expectativas de desarrollo de una comunidad particular reunida alrededor de ciertos relatos colectivos.

\section{Bibliografía}

\section{Fuentes primarias}

\section{Libros}

Barros, Diego.Don Claudio Gay. Su vida i sus obras: estudio biográfico y crítico. Santiago: Imprenta Nacional, 1876.

Feliu, Guillermo. "Perfil de un sabio: Claudio Gay a través de su correspondencia”. En Vida de Claudio Gay: escritos y documentos, vol. 1, editado por Stuardo Ortiz. Santiago de Chile: Fondo Histórico y Bibliográfico José Toribio Medina, 1973.

Gay, Claudio. Atlas de la historia fisica y politica de Chile, 2 vols. París: Imprenta de E. Thunot, 1854 .

Gay, Claudio. Consideraciones sobre las minas de mercurio de Andacollo e Illapel con su posición geológica. París: Imprenta de E. Thunot, 1851.

Gay, Claudio. Historia de la independencia chilena. París: Imprenta de E. Thunot, 1856. Montt, Manuel. Búlnes, 5 de noviembre de 1841. 


\section{Publicaciones periódicas}

Agricultor. Santiago de Chile, 1841.

\section{Fuentes secundarias}

Atria, Raúl y Matías Tagle. Estado y política en Chile: ensayos sobre las bases sociales del desarrollo politico chileno. Santiago de Chile: Corporación de Promoción Universitaria, 1991.

Besse, Jean Marc. "El nacimiento del atlas moderno". En El mundo de los mapas, editado por Lafreti Ortelius, 93-139. Madrid: Fundación Botín, 2007.

Bhabha, Homi K. El lugar de la cultura. Buenos Aires: Manantial, 2002.

Biggs, Michael. "Putting the State on the Map: Cartography, Territory, and European State Formation". Comparative Studies in Society and History 42, n. ${ }^{\circ} 2$ (1999): 374-405.

Bravo, Bernardino, El absolutismo ilustrado en Hispanoamérica: Chile (1760-1860) de Carlos III a Portales y Montt. Santiago de Chile: Imprenta y Oficina de la Democracia, 1994.

Castro, Hortencia. "Otras miradas, otros lugares: los relatos de viajeros en la construcción de la Puna argentina”. En Viajesy geografias, editado por Perla Zusman, Carla Lois y Castro Hortencia, 93-114. Buenos Aires: Prometeo, 2007.

Cecchetto, Gabriela. "Explorar, imaginar y relatar el territorio: viajes y tecnologías de poder en la producción y legitimación de saberes geográficos en la universidad nacional de Córdoba, 1876-1882”. Trabajo presentado en el XIII Coloquio Internacional de Geocrítica, Barcelona, España, 5-10 de mayo de 2014.

Chartier, Roger. Elmundo como representación. Historia cultural: entre práctica y representación. Barcelona: Gedisa, 1992.

Crampton, Jeremy. "Maps as Social Constructions: Power, Communication and Visualization”. Progress in Human Geography, n. 25 (2001): 235-252.

Derrida, Jacques. La escritura y la diferencia. Barcelona: Anthropos, 1989.

Díaz, Sebastián, Santiago Muñoz y Mauricio Nieto. “Desensamblando la nación: el caso del Atlas geográfico e histórico de Colombia de 1889”. En Proyecto ensamblado en Colombia. Vol. 1., editado por Olga Restrepo Forero, 182-218. Bogotá: Universidad Nacional de Colombia, 2013.

Encina, Francisco. Historia de Chile. Vol. 10. Santiago de Chile: Nascimiento, 1952. Foucault, Michel. "Preguntas a Michel Foucault sobre la geografia". En Estrategias de poder: obras esenciales. Vol. 2, editado por Julia Varela y Fernando Álvarez, 313-326. Barcelona: Paidós, 1999. 
Galdames, Luis. La evolución constitucional de Chile, 1810-1825. Santiago de Chile: Imprenta Balcells y Cía., 1926.

García Canclini, Néstor. La globalización imaginada. México: Paidós, 1999.

García-Huidobro, Cristóbal. "Reseña de Construcción de Estado en Chile (1800-1837).

Democracia de los 'pueblos', militarismo ciudadano, golpismo oligárquico, de Gabriel Salazar”. Historia 40, n. ${ }^{\circ} 1$ (2007): 194-198.

González, Benjamín. Historia cartográfica resumida en los límites de Chile. Santiago de Chile: Cristian Salazar, 2001-2002.

González, José. “Cartografía y república: información territorial, soberanía y organización político-administrativa en Chile siglo xIx". Boletín de la Academia Chilena de la Historia, n. ${ }^{\circ} 18$ (2009): 57-90.

González, José. "Primeros levantamientos cartográficos generales de Chile con base científica: los mapas de Claudio Gay y Amado Pissis". Revista de Geografía Norte Grande, n. 38 (2007): 21-44.

Harley, John. La nueva naturaleza de los mapas. México: Fondo de Cultura Económica, 2005.

Laudam, Larry. Progress and its Problems: Toward a Theory of Scientific Growth. Berkeley: University of California Press, 1977.

Loaiza, Miriam. “Iconografía cartográfica, un método para la lectura”. Memoria y Sociedad 6, n. ${ }^{\circ} 12$ (2002): 61-84.

Lois, Carla. "La elocuencia de los mapas: un enfoque semiológico para el análisis de cartografías". Anales de Geografía, n. 36 (2000): 93-109.

Montoya, Vladimir. "El mapa de lo invisible: silencios y gramática del poder en la cartografía”. Universitas Humanistica, n. ${ }^{\circ} 63$ (2007): 155-179.

Morães, Antônio. "Notas sobre a identidade nacional e a institucionalizacão da geografia no Brasil”. Estudos Históricos 4, n. ${ }^{\circ} 8$ (1991): 166-176.

Ortiz, Carlos. Los atlas de historia fisica y politica de Chile por Claudio Gay. Santiago de Chile: Imprenta Universitaria, 1954.

Ortiz, Carlos. Vida de Claudio Gay. Santiago de Chile: Fondo Histórico y Bibliográfico José Toribio, 1973.

Reclus, Elisée. El hombre y la tierra. México: Fondo de Cultura Económica, 1986.

Rodríguez, Beatriz. "El ensamblaje visual del cuerpo negro: el caso de la Comisión Corográfica de la Nueva Granada”. Tabula Rasa, n. ${ }^{\circ} 17$ (2012): 43-61.

Rosenblitt, Jaime y Carolina Sanhueza. "Prólogo”. En Cartografía histórica de Chile, editado por Rafael Sagredo Baeza, ix-lxvi. Santiago de Chile: Pontificia 
Universidad Católica de Chile; Cámara Chilena de la Construcción; Biblioteca Nacional, 2010.

Wood, Denis y John Fels. "Designs on Sings: Myth and Meaning in maps". Cartogrphyca 23, n. 3 (1986): 54-103.

Zusman, Perla y Sandra Minvielle. "Sociedades geográficas y delimitación del territorio en la construcción del Estado-nación argentino". Trabajo presentado en el V Encuentro de Geógrafos de América Latina, La Habana, Cuba, agosto, 1995, http://repositoriorecursos-download.educ.ar/repositorio/ Download/file?file_id=05573c0d-7a0b-11e1-821e-ed15e3c494af 


\title{
Alegorías, ornamentaciones y heroínas: la presencia de las representaciones femeninas en los billetes colombianos y su aporte al imaginario nacional
}

\author{
LERY MUNAR \\ Sebastián GaCha
}

Actualmente, la palabra dinero cuenta con más de ocho definiciones, según la Real Academia Española. La más familiar nos remite a pensarlo como medio de cambio o de pago aceptado en general; adicionalmente, cuatro de ellas nos hablan concretamente del dinero como moneda. El papel moneda, entonces, es un término heredero de la asociación entre el valor de una representación cuantitativa y el medio metálico que porta dicha representación en unidades de cuenta estandarizadas. Hoy en día, las transformaciones en el medio material con el que se realizan dichas transacciones de intercambio nos inscriben en una estrecha relación con múltiples objetos que representan el dinero y, simultáneamente, con el contenido visual que los identifica y distingue de otros.

Respecto a los billetes, su valor cuantitativo se materializa en "piezas de papel impreso que cumplen con la función práctica del intercambio" 1 y que, a su vez, son emitidas por la autoridad pública. A partir de un análisis sobre el contenido impreso de estos objetos rutinarios y su respectiva circulación, la forma en que se representa la moneda pasa a considerarse una construcción cultural. Lo anterior se observa en la medida en la que, mediante el papel moneda, se comunican mensajes visuales acerca de las características con las cuales se imagina e identifica la nación. De este modo, detenerse en el estudio de otras dimensiones propias a los

\footnotetext{
1 Patricia Ávila, Y tútambién te vas: Argentina y el dinero. Representación de la Nación en el papel moneda argentino (Buenos Aires: Adriana Hidalgo, 2007), 19.
} 
billetes — adicionales a las de su valor monetario — sugiere cambiar la mirada con la que nos relacionamos con ellos a diario. En el caso colombiano, encontramos personajes, alegorías, paisajes y representaciones de temas históricos, usados con la pretensión de crear un inventario de imágenes que edifican el repertorio visual de la identidad y memoria del país.

A propósito, la presencia de imágenes de mujeres en los billetes colombianos constituye un ejemplo pertinente para pensar cómo operan las continuidades y los cambios en la selección de los contenidos iconográficos para el papel moneda en un momento dado. La incorporación de representaciones femeninas en los billetes del país varía en función de los significados que los emisores responsables les han atribuido a imágenes consideradas, por una parte, símbolos de representación de la identidad nacional y, por otra, instrumentos estéticos de la pieza en sí misma. Desde 1861, cuando empiezan a difundirse billetes a cargo de entidades relativamente centralizadas como la Tesorería Jeneral, ${ }^{2}$ las imágenes de las mujeres han estado presentes. Para la integración de estas figuras, los productores de dinero han adoptado ciertas convenciones europeas de modelos alegóricos sobre la República y la libertad. A partir de aquel periodo y hasta la actualidad, su aparición va a estar mediada por las transformaciones que sufre la traducción del discurso nacional al discurso visual institucional, mediante lo que Pamela Rosero llama la "construcción de la galería edificante" de imágenes de la patria, ${ }^{3}$ basada en la exaltación de un pasado decimonónico como el único "memorable".

En ese contexto, la difusión masiva de imágenes femeninas a través del papel moneda nos lleva a preguntarnos qué tipo de visibilidad adquieren las mujeres en el imaginario nacional transmitido por dichas fuentes de circulación cotidiana. Lo anterior, con el ánimo de explorar la conformación de una suerte de epos patriótico, desde el cual los billetes participan como vehículos de identidad, al dotar con imágenes las representaciones de lo que se entiende por nacional. Así, los soportes materiales del dinero, subordinados a una lógica de reproductibilidad en series, transmiten textos y ornamentos de los rostros y lugares registrados por el discurso de la historia patria. Por esta razón, la práctica artística y las dinámicas de impresión se vinculan con la composición de las piezas desde su génesis.

2 Ignacio Alberto Henao Jaramillo, Billetes de Colombia: época del Banco de la República 1923-2006 (Bogotá: Grupo op Gráficas, 2006), 13.

3 Pamela Rosero García, "Los billetes, una ventana al pasado: identidad y memoria 1959-1979" (Trabajo de maestría en Historia, Universidad Nacional de Colombia, 2009), 13. 
En el presente capítulo se lleva a cabo una lectura iconográfica del discurso visual e institucional que ha circulado en el papel moneda colombiano, a partir de un análisis de su contexto de producción y actualización, buscando explorar cómo se ha visibilizado la figura de la mujer. Se hace hincapié, por tanto, en el debate en torno a la cadena de producción de lo "visualmente dado" (lo puesto en circulación) y a las discusiones ideológicas que, suponemos, han orientado las decisiones de las entidades emisoras de las piezas en cuestión. En primera instancia, la reflexión parte del análisis sobre la materialidad y movilización de los billetes para pensar su lugar como piezas simbólicas del engranaje nacional.

En un segundo momento se discute la construcción de la iconografía numismática en Colombia, entendida como un fenómeno alimentado por el desarrollo decimonónico de las tecnologías gráficas y la producción pictórica europea. Lo anterior, con miras a reflexionar sobre la influencia de tales representaciones foráneas de la nación en Colombia, al igual que indagar por qué se tomaron como referentes para el discurso oficial y visual difundido a partir de la Independencia; dichos discursos fueron enunciados en una "nueva materialidad" del dinero, la cual sustituyó su soporte metálico a partir de 1860 y fue producida por entidades bancarias extranjeras hasta mediados del siglo xx.

En un tercer momento se aborda la permanencia, la desaparición o los cambios en las figuras femeninas que han estado presentes en los billetes nacionales. En esta instancia, es preciso describir la transformación del papel moneda colombiano en relación con las crisis económicas previas a la creación del Banco de la República, en 1923, ya que, sin lugar a dudas, esta institución centraliza y cambia considerablemente la estructura financiera del país. En consecuencia, la regulación en la emisión le imprime otro carácter al billete como medio oficial de intercambio. De ahí que el análisis del inventario visual incluido en dicha transición institucional sugiera pensar qué elementos han sido privilegiados en la representación iconográfica de las piezas señaladas. Por ejemplo, desde comienzos del siglo xx, una figura femenina marcó un largo protagonismo en los billetes: Marianne, la representación de la República francesa. Explorar por qué esta imagen se institucionaliza como el logo del Banco de la República, así como analizar la forma en la que se representa, es una de las discusiones concernientes para el apartado sugerido.

Posteriormente, es necesario analizar la producción de billetes fabricados por la Imprenta Nacional, desde 1959, mediante la cual se inició la fabricación de papel moneda en el país. La iconografía numismática se hizo local al incluir un diálogo entre su dimensión patrimonial y la galería patriótica de antaño. En cuanto a la 
imagen femenina, se dio un cambio significativo. La aparición del billete de dos pesos de 1972 irrumpió las representaciones convencionales con el rostro de una mujer: la prócer independentista Policarpa Salavarrieta. Su aparición simbólica nos habla del interés por visibilizar una forma específica de la participación femenina en la vida pública del país, en un contexto internacional de transformaciones culturales como el que se dio desde finales de los años sesenta.

Ahora bien, una vez puesta en circulación la primera "familia de billetes" $\mathrm{en}$ Colombia, solo hasta la creación de la Constitución de 1991 — punto de quiebre para repensar "lo nacional" - los billetes encarnan de forma más evidente una coyuntura política. El reconocimiento del país en el discurso oficial como una nación pluriétnica y multicultural creó, en teoría, un marco social y legal de reivindicación de los derechos humanos, la identidad y la memoria de grupos invisibilizados por la ley e, incluso, por la historia nacional. Analizar cómo se traduce esta idea de nación a través de dispositivos culturales como los billetes, nos lleva a destacar el análisis en específico de dos piezas: el billete de 10.000, emitido en 1992, que evoca los cinco siglos del descubrimiento de América, y el de 10.000, de 1996, que conmemora 200 años del natalicio de Policarpa Salavarrieta. De esta manera, concluimos el análisis con una reflexión más reciente sobre la colección de billetes que actualmente circula en el país y los debates que atañen a su renovación, llevada a cabo en el 2016.

\section{Los billetes: piezas del engranaje ideológico de la nación}

El recuerdo y el olvido de los contenidos visuales impresos en el papel moneda dependen de códigos impuestos desde la oficialidad, creados para visibilizar las imágenes que llenan de contenido la memoria nacional del país, reconocida e identificada por el pueblo a través del uso diario de objetos culturales como los billetes. Según Benedict Anderson, la nación es una comunidad imaginada porque, ante la imposibilidad de que cada ciudadano se conozca, el vínculo inmaterial que los cohesiona es el acto de imaginarse y proyectarse en su comunión. ${ }^{5}$ Igualmente, es una comunidad limitada por estar ligada a un territorio medido por fronteras y a unas tradiciones particulares, que constituyen el estilo empleado para imaginar la comunidad como "única”, aquello que diferencia a una nación de otra. Sin embargo,

4 Henao Jaramillo, Billetes de Colombia, 12.

5 Benedict Anderson, Comunidades imaginadas: reflexiones sobre el origen y difusión del nacionalismo (México: Fondo de Cultura Económica, 1993), 23. 
los intentos por construir los elementos de ese vínculo “inmaterial” se tornan centrales al momento de reflexionar sobre la visibilidad de unos actores sobre otros para representar la nación.

Al referirnos a un sistema simbólico de representación, pensamos en una forma cambiante de expresión que busca darle sentido a la experiencia de la comunicación humana. ${ }^{6}$ En la incipiente construcción de la nación colombiana, a comienzos del siglo XIX, se justificaba el desprendimiento político de España como principal consigna. Algunas décadas más tarde, los ideales de modernidad económica gestados en Europa tras la Revolución Industrial acapararon la atención de élites e intelectuales para representar a la nación como "progresiva" y dejaron el tema de la independencia política en un segundo plano simbólico. De ahí que pensar el proceso de construcción de la nación republicana en Colombia implique historizar la instrumentalización de una retórica que ha incluido tanto instrumentos narrativos como visuales, a fin de solidificar un sistema mítico-político que renueva el contenido de los códigos culturales con los que se identificaban los ciudadanos. ${ }^{7}$

Por esto, las imágenes movilizadas de forma pública y masiva en los billetes son parte del discurso visual institucional que se articula con el engranaje ideológico de la nación. No es fortuito que Benedict Anderson exponga de qué modo los ciudadanos se identifican como miembros de la comunidad nacional antes de pensar su lugar en las jerarquías de desigualdad y explotación del sistema. Esa suerte de fraternidad entre miembros de una nación imaginada, que invisibiliza las desigualdades entre unos y otros, está sustentada en una serie de figuras construidas socialmente; representaciones jurídicas, artísticas, militares, históricas, entre otras, conforman ese conjunto cultural diferenciador, evidentemente político y defendido hasta la actualidad en múltiples escenarios.

Uno de estos escenarios es el de la memoria. Si los billetes son dispositivos culturales subordinados a la ideología nacional vigente, lo son por las decisiones

6 Pascal Ory, L'histoire culturelle (Paris: Presses Universitaires de France, 2011), 9.

7 En el campo de la historia, algunos estudios han analizado a profundidad el proceso de transformación de aquellos instrumentos diseñados para encarnar los valores de la república independiente, invitando a la reflexión sobre la dimensión memorial de elementos inmateriales y materiales que sustentan la simbología nacional de los países latinoamericanos. Véase Rebecca Earle, "Sobre héroes y tumbas: National Symbols in Nineteenth-Century Spanish America", Hispanic American Historical Review 85, n. ${ }^{\circ} 3$ (2005): 375-416; Hans Joachim König, "La función de las imágenes en el proceso de construcción de las naciones latinoamericanas", en La nación expuesta: cultura visual y procesos de formación de la nación en América Latina, ed. por Sven Schuster (Bogotá: Universidad del Rosario, 2014), 1-28. 
sobre su contenido visual, por el valor monetario que se les asigna y por la acumulación de saberes técnicos implícitos en su producción. En el caso colombiano, pensar la visibilidad de la mujer en estas piezas de uso común, abre un abanico de posibilidades para reflexionar sobre las lógicas y estilos con los que se imagina una comunidad que lleva casi dos siglos construyendo nociones sobre "lo colombiano". De esta manera, los billetes entran al escenario político de la memoria, a partir de su valor histórico como mecanismos de representación en los cuales figuran algunos rostros, lugares u objetos reconocidos y apropiados por los mismos ciudadanos.

El historiador Pierre Nora sugiere que la memoria colectiva abarca el conjunto de recuerdos transmitidos, bien sea por prácticas informales o instituciones, que promueven la escenificación del imaginario de lo común; por otra parte, la memoria histórica es producto de una tradición intelectual que analiza, filtra, precisa, capitaliza y difunde un relato unificador. ${ }^{8}$ En este sentido, el papel moneda es una fuente perteneciente a ambos niveles de la memoria: es parte de la memoria colectiva, porque su contenido visual obedece a unas dinámicas de transmisión que llenan de contenido los sucesos de la historia nacional, y, a su vez, es parte de la memoria histórica, porque las imágenes allí plasmadas traducen o sintetizan varias de las representaciones elaboradas alrededor de la nación y sus definiciones.

No obstante, cabe resaltar que las imágenes ilustradas en los billetes no solo circulan por este medio; la legitimación del discurso nacional suele operar, de hecho, a través del arte y sus distintas expresiones. Estatuas, pinturas, estampillas, monumentos, entre otros, son muestras de algunas percepciones hegemónicas sobre el pasado, que para finales del siglo XIX definieron los insumos estéticos de la numismática local. De esta manera, al detenerse en las representaciones visuales que acompañan el discurso nacional de un país latinoamericano como Colombia, el intercambio cultural, por su condición de excolonia española, se vuelve un factor central para pensar cuáles estilos han primado para pensar y visibilizar la nación después de su configuración como República.

¿El contenido de los billetes complementa los alcances de monumentos, museos y fiestas patrias o acaso los repite? Los tipos de representaciones inscritas en este inventario de imágenes reciben influencias foráneas modificadas localmente y difundidas con propósitos diversos. Debido a sus cambios y resignificaciones históricas, los grabados alegóricos de la libertad de los billetes del siglo XIX no comunican lo mismo que la Marianne del Banco de la República. De hecho, el estilo de

8 Pierre Nora, Présent, nation, mémoire (Paris: Gallimard, 2011), 300. 
la representación es un indicio sobre las percepciones que adquiere un rostro, lugar u objeto dentro de una comunidad. Por esta razón, encontramos pertinente señalar que las modalidades para representar "lo nacional" desde los billetes deben pensarse como parte influyente de los marcos sociales de la memoria en el sentido de Maurice Halbwachs, y no como el resultado de experiencias individuales o aisladas. Dado que estos marcos no son fijos, sino cambiantes en el tiempo, ${ }^{9}$ el contenido visual que acompaña el discurso de nación, para el caso colombiano, cambia estilísticamente según el paradigma estético que en diferentes momentos un sector privilegiado de la población (hombres de letras, artistas, banqueros, juntas de dirección, etc.) ha imaginado como el indicado para monopolizar la memoria nacional a través de diversos vehículos. En este sentido, si bien la exposición pública de imágenes nacionales conserva una dimensión colectiva debido a su circulación, el discurso que allí se materializa responde a la decisión de un sector oficial de establecer su autoridad respecto al pasado.

Como ya se mencionó, en Colombia los billetes entran en circulación hacia los años sesenta del siglo republicano y fueron producidos en su primera etapa por entidades bancarias europeas y estadounidenses. La descentralización de los emisores promovió que la imaginación de las representaciones simbólicas de las piezas se tejiera con base en su procedencia internacional, así como en las rutas del progreso económico y político fijadas por los mismos países industrializados como Inglaterra o Francia, donde se gestaba dicho diseño y elaboración. De este modo, el análisis del contenido visual que en los billetes se impone y circula es también un esfuerzo por pensar las instituciones bancarias como creadoras de una visión institucional de la identidad y la memoria en un país. Sin duda, estas dialogan con otros elementos del inventario visual de representaciones nacionales e ilustran, desde criterios particulares, las experiencias que cohesionan a los habitantes de la nación. De ahí que los billetes puedan considerarse "ventanas al pasado" para estudiar la historia de Colombia, tal como lo expone Jorge Orlando Melo en el Catálogo de la Casa de la Moneda, ${ }^{10}$ en el cual reivindica no solo el potencial de las fuentes iconográficas, sino, a su vez, el uso de cuestionamientos más críticos para ubicar el papel moneda en escenarios diferentes al intercambio económico o el coleccionismo. A pesar de

9 Maurice Halbwachs, Los marcos sociales de la memoria (Barcelona: Anthropos, 2004), 10.

10 Jorge Orlando Melo, "Catálogo de la Casa de la Moneda". Colección de numismática Banco de la República, 1999, http://www.banrepcultural.org/sites/default/files/lablaa/num/pdf/numismatic. $\operatorname{pdf}(31 / 03 / 2017)$. 
que los estilos de representación en los billetes colombianos han cambiado considerablemente, hay un proceso primigenio del que parten las elaboraciones discursivas sobre lo nacional y, con ello, sus manifestaciones visuales que están por analizar: la Independencia de España y la formación de la República. La pretensión de crear una "galería patria","11 donde las imágenes ilustran la narración de una historia común (nacional), sugiere un interés por cimentar el contenido de la memoria colectiva y argumentar el discurso de la memoria histórica con base en un pasado heroico que debía perdurar como mito fundacional de los colombianos

\section{Construcción de la iconografía del billete: un proyecto cultural europeo}

El papel moneda se deriva de la relación entre las técnicas modernas de impresión y la práctica artística. Desde sus inicios, la producción de billetes en Europa mantuvo intereses en el estilo de la forma y, con ello, en la vehiculización de códigos temáticos expresados mediante imágenes impresas. El billete pasó a remplazar productos gráficos con alta repercusión como los grabados, principalmente en capitales como Londres y París, gracias al descubrimiento y desarrollo de la litografía. En el arte europeo, el grabado de los siglos XVI, XVII y XVIII constituyó una representación pictórica con fines ilustrativos y comerciales, puesto que su técnica — basada en una fiel reproducción de las imágenes dibujadas - permitió transportar copias de pinturas y esculturas resguardadas en palacios o iglesias, así como ampliar el horizonte de la autonomía del artista, al desarrollar una técnica de dibujo que conjugaba la monocromía, el tratamiento de la luz, la sombra y el manejo de la línea. ${ }^{12}$

Así, este tipo de imágenes, inmersas en novedosas prácticas de circulación industrial, se emplearon en los dispositivos que sustituyeron el dinero metálico de alta denominación; gracias a la evolución del diseño gráfico, se confería una nueva plasticidad al soporte del intercambio. Por otra parte, en el marco de una época de efervescencia patriótica e intensificación de los nacionalismos, la intención de dotar simbólicamente los billetes transforma la percepción sobre el valor social de la moneda; ciertamente, se renueva el ejercicio de invención de una iconografía que debía circular en varias manos, al mismo tiempo que se construía un nuevo paradigma estético: uno capaz de desarrollar un estilo pictórico para articular a la comunidad nacional. Así es como la práctica artística realza tanto el contenido

11 Rosero García, "Los billetes, una ventana al pasado”.

12 Ávila, $Y$ tú también te vas, 22. 
histórico como el simbólico, mientras los billetes contribuyen a su movilización. Según Danuta Teresa Mozejko, el protagonismo de la historia en las producciones culturales decimonónicas, además de crear el discurso base de la comunidad imaginada, reproduce las estructuras estereotipadas de la época como los acontecimientos que definen la identidad de la nación, lo cual configura, a su vez, una reacción de pertenencia en los destinatarios del discurso. ${ }^{13}$

Además de los bancos privados, regionales y extranjeros, la emisión temprana de billetes en Colombia estuvo a cargo de la Tesorería Jeneral, como respuesta a las crisis económicas desatadas por diferentes guerras civiles. Los diseños de las piezas puestas en circulación ya incorporaban representaciones femeninas (figura 1), aspecto que tuvo poca aceptación entre el público. ${ }^{14}$

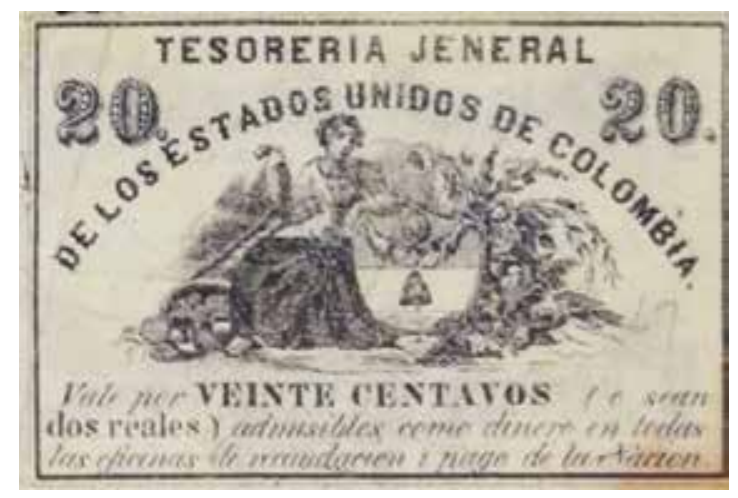

Figura 1. Tesorería Jeneral, 1861, "Billete de 20 centavos" (grabado sobre papel, $52 \times 45 \mathrm{~mm}$, Casa de la Moneda, Bogotá).

El billete de 20 centavos de la figura 1 incluye, además del escudo de los Estados Unidos de Colombia, el dibujo a mayor escala de una mujer que sostiene un cuerno de la abundancia, rodeada a su vez por una frondosa vegetación. Se puede identificar que la mujer, por su vestimenta y apariencia física, guarda semejanzas con una representación griega, dado el vínculo de la simbología del cuerno. ${ }^{15}$ Sabemos

13 Danuta Teresa Mozejko de Costa, "La construcción de los héroes nacionales", Revista Estudios, n. 6 (1995): 79 .

14 Henao Jaramillo, Billetes de Colombia, 13.

15 La idea de fortuna y abundancia está ligada permanentemente a la tierra y al territorio desde la Antigüedad. Su origen se remonta a la mitología griega, donde un cuerno caprino repleto de frutos y 
que la Tesorería emitió billetes hasta 1864; en ese sentido, estamos hablando de un corto periodo de circulación tanto de la pieza como de la imagen alegórica, la cual parece complementar la ornamentación del escudo. La combinación de elementos que podrían identificarse como "locales" (el escudo y la vegetación) entran en diálogo con una figura femenina, armoniosa con la composición de la decoración, pero distanciada de las representaciones que los artistas de la época privilegiaban como elementos del inventario estético nacional. Pintores como José María Espinosa, Ramón Méndez Torres, Pedro José y José Miguel de Figueroa, entre otros artistas emblemáticos de la iconografía prócera republicana, creaban representaciones pictóricas en las que se manifestaba la experticia del retrato y la devoción a la efervescencia patriótica. ${ }^{16}$ Empero, la no correspondencia del discurso visual de unas producciones con otras — como se observará en las siguientes imágenes de billetes que circularon durante los últimos veinte años del siglo XIX — radica en dos elementos que obedecen a las lógicas de producción numismática: la elaboración de sus impresiones en el extranjero y la descentralización de los bancos privados en el país.

La autorización del Gobierno colombiano a estos últimos confería autonomía suficiente para que cada banco emitiera sus propios ejemplares. Adicionalmente, sus propietarios mantuvieron nexos cercanos con firmas financieras inglesas y norteamericanas para la fabricación de las piezas, lo cual permitió que el diseño fuera sugerido e intervenido desde otros países. Entre las entidades que más participaron durante el proceso se encuentran Bradbury, Wilkison \& Co., Hamilton Bank Note, entre otras. Por otra parte, la litografía en el país se desarrollaba a menor escala y con escasos recursos, aun cuando se destacó como caso excepcional la imprenta Paredes y Villaveces. ${ }^{17}$ De esta manera, los modelos de aquellos grabados que configuraban la estética del billete se basaban en ilustraciones inspiradas en las alegorías femeninas europeas y el uso de contenidos visuales alusivos a la Revolución Industrial.

Estas imágenes toman como referente artístico un estilo de ornamentación clásica que la política simbólica de las repúblicas europeas - especialmente la francesa - adoptó para dotar de significado los nuevos valores de la organización

flores es obsequiado por Amaltea (ninfa o cabra) a Zeus. Véase: Irma Beatriz García, "El cuerno de la abundancia: mito e identidad en el discurso sobre el territorio y la nación mexicanos", historie(s) de l'Amérique latine, 1 (2005): 1-28.

16 Eugenio Barney Cabrera, "Reseña del arte en Colombia durante el siglo XIx", Anuario Colombiano de Historia Socialy de la Cultura 2, n. 3 (1965): 92.

17 Henao Jaramillo, Billetes de Colombia, 13. 
social del Estado-nación. Lo anterior implica que el modelo del que se parte para movilizar un contenido visual foráneo influye en el cambio de códigos culturales con los que se representaría el dinero colombiano. Si bien las imágenes de mujeres alegóricas ya se habían visibilizado en el país a través de las monedas metálicas, ${ }^{18}$ su circulación en billetes las enriqueció con nuevos detalles y promovió las piezas como un espacio de protagonismo para las representaciones artísticas femeninas.

El uso recurrente de imágenes alegóricas al progreso y la libertad se perfilaba como una pedagogía universal sobre los principios del modelo de Estado que se anhelaba para la República soberana. Por ejemplo, desde los años en que Antonio Nariño fue el presidente de Cundinamarca, una mujer de traje romano sosteniendo una lanza con el gorro frigio ${ }^{19}$ ya simbolizaba la libertad de origen europeo. La justicia, por su parte, la representaba una mujer asociada a la diosa Temis, consejera y esposa de Zeus, que luego en Roma fue apreciada como la obediencia hacia las leyes en el imperio. ${ }^{20}$ Estas referencias de la historia clásica de occidente representan a la mujer esbelta, fuerte y joven, ya que reúnen el lenguaje cifrado de un valor como símbolo, que le adjudican también una permanencia a la estética femenina como referente de la estabilidad de aquellos principios que evoca.

No obstante, en la medida en la que estas imágenes representan un contenido alegórico que "otorga corporalidad" al imaginario decimonónico del progreso impartido desde Europa, su extrapolación a otros contextos como el colombiano no pasa por un proceso gráfico de apropiación local tan marcado en lo que respecta al diseño de los billetes. Si observamos las figuras 2 y 3 , la presencia de dos imágenes femeninas - aunque diferentes entre sí- ejemplifica la intención de difundir un mensaje de símbolos o códigos políticos culturales europeos que no están arraigados en el inventario de imágenes específicas de una nación. Así, al observar las alegorías de las figuras 2, 3 y 4, resulta complejo establecer una relación directa con el país en el que se producen; si bien identificamos detalles europeos como la piel de color claro en la mujer, su juventud o vestimenta de estilo romano, no le adjudicamos una nacionalidad a la imagen, aspectos donde precisamente radica el poder de su movilización como símbolos “desterritorializados".

18 Fernando Barriga del Diestro, "Orígenes del simbolismo en las figuras consignadas en nuestras primeras monedas", Boletín Numismático, n. 71 (2001): 5.

19 Ibid., 5.

20 Alejandro Linares Zárate. "La justicia: su simbología y valores que concurren en su aplicación”, 2009, http://web.uaemex.mx/identidad/docs/JUSTICIA.pdf(31/03/2017). 


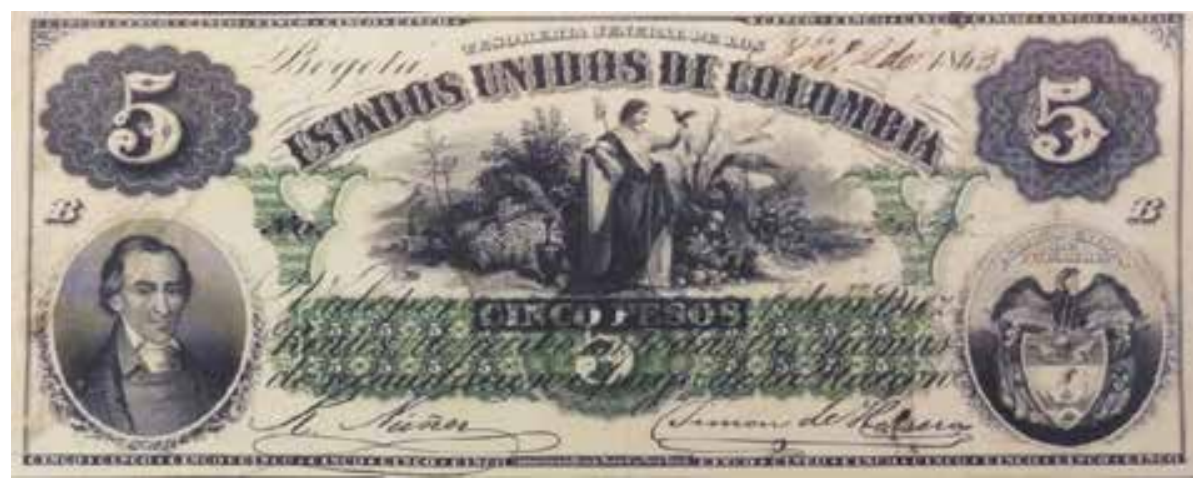

Figura 2. Banco de los Estados Unidos de Colombia, 1863, "Billete de 5 pesos" (litografía, Casa de la Moneda, Bogotá).

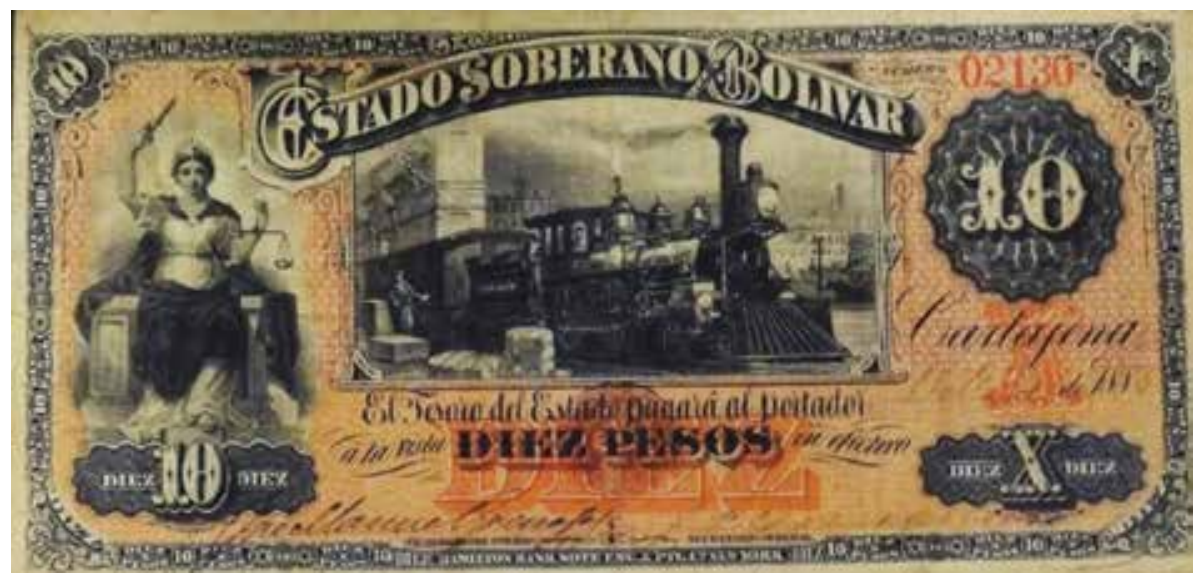

Figura 3. Banco del Estado Soberano de Bolívar, 1870, "Billete de 10 pesos” (litografía, Casa de la Moneda, Bogotá).

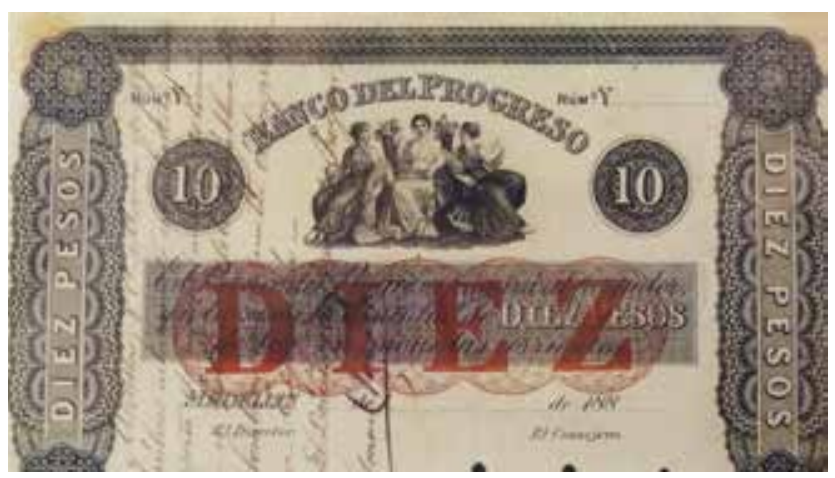

Figura 4. Banco del Progreso, 188..., “Billete de 10 pesos” (litografía, Casa de la Moneda, Bogotá). 
Las ideas plasmadas en estas piezas, de hecho, pueden aplicarse a distintos contextos. En Colombia, los códigos simbólicos de las manifestaciones culturales europeas ya habían estado en circulación antes de las emisiones de papel moneda, por lo que a pesar de que las imágenes en cuestión representaran conceptos abstractos, ya existía cierta familiarización con estas por parte de los receptores. En los billetes del siglo XIX, la mayoría de alegorías hacían referencia a elementos ideológicos republicanos y representaciones clásicas de la primavera o la agricultura. Su circulación a través del dinero estaba mediada por la relación entre el lugar de producción de las plantillas (que en realidad eran piedras litográficas) en Inglaterra, Francia y Estados Unidos, y la imposición de su discurso visual como modelo de representación para todos los demás países consumidores de las imágenes.

Los anteriores billetes proyectan a las mujeres como protagonistas de los anversos y comparten espacio en la pieza con otros elementos, como los retratos de los propietarios de los bancos, el escudo nacional o los ferrocarriles cada vez más presentes en la geografía del país. Esto transmite un mensaje idealizado del progreso algo fragmentado, pues parece que cada elemento tuviera una función ornamental aislada y poco relacionada con los demás detalles. No obstante, la relevancia y pluralidad de imágenes en la pieza nos sugiere que si bien las firmas extranjeras no tenían el objetivo de fabricar un tiraje de "familia de billetes" que le confiriera unidad temática a su discurso visual, sí es probable identificar una intencionalidad por hacer del billete un lugar para la circulación de representaciones artísticas; así sería posible situar el dinero como referencia de valor de uso y cambio, estéticamente adaptado al imaginario político europeo decimonónico.

Para 1881, bajo el primer Gobierno de Rafael Núñez, se funda el Primer Banco Nacional. En la última mitad del siglo XIX, la búsqueda de un auténtico nacionalismo colombiano ocupaba la plana principal del debate político protagonizado por las élites letradas; no obstante, los referentes de aquella consigna seguían siendo europeos. En 1880, el presidente Núñez, tras una experiencia diplomática positiva en el extranjero, ${ }^{21}$ busca retomar la centralización del Estado y sus instituciones, apelando a la crítica de la "utopías importadas". El mandatario señalaba que el fracaso del radicalismo liberal en Colombia se debía al culto excesivo hacia Francia, lo cual sugería que su madurez y experiencia política en el exterior sentarían los lineamientos ideológicos de su Gobierno regeneracionista. En este contexto, el

21 Frédéric Martínez, "En los orígenes del nacionalismo colombiano: europeísmo e ideología nacional en Samper, Núñez y Holguín”, Boletín Cultural y Bibliográfico 39, n. ${ }^{\circ} 32$ (1995): 39. 
Banco Nacional y su propia producción de billetes coexistían con los demás bancos privados, lo cual incrementó tanto el número de ejemplares, al punto de causar una suerte de inundación de piezas con diseños heterogéneos. Según indican las fuentes, llegaron a existir simultáneamente veintiséis formas diferentes de papel moneda; pequeñas y grandes, procedentes de varias litografías tanto extranjeras como locales. ${ }^{22}$

En el billete de 100 pesos emitido por esta institución en 1885 (figura 5) persiste la intención de ornamentar el papel con figuras alegóricas femeninas. Sin embargo, esta imagen proviene de un grabado menos detallado y minucioso que los anteriores; se trata de una mujer que para la época podía representar la libertad o la República francesa, a la cual se atribuyó el nombre de Marianne. De hecho, la imagen remite a representaciones como Libertad guiando al pueblo (1830), de Eugène Delacroix, o La República (1848), de Honoré Daumier; principalmente por la presencia del gorro frigio, el cual —además de simbolizar el atuendo de esclavos liberados en Grecia y Roma- ya figuraba en el escudo nacional de Colombia, y también, por la vestimenta de la mujer que deja al descubierto su seno derecho. Esto hace referencia a la capacidad de la República de alimentar al hombre emancipado del Antiguo Régimen. ${ }^{23}$
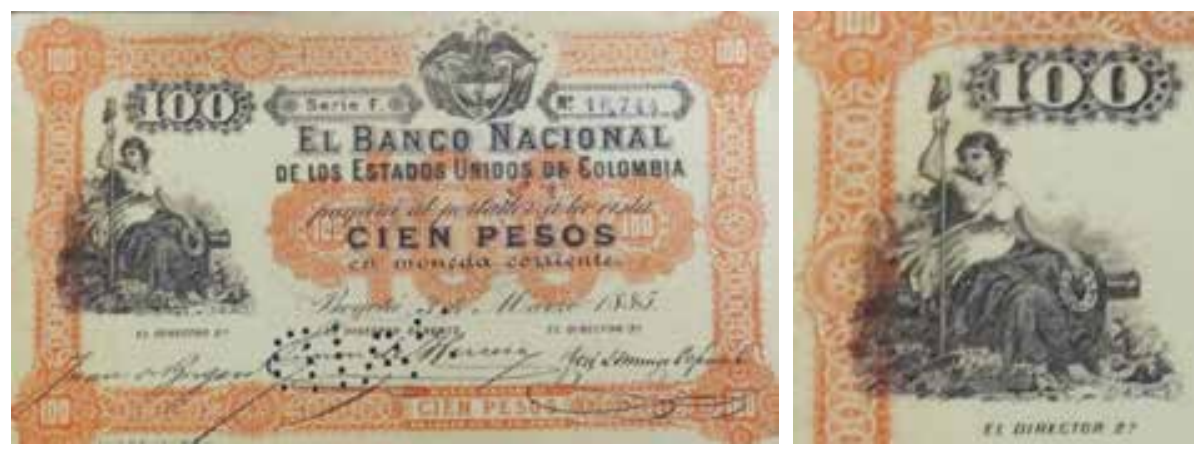

Figura 5. Banco Nacional de los Estados Unidos de Colombia, 1885, "Billete de 100 pesos" (litografía, Casa de la Moneda, Bogotá).

\footnotetext{
22 Los billetes del Banco Nacional fueron impresos en la litografía colombiana Paredes y Villaveces. Revise: Henao Jaramillo, Billetes de Colombia, 14.

23 Elysee.fr, "Marianne”, http://www.elysee.fr/la-presidence/marianne/ (31/03/2017).
} 
En ese sentido, el modelo iconográfico francés nunca dejó de ser un referente para los gobiernos del siglo XIX, a pesar de las divisiones entre liberales y conservadores. Frédéric Martínez sugiere que parte de esta polarización protagonizada por las élites fue un proceso indirecto, pero a su vez conveniente, para excluir la participación de las masas en el debate político. Por esto, el lugar de enunciación de la persona letrada que escribía sobre política y participaba en ella es central para entender por qué se privilegian ciertos elementos sobre otros en el conjunto de las representaciones nacionales. El lugar de este individuo lo ocupaba un hombre "blanco", burgués e intelectual, partícipe de la milicia, el periodismo o las leyes y quien muchas veces se encargaba de escribir extensos manuscritos de historia patria. Según Germán Colmenares, en Latinoamérica "se adoptaron las convenciones europeas en el oficio historiográfico; estas servían para construir un epos patriótico en torno a actores que desarrollaban una acción casi siempre ejemplar". ${ }^{24}$ De esta manera, el relato casi siempre fue protagonizado por una figura masculina, cuyo legado debía representarse dentro de la colectividad al tomar sus hazañas como modelo para el deber ser del ciudadano.

De ahí que gran parte del arte decimonónico en Colombia esté protagonizado por retratos de Simón Bolívar, Francisco de Paula Santander, Antonio Nariño, Camilo Torres, Jorge Tadeo Lozano, Antonio José de Sucre, entre otros tantos próceres vinculados a la Independencia de Colombia. Con dichos referentes, los presidentes en el transcurso del siglo XIX figuraron como continuadores de este legado bajo el mismo simbolismo heroico. De modo que el arte decimonónico sustenta también la historia del país y, con ello, es enmarcado en el conjunto de representaciones que promovieron la idea de concebir a la comunidad nacional valiente, libre y soberana a partir de la ruptura con su pasado colonial.

Volviendo al análisis sobre el contexto de producción, la emisión de billetes por parte de los bancos privados se prohíbe en 1886 y el Banco Nacional se establece como única entidad autorizada a sacar tirajes. Las imágenes de mujeres continuaron estando presentes en los billetes, pero esta vez se incorporaron en las piezas retratos de próceres y presidentes. Así, el protagonismo de las alegorías se reducía; las mujeres que aparecían entonces eran representaciones de diosas griegas o personajes que no se asocian fácilmente con significados específicos. La visibilidad que adquieren tales figuras femeninas es entonces mucho más ornamental que antes,

24 Germán Colmenares, Las convenciones contra la cultura: ensayos sobre historiografía hispanoamericana del siglo XIX (Bogotá: Tercer Mundo, 1997), 59. 
pues de igual manera el epos patriótico del imaginario nacional continuó siendo mayoritariamente masculino, político y militar. No obstante, la aparición de estos retratos tampoco ocupa un lugar totalmente protagónico dentro del billete.

En la figura 6 se observa la intención de dotar con mayor intensidad al papel moneda de símbolos nacionales, razón por la que es probable considerar que entre más regulación de las políticas de emisión, mayor interés estatal por hacer de los billetes dispositivos pedagógicos de la ideología nacional. El patrón de diseño se hace más homogéneo en los billetes de diferente denominación; por ejemplo, el uso del escudo nacional es más recurrente y la ubicación de las imágenes para cada pieza es similar en los ejemplares impresos por la American Bank Note de Nueva York, los cuales, a pesar de seguir siendo producidos en el exterior, ahora seguían las pautas de una banca central. Sin embargo, la alta inflación que produjo la guerra de 1895 llevó al Gobierno a realizar autopréstamos con el Banco Nacional y, con ello, a producir billetes en la Litografía Nacional hasta 1900, a pesar de que el Banco fuera liquidado por decreto en 1896.

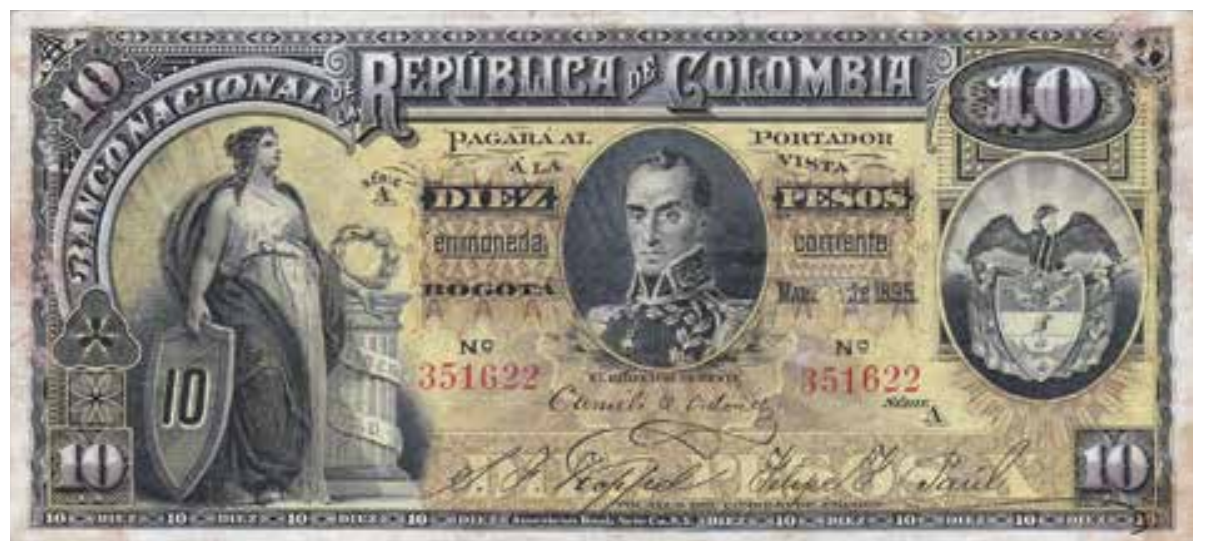

Figura 6. Banco Nacional de la República de Colombia, 1888, "Billete de 10 pesos"

(litografía, Casa de la Moneda, Bogotá).

Estos incidentes provocaron en la numismática colombiana del siglo XIX tardío una producción poco regulada y dispersa. Si bien la ornamentación algo barroca abarca el diseño de la mayoría de billetes, la inclusión de unas y otras imágenes, según referentes extranjeros cambiantes, ubicó al papel moneda como una pieza fundamental para insertar lo monumental en lo cotidiano, al tiempo que se transformaba según la centralización de las instituciones bancarias. 


\section{El nuevo siglo y la institucionalización del discurso visual desde el papel moneda}

La Guerra de los Mil Días sigue siendo el conflicto armado que más inflación ha generado en la historia de Colombia. Para cubrir los gastos ocasionados se imprimieron cerca de 870 millones de billetes en la Litografía Nacional. Esta vez, rompiendo con el patrón estilístico que intentó producir el Banco Nacional, los billetes eran diversos en color, tamaño y estilo; los coleccionistas los catalogan como "horribles", pues se evidencia la premura por imprimir numerosas cantidades para financiar una guerra que generaría el $300 \%$ de inflación del peso en el país. ${ }^{25}$ Se creó entonces, bajo orden del Gobierno de Manuel Antonio Sanclemente, una Junta de Emisión autorizada para producir el papel moneda que fuera necesario en el marco de un restablecimiento nacional. Pero la emisión se diversificó y cada gobierno regional, así como el ejército liberal, emitieron sus propios billetes. ${ }^{26} \mathrm{El}$ discurso visual que empezaba a consolidarse a finales de siglo se fragmentó, y el diseño de papel moneda privilegió solamente el escudo nacional antes que los próceres u otras alegorías. Sin embargo, la demanda de dinero superó la capacidad de las imprentas nacionales; como solución provisional, la Junta de Emisión negoció con los antiguos bancos regionales el regreso de sus billetes (los que habían sido suspendidos), bajo la condición de resellarlos con el nombre del Banco Nacional o de la misma Junta. ${ }^{27}$ Esto permitió que los tirajes importados de Inglaterra, Francia y Estados Unidos tuvieran valor circulante de nuevo. La situación permite pensar el papel moneda simultáneamente como un espacio simbólico de tensión dentro de la guerra, en la medida en la que parte de la legitimidad proyectada por el Banco Nacional, al establecerse en 1886 como único emisor, se vio truncada por la necesidad de hacer circular dinero para restablecer el orden económico del país (figura 7).

25 Pedro Pablo Hernández, Catálogo de billetes de Colombia: siglo antepasado 1813-1915, Banco de la República 1923-2000 (Cali: El Búho, 2000), 95.

26 Henao Jaramillo, Billetes de Colombia, 14.

27 Ignacio Alberto Henao Jaramillo, “Cien años de los mil días: billetes en tiempo de guerra”, Revista Credencial Historia, n. ${ }^{\circ} 128$ (2000): 7. 


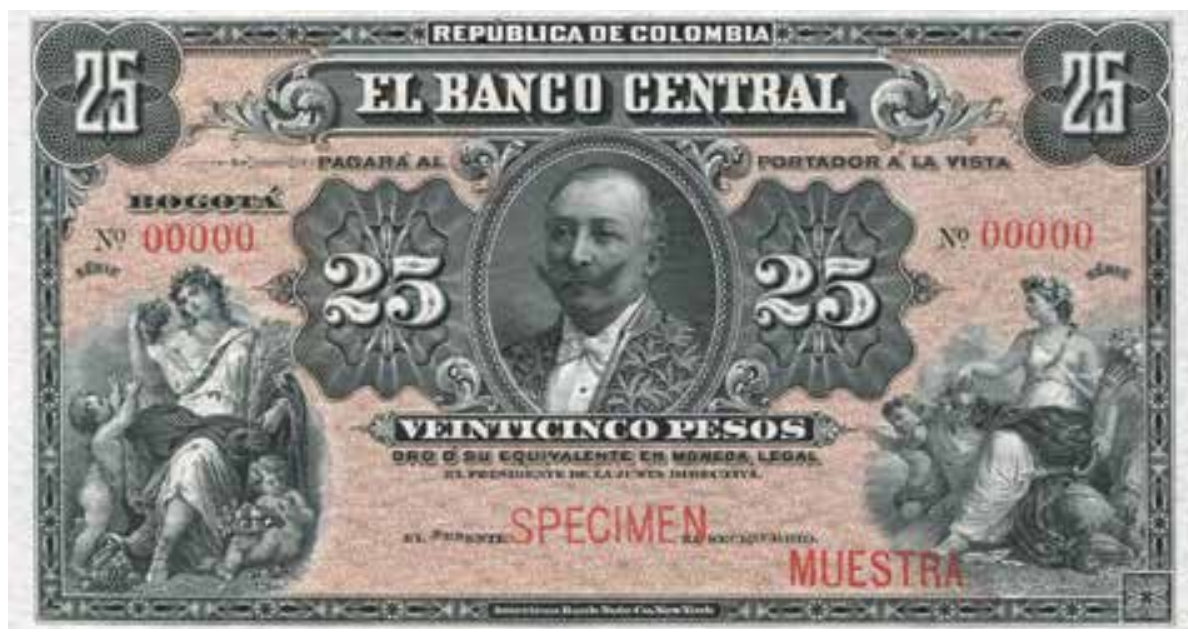

Figura 7. Banco Central de la República de Colombia, 1907, "Billete de 25 pesos" (litografía, Casa de la Moneda, Bogotá).

Al finalizar la guerra, en 1902, se crea la Junta de Amortización, diseñada para retirar mediante subastas de oro todos los tipos de papel moneda que estuvieran en circulación y, así, otorgar la concesión a la financiera inglesa Waterlow \& Sons. Este episodio renovó la iconografía de los billetes, al materializarse con más intensidad la difusión del héroe nacional, del prócer de la Independencia, y retomar su retrato como imagen protagónica del anverso de los billetes con diferente denominación. Desde este periodo hasta la formación del Banco de la República, en 1923, las piezas cambiaron su estilo según la junta al mando; la regulación de la emisión se concentró en elaborar instituciones centralizadas que evitaran las impresiones falsas y amortizaran la inflación.

Así, durante el Gobierno de Rafael Reyes, la bonanza cafetera dio un nuevo aire a la economía del país y, con ello, a la política fiscal de establecer un Banco Central para amortizar los billetes; una Junta de Conversión fue la encargada de que el papel moneda remplazara su representación en oro por monedas de plata. ${ }^{28}$ En lo que respecta al diseño de los tirajes, se privilegió la excesiva ornamentación del billete, un aumento en su tamaño y la centralidad del retrato de Reyes como imagen principal. Hubo una suerte de retorno a los diseños sobrecargados de las primeras emisiones — al igual que a la contratación extranjera—, asunto que dio

28 Henao Jaramillo, Billetes de Colombia, 21. 
más protagonismo a las alegorías feminizadas de progreso, libertad y República, justamente en un contexto en el que la acumulación de capitales para una temprana industrialización, así como la inversión de empresas extranjeras como la United Fruit Company en el país, configuraba un panorama económico más dinámico interno y externo. La visibilidad simbólica de la mujer en los billetes, en este contexto global donde otros países comenzaban a integrar el debate por los derechos ciudadanos de las mujeres, nos habla entonces del grado de interés por representar a la "mujer real" en el inventario de imágenes del discurso nacional.

Durante el periodo de hegemonía conservadora en el país, los resultados de la Misión Kemmerer cambian sustancialmente la economía del país. El grupo de economistas al mando del profesor Edwin Kemmerer de la Universidad de Princeton fue contratado por el Gobierno de Pedro Nel Ospina para analizar y diseñar soluciones estructurales a las crisis financieras, las cuales podrían haberse intensificado ante un mal manejo de las exportaciones cafeteras. El Congreso aprueba mediante la Ley del 4 de julio de 1923 la creación del primer Banco de la República, "como una sociedad anónima mixta, de derecho privado, pero de interés público". En el continente, a Kemmerer se le conoció como "Money Doctor", dada la intervención en el diseño de políticas monetarias y fiscales en países como Chile, Ecuador, Bolivia y Perú. ${ }^{29}$ Esta similitud de la situación bancaria entre economías latinoamericanas no era nueva; si nos remitimos al plano estético, desde el siglo XIX el diseño del papel moneda de países vecinos era muy similar al colombiano, debido a su producción en casas extranjeras. En las figuras 8, 9 y 10 es posible apreciar cómo los bancos de Venezuela y Chile emplearon los mismos grabados que los billetes colombianos. Hasta mediados del siglo $\mathrm{xx}$, las firmas inglesas, francesas y estadounidenses conservaron el monopolio global del diseño para el papel moneda, lo que causó la estandarización de sus referentes visuales y, con ello, la imposición de sus códigos estéticos en la numismática de varios Estados nacionales en formación.

29 Paul W. Drake, "Kemmerer y la creación de bancos centrales en los países andinos", en Banco de la República: 90 años de la Banca Central en Colombia, ed. por Gloria Alonso Másmela (Bogotá: Banco de la República, 2013), 17. 


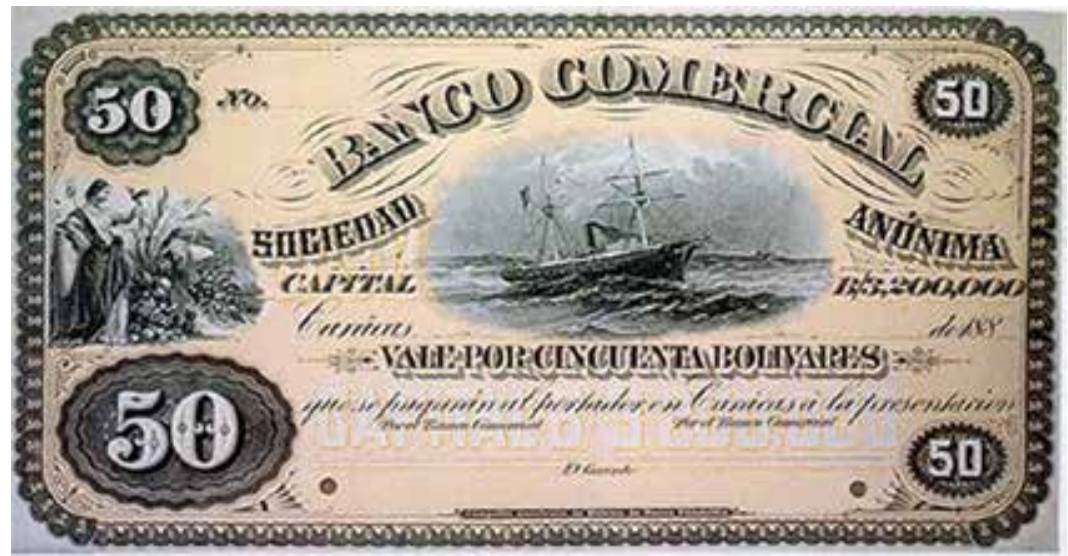

Figura 8. Banco Comercial-Sociedad Anónima, 1886, "Vale por 50 bolívares" (litografía, $104 \times 224 \mathrm{~mm}$ ), obtenido de Richard L. Rosenman, Billetes de Venezuela (Caracas: Corimon, 1980).

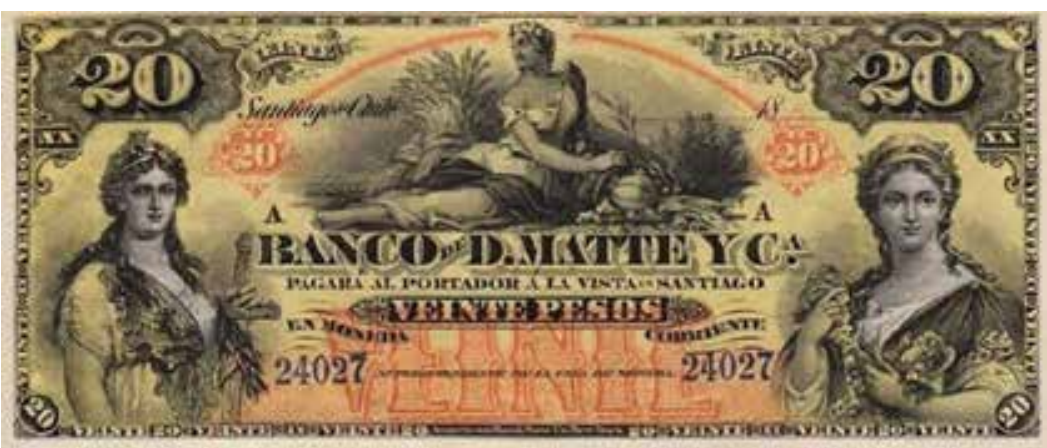

Figura 9. Banco D. Matte y Cia., 188..., "Billete de 20 pesos"

(litografía, tomado de http://www.billetesdelmundo.org/catalogo/Chile/19148301.html).

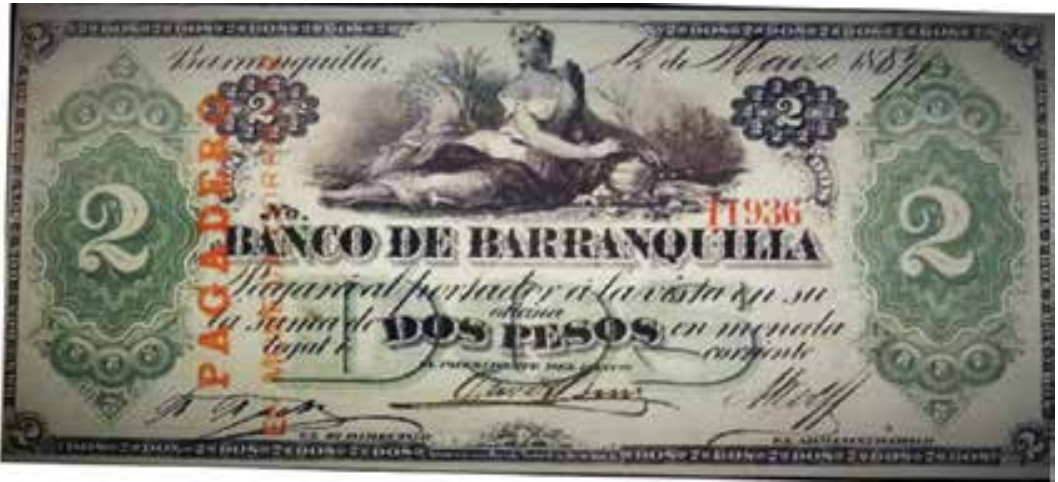

Figura 10. Banco de Barranquilla, 1883, "Billete de dos pesos” (litografía, Casa de la Moneda, Bogotá). 
Ahora bien, la creación del Banco de la República en esta época implica pensar en la necesidad económica del país de regular su política fiscal y monetaria en la carrera de la modernización nacional. En este contexto, y como venía manejándose hasta el momento, el Banco contrata oficialmente la impresión de billetes con firmas norteamericanas e inglesas; la American Bank Note, Waterlow \& Sons, Bradbury, entre otras, se encargan de la fabricación. Es un momento en el que la estética del billete cambia radicalmente, pues se establece un solo tamaño para todas las denominaciones, además de fijar el modelo de un prócer en el anverso y el emblema del Banco en el reverso. En ningún punto de esta nueva contratación se incluyó la imagen de una mujer, a excepción de nuevo, de una figura ya conocida por los colombianos: la alegoría de la libertad.

El referente artístico en el que se basa la iconografía del papel moneda durante los años precedentes a la creación de la Imprenta Nacional (1959) encarna con mayor vehemencia la idea gloriosa de un pasado independentista poblado por personajes ejemplares, y la representación de estos últimos con fines pedagógicos debía conservar cierta coherencia narrativa, ya que sus ilustraciones cuidan en detalle la gallardía y franqueza de los retratos, al mostrar su faceta como hombres públicos y al seleccionar "lo políticamente correcto" de su accionar..$^{30}$ Ahora bien, Marianne, según señalábamos, es una alegoría de la República francesa y de la libertad; el republicanismo colombiano, heredero de las consignas emancipadoras contra el Antiguo Régimen, la ha empleado igualmente como símbolo de libertad en dispositivos como monedas, estampillas y billetes. No obstante, Marianne marca una diferencia significativa con alegorías previas al posicionarse como logo oficial del Banco de la República. La entidad sustenta esta decisión apelando a la historia política: desde su página institucional se expone que tanto la traducción de los Derechos del Hombre, hecha por Antonio Nariño, como la consolidación de la Tercera República francesa influyeron para que los fundadores escogieran el nombre del Banco. Así mismo, sugieren que tampoco fue extraño que adoptaran el símbolo de Marianne como logo (figura 11).31

30 Rosero García, Los billetes, una ventana al pasado, 42.

31 Banco de la República, “El logo", http://www.banrep.gov.co/es/logo (31/03/2017). 

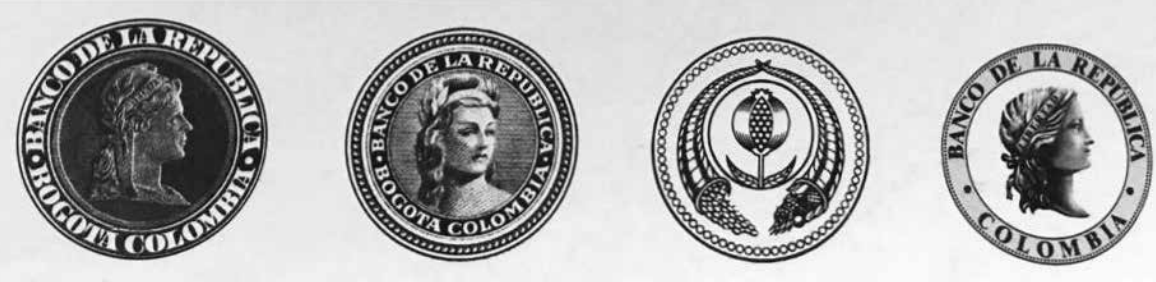

Figura 11. Banco de la República, s. f., "Logos del Banco de la República de Colombia". Tomado de Ignacio Alberto Henao Jaramillo, Billetes de Colombia: época del Banco de la República 1923-2006 (Bogotá: Grupo op Gráficas, 2006).

En la figura 11 vemos cómo Marianne se ha transformado en el lapso de 1923 a 2006. En un orden de izquierda a derecha, el personaje simbólico pasó de tener un perfil plano y poco nítido, a ser una representación con más “movimiento", acompañada de la corona de laurel y el gorro frigio; luego, y excepcionalmente, el logo de los años noventa pasan a ser los ya mencionados cuernos de la abundancia rodeando una granada; finalmente, la Marianne actual regresa más estilizada, lo que reafirma su significado a través de la banda que lleva en su cabeza con la palabra "libertad".

Respecto a la presencia de más representaciones femeninas en el transcurso del contrato con imprentas extranjeras, las alegorías helénicas completaron la composición en el anverso de los billetes, dentro de las cuales se destacan las diosas Atenea y Era. Según Pamela Rosero, estas representaciones completan el estilo clásico de los billetes y promulgan simultáneamente valores clásicos adaptados al país receptor de las piezas y sus marcos culturales. ${ }^{32}$ Antes de examinar la aparición de la mujer no alegórica (real) en los billetes colombianos, es preciso señalar que si bien el lugar de las imágenes femeninas en la numismática ha sido constante desde el siglo XIX, su visibilidad en el imaginario nacional hasta avanzado el siglo Xx es difusa, en contraste con la presencia masculina de la galería patria o procera. Sin embargo, en el periodo del Frente Nacional, los conjuntos de representaciones iconográficas son renovados, en el marco de una nueva búsqueda de cohesión nacional, contemporánea a la fuerte oleada de violencia de los años cuarenta y cincuenta.

32 Rosero García, Los billetes, una ventana al pasado, 42. 


\section{El rostro de la mujer criolla y la mujer emberá: las emisiones nacionales}

Finalizada la Segunda Guerra Mundial, la oferta de maquinaria para impresión de billetes fue tan grande que el Banco decidió adquirir equipos para volverse autosuficiente. Tras un proceso de formación de grabadores y diseñadores, fue fundada en 1959 la Imprenta Nacional, la cual fue la tercera de América Latina con un grupo de trabajo conformado por técnicos de diseño de la Banca D’Italia en Roma. ${ }^{33}$ En el papel moneda producido durante estos años, la estética es menos recargada y el protagonismo continúa siendo ocupado por los miembros del pasado político independentista; sin embargo, a manera de detalle inédito, el reverso del billete empieza a concebirse como un espacio propicio para la exhibición de lugares nacionales que comienzan a considerarse patrimoniales. Esta iconografía es característica en el régimen militar de Gustavo Rojas Pinilla y en el Frente Nacional. Colombia experimentaba la Violencia bipartidista y las tensiones por la tenencia de la tierra; de cara a tales problemáticas, el sector oficial empezó a manifestar su preocupación por reconstruir el tejido social de un país en conflicto. Tan solo observando el Decreto 2388 de 1948 (emitido el mismo año de "El Bogotazo"), se puede percibir el interés estatal por reeducar a los ciudadanos desde el discurso moralizante de las historias patrias:

El conocimiento de la historia patria, el culto a los próceres y la verificación por los símbolos de la nacionalidad son elementos inapreciables de fuerza social, de cohesión nacional y de dignidad ciudadana; Que la educación debe tener una función eminentemente social, y todas las materias de los pénsumes y programas escolares deben estar orientadas a formar en las nuevas generaciones hábitos democráticos, de decoro personal y de orgullo nacional; Que los graves acontecimientos que en los últimos tiempos han agitado a la República han puesto de manifiesto, una vez más y con carácteres de grande apremio, que el estudio concienzudo de la historia patria y la práctica de las virtudes cívicas por todos los hijos de Colombia debe ser preocupación permanente y desvelada del Gobierno. ${ }^{34}$

33 Ignacio Alberto Henao Jaramillo, Billetes de Colombia, 21.

34 Ministerio de Educación Nacional de la República de Colombia, “Decreto 2388 de 1948”, http:// www.mineducacion.gov.co/1621/article-103421.html (31/03/2017). 
Esta consigna se tradujo al diseño del papel moneda. El panteón de próceres masculinos entró en diálogo con ilustraciones de lugares que el Banco consideró emblemáticos y que renovaron el contenido de la memoria colectiva de los ciudadanos. ${ }^{35}$ Sin embargo, tras muchos años en los que la mujer solo ocupó alegorías ornamentales en los billetes, su aparición y función pedagógica cambió en el marco de cierta "revolución iconográfica". Este cambio se dio en el billete de dos pesos, emitido hasta 1955, y en el cual se encontraba Camilo Torres. El ejemplar fue remplazado en 1972 por el rostro de Policarpa Salavarrieta (figura 12); se trata de la primera vez en que una mujer protagoniza la composición de la pieza, incluso quince años después de que la población femenina obtuviera el derecho al voto en 1957 y, con ello, mayor visibilidad como agente político. Con un diseño aprobado por la Gerencia y la Junta Directiva del Banco e impreso por la American Bank Note Company de Nueva York, el billete circuló por el territorio colombiano hasta 1977. Cabe anotar, además, que este billete solo fue impreso por el Banco de Nueva York hasta 1973; las siguientes ediciones se realizaron en la Imprenta Nacional, ${ }^{36}$ que ya contaba con la infraestructura suficiente para llevar a cabo las operaciones de emisión. La pieza, aunque ligada al concepto canónico de próceres independentistas, es también innovadora al incluir en el reverso la balsa muisca, representativa de una entidad aún regulada por el Banco de la República: El Museo del Oro de Bogotá.

Para esta época, instituciones como el Museo Nacional de Colombia y el Museo del 20 de Julio privilegiaron el periodo independentista como base de sus exposiciones permanentes. Entre las pinturas más representativas se encuentra un ejemplar de Epifanio Garay, que fue el motivo base para el diseño del nuevo billete de 2 pesos, y la pintura de José María Espinosa utilizada posteriormente en el billete de 10.000 pesos de 1995 . El rostro de Policarpa Salavarrieta no era desconocido para los colombianos. Recordada como una mártir fusilada en el periodo de La Reconquista, el 14 de noviembre de 1816,37 la memoria del personaje ya se conmemoraba en estatuas, retratos, estampillas y placas que evocaban sus acciones en la historia colombiana. "La Pola" — como es conocida popularmente por los colombianos- es una heroína diferente, pues no procede de las élites de su época.

35 Sobre el proceso de patrimonialización y su relación con el Banco de la República como gestor cultural del país, véase: Rosero García, Los billetes, una ventana al pasado, 13 y 14. Henao Jaramillo, Billetes de Colombia, 52.

37 Beatriz Castro Carvajal, "Policarpa Salavarrieta: heroína por excelencia de la República”, Revista Credencial Historia, . $^{\circ} 73$ (1996), http://www.banrepcultural.org/node/32482. 


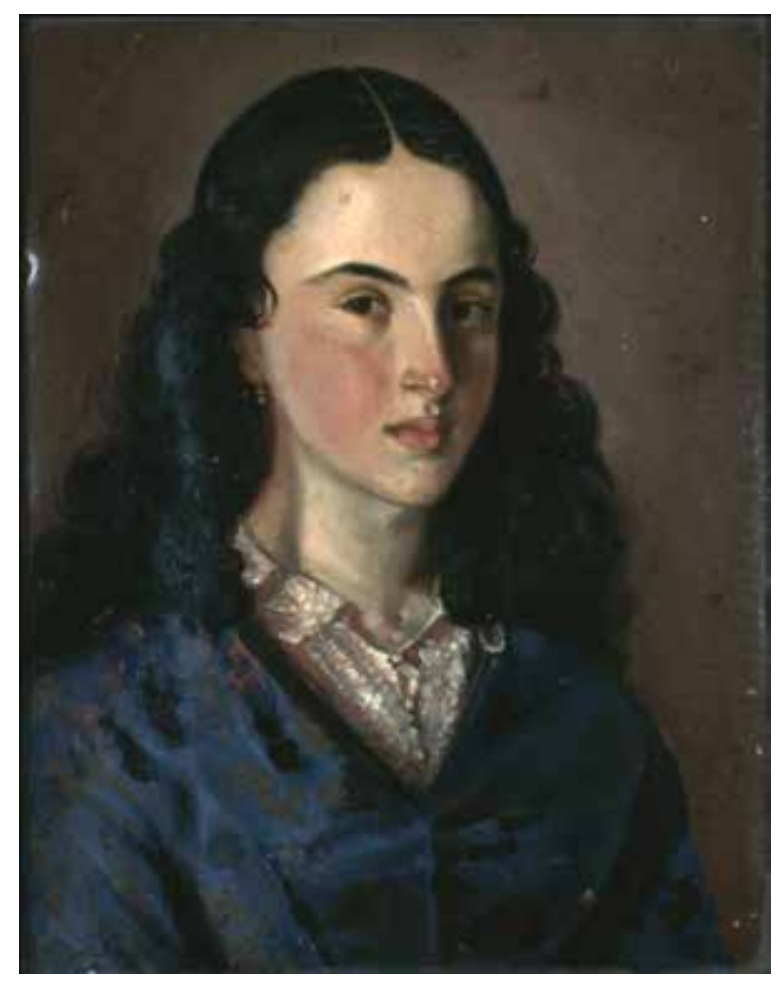

Figura 12. José María Espinosa, 1857, "Policarpa Salavarrieta" (óleo sobre tela, $34 \times 24,3 \mathrm{~cm}$, Museo Nacional de Colombia, Bogotá, número de registro: 2094).

Este elemento es central, por cuanto puede pensarse que la apropiación "popular" de la heroína, se dio de manera más temprana en prácticas como la estatuaria que en el reconocimiento institucional del papel moneda.

En 1894 se había expedido una ley nacional de conmemoración al legado de Policarpa, que incluía dentro de sus objetivos la instalación de una estatua en Guaduas (su ciudad natal), la cual solo se llevó a cabo hasta 1911. En segundo lugar, la ley buscaba renombrar la plazoleta de Las Aguas de Bogotá con el nombre de Plaza de Policarpa Salavarrieta; no obstante, solo hasta 1910 la estatua de la mujer, realizada por Dionisio Cortés, se instaló en aquel lugar que todavía lleva su nombre. Según Carolina Vanegas, en la inauguración hubo una escasa presencia de la élite política de la capital colombiana: "El secretario general de la Presidencia en representación del presidente de la República, el ministro de Guerra, el gobernador de Cundinamarca y un representante de la Comisión Nacional del Centenario, además de miembros del barrio 'Las Aguas' — destacándose la participación de 
señoras, señoritas y niñas de las escuelas aledañas_" 38 fueron quienes celebraron con lluvias de flores la instalación del monumento, ubicado en el mismo lugar hasta la actualidad.

El ejemplo anterior ilustra por qué la Pola está vinculada con un imaginario de heroína popular, a pesar de su tardía inclusión en el discurso visual del papel moneda. ${ }^{39}$ Regresando a esta aparición de la prócer en billetes durante la segunda mitad de siglo, cabe recordar que, hacia los años setenta, las mujeres de países denominados occidentales estaban llegando con mayor intensidad a otros espacios de sociabilidad tradicionalmente masculinos como la academia, la milicia, la vida política, el arte, entre otros. Eric Hobsbawm habla de la revolución cultural, refiriéndose a este periodo en el que los núcleos familiares se reestructuraron en términos generales debido al aumento en la tasa de divorcios y la planificación sexual; ${ }^{40}$ además, la participación de la mujer fuera de la esfera doméstica y la visibilidad de la cultura juvenil como actor político fueron algunas de las principales transformaciones sociales que aludían a la búsqueda de igualdad de sexos en el marco polarizado de la Guerra Fría.

Con relación a la instrumentalización icónica de Policarpa Salavarrieta y la evolución de los derechos de la mujer, la figura 13 sintetiza la manera en la que opera el discurso conmemorativo a los próceres independentistas desde otro tipo de fuentes cotidianas como las estampillas: en la imagen, los logros de la mujer en el siglo Xx son integrados gráficamente a la historia nacional, pues a pesar de distanciarse del pasado decimonónico, estos conmemoran el sacrificio de la mártir que contribuyó a una causa popular para la independencia nacional. Así, las mujeres que en los años cincuenta entraban legalmente a la esfera política, continuaban de cierto modo el

38 Carolina Vanegas, Disputas simbólicas en la celebración del Centenario de la Independencia de Colombia en Bogotá (1910): Los monumentos a Simón Bolivar y a Policarpa Salavarrieta (Bogotá: Ministerio de Cultura, 2011), 99.

39 Como parte del análisis iconográfico de Policarpa Salavarrieta y su relación con la memoria colectiva de los colombianos, es preciso tener en cuenta que su imagen fue empleada como publicidad comercial de las primeras cervezas que la empresa Bavaria comercializó en el país. En 1910, dicha empresa sacó al mercado la cerveza La Pola, lo que generó que una gran parte de la población asociara a la heroína con la bebida, y así, que a la cerveza se le asignara el nombre de Policarpa. Véase: Biblioteca Luis Ángel Arango, "Policarpa 200: Exposición conmemorativa del Bicentenario del nacimiento de Policarpa Salavarrieta”, http://www.banrepcultural.org/blaavirtual/todaslasartes/pola/icono1.htm (31/03/2017).

40 Eric Hobsbawm, Historia del siglo XX, 1914-1991 (Barcelona: Crítica, 2013), 322-330. 
legado del deber ser de la mujer colombiana. Por orden de Esmeralda Arboleda, ${ }^{41}$ senadora, diplomática y encargada del Ministerio de Comunicaciones, se elaboró esta estampilla con la imagen de Policarpa Salavarrieta de fondo, y en primer plano, una madre con su hijo de brazos depositando el voto en una urna. Este homenaje a la ciudadanía femenina en Colombia destacaba la plenitud de los derechos de la mujer, conforme al artículo 15 de la Constitución Nacional, el cual afirmaba que: "Las mujeres tendrán los mismos derechos políticos que los varones".42

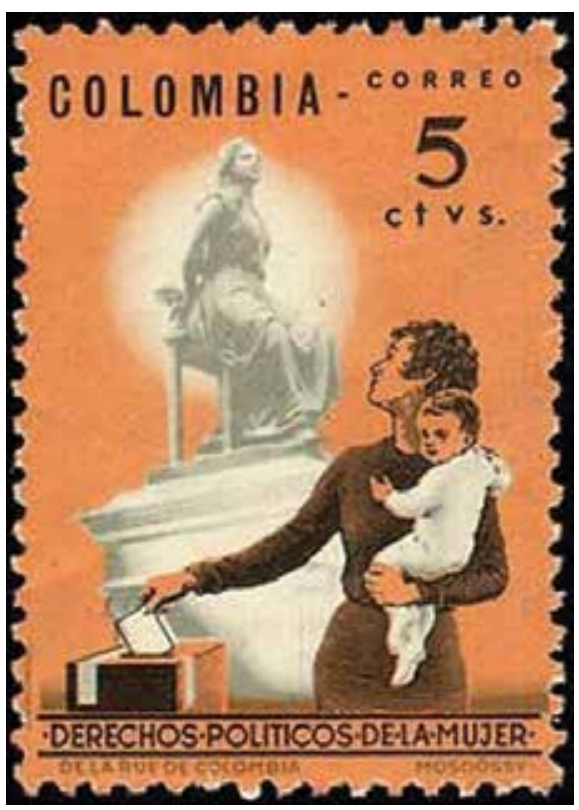

Figura 13. Correo aéreo, 1962, "Sello por 5 centavos: conmemorativo de los derechos políticos de la mujer" (sello postal, perforación de $12 \times 121 / 2$ ).

La iconografía de Policarpa Salavarrieta está inspirada en los testimonios de personajes que asistieron a su ejecución, pues nunca se le retrató en vida. Los artistas crearon una representación póstuma que encarna el cuerpo de una mujer joven, con piel clara y un semblante fuerte —alimentado por las descripciones de su rechazo al Gobierno español一, que la conmemoran desde sus últimos instantes en el patíbulo.

\footnotetext{
41 María Alexandra Méndez Valencia, “Arboleda, Esmeralda”, http://www.banrepcultural.org/blaavirtual/biografias/arboesme.htm (31/03/2017).

42 Flor Romero, "Esmeralda Arboleda, mujer paradigma", Pensamiento y Cultura, n. ${ }^{0} 1$ (1998): 173-175.
} 
Estos rasgos no difieren mucho de las piezas de papel moneda que han utilizado su imagen. En el billete de 2 pesos (1972), la prócer ocupa la centralidad del anverso, acompañada de datos como la denominación monetaria de la pieza, el serial, las fechas de emisión y las firmas tanto del gerente como del secretario del Banco. En el reverso, la balsa muisca complementa la pieza en calidad de objeto representativo, acompañada de la ya mencionada Marianne como logo oficial (figura 14).
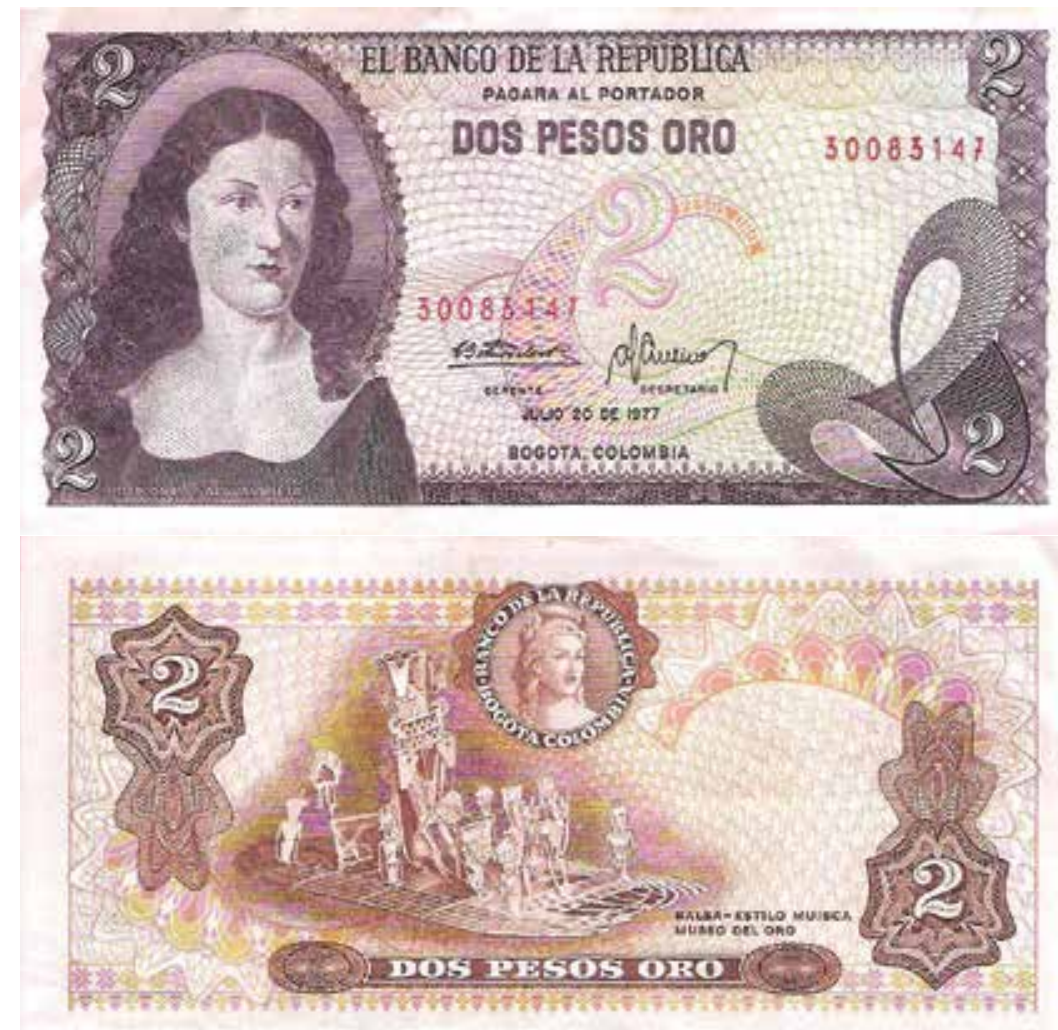

Figura 14. Banco de la República, 1972, “Billete de dos pesos oro” (impresión, Casa de la Moneda, Bogotá).

Por su parte, el billete de 10.000 pesos, de 1995 , muestra en un primer plano el rostro de Policarpa Salavarrieta, acompañada en su respaldo por una imagen panorámica de la plaza de Guaduas. El pueblo conserva una apariencia colonial en medio del entorno rural que se evidencia por la presencia de animales domésticos en ambos costados del billete. Tanto el retrato de la Pola como la imagen de Guaduas están basados en obras del siglo XIX; lo más seguro es que el primero sea una 
reproducción ligeramente modificada del óleo de José María Espinosa, mostrado anteriormente. El segundo es una acuarela atribuida al diplomático inglés Edward Walhouse Mark, quien residió en el país de 1843 a $1856 .{ }^{43}$ La circulación de este billete inició en 1996 y se mantiene vigente hasta la actualidad. Para esta ocasión, el rostro de Policarpa figuró a la luz de una conmemoración especial: los 200 años de su nacimiento (figura 15). Desde hacía varios años, la narrativa histórica del personaje venía consolidándose en la memoria colectiva del país. No obstante, el contexto en el que circula esta pieza es muy diferente al de los años setenta: Colombia estaba acomodándose a cambios estructurales importantes, entre estos la reformulación de la Constitución de 1991 y la apertura económica bajo el Gobierno de César Gaviria.

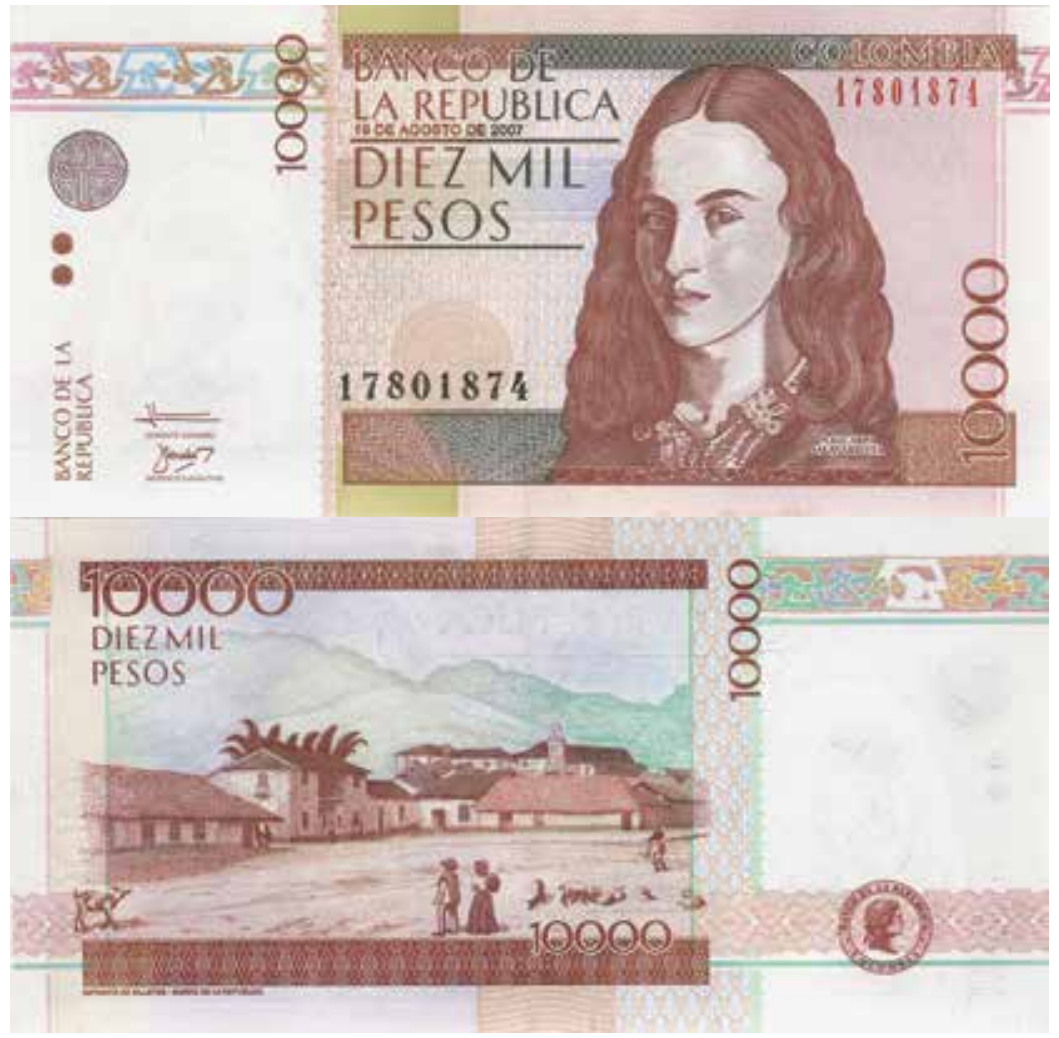

Figura 15. Banco de la República, 1995, "Billete de diez mil pesos" (grabado sobre papel, $7 \times 14$ cm, ilustración a partir de cuadros de José María Espinosa y Edward Walhouse Mark, Casa de la Moneda, Bogotá).

43 Banco de la República, "Policarpa: billete de diez mil", http://www.banrepcultural.org/visitastematicas/numismatica/policarpa-billete-diez-mil (31/03/2017). 
Cabe anotar que esta pieza remplazó al billete de misma denominación lanzado en 1992 y protagonizado por una mujer emberá, en lugar de la prócer independentista. Según el análisis propuesto para este capítulo, el cambio más llamativo de la presencia femenina en la numismática nacional es el que otorgaría visibilidad a poblaciones antes no resaltadas en la política colombiana. Las minorías étnicas, además de integrarse al ensamblaje iconográfico de la nación, adquirieron mayor representación política según se encuentra consagrado en el artículo 7 de la Constitución de 1991. ${ }^{44}$ En vista de este reconocimiento legítimo a grupos marginados por la historia y la ley como los indígenas, afrodescendientes, mujeres, entre otros, el discurso de nación debía replantearse en términos de pensar el territorio como plural culturalmente, de manera que el respaldo de la carta magna llegara a transformar el imaginario nacional, aún ligado a la glorificación exclusiva del periodo colonial tardío. En ese contexto, la familia de billetes que estaba en circulación desde 1980 contradecía de cierta manera lo que la Constitución estaba planteando. En esta última se dispone el reconocimiento del mestizaje y de la riqueza racial del país; sin embargo, los personajes de los billetes conservaban paradójicamente sus facciones europeas.

El billete de la indígena emberá (figura 16) aparece en esta renovada construcción de la nación y fue lanzado en el marco conmemorativo de los 500 años del descubrimiento de América. Su circulación resulta polémica, al representar una nueva ruptura con las convenciones estilísticas del papel moneda. A pesar de que los billetes de esta familia ya fueran impresos en el país, para el diseño del ejemplar se movilizó una red de producción internacional significativa. Fue la primera vez que el Banco de la República abrió un concurso dirigido a artistas colombianos para la propuesta del diseño. La ganadora fue Liliana Ponce de León. Posteriormente, la imprenta suiza De la Rue Giori preparó el material preliminar de su fabricación y, finalmente, la primera edición fue encargada a la fábrica de billetes del Banco de México, el cual ya tenía familiaridad con la representación de figuras ligadas al pasado indígena, como Cuauhtémoc o la simbología del imperio azteca. ${ }^{45}$

\footnotetext{
44 Procuraduría General de la Nación, “Constitución Política de 1991”, http://www.procuraduria.gov. co/guiamp/media/file/Macroproceso\%20Disciplinario/Constitucion_Politica_de_Colombia.htm (31/03/2017).

45 Henao Jaramillo, Billetes de Colombia, 125.
} 


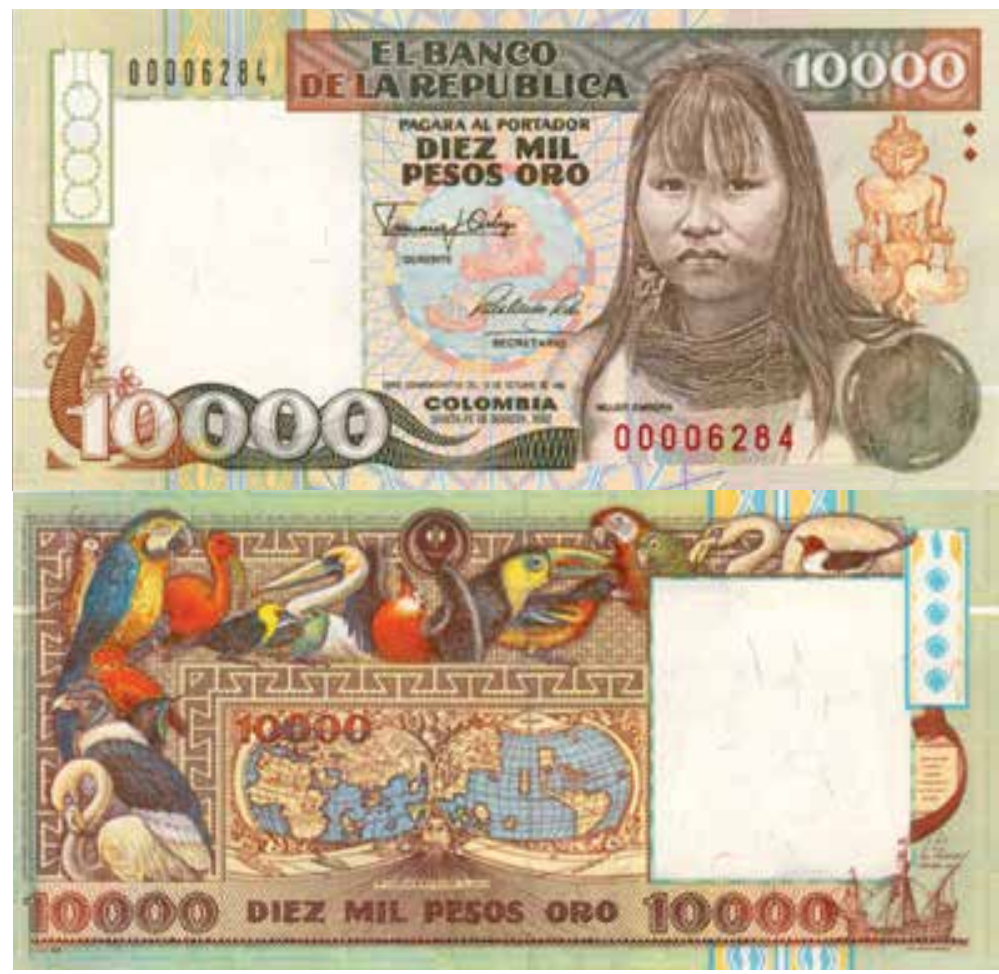

Figura 16. Banco de la República, 1992, "Billete de diez mil pesos: conmemorativo de la indígena emberá” (grabado sobre papel, Banco de la República, Bogotá).

La pieza está llena de detalles: en el costado derecho tiene la imagen protagónica de la indígena emberá. Detrás de la mujer, se observa una figura antropomorfa, la cual es un poporo quimbaya con un conjunto funerario de doce piezas pertenecientes a la colección del Museo del Oro. En el centro se encuentra un medallón basado en una xilografía italiana de 1493 y en el cual se advierten dos carabelas alusivas al descubrimiento. El anverso está ocupado por distintos tipos de aves: guacamayos, un tucán, flamencos, un cóndor, entre otras, cuyos nombres se localizan en el borde del rectángulo que hace las veces de fondo. Adicionalmente, observamos un mapamundi elaborado en 1507 por Martin Waldseemüller, que ocupa la zona central-inferior del billete; este mapa fue impreso en la abadía Saint Dié en Lorena, y fue la primera representación en la que se registra el nombre de América para el nuevo continente, en homenaje a Américo Vespucci. ${ }^{46}$ En la esquina

46 Ibid., 124. 
inferior derecha se observa, nuevamente, una pequeña carabela como símbolo del "encuentro entre dos mundos".

El billete despertó muchas opiniones entre la población. El Boletín de la Asociación Numismática Granadina rezaba en sus páginas el siguiente criterio: "su excelente composición artística encierra gran simbolismo y es el máximo exponente de lo que es Nuestra América." ${ }^{47}$ Esta referencia no solo al pasado indígena colombiano, sino al del continente sugiere pensar en cierto vínculo entre el indigenismo y una especie de comunidad imaginada que trasciende el marco de la nación moderna para evocar el pasado aborigen como algo también común. Además, los coleccionistas describen con un carácter paternalista las facciones de la indígena: "el rostro es bellísimo y, por su expresión, deja entrever la pureza de sus sentimientos y la grandeza de su alma: en sus facciones se muestra la candidez y la ingenuidad, características de nuestros naturales esparcidos por en todo el regio continente de América” ${ }^{48}$ En buena medida, la apreciación resulta contradictoria y violenta; si bien se quería visibilizar el pasado indígena, la misma temática de la conmemoración celebraba más la colonialidad que el mestizaje. Lo que para algunos era la exaltación de un glorioso pasado del continente, puede verse como el producto de una representación idealizada, la cual proyectaba a los nativos como seres pacíficos e indefensos, inmersos en un entorno "armónico” asociado con la América prehispánica.

Por otra parte, debe señalarse que desde los años ochenta, el Gobierno colombiano se encontraba en el proceso de abrir sus barreras comerciales a la economía mundial, a fin de promover la inversión extranjera para el país. ${ }^{49}$ Se observa, entonces, un interés multidimensional por la promoción de la biodiversidad, la pluralidad poblacional y la particularidad de los productos locales. Adicionalmente, la pieza traduce un mensaje revolucionario en la numismática colombiana por la inserción de una persona "del común" en un billete conmemorativo; los receptores podían articular los cambios políticos en el entramado cultural que suponía la renovación de la Constitución de 1991. Por otro lado, la mujer indígena pertenece a una población chocoana, es decir, procede de una de las regiones más pobres del país.

\footnotetext{
47 Antonio Deana Salmeron, "El billete de 10.000 pesos oro de Colombia que conmemora los cinco siglos del descubrimiento de América”. El Granadino: Boletín de la Asociación Numismática Granadina, n. ${ }^{\circ} 4$ (1992): 19.

Ibid., 20.

49 Para mayor información, revise: Antonio Hernández Gamarra, La moneda en Colombia (Bogotá: Banco de la República, 2001).
} 
La imagen tuvo un gran impacto en las minorías étnicas, quienes, en la misma fecha de lanzamiento del billete, marcharon pacíficamente en las calles para conmemorar los 500 años del encuentro entre Europa y América. No obstante, el desfile no solo cuenta con indígenas; campesinos, estudiantes, obreros y sindicatos marcharon por las principales ciudades colombianas con muestras artísticas, reclamando por algunas necesidades particulares de sus comunidades. ${ }^{50}$

Es plausible considerar que en la historia de los billetes colombianos solo esta pieza pueda ser denominada como un lugar de memoria. El discurso visual que le precedía - y el que le siguió - manejaba escasas referencias al pasado prehispánico de Colombia; las pocas veces que lo hacía era difundiendo objetos de la colección del Museo del Oro o aludiendo a los lugares patrimoniales en los que el Banco tenía algún tipo de intervención. Puede pensarse entonces que la iconografía del billete entró a formar parte de los referentes colectivos de la memoria, debido a la exoticidad de su diseño, mas no debido a la permanencia, frecuencia o conmemoración de este tipo de ilustraciones durante los años señalados. No obstante, el billete sí es un lugar de memoria, en cuanto su celebración imprimió un toque monumental a pesar de su uso cotidiano y masivo; fue un dispositivo con el que diversos grupos se sintieron lo suficientemente identificados, al punto de considerarlo coherente en su propósito original de representar alegóricamente el encuentro de América con Europa.

La logística de producción del billete recalca el interés estatal por su reconocimiento nacional e internacional. Al resaltar el pasado prehispánico y no el decimonónico — al menos en uno de los ejemplares de la familia de billetes — , se evidencia la intencionalidad por renovar el inventario de imágenes nacionales. El indígena como símbolo de la identidad colombiana ya había sido instrumentalizado en los albores de la república como representante de la autenticidad prehispánica y de la lucha originaria contra la dominación española. La figura de la indígena emberá, distanciada de este propósito alegórico, surgió en un momento cuando la inclusión política y el desarrollo de la economía en Colombia demandaban la participación de todos los ciudadanos. No obstante, tras su desaparición, no ha vuelto a existir otro tipo de iniciativa incluyente de las diferentes etnias que conforman la nación.

50 Redacción Nacional, “En paz se conmemoró el quinto centenario”, El Tiempo, 13 de octubre, 1992, http://www.eltiempo.com/archivo/documento/MAM-222154; Nullvalue, "Prográmese todo el día por cuenta de Colón”, El Tiempo, 12 de octubre, 1992, http: //www.eltiempo.com/archivo/ documento/MAM-221575; Juan José Saavedra, “La Conquista al revés”, El Tiempo, 4 de mayo, 1992, http://www.eltiempo.com/archivo/documento/MAM-114583. 
De ahí que sea útil revisar los billetes dentro del conjunto de representaciones visuales que reproducen imágenes sobre lo "nacional", desde una perspectiva comparativa e iconográfica. Considerar los elementos no manifiestos en su diseño es también una ruta para descubrir el potencial de estos dispositivos como fuente para estudiar cómo se articula la relación entre las ideas de poder vigentes de una época con las estrategias que movilizan los sectores oficiales para imponer imágenes específicas en los sistemas de representación visual de la sociedad. Al pensar los billetes como parte del conjunto de representaciones artísticas, se les puede ubicar como piezas del engranaje ideológico de lo que una nación idealiza ser y aspira reflejar que es.

Lo político que se torna la relación entre los contextos de producción y circulación con los códigos especiales de concebir la historia, el patrimonio y lo "típico" de un país hace que, por ejemplo, el lugar de las representaciones femeninas sea un espacio de reflexión sobre la armonía y la disputa en el arte que se piensa como “oficial” de la nación. Analizar las trasformaciones iconográficas con las que se plasmaron las imágenes de las mujeres en los billetes, abre el camino de la problematización del arte como un entramado de relaciones que legitiman imaginarios e idealizaciones mediante la interacción de dispositivos (historiografía, pintura, estatuaria, filatelia, numismática, entre otros) que, como hemos visto, silencian e iluminan rostros, paisajes y emblemas a favor de la construcción de relatos gloriosos y "valiosos" de un país, condensados en este caso en una composición visual de uso diario para todos: los billetes.

\section{Conclusión}

La manera en la que se han representado las figuras femeninas dentro del espacio visual numismático ha cambiado según las condiciones de producción y paradigmas estéticos aceptados en el país; estos últimos han estado mediados considerablemente por el intercambio cultural entre una élite que decide el diseño de los tirajes y las entidades financieras extranjeras que conquistaron el mercado de la impresión de billetes desde mediados del siglo XIX hasta el siglo XX avanzado. La constancia de este intercambio designó, a su vez, estabilidad a la figura de la mujer alegórica como protagonista del papel moneda; un protagonismo que se debate entre lo ornamental y la pretensión consciente de incorporar este tipo de representaciones como referente de los códigos culturales con los cuales configurar visualmente los significados de la República. 
Sin embargo, los valores republicanos de un Estado social de derecho con los que fueron imaginadas la mayoría de potencias europeas - en el marco de la revolución política de los nacionalismos y la Revolución Industrial- influyeron notablemente en las consignas debatidas por las élites colombianas para el proyecto de construcción nacional y, con ello, en la construcción de la memoria histórica del país, al dictar una serie de lineamientos sobre la edificación simbólica del héroe patrio, a partir de su pasado independentista y la respectiva visibilidad política, militar e intelectual masculina que caracterizaba la mayoría de representaciones decimonónicas, incluyendo las del papel moneda.

En este sentido, el valor simbólico de los billetes está determinado por el estilo y por los contenidos visuales transmitidos verticalmente desde un sector oficial, con la pretensión de que sus receptores interioricen aquel mensaje como un espacio cotidiano de comunión. Antes de la creación del Banco de la República, la pluralidad y la descentralización de políticas fiscales permitieron que la visibilidad exclusivamente alegórica de la mujer se enmarcara en un imaginario republicano regido por las aspiraciones como la de nación, fijadas a su vez por las potencias industriales europeas. Sin embargo, con la posterior institucionalización de las emisiones monetarias, se privilegió la representación de un pasado lleno de hombres ilustres que enseñan "lo políticamente correcto" de sus biografías y, consecuentemente, el lugar de la institución como gestor cultural de la identidad y memoria nacional.

En cuanto la oficialidad del discurso visual del papel moneda es parte de ese conjunto cultural de representaciones nacionales, esta no puede darse la oportunidad de estar desactualizada frente a las transformaciones y tensiones ideológicas en el poder político vigente. De ahí que la incorporación de figuras femeninas como protagonistas, puestas en circulación la mayoría de veces bajo la justificación de conmemoraciones históricas, aluda a la precaria intención de hacer de tal discurso un espacio de renovación y reimaginación de la comunidad nacional imaginada. Policarpa Salavarrieta y la indígena emberá, aunque históricamente distantes, nos indican cómo su aparición está atada a la relación de Colombia con su pasado hispánico.

Hay que mencionar que el paradigma de la nación colombiana pluriétnica y biodiversa nunca se había visto tan materializado en la iconografía del dinero como en la actualidad. La inclusión reciente de un "pasado actualizado", que privilegia un inventario de imágenes del siglo Xx en los billetes lanzados durante el 2016, alude a la renovación estilística, ideológica y cultural de uno de los dispositivos culturales que más ha alimentado el vínculo de los ciudadanos con su nacionalidad; tal vez el 
único dispositivo que al ser emitido por un sector oficial puede posicionar rápidamente las nociones de lo nacional. Queda abierto el debate sobre la intencionalidad de la nueva familia de billetes; de la permanencia de José Asunción Silva en el de 5000, así como el billete de 50.000, que conserva la línea de la literatura al remplazar el rostro de Jorge Isaacs por el de Gabriel García Márquez; igualmente, del remplazo de un ingeniero y astrónomo como Julio Garavito por el de un político liberal como Alfonso López Michelsen; la continuidad de la línea femenina para la denominación de 10.000 pesos, cambiando a Policarpa Salavarrieta por la antropóloga Virginia Gutiérrez, y el desplazamiento de un prócer como Francisco de Paula Santander por el rostro de una de las artistas más censuradas en su época: Débora Arango. Además, resulta pertinente indagar por los criterios que otorgaron la más alta denominación (100.000 pesos) al político liberal Carlos Lleras Restrepo, y el mensaje de promoción de la biodiversidad, sustentada en todos los reversos con paisajes declarados patrimonio natural.

\section{Bibliografía}

\section{Fuentes primarias}

\section{Imágenes}

Casa de la Moneda, Bogotá.

Biblioteca Luis Ángel Arango, Bogotá.

“Catálogo de billetes de Chile”, en Billetes del mundo, http://www.billetesdelmundo. org/catalogo/Chile/19148301.html.

Museo Nacional de Colombia, Bogotá.

\section{Impresas}

Henao Jaramillo, Ignacio Alberto. Billetes de Colombia: época del Banco de la República 1923-2006. Bogotá: Grupo op Gráficas, 2006.

Ministerio de Educación Nacional, República de Colombia. Decreto 2388 de 1948, escrito por Mariano Ospina Pérez y Fabio Lozano. Diario Oficial 26779. Bogotá, 15 de julio de 1948, http://www.mineducacion.gov.co/1621/ article-103421.html.

Rosenman, Richard. Billetes de Venezuela. Caracas: Corimon, 1980. 


\section{Publicaciones periódicas}

El Tiempo. Bogotá, 1992.

\section{Fuentes secundarias}

Anderson, Benedict. Comunidades imaginadas: reflexiones sobre el origen y difusión del nacionalismo. México: Fondo de Cultura Económica, 1993.

Barriga, Fernando. "Orígenes del simbolismo en las figuras consignadas en nuestras primeras monedas". Boletín Numismático, n. ${ }^{\circ} 71$ (2001): 4-11.

Cabrera, Eugenio Barney. "Reseña del arte en Colombia durante el siglo XIX”. Anuario Colombiano de Historia Socialy de la Cultura 2, n. 3 (1965): 71-118.

Castro Carvajal, Beatriz. "Policarpa Salavarrieta: heroína por excelencia de la República”. Revista Credencial Historia, n. 73 (1996). http://www.banrepcultural.org/node/32482.

Colmenares, Germán. Las convenciones sobre la cultura: ensayos sobre la historiografia hispanoamericana del siglo XIX. Bogotá: Tercer Mundo, 1997.

Deana Salmerón, Antonio. "El billete de 10.000 pesos oro de Colombia que conmemora los cinco siglos del descubrimiento de América”. El Granadino. Boletín de la Asociación Numísmática Granadina, n.o 4 (1992): 18-26.

Drake, Paul. "Kemmerer y la creación de bancos central en los países andinos". En Banco de la República: 90 años de la banca central en el país, editado por Gloria Alonso Másmela, 17-31. Bogotá: Banco de la República, 2013.

Earle, Rebecca. "Sobre héroes y tumbas: National Symbols in Nineteenth-Century Spanish America”. Hispanic American Historical Review 85, n. 3 (2005): 375-416.

Elysee.fr., "Marianne”, http://www.elysee.fr/la-presidence/marianne/ (31/03/2017).

García, Irma Beatriz. "El cuerno de la abundancia: mito e identidad en el discurso sobre el territorio y la nación mexicanos". HISTORIE (S) de l'Amérique latine, 1 (2005): 1-28.

Halbwachs, Maurice. Los marcos sociales de la memoria. Barcelona: Anthropos, 2004. Henao Jaramillo, Ignacio Alberto. "Cien años de los mil días: billetes en tiempo de guerra”. Revista Credencial Historia, n. ${ }^{\circ} 128$ (2000): 7-12.

Hernández, Pedro. Catálogo de billetes de Colombia: siglo ante pasado 1813-1915, Banco de la Repúblia 1923-2000. Cali: El Búho, 2000.

Hobsbawm, Eric. Historia del siglo XX, 1914-1991. Barcelona: Crítica, 2013.

König, Hans-Joachim. “La función de las imágenes en el proceso de construcción de las naciones latinoamericanas". En La nación expuesta: cultura visual y procesos 
de formación de la nación en América Latina, editado por Sven Schuster, 1-28. Bogotá: Universidad del Rosario, 2014.

Linares Zárate, Alejandro, "La justicia: su simbología y valores que concurren en su aplicación”, http://www.uaemex.mx/identidad/docs/JUSTICIA.pdf (31/03/2017).

Martínez, Frédéric. "En los orígenes del nacionalismo colombiano: europeísmo e ideología nacional en Samper Núñez y Holguín”. Boletín Culturaly Bibliográfico 39, n. 32 (1995): 27-59.

Melo, Jorge Orlando, “Catálogo de la casa de la moneda”. http://www.banrepcultural. org/sites/default/files/lablaa/num/pdf/numismatic.pdf(31/03/2017).

Mozejko de Costa, Teresa. "La construcción de los héroes nacionales". Revista Estudios, n. ${ }^{\circ} 6(1995): 79-82$.

Nora, Pierre. Présent, nation, mémoire. Paris: Gallimard , 2011.

Ory, Pascal. L'histoire culturelle. Paris: Presses Universitaires de France, 2011.

Rosero García, Pamela. "Los billetes, una ventana al pasado: identidad y memoria, 1959-1979”. Tesis de maestría en Historia, Universidad Nacional de Colombia, Bogotá, 2009.

Vanegas, Carolina. Disputas simbólicas en la celebración del Centenario de la Independencia de Colombia en Bogotá (1910): los monumentos a Simón Bolivar y a Policarpa Salavarrieta. Bogotá: Ministerio de Cultura, 2011. 


\section{Propaganda política e imagen}




\title{
Difundir el Estado: la propaganda del Estado Novo en Brasil durante la Segunda Guerra Mundial y su contradicción posterior
}

\author{
Paulo Córdoba
}

\begin{abstract}
Estepais [Estados Unidos] faz oposição formal ao regime das compensaçôes, quer a liberdade comercial, e convida o Brasil a acompanhá-lo. Se o fizermos, teremos todas as facilidades; se recusarmos, nada obteremos. $O$ assunto é sério, porque acompanhar os Estados Unidos em sua politica comercial exterior éfechar as portas ao comércio de um grande número de paises de moeda bloqueada, que nos compram mercadorias que os Estados Unidos não adquirem. Getúlio Vargas, noviembre de 1934. ${ }^{1}$
\end{abstract}

\section{Introducción: El escenario y la estrategia}

A mediados de la década de los treinta del siglo pasado, el presidente brasileño Getúlio Vargas tuvo que asumir una posición en términos de relaciones internacionales: Brasil debía escoger uno de los dos bandos que protagonizaban la Segunda Guerra Mundial (Eje o Aliados). Sin embargo, el mandatario parecía prever el camino que debía seguirse en aquella transición: una crisis económica precedente (Crisis de 1929) y los mismos avatares de la guerra definirían los criterios de su elección. Según explica Maria Celina D’Araújo, Vargas empezó a maquinar desde 1934 una estrategia política que cobró forma en 1942 con el apoyo de Brasil a los

1 Citado en Maria Celina D’Araújo, "Entre a Europa e os Estados Unidos: diálogos de Vargas com seu diário", Luso-Brazilian Review 34, n. 1 (1997): 23. 
Aliados. Las palabras rescatadas de su diario personal dan cuenta de las principales preocupaciones que lo llevaron a tomar su postura: el comercio y las relaciones diplomáticas — principalmente con Estados Unidos_ garantizaban la estabilidad económica, prioritaria para un Gobierno sin implicaciones directas en el conflicto.

Ahora bien, abandonar la postura "neutra" que el país había mantenido durante gran parte de la guerra permitió a Vargas alcanzar algo más que garantías económicas para Brasil, ya que, con ello, pudo legitimar un polémico régimen instaurado por su administración en 1937. Por lo tanto, había una doble intención en las decisiones políticas tomadas recientemente, aspecto que Fernanda dos Santos Bonet invita a pensar ${ }^{2}$ cuando sostiene que la entrada de Brasil a la conflagración se debió a que el régimen varguista necesitaba sustentar el discurso de unidad nacional en el interior del territorio, con el fin de desviar la atención del pueblo en torno a los problemas internos del país y, así, justificar el accionar del aparato estatal militarista en todos los sectores sociales que pretendía abarcar.

Si bien el Gobierno de Vargas comprende un periodo entre 1930 y 1945 , solo desde 1937 se implementó el régimen político conocido como Estado Novo, ${ }^{3}$ diseñado como una plataforma desde la cual el mandatario aseguró su permanencia en el poder. En consecuencia, debe agregarse que aquella estructura administrativa no solo sustentó el accionar más polémico de Vargas, sino el de varios funcionarios y representantes políticos, los cuales contribuyeron a maquinar gran parte de las

2 Fernanda dos Santos Bonet, "O discurso oficial brasileiro durante a $2^{\circ}$ Guerra Mundial: O Brasil se une para a guerra”, en Anais do Encontro Estadual de História (Porto Alegre: Associação Nacional de História-Seção Rio Grande do Sul [ANPUH-RS], 2008), s. p.

3 Debe aclararse que la idea de Estado Novo no es una propuesta original de Vargas. Este se inspiró en algunos sucesos que se presentaron en otros lugares del mundo, sobre todo en el Portugal del dictador António de Oliveira Salazar. De hecho, el nombre Estado Novo en sí mismo proviene del proyecto político salazarista, que pretendía aminorar la crisis económica que surgió en 1929, y sus características respondieron a una novedosa estructura estatal, cuyos ideales eran por definición antiliberales, antidemocráticos y anticomunistas. A pesar de sus similitudes con el fascismo italiano, por su ideología conservadora, represiva y corporativista, el Estado Novo posee características muy particulares que lo hacen único en el contexto en el que surgió. Para ampliar información sobre el tema, véase: Alberto Pena, "El Estado Novo de Oliveira Salazar y la Guerra Civil Española: información, prensa y propaganda (1936-1939)" (tesis de doctorado en Ciencias de la Información, Universidad Complutense de Madrid, 1997), 60-61 y 703; para la comparación con el fascismo, véase: António Costa Pinto, $O$ salazarismo e o fascismo europeu: problemas de interpretação nas Ciências Sociais (Lisboa: Estampa, 1992) y Fernando Rosas, "Cinco pontos em torno do estudo comparado do fascismo", Revista Vértice 2, n. $^{\circ} 13$ (1989): 21-29. 
estrategias y decisiones del gobernante; esto demuestra que aquel nuevo esquema no era autónomo por antonomasia.

Entre las formas de actuación política más empleadas por el estadonovismo para justificar el mandato de su líder, se destaca la circulación de imágenes y discursos estatales en la prensa local brasileña, cuyo objetivo era presentar las decisiones gubernamentales como las más acertadas, según fuera el caso. En este punto es donde el presente texto encuentra lugar, ya que su propósito es formular algunas reflexiones sobre la entrada de Brasil a la Segunda Guerra Mundial, al igual que sobre las estrategias visuales que sustentaron esa decisión, implementada por Getúlio Vargas a finales de los años treinta e inicios de los cuarenta. Así, es posible plantear un interrogante sobre los medios empleados por el mandatario y los representantes del Estado Novo para naturalizar el régimen: ¿cómo funcionó la propaganda política de Brasil para legitimar el ingreso a la guerra y el apoyo al frente Aliado liderado por Estados Unidos?

En efecto, responder a esta pregunta implica partir del hecho de que, a través de la manipulación de imágenes y del discurso político difundido en los medios de comunicación durante la época del Estado Novo, Getúlio Vargas intentó legitimar un Gobierno construido con base en los desórdenes internos de Brasil, es decir, en pugnas como las que enfrentaron a los miembros de la oligarquía brasileña entre sí y posibilitaron el fenómeno del tenentismo, ${ }^{4}$ lo que marcó, a su vez, el inicio del nuevo sistema impuesto. Sin duda alguna, la circulación de imágenes fue una estrategia gubernamental que sirvió no solo para respaldar la entrada de Brasil al conflictivo escenario internacional, sino también para ocultar sus problemas interiores. Mientras los medios brasileños se centraban en divulgar imágenes de la "amistad" entre su país y Estados Unidos, las contradicciones del régimen permanecían ocultas tras "buenas noticias".

En términos formales, para sustentar dicha tesis, este capítulo se basa en fuentes visuales que dan cuenta de cómo el Estado Novo intentó crear una ilusión de armonía brasileña interna y externa durante la Segunda Guerra Mundial; en este sentido, las relaciones favorables entre Brasil y Estados Unidos resultaron ser un "falso indicador" de bienestar en el país. Para ello, se analiza la función de la

4 El tenentismo abogaba por un Estado centralista que se enfocara en proteger el patrimonio nacional brasileño de la explotación extranjera, a partir del precepto de organizar la acción nacional con miras a una revolución que protegiese lo local ante la amenaza internacional. Véase: John D. Wirth, “Tenentismo in the Brazilian Revolution of 1930", Hispanic American Historical Review 44, n. 2 (1964): 165 . 
prensa local como un importante contribuyente del ambicioso proyecto ideado por Getúlio Vargas y se contrasta su contenido con algunos documentos encontrados en los archivos de Anísio Teixeira y en el archivo del mismo mandatario, los cuales reposan actualmente en la Fundación Getúlio Vargas, situada en Río de Janeiro.

\section{La emergencia del Estado Novo}

Como se mencionó, la economía fue una de las preocupaciones clave durante el Gobierno de Vargas. A juicio de Boris Fausto, la Crisis de 1929 tuvo dos consecuencias importantes en el Brasil de principios de los años treinta: 1) la falta de un mercado para la exportación de productos agrícolas, lo cual representó una seria problemática para los campesinos, y 2) el desempleo urbano, evidente en el incremento de la pobreza en las grandes ciudades. ${ }^{5}$ Una de las medidas adoptadas por el Gobierno para intentar solventar tales inconvenientes fue la llamada politica trabajista ${ }^{6}$ que buscaba incorporar cualquier posible sindicato a la tutela del Gobierno, con el fin de conseguir el apoyo popular. ${ }^{7}$ A pesar de haber sido bastante voluble — atravesó varias fases a lo largo del periodo 1930-1945-, esta se presentó como una novedosa alternativa en relación con todo aquello que había sido implementado en materia económica. No obstante, entre los objetivos principales de la perspectiva trabajista no solo aparecía la solución de las dificultades laborales de los brasileños; igualmente, se contemplaba la represión de cualquier intento organizativo de la clase trabajadora urbana que intentase quedar por fuera del control estatal.

Como se puede inferir, desde la llegada de Vargas al poder, como una alternativa política transitoria al régimen oligárquico que emergió después de 1889 (periodo conocido como Primeira República), este intentó arduamente contrarrestar cualquier amenaza subversiva que pudiese surgir, en una época en la que la fuerte sectorización regional imponía las normas de funcionamiento administrativo. Esto

5 Boris Fausto, História concisa do Brasil (São Paulo: Universidade de São Paulo, 2008), 185.

6 Este nombre es una traducción libre del autor; en la literatura en portugués se encuentra como política trabalhista. Véase: Fausto, História concisa, 187; Rafael Vicente de Moraes, "Estado, burguesia e legislação trabalhista brasileira no limiar dos anos 30: notas para uma discussão", Revista de Estudios Sociales, n. 33 (2009): 129-145; Joel Wolfe, "The Faustian Bargain Not Made: Getúlio Vargas and Brazil's Industrial Workers, 1930-1945”, Luso-Brazilian Review 31, n. ${ }^{\circ}$ (1994): 77-95. En adelante, las citas textuales de documentos originalmente redactados en portugués son traducciones libres del autor.

$7 \quad$ Fausto, História concisa, 187. 
puede evidenciarse en el enfrentamiento entre el Estado central, las regiones y el tenentismo, duelo que presionó, en 1934, la promulgación de una Constitución Federal similar a la de la República de Weimar en Alemania. Precisamente, dicho acto se hizo oficial por la Asamblea Nacional Constituyente, el mismo organismo que eligió aquel año por voto indirecto a Getúlio Vargas como presidente oficial de la República, lo que le permitió legitimar su administración transitoria de cuatro años previos.

Sin embargo, dado que los debates internos no cesaban y se agudizaban con el paso del tiempo, lo que provocó una especie de paranoia en el Gobierno de Vargas respecto a una posible guerra civil en Brasil — presumiblemente impulsada por ideologías de izquierda, entre las que destaca (como sucedió en otros países del mundo) el comunismo-, para 1937 los planes de mantener vigente un Estado federal en el territorio se derrumbaron y abrieron paso a un nuevo proyecto impulsado por el varguismo, el Estado Novo: un sistema político promotor de la centralización estatal y el ingreso del país a la modernidad. Mediante la eliminación de las oligarquías y el fortalecimiento de un aparato burocrático racionalista heredado de las ideas ilustradas, ${ }^{8}$ vigentes en la mentalidad política de los más altos sectores sociales de la época, Brasil parecía encaminarse hacia el ideal de progreso, al que rendía culto desde el siglo XIX y que, incluso, aparece explícito en la frase de Auguste Comte "Ordem e progresso", también consignado en la bandera del país sudamericano.

Durante el naciente régimen de 1937, Vargas intentó prolongar su accionar, favoreciendo ficticiamente a los trabajadores. Así mismo, aprovechó su plataforma política para construirse una imagen de "protector de los trabajadores", valiéndose de la opinión pública, esto es, censurando a sus detractores y elaborando su propia versión tanto de la historia como de los fundamentos del Estado Novo. Para esa función, en 1939 se fundó el órgano regulador de la información que circulaba en el territorio: el Departamento de Imprenta y Propaganda (DIP), cuyo objetivo principal era precisamente el de evocar una imagen positiva del presidente en Brasil y fuera de este, además de aplacar todo aquello que impidiese conseguir tal fin. ${ }^{9}$

Principalmente, el DIP se creó como respuesta a la oposición interna que sufría el régimen de Vargas desde que se había formalizado. A este respecto, puede citarse como ejemplo un documento redactado y firmado por algunos intelectuales

8 Ibid., 208.

9 Mónica Almeida, "Imagens do autoritarismo em tempos de democracia: Estrategias de propaganda na campanha presidencial de Vargas em 1950”, Revista de Estudos Históricos, n. 34 (2004): 72. 
brasileños en el exilio. El escrito tenía por objeto llegar a manos del presidente norteamericano Franklin D. Roosevelt (de hecho, lleva por título O Brasil ao presidente Roosevelt); en este se encuentran plasmados los nombres de Armando Salles de Oliveira, Octavio Mangabeira, Mario Brant, Luiz Piza Sobrinho, Julio de Mesquita Filho, Paulo Nogueira y Paulo Duarte, todos detractores del varguismo. Allí describen la situación política de Brasil como la de un país donde quedó

[...] instituido el más totalitario de los regímenes, pues allí no hay siquiera ninguno de los simulacros que otras dictaduras admiten, como sea, por ejemplo, el del funcionamiento de las cámaras. No hay vislumbre de libertad de prensa o cualquier otra libertad pública, ni se habla tampoco de ningún modo de pronunciamiento por el voto. Sobre la responsabilidad oficial, es hecha propaganda sistemática de los gobiernos de fuerza, procurando instilar en los ánimos, además de inútilmente, la doctrina de falencia de las instituciones libres. ${ }^{10}$

Se desconoce si el documento realmente llegó a manos de Roosevelt, probablemente no; lo que resulta destacable del escrito es que constituye una muestra de las iniciativas tomadas por algunos de los opositores del régimen para denunciar las anomalías que se presentaban en Brasil. El rechazo de algunos intelectuales a la represión de la libertad de prensa por cuenta de la misma propaganda oficial del Estado es un aspecto para considerar en este capítulo, debido a que enseguida se presentan los mecanismos que usó Vargas para manipular la prensa, con lo que pretendía legitimar su decisión de entrar a la guerra a favor de Estados Unidos y, por extensión, los Aliados.

\section{La guerra y la propaganda}

No hay una huella que denote un cambio radical en la administración de Vargas como la entrada de Brasil a la Segunda Guerra Mundial, en 1942. Hasta ese momento, el Gobierno del presidente había desempeñado un papel de doble agente en las relaciones internacionales, ya que mantenía negociaciones con quien le ofreciese las mejores condiciones económicas, sin importar la división geopolítica en que se encontrara inmerso el mundo del periodo de entreguerras. De esta forma,

10 “'O Brasil ao presidente Roosevelt'. Mensagem denunciando a ditadura instaurada em 1937. Paris, 7 de janeiro, 1939”, Fundação Getúlio Vargas (FGV), Arquivo Anísio Teixeira, série pi (produção inteletual), classificação: AT pi Oliveira, A. de S. 1939.01.07, Rio de Janeiro, Brasil. 
las relaciones exteriores brasileñas, hasta 1942, se caracterizaron por enmarcarse en controversiales negociaciones que lo vinculaban simultáneamente con Estados Unidos y con Alemania.

Por supuesto, se puede aseverar que la balanza de intereses brasileños favorecía más al vecino del norte que al país del Führer. Como afirma Fernanda dos Santos Bonet, enemistarse con los norteamericanos implicaba reñir por extensión con todos los demás países que configuraban el frente Aliado, incluida Inglaterra, agente que controlaba las rutas marítimas del Atlántico, las cuales conectaban Europa con América. Por lo tanto, una posible situación de hostilidad entre Brasil y los Aliados hubiera resultado desfavorable para Vargas, por cuanto hubiese tenido que renunciar al comercio con el viejo continente. ${ }^{11}$

Aparte de esto, la presión de los Estados Unidos para vincular al Estado brasileño a las filas de los Aliados crecía constantemente en 1942, en particular después del ataque japonés a la base de Pearl Harbor. Los norteamericanos, como bien informó el diario Jornal do Brasil, eran conscientes de que "Brasil contribuyó con vastas reservas de materiales para ganar la última guerra y como aliado de las potencias democráticas, tanto su comercio como su desarrollo económico [podían] beneficiar en gran escala esa asociación". ${ }^{12}$ No obstante, dicha alianza no sucedería hasta el hundimiento de algunas embarcaciones brasileñas en el Atlántico a manos de submarinos alemanes. El periódico local $O$ Radical reaccionó a los hechos de la siguiente manera: “[...] protesta por el hundimiento de nuestros navíos mercantes, traicioneramente, por los 'ejistas' [...] Durante esos 'meetings' son delirantemente aclamados los nombres del Presidente Vargas, Roosevelt y otras figuras del momento nacional e internacional". 13

Con base en lo que postula Bonet, la entrada de Brasil a la guerra resultó ser la excusa perfecta para sustentar el discurso varguista de unidad nacional, ocultar

11 Bonet, “O discurso oficial brasileiro", s. p.

12 "Considerada como importante, a colaboração do Brasil na defesa da Democracia", Jornal do Brasil, 11 de marzo de 1942,7.

13 "Vibra o Rio Grande do Sul contra os atentados ao Brasil", O Radical, 3 de marzo de 1942, 3. Es importante aclarar que este medio de prensa fue uno de los periódicos brasileños que más sirvieron al Estado Novo para sustentar las decisiones de Getúlio Vargas y, por tal razón, sus declaraciones se enfocan ampliamente en exacerbar los ánimos de la población brasileña, con el fin de implementar una base de apoyo popular para las decisiones del Estado Novo, apoyo de gran importancia para el régimen. Véase: Tania Regina de Luca, "A grande imprensa na primeira metade do século xx", en Historia da imprensa no Brasil, ed. por Ana Luiza Martins y Tania Regina de Luca (São Paulo: Contexto, 2008), 170-171. 
las problemáticas internas del país y justificar el excedido accionar de los militares que atentaban contra la población civil, ${ }^{14}$ con el fin de encubrir, en últimas, aquel controversial aparato militarista que se enmarcaba perfectamente en aquel fenómeno descrito por Alain Rouquié como "poder por encima del poder, contra el cual no se puede gobernar". 15

Con la integración de Brasil al conflicto internacional, el Estado Novo no solo legitimó su accionar dentro de sus fronteras, sino que también rindió homenaje a su política de pretender ser un actor en condición permanente de potencialización; en otras palabras, como un actor empeñado arduamente en el crecimiento político, económico y militar, cuyo fin último radicaba en alcanzar un poder que le permitiese competir en el escenario internacional con otros Estados mucho más fuertes, en términos de esos tres aspectos. Cabe destacar que dicha tendencia tiene su génesis durante los primeros días del país como república independiente e, incluso, pervive hasta la actualidad. ${ }^{16}$

\section{Un sustento para la guerra}

Mediante un óptimo manejo de los medios de comunicación, como la prensa - fuente privilegiada para esta investigación - y una efectiva puesta en escena de ciertas imágenes divulgadas en algunos de los más importantes periódicos locales, el Estado Novo logró mantener su legitimidad hasta el final de la Segunda Guerra Mundial (1945). Algunos ejemplos de la autoimagen ingeniada por los exponentes del Estado Novo para sustentar el régimen en tiempos de guerra permitirán reconstruir lo sucedido en el Brasil de Vargas. Para ello, se seleccionaron algunas imágenes que pueden considerarse interesantes al analizar la función política de los elementos visuales inscritos en algunos periódicos del momento.

Uno de estos medios locales puede observarse con particular atención: el Correio da Manhãa, un diario que nació en Río de Janeiro, al que comúnmente se le recuerda en la actualidad por su supuesto "carácter combativo" contra la opresión, según afirma Bruno Brasil. Sin embargo, lo cierto es que el diario parece haber cedido ante las presiones del Estado Novo y terminó por contribuir a la construcción

14 Bonet, "O discurso oficial brasileiro", s. p.

15 Alain Rouquié, El Estado militar en América Latina (México: Siglo xxi, 1984), 310.

16 Dirceo Córdoba, "Brasil y su actual condición de potencia en la política mundial: entre juegos de percepciones y definiciones académicas (1994-2010)" (tesis de maestría en Estudios Políticos Internacionales, Universidad del Rosario, 2012), 7-8 y 126. 
positiva de la imagen de Getúlio Vargas. Cosa muy distinta ocurrió con O Radical y Gazeta de Notícias, los cuales no se caracterizaban por ser medios de prensa contestatarios ante el régimen de Vargas; por el contrario, formaron parte de los diarios que apoyaron fervorosamente las decisiones del Estado desde sus inicios.

En particular, resulta necesario acentuar que la entrada de Brasil al bando de los Aliados parecía inevitable, ya que desde 1941 se podía evidenciar la presencia militar norteamericana en el interior del territorio. De hecho, la censura evitaba constantemente que se hablara de lugares como Natal, la ciudad que sirvió de punto estratégico para la guerra en el Atlántico. Una carta anónima escrita el 28 de mayo de 1941, la cual debía enviarse desde Brasil hacia Nueva York, con destinatario a una persona de apellido Landon — probablemente un partidario de la oposición brasileña—, asílo ratifica: “[...] todas las referencias a Dakar, Islas de Cabo Verde, Natal, etc., han sido, o bien censuradas, o eliminadas por el Dip o de ese modo despreciadas, hasta perder su significado en el levantamiento de la opinión pública". ${ }^{17}$ Según los datos de archivo del documento, este fue interceptado por la censura y enviado por el político y militar brasileño Filinto Müller (jefe de la Policía Política) a Benjamin Vargas (hermano y brazo derecho de Getúlio Vargas durante su mandato), lo cual corrobora la intensificación de los actos de censura que imperaban en la época, cuyo principal objeto era proteger el régimen frente a cualquier amenaza. Si se hacía pública la presencia norteamericana en Brasil, el Estado hubiese tenido que responder ante Alemania por traición, lo que hubiera afectado antes de tiempo sus relaciones económicas; de ahí la censura a las referencias a Natal.

No obstante, la Carta apócrifa a J. Landon, además de señalar las problemáticas de censura obsesiva experimentadas en Brasil durante los inicios de la década de los cuarenta, brinda una pista para seguir la investigación: Natal se constituyó como un centro determinante de las diferentes decisiones tomadas por Getúlio Vargas. De este modo, se observan tres elementos a partir de este último documento y las imágenes seleccionadas, las cuales se presentarán a continuación: 1) desde 1941 se censuró toda referencia a Natal; 2) en 1942 se desarrollaron iniciativas en el territorio brasileño para exacerbar los ánimos guerreristas de la población y 3) en 1943 tuvo lugar una prudente visita del presidente Roosevelt a Natal, la cual, al parecer,

17 "Carta apócrifa a J. Landon, interceptada pela censura e enviada por Filinto Müller a Benjamin Vargas sobre a reação dos brasileiros ao discurso de Roosevelt e a existência, no Exército, de elementos pró-nazistas, comentando o recente decreto-lei que estabelece uma base aérea em Natal, $28 \mathrm{de}$ maio de 1941". FGV, Arquivo Getúlio Vargas, série: confid. (confidencial), classificação: GV confid. 1941.05.28/2, folio 2, Rio de Janeiro, Brasil. 
pretendía fortalecer con acto de presencia, los lazos que unían a Brasil con Estados Unidos y el resto de países Aliados en la guerra.

Respecto a los intentos por encender los ánimos guerreristas, puede observarse la portada del periódico $O$ Radical del 6 de septiembre de 1942, en la que ya se evidencia la iniciativa tomada por el Estado Novo para legitimar su participación en el conflictivo escenario internacional (figura 1).

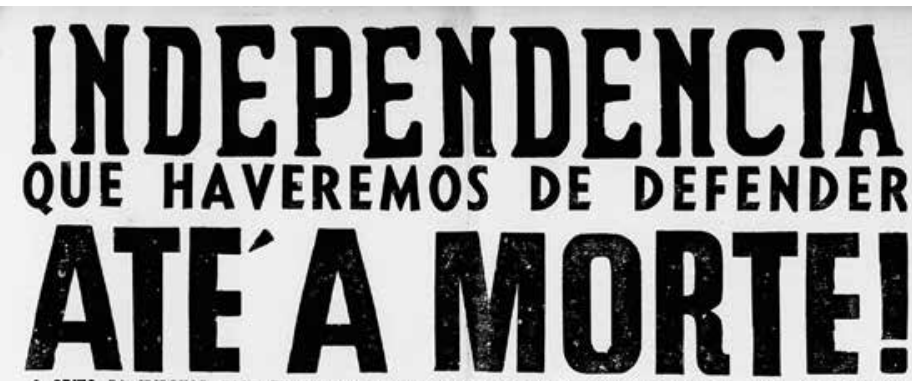

O GRITO dO IPIRAMGA ECOA EM TODOS QUADRANTES DA PATRIA! - A NACÁO HOJE E TODA DE SOLDADOS DISPOSTOS A SOBREVIVER LIVRES COMTRA O MAZISUO, PELA SOBERAMIA DO BRASIL - DESFILARAOO OS VANGUARDEIROS DA MOSSA DEFESA, NO EXERCITO DE MAIORES TRADIÇOES MILITARES DA AMÉRICA

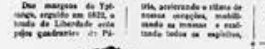
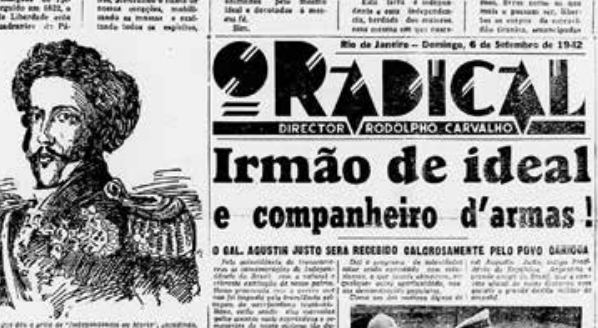

"'grave momentopara os operarios de todo o mundo!"

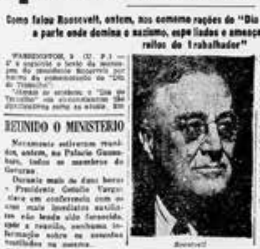

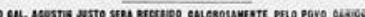
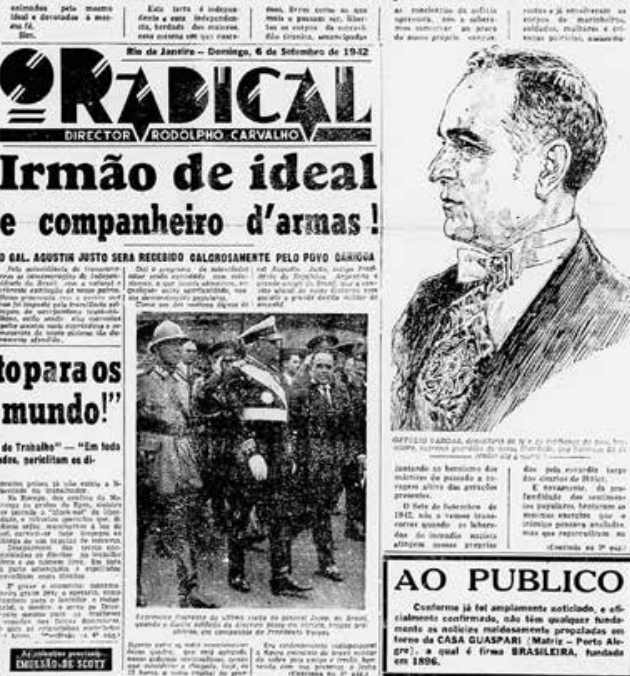

"Black-out" total nas ruas e avenidas da orla maritima!

HO CEMTRO DA CIOADE SO PODEM PERMAMECER ACESOS OS AHUNCIOS LUMIMOSOS SITUADOS ATE OS TERCEIROS PAVIHEMTOS DOS EDIFICIOS

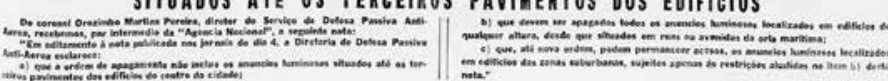

Figura 1. “Independencia que haveremos de defender até a morte!”, O Radical, Rio de Janeiro, 6 de septiembre de 1942, 1 (Biblioteca Nacional Digital do Brasil). 
El encabezado del titular ("Independencia que habremos de defender hasta la muerte") resulta bastante tajante al percibirse la intención nacionalista que subyace en él. ${ }^{18}$ Enseguida, se advierte un enunciado que describe la estructura del diario y, sin embargo, en él se recuerda el famoso Grito do Ipiranga de Pedro I, quien aparece en la imagen de la parte superior izquierda y cuya figura constituye el mito fundacional del Brasil independiente. El Grito do Ipiranga alude a las supuestas intenciones de la población brasileña de defender al país en su condición libre y soberana. Quizá esa es la razón por la que en la misma edición del diario aparece la frase “ ¡El grito de Ipiranga hace eco en todos los cuadrantes de la patria! La nación hoy es toda de soldados dispuestos a sobrevivir libre al nazismo por la soberanía de Brasil".

Ahora bien, se deben analizar las representaciones de Vargas y Roosevelt, ubicadas a la derecha y a la izquierda de la portada del diario, respectivamente, con la finalidad de identificar las particularidades de su divulgación, ya que ciertamente existía un objetivo detrás de la circulación masiva de tales imágenes.

El dibujo del presidente Vargas, ubicado en el extremo derecho de la portada del periódico, está acompañado de un enunciado que reza: "GETÚLIO VARGAS, depositario de la fe y la confianza del pueblo brasileño, supremo guardián de nuestra libertad, que habremos de defender hasta la muerte". La frase, estrechamente conectada con el encabezado del diario, es un claro ejemplo de los intentos por elaborar una imagen positiva del líder político llevados a cabo por los actores que hacían posible la existencia del Estado Novo, entre los cuales figuraba el propio Vargas. La tendencia del presidente brasileño a denominarse a sí mismo como el "supremo guardián de la libertad", en realidad, apuntó a encumbrarlo como el supremo protector de su país, para así legitimar sus ideas, al otorgarles un estatus de "necesarias" en la liberación del pueblo brasileño.

En cuanto a la fotografía de Roosevelt, ubicada en la parte inferior izquierda del diario, puede afirmarse que esta constituye una representación del juego discursivo antinazi-fascista que predominaba en los medios de la época. En el enunciado que

18 A pesar del gran debate en torno al concepto nacionalismo, es necesario entender este desde la concepción propuesta por Hans-Joachim König, es decir, como un "instrumento para motivar la actividad y la solidaridad políticas. Sirve para movilizar aquellas partes de la sociedad equiparadas con la 'nación', o a la colectividad concebida como 'nación', contra opositores internos o externos, o contra cualquier amenaza”. Véase: Hans-Joachim König, En el camino hacia la nación: nacionalismo en el proceso de formación del Estado y de la Nación de la Nueva Granada, 1750 a 1856 (Bogotá: Banco de la República, 1994), 25. 
precede la imagen se pueden leer algunas palabras proclamadas por el presidente norteamericano durante su discurso del Día del Trabajo; el objetivo de difundir esas palabras era crear un argumento de corte populista en apoyo a la clase trabajadora, que permitiera dar razones a la supuesta lucha por la libertad brasileña, la cual se hallaba "amenazada", según la versión estatal, por la presión de los ideales totalitarios europeos. Por lo tanto, al seleccionar la parte de la arenga en la que Roosevelt afirma que “[e]n todas partes donde predomina el nazismo, espoliados y amenazados, periclitan los derechos del trabajador", Vargas no solo hace creer que su aliado comparte sus ideales "trabajistas", sino también que el Gobierno norteamericano se opone a cualquier atentado contra la clase obrera y, por ende, merece todo el apoyo posible.

Sin embargo, resulta bastante paradójico observar que, gracias a ese mismo régimen que se autoproclamaba defensor de la libertad brasileña, se presentaron situaciones de represión política ejecutadas por el mismo Gobierno, vocero de garantías ambiguas. Así, se puede percibir que existió una estrecha relación entre el silencio deliberado del Estado Novo sobre sus asuntos internos y la proliferación de imágenes en los diarios que pretendían crear una visión positiva de Brasil en tiempos de guerra.

Ejemplos de la relación entre discurso e imagen pueden encontrarse si se tiene en mente la citada portada de $O$ Radical del 6 de septiembre de 1942 y se realiza una retrospectiva comparativa con la edición que el mismo diario publicó cuatro días antes. En aquella edición, existe un enunciado en el que se afirma que:

[1]a guerra contra el eje, la proclamaron los operarios mucho antes de la proclamación oficial porque desde que el fascismo existe los trabajadores contra él luchan, combatiendo todas sus manifestaciones y sufriendo también las consecuencias de las persecuciones que desencadenaron sus defensores disfrazados. ${ }^{19}$

La comparación entre ambas ediciones corrobora el discurso populista manejado por el periódico en la época, lo cual permite, incluso, ir más lejos y afirmar que se aprecia el intento de presentar una imagen de unidad nacional; unidad que, sin duda alguna, se hallaba fragmentada en la realidad, según muestran los académicos aquí citados.

19 “Os trabalhadores se levantam para afirmar que o Brasil não cairá!", O Radical, 2 de septiembre de 1942, 4. 
Además de las consignas populistas, pueden encontrarse en $O$ Radical más enunciados ciertamente optimistas en relación con la alianza entre Brasil y Estados Unidos. Por ejemplo, aquel que por razón del aniversario de la emancipación política de Brasil hizo Jefferson Caffery, embajador norteamericano, en compañía del Gobierno brasileño: “[s]obre el liderazgo de estos dos grandes líderes, Vargas y Roosevelt, los destinos de nuestras Naciones están en manos seguras y capaces”; luego, Caffery termina con: "[m] is compatriotas, con los hombres libres de toda América hermanémonos con el pueblo brasileño para hacer resonar de nuevo la gloriosa divisa brasileña: ¡Independencia o muerte!". ${ }^{20}$

Igual que estos enunciados, los cuales se conectan con la imagen de la figura 1, existen muchos otros que hizo circular el Estado Novo por medio de diferentes periódicos locales, con el fin de realzar la aceptación del régimen y de su gobernante; sin embargo, resulta imposible citarlos a todos en un trabajo de esta índole. Por lo demás, queda por mencionar que, en medio del exhaustivo esfuerzo de Vargas por crear un universo simbólico que le permitiera sostenerse en el poder hasta 1945, ocurrió un hecho significativo que fortaleció aún más los vínculos diplomáticos entre Brasil y Estados Unidos: su encuentro personal con el presidente Roosevelt, en Natal.

\section{Un encuentro fundamental}

La reunión en Natal, que tuvo lugar el 28 de enero de 1943, resulta importante para esta investigación, porque constituye un hecho paradigmático para explicar cómo Getúlio Vargas empleó la prensa a su favor, valiéndose de imágenes y palabras clave que contribuyeron a la legitimación de sus decisiones políticas. Ante todo, es plausible aseverar que Roosevelt viajó a Natal con el objetivo de convencer al mandatario brasileño de enviar tropas al frente de batalla. No es fortuito que el 23 de noviembre de ese mismo año se creara la Fuerza Expedicionaria Brasileña, ${ }^{21}$ el mismo organismo militar que envió combatientes a Europa en 1944 para cerrar el pacto de lealtad entre Brasil y el llamado frente antifascista. ${ }^{22}$

\footnotetext{
20 “Marchamos juntos para a vitória!", O Radical, 8 de septiembre de 1942, 4.

21 Roberto Muylaert, 1943-Roosevelt e Vargas em Natal (São Paulo: RMC, 2012), 41. Comparar con: Alfredo Salun, "Noticias sobre o Brasil na guerra e a criação da FEB", en A força expedicionaria brasileira e a Segunda Guerra Mundial: estudos e pesquisas, ed. por Denison de Oliveira (Rio de Janeiro: Centro de Estudos e Pesquisas de História Militar do Exército, 2012), 14.

22 Fausto, História concisa, 211.
} 
Sin embargo, parece que el envío de soldados brasileños al frente de batalla era un proyecto que Vargas había previsto, sobre todo al considerar que con ello su régimen podría garantizar un futuro para Brasil, por cuanto le permitiría configurarse de facto como el bastión clave del Cono Sur, al que se aproximaba Estados Unidos desde hacía varios años con intentos como el discurso del panamericanismo y las políticas de la buena vecindad. ${ }^{23}$ Tras la reunión de Natal, el periódico $A$ Noite publicó la siguiente nota:

Luchando lado a lado por los mismos ideales de justicia y libertad, los soldados y marineros de Brasil y de los Estados Unidos comprenden, mejor que nadie los verdaderos propósitos de la política de buena vecindad preconizada por Monroe y puesta en práctica por los dos grandes presidentes de las Américas, Vargas y Roosevelt. Esa colaboración leal seguirá así, siempre creciendo, hasta el día de la victoria, continuando, en ritmo sorprendente, en el futuro pacífico por el que estamos luchando. ${ }^{24}$

Una consigna de esa magnitud permite comprender, con mayor precisión, las pretensiones del Estado Novo respecto a la imagen que quería construir en torno a la alianza entre Brasil y Estados Unidos. En este enunciado se intenta mostrar que la unión con el vecino del norte constituía una garantía a futuro de paz y libertad, dos condiciones necesarias para un país que ambicionaba progresar política, económica, social e, incluso, militarmente. Dos fuentes visuales resultan relevantes al momento de defender esta afirmación: la primera hace hincapié en la unidad entre los dos países como fundamento de la fuerza necesaria para afrontar la guerra (figura 2) y la segunda se refiere a la búsqueda unitaria de sus ideales comunes (figura 3). Ambas forman parte del periódico $O$ Radical y configuran la antesala de lo que vendría tras la conferencia de Natal. Según se observa en materia lingüística, las dos fuentes exaltan los intercambios de ideas entre los presidentes Vargas y Roosevelt.

\footnotetext{
23 Salun, "Noticias sobre o Brasil", 13.

24 “Americanos em Recife", A Noite, 24 de febrero de 1943, 3.
} 


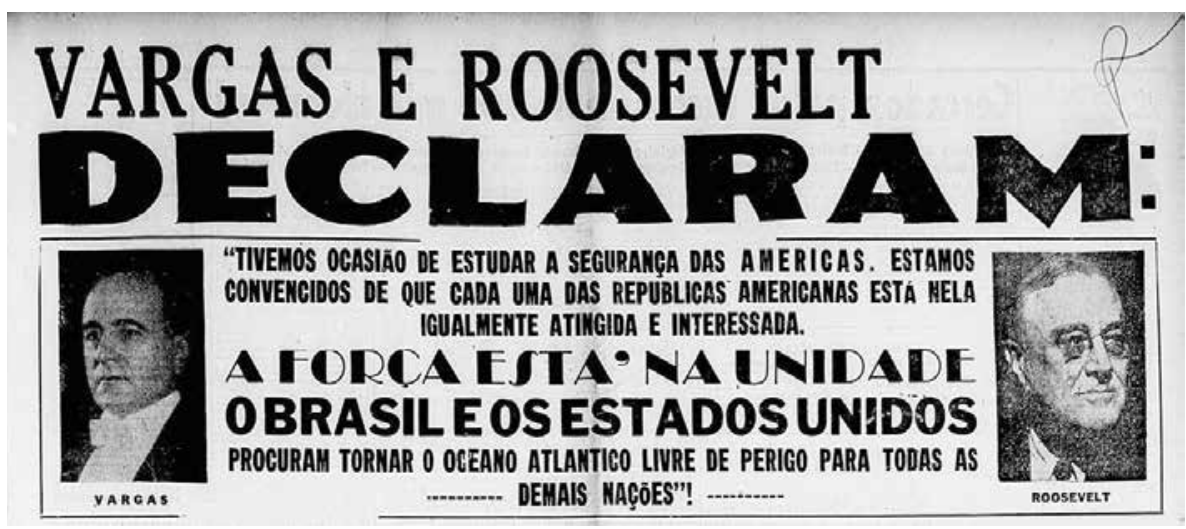

Figura 2. "A força está na unidade. O Brasil e os Estados Unidos”, O Radical, Rio de Janeiro, 30 de enero de 1943, 1 (Biblioteca Nacional Digital do Brasil).

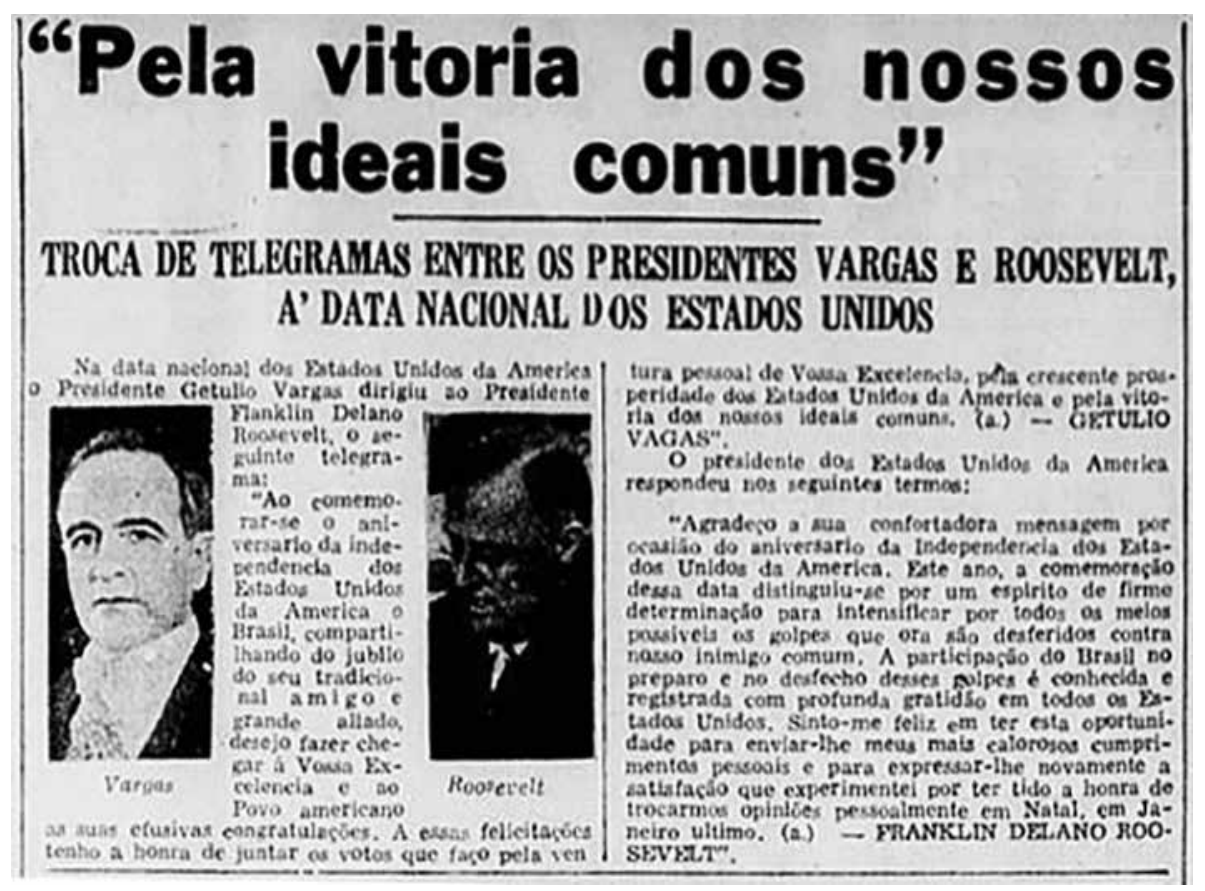

Figura 3. "Pela vitoria dos nossos ideais comuns", O Radical, Rio de Janeiro, 15 de julio de 1943, 2 (Biblioteca Nacional Digital do Brasil). 
Por un lado, en la figura 2 las declaraciones resultan mucho más informales, ya que el enunciado es una transcripción literal de las palabras que expresaron verbalmente los dos presidentes en sus respectivos discursos — una vez terminada la conferencia de Natal — sobre la alianza entre Brasil y Estados Unidos. Por otro lado, la figura 3 se trata de un telegrama intercambiado entre ambos mandatarios, lo que resalta la costumbre adoptada por Vargas de hacer públicos algunos comunicados diplomáticos importantes, cuando las circunstancias así lo exigían. Respecto a las imágenes que forman parte de estas dos fuentes, es decir, los rostros de los presidentes Vargas y Roosevelt, ubicados a lado y lado de cada uno de los enunciados, puede afirmarse que la ubicación de los retratos tiene por finalidad básica la presentación explícita de los sujetos con quienes se relacionan los textos, lo cual seguramente tuvo un efecto de precisión del mensaje en los lectores de los periódicos en la época.

En este punto puede agregarse una reflexión desarrollada por W. J. T. Mitchell, quien, al retomar la obra Las técnicas delobservador, de Jonathan Crary, afirma que los observadores pueden convertirse en los verdaderos artífices de determinados procesos históricos. ${ }^{25}$ Vargas parecía tener muy claro eso: si el mensaje llegaba de manera contundente al público al que iba destinado, incluso, podría llegar a dominar amplios sectores de la sociedad brasileña. De hecho, esa era su meta, por lo que la explicación de Daryle Williams sobre la creación de instituciones en el Brasil de la era Vargas destinadas a operar como "centinelas" para controlar la "brasilidad"26 (lo propiamente brasileño) no resulta para nada desdeñable, ya que así se maquinaron las diferentes estrategias políticas que siguió el presidente durante su estancia en el poder. Entre ellas, es posible destacar el uso de las imágenes y discursos que circularon en la prensa local desde 1939, con la aparición del DIP, hasta

25 W. J. T. Mitchell, Teoría de la imagen: ensayos sobre representación verbal y visual (Madrid: Akal, 2009), 27.

26 De hecho, el concepto de Williams dice explícitamente brasilidade, pero una traducción aproximada del término puede ser la de brasilidad, pues se refiere a la condición de lo propiamente brasileño. Véase: Daryl Williams, Culture Wars in Brazil: The First Vargas Regime, 1930-1945 (Durham: Duke University Press, 2001), 52-89. Además del texto de Williams, existe bibliografía que explica de manera específica la construcción de vehículos de identidad colectiva con la nación en Brasil; al respecto, véase: Ursula Prutsch, "Nelson A. Rockefeller's Office of Inter-American Affairs in Brazil", en iAméricas Unidas! Nelson A. Rockefeller's Office of Inter-American Affairs (1940-46), ed. por Gisela Cramer y Ursula Prutsch (Frankfurt/Madrid: Vervuert/Iberoamericana, 2012), 251-255. 
1945, cuando Vargas pierde el poder, gracias a los propios hombres que lo habían ayudado a subir en $1930 .{ }^{27}$

A partir de esto, se puede inferir que, antes del encuentro en Natal, se había preparado todo un imaginario visual que permitiría aprovechar de manera contundente gran parte de los sucesos de la reunión a favor del régimen de Vargas. Por consiguiente, cuando los periódicos empezaron a divulgar masivamente la relevancia de la visita de Roosevelt a Brasil, en febrero de 1943, se pretendía reforzar aún más aquello que ya se había venido construyendo desde tiempo atrás. Incluso, puede afirmarse que se consideró el encuentro en Natal como algo que marcaría “[...] la historia como uno de los acontecimientos más sensacionales de los últimos tiempos, ${ }^{28}$ tal como lo hizo el Diario de Noticias de Río de Janeiro del 30 de enero de 1943; ello realmente evitó que se derribase la estructura simbólica creada con antelación por el Estado Novo en torno a la relación Brasil-Estados Unidos.

Una vez que la conferencia empezó a ser noticia para los periódicos locales, esta se constituyó en un hito propagandístico en la historia del Estado Novo, el cual fortaleció aún más las estrategias que se habían llevado a cabo hasta 1943. Diarios como $O$ Radical relataron los hechos, al afirmar que "[d]urante el viaje hasta Parnamirim [la base aérea situada en Natal], los dos presidentes y sus comitivas fueron vivamente ovacionados por la población, que reconoció los ilustres jefes de Estado"; ${ }^{29}$ A Noite, por su parte, relató que:

[1]a llegada de los presidentes Vargas y Roosevelt era absolutamente inesperada, visto que los viajes de sus Excelencias se cercaron de un sigilo indispensable. Justo después del desembarque, los dos grandes estadistas se acogieron a bordo de un navío de guerra, en el cual se mantuvieron en conferencia hasta esta madrugada. ${ }^{30}$

Por último, el boletín mensual del Orgão Oficial do Instituto Nacional de Ciência Política de Brasil, llamado Ciência Política, publicó lo siguiente:

\footnotetext{
27 El mismo poder militar que había sido clave para la transición entre la Primeira República y la Era Vargas fue la responsable del final de esta última. Véase: Fausto, História concisa, 215; Rouquié, El Estado militar, 309-316.

28 "Manifestações populares", Diario de Notícias, 30 de enero de 1943, 2.

29 "Comunicados de Natal", O Radical, 30 de enero de 1943, 2.

30 "Até a madrugada", A Noite, 30 de enero de 1943, 2.
} 
La Conferencia de los Presidentes Vargasy Roosevelt. El día 28, en Natal los Presidentes Getúlio Vargas y Franklin Roosevelt estuvieron en conferencia durante varias horas. Fueron estudiadas las más importantes cuestiones de la guerra, principalmente las relacionadas con la defensa del continente. Este encuentro entre los dos Presidentes de los dos mayores países de América, fue considerado de gran importancia para la victoria de los Aliados y tuvo la más larga repercusión en todo el mundo. ${ }^{31}$

Con todo, se puede percibir que el impacto histórico del encuentro no solo fue nacional, sino también internacional. ${ }^{32}$ De hecho, en el ámbito local cobró importancia una fotografía que presenta el reconocido y divulgado acontecimiento de Natal (figura 4), dado que se trata de una imagen en la que los presidentes Vargas y Roosevelt dialogan en una mesa en el interior de una embarcación de guerra, la cual sirvió de refugio para que ambos discutieran cuestiones políticas imperativas en aquel momento.

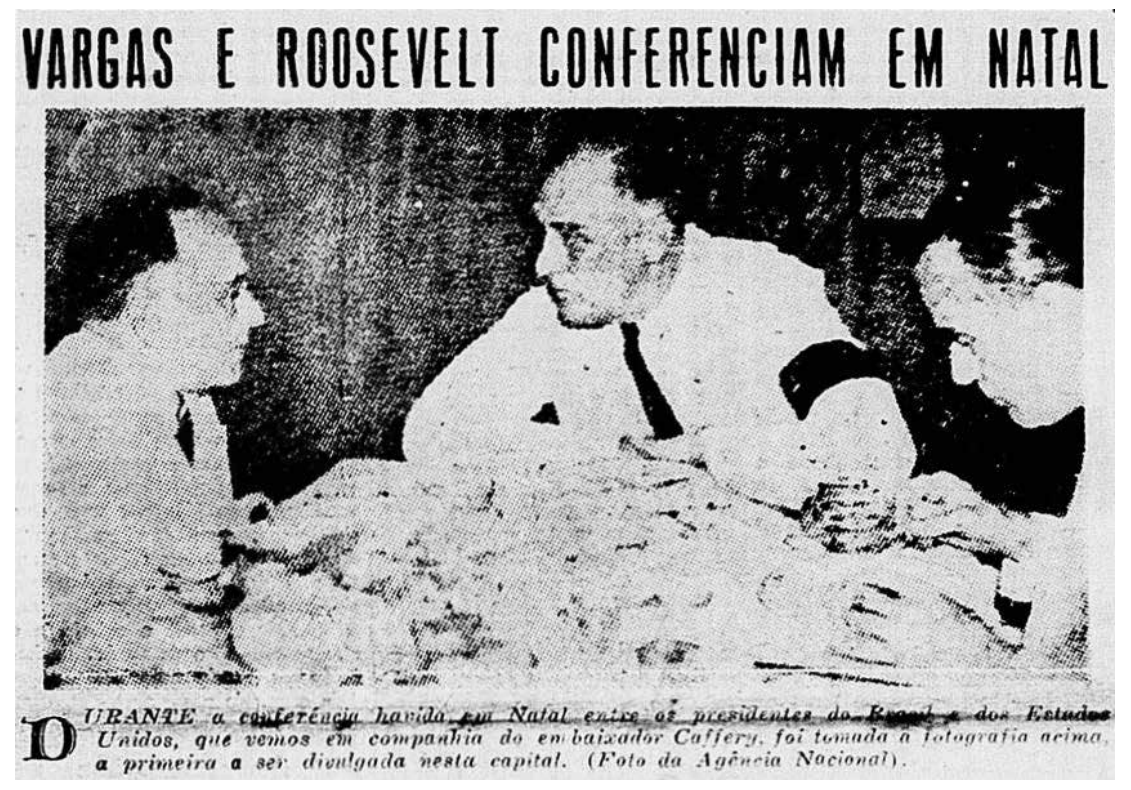

Figura 4. Agencia Nacional, 7 de febrero de 1943, "Vargas e Roosevelt conferenciam em Natal”, Gazeta de Notícias, Rio de Janeiro, 7 de febrero de 1943, 1 (Biblioteca Nacional Digital do Brasil).

\footnotetext{
31 “Acontecimentos de importância ocorridos durante o mês de janeiro", Ciência Política, 1943, 87.

32 Para una referencia norteamericana, puede consultarse: "President flies to Brazil", Los Angeles Examiner, 29 de enero de 1943, s. p.
} 
De acuerdo con la breve descripción que la imagen posee en su parte inferior, la Agencia Nacional se encargó de tomar la fotografía, que muestra a los dos presidentes aliados sentados a la mesa, junto al embajador norteamericano Jefferson Caffery. Su importancia radica en que Getúlio Vargas la hizo circular en el periódico Gazeta de Notícias para proseguir con su campaña de creación de símbolos, los cuales determinarían la buena imagen de su Gobierno. En términos locales, es posible inferir la trascendencia que tuvo la noticia, debido a que, como ya se intentó explicar, los medios de comunicación nacionales estaban fuertemente censurados y trabajaban al servicio del Estado Novo; sin embargo, en materia internacional, cabe citar al propio periódico Gazeta de Notícias, el cual publicó una referencia al diario argentino Noticias Gráficas, en la que se subraya cómo dicho medio aseveró que:

El Gobierno de Brasil acaba de dar un nuevo paso de gran significación en el terreno de la beligerancia. Se incorporó con su fuerza incontestable al grupo de las Naciones Unidas, adhiriéndose al protocolo de acción colectiva suscrita por esos países el 1 de febrero de 1942 [...] La actitud que asume Brasil, al ocupar el puesto de vanguardia en la defensa de los mares del sur, permitiendo la manutención de rutas comerciales y de navegación pacífica, es un acontecimiento trascendental y revelador de la integridad con que el país vecino coopera en la causa de los pueblos que defienden la democracia, y precursor de acontecimientos que se irán adicionando hasta la victoria definitiva, en la cual tendrá una participación relevante..$^{33}$

Así, por ejemplo, se observa que la presencia de Brasil en la guerra fue asumida de manera positiva por un periódico suramericano como Noticias Gráficas, el cual apoyó la iniciativa belicista del Estado Novo. Días más tarde, O Radical haría su propia referencia a un periódico internacional con sede en el norte de Estados Unidos, como fue el caso del Times; en efecto, el medio local, en un intento por exacerbar los ánimos conflictivos en Brasil, destacó que:

Aquel periódico [Times] subrayó la importancia de la declaración firmada por los presidentes y elogió el esfuerzo de guerra de Brasil, cuyas materias primas y ventajas estratégicas fueron puestas enteramente a disposición o al servicio de

33 “Repercussão da entrevista de Natal, na Argentina", Gazeta de Notícias, 12 de febrero de 1943, 87. 
las Naciones Unidas. Otro aspecto importante realzado por el “Times” fue el patrullaje que se hace en el Atlántico, con resultados positivos.

Pero no basta leer y recordar ese y otros comentarios. ¡Lo que el momento reclama es acción! $!^{34}$

No obstante, dejando de lado la fuerte carga ideológica del enunciado, se advierte que, aun cuando la importancia de la alianza entre Brasil y Estados Unidos trascendió a un plano internacional, dicho aspecto solo importó al Estado Novo, por cuanto le brindó ciertas posibilidades de legitimar sus decisiones y ocultar las problemáticas internas que el régimen le había causado al país. En este sentido, el encuentro en Brasil de Vargas y Roosevelt, analizado desde una perspectiva simbólica, parece resumirse muy bien en un artículo publicado por la Gazeta de Notícias, en el que se recalca que “[...] en la comunión de las armas, Natal se convirtió en la fortaleza del Panamericanismo", ${ }^{35}$ pues ciertamente allí se terminó de consolidar el gran pacto de la "unidad anti-totalitaria", que produjo un potenciamiento del discurso legitimador estadonovista.

\section{Un recuerdo constante}

El tema de la conferencia en Natal no se agotaría pronto en Brasil. Para agosto de 1943, siete meses después del acontecimiento, el diario Correio da Manhã publicó - con lo que contradijo la supuesta asociación que lo convertía en un periódico, en teoría, "libre de la ideología estadonovista" — una imagen de los presidentes Vargas y Roosevelt en Natal (figura 5), con el fin de contextualizar una noticia sobre un discurso del embajador Caffery en Brasil. Debajo de la fotografía, el diario enuncia que "[1]a base de Natal fue el trampolín que facilitó el salto decisivo a África. En el grabado vemos a los presidentes Getúlio Vargas y F. D. Roosevelt en aquella capital nordestina en excursión e inspección".

\footnotetext{
34 “O que o momento reclama é mais ação!", O Radical, 18 de febrero de 1943, 1.

35 “A conferência de Natal”, Gazeta de Notícias, 30 de enero de 1943, 3.
} 


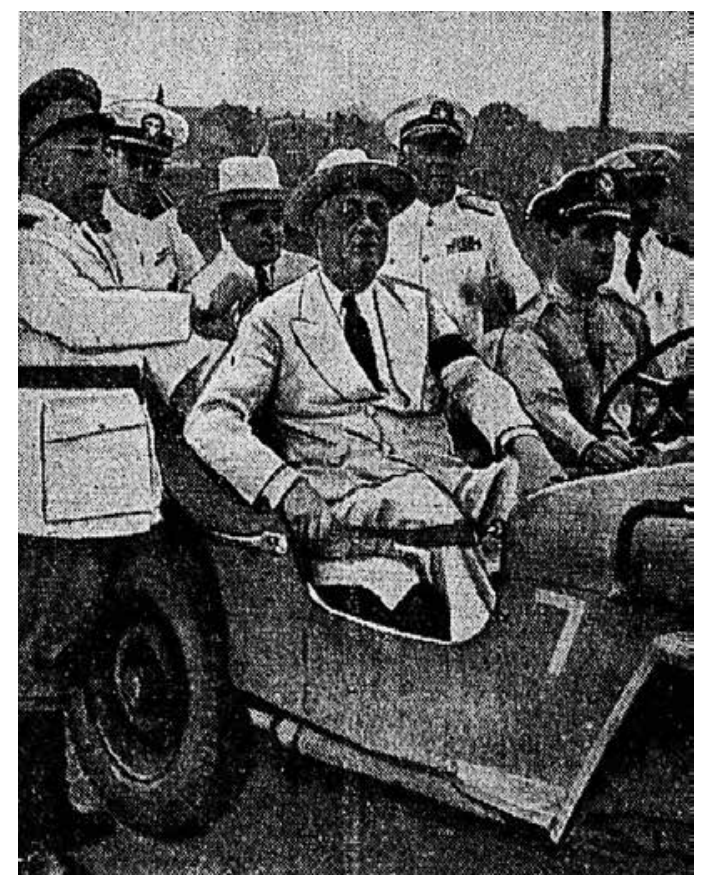

Figura 5. "Declarações do embaixador dos Estados Unidos”, Correio da Manhã, Rio de Janeiro, 22 de agosto de 1943, 1 (Biblioteca Nacional Digital do Brasil).

Si bien en esta fotografía aparecen con cierta nitidez los presidentes Getúlio Vargas y Franklin D. Roosevelt, la ubicación de cada uno en el vehículo que los conduce por la base militar sugiere un posible ámbito de análisis: mientras que el líder de Estado brasileño se halla en la parte trasera del automóvil, el norteamericano se ubica justo al frente. En materia simbólica, esto puede interpretarse como una especie de sometimiento de parte de Vargas hacia Roosevelt; ${ }^{36}$ así, es posible pensar someramente en el fenómeno de americanización por el que pasó Brasil durante su cercanía coyuntural con los Estados Unidos de América. No obstante, antes de revisar este asunto, es relevante subrayar que para agosto de 1943 el evento de Natal aún era objeto de manipulaciones por parte del Estado Novo y de Vargas,

36 Si bien ya era vigente para la época la preconcepción norteamericana que caracterizaba todo lo latinoamericano como algo débil (por lo cual se representaba lo latino con figuras de mujer o niño), la composición de la fotografía de los dos presidentes en Natal refuerza más esa idea. Véase: Antonio Pedro Tota, “A americanização no condicional: Brasil nos anos 40", Perspectivas, n. 16 (1993): 208. 
a quien un encuentro de tal magnitud favorecía considerablemente, como fundamento de su plataforma política.

Por tal razón, vale la pena revisar el origen de la imagen que circuló en Correio da Manhãa, dado que ello permitirá comprender el desenlace que tuvo la puesta en escena que la compone. La fotografía fue tomada por el retratista personal de Roosevelt y enviada por este último a Getúlio Vargas, tal y como señala Pedro Corrêa do Lago, con base en las rúbricas ubicadas en la parte inferior de la lámina original (figura 6), las cuales constituyen una clara dedicatoria de Roosevelt a Vargas. ${ }^{37}$

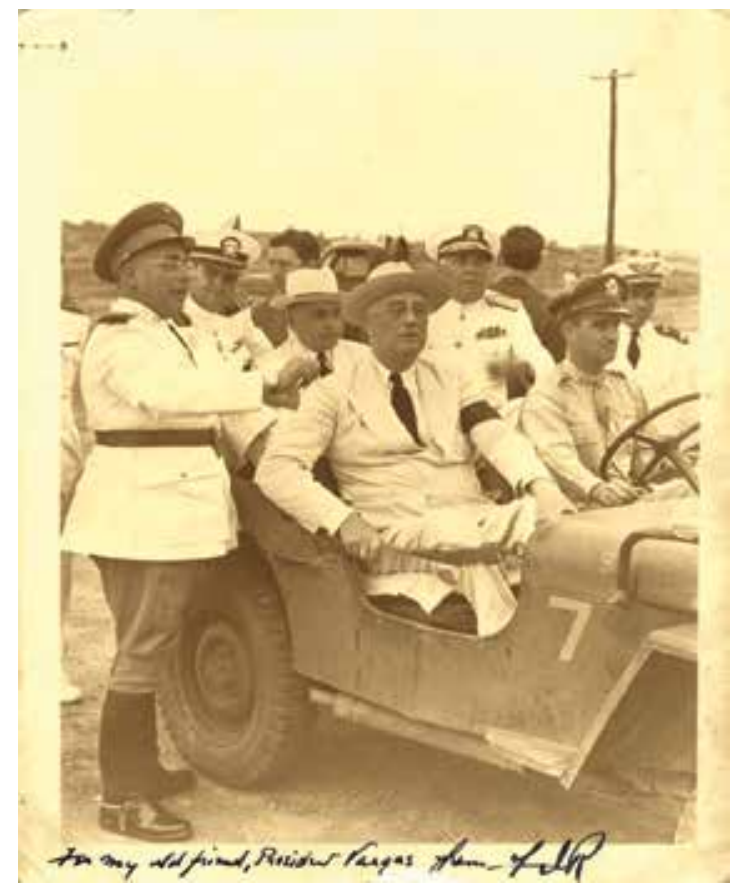

Figura 6. Anónimo, 1943, “A dedicatória de Roosevelt para Getúlio Vargas” (fotografía, Fundação Getúlio VargasCentro de Pesquisa e Documentação de História Contemporânea do Brasil [CPDOC], Rio de Janeiro).

Sin embargo, en segundo lugar, habría que analizar otra afirmación hecha por Corrêa do Lago, en la que se destaca la existencia de una segunda fotografía (muy similar a la primera) tomada por el retratista personal de Vargas (figura 7$).{ }^{38} \mathrm{Con}$

37 Pedro Corrêa Do Lago, "Adedicatóriade Rooseveltpara Getúlio Vargas", Revista Piauí,4dejuniode2013, http://piaui.folha.uol.com.br/questoes-manuscritas/a-dedicatoria-de-roosevelt-para-getulio-vargas/

Corrêa Do Lago, “A dedicatória...." 
base en esa imagen, el pintor norteamericano Raymond P. R. Neilson realizó, en 1943, su cuadro "Retrato de Franklin Roosevelt e Getúlio Vargas, em visita à Base Aérea Americana, instalada em Natal (RN), em 1943" (figura 8), hoy expuesto en el Museu da República-Palácio do Catete en Rio de Janeiro.

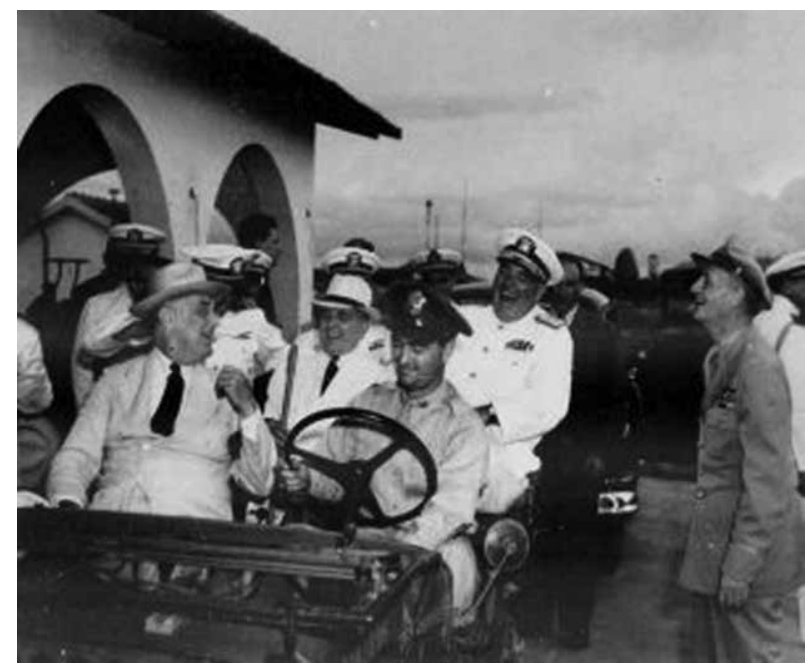

Figura 7. Anónimo, 1943, sin título (Fundação Getúlio Vargas-Centro de Pesquisa e Documentação de História Contemporânea do Brasil [CPDOC], Rio de Janeiro).

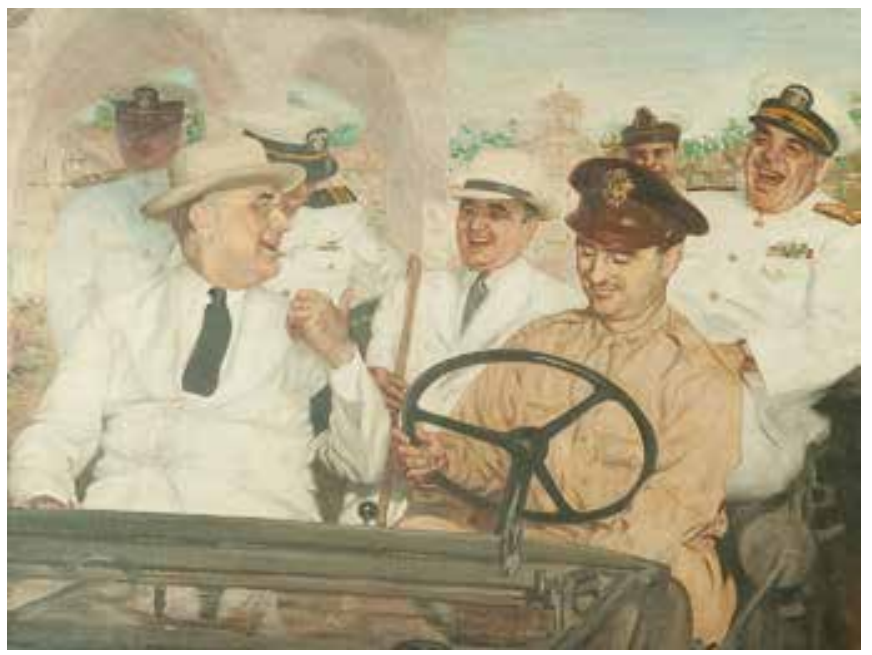

Figura 8. Raymond P. R. Neilson, 1943, "Retrato de Franklin Roosevelt e Getúlio Vargas, em visita à Base Aérea Americana, instalada em Natal (RN), em 1943 ” (Óleo sobre tela, Museu da República, Rio de Janeiro, Brasil). 
De acuerdo con Corrêa do Lago, es muy probable que Roosevelt nunca haya conocido la fotografía que sirvió de base para la realización del cuadro de Neilson. ${ }^{39}$ Lo que resulta muy claro es que Vargas aprovechó lo máximo que pudo aquella imagen para fortalecer el universo simbólico que había creado su régimen con gran empeño. En realidad, es llamativo y alegórico el hecho de que el cuadro aún hoy continúe expuesto en el Palácio do Catate, teniendo en cuenta que esa fue la sede de Gobierno durante la era Vargas, y quizá sea esa la intención del museo: mostrar que el retrato pertenece a un tiempo y un espacio específicos; si bien el tiempo no puede recrearse, no cabe duda de que el espacio es mucho más propenso a materializar esa intención.

En este punto, asumiendo alguna idea del contexto de la pintura, es importante describir esta en términos concretos. En consecuencia, se puede empezar señalando quiénes aparecen representados en el cuadro: al frente del automóvil, en la parte izquierda, el presidente Roosevelt; en esa misma dirección, pero detrás, el presidente Vargas; al lado de este, el almirante norteamericano Jonas H. Ingram; ${ }^{40}$ y al volante, David Channing Moore, ${ }^{41}$ capitán norteamericano al servicio de las fuerzas armadas estadounidenses. Así, se percibe lo que se mencionó respecto a una posible interpretación simbólica en torno a la imagen: la ubicación de los personajes puede resultar muy diciente si se fija la atención en ella, ya que los norteamericanos se encuentran al frente del vehículo retratado y uno de ellos se encuentra al volante, es decir, conduce a los demás a partir de las órdenes de Roosevelt, su presidente.

En este sentido, la tesis de Antonio Pedro Tota es decisiva: parte del hecho de que la Segunda Guerra Mundial cambió sustancialmente las relaciones entre Estados Unidos y Brasil, para luego afirmar que gracias a esa coyuntura emergió en Brasil un fuerte proceso que permitió la entrada de todo lo norteamericano al país. ${ }^{42}$ Lo anterior ocurrió debido a una iniciativa que, en principio, pretendía simplemente garantizar - como el propio Vargas lo manifiesta a lo largo de su diario personal - los intercambios comerciales entre los Estados brasileño y estadouni-

39 Se sabe que el cuadro se pintó a partir de la foto, según la información suministrada por el Museu da República. Véase: Revista Museu da República-Palácio do Catete, http://www.revistamuseu.com.br. "Dedicatorias a Getúlio Vargas", Museu da República, http://museudarepublica.museus.gov.br/ exposicoes/dedicatorias/paginas/rooseveltGV101.htm (31/03/2017).

41 Rostand Medeiros, “Tok de História”, http://tokdehistoria.com.br/2014/02/10/1943-quem-foi-o-motorista-do-jipe-de-roosevelt-e-vargas-em-natal/ (31/03/2017).

42 Antonio Pedro Tota, O imperialismo sedutor: a americanização do Brasil na época da Segunda Guerra Mundial (São Paulo: Companhia das Letras, 2000), 28. 
dense. De manera notoria, la última imagen no demuestra en lo más mínimo lo contrario; en efecto, lo ratifica en términos simbólicos: Brasil quedó subordinado al dominio norteamericano para garantizar su poderío político, económico y militar, al costo de perder aquello que Daryle Williams denomina su brasilidad. ${ }^{43}$ Fue entonces cuando los ideales tenentistas de protección del patrimonio nacional, esos mismos ideales que se encargaron de subir a Vargas al poder en 1930, se vieron demasiado vulnerados y terminaron por enfrentar y derrocar al mandatario y su régimen en $1945 .{ }^{44}$

Sin embargo, Vargas volvió al poder en 1951 por vía democrática —y se suicidó en 1954, antes de aceptar su nuevo derrocamiento-. Este dejó como legado un último discurso político de represalia contra el pueblo brasileño, discurso enaltecido por el poder de los medios que tanto le sirvieron para legitimar sus decisiones, aunque en esa singular ocasión la arenga se transmitió por radio y, por ende, su difusión fue mucho más amplia. ${ }^{45}$

\section{El legado de Vargas}

Las acciones de Getúlio Vargas y el Estado Novo dejaron en Brasil una marca indeleble para la posteridad. Hacia el final de la Segunda Guerra mundial, una vez que la maquinaria estatal de Vargas logró mantenerse intacta a través del uso de la propaganda en medios masivos como la prensa, inició el declive del presidente y su estrategia poco a poco se encaminó en dirección a la historia, es decir, en dirección a las estrategias que le permitirían vivir en la memoria del pueblo brasileño.

Como evidencia del declive de Vargas, se destaca una fotografía (figura 9) muy particular y llamativa: esta muestra la reacción de una buena parte del pueblo brasileño frente a los muchos años de dictadura disfrazada que sufrieron por cuenta de la maquinaria política instaurada por el Estado Novo. Al terminar la Segunda Guerra Mundial, se fue con ella la cortina de humo más eficaz que había encontrado

43 Williams, Culture Wars in Brazil, 52.

44 Sin embargo, la prensa no presentó la salida de Vargas como un derrocamiento, sino como una renuncia, lo cual sería legítimo si no hubiese existido ninguna presión por parte de algunos altos mandos del ejército (brigadier Eduardo Gomes, general Dutra, general Góis Monteiro) ni se hubiesen sustituido todos los ministros de Estado de Vargas tras su supuesta renuncia. Al respecto, véase: "Renunciou o presidente Getúlio Vargas", Jornal do Brasil, 30 de octubre de 1945, 5 y "Vargas renunciou”, O Jornal, 30 de octubre de $1945,1$.

45 Othon Jambeiro et al., Tempos de Vargas: o rádio e o controle da informação (Salvador da Bahia: Universidade Federal da Bahia, 2004), 166. 
Vargas para mantenerse en el poder; de esta manera, empezaron a salir a la luz las inconformidades locales frente al régimen.

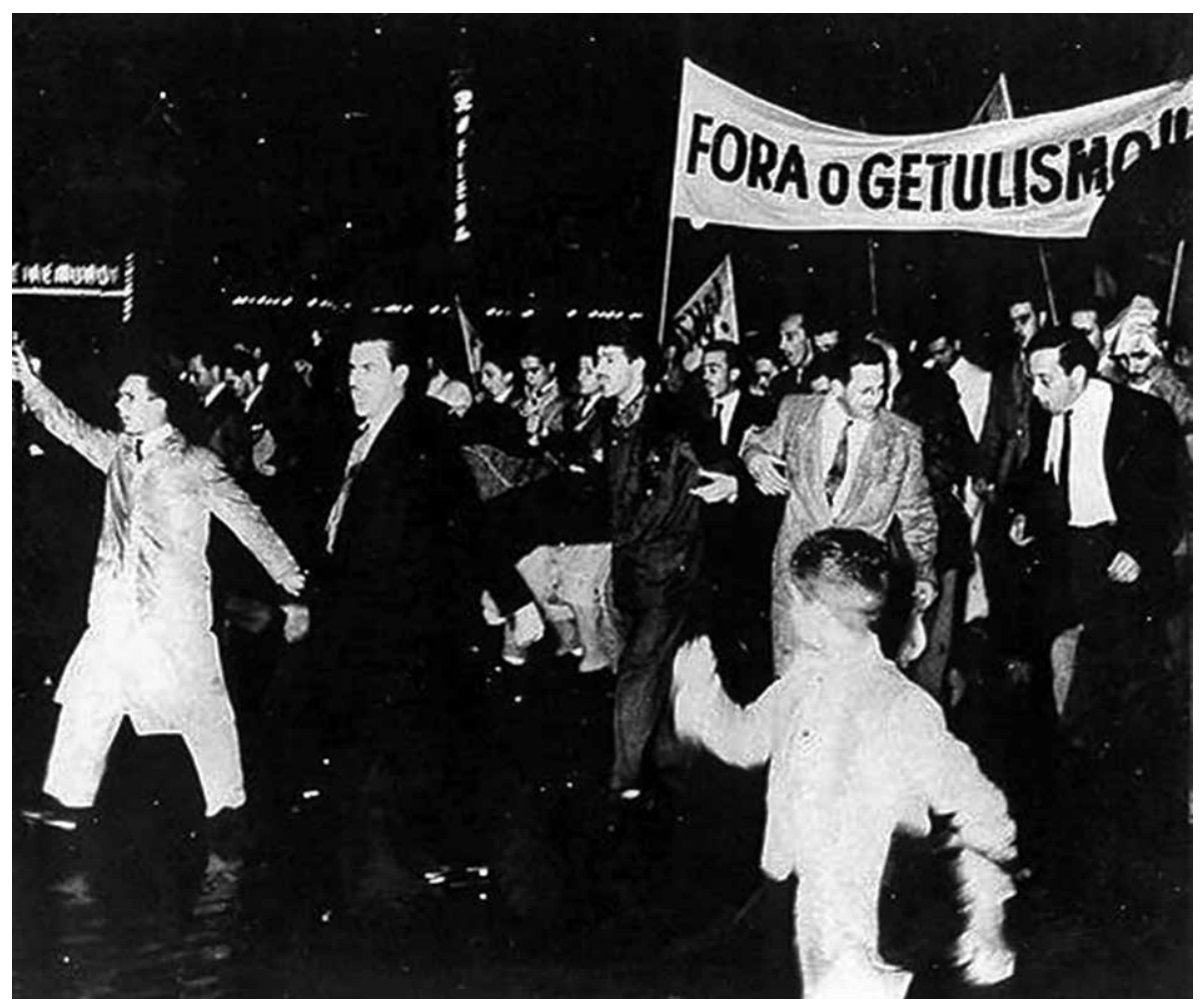

Figura 9. Anónimo, 1945, "Manifestação anti-getulista realizada na praça da Sé, São Paulo (sp)" (fotografia, Fundação Getúlio Vargas-Centro de Pesquisa e Documentação de História Contemporânea do Brasil [CPDOC], Rio de Janeiro).

En la fotografía es posible observar una multitud que carga consigo un cartel, cuya consigna reza “iAfuera el getulismo!”. A partir de la descripción de la imagen que estipuló la Fundación Getúlio Vargas, es posible determinar que el lugar de la manifestación es la ciudad de São Paulo y el año en el que se presentó fue 1945, justo hacia el final de la guerra. Esto permite comprobar, al menos, dos aspectos: 1) en São Paulo se reunieron diferentes actores de la oposición contra el estadonovismo, los cuales empezaron a hacer públicas sus inconformidades cuando ya no existía ningún obstáculo para que el resto de la población los escuchara; y 2) el declive general del presidente Vargas inició precisamente en el año de la fotografía, cuando se presenta su primer derrocamiento. 
Tras esa primera caída, Vargas implementó una estrategia de retorno al poder que le sería efectiva, como ya se mencionó, en 1951, cuando fue elegido democráticamente presidente de Brasil; sin embargo, una vez de vuelta al poder, enfrentó una oposición mucho más consolidada y fuerte, que lo derroca nuevamente en 1954. Una de las más importantes figuras de esta oposición fue el periodista y político Carlos Lacerda, quien a través de su periódico Tribuna da Imprensa propugnó por la erradicación de cualquier intento de populismo en Brasil, entre los años 1950 y 1955. Aun así, llama la atención de manera casi paradójica que ese mismo intelectual tomara el liderazgo del partido de la Unión Democrática Nacional (UDN) en Brasil e instaurara en el interior de dicho movimiento su ala lacerdista, con la cual apoyó el Golpe Militar en Brasil que tuvo lugar en $1964^{46}$ y abrió paso a otra dictadura contra la población brasileña.

Ahora bien, respecto a la coyuntura de 1954, habría que resaltar que la oposición ejercida por Lacerda resultó de gran importancia para el segundo intento de derrocamiento de Vargas. En su edición del 11 de agosto, el periódico de Lacerda anunció una de las frases más recordadas de este opositor que se expresara contra Vargas, entonces presidente electo democráticamente: "Renuncie a la presidencia para salvar a la República". ${ }^{47}$

La frase fue anunciada cuando Vargas ya había sido depuesto por la vía de los mecanismos de control político brasileños, pero este se negaba a salir de la sede de Gobierno en Río de Janeiro (Palácio do Catete). En ese punto se presentó el segundo giro de la estrategia política de Getúlio Vargas: el mandatario pasó de enfocar sus esfuerzos desde estrategias para la conservación del poder hacia estrategias para entrar a formar parte de la memoria de la población brasileña. Para tal fin, llevó a cabo una acción muy congruente con una personalidad que no podía vivir si no era en el poder: el suicidio. Además, empleó dos herramientas para la difusión de dicho acto que remplazaron el uso de las imágenes por vía de la prensa: el testamento y la radio.

Existen dos confesiones testamentarias que fueron escritas por Vargas antes de su suicidio: una se emitió radialmente a todo el país y la otra permaneció en manos

46 Marcio de Paiva Delgado, "O Jornalista e Político Carlos Lacerda nas Crisis Institucionais de 19501955”, en I Coloquio do Laboratorio de Historia Econômica e Social (LAHES) (Juiz de Fora: Universidade Federal de Juiz de Fora, 2003), s. p.

47 "Vargas, virtualmente deposto há 48 horas, não quer sair do Catete", Tribuna da Imprensa, $11 \mathrm{de}$ agosto de 1954, 1 . 
de su familia hasta que se divulgó en 1970. De la emisión radial se recuerda, sobre todo, la famosa frase final de Vargas: "Serenamente doy el primer paso en camino hacia la eternidad y salgo de la vida para entrar en la historia"; 48 mientras que de la confesión que permaneció en manos de su familia me gustaría rescatar el siguiente fragmento: "Que la sangre de un inocente sirva para aplacar la ira de los fariseos". ${ }^{49}$

Con base en ambas frases, se puede percibir cómo Vargas aún se apoyaba en la idea mesiánica de erigirse como un héroe de las masas, para lo que aprovechó cada instante de sus últimas horas con el objeto de alcanzar dicha meta. En la primera frase es posible descifrar el cambio de objetivo del mandatario, quien antes de suicidarse no piensa más en mantenerse en el poder, sino en entrar a la historia por medio del recuerdo de la población. Por otro lado, en la segunda frase intenta asemejarse a la figura de un Cristo, quien muere enfrentando a los "fariseos" de su tiempo. No obstante, sin duda alguna, la revisión de su legado político permite confrontar ese discurso mesiánico y reconocer los puntos más grises de su accionar como mandatario.

La imagen que intentó construirse Vargas por medio de la difusión del Estado Novo, a través de la circulación masiva de imágenes y discursos en medios de prensa, y aprovechando coyunturas mundiales como la Segunda Guerra Mundial, termina por contradecirse - a mi juicio - a partir de una frase que fue recordada por el periódico Ultima Hora, de Río de Janeiro, el 24 de agosto de 1954, tras el suicidio del mandatario: “¡Solo muerto saldré del Catete!” ${ }^{0}$ Esta frase, más que evocar la imagen de un mártir del pueblo brasileño, recuerda a un político que se negaba a dejar el poder que ya había probado y el cual estaba dispuesto a conservar a toda costa.

\section{Conclusión: el Estado imaginado}

Con el objeto de encaminar todo lo mencionado a lo largo de este capítulo hacia una conclusión, puede mencionarse que en el Brasil del Estado Novo se presentó una fuerte propensión hacia la imaginación de un Estado ideal: guiados por Getúlio Vargas, diversos actores que conformaban el régimen emergente de los años treinta fueron facilitadores y muchas veces artífices de estrategias propagandísticas, las

\footnotetext{
48 Maria Celina D’Araújo, Getúlio Vargas (Brasília: Câmara dos Deputados, Edições Câmara, 2011), 773.

49 Ibid., 774.

50 “Matou-se Vargas!", Ultima Hora, 24 de agosto de 1954, 1.
} 
cuales pretendían hacer posible que el líder (Vargas) y su régimen (Estado Novo) se constituyesen positivamente en términos históricos.

Los representantes del Estado Novo, primero, tuvieron que imaginar el tipo de aparato estatal que debían implementar en Brasil, por lo que acuñaron el modelo portugués vigente en la década de los treinta. Luego, debieron pensar en los mecanismos que les permitirían sustentar ese sistema de Gobierno y, finalmente, intentaron crear su propia versión de la historia a través de la difusión del Estado en los medios de comunicación locales, así como mediante la censura.

No bastaba con imaginar el Estado ideal: era necesario difundirlo. Esa fue la única manera de sustentar un régimen como el Estado Novo, cuyas maniobras de represión política atemorizaron fuertemente a la población brasileña, hasta el punto de llevar a algunos intelectuales locales hacia el exilio, porque no había garantías de libertad de opinión pública en el país.

Esto último respondía al hecho de que, para Vargas y su régimen, difundir el Estado tampoco era suficiente; era preciso asegurar que nada atentase contra lo establecido, por lo que se tomaron decisiones radicales para reprimir cualquier intento de sublevación interna. Una vez controlados esos intentos, se garantizó la existencia del Estado Novo hasta 1945. Por supuesto, la Segunda Guerra Mundial contribuyó también a esto, ya que permitió crear una cortina de humo en Brasil que ocultó los abusos de un régimen apoyado fuertemente en el ejército y en mecanismos como la censura o la violencia sistemática.

Todas estas iniciativas pensadas o apoyadas por Vargas para representarse a sí mismo y a su régimen fueron vastas e innovadoras, por eso lo que se trató de mostrar en este texto es que existe la posibilidad de pensar la difusión del Estado a través de la prensa, gracias a dos elementos diferentes pero complementarios: el discurso y la imagen. Esto tiene como objetivo hacer un aporte mínimo al estudio de la historia de Brasil, la cual ha sido objeto de análisis por parte de múltiples investigadores, pero, aun así, sigue mereciendo considerable atención.

Ciertamente, quedan abiertas diversas posibilidades de investigación que no se abordaron aquí. Algunas de estas pueden tener en cuenta los universos del discurso subyacentes en el imaginario de la población brasileña y en las formas de oposición que tuvieron lugar dentro del territorio durante el Estado Novo. Igualmente, queda abierta la posibilidad de indagar más sobre las fotografías y el cuadro trabajados en este ensayo, desde perspectivas diferentes a la propaganda, incluso desde su consumo actual, cuando se han decantado los hechos que en su momento desataron complejos debates al interior de Brasil. 


\section{Bibliografía}

\section{Fuentes primarias}

\section{Archivos}

Biblioteca Nacional Digital do Brasil, Rio de Janeiro.

Fundação Getúlio Vargas (FGV), Arquivo Anísio Teixeira, Rio de Janeiro, Brasil, série: pi (produção inteletual), classificação: AT pi Oliveira, A. de S.

Fundação Getúlio Vargas (FGV), Arquivo Getúlio Vargas, Rio de Janeiro, Brasil, série: confid. (confidencial), classificação: GV confid.

Museu da República-Palácio do Catete, Rio de Janeiro.

\section{Publicaciones periódicas}

A Noite. Rio de Janeiro, 1943.

Ciência Política. Rio de Janeiro, 1943.

Correio da Manhã. Rio de Janeiro, 1943.

Diario de Notícias. Rio de Janeiro, 1943.

Gazeta de Notícias. Rio de Janeiro, 1943.

Jornal do Brasil. Rio de Janeiro, 1942 y 1945.

Los Angeles Examiner. Los Ángeles, 1943.

OJornal. Rio de Janeiro, 1945.

O Radical. Rio de Janeiro, 1942-1943.

Tribuna da Imprensa. Rio de Janeiro, 1954.

Ultima Hora. Rio de Janeiro, 1954.

\section{Fuentes secundarias}

Almeida, Mónica. "Imagens do autoritarismo em tempos de democracia: estrategias de propaganda na campanha presidencial de Vargas em 1950". Revista de Estudos Históricos, n. 34 (2004): 71-90.

Bonet, Fernanda dos Santos. "O discurso oficial brasileiro durante a $2^{\circ}$ Guerra Mundial: o Brasil se une para a guerra”. En Anais do Encontro Estadual de História. Porto Alegre: Associação Nacional de História-Seção Rio Grande do Sul (ANPUH-Rs), 2008.

Córdoba, Dirceo. "Brasil y su actual condición de potencia en la política mundial: entre juegos de percepciones y definiciones académicas (1994-2010)”. Tesis de 
Maestría en Estudios Políticos Internacionales. Colegio Mayor de Nuestra Señora del Rosario, 2012.

Corrêa do Lago, Pedro. "A dedicatória de Roosevelt para Getúlio Vargas”. Revista Piauí, 4 de junio de 2013. http://piaui.folha.uol.com.br/questoes-manuscritas/adedicatoria-de-roosevelt-para-getulio-vargas/ (31/03/2017).

D’Araújo, Maria Celina. “Entre a Europa e os Estados Unidos: diálogos de Vargas com seu diário”. Luso-Brazilian Review 34, n. 1 (1997): 17-41.

D’Araújo, Maria Celina. Getúlio Vargas. Brasília: Câmara dos Deputados; Edições Câmara, 2011.

Delgado, Marcio de Paiva. “O jornalista e político Carlos Lacerda nas crisis institucionais de 1950-1955". En I Coloquio do Laboratorio de Historia Econômica e Social (LAHES). Juiz de Fora: Universidade Federal de Juiz de Fora, 2003.

Fausto, Boris. História concisa do Brasil. São Paulo: Universidade de São Paulo, 2008. Jambeiro, Othon et al., Tempos de Vargas: o rádio e o controle da informação. Salvador da Bahia: Universidade Federal da Bahia, 2004.

König, Hans-Joachim. En el camino hacia la nación: nacionalismo en el proceso de formación del Estado y de la Nación de la Nueva Granada, 1750 a 1856. Bogotá: Banco de la República, 1994.

Luca, Tania Regina de. “A grande imprensa na primeira metade do século xx”. En Historia da imprensa no Brasil, editado por Ana Luiza Martins y Tania Regina de Luca, 149-175. São Paulo: Contexto, 2008.

Medeiros, Rostand. Tok de História, 10 de febrero de 2014, http://tokdehistoria.com.br/2014/02/10/1943-quem-foi-o-motorista-do-jipe-de-roosevelt-e-vargas-em-natal/ (31/03/2017).

Mitchell, W. J. T. Teoría de la imagen: ensayos sobre representación verbal y visual. Madrid: Akal, 2009.

Morães, Rafael Vicente de. "Estado, burguesia e legislação trabalhista brasileira no limiar dos anos 30: notas para uma discussão”. Revista de Estudios Sociales, n. 33 (2009): 129-145.

Museu da República. “Dedicatorias a Getúlio Vargas”. http://museudarepublica. museus.gov.br/exposicoes/dedicatorias/paginas/rooseveltGV101.htm

Muylaert, Roberto. 1943-Roosevelt e Vargas em Natal. São Paulo: RMC, 2012.

Pena, Alberto. “El Estado Novo de Oliveira Salazar y la Guerra Civil española: información, prensa y propaganda (1936-1939)”. Tesis de doctorado en Ciencias de la Información, Universidad Complutense de Madrid, 1997. 
Pinto, António Costa. O salazarismo e o fascismo europeu: problemas de interpretação nas ciéncias sociais. Lisboa: Estampa, 1992.

Prutsch, Ursula. "Nelson A. Rockefeller's Office of Inter-American Affairs in Brazil”. En ;Américas Unidas! Nelson A. Rockefeller's Office of Inter-American Affairs (1940-46), editado por Gisela Cramer y Ursula Prutsch, 249-283. Frankfurt am Main/Madrid: Iberoamericana/Vervuert, 2012.

Revista Museu da República-Palácio do Catete. http://www.revistamuseu.com.br/ emfoco/emfoco.asp?id=2848 (31/03/2017).

Rosas, Fernando. "Cinco pontos em torno do estudo comparado do fascismo". Revista Vértice 2, n. ${ }^{\circ} 13$ (1989): 21-29.

Rouquié, Alain. El Estado Militar en América Latina. México: Siglo XXI, 1984.

Salun, Alfredo. "Noticias sobre o Brasil na guerra e a criação da FEBA”. En A força expedicionaria brasileira e a Segunda Guerra Mundial: estudos e Pesquisas, editado por Denison de Oliveira, 9-17. Rio de Janeiro: Centro de Estudos e Pesquisas de História Militar do Exército, 2012.

Tota, Antonio Pedro. “A americanização no condicional: Brasil nos anos 40”. Perspectivas, n. ${ }^{\circ} 16$ (1993): 191-212.

Tota, Antonio Pedro. O imperialismo sedutor: a americanização do Brasil na época da Segunda Guerra Mundial. São Paulo: Companhia das Letras, 2000.

Williams, Daryl. Culture Wars in Brazil: The First Vargas Regime, 1930-1945. Durham: Duke University Press, 2001.

Wirth, John D. “Tenentismo in the Brazilian Revolution of 1930”. Hispanic American Historical Review 44, n. 2 (1964): 161-179.

Wolfe, Joel. “The Faustian Bargain Not Made: Getúlio Vargas and Brazil’s Industrial Workers, 1930-1945”. Luso-Brazilian Review 31, n. 2 (1994): 77-95. 


\title{
Representando la revolución: la propaganda política del Gobierno de Juan Velasco Alvarado en Perú (1968-1975)*
}

\author{
Anna Cant
}

El Gobierno militar liderado por el general Juan Velasco Alvarado tomó el poder a través de un golpe de Estado el 3 de octubre de 1968. A diferencia de otros gobiernos militares en América Latina que defendían los privilegios de las élites, el autodenominado Gobierno Revolucionario de las Fuerzas Armadas proclamó su intención de derrocar a la oligarquía y llevar a cabo grandes cambios sociales en beneficio de los sectores populares. En su época, el Gobierno de Velasco llamó la atención de los politólogos por su carácter inusual. Estos expertos se preguntaban si se podía clasificar el régimen como un sistema corporativista, si los militares privilegiaban los intereses de una clase social en particular y si el modelo burocrático establecido por el Gobierno ofrecía lecciones para el desarrollo en el llamado tercer mundo. ${ }^{1}$ Sin embargo, se prestaba poca atención a las dinámicas internas del proyecto de movilización social del Gobierno y su recepción entre diferentes sectores de la población.

* La investigación que se presenta en este capítulo formó parte de mi tesis doctoral en historia, de la Universidad de Cambridge (2015). Fue financiada por una beca de doctorado del Arts and Humanities Research Council del Reino Unido.

1 Véase: Peter S. Cleaves y Martín J. Scurrah, Agriculture, Bureaucracy, and Military Government in Peru (Ithaca: Cornell University Press, 1980); Alfred C. Stepan, The State and Society: Peru in Comparative Perspective (Princeton: Princeton University Press, 1978); David Chaplin, ed., Peruvian Nationalism: A Corporatist Revolution (New Brunswick: Transaction Books, 1976). Durante la época, se utilizó el término corporativismo para describir un sistema político en que el Estado canaliza el poder a través de grupos económicos o sociales, por ejemplo, las cooperativas. Desde una perspectiva estructuralista, este sistema fue criticado por limitar la participación política y cooptar los movimientos sociales orgánicos. Véase: Julio Cotler, Clases, Estado y nación en el Perú (Lima: Instituto de Estudios Peruanos, 1978). 
A pesar de ser una "revolución por decreto" - las grandes reformas se llevaron a cabo por medio de decretos y leyes,- 2 en términos prácticos, el éxito de las reformas dependía del trabajo de los funcionarios del Estado en el ámbito local y su capacidad de mantener el apoyo popular. ${ }^{3}$ Así mismo, el Gobierno utilizaba la comunicación de masas de una manera innovadora y extensa para generar el respaldo popular, por lo que acudieron a periodistas, artistas e intelectuales para promover sus reformas. $\mathrm{Al}$ respecto, se pueden hacer comparaciones con los usos de las imágenes que se implementaron durante la Revolución Cubana, en las campañas de Unidad Popular en Chile o en la iconografía del peronismo en Argentina: a través de las imágenes, el Gobierno de Velasco pretendía difundir un nuevo proyecto nacional. Por medio del análisis visual de la propaganda política, este capítulo muestra cómo el Gobierno militar intentó dirigir su "revolución desde arriba" y explora las tensiones que surgieron en esta. Al tomar como enfoque la reforma agraria (Decreto Ley 17716 de 1969), se analizarán las diferentes funciones que tenían las imágenes dentro de la propaganda oficial y se ofrecerán algunas reflexiones sobre la recepción y la apropiación de estas imágenes por parte de otros actores políticos.

La propaganda política asumió especial importancia en el contexto de la reforma agraria, ya que esta pretendió lograr un cambio masivo en la propiedad de la tierra. Cuando el Gobierno de Velasco tomó el poder, el nivel de la desigualdad en la propiedad de la tierra en el Perú era uno de los más altos en toda la región: según el censo nacional de 1961, el $56 \%$ de la extensión agrícola estaba en manos del $3,9 \%$ de las unidades agropecuarias; mientras que el $96 \%$ de las unidades restantes ocupaban solo el 7,5\% de las tierras de cultivo. ${ }^{4}$ Anteriormente se habían intentado llevar a cabo dos reformas agrarias en el país: primero, durante el Gobierno militar de Lindley Godoy (1963), que abarcaba solo los departamentos de Cusco y Apurímac; luego, bajo el Gobierno de Fernando Belaúnde Terry (1963-1968). A pesar de haber proclamado la necesidad de una verdadera reforma agraria durante su campaña electoral, Belaúnde se encontró incapacitado por la oposición conservadora en el Congreso. La ley de reforma agraria que su Gobierno promulgó en

2 Dirk Kruijt, Revolución por decreto: Perú durante el Gobierno militar, trad. por R. B. Smith (San José: Facultad Latinoamericana de Ciencias Sociales [Flacso], 1991).

3 Anna Cant, "Promoting the Revolution: Sinamos in Three Different Regions of Peru", en The Peculiar Revolution: Rethinking the Peruvian Experiment Under Military Rule, ed. por Carlos Aguirre y Paulo Drinot (Austin: University of Texas Press, 2017), 213-239.

4 José Matos Mar y José Manuel Mejía, La reforma agraria en el Perú (Lima: Instituto de Estudios Peruanos, 1980), 27-28. 
1964 sufrió varias limitaciones y dejó sin efecto a los grandes latifundios, que aún dominaban el acceso a la tierra y la estructura de la economía peruana.

De ahí que el Gobierno de Velasco llegara al poder con una clara percepción de cuán difícil iba a ser desarrollar una reforma agraria de verdad. Benjamín Semanez Concha, uno de los encargados de redactar la nueva ley, describió la intención del comité en que trabajaba de la siguiente manera:

Queríamos realizar una Reforma Agraria de tipo estructural, no una reforma convencional como la que propiciaba la Ley 15037 [la reforma agraria del Gobierno de Belaúnde] y como las que estaban en vigencia en otros países. Una ley avanzada que planteara una reforma agraria que pudiera ser masiva, rápida y drástica. ${ }^{5}$

El Decreto Ley 17716, promulgado el 24 de junio de 1969, inició un proceso ambicioso: expropiar las grandes haciendas y redistribuir la tierra a nuevas cooperativas agrarias y comunidades campesinas. A diferencia de procesos de reforma agraria en otras partes del mundo, el Decreto Ley 17716 no funcionó con base en peticiones individuales hacia el Estado, sino que se implementó por zonas agrarias. Una vez que se declaraba una zona de reforma agraria, se requería que todos los hacendados remitieran pruebas de sus derechos de propiedad y del tamaño de esta; posteriormente, los funcionarios empezaban el proceso de expropiación de las tierras, según las prioridades del Estado. Este modo de implementación hizo que la reforma tuviera un carácter intenso, con muchas intervenciones simultáneas en diferentes partes del país. En este contexto, la propaganda oficial sirvió para neutralizar la oposición y alentar la participación popular en el nuevo sistema cooperativo.

La resistencia a la reforma agraria, y al Gobierno en general, provenía de diferentes sectores. Por una parte, los grandes hacendados utilizaron su influencia en los medios de comunicación para desacreditar la ley. En el ámbito local, se valieron de sus contactos personales en los ministerios de Gobierno para evadirla y presionaron a sus trabajadores para no participar en la adjudicación de tierras y el establecimiento de las cooperativas. Por otra parte, la ley fue altamente criticada por los partidos de la izquierda por ser "reformista" en vez de "revolucionaria"; opinaban

5 Benjamín Samanez Concha, en discusión con María del Pilar Tello, Lima, 1981. Agradezco a María del Pilar Tello por darme acceso a las transcripciones inéditas de sus entrevistas a varias figuras importantes de la época. 
que no se debía ofrecer ningún tipo de compensación a los exhacendados y veían el sistema cooperativo como un desplazamiento de los sindicatos y las comunidades indígenas vigentes. Cabe decir que, apenas una década después del triunfo de Fidel Castro en Cuba, los activistas de la izquierda veían probable que aconteciera una revolución parecida en el Perú e interpretaron las intervenciones del Gobierno militar como un intento por disminuir el potencial revolucionario de los campesinos. La propaganda oficial tenía varias funciones: generar el interés de los campesinos, quienes desempeñaron un papel central en el funcionamiento de las cooperativas; desmentir los mensajes de los hacendados, quienes buscaron posicionarse como las víctimas de una política insensata, y competir con los izquierdistas, quienes denunciaron a los funcionarios del Gobierno por ser autoritarios e ingenuos. ${ }^{6}$

Antes de entrar en el análisis, es importante clarificar lo que se entiende por el término propaganda. A veces, es difícil distinguir entre la propaganda y otros tipos de representación. El planteamiento de este capítulo coincide con la perspectiva del historiador del arte Timothy J. Clark, quien sostiene que:

La propaganda es una representación de los acontecimientos y problemas, simplificados de tal manera que el significado de los eventos, y la solución a los problemas, parecen estar inmediatamente presentes en la representación en sí; y perceptibles en un instante, de manera que no admite argumentos. La representación sirve a los intereses de los que la ordenaron. Se invita a sus lectores y espectadores a tomar partido, o mejor, se supone que solo existe un partido que los lectores y espectadores (a diferencia de los enemigos y los cretinos) pueden tomar. Intenta desconectarse de, o ahogar, los entendimientos contrarios. Pronuncia los hechos - los hechos éticos, los hechos de la lealtad y la simpatía humana- para ellos mismos. ${ }^{7}$

6 Anna Cant, "Representations of the Peruvian Agrarian Reform, 1968-75" (tesis de doctorado, Universidad de Cambridge, 2015), 133-180.

7 "Propaganda is a representation of events and problems, simplified in such a way that the meaning of the events, and the solution to the problems, seems immediately present in the representation itself; and perceivable in a flash, in a manner that brooks no argument. The representation serves the interests of those who ordered it. It invites its viewers and readers to take sides, or better, it assumes that there is only one side for viewers and readers (as opposed to enemies and cretins) to take. It tries to tune out or drown out contrary understandings. It says the facts-the ethical facts, the facts of allegiance and human sympathy-for themselves". T. J. Clark, Farewell to an Idea: Episodes from a 
La definición de Clark es útil porque nos lleva más allá de aquella idea que define la propaganda simplemente como comunicación persuasiva, una categoría tan amplia que puede perder el valor analítico. Más bien, Clark resalta los mecanismos particulares a través de los cuales la propaganda intenta convencer, así como la relación que establece con el espectador. Esta relación se configura dentro de imágenes específicas, pero también se refuerza de manera repetitiva mediante lo que Clark — de acuerdo con Noam Chomsky— denomina sistema de propaganda. ${ }^{8}$ En otras palabras, la repetición sostenida de motivos e ideas forma el contexto en el que se reciben y se interpretan las representaciones específicas. En el caso del Perú, las representaciones del Gobierno a través de diferentes medios de comunicación y esferas sociales funcionaron juntas para posicionar a la reforma agraria como parte de un "proceso revolucionario" más amplio. Así mismo, la definición de Clark señala las diferentes maneras en las que la propaganda puede influenciar el comportamiento político. En efecto, además de instruir al lector o espectador para llevar a cabo una acción específica, la propaganda puede contribuir al desarrollo de una orientación política o una simpatía más general. En el caso de la reforma agraria peruana, tanto la propaganda del Gobierno como la de la oposición alentaron al público a tomar partido; así, las consignas e imágenes desempeñaron un papel importante en la formación de las identidades de grupo.

En cuanto a la metodología, esta investigación se fundamenta en el trabajo de la socióloga Victoria Bonnell y sus esfuerzos por descubrir los "repertorios culturales" del espectador. La expresión repertorio cultural hace referencia a "los hábitos de ver e interpretar las imágenes" de una población específica y "el contexto en que se interpretaba el arte político". ' La investigación de Bonnell sobre los afiches políticos de la Unión Soviética revela las conexiones que existen entre estas piezas y las diferentes tradiciones artísticas rusas, con respecto a su contenido y estilo artístico. Por ejemplo, la autora analiza cómo la larga tradición de los iconos religiosos influenció la manera en que los rusos interpretaron los afiches soviéticos; en particular, el hecho de que tradicionalmente se utilizaba el color rojo en los iconos para significar la

History of Modernism (New Haven: Yale University Press, 1999), 292. Todas las traducciones son de mi autoría, a menos que se indique lo contrario.

8 Ibid. Véase también: Noam Chomsky, Necessary Illusions: Thought Control in Democratic Societies (Boston: South End Press, 1989).

9 Victoria E. Bonnell, Iconography of Power: Soviet Political Posters Under Lenin and Stalin (Berkeley: University of California Press, 1999), 12-13. 
santidad: "Cuando los artistas bolcheviques utilizaban el color rojo para representar los obreros, invocaban a una convención antigua del simbolismo de colores que a la mayoría de los rusos les resultaba familiar". ${ }^{10}$ Para el caso del Perú, este capítulo identifica patrones en las imágenes que se utilizaron para representar la reforma agraria y reflexiona sobre las formas en las que el texto y la imagen se contradecían o funcionaban en conjunto para transmitir un mensaje específico.

Es importante tener en cuenta que, aunque el Gobierno militar dio mucha importancia a la movilización política, en un comienzo no tenía un plan claro sobre cómo conseguirla. El llamado Sistema Nacional de Apoyo a la Movilización Social (Sinamos) desempeñó un rol fundamental en la coordinación oficial de las actividades políticas en el país: desde mítines masivos hasta la creación de cooperativas y la capacitación de estas. Sin embargo, esta agencia estatal se creó en 1972, aproximadamente cuatro años después del golpe de Estado. A menudo, el Gobierno se cuestionaba acerca de la mejor manera de generar el apoyo político; por lo tanto, en vez de concebir la propaganda oficial como la articulación de un plan preestablecido, es importante considerar las tensiones que rodeaban las estrategias de comunicación política y la naturaleza volátil de las relaciones entre el Gobierno y sus artistas patrocinados. Por ejemplo, en 1973, Nora de Izcue produjo una película, bajo los auspicios de Sinamos, llamada Runan Caycu, la cual documentó una exitosa lucha por la tierra llevada a cabo por un grupo de campesinos antes de la reforma agraria de 1969 . Hoy en día esta película es ampliamente aclamada por sus innovadoras técnicas documentales; no obstante, debido a la censura oficial, no se aprobó hasta 1976, a pesar de haber sido patrocinada por el Gobierno. ${ }^{11}$ Así, prestar atención a las diferentes personas e ideas involucradas en la comunicación masiva ayuda a no caer en el error - advertido por Harriet Evans y Stephanie Donald- de interpretar cualquier ejemplo de propaganda estatal como "una expresión uniforme de la retórica política autoritaria”.12

$10 \quad$ Ibid., 13.

11 Ricardo Bedoya, 100 años de cine en el Perú: una historia crítica (Lima: Universidad de Lima, 1992), 202.

12 Harriet Evans y Stephanie Donald, eds., Picturing Power in the People's Republic of China: Posters of the Cultural Revolution (Oxford: Rowman \& Littlefield, 1999), 20. 


\section{La participación popular}

Antes de que se anunciara la ley de reforma agraria, el Gobierno contrató a Efraín Ruiz Caro, un periodista experimentado, para ayudar en la proyección de su imagen oficial. Además de escribir los discursos del presidente Velasco, Ruiz Caro era el encargado de fundar la Dirección de Promoción y Difusión de la Reforma Agraria (DPDRA), un equipo pequeño de publicistas, artistas y escritores: Jesús Ruiz Durand, Mirko Lauer, José Bracamonte, Emilio Hernández Saavedra, José Adolph, entre otros. Estas personas ya tenían carreras exitosas en sus respectivos campos: Lauer era un poeta conocido y Ruiz Durand había exhibido su obra en el Museum of Modern Art de Nueva York. La DPDRA produjo afiches, panfletos y volantes que se distribuían por todo el país para anunciar las actas de expropiación y adjudicación de tierras. ${ }^{13}$ De igual manera, se utilizaban los panfletos para informar a los campesinos sobre los términos de la nueva ley. Dados los altos índices de analfabetismo en el país (38,9\% de la población mayor de 15 años en las áreas rurales, hacia 1961), se esperaba que estos folletos formaran la base de discusiones entre los letrados y los iletrados. ${ }^{14}$ Por ejemplo, un panfleto dirigido a los feudatarios incluyó el siguiente aviso: "No arrojes este folleto, no lo guardes, muéstraselo a tus hermanos feudatarios. Infórmalos de sus deberes y derechos en relación a la nueva Ley de Reforma Agraria.. ${ }^{15}$ Así mismo, un folleto titulado "abc de la reforma agraria peruana” se estructuró con una serie de preguntas y respuestas para exponer a los campesinos lo que ofrecía la reforma. ${ }^{16}$

Los afiches y panfletos también expresaban la ideología y las expectativas del régimen. De esta manera, un folleto dirigido a la población urbana daba instrucciones sobre la mejor manera de contribuir al proceso de la reforma agraria: " $\mathrm{Si} \mathrm{Ud}$. piensa capacitar en el campo RECUERDE que su aporte más valioso será en el aspecto personal y humano. Si está Ud. trabajando para la Reforma Agraria no OLVIDE que el protagonista de la Reforma Agraria es el campesino" (figura 1). Así mismo,

13 Véase: Anna Cant, “'Land for those Who Work It': A Visual Analysis of Agrarian Reform Posters in Velasco's Peru", Journal of Latin American Studies, n. ${ }^{\circ} 44$ (2012): 1-37.

14 Instituto Nacional de Estadística, ed., Compendio de estadísticas sociales 1991 (Lima: Instituto Nacional de Estadística, 1992).

15 "A los yanaconas, aparceros, arrendires..." (Lima: Dirección de Promoción y Difusión de la Reforma Agraria, 1969), 10, en Senate House Library, Contemporary Archive on Latin America (shlCALA), Londres, Reino Unido, K320 Pam Box 3.

16 "abc de la Reforma Agraria Peruana" (Lima: Dirección de Promoción y Difusión de la Reforma Agraria, 1969), en SHLCALA, K320 Pam Box 3. 
un anuncio en el periódico dirigido a estudiantes y jóvenes llevaba el lema: "No hay revolución sin juventud. Porque no hay juventud sin revolución”. Por medio de una invitación a los estudiantes para participar en el programa de reformas del Gobierno, el anuncio preguntó: “QQuién puede darse el lujo de seguir siendo espectador, ser barrido por la historia y quedar al margen de la revolución peruana?”. ${ }^{17}$
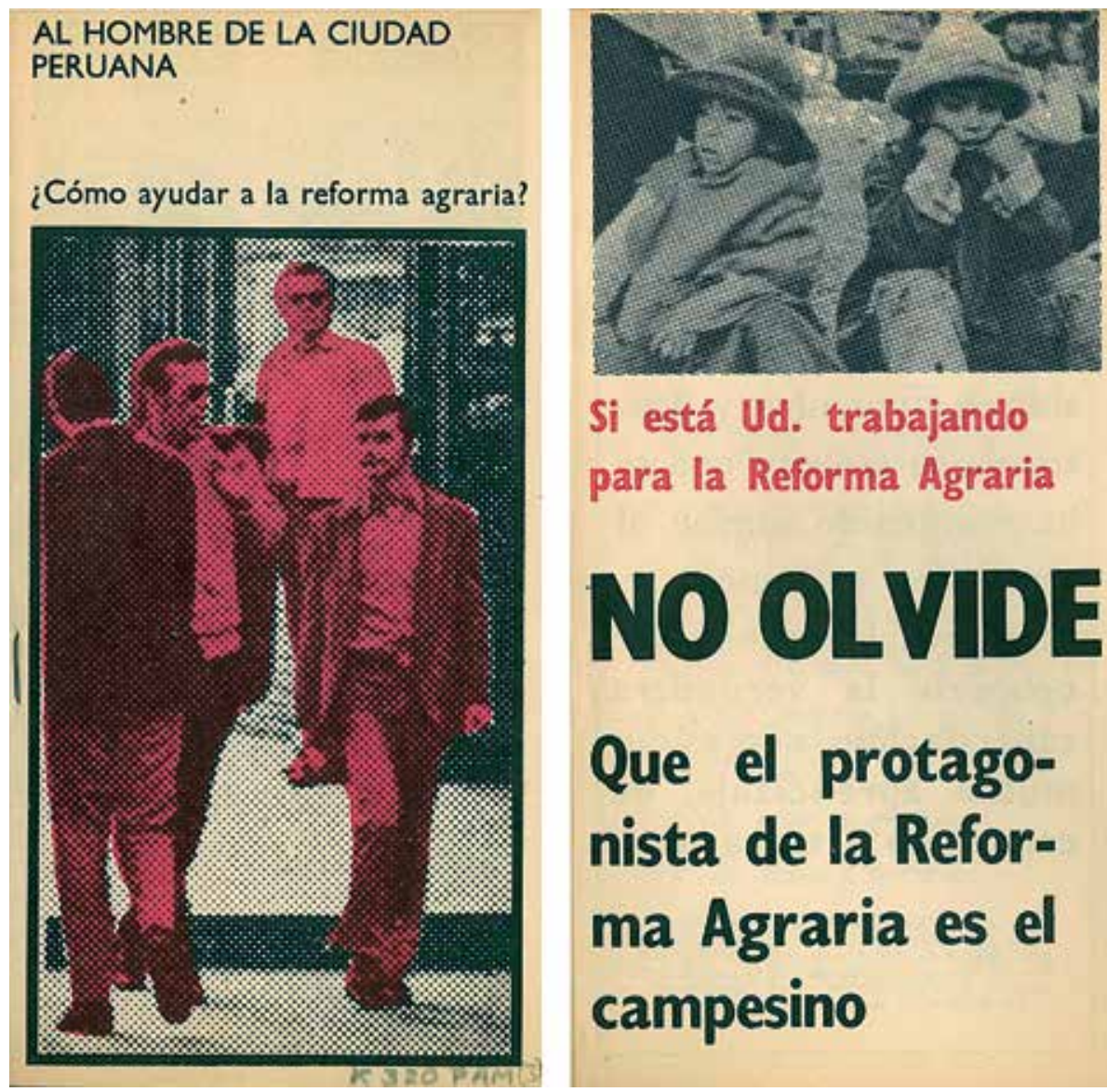

Que el protagonista de la Reforma Agraria es el campesino

Figura 1. Dirección de Promoción y Difusión de la Reforma Agraria (DPDRA), 1969, "Al hombre de la ciudad peruana: ¿Cómo ayudar a la reforma agraria?” (panfleto, DPDRA, Lima).

17 “La Revolución les pertenece”, El Comercio, 8 de octubre de 1969, 19. 
Comparar los textos y las imágenes de estos ejemplos de propaganda oficial revela contradicciones y tensiones relevantes en los esfuerzos por expresar el significado político de la reforma agraria. A pesar de que el Gobierno intentó presentar la reforma como un momento de reivindicación del campesinado, las imágenes que aparecían en la propaganda oficial no siempre reflejaban esta narrativa. Por ejemplo, el folleto dirigido a los sectores urbanos (figura 1) ofrece un fuerte contraste visual entre el hombre urbano, que lleva buena ropa y anda muy relajado, y sus homólogos rurales, quienes llevan ropa raída y tienen aire de desesperados. En el mismo momento en que el folleto invoca al campesinado, las imágenes parecen disminuir la fuerza independiente de los campesinos. Dada la larga historia de luchas campesinas en el país y la escala de las sublevaciones que se habían presentado en la sierra entre 1963 y 1964, este tipo de elecciones en la proyección del imaginario oficial son muy significativas. ${ }^{18}$ El efecto en conjunto del panfleto es incitar la empatía, más que animar al lector a tomar una acción en particular. El mensaje implícito parece ser que la reforma agraria será coordinada por el Gobierno, pero no por los campesinos o los hacedores urbanos.

El poder omnisciente del Estado también se expresa en una foto que apareció en otro panfleto sobre la reforma agraria, en la que un campesino tiene dos cartillas de la DPDRA en sus manos (figura 2). El sujeto sostiene uno de los panfletos como si fuera una bandera o pancarta y parece mirarlo simplemente, en vez de leerlo. La escena es bastante artificial y celebra la información que se repartía desde arriba: no captura el compromiso del campesino con la reforma. Esta imagen apareció en un folleto titulado "Del latifundio a la cooperativa", el cual se publicó para coincidir con el primer aniversario de la "revolución" (el golpe de Estado del 3 de octubre de 1968). Así, forma parte de los esfuerzos del Gobierno para conmemorar sus propias acciones; de igual forma, es una expresión simbólica de la posición del campesino dentro de la "nueva política" y está dirigida a los funcionarios y observadores externos del proceso de la reforma agraria, más que a sus beneficiarios. Aun así, sugiere una forma de empoderamiento muy indirecta: la reforma agraria se presentó como una revolución en nombre del campesinado, en lugar de una revolución que involucrara a los campesinos. Hasta cierto punto, las imágenes ofrecieron al Gobierno la posibilidad de insertar a los campesinos en la revolución en un ámbito simbólico, sin la necesidad de abrir el proceso político por completo a un movimiento desde abajo.

18 Sobre estos levantamientos, véase: Hugo Neira, Cuzco: tierra y muerte (Lima: Herética, 2008). 


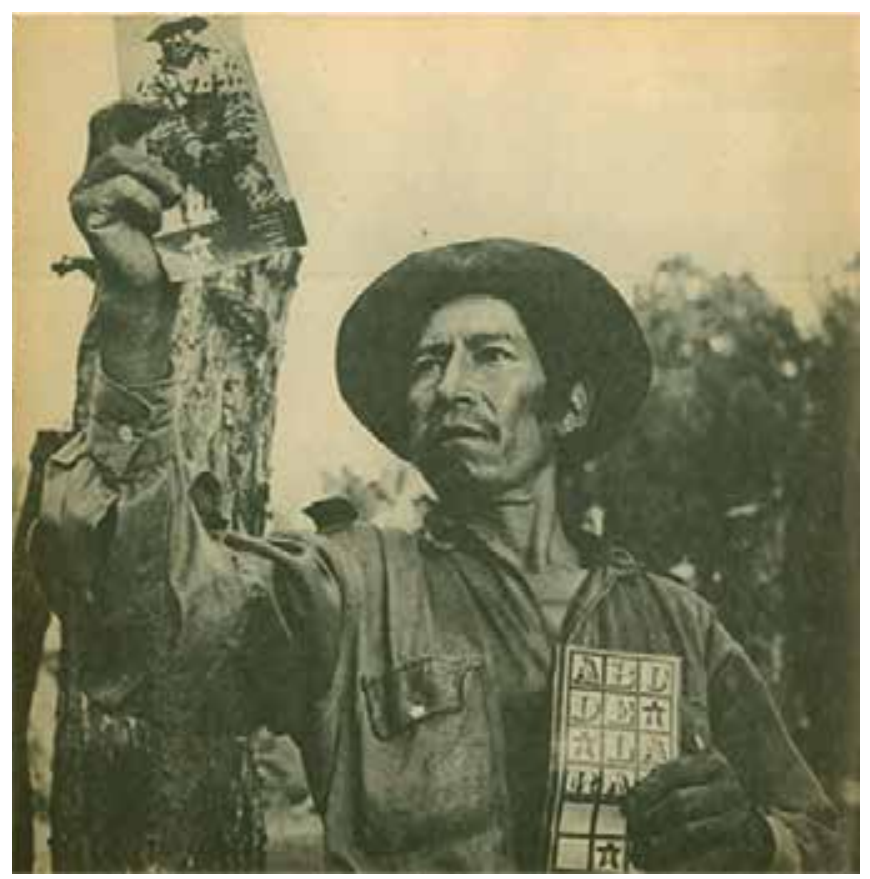

Figura 2. Dirección de Promoción y Difusión de la Reforma Agraria (DPDRA), 1970, "Del latifundio a la cooperativa" (fotografía, DPDRA, Lima).

Esta estrategia, quizás algo cínica, no fue compartida por todas las personas que participaron en la difusión y aplicación de las reformas. De hecho, hubo tensiones importantes entre los militares y los civiles que trabajaban en Sinamos, la agencia encargada de promover la participación popular. Con frecuencia, la perspectiva de los militares sobre la organización política chocaba con las tendencias del activismo de los civiles. Carlos Franco, una figura clave dentro del liderazgo de Sinamos, unos años después, en una entrevista con la periodista María del Pilar Tello, comentó:

Aunque la posición de los militares variaba de uno a otro, había gente que no ocultaba sus dudas respecto a la naturaleza leal o infiltrada de nuestra colaboración. Para otros nuestro estilo no les daba seguridad en la medida que insistíamos en que promover la organización popular implicaba plazos largos, logros por persuasión, respeto por las diferencias y los conflictos que se podían tener entre miembros del equipo revolucionario e intereses parciales o sectoriales. ${ }^{19}$

19 Carlos Franco, en discusión con María del Pilar Tello, Lima, 1981. 
Muchos de los militares abogaron por una forma de organización jerárquica y temieron que un estilo o estructura más flexible abriera la puerta a la infiltración política. Es importante resaltar que no todas las imágenes oficiales vinieron desde el Gobierno central. Sinamos se convirtió en un espacio en el que muchos artistas y escritores podían desarrollar su arte; en efecto, allí tenían bastante autonomía para experimentar con diferentes métodos de "comunicación popular". ${ }^{20}$ La organización se estructuraba por regiones; dentro de cada región de Sinamos había varias oficinas zonales, responsables de las actividades de los promotores locales en una o más provincias. Los promotores locales tenían bastante libertad y recursos para implementar sus propios programas de capacitación y propaganda; se preocupaban por reflejar las condiciones y culturas locales para tener un mayor impacto. Por ejemplo, en un afiche que produjo la oficina zonal en Azángaro, Puno, en el altiplano sur, aparece un hombre que usa la chaquitaclla, una herramienta de origen preincaica, la cual aún hoy en día se utiliza en algunas partes de los Andes (figura 3). La chaquitaclla es un mecanismo de arado de pie, construido con base en un palo largo que termina en punta y un palo transversal, en el cual el agricultor coloca el pie y presiona para remover la tierra. Históricamente, es una herramienta adecuada para las tierras sobre pendientes de la sierra alta, donde el uso de bueyes o maquinaria avanzada era - y, en unos casos, aún es— logísticamente difícil. ${ }^{21}$ Además de hacer referencia a las tradiciones de la agricultura local, el afiche resalta la fuerza de la población local y sus raíces indígenas: el hombre que usa la chaquitaclla tiene rasgos indígenas y su cuerpo musculoso tiene las proporciones de un superhéroe. El lema que acompaña esta imagen ("la tierra es de quien la trabaja”) parece afirmar una verdad eterna, pero no una innovación del Gobierno. Aquí hay un contraste importante con el imaginario que se utilizó para promover la reforma agraria en los grandes complejos azucareros del norte del país, en el cual se subrayó la modernidad y los nuevos derechos económicos que vendrían con la reforma agraria. De esta manera, las imágenes que se producían en el ámbito local tenían un papel importante en la formación de la percepción popular sobre la reforma, en diferentes partes del país.

20 Los resultados de este espacio y este interés por la comunicación popular se sentirán en décadas posteriores, cuando artistas gráficos que trabajaron como promotores de Sinamos desarrollan nuevas formas de comunicación visual. Véase en este libro el capítulo de Natalia Mahecha Arango, "Un conflicto entre viñetas: historietas de la violencia política en el Perú (1989-2010)”.

21 Daniel W. Gade y Roberto Ríos, "Chaquitaclla, the Native Footplough and its Persistence in Central Andean Agriculture”, Tools and Tillage 2, n. ${ }^{\circ} 3$ (1972): 3-15. 


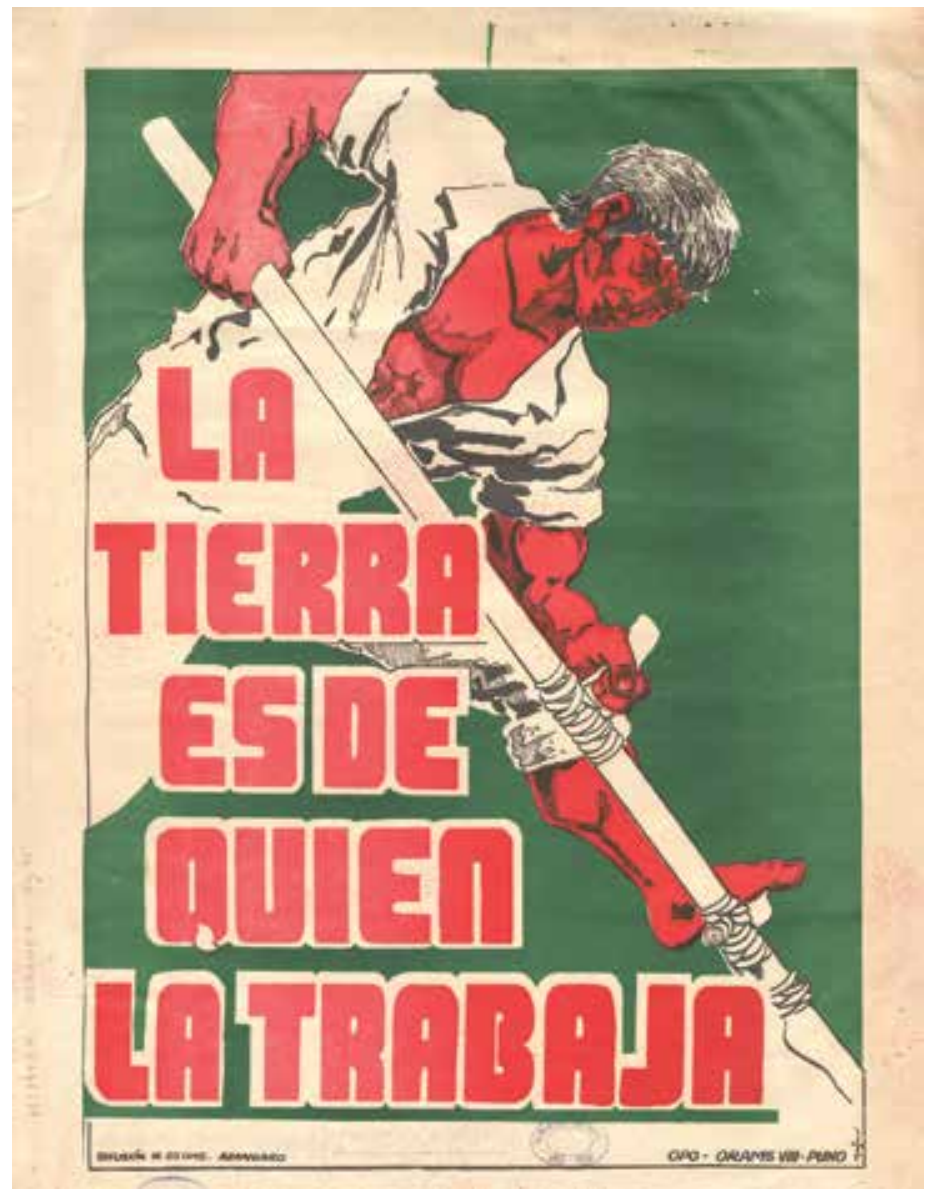

Figura 3. Oficina local de Sinamos en Azángaro (Puno), 1973, "La tierra es de quien la trabaja" (Afiche, Biblioteca Nacional del Perú, Lima, Colecciones Especiales [sin catalogar]).

\section{La legitimidad política}

El Gobierno de Velasco dedicó considerables esfuerzos a la consolidación de su lugar en la historia. Por ejemplo, patrocinó la edición de un libro de tres volúmenes titulado Historia general de los peruanos. ${ }^{22}$ El tercer volumen tuvo el grandioso título: El Perú: primera y segunda independencia 1821 y 1968, lo que insinuaba que el comienzo del régimen de Velasco marcó un cambio de igual importancia que la independencia en la Colonia. Aunque el libro se publicó en 1973, cuando la implementación de la reforma agraria estaba apenas en medio de su primera fase,

22 Federico Kauffman Doig et al., Historia general de los peruanos (Lima: Peisa, 1973). 
se dedicaron varias páginas a la "historia" de la reforma y su significado nacional. En anticipación de la resistencia contemporánea y las contrarreformas del futuro, el Gobierno de Velasco intentó definir la reforma agraria como una transformación irreversible de la "historia del pueblo", en lugar de una política del Gobierno impuesta desde arriba.

Mis investigaciones en los periódicos regionales de la época muestran que los actos de conmemoración de la reforma agraria incorporaron elementos de la historia nacional y local. Por ejemplo, en la ciudad de Piura (norte del país) se celebró el primer aniversario de la reforma con una procesión y varios discursos. Uno de estos discursos hizo referencia a la memoria del precursor del movimiento cooperativista en Piura, Manuel Negri Ulloa, y pidió un minuto de silencio en su memoria. Así mismo, un representante del pueblo de Andando habló de la tragedia que este experimentó en 1954, cuando los hacendados quemaron sus casas y cometieron "abusos inhumanos" a los pobladores. ${ }^{23}$ Alvincular la conmemoración de la reforma agraria con la cultura y la historia regionales, el Gobierno intentó incorporarla a una concepción más amplia de la "historia del pueblo".

Esta estrategia es muy evidente en las imágenes que poblaron la propaganda oficial, sobre todo en el tratamiento de la imagen de Túpac Amaru II. Originalmente llamado José Gabriel Condorcanqui, Túpac Amaru II fue un cacique cusqueño que lideró una sublevación indígena en contra del Virreinato en 1780. Al capturarlo, en 1781, los españoles lo descuartizaron y reprimieron a sus seguidores. Como comenta Nanda Leonardini: "El Gobierno militar revolucionario enarbola esta imagen como un ideal de alguien que, como ellos, también cuestionó el sistema establecido en la búsqueda de reivindicar los derechos ciudadanos y económicos del pueblo oprimido por una élite no interesada". ${ }^{24} \mathrm{El}$ poder de prócer como un emblema de la revolución se acentuó a través del uso repetitivo de su nombre e imagen en la esfera pública, desde la construcción de nuevos monumentos, plazas y calles hasta los nombres y logotipos de las nuevas cooperativas agrarias; incluso, los supermercados estatales llevaban un símbolo estilizado de Túpac Amaru.

El cacique cusqueño es un héroe popular no solo por sus actos de rebelión, sino también porque encarnó la creencia de que el espíritu de los incas había sobrevivido en la población peruana tras la invasión española. Condorcanqui asumió el

23 "Desfile tres horas de campesinos en apoyo a Reforma", La Industria, 25 de junio de 1970, 1.

24 Nanda Leonardini, "Identidad, ideología e iconografía republicana en el Perú, ARBOR Ciencia, Pensamiento y Cultura 185, n. 740 (2009): 1265. 
nombre de Túpac Amaru con la intención de asociarse con el linaje inca; también, afirmó ser descendiente directo del último rey inca, Atahualpa. A nivel más literal, según el mito de Inkarri, Atahualpa, cuyo cuerpo estaba enterrado por partes en diferentes regiones del país, estaba regenerándose bajo tierra y algún día regresaría a la superficie para restaurar la armonía del Imperio inca. ${ }^{25}$ Así, la representación de la reforma agraria como una continuación de la lucha de Túpac Amaru aludió tanto a la tradición de la rebelión popular auténtica como al mito del espíritu inca. La figura 4 es un ejemplo claro de la manera en que el Gobierno de Velasco construyó estas asociaciones políticas e históricas por medio de las imágenes. Esta pieza es un afiche de Sinamos (reproducido en el libro Historia general de los peruanos), en el cual la figura del líder revolucionario se superpone sobre una foto de campesinos vestidos con prendas típicas del sur de la sierra. La composición de la imagen es interesante porque Túpac Amaru aparece detrás del grupo de campesinos, en lugar de tomar una postura de liderazgo en primera fila, lo que sugiere una relación horizontal entre el rebelde y los campesinos. De igual manera, parece insinuar que estos avanzan hacia el futuro acompañados por la herencia de Túpac Amaru. Esta idea de una presencia espiritual se refuerza gracias al lema “está con nosotros”, el cual acompaña la imagen. Por otra parte, el lema también es una muestra de la ubicuidad de la representación de Túpac Amaru: ni siquiera hay necesidad de nombrarlo, pues su presencia es instantáneamente reconocible.

La representación de Túpac Amaru como un "espíritu” que vivía en todos los peruanos ayudó al Gobierno militar a apropiarse del prócer como símbolo de su revolución. Esto se evidencia muy claramente en la publicidad que produjo el Gobierno para Inkarri, un festival cultural anual que reunía a cientos de artistas y exhibía el folclor, la danza, la música y las tradiciones artísticas de cada región. En el folleto conmemorativo para el Inkarri de 1973 se combinan las fotos de los participantes con extractos de un texto colonial, el cual prohibió a los “indios” mantener sus prácticas culturales o conservar los artefactos relacionados con su herencia inca (el texto se emitió originalmente como respuesta a la rebelión de Túpac Amaru en 1780). Así, las fotos sirven como expresión de la resistencia popular y la capacidad de la gente para mantener sus tradiciones culturales.

25 Gustavo Buntinx, "Pintando el horror: sobre memorias de ira y otros momentos en la obra de Jesús Ruiz Durand", en Batallas por la memoria: antagonismos de la promesa peruana, ed. por. Marita Hamann et al. (Lima: Pontificia Universidad Católica del Perú, Universidad del Pacífico, Instituto de Estudios Peruanos, 2003), 318. 


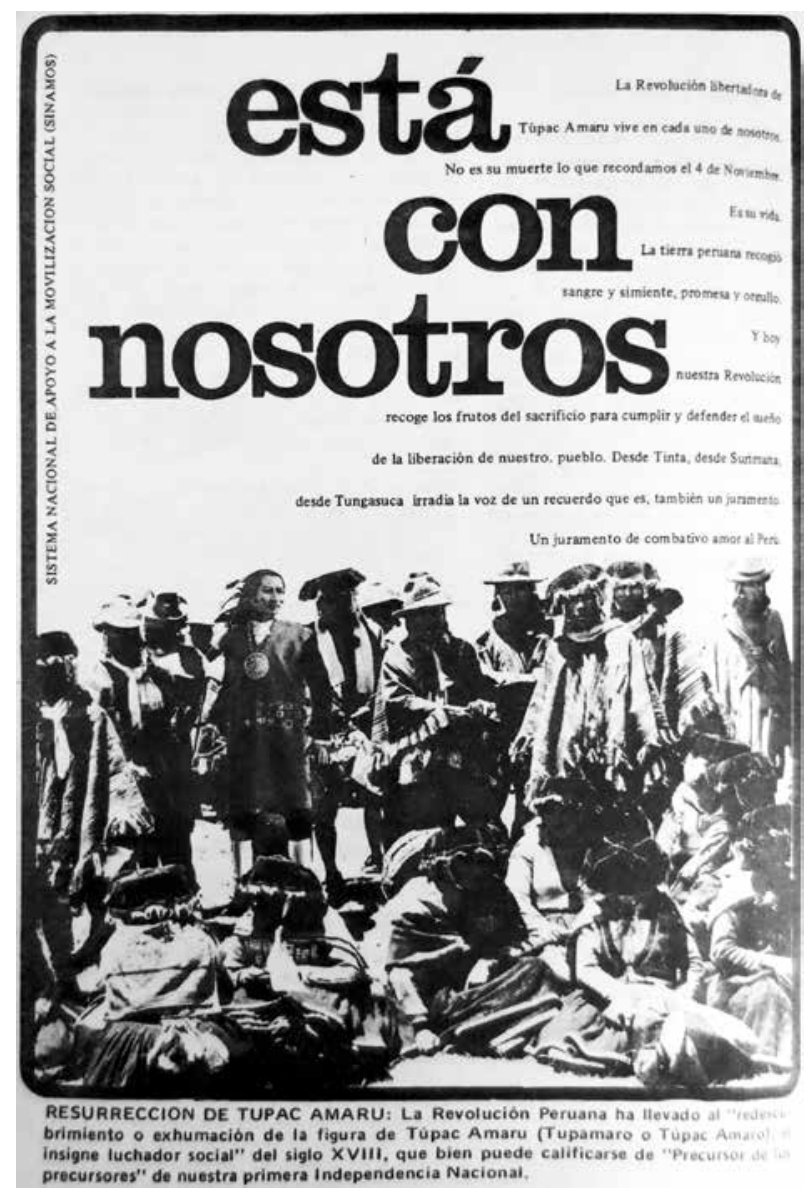

Figura 4. Sistema Nacional de Apoyo a la Movilización Social (Sinamos), c. 1972, "Está con nosotros" (afiche, tomado de Federico Kauffman Doig et al., Historia general de los peruanos [Lima: Peisa, 1973], 316).

$\mathrm{Al}$ mismo tiempo, el folleto introduce al Gobierno en estas tradiciones por medio de imágenes en las que los militares aparecen como espectadores o, incluso, como inspiración para las obras de arte. El tríptico de fotos que se presenta en la figura 5 muestra cómo el Gobierno buscó asociarse tanto con las tradiciones andinas (los danzantes) como con la artesanía contemporánea (el artista que moldea una figura de Velasco con arcilla). Así mismo, el texto que acompaña la imagen conecta ambos fenómenos con el desafío de combatir la dominación cultural de los españoles: "por causa del rebelde, mandase que los naturales se deshagan o entreguen a sus corregidores cuantas vestiduras tuvieren, como igualmente las pinturas o retratos de sus incas...”. La organización de las imágenes en la página también es 
interesante, porque surgiere una relación recíproca entre el Gobierno militar y el arte popular. A través del uso cuidadoso de la retórica visual, el Gobierno logró presentarse como la expresión de un movimiento popular, en lugar de una dictadura impuesta desde arriba.

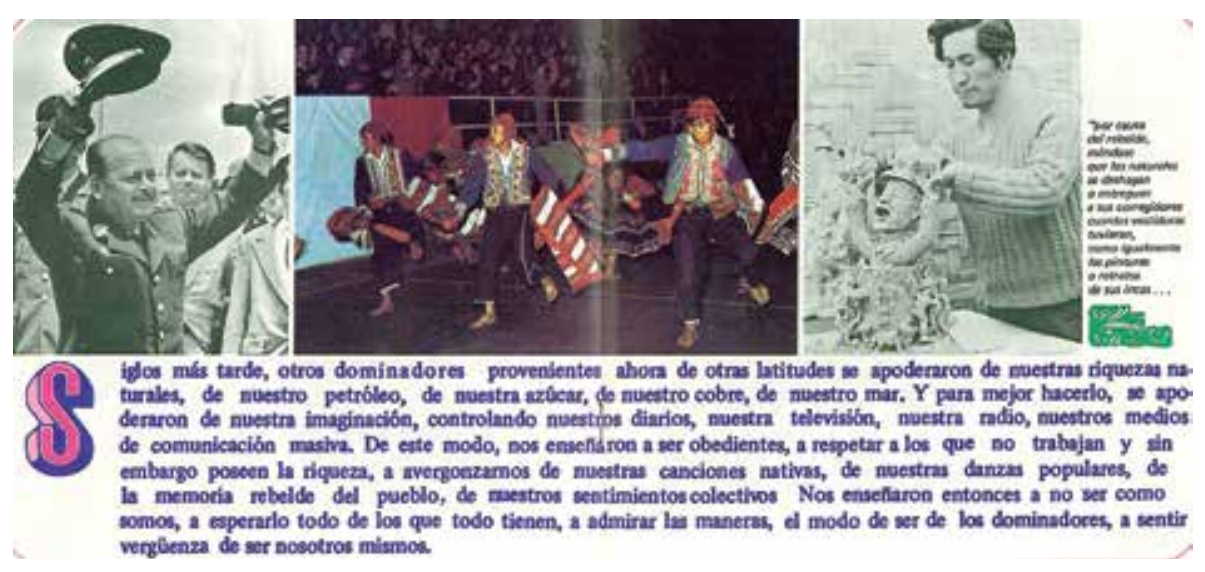

Figura 5. Carlos Sánchez, 1973, “iHermanos! Una mañana del mes de noviembre de 1781, y luego de la transitoria derrota de Túpac Amaru, apareció en bandos públicos diseminados a lo largo del Cuzco la siguiente sentencia contra el pueblo..." (folleto conmemorativo del festival cultural Inkarri, Sinamos, Lima).

Si bien la imagen de Túpac Amaru desempeñó un papel importante en la legitimación del Gobierno de Velasco, no existía una sola versión de dicha imagen. La primera versión distribuida por el Gobierno militar fue la imagen elaborada por el artista Jesús Ruiz Durand para los carteles que anunciaban la reforma agraria en junio de 1969. El artista creó esta representación con base en la versión que había visto en sus libros de texto del colegio, en la cual apareció con corbata, sombrero y pelo largo. La imagen logró tener una "condición masiva" y se reprodujo en todo tipo de propaganda oficial, así como en las pancartas caseras que aparecían en los mítines públicos. ${ }^{26}$ Sin embargo, a partir de 1970 varios periódicos cuestionaron si el retrato velasquista de Túpac Amaru era históricamente fiel o no. Algunos comentaristas expresaron dudas de que Túpac Amaru, un cacique del siglo XVIII, hubiera llevado un sombrero como el que apareció en el logotipo oficial. Otros

26 Gustavo Buntinx, "Modernidades cosmopolita y andina en la vanguardia peruana”, en Cultura y política en los años '60, ed. por Enrique Oteiza (Buenos Aires: Instituto de Investigaciones Gino Germani, 1997), 279. 
opinaron que este tipo de especulación era un intento de socavar la revolución. ${ }^{27}$ En su libro, El verdadero rostro de Túpac Amaru, Leopoldo Lituma Agüero relata:

Dado que la imagen creada por Durand fue objeto de críticas por su supuesta falta de veracidad y considerado el fervor que el recuerdo de Túpac Amaru causaba en las masas, se hizo necesario encontrar una imagen "oficial", para lo cual se convocó a los artistas nacionales buscando representar una imagen aparente y fidedigna del curaca. ${ }^{28}$

La convocatoria se publicó en El Peruano (el periódico oficial) en septiembre de 1970; en total, se presentaron 98 obras. ${ }^{29}$ Sin embargo, el 28 de enero de 1971 , se declaró desierto el concurso mediante una resolución ministerial que dio el siguiente motivo: "ninguna de las obras presentadas logra encarnar la imagen arquetípica del héroe, cuyo significado histórico se quiere perpetuar para exaltar su memoria y rendirle homenaje". ${ }^{30}$ Sin entrar en más detalles sobre esta convocatoria, el hecho de que el jurado no encontrara ninguna obra que le satisficiera, a pesar de recibir un número importante de trabajos de alta calidad, revela algo interesante sobre la importancia del rol que se había asignado a esta imagen oficial y lo que se quería expresar con ella. Al final, parece que tener varias imágenes plásticas de Túpac Amaru en circulación ofrecía más flexibilidad al Gobierno al momento de resaltar diferentes facetas de este personaje histórico. Una muestra de esto es que, a pesar de declarar anulada la convocatoria, el jurado dio menciones honrosas a cuatro de las obras presentadas. El Gobierno empezó a utilizar estas en distintos contextos, a pesar de no llevar el sello de "imagen oficial".

La versión de Túpac Amaru que aparece en la figura 4, el retrato hecho por Milner Cajahuaringa, es una de las cuatro obras que recibió menciones honrosas. Según Leopoldo Lituma Agüero, el artista se inspiró en los libros del historiador Carlos Daniel Valcárcel e, incluso, visitó la casa del académico en varias ocasiones para conversar sobre los posibles rasgos físicos del prócer, así como para realizar bocetos. El artista y el historiador llegaron a un acuerdo sobre cuál de estos

\footnotetext{
27 “Es necesario mantener el símbolo", Expreso, 5 de enero de 1971.

28 Leopoldo Lituma Agüero, El verdadero rostro de Túpac Amaru (Perú, 1969-1975) (Lima: Pakarina Ediciones, 2011), 81 .

29 Lituma Agüero, El verdadero rostro, 83.

30 Ibid.
} 
representaba mejor a Túpac Amaru; luego, el boceto elegido se incorporó en el cuadro de Cajahuaringa (también apareció en varios libros de Carlos Daniel Valcárcel). ${ }^{31}$ Como anota Lituma Agüero, el cuadro de Cajahuaringa es el único de las cuatro obras reconocidas con mención honrosa en el que Túpac Amaru tiene puestas las vestimentas de un noble indígena; por el contrario, en los otros tres retratos aparece con la ropa característica de un "español elegante" o un "criollo citadino”. Así mismo, la versión de Cajahuaringa es la única en la que Túpac Amaru tiene rasgos físicos indígenas. ${ }^{32}$ De esta manera, es factible suponer que se escogió este retrato para el afiche de Sinamos, precisamente porque en él Túpac Amaru era más parecido físicamente a los campesinos indígenas de la foto; además, su aire de rebelión refuerza el significado del texto que la acompaña: "La Revolución libertadora de Túpac Amaru vive en cada uno de nosotros”. En otras circunstancias, otras versiones de Túpac Amaru sirvieron mejor al mensaje que se quería comunicar. Por ejemplo, en las revistas internas dirigidas al personal de Sinamos, el logotipo diseñado por Ruiz Durand, con sus líneas limpias y sus asociaciones con el arte pop, funcionó mejor como expresión de las ideas de modernidad y cambió con las que el Gobierno pretendía asociar sus reformas y el trabajo de Sinamos (figura 7, la cual será discutida con más detalle en la sección siguiente).

\section{Las imágenes como expresión de una nueva forma del Estado}

Las "imágenes revolucionarias" no solo se utilizaron en afiches y panfletos, sino en todo tipo de documento oficial o administrativo, con el fin de vincular las actividades del Gobierno con el “proceso revolucionario”. Así, en la portada del informe de la Sociedad Agrícola de Interés Social (sAIs) Cahuíde (una cooperativa en Huancayo, en la sierra central) aparece la imagen de un hombre indígena en postura de guerrero, debajo de la palabra jatari — que en quechua significa "levántate" - en letra grande (figura 6). El hombre levanta una porra en la mano y se defiende con un escudo, en referencia a las formas de batalla de la época prehispánica. El cuerpo musculoso y la expresión intensa de su figura proyectan una imagen de fuerza y evocan los mitos incaicos; así mismo, los detalles de la ropa y la cinta que lleva en su cabeza refuerzan esta asociación. Se podría esperar que este tipo de imágenes se reproduzcan en los afiches y folletos del Gobierno, pero sorprende que figuren también en los informes internos, textos que, en otros aspectos, son bastante buro-

\footnotetext{
31 Ibid., 102-103.

32 Ibid., 109.
} 
cráticos y convencionales. Esto nos hace pensar en un polémico artículo escrito por la historiadora Cecilia Méndez, en el cual argumenta que el "nacionalismo criollo" que surgió durante la primera mitad del siglo XIX se caracterizó por la combinación simultánea del rechazo a "lo indio" y la celebración del pasado inca. ${ }^{33}$ Méndez afirma:

Esta situación aparentemente contradictoria no carecía, sin embargo, de cierta lógica. Apropiándose de y oficializando un discurso que había sido originalmente propio de la aristocracia indígena, los criollos neutralizaron cualesquiera connotaciones políticas que las expresiones indias habrían representado en el pasado. Es más, apelar a las glorias imaginadas o reales de los incas para defender el Perú de una invasión era un modo de establecer el carácter nacional como algo ya dado o fijo, y de negar a los indios, los mestizos y las castas cualquier posibilidad de forjarlo ellos solos. ${ }^{34}$

Lo que se observa en el informe de la sais Cahuíde es, de cierta manera, una inversión de esta lógica: la portada del informe vincula la imagen del "inca prócer" directamente con las actividades de la cooperativa, cuyos miembros son justamente los "campesinos indios" rechazados por los fundadores del "nacionalismo criollo". Mientras que estos últimos cuidaron la brecha entre el "pasado glorioso" de los incas y la "condición miserable" de los indígenas contemporáneos, las imágenes utilizadas en documentos como el informe de la sAIs Cahuíde sugieren, por el contrario, que las acciones de las cooperativas representan una continuación o reactivación de la historia de los incas. Este cambio en el discurso del Estado es un indicio significativo de lo que Méndez llama crisis del sistema normativo oligárquico: a partir del Gobierno de Velasco hay un rechazo generalizado de las jerarquías que

33 Cecilia Méndez G., "Incas sí, indios no: Notes on Peruvian Creole Nationalism and its Contemporary Crisis", Journal of Latin American Studies 28, n. 1 (1996): 197-225.

34 "This apparently contradictory situation did not, however, lack a certain logic. Appropriating and officialising a discourse that had originally belonged to the indigenous aristocracy, the creoles neutralized whatever political connotations Indian expressions might formerly have embodied. Moreover, to appeal to the real or imagined glories of the Incas so as to defend Peru from an invasion was a way of establishing the national character as something already set or given, and of denying the Indians, the mestizos and the castas any possibility of forging it on their own". Méndez, "Incas sí, indios no", 222. 
caracterizaban este sistema y "una reconfiguración de la posición asignada a los que siempre se suponía quedarían abajo: los indios". 35

Los usos del imaginario incaico que el Gobierno militar llevó a cabo son también un reflejo del resurgimiento del indigenismo en el país durante aquella época. El indigenismo, en su más amplia definición, fue una serie de movimientos que abogaban por el mejoramiento de las condiciones de la población indígena en diferentes regiones de Latinoamérica, a partir de las primeras décadas del siglo XX. En el caso del Perú, Juan Martín-Sánchez identifica dos grandes tendencias dentro del indigenismo: una que hacía hincapié en el carácter económico de la opresión de los indígenas, lo cual se tenía que solucionar a través de grandes reformas a las estructuras socioeconómicas (especialmente, la tenencia de la tierra), y otra que concebía el "problema del indio" como una cuestión de retraso cultural. Para este segundo grupo, por efecto de la historia, los indígenas se encontraban en un estado de inferioridad cultural y política. Esto se podía mejorar al promover leyes paternalistas dirigidas a la protección de estos sectores de la población, con el objetivo de "incorporarlos" a la nación peruana, como parte del paulatino proceso de modernización. ${ }^{36}$ Martín-Sánchez caracteriza el indigenismo del Gobierno de Velasco como "bifronte", es decir, una mezcla de estas dos tendencias. ${ }^{37}$ Mientras que las reformas económicas del Gobierno reflejaron el diagnóstico de la primera tendencia, estas se presentaron por medio de un lenguaje e imaginario que se relacionaba más con la segunda tendencia, la cual subrayaba la necesidad de la "reivindicación" de los indígenas y concebía la cultura como un verdadero elemento estructurador de la sociedad. ${ }^{38}$

35 Ibid., 200.

36 Juan Martín-Sánchez, "Indigenismo bifronte en el Gobierno peruano de Velasco Alvarado: continuidad y alternativa, sierra y selva", en La ambivalente historia del indigenismo: campo interamericano y trayectorias nacionales, 1940-1970, ed. por Laura Giraudo y Juan Martín-Sánchez (Lima: Instituto de Estudios Peruanos, 2011), 195-197.

37 Ibid., 191-250.

38 Ibid., 207. 


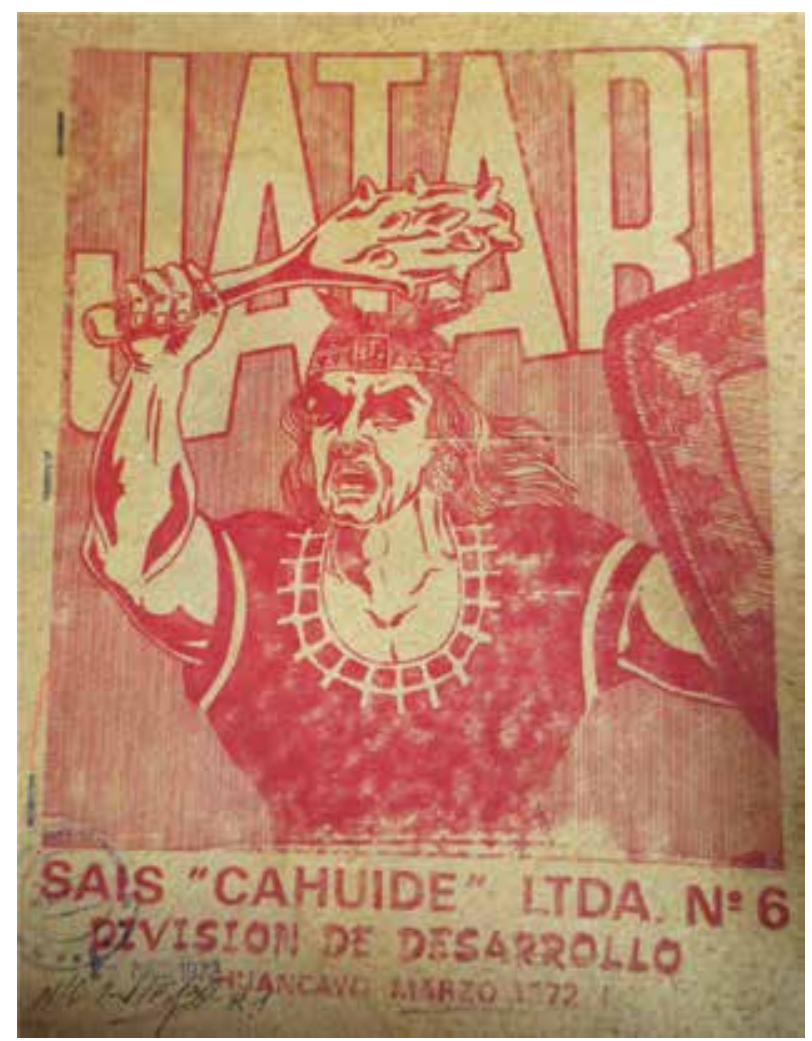

Figura 6. División de Desarrollo-Huancayo, “Jatari”, marzo de 1972 (portada del informe de la SAIS "Cahuide" Ltda., n. ${ }^{\circ}$ 6, Centro de Estudios Histórico-Militares del Perú, Lima).

A pesar de que el Gobierno cambió la palabra indio por campesino, al considerar que esta última era más neutral y carecía de las connotaciones racistas de la primera, sí se apropió del lenguaje y las imágenes del indigenismo para caracterizar su revolución y su visión del “nuevo Perú”. Martín-Sánchez resume el objetivo central que subyace de esta posición contradictoria de la siguiente manera:

[...] nacionalizar a los indígenas mediante su campesinización oficial, que suponía la expulsión de los hacendados, e indigenizar a la nación adoptando para esta, no para los indígenas, un discurso de exaltación de "lo autóctono" en la definición cultural, demográfica, histórica y aunque menos, política del Perú. ${ }^{39}$

39 Ibid., 220-221. 
Desde esta perspectiva, incluir imágenes indigenistas en los documentos comunes y corrientes de la burocracia del Estado tiene mucho sentido: a través del uso repetitivo de estas imágenes el Gobierno intentó proyectar una nueva imagen del Estado, como un actor que interviene en beneficio de las grandes mayorías, ahora concebidas descendientes de una historia indígena común.

Una parte importante del proceso de reformular el carácter del Estado peruano fueron los esfuerzos dentro de los ministerios de Gobierno para formar una nueva generación de funcionarios. Como organización, Sinamos pensó cuidadosamente cómo "crear conciencia" entre su personal. En 1972, la división de capacitación nacional comenzó a producir cartillas agrupadas en cuatro series: la problemática nacional, el proceso revolucionario peruano, la movilización social y la administración pública. Estas cartillas se diseñaron para uso exclusivo del personal de Sinamos. Un artículo en la revista interna, Sinamos Informa, explicó que se debía estudiar las cartillas en grupos de 15 personas, acompañadas por un coordinador. El objetivo era "iniciar el diálogo" y facilitar la discusión en grupo. Como señaló el artículo, se trataba de una nueva forma de capacitación dentro de la burocracia estatal:

Nunca antes se había hecho esto en la administración pública. Ahora se está dando los medios al funcionario para que sea consciente de lo que está haciendo; se le está posibilitando a enjuiciar nuestra realidad. En esta forma, los del Sinamos no solo promoveremos la participación popular, sino que estaremos participando, y muy comprometidamente, en nuestro proceso revolucionario. ${ }^{40}$

A menudo, el personal de Sinamos se enfrentó con la indiferencia y la oposición desde otros sectores de la burocracia estatal, por ejemplo, el Ministerio de Agricultura. Por medio de la propaganda política, Sinamos intentó crear funcionarios comprometidos con el "proceso revolucionario", capaces de defender las reformas frente a la oposición y el sabotaje. En esta propaganda se utilizaron colores brillantes y diseños modernos para transmitir un sentimiento del optimismo juvenil. Los ministros de Gobierno - en su mayoría, generales militares - se presentaron como personas con los pies en la tierra, sin la parafernalia formal que frecuentemente se asocia con las fuerzas armadas (figura 7).

40 "La participación comenzó por casa", Sinamos Informa 1, n. 2 (Lima, 1972): 25. 

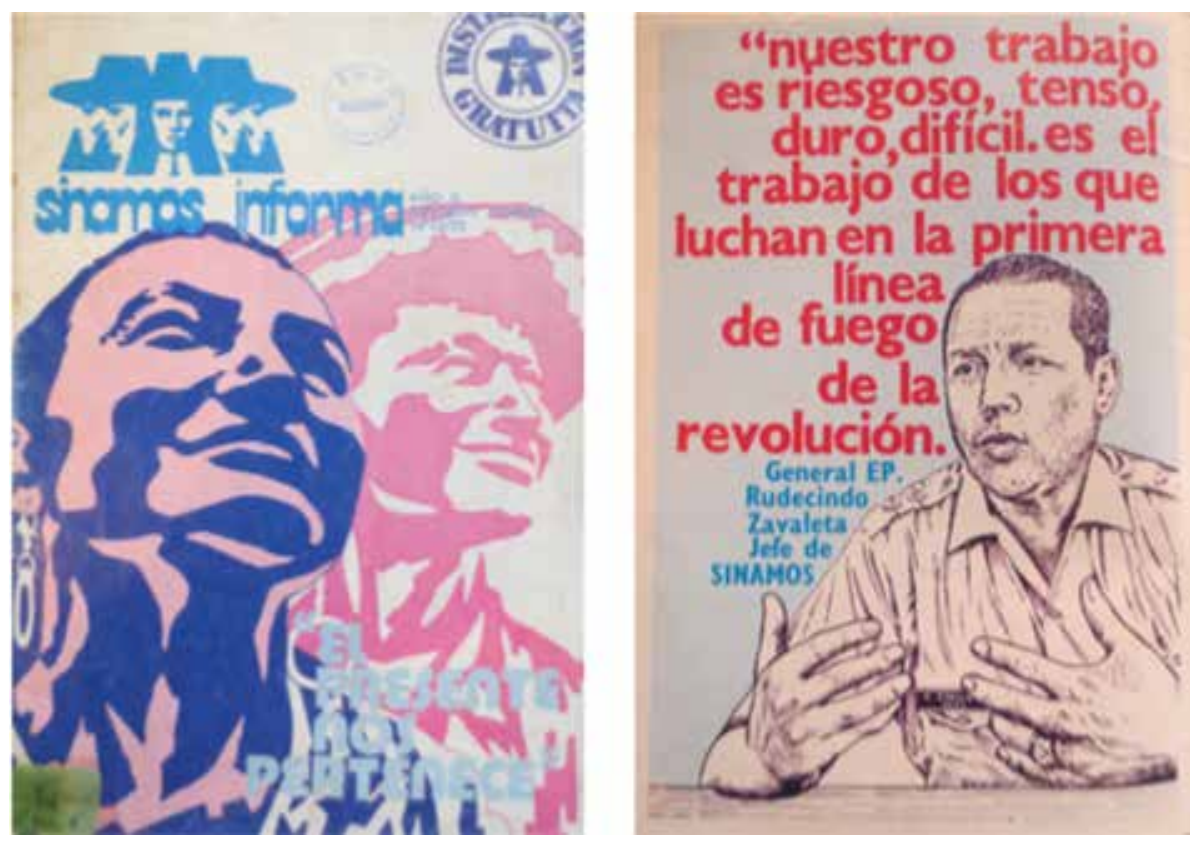

Figura 7. Portada (izquierda) y primera página (derecha) de la revista Sinamos Informa, año 2, diciembre de 1973 (Centro de Estudios para el Desarrollo y la Participación, Lima).

\section{El pueblo responde: críticas y apropiaciones del imaginario revolucionario}

Una muestra del éxito de la iconografía velasquista es que los campesinos empezaron a utilizarla en sus propias publicaciones y en las pancartas que llevaban a los mítines públicos. El logotipo de Túpac Amaru, compuesto por la silueta de su cara y su sombrero, no solo era especialmente fácil de reproducir, sino que se podía combinar con otras imágenes. Por ejemplo, en un anuncio elaborado por una cooperativa comunal, en Piura, se colocaron las fotos de sus actividades en el contorno del logotipo de Túpac Amaru (figura 8). En cierta medida, esta imagen es una inversión de la que se observa en el afiche de Sinamos de la figura 1: mientras en el afiche de Sinamos Túpac Amaru aparece como una presencia histórica que acompaña a los campesinos contemporáneos y fortalece sus acciones, en el anuncio de la cooperativa los campesinos son quienes conforman el símbolo de Túpac Amaru y sus acciones son las que le dan validez. 


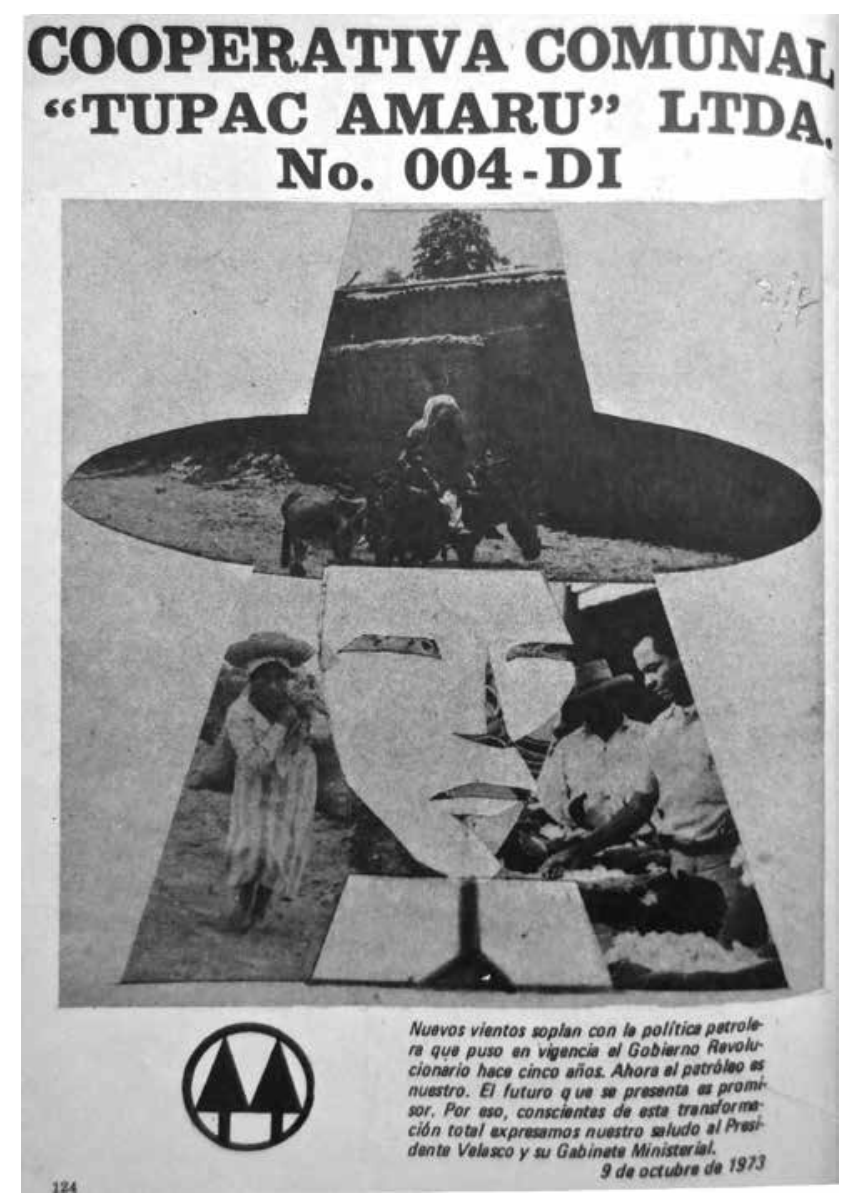

Figura 8. Revista Catacaos, 24 de junio de 1973, "Día histórico para el campesino piurano, Cooperativa Comunal ‘Túpac Amaru’ Ltda. n. ${ }^{\circ}$ 004-di” (Centro de Investigación y Promoción del Campesinado, Piura).

Es importante señalar que este anuncio apareció en una revista oficial; por lo tanto, es difícil saber hasta qué punto el Gobierno influyó directamente en la creación de esta imagen. Así, es posible afirmar, por lo menos, que las imágenes producidas por las cooperativas tendían a seguir el ejemplo del Gobierno, ya que eran creadas y patrocinadas por este. Sin embargo, también es importante reconocer que los campesinos, así como la población en general, empezaron a apropiarse de la iconografía oficial para sus propios proyectos y agendas políticas. Al respecto, Leopoldo Lituma Agüero ofrece un ejemplo importante: la organización subversiva Movimiento Revolucionario Túpac Amaru (MRTA) utilizó el rostro del retrato 
pintado por Milner Cajahuaringa (discutido anteriormente) para su logotipo. De inspiración marxista, el MRTA se fundó en los primeros años de la década de los ochenta y llevó a cabo diversos actos de guerrilla urbana a partir de $1988 .{ }^{41}$ Esto muestra la eficacia de la imagen de Cajahuaringa, en particular, y la relevancia de Túpac Amaru como símbolo revolucionario. Aunque Túpac Amaru había sido tomado como figura emblemática e inspiración política en varios contextos durante las décadas anteriores, en el Gobierno de Velasco su imagen visual asumió una presencia masiva y se volvió instantáneamente reconocible.

Las campañas propagandísticas del Gobierno fueron de gran escala y penetraron las áreas rurales de una manera sin precedentes. En Cusco, la proliferación de los afiches y volantes llegó hasta el punto de que provocó comentarios de irritación en la prensa local. Por ejemplo, en un resumen de las noticias en la provincia de Calca (departamento de Cusco), el periódico El Sol se quejó:

Está bien que Sinamos y otras organizaciones laborales, sindicatos y cooperativas hagan propaganda mural, pero lo que realmente está mal es que sean colocados en todo lugar, inclusive en los portales del Palacio Municipal, malogrando el ornato. En todo caso los q' [sic] mandan poner deben aprender a respetar a las instituciones y no malograr las paredes. ${ }^{42}$

Este comentario muestra que, además de crear imágenes simbólicas y expresar ideas específicas, la propaganda política del Gobierno de Velasco tuvo un impacto acumulativo en el espacio público, es decir, hubo una "invasión" de mensajes políticos en las plazas, las calles y las paredes de los edificios públicos. Este caso no solo se presentó en Cusco, sino en muchas partes del país. Un funcionario que trabajaba para Sinamos en el departamento de Piura (norte del país) relató en una entrevista cómo él y sus colegas salían a partir de las dos de la mañana a pintar lemas en las calles y las paredes en la ciudad de Sullana. Así mismo, recordó que había bastante libertad para hacer este tipo de actividad, ya que tenían el apoyo del director regional de Sinamos, un coronel; de este modo, todo reclamo del público tendría que dirigirse a él. ${ }^{43}$

41 Lituma Agüero, El verdadero rostro, 108.

42 El Sol, 9 de mayo de 1973, 6.

43 Nelson Peñaherrera, en discusión con la autora, Sullana, 11 de abril de 2013. 
Las intervenciones del Gobierno en la comunicación de masas incitaron varias respuestas de diferentes sectores sociales. Los radicales de la izquierda rechazaron por completo el "reformismo" del Gobierno y las intervenciones políticas de Sinamos. De hecho, produjeron sus propios periódicos, en los cuales aparecieron sátiras contra el discurso del Gobierno. ${ }^{44}$ En estas publicaciones se hizo referencia a Sinamos y los burócratas del Ministerio de Agricultura, a quienes acusaron de manipular y engañar a los campesinos. Por ejemplo, en un periódico de la Confederación Campesina del Perú (CCP) se publicó una historieta titulada "La Liga Agraria divide al campesino para bien de los ricos" (figura 9), la cual critica a las organizaciones creadas por el Gobierno para representar los intereses campesinos. Para la CCP, las ligas y las federaciones agrarias eran un intento por quebrar las organizaciones campesinas independientes (como la CCP) y canalizar el trabajo de los campesinos, con el fin de servir a los intereses capitalistas. En la historieta, la figura del funcionario aparece como un burgués pretencioso, quien usa esmoquin y corbata de lazo y luce un peinado cuidadosamente moldeado. La burbuja de diálogo está abierta, como si fuera incapaz de contener la cantidad de "bla bla bla" que se derrama desde la boca del caballero. En una de las escenas siguientes se representa a Sinamos con el logotipo de Túpac Amaru, pero las palabras que pronuncia este supuesto ícono de la revolución se etiquetan como "demagogia”. Estas ilustraciones revelan qué tan visible y familiar se había vuelto Sinamos y su iconografía en el contexto rural: sin esta familiaridad la sátira no hubiese funcionado. Así mismo, muestran las estrategias que utilizaba la izquierda para desacreditar los argumentos del Gobierno sobre su "tercera vía” económica y política. En particular, se retrata la retórica oficial sobre la armonía social y la gestión cooperativa como piadosa y falsa, un velo que cubría los motivos más siniestros del control político y la agenda capitalista. De ahí que el boceto cierre con el siguiente argumento: "El pueblo responde: 'solo puede haber unión, concordia con los de su clase: pobre con pobre; ricos con ricos. ¡ Viva la lucha!’”.

44 Para el investigador es difícil acceder a la propaganda política de estas organizaciones, debido a su carácter efímero y porque generalmente carecían de la infraestructura de archivos, de la que sí disponía el Gobierno. Sin embargo, unos ejemplos han sobrevivido en archivos institucionales y en las colecciones privadas de ciertos individuos, entre ellos: el Archivo de Partidos Políticos en la Pontificia Universidad Católica del Perú; el Archivo Central de la Confederación Campesina del Perú (Lima) y el archivo personal de Ricardo Letts Colmenares, exmiembro de Vanguardia Revolucionaria. 


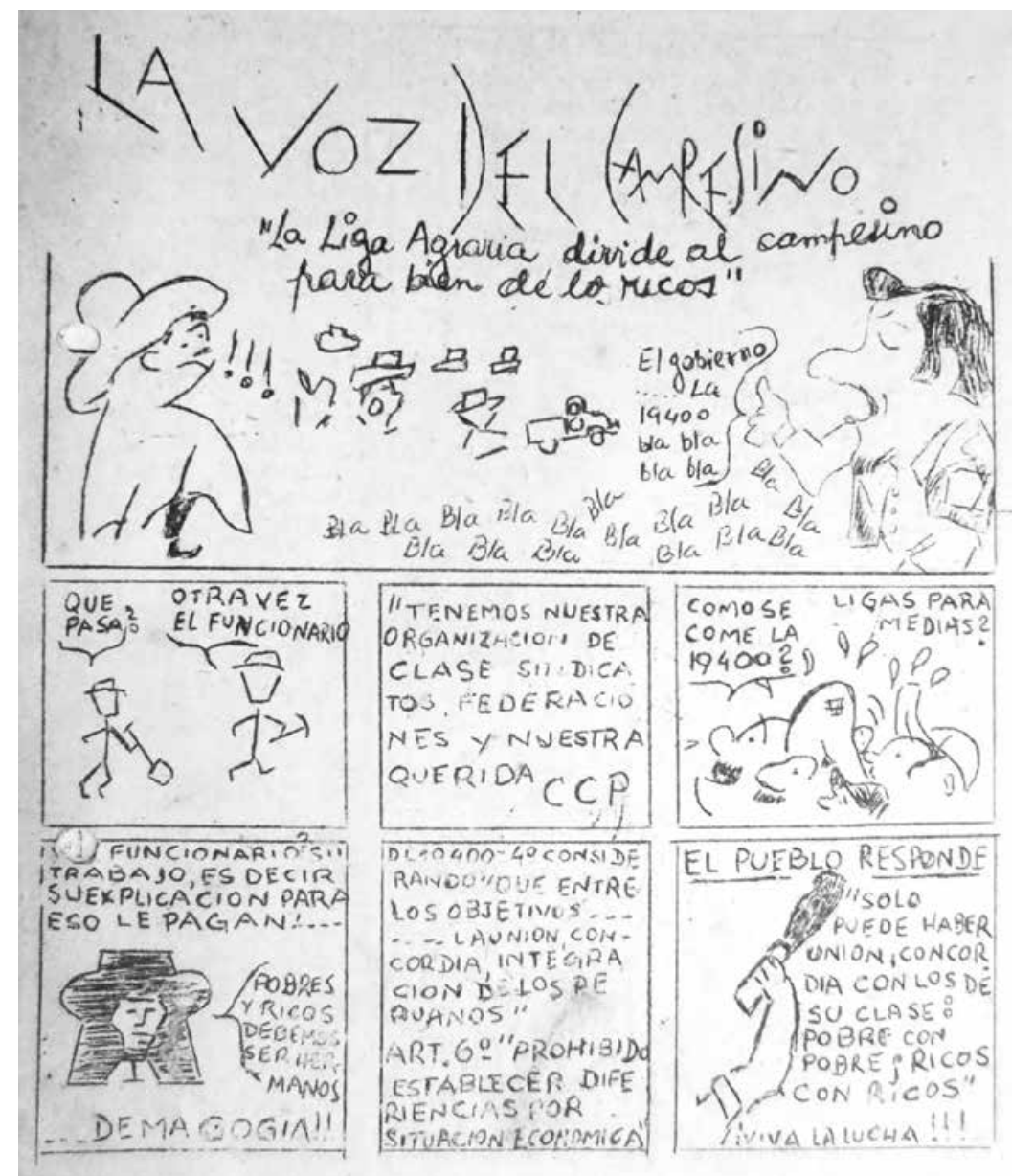

Figura 9. Confederación Campesina del Perú (CCP), 1972, "La voz del campesino” (titular de prensa, Archivo Central de la CCP, Lima).

Tanto el Gobierno como los activistas ahora veían al campesinado como la más importante base de apoyo potencial. Vanguardia Revolucionaria, que había comenzado como un partido político de carácter urbano, compuesto por estudiantes e intelectuales, cambió su enfoque para construir las bases campesinas. Esto implicó desarrollar operaciones dirigidas para neutralizar las campañas mediáticas del Gobierno. Por ejemplo, una circular interna, con fecha del 18 de junio de 1975, incluyó planes detallados sobre cómo combatir la propaganda del Gobierno que rodeaba el 24 de junio, el aniversario de la ley de reforma agraria. Así, se recomendó a los miembros del partido usar la información que se recibía en las bases para 
producir volantes promotores de las luchas de los pobres rurales. Además, la circular dio las siguientes órdenes a los "camaradas de cada frente":

[...] deben producir contactos con dirigentes de las comunidades, pueblos, comités, ligas que son llevados a los actos del 24 de junio, sea antes o después, o durante los actos. Se les hará entrega de materiales informativos y se buscará un contacto conversación para ampliar la información. Al mismo tiempo se distribuirá los volantes sobre las luchas actuales —incluyendo la toma de tierras que es preparada en Cajamarca ese mismo día. ${ }^{45}$

Estos comentarios ofrecen nuevas perspectivas sobre las estrategias políticas que utilizaban organizaciones como Vanguardia Revolucionaria. De hecho, lo más importante es que estos comentarios revelan cómo el éxito de las campañas mediáticas del Gobierno impulsó a estas organizaciones a responder de la misma manera y a buscar nuevos modos de ganar el apoyo de los campesinos.

Los conservadores también trataron de cambiar los términos del debate establecido por el Gobierno, el cual había lanzado la reforma agraria como parte de un cambio general de la sociedad, con el que todos los peruanos debían comprometerse. Los periódicos conservadores rechazaron esta perspectiva y prefirieron definir la reforma agraria como un proceso fundamentalmente técnico, en el que el idealismo juvenil era, en el mejor de los casos, algo irrelevante e irritante. El diario nacional La Prensa tomó una posición especialmente crítica frente a la reforma: en febrero de 1970, publicó una editorial en la que sostuvo que los "propagandistas" de la reforma agraria deberían cesar sus actividades en la capital y centrar sus esfuerzos en el campo; de esta manera, se insinuó que la reforma no era un tema sobre el que la gente de los sectores urbanos debiera preocuparse. ${ }^{46}$ Igualmente, los hacendados utilizaron la publicidad para retratarse a sí mismos como participantes de la reforma agraria, en lugar de ser parte del problema que esta pretendía solucionar. Días antes del anuncio de la ley de reforma agraria, un grupo de asociaciones de terratenientes publicó un anuncio en La Prensa, en el que demandaban que el Gobierno escuchara sus opiniones. Al hacer eco a la retórica del Gobierno, los terra-

45 Vanguardia Revolucionaria, “Circular No. 2-18.6.75. Propagandizar la alianza obrero-campesina el 24 de junio", Pontificia Universidad Católica del Perú, Archivo de Partidos Políticos, Ítem APp3/vR 98.

46 "Propaganda y reforma agraria", La Prensa, 22 de febrero de 1970, 13. 
tenientes intentaron incluirse dentro de la categoría moral de los que trabajaban la tierra, por lo que merecían ser escuchados.

A diferencia de Chile, donde los terratenientes formaron sus propias organizaciones para resistir la reforma agraria, en Perú, por lo general, los hacendados buscaron soluciones particulares para sus propios casos. El carácter elitista de la Sociedad Nacional Agraria dificultó la creación de un frente unido entre los grandes y medianos propietarios. Además, la estrategia de la ley de reforma agraria de expropiar primero los latifundios y luego las haciendas más pequeñas hizo que los propietarios medianos no apoyaran a los grandes hacendados (creían que sus propios intereses no serían afectados); de esta manera, cuando la reforma empezó a expropiar las haciendas más pequeñas, los grandes hacendados ya no tenían motivos para apoyarlas. Cuando se liquidó la Sociedad Nacional Agraria mediante el Decreto Ley 19400, en 1972, había demasiadas divisiones entre los hacendados como para llevar a cabo una defensa eficaz. ${ }^{47}$ Sin embargo, aún expresaban sus inquietudes sobre la reforma por medio de la prensa nacional; en algunos casos, utilizaron su influencia local dentro de la burocracia estatal para limitar la aplicación de la reforma.

\section{Conclusiones}

La propaganda política fue una parte central de los esfuerzos del Gobierno para movilizar su "revolución desde arriba”. Esto era especialmente importante en el contexto de la reforma agraria, proceso que inició grandes cambios en la distribución de la tierra y que requería el apoyo popular para establecer su nuevo sistema de cooperativas agrarias. Hemos visto que las imágenes desempeñaron varios papeles dentro de la propaganda oficial. Primero, contribuyeron a generar apoyo popular para la reforma agraria y a construir alianzas entre el Gobierno militar y el campesinado. Segundo, la retórica visual sirvió para insertar el régimen dentro de una tradición revolucionaria, que había comenzado con la rebelión de Túpac Amaru II, lo que otorgó legitimidad política a las acciones del Gobierno. Tercero, las imágenes hacían referencia al indigenismo y servían para formular un nacionalismo más inclusivo y “autóctono”, que uniría todas las actividades del régimen.

47 Cynthia McClintock, "Velasco, Officers, and Citizens: The Politics of Stealth", en The Peruvian Experiment Reconsidered, ed. por Cynthia McClintock y Abraham F. Lowenthal (Princeton: Princeton University Press, 1983), 285. 
Además de explorar las intenciones detrás de la iconografía política del Gobierno de Velasco, este capítulo resaltó las tensiones que surgieron en el acto mismo de comunicarse con la población. A pesar de que el Gobierno proclamó que el protagonista de la reforma agraria era el campesino, a veces las imágenes contaban otra historia, ya que se invocaba al campesino al mismo tiempo que se restringía su rol político. Por ejemplo, el uso de la fotografía montada refleja el temor, dentro de un proceso dirigido mayormente por militares, de que el movimiento popular saliera de sus esquemas. Por medio de las imágenes se intentó manejar la línea que separaba la movilización popular y el control político. Así mismo, el hecho de que el concurso por una imagen oficial de Túpac Amaru concluyera sin éxito es una muestra de los problemas que enfrentaba el Gobierno a la hora de representarse visualmente. Dadas las divisiones internas del Gobierno y las múltiples críticas que venían desde diferentes sectores del espectro político, era importante para el régimen poder representar su revolución de diferentes maneras, según el contexto político.

Es difícil hacer distinciones entre las reacciones que incitó la propaganda oficial y las respuestas al Gobierno de Velasco en general. Aunque el régimen tenía la misión de generar el respaldo popular y convencer a la población sobre el valor de sus reformas, la propaganda era tan solo una parte de este proyecto de movilización social, que también abarcaba la educación y las intervenciones culturales y políticas en el ámbito local. Mientras las imágenes ejercieron un papel clave en las comunicaciones masivas del Gobierno, el objetivo central no era difundir imágenes, sino dar a conocer y conseguir apoyo para el proyecto político. Este proyecto de movilización social constituyó el contexto en el que se interpretaba y se respondía a las imágenes de la propaganda oficial. En efecto, los movimientos de la izquierda y de la derecha reconocieron el poder de la comunicación masiva del Gobierno; ellos adaptaron, apropiaron o criticaron la iconografía para desafiar la narrativa oficial de la revolución. Con base en el ejemplo del Gobierno, la oposición también buscó nuevas audiencias, especialmente en el campo. En el contexto de la reforma agraria y la comunicación de masas que la rodeaba, la figura del campesino asumió una nueva importancia dentro del discurso público y la iconografía indigenista se volvió más visible dentro de la política nacional. A largo plazo, más allá de la comunicación de un mensaje específico, la propaganda política del Gobierno de Velasco cambió los términos del discurso público en el Perú. 


\section{Bibliografía}

\section{Fuentes primarias}

\section{Archivos}

Biblioteca Nacional del Perú (BNP), Lima. Material Gráfico.

Centro de Estudios para el Desarrollo y la Participación (CEDEP), Lima.

Centro de Investigación y Promoción del Campesinado (CIPCA), Piura. Centro de Documentación.

Confederación Campesina del Perú (CCP), Archivo Central, Lima.

Pontificia Universidad Católica del Perú (PUCP), Lima. Archivo de Partidos Políticos. Senate House Library, Contemporary Archive on Latin America (sHLCALA), Londres. K320 Pamphlets Box 3.

Franco, Carlos, en discusión con María del Pilar Tello.

Peñaherrera, Nelson, en discusión con la autora.

Samanez Concha, Benjamín, en discusión con María del Pilar Tello.

\section{Publicaciones periódicas}

El Comercio. Lima, 1969.

El Sol. Cusco, 1973.

Expreso. Lima, 1971.

La Industria. Piura, 1970.

La Prensa. Lima, 1970.

Sinamos Informa. Lima, 1972.

\section{Libros}

Kauffman Doig, Federico et al. Historia general de los peruanos. Lima: Peisa, 1973.

\section{Fuentes secundarias}

Bedoya, Ricardo. 100 años de cine en el Perú: una historia crítica. Lima: Universidad de Lima, 1992.

Bonnell, Victoria E. Iconography of Power: Soviet Political Posters Under Lenin and Stalin. Berkeley: University of California Press, 1999.

Buntinx, Gustavo. "Pintando el horror: sobre memorias de ira y otros momentos en la obra de Jesús Ruiz Durant”. En Batallas por la memoria: antagonismos de la promesa peruana, editado por Marita Hamann et al., 315-336. Lima: 
Pontificia Universidad Católica del Perú, Universidad del Pacífico, Instituto de Estudios Peruanos (IEP), 2003.

Buntinx, Gustavo. "Modernidades cosmopolita y andina en la vanguardia peruana”. En Cultura y politica en los años '60, editado por Enrique Oteiza, 267-286. Buenos Aires: Instituto de Investigaciones Gino Germani, Universidad de Buenos Aires, 1997.

Cant, Anna. "'Land for Those Who Work It': A Visual Analysis of Agrarian Reform Posters in Velasco's Peru", Journal of Latin American Studies 44, n. 1 (2012): $1-37$.

Cant, Anna. "Promoting the Revolution: Sinamos in Three Different Regions of Peru". En The Peculiar Revolution: Rethinking the Peruvian Experiment Under Military Rule, editado por Carlos Aguirre y Paulo Drinot, 213-239. Austin: University of Texas Press, 2017.

Cant, Anna. "Representations of the Peruvian Agrarian Reform, 1968-75". Tesis de doctorado en Historia. Universidad de Cambridge, Inglaterra, 2015.

Chaplin, David, ed. Peruvian Nationalism: A Corporatist Revolution. New Brunswick: Transaction Books, 1976.

Chomsky, Noam. Necessary Illusions: Thought Control in Democratic Societies. Boston: South End Press, 1989.

Clark, T. J. Farewell to an Idea: Episodes from a History of Modernism. New Haven: Yale University Press, 1999.

Cleaves, Peter S. y Martín J. Scurrah. Agriculture, Bureaucracy, and Military Government in Peru. Ithaca: Cornell University Press, 1980.

Cotler, Julio. Clases, Estado y nación en el Perú. Lima: Instituto de Estudios Peruanos, 1978.

Evans, Harriet y Stephanie Donald, eds. Picturing Power in the People's Republic of China: Posters of the Cultural Revolution. Oxford: Rowman \& Littlefield, 1999.

Gade, Daniel W.y Roberto Ríos. "Chaquitaclla, the Native Footplough and its Persistence in Central Andean Agriculture", Tools and Tillage 2, n. 3 (1972): 3-15.

Instituto Nacional de Estadística. Compendio de estadisticas sociales 1991. Lima: Instituto Nacional de Estadística, 1992.

Kruijt, Dirk. Revolución por decreto: Perú durante el Gobierno militar, traducido por R. B. Smith. San José: Facultad Latinoamericana de Ciencias Sociales (Flacso), 1991. 
Leonardini, Nanda. "Identidad, ideología e iconografía republicana en el Perú". ARBOR Ciencia, Pensamiento y Cultura 185, n. ${ }^{\circ} 740$ (2009): 1259-1270.

Lituma Agüero, Leopoldo. El verdadero rostro de Túpac Amaru (Perú, 1969-1975). Lima: Pakarina, 2011.

Martín-Sánchez, Juan. “Indigenismo bifronte en el Gobierno peruano de Velasco Alvarado: continuidad y alternativa, sierra y selva”. En La ambivalente historia del indigenismo: campo interamericano y trayectorias nacionales, 1940-1970, editado por Laura Giraudo y Juan Martín-Sánchez, 191-250. Lima: Instituto de Estudios Peruanos, 2011.

Matos Mar, José y José Manuel Mejía. La reforma agraria en el Perú. Lima: Instituto de Estudios Peruanos, 1980.

McClintock, Cynthia, "Velasco, Officers, and Citizens: The Politics of Stealth". En The Peruvian Experiment Reconsidered, editado por Cynthia McClintock y Abraham F. Lowenthal, 275-308. Princeton: Princeton University Press, 1983.

Méndez G., Cecilia. “Incas sí, indios no: Notes on Peruvian Creole Nationalism and its Contemporary Crisis". Journal of Latin American Studies 28, n. ${ }^{\circ}$ (1996): 197-225.

Neira, Hugo. Cuzco: tierra y muerte. Lima: Herética, 2008.

Stepan, Alfred C. The State and Society: Peru in Comparative Perspective. Princeton: Princeton University Press, 1978. 


\section{Fuentes visuales en la cultura de masas: producción y consumo de estereotipos}




\title{
El blanqueamiento de Blanquita: las imágenes del ascenso social y la disputa identitaria de la población negra en Colombia
}

\author{
Andrés Pérez Carvajal
}

En 2011, la revista española HOLA, con circulación en Colombia, presentó como apoyo a un reportaje sobre las mujeres de la clase alta del Valle del Cauca ("Las mujeres más poderosas del Valle del Cauca, en Colombia, en la formidable mansión hollywoodiense de Sonia Zarzur, en el Beverly Hills de Cali") una fotografía en la que Sonia Zarzur, cabeza de una de las familias más adineradas e importantes de Colombia, junto a su hija, nieta y bisnieta en su ostentosa casa de la ciudad de Cali. La imagen no habría causado mayor impacto si no fuera porque, además de la señora Zarzur y su familia, en el fondo de la imagen aparecían dos mujeres negras, vestidas como empleadas del servicio doméstico, sosteniendo el elegante juego de té de la poderosa familia caleña. ${ }^{1}$ A pesar de la sorpresa de Sonia Zarzur y de Andrea Savini (fotógrafa), quienes declararon que su intención únicamente fue incluir en la fotografía a las personas que trabajaban para la familia caleña (casi a modo de escenografía), la foto generó un importante debate en los medios de comunicación y la sociedad colombiana, que perduró durante semanas. ${ }^{2}$

En términos generales, la controversia se centró en la indignación que la fotografía causó entre múltiples agrupaciones sociales, entre ellas varias enfocadas en los derechos y el reconocimiento de las comunidades afrodescendientes en

\footnotetext{
1 Revista Cromos, "Polémica por fotografía del 'Beverly Hills caleño", 5 de diciembre de 2011, http:// www.cromos.com.co/personajes/actualidad/articulo-142915-polemica-fotografia-del-beverly-hillscaleno $(31 / 03 / 2017)$.

2 Ibid.
} 
Colombia, para quienes la fotografía contenía evidentes rasgos racistas y clasistas que resultaban en extremo ofensivos e incluso rememoraban la época de la esclavitud. La situación resultó tan molesta para estos grupos que la Fundación para el Desarrollo de la Raza Negra denunció de manera pública y penal a la revista por la divulgación de este material controversial. ${ }^{3}$ Tan significativo fue el rechazo de esta imagen por parte de la población afro en Colombia que dicha publicación estimuló el lanzamiento de una de las campañas contra la discriminación más importantes y exitosas en la historia del país, titulada "chao racismo", que, bajo el liderazgo de Ray Charrupi, se convirtió en una de las organizaciones más representativas del país en la defensa de los derechos de las personas negras. ${ }^{4}$

La presión social y mediática llegó tan alto que Andrea Savini y la revista $H O L A$ tuvieron que disculparse públicamente por la fotografía; mientras que Sonia Zarzur se mantuvo por varias semanas en el centro de los medios de comunicación, tras declarar que no podía entender el debate generado por la imagen, puesto que ella, como empresaria caleña, lo único que hacía con estas dos mujeres era generar empleo en Cali, y que en todo caso el trabajo manual que ellas realizaban no era una deshonra para nadie. ${ }^{5}$

Este debate fue apenas el primer acto de una controversia que envolvió a múltiples medios de comunicación (revistas HOLA, Soho y Universo Centro), la academia y la sociedad colombiana, en relación con una fotografía donde se confrontaban nuevas y viejas formas de representar a la población afrodescendiente en el país. La siguiente aproximación busca destacar la naturaleza histórica del problema, puesto que la manera en la que las mujeres negras fueron presentadas en la fotografía de HOLA evocó entre los colombianos a uno de los íconos más reconocidos dentro de la publicidad del país: Blanquita, el personaje emblemático del líquido blanqueador Límpido, que por más de tres décadas estuvo presente en la televisión, la prensa y la radio colombiana. ${ }^{6}$

En términos generales, Blanquita hace referencia al personaje central de una extensa campaña publicitaria (la imagen se utilizó desde la década de los ochenta

3 Revista Kienyke, "Los negros de Cali se rebelaron contra la revista Hola", s. f., http://www.kienyke. com/historias/los-negros-de-cali-se-rebelaron-contra-la-revista-hola/ (31/03/2017).

4 Ibid.

5 Revista Cromos, "Polémica por fotografía".

6 Alicia García, "Yo soy Blanquita, la del Límpido", Soho, 19 de julio de 2007, http://www.soho.com. co/testimonio/articulo/yo-soy-blanquita-la-de-limpido/5619(31/03/2017). 
hasta el 2012, de forma reiterada), en la que una mujer afrodescendiente, debido su labor como trabajadora doméstica, y luego como ama de casa, poseía un conocimiento avanzado en cuáles eran los mejores productos de aseo disponibles en el mercado. El lema de la campaña era que el blanqueador podía dejar la ropa blanquita, como ella (que siendo negra, se llamaba Blanquita), en un juego de palabras que involucraba su condición racial y su posición socioeconómica a través de la labor que desempeñaba. En este sentido, a pesar de las trasformaciones regulares que evidencia cualquier pieza publicitaria, y del cambio de actriz (Blanquita) en tres oportunidades, la publicidad siempre apeló a referencias raciales, de clase $y$, en ciertos contextos, de género para la venta de un producto de aseo. ${ }^{7}$ De esta forma, el parecido entre la fotografía de $H O L A$ y los comerciales de Blanquita resulta en el menor de los casos significativa, puesto que, más allá de la coincidencia temática que suscita la imagen de empleadas domésticas negras con patronas blancas, se reproducen parámetros e ideas a propósito de la condición social y racial de las mujeres afrodescendientes en el país.

En este caso, lo que resulta particularmente interesante es la respuesta diferenciada que la sociedad tuvo con respecto al contenido de las dos imágenes, que resultan muy parecidas, puesto que si bien organizaciones a favor de los derechos de la población afrodescendiente criticaron en su momento la imagen de Blanquita, la publicidad se reprodujo de forma continua durante tres décadas; mientras que la presión alrededor de las fotografías de la revista $H O L A$ obligó en un par de semanas a que los involucrados se disculparan o quedaran inmersos en fuertes acusaciones de tipo racista. Dicho fenómeno revela, cuando menos, un cambio en las formas socialmente aceptadas en las que la población afrodescendiente puede ser retratada en los medios de comunicación en Colombia. En este sentido, vale la pena preguntarse cuál fue el cambio en las condiciones válidas de representación de la población afrodescendiente desde los años ochenta hasta el presente y cuáles fueron los procesos sociales que alimentaron este cambio, para luego analizar la manera en que la revista HOLA transgredió dichos consensos con su fotografía de 2011. En este caso, la imagen de Blanquita se convierte en una herramienta adecuada para rastrear los cambios cualitativos en la forma como fue representada la población afrodescendiente del país, puesto que su tiempo de exposición es ideal para rastrear estas viejas y nuevas formas de presentar a los afros en los medios de comunicación colombianos.

$7 \quad$ Ibid. 
Para alcanzar los anteriores objetivos, el presente texto se divide en cuatro grandes partes. En primer lugar, se describen los instrumentos teórico-analíticos y metodológicos usados para examinar las imágenes de Blanquita, HOLA, Soho y Universo Centro. En segundo lugar, se exponen los elementos más significativos de la evolución interna de la imagen de Blanquita, en dimensiones como la raza, la clase y el género. En tercer lugar, se presenta el componente externo de las imágenes, es decir, el momento social en el que se inscriben y desarrollan como representación de la población negra en el país. Por último, el texto se concentra en el episodio de la revista $H O L A$ y la forma como la evolución de Blanquita permite entender la dimensión histórica del problema de la representación de la población afrodescendiente en Colombia. Con la anterior división no estoy planteando un divorcio o separación entre las dimensiones interna y externa de las imágenes; ambas son complementarias, pues una forma parte de la otra, pero sí es necesario señalar que en su condición de ícono, la imagen Blanquita no puede ser leída únicamente a través de lo que se buscaba representar por medio de ella, puesto que una dimensión fundamental de su observación radica en las maneras en que fue apropiada, tanto en sintonía con la imagen proyectada por la pieza publicitaria como en el desafío o crítica a los valores e ideales de ascenso social planteados por Blanquita.

\section{Instrumentos teórico-analíticos}

La compresión de la imagen de Blanquita demanda observar una serie de categorías analíticas a través de las cuales se mueve la pieza publicitaria y que servirán como insumo teórico en el momento de analizar los cambios en la representación de la población afrodescendiente en el país. Dentro de estas están la racialización, la interseccionalidad, la ideología del mestizaje y el blanqueamiento, la representación y el ícono.

Como punto de partida se debe establecer una clara distinción entre la raza y la racialización. Es un hecho evidente que los seres humanos no son todos físicamente iguales y que un componente de esa diferencia se encuentra en la pigmentación de la piel. ${ }^{8}$ Sin embargo, la asignación de atributos, contenidos y características que se hace con respecto a esa diferencia — la del color de piel — no es un hecho natural ni evidente, sino que es el resultado de un proceso social en el que esas características se

8 Claude Lévi-Strauss, Antropología estructural: mito, sociedad, humanidades (México: Siglo XXI, 2004), 305-308. 
asumen como esenciales y naturales para ese grupo particular. ${ }^{9}$ La cuestión, y así lo propone Klára Hellebrandová, es que esta asignación de atributos que llamaremos racialización "es un proceso de construcción de relaciones de dominación, a través de la determinación de diferencias humanas — culturales y fenotípicas - y de las relaciones sociales. Es un proceso dialéctico-político, social, cultural y cognitivo de construcción de diferencias que sirven de base para la jerarquización de grupos humanos". ${ }^{10}$ La racialización es, entonces, uno de los procesos por los cuales las sociedades construyen diferencias jerarquizadas, para organizar a los individuos bajo parámetros de dominación. ${ }^{11}$ No obstante, es clave advertir que este proceso no es estático ni mucho menos completo o perfecto. Los grupos racializados se mueven bajo constantes procesos de negociación, donde se enfrentan y resisten la construcción de significados raciales, todo ello bajo las trasformaciones sociales, políticas y económicas que se dan en los grupos humanos. ${ }^{12}$

Por otro lado, siguiendo a Hellebrandová y a Pietro Pisano, ${ }^{13}$ es imposible pensar la racialización como un proceso únicamente vinculado a la pigmentación de la piel. La raza, pensada como categoría socialmente construida, es parte de un conjunto de elementos en diálogo, en los que tanto el género como la clase social hacen parte integral de la construcción y definición de significados, y en este sentido, de las particularidades que una sociedad le asigna a un grupo. ${ }^{14}$ La interseccionalidad, así, se refiere a la forma cómo estas tres dimensiones (raza, clase y género) interactúan en el momento de esencializar a un individuo. ${ }^{15}$ Entonces, a una persona afrodescendiente no solo se le atribuyen dimensiones y características en función de cómo se inscribe en términos raciales, sino de cómo se ubica con respecto al género (como es el caso de Blanquita) y al segmento social (siendo precisamente

\footnotetext{
$9 \quad$ Ibid., 305-308.

10 Klára Hellebrandová, "El proceso de etno-racialización y resistencia en la era multicultural: ser negro en Bogotá", Universitas Humanistica, n. ${ }^{\circ} 77$ (2014): 88.

11 Ibid., 87-90.

12 Ibid., 87-90.

13 Pietro Pisano, “Triunfadores, desplazados sociales y cenicientas: representaciones sobre raza y ascenso social en la segunda mitad del siglo xx", Universitas Humanistica, n. 77 (2014): 95-119.

14 Ibid., 95-105.

15 Ibid., 95-105.
} 
la idea de una clase media-alta negra, la que desafía los parámetros atribuidos a la población afrodescendiente). ${ }^{16}$

Teniendo en cuenta lo anterior, al referirse a la ideología del mestizaje y del blanqueamiento, se está aludiendo a una particular combinación de estas tres dimensiones. La idea, expuesta por Pietro Pisano, es que desde la Colonia, y luego con marcado relieve en la República, las sociedades latinoamericanas se fundaron bajo la idea del mestizaje, es decir, de la idea de la combinación racial como un elemento significativo de su propia identidad. ${ }^{17}$ Sin embargo, la lógica de racialización que acompañó este proceso se hizo en clave de blanqueamiento, es decir, que no todas las combinaciones raciales eran positivas. En este sentido, solo aquella que apuntaba hacia el acercamiento de las personas a la condición de blanco, en términos europeos, como forma de jerarquizar a la sociedad, resultaban positivas, debido a la supuesta condición racial superior de estos últimos. ${ }^{18}$ Esta lógica de blanqueamiento implicó también significaciones de género y clase, puesto que el hecho de aspirar a la blancura, que al mismo tiempo era entendida como la posibilidad de formar parte de las élites, implica la adopción de una serie de comportamientos morales aceptados por esa misma élite, como el conjunto de conductas que les eran propias a los blanco y a los no blancos. ${ }^{19}$ En este sentido, el poder económico es solo uno de los componentes de la estructura de clase, porque el ser de las élites también implica ser blanco o aspirar a serlo (blanqueamiento), lo que significa aplicar de forma evidente y pública la moral y el accionar de lo entendido como blanco.

Los anteriores son los elementos que podríamos denominar como estrictamente vinculados a la problemática social en la que se inscribe la investigación. Ahora, es necesario también mirar los insumos vinculados al análisis y comprensión de las imágenes seleccionadas. Estos componentes permitirán rastrear las categorías mencionadas, dentro de los productos visuales escogidos.

En el primer caso, cuando se hace referencia a las representaciones, de lo que se habla es de los medios materiales, posibles de historizar (ubicar en un determinado contexto y tiempo), a través de los cuales dentro de una sociedad se trató de dar sen-

\footnotetext{
16 Ibid., 95-105.

17 Ibid., 95-105.

18 Ibid., 95-105.

19 Ibid., 106-119.
} 
tido a un determinado proceso. ${ }^{20}$ Las representaciones entonces no son reflejos de la realidad, sino instrumentos, insertos en un entramado simbólico construido socialmente, que buscan dar sentido a la realidad de un determinado grupo humano. ${ }^{21}$ Así, la manera como los grupos son representados, en sus elementos constitutivos, es el resultado de las luchas y negociaciones por la jerarquización social, y en este sentido, su efectividad depende de elementos como la producción, la distribución y las formas de consumo. ${ }^{22}$ Aquí es clave dejar en claro que la sola existencia de una determinada forma de representar no da cuenta del proceso social, sino que es un modo particular de darle sentido a la realidad, por parte de un grupo, en medio de complejas disputas sociales.

En cuanto a los íconos, en este caso se entienden las imágenes icónicas como aquellos productos visuales que, debido a su tiempo de exposición y a la expansión de los espacios y públicos que tienen acceso a ellas o que las consumen, desarrollan una historia o existencia propia, por fuera del propósito inicial de su creación. ${ }^{23} \mathrm{En}$ este sentido, tales imágenes se independizan de los propósitos de su formación; ${ }^{24}$ por ejemplo, al vender un producto de aseo (un blanqueador), se crea la imagen de Blanquita como un referente en las representaciones de los afrodescendientes en Colombia. Por esto, además de observar la evolución interna de la imagen, su comprensión demanda estudiar los significados que los públicos le dan a esta representación y el uso que hacen de ella.

En concordancia con lo anterior, el análisis de la imagen de Blanquita se hizo en dos planos: uno interno y otro externo. Para el primero se adoptó una doble metodología de estudio, dependiendo de la naturaleza de la fuente visual. Primero, para los productos audiovisuales complejos, los comerciales de televisión, se empleó una descripción a profundidad del material, apelando a las conexiones y diferencias entre las cuatro piezas comerciales seleccionadas, destacando en todos los casos el sentido global del conjunto de piezas publicitarias. Segundo, para las imágenes simples (fotografías de HOLA, Sobo y Universo Centro) se empleó un análisis

20 Max Hering y Amada Pérez, "Apuntes introductorios para una historia cultural desde Colombia”, en Historia cultural desde Colombia: debates y categorias, ed. por Max Hering y Amada Pérez (Bogotá: Universidad Nacional; Universidad Javeriana; Universidad de los Andes, 2012), 32-34.

21 Ibid., 32-34.

22 Ibid., 32-34.

23 Gerhard Paul, "Visual History”, Docupedia-Zeitgeschichte, 7 de noviembre de 2011, https://docupedia.de/zg/Visual_History_\%28english_version\%29\#artikel_inhalt_zitation (31/03/2017).

24 Ibid. 
fundado en los preceptos de la psicología de la Gestalt. ${ }^{25}$ En términos generales, esta metodología propende a comprender las imágenes como un todo funcional e interconectado, y no las partes como unidades independientes dentro de la percepción. La idea es que el observador obtiene la mayor cantidad de información posible de la imagen con la que se relaciona, en el menor tiempo, a través de operaciones que le dan un sentido general a la imagen con la que se está relacionando, por medio de las conexiones que puede hacer entre lo que conoce y la forma como son presentadas en la imagen que observa. Desde esta perspectiva, al ver la fotografía de un bosque, quien visualiza la imagen no la entenderá como un conjunto de árboles en un espacio, sino que se relacionará con ella como un todo, es decir, por lo que él entiende como un bosque. ${ }^{26}$ Entre los principios de percepción y análisis visual que se proponen desde la psicología de la Gestalt, se usaron los siguientes: pregnancia, proximidad, semejanza y relación figura-fondo. ${ }^{27}$

La pregnancia dicta que las abstracciones se realizan dentro de la mayor simplicidad posible, agrupando los múltiples componentes que crean una imagen a través de la regularidad, la simetría, la homogeneidad, el equilibrio y la sencillez. El punto está en que la visualización se hace con respecto a la coherencia estructural de la imagen y no a su descomposición por elementos. La proximidad establece que se tiende a agrupar los elementos por su cercanía. La semejanza premia la homogeneidad de lo percibido para aglomerar los componentes de la abstracción. La relación figurafondo es un principio bajo el cual la percepción separa los elementos o figuras que se destacan dentro de una imagen de las características del fondo. Lo anterior sucede bajo el entendido de que el fondo ofrece al espectador una serie de características constantes, fácilmente categorizables, que le permiten enfocar su atención en las figuras que rompen la homogeneidad de la base y le dan sentido a lo percibido. ${ }^{28}$

25 Gilberto Oviedo, "La definición del concepto de percepción en Psicología con base en la teoría Gestalt", Revista de Estudios Sociales, n. 18 (2004): 89-96.

26 Según Oviedo "La conciencia, en el momento de percibir un objeto externo como la mesa, no solo tiene un conjunto de informaciones sobre este objeto llamado mesa, sino que tiende a tener noción de la meseidad. Es decir, esta mesa es un objeto que en esencia es algo plenamente identificado, ordenable, reconocible y con el cual puedo relacionarme como algo que conozco y puedo imaginar mentalmente, recordar, rotar imaginariamente y hacer cálculos y predicciones". Véase: Oviedo, "La definición del concepto", 93.

27 Ibid., 89-96.

28 Ibid., 89-96. 
Para el segundo nivel, el externo, se buscó entender las diferentes transformaciones que ha tenido el grupo representado a través de Blanquita, durante el periodo de exposición y desarrollo del ícono publicitario. Para ello se llevó a cabo una revisión general del material bibliográfico existente a propósito de esta temática, centrándose especialmente en las dinámicas de representación de este grupo social, y su situación social frente al proceso de urbanización que experimentó como grupo durante la segunda parte del siglo $\mathrm{xx}$.

\section{Blanqueando a Blanquita: las imágenes del blanqueamiento}

Las razones que llevan a considerar a Blanquita como un ícono fundamental en la historia de la publicidad en Colombia no se queda únicamente en su tiempo de exposición, sino que trascienden la órbita de las representaciones sociales, puesto que dicha imagen creó una serie de referencias que la vinculan directamente con los imaginarios a propósito de la población afrodescendiente en el país. ${ }^{29}$ Una muestra de lo anterior la dieron la agencia de los Estados Unidos para el Desarrollo Internacional y BrandAsset Consulting, que en marzo de 2014 realizaron un sondeo de las marcas y elementos que más relacionaban los colombianos con la población afrodescendiente, en cuyos resultados apareció en primer lugar precisamente la imagen de Blanquita, por encima de políticos de alto reconocimiento nacional como Piedad Córdoba. ${ }^{30}$

Es importante señalar como punto de arranque que aun cuando el personaje de las campañas de Límpido no varió en el tiempo (siempre fue Blanquita, una mujer negra, de mediana edad, en un contexto urbano y vinculada a los quehaceres y cuidado de la casa), la forma en la que ella fue representada sí se alteró de múltiples maneras con el paso de los años. Para mostrar lo anterior, a continuación, paso a describir cuatro piezas publicitarias en las que estuvo presente la imagen de Blanquita, que abarcan un margen temporal de 26 años (1986-2012), y en las que

29 Autores como Pietro Pisano han trabajado el caso de otros personajes icónicos de la representracion afrodescediente en Colombia, como es el caso de Pambelé. En estos casos tambien se evidencia la existencia de lógicas de racialización que dan forma a los procesos de ascenso social.

30 Redacción Negocios, "Límpido y Piedad Córdoba, la marcas que más identifican a la comunidad afro",ElEspectador, 1 de marzo de 2014, http://www.elespectador.com/noticias/economia/limpidoy-piedad-cordoba-marcas-mas-identifican-comunid-articulo-477948 (31/03/2017). 
es posible rastrear elementos significativos de las trasformaciones experimentadas por Blanquita. ${ }^{31}$

En términos generales, en la primera pieza publicitaria analizada, de 1986, la escena se desenvuelve cuando una mujer blanca, al revisar la ropa recién lavada en el patio de su casa, exclama “¡Blanquita!”, palabra a la que su empleada del servicio doméstico responde de forma casi inmediata “llamaba, mi señora”, pues esta última supuso que su empleadora la estaba llamando. Sin embargo, la mujer advierte que se refería a la ropa, y no a su empleada, que acto seguido pasa a describir al blanqueador Límpido de JGB como rendidor y efectivo, todo ello mientras realiza el lavado de la ropa de su patrona con dicho producto. El comercial termina cuando en medio de su actividad, la mujer blanca exclama nuevamente “ ¡Blanquita!” y acto seguido Blanquita sale presurosa al encuentro de su patrona. ${ }^{32}$

En esta pieza publicitaria, el personaje de Blanquita fue interpretado por una mujer negra, con un acento marcado de la costa pacífica colombiana, que es fácilmente identificable como empleada del servicio doméstico, tanto por su indumentaria como por el contexto general del video, al servicio de una mujer blanca. En términos de escenografía, las dos mujeres están vestidas de blanco y las acciones se desenvuelven entre ropa blanca, siendo únicamente el tono de piel de Blanquita lo que rompe la homogeneidad del cuadro.

En el segundo comercial, perteneciente a la década de los noventa, el contexto es diferente, pues la figura de la patrona blanca desaparece, y ahora Blanquita (segunda actriz) con un acento aún del Pacífico pero matizado interactúa con otra mujer que, al igual que ella, porta la indumentaria tradicionalmente asignada a las empleadas del servicio doméstico; pero ella es blanca, aunque con un acento que la identifica fácilmente como de origen campesino. ${ }^{33}$

Las acciones inician cuando la segunda empleada le pregunta a Blanquita por la manera como hizo para encontrar novio, situación a la que ella responde que es el resultado del uso de blanqueador Límpido, pues este deja la ropa en una tonalidad blanca que se nota y llama la atención (en la escena ella aplica el producto en su

\footnotetext{
31 Las cuatro piezas publicitarias son de acceso público y se encuentran en los cuatro casos disponibles a través de internet, en los sitios que se referenciarán cuando se analice su contenido.

32 Archivo audiovisual de Colombia, “Comercial de Límpido JgB con blanquita 1986" [1986], video de YouTube; 0:42; octubre de 2007, https://www.youtube.com/watch?v=Jbsed8p1nU4.

33 Flambil, “j”, s. f., video de YouTube, 0:17; julio de 2007, https://www.youtube.com/watch?v= i4Rik7JqCX4.
} 
indumentaria laboral). Posteriormente, la mujer campesina le pregunta a Blanquita cómo es el novio que ha conseguido, a lo que ella responde "divino, blanquito, aseadito", momento en el que aparece el novio de Blanquita, un hombre negro vestido completamente de blanco, con un acento marcado de la costa pacífica colombiana. Al final, la pieza publicitaria cierra con un plano cerrado sobre Blanquita, en la cual ella advierte que Límpido por tradición es blancura y desinfección. En este comercial, nuevamente, todas las interacciones se desenvuelven en medio de una escenografía marcada por el blanco, pues todos los personajes visten de este color y dialogan en medio de la ropa blanca recién lavada. La uniformidad del entorno es únicamente rota por la presencia del negro, que aportan tanto blanquita como su novio.

En el tercer comercial, aún con la segunda actriz que interpretó a Blanquita y su acento de la costa pacífica matizado, el cambio de contexto es absoluto, puesto que en este caso el único personaje de toda la pieza es Blanquita, que ahora, desprovista de su uniforme, y utilizando el producto Límpido en un contexto que refiere a la limpieza de su propio hogar, no da ningún indicio de estar al servicio de nadie. En este caso es fácil proponer que ahora Blanquita es un ama de casa que comenta la efectividad del producto de limpieza. Las acciones, en este caso, son muy básicas, pues Blanquita inicia el comercial reflexionando desde el sofá de su casa, a propósito de la aparición de nuevos productos de limpieza, pero ninguno de la calidad de Límpido (que ahora es multiusos), puesto que al momento de limpiar y desinfectar nada se compara con la versatilidad de esta marca y su economía, tesis que ella comprueba al hacer por sí misma las actividades hogareñas. Hacia el final de la pauta, Blanquita usa una de sus frases más representativas, en la que advierte que Límpido deja la ropa blanquita, como ella, y cierra con la expresión "bueno limpiando y el bolsillo cuidando".34

En este caso, en la primera parte del comercial, la escenografía ha perdido la preponderancia del blanco, pues las acciones se desarrollan en medio de la sala de una casa convencional; sin embargo, en el momento en que Blanquita se da a la tarea de demostrar la versatilidad y poder del límpido, el color blanco se apodera de la imagen, esta vez no solo en el patio de la casa, sino en la cocina, en los baños y corredores pues, como dice Blanquita, Límpido le permite mantener las paredes, los pisos y la ropa blanquitos, como ella.

34 57FmVideos, "Límpido", s. f., video de YouTube, 0:31; julio de 2009, https://www.youtube.com/ watch?v=3OZbjcOOdYk. 
En el último comercial, este del 2011, una de las piezas finales de la exitosa campaña publicitaria, muestra a la tercera actriz que interpretó a Blanquita, a la que se le puede calificar de morena o incluso trigueña antes que de negra, vestida de forma convencional y sin ningún tipo de acento posible de ubicar. En este caso, las acciones nuevamente se centran en Blanquita, único personaje del comercial, que inicia aclarando que ella no tiene un posgrado, ni trabaja en la bolsa de valores, pero sí tiene un conocimiento experto en la economía familiar, pues ella sí sabe cómo hacer rendir la platica en su hogar. ${ }^{35}$

En este caso no hay duda de que Blanquita realiza la limpieza en su propia casa, incluso se podría formular nuevamente que es un ama de casa, aunque no da evidencia de que estar casada (no porta anillo de matrimonio) y tampoco se evidencia en absoluto la presencia de niños en el hogar. Esto contrasta con la recurrente alusión de Blanquita al ahorro familiar, pues, visto en perspectiva, en el comercial Blanquita no parece estar a cargo de nadie en particular. Lo anterior conduciría a pensar en dos hipótesis: o Blanquita vive sola y su obsesión con el ahorro deriva de sus bajos ingresos, situación descartable si se tiene en cuenta el tipo de casa en la que habita (de clase media, sin duda), o Blanquita convive con su pareja, situación en la que la omisión del anillo podría ser simplemente un descuido de producción, subsanable por el contexto que la identifica como ama de casa. En este caso, el suponer las connotaciones de una unión libre u otro tipo de vínculo informal sería caer en la sobreinterpretación de la pieza publicitaria. En todo caso, el color blanco ha perdido su preponderancia, porque, aunque todavía está presente, no se impone sobre la imagen en ningún momento; incluso es marginal cuando Blanquita se refiere al poder limpiador y desinfectante del producto.

$\mathrm{Al}$ revisar la transformación cualitativa que evidencia la pieza publicitaria, en un periodo de treinta años, el salto es drástico en términos raciales, de clase social y género. En cuestión de tres décadas, en lo racial, Blanquita pasó de ser una persona negra a morena (las actrices que se han escogido son de un color de piel cada vez más claro) y sin acento regional posible de vincular a una zona predominantemente de afrodescendientes de Colombia. Desde una oposición total, demarcada por la relación patrón blanco a empleada negra, aclimatado en una escenografía construida con el propósito de resaltar esa diferencia, se pasa a una situación donde el componente racial es sistemáticamente matizado y flexibilizado, solo rastreable

35 Canal de Límpido Colombia, "Ahorrando con Blanquita", s. f., video de YouTube, 0:25; 18 de octubre 2011, https://www.youtube.com/watch? $\mathrm{v}=\mathrm{kCaU} 8 \mathrm{Q} \_79 \mathrm{gc}$. 
discursivamente en las imágenes y en enunciaciones como "deja la ropa blanquita, como yo", hasta terminar en un contexto donde la dimensión de la racialización es únicamente evidente al hacer una lectura visual y contextual de la pieza.

En cuanto a su clase social, Blanquita evidencia un claro ascenso social y económico, pasando de empleada del servicio a ama de casa, elemento que da cuenta de una situación económica acomodada, que le permite abstenerse de trabajar; pero que no le permite tener excesos económicos, pues ella es "la autoridad en el cuidado del bolsillo". Es interesante cómo Blanquita pasa de trabajar en la casa de su patrona, en el patio o en el cuarto de lavado, hasta desempeñarse en medio de su hogar, que por contexto se puede asociar con una vivienda de clase media.

En lo que se refiere al género, Blanquita transitó entre tener un novio negro, que evidenciaba ser también empleado no calificado, y al que define como "divino, blanquito, aseadito", a ser una mujer que da nociones de estar casada, sin ningún tipo de referencia a ser madre, incluso a una avanzada edad, advirtiendo que ella se declara a sí misma como carente de alta formación universitaria, pero sí experta en economía familiar. De esta forma, Blanquita pasó de tener un novio a dar la impresión de estar casada, pero siempre manteniendo la idea de que no tiene hijos. Todo esto en un personaje que, salvo en el caso de la segunda publicidad analizada, es prácticamente asexual o, cuando mínimo, de una sexualidad plenamente controlada, que se asienta de la mano del ascenso social y del cambio racial hacia una tonalidad cada vez más blanca.

Lo anterior permite ver cómo Blanquita combina, en treinta años de historia, cambios cuando menos en tres perspectivas: de raza, clase y género, que da saltos gigantes en cada una de esas categorías, en plena sintonía con lo que antes se denominó ideología del blanqueamiento. Estas trasformaciones difícilmente se podrían entender solo desde la dimensión interna de la imagen, por lo que en el siguiente apartado se pasa a indagar sobre el contexto social en el que se presentaron estos cambios.

\section{La formación de una población urbana afrocolombiana en el siglo $X X$}

Un componente fundamental en la comprensión de las trasformaciones que experimentó Blanquita durante la segunda parte del siglo xx se encuentra en la dimensión externa de la imagen, es decir, en las condiciones contextuales de producción y el momento histórico en el que se dieron las diferentes versiones del ícono publicitario. Por lo anterior, a continuación, se abordan, primero, algunos elementos relacionados con la formación de las clases medias urbanas negras en 
las principales ciudades del país, dentro del marco de la formación de una identidad negra en la segunda parte del siglo xx. En un segundo momento se llama la atención sobre la aparición de la Constitución del 1991, y cómo este momento fue clave en la formación de una nueva perspectiva institucional y social a propósito de la población negra en Colombia.

Para la segunda parte del siglo xx, ciudades como Bogotá y Cali se convirtieron en escenarios de recepción de una creciente población afrocolombiana de clase media. ${ }^{36}$ La mayoría de los sujetos migrantes compartían el haber acumulado cantidades significativas de recursos (bienes, tierras, capital, etc.) en sus zonas de origen, a finales del XIX y comienzos del xx, lo que les permitía enviar a sus hijos a estudiar en la capital o Cali; mientras que en otros casos eran los mismos propietarios quienes se desplazaban hacia las urbes para crear un núcleo migrante base, y a partir de allí vincular a toda su estructura familiar en una dinámica de ascenso social a través de los recursos acumulados de generación en generación. ${ }^{37}$ También se presentaba el caso, mayoritariamente para la población mulata y de ascendencia sirio-libanesa en lugares como Cartagena, que siendo parte de las élites de esa ciudad, se trasladaban hacia Bogotá a desempeñar cargos públicos, o en sectores privados como el derecho y la medicina, alcanzando la estabilidad económica, e iniciando una vida en Bogotá o Cali. ${ }^{38}$

En este sentido, según Fernando Urrea Giraldo, fue la educación superior, tanto la universitaria como la impartida en las escuelas normales, la que en muchos casos actuó como dinamizadora de un sector social afro que se fue integrando a la población urbana de clase media, a partir del desempeño de labores cada vez más calificadas y del abandono sistemático de las zonas económicamente deprimidas. Aunque compartían ciertas dinámicas, la situación en Cali y Bogotá resultaba diferente, puesto que mientras en la segunda era posible un ascenso social limitado, pero relativamente ágil, en la primera las condiciones eran mucho más complicadas por unas élites blancas tradicionalmente asentadas en concepciones racistas, y más reacias a la vinculación de población afrodescendiente en cargos de poder. ${ }^{39}$

\footnotetext{
36 Fernando Urrea Giraldo, "La conformación paulatina de clases medias negras en Cali y Bogotá a lo largo del siglo xx y la primera década del XxI", Revista de Estudios Sociales, n. ${ }^{\circ} 39$ (2011): 24-41.

37 Ibid., 24-41.

38 Ibid., 24-41.

39 Ibid., 24-41.
} 
Más allá de estas diferencias, en general, según Pietro Pisano, la conformación de estas clases medias creaba una situación social nueva, pues en los centros urbanos donde la población afrodescendiente no había tenido gran participación o visibilidad, estas clases medias relativamente acomodadas desafiaban el estereotipo o imagen que se tenía de los negros entre la población blanca de clase alta o media: mientras que estos últimos gozaban de educación universitaria y puestos relativamente importantes, los imaginarios tradicionales los vinculaban con la pobreza, la sexualidad desbordada, el desorden y la ignorancia. ${ }^{40}$ De esta forma, la consolidación de este grupo afrodescendiente de clase media abrió una serie de procesos de lucha y negociación en torno a la definición de sus propias representaciones, puesto que el choque entre los imaginarios tradicionales (que continuaron operando para las comunidades aún existentes en el Pacífico) y las nuevas realidades sociales urbanas hizo necesaria la adecuación de los elementos con los que se relacionaba a la población afrocolombiana. ${ }^{41}$

En este sentido, se abrieron dos caminos en el proceso de readaptación de los imaginarios sobre la población negra. Por un lado, apareció lo que Pisano ha denominado máscaras de blancura, como una serie de prácticas e ideas que debía adoptar la población negra en ascenso socioeconómico para poder integrarse de forma limitada y controlada en las élites predominantemente blancas..$^{42}$ Aquí Pisano explica que para hacerse parte de la estima social, las personas negras de clase media debían adquirir los valores y comportamientos atribuidos socialmente a su contraparte blanca, para que asílas élites urbanas pudieran entenderlos como alejados de sus condiciones de origen (zonas mayoritariamente negras, como los palenques), y así fuera factible que los consideraran parte de su mundo, sin llegar nunca a tener el mismo nivel que un blanco. ${ }^{43}$

Por otro lado, en una forma diferente de comprensión del ascenso social, la educación y el contacto con las ideas del movimiento de los derechos civiles en Estados Unidos dio forma a la creación, por parte de un sector de esa misma población migrante, de agrupaciones contra el racismo y por los derechos de las

\footnotetext{
40 Pisano, "Triunfadores, desplazados sociales y cenicientas", 95-105.

41 Ibid., 95-105.

42 Ibid., 95-105.

43 Ibid., 95-105.
} 
comunidades afrodescendientes. ${ }^{44}$ Aquí, según el mismo Pisano, se formaron las bases para los liderazgos populares negros en las décadas de los ochenta y de los noventa, que permitían visiones alternativas de lo que se requería por parte de la población afro para ascender socialmente. ${ }^{45}$ Grupos como El Club Negro, el CIDCUN y el Centro de Estudios Afrocolombianos, en los años sesenta y setenta; la Organización Cimarrones, en los años ochenta, y Chao Racismo, en la actualidad, fueron creando formas de identificación alternativas a través de publicaciones como Presencia Negra y Negritudes, en las décadas de los setenta y de los ochenta, donde los límites de la identificación racial y de clase eran borrosos, lo que les permitía a esas clases medias acomodadas entenderse en clave de grupos oprimidos similares a los obreros o el campesinado. El factor central en estos casos era la exaltación del hombre negro y de su condición que, en clave de lucha racial y de clase, se manifestaba contra la oligarquía blanca. ${ }^{46}$

Estos debates por la identidad de la población negra urbana en Colombia tomaron un nuevo rumbo con la aparición de la Constitución de 1991. El elemento central del texto constitucional, en referencia a la población afro e indígena, fue la aparición de las ideas del multiculturalismo, que entraron a remplazar las del reconocimiento positivo básico, que antes de ese año entremezclaban problemas de clase, raza y género. ${ }^{47}$

Bajo la tutela de esta nueva perspectiva, según Peter Wade y Klára Hellebrandová, se produjo una transformación general en la manera como fueron entendidos en el plano institucional los negros en Colombia, puesto que entraron a ser asimilados por el Estado como un grupo diferenciado al prototipo nacional mestizo, en cuanto a sus particularidades culturales y étnicas, lo que los identificaba como un

44 Pietro Pisano, "Movilidad social e identidad negra en la segunda parte del siglo xx", Anuario Colombiano de Historia Socialy de la Cultura, n. 41 (2014): 179-199. 
grupo externo al que era necesario integrar. ${ }^{48}$ En este sentido, lo que sucedió con la Constitución de 1991 fue un reconocimiento de la población negra en términos de etnización, lo que produjo un discurso único y hegemónico de las diferencias étnicas y culturales de la población negra frente a la mestiza o blanca, como una manera de demarcar y valorar sus raíces africanas y de liberación esclavista. ${ }^{49}$ Elementos como la noción de diáspora africana y de particularidad cultural se convirtieron en el lenguaje básico del reconocimiento de una comunidad como "genuinamente negra”, por su pertenencia a espacios y prácticas entendidas como tradicionales. ${ }^{50}$

La anterior situación recayó en beneficio exclusivo de las comunidades negras de las zonas periféricas, vinculadas en muchas ocasiones a la idea de los palenques ancestrales y entendidas como aquellas donde prevalecían dichas particularidades culturales. Sin embargo, esta resignificación institucional de la identidad negra excluyó de forma directa a las poblaciones afrocolombianas urbanas, puesto que ellos, al estar insertos dentro de las ciudades, perdían de forma indirecta la pertenencia al grupo ancestral y quedaron en un limbo incierto, en cuanto al reconocimiento de sus particularidades y de sus problemas como grupo dentro de la sociedad, estos últimos claramente diferentes a los de las comunidades institucionalmente reconocidas como negras. ${ }^{51}$ De esta forma, desde la institucionalidad se negó en cierta medida los procesos y realidades que se venían configurando desde los años ochenta, a propósito de la inserción de las clases medias negras en las principales ciudades del país, al invisibilizarlos como parte de un conjunto social urbano, que en este caso se homogeneiza en detrimento de sus intereses particulares.

Para Klára Hellebrandová, lo que se produjo fue entonces una escisión entre esas comunidades etnizadas y la población negra urbana, puesto que mientras los problemas de una parte de ellos fueron reconocidos, los de la segunda porción quedaron ocultos tras la idea del reconocimiento a la diferencia étnica. ${ }^{52}$ Lo anterior le permite a Hellebrandová proponer que las políticas del multiculturalismo actual, en lugar de redefinir los elementos básicos de la ideología del blanqueamiento, demarcan más las diferencias, que si bien les traen algunos beneficios limitados a

\footnotetext{
Ibid., 21-42.

50 Klára Hellebrandová, "Escapando a los estereotipos (sexuales) racializados: el caso de las personas afro descendientes de clase media en Bogotá", Revista de Estudios Sociales, n. 49 (2014): 87-100.

51 Wade, “Definiendo la negridad”, 21-42.

52 Hellebrandová, "Escapando a los estereotipos”, 87-100.
} 
las comunidades etnizadas, en el caso de la población urbana se convierten en un nuevo aliciente para las ideologías del blanqueamiento y el mestizaje, debido al limbo de identidad en el que quedan dichos individuos. ${ }^{53}$ Peter Wade describe esta misma problemática cuando plantea la existencia de una especie de hegemonía en el entendimiento de lo negro, como un factor que en cierto sentido ha conducido a la esencialización de las diferencias. ${ }^{54}$ No obstante, de la misma forma que sucedió en la década de los ochenta con El Club Negro, en la actualidad, organizaciones como Chao Racismo están conduciendo una visibilización de estas problemáticas directamente asociadas a las poblaciones negras en zonas urbanas, exponiendo que es imposible limitar el reconocimiento de lo afro a las poblaciones palenqueras exclusivamente..$^{55}$

Esta distinción entre población etnizada y la población negra urbana se trasmite también al campo de las representaciones, pues mientras que desde el Estado se crea un escenario de valorización de las diferencias culturales de la población afrocolombiana a través de la imagen del palenque y sus prácticas, las referencias a propósito de la población negra urbana pasan a un segundo plano para la institucionalidad colombiana, sin que el problema de las máscaras de la blancura sea realmente atajado; ello en la medida en que, a partir del punto de vista del Estado, la población genuinamente negra es aquella que se mantiene periférica para conservar sus valores étnicos y culturales. De esta forma, como lo evidencia Klára Hellebrandová en su investigación a propósito de la racialización de las personas afrodescendientes de clase media en Bogotá, la ideología del blanqueamiento continúa siendo el patrón general de ascenso social en élites urbanas, que siguen resistiendo la integración de la población negra, que queda relegada a una posición ambigua de homogeneización o exclusión social. ${ }^{56}$

53 Ibid., 87-100.

54 Wade, "Definiendo la negridad en Colombia", 21-42.

55 El término población palenquera se refiere al grupo humano descendiente de las poblaciones creadas por esclavos, que han desarrollado una identidad propia y un conjunto de prácticas culturales particulares. Véase: Pisano, "Triunfadores, desplazados sociales", 95-105.

56 Klára Hellebrandová, “Escapando a los estereotipos”, 87-100. 


\section{La vía de Blanquita: el camino del blanqueamiento como ascenso social}

Los anteriores apartados nos han presentado la evolución interna de Blanquita, en cuanto pieza audiovisual, y el escenario social en el que esta representación se inscribe. Ahora, aprovechando esos insumos y el acervo teórico y conceptual al que me referí en la primera parte del texto, se plantea un diálogo entre la dimensión externa e interna que caracterizó a Blanquita.

En primer lugar, se puede establecer que para la segunda parte del siglo xx, la urbanización y consolidación de una clase media afrodescendiente en las principales ciudades de Colombia era una realidad y que este proceso se caracterizó por la aparición de personas negras en múltiples espacios y ámbitos que en el pasado eran monopolio absoluto de élites blancas. En este sentido, al igual que lo han propuesto otros autores como Prieto Pisano, los imaginarios y estereotipos pensaban a los afrocolombianos como ubicados en zonas periféricas no urbanas; en pésimas condiciones económicas y carentes de cualquier nivel de educación; además de dueños de una sexualidad desbordada; tendientes a la violencia y carentes de autocontrol, que resultaban simplemente inadecuados para las realidades que evidenciaba esta población negra urbana, que en general se encontraba en condiciones económicas y sociales similares a las de su contraparte blanca, y ahora estaba demandando el acceso a espacios de poder y prestigio social que les eran negados por esa élite tradicional.

Este desbarajuste entre la realidad y el imaginario demandó un cambio de la forma en la que eran representados los afrocolombianos, a los que ya no se les podía encuadrar o resistir su progreso social dentro de lógicas raciales anteriores. Así, en medio de la contraposición de formas de representación que se planteaban, en la segunda parte del siglo Xx, entre las máscaras de blancura y el autorreconocimiento de la población negra en clave de exaltación, aparece una figura icónica como la de Blanquita, que entra a convertirse en una excelente representación del blanqueamiento como forma de ascenso social, a través del abandono sistemático de lo que podríamos denominar condiciones de origen y la adopción paulatina de una conducta y moral supuestamente blancas. De esta forma, se puede leer a Blanquita como un ejemplo visual de la manera en que las élites tradicionales blancas planteaban la integración controlada de la población negra dentro de algunos espacios sociales, sin que ello significara una integración completa, puesto que en todo caso se mantiene a los negros en una posición subordinada al poder de los blancos. 
En general no resulta difícil apoyar las anteriores apreciaciones sobre el material empírico analizado, pues, por una parte, además del aclaramiento de piel que experimentó Blanquita con el paso de los años; por otra, su comportamiento social y como mujer responde a las lógicas del blanqueamiento, en las que se experimenta un progreso económico basado en el autocontrol y total manejo de los impulsos y deseos personales bajo la noción del ahorro familiar (tema en el que Blanquita es experta). En cuanto al género, se presenta una eliminación total del componente sexual del ícono, planteando entre líneas discursivas que Blanquita hace parte de una relación matrimonial, que en total control de los impulsos sexuales desaforados propios de los negros no presenta evidencia alguna de tener hijos.

Aquí aplica un factor interesante de la interseccionalidad, pues no resultaría desatinado pensar que uno de los bastiones del progreso económico de Blanquita se asienta precisamente en el no tener hijos, como evidencia de las ventajas financieras que otorga estar en control de su sexualidad, originalmente desaforada. Tal situación se consolida en el hecho de que Blanquita pasa de trabajadora doméstica a ama de casa, sin ninguna referencia a tener un oficio en particular, pues junto a su ascenso social no se registra un progreso educativo, situación por la cual, ahora que su trabajo no es requerido como parte del sustento económico familiar, el mejor lugar que puede ocupar es el de ama de casa, alejada de posibles situaciones que corrompan su nueva condición moral de estricto autocontrol.

Uno de los elementos más significativos del ícono Blanquita está precisamente en las sutilezas a través de las cuales se evidencia una integración subordinada o limitada de las personas negras en el mundo urbano. En este sentido, es diciente, por ejemplo, cómo a pesar de adoptar un comportamiento y una moral plenos del blanqueamiento, Blanquita nunca llega a contar con la holgura económica que le permita abandonar su obsesión por el autocontrol económico y reproductivo. Todo el tiempo las piezas publicitarias le recuerdan al espectador que el fundamento de todo el ascenso social de Blanquita es la inexistencia de excesos de ningún tipo, incluso el que representaría que ella trabajase. De igual forma, es central observar cómo los conocimientos superiores que ella adquirió en economía familiar son el resultado de su experiencia empírica, pues si bien no se descarta que tenga algún tipo de formación académica, este no alcanza la de un posgrado, pues eso mismo representaría uno de los temidos excesos económicos o morales que podrían hacer que Blanquita retornara a su condición de origen, es decir, volver a ser negra.

Desde aquí entonces proponemos, bajo la lógica con la que fue construida Blanquita, al afrocolombiano urbano de las máscaras de la blancura como aquel 
negro blanqueado que ha logrado controlar sus excesos físicos, económicos y morales, casi con la total neutralización del deseo individual. De igual forma, es una persona, en el mejor caso, trigueña, pues con ello se evidencia el contacto racial con los blancos en algún momento de su línea familiar, y que de algún modo posee nivel de educación, sin que el mismo sea excepcionalmente alto, puesto que la formación académica y empírica hace parte de los sistemas de autocontrol que le permitieron el progreso social; pero que en general es muy reducido para permitirle exigir o incluso demandar algún acceso al poder.

\section{La imagen de la discordia}

Como se mencionó en la introducción, en 2011, la revista española HOLA presentó como apoyo a un reportaje titulado "Las mujeres más poderosas del Valle del Cauca, en Colombia, en la formidable mansión hollywoodiense de Sonia Zarzur, en el Beverly Hills de Cali", una fotografía en la que mujeres de la élite blanca caleña posaban con las que, se supone, eran sus empleadas del servicio, de raza negra. En el presente apartado me refiero de manera detallada a los acontecimientos que rodearon la polémica suscitada por la revista $H O L A$, manteniendo un diálogo entre el análisis formal de las imágenes involucradas y las reacciones y apropiaciones sociales que dichas publicaciones hicieron de los imaginarios de la población negra en Colombia. El ejercicio es valioso, puesto que confronta un caso extremo en el que una serie de publicaciones prestigiosas se ven envueltas en controversias racistas, clasistas y de género, por haber presentado a la población afrodescendiente bajo parámetros que resultaban inadecuados a la evolución histórica de su imagen o, como se llamó antes, a la evolución del afrodescendiente urbano de las máscaras de la blancura (casos HOLA y Soho). Dicho proceso luego choca con la indefinición de una representación o imagen clara de las personas negras urbanas, cuya imagen se mantiene en la indefinición causada por la Constitución de 1991 (caso Universo Centro).

$\mathrm{Al}$ analizar la imagen original ( $H O L A)$ bajo los postulados de la psicología de la Gestalt, se puede plantear que la fotografía de la revista HOLA combina tres fenómenos de la percepción: semejanza, proximidad y la relación fondo-figura. ${ }^{57}$ Así, en

57 La idea original de este capítulo era presentar directamente la imagen para que los lectores pudieran confrontar de primera mano los análisis realizados; sin embargo, al solicitar permiso de la publicación para la reproducción de la imagen, la revista se negó aduciendo derechos de exclusividad sobre el material. En cualquier caso, se pueden consultar la imagen aquí: Revista Cromos, "Polémica por fotografía del 'Beverly Hills caleño’”. 
un plano general, es posible percibir en la imagen la existencia de dos órbitas separadas que le dan coherencia estructural por medio de una relación de fondo-figura, que ubica a Sonia Zarzur y a su hija mayor en una posición al centro y al frente de la fotografía, mientras que sus empleadas, que se mantienen en un lugar relegado de la imagen, se convierten casi en instrumentos de escenografía periférica de baja importancia. Lo anterior crea una sensación, en el espectador, de jerarquización en los protagonistas de la fotografía, pues se relacionan a través de dos espacios diferentes, en el que el rol que desempeñan las mujeres Zarzur dentro del marco general de las fotos es de primacía o importancia absoluta sobre sus empleadas domésticas, que aun estando presentes en la fotografía, no se atreven a mirar directamente a la cámara, como sí lo hacen sus patronas.

Esta división de los sujetos se consolida dándole un sentido de semejanza y proximidad aún mayor a los sujetos diferenciados en la fotografía, puesto que al observar la manera en la que las seis mujeres presentes visten ropa blanca, en una escenificación donde este es el color predominante, la homogeneidad de la imagen se rompe únicamente por las empleadas domésticas que, al ser negras, marcan una diferencia insalvable con las mujeres Zarzur. Para el espectador se crea inmediatamente un vínculo no solo a partir de los espacios diferenciados que ocupan, sino de las lógicas raciales y sociales que las distancian, al crearse dos grupos que si bien puede estar próximos, son evidentemente diferentes, pues la semejanza y proximidad apuntan nuevamente a una relación jerarquizada, en la que las patronas blancas y las empleadas negras constituyen dos universos cercanos aunque diferenciados.

La anterior referencia de distancia social, basada en los componentes de raza y clase, nos remite a los factores que eran referenciados en la primera versión de Blanquita, que para 2011, cuando aparece la imagen de $H O L A$, habían desaparecido ya hace largo tiempo del panorama de representaciones aceptadas sobre las personas afrodescendientes en el país. La situación desencadenada por la fotografía no resulta exagerada, como argumentaba Sonia Zarzur, pues las sensaciones y las referencias que la fotografía despiertan en el espectador son extrañas y de rechazo, puesto que en este punto es inválida la manera directamente jerarquizada de representar a la población afrodescendiente.

Aquí solo habría que hacer una comparación entre la Blanquita de 2012 y su exitoso blanqueamiento, con las dos empleadas domésticas de la familia Zarzur, para comprender el tamaño del desajuste simbólico en que cayó la revista $H O L A$ con sus fotografías. Este choque en relación con las formas de representación explica en parte por qué la controversia no paró en ese punto y, simplemente, fue escalando a 
través de las maneras cada vez más desafortunadas de asumir y tratar de explicar los problemas estructurales de la fotografía. En este sentido, a las pocas semanas de la publicación de $H O L A$, en una reacción que merece el mismo análisis de la primera fotografía, la revista Soho trató de parodiar la imagen invirtiendo los papeles de la representación con mujeres de raza blanca presentadas como empleadas del servicio doméstico; pero en esta ocasión el espacio central de la imagen era para modelos negras posando desnudas. ${ }^{58}$ Bajo el título, "Elogio de la mujer negra", las relaciones de semejanza, proximidad y fondo-figura, que fueron destacadas para la primera fotografía, se mantienen, pero ahora los elementos de referencia que dan sentido estructural a la imagen cambian de manera totalmente desafortunada para el título que puso la revista, pues en dicha representación se resaltó la exacerbación sexual como lógica de representación de la segunda imagen.

De esta forma, si en el primer caso la oposición entre blancura y negritud era evidente, en la fotografía de Soho el hilo conductor de la representación se situó en una clara connotación sexual de las mujeres negras, pues precisamente este es el elemento de semejanza y proximidad que hermana al grupo destacado; mientras que la relación sujeto-fondo termina por distanciar a su contraparte blanca que se percibe como alejada de la situación de hipersexualización en el que caen las primeras. En este caso, la escenografía que rodea a las modelos no demarca ninguna relación de contraste particularmente racial, como sí sucede en la fotografía original, pues en este caso la raza es un elemento vinculado, pero solo es un plus, sobre un espacio central sexualizado a través de las modelos, y un fondo neutral. De esta forma, los personajes del fondo de la imagen cambian por la transformación en el hilo conductor o elemento armonizado en esta segunda imagen, pues al reconocer que ahora el elemento que produce semejanza y proximidad no es la raza, sino la connotación sexual, el lugar social delimitado por la referencia al trabajo doméstico y su raza blanca, pasa a un segundo plano.

Esta última imagen, la de Soho, por su connotación sexual, que como vimos en el caso de Blanquita está íntimamente ligada a la idea de la raza negra y su blanqueamiento, despertó igual o mayor rechazo que la producida por $H O L A$. Evidencia de la incomodidad surgida por la fotografía de Soho dio una carta enviada a la

58 La idea original de este capítulo era presentar directamente la imagen para que los lectores pudieran confrontar de primera mano los análisis realizados. Sin embargo, al solicitar permiso de la publicación para la reproducción de la imagen, la revista se negó aduciendo derechos de exclusividad sobre el material. En cualquier caso, se pueden consultar la imagen aquí: Soho, "Elogio de la mujer negra”. 
revista por varios profesores de la Universidad Autónoma de Occidente ${ }^{59}$ titulada: "La respuesta desatinada de SoHo a Hola", en la que acusaban a la publicación de continuar reproduciendo la imagen de las mujeres negras como objetos netamente sexuales, incapaces de valer por su intelecto o capacidad artística, al mismo tiempo que reproducía la idea del patriarcado machista. ${ }^{60} \mathrm{De}$ esta forma, señalaban que la parodia era aún más ofensiva, puesto que incluso dentro del juego propuesto por Soho las mujeres presentadas como empleadas del servicio no eran blancas, pues presentaban notorios rasgos mestizos que daban cuenta de los estereotipos hacia otro sector poblacional que, al igual que los negros, es objeto de constante discriminación. ${ }^{61}$ La protesta proveniente de los profesores de la Universidad Autónoma de Occidente estuvo, precisamente, enfocada en el cambio de hilo conductor o factor de semejanza y proximidad en la segunda foto, y de cómo esa nueva relación logró profundizar en la hipersexualización de las protagonistas afrodescendientes, y no su reconocimiento o dignificación en términos raciales.

En este caso cabe destacar también la respuesta de las directivas de la revista Soho ante los cuestionamientos surgidos por la connotación sexual y racial de su fotografía, pues respondieron, en un tono de indignación similar al de Sonia Zarzur, que ellos solo parodiaban la publicación de $H O L A$ al estilo de su revista, con desnudos y actos de exposición corporal, y que para ellos la fotografía lograba el efecto deseado de inversión de los papeles y roles asignados a las razas. ${ }^{62}$ Incluso el director de Soho, Daniel Samper Ospina, llegó a acusar públicamente a los académicos de la Universidad Autónoma de Occidente de retrógrados y anquilosados, por lo que él entiende es su incapacidad de comprender la naturaleza erótica de su publicación, situación que podría equipararse al reclamo de Sonia Zarzur cuando en medio de la polémica declaró que su intención nunca fue racista, pues ella únicamente da trabajo a las personas de las clases populares en Cali. ${ }^{63}$ En ambos

59 Profesores Elizabeth Gómez Etayo, Hernando Uribe Castro, Germán Ayala Osorio, Guido Germán Hurtado Vera y Carmen Jimena Holguín.

60 Elizabeth Gómez, Hernando Uribe, Germán Ayala, Guido Hurtado y Carmen Holguín, "La respuesta desatinada de SoHo a Hola", Revista Semana, 14 de marzo de 2012, http://www.semana.com/nacion/ articulo/la-respuesta-desatinada-soho-hola/254875-3 (31/03/2017).

61 Ibid.

62 Daniel Samper Ospina, “La acertada respuesta de Soho a la Revista ¡Hola!”, Soho, 23 de marzo de 2012, http://www.soho.com.co/web/articulo/la-acertada-respuesta-soho-revista-hola/26202 $(31 / 03 / 2017)$

63 Ibid. 
casos, los dos personajes desconocen la relación clase-raza y género-raza y cómo esos vínculos refieren a una serie de representaciones a propósito del lugar social de la población afrodescendiente en Colombia.

Lo anterior nos remite inevitablemente a una característica que ya se había mencionado a propósito de la imagen de Blanquita, y es el lugar que ocupa la sexualidad en el progreso social evidenciado por el personaje, puesto que bajo la tesis del blanqueamiento, la oposición o juego racial que plantea Soho en su imagen se invalida a través de la hipersexualización de las protagonistas, puesto que el vínculo entre raza y sexualidad termina por apelar al conjunto viejo de referencias que bien representaba Blanquita en sus inicios, y que para este momento resulta claramente atípico y molesto para los espectadores, que esperan encontrar a una Blanquita asexualizada y de impulsos plenamente controlados.

Tiempo después, en lo que se podría llamar la última escena de esta controversia, en un nuevo intento por parodiar la imagen de la revista $H O L A$, y en cierto sentido también la producida por Soho, el diario Universo Centro, de la ciudad de Medellín, realizó una nueva fotografía en la que varios de los elementos criticados por los profesores de la Universidad Autónoma de Occidente desaparecieron y se planteó una oposición básica entre los elementos destacados en la imagen original. ${ }^{64}$

En dicha ocasión, la imagen se invirtió manteniendo los patrones fundamentales de la foto original y se les dio la centralidad a las mujeres afrodescendientes, ahora vestidas; mientras que su contraparte blanca es enviada al fondo de la imagen a modo de empleadas del servicio. ${ }^{65}$ Sin embargo, incluso dentro de esta representación donde la connotación sexual de la imagen está neutralizada, se matizaron y suavizaron varios de los componentes raciales con respecto a la fotografía original. Si bien se mantiene una relación de clase que trata de vincular a las mujeres blancas con el oficio de empleadas domésticas, en la imagen se presentan algunos cambios que se podrían pensar como menores; pero que, al final, cambian el sentido estructural de la fotografía. Así, por ejemplo, en la fotografía de Universo Centro, además de que las mujeres del fondo miran hacia la cámara y rompen la idea de ser simple escenografía, tampoco se presenta una oposición racial total, puesto que no se hace un juego equivalente al de la primera fotografía con la ropa y la indumentaria, lo que produce que al final se pierda la condición de subordinación presente en las

64 Juan Ospina, “Arte central”, Universo Centro, 2011, http://www.universocentro.com/NUMERO30/ Artecentral.aspx (31/03/2017).

65

Ospina, "Arte Central". 
imágenes de $H O L A$. Aquí, para el espectador, los personajes del fondo y el centro están ubicados casi en el mismo plano, situación que, aunque no elimina la oposición grupal, que se sucede por la relación objeto-fondo, sí se matiza en alto grado. En general, aunque se invierten las relaciones raciales y de clase, además de eliminar la de género, el poder de la representación es mucho menor y la fotografía termina por ser simplemente anecdótica dentro de los hechos.

Una explicación alternativa a la poca contundencia de la fotografía de Universo Centro se encuentra también en el proceso de etnización de la población negra, que se explicó en apartados anteriores. Si partimos de que gran parte de la controversia producida por HOLA y Sobo se encuentra en el uso de representaciones sociales no acordes con la evolución de la imagen de los afrocolombianos en la publicidad, se tendría que advertir que en el caso de Universo Centro ni las mujeres blancas asociadas al trabajo doméstico, ni las mujeres negras urbanas llevan a algún tipo de referencia que choque con los preceptos de representación de algún grupo social, como sí lo hicieron la primera y segunda versión de esta fotografía. Aquí se podría argumentar, hasta cierto punto, que al igual que Blanquita las mujeres de las tres fotografías caen en el limbo de indeterminación que se ha sucedido desde la introducción del multiculturalismo, pues en su condición urbana no denotan elementos que las acerquen o alejen del proceso de blanqueamiento o de alguna de las vertientes de reconocimiento afro en clave de exaltación.

En este sentido, el sistemático fracaso en el que caen los intentos de parodiar a la revista $H O L A$ puede estar precisamente en que no existe un referente claro con el cual combatir los componentes racistas, clasistas y sexistas de la fotografía original. Aquí bien valdría preguntarse, ¿cuál es el símbolo afrodescendiente no blanqueado al que podrían haber apelado las respuestas a $H O L A$ ? La anterior es una pregunta que, por lo pronto, no tiene respuesta, pero que en cualquier caso debería tenerla en el futuro cercano.

\section{Conclusiones}

A partir de las páginas anteriores se estableció cómo uno de los íconos fundamentales de la publicidad en Colombia, Blanquita, representa una de las maneras en las que se le dio sentido y canalización al progreso de la población afrodescendiente en el país, en términos de blanqueamiento. Así es como se identificaron las líneas generales de los presupuestos morales y de comportamiento que caracterizaron y caracterizan dicho proceso. De esta forma, y no solo a partir del modelo de análisis visual aquí utilizado, se pueden multiplicar las fuentes para la comprensión de 
los referentes visuales del ascenso social, tanto para la población afrodescendiente como para otros grupos sociales (campesinos, indígenas, etc.) que entran en el juego ambivalente del blanqueamiento como lógica de funcionamiento social.

En este sentido, las fuentes visuales se presentaron como una herramienta a través de la cual es posible rastrear las ideas y significados con los que se ha vinculado esta población, bajo la noción que un producto audiovisual de consumo masivo durante un tiempo prolongado puede influir en la sociedad y su capacidad de generar referentes o imágenes a propósito de los grupos que la componen. Además, las imágenes de la discordia (HOLA, Soho y Universo Centro) me llevaron a observar cómo los patrones creados a partir de herramientas como Blanquita crean marcos por medio de los cuales se mueven las representaciones que, al ser desconocidas en cualquier dirección, generan en la sociedad una sensación de rechazo y oposición. También establecí nuevas preguntas a propósito de no solo la actual representación de la población negra urbana en Colombia por fuera del blanqueamiento, sino respecto de la necesidad de explorar a fondo la evolución de los referentes de la población afrocolombiana en clave de exaltación, pues en esta investigación únicamente se recrea una de las partes de dicha disputa.

Así mismo, también establecí una de las múltiples formas en las que las fuentes de tipo visual pueden entrar en diálogo con los referentes teóricos de diferentes disciplinas, como la historia y la antropología, todo ello para crear nuevas aproximaciones a las problemáticas sociales. Por lo anterior, es siempre significativo el llamado a observar en los demás trabajos de este libro, y en otras publicaciones, la manera en la que la cultura visual empieza a crear un lugar dentro de la investigación en humanidades y ciencias sociales.

\section{Bibliografía}

\section{Fuentes primarias}

\section{Canales de YouTube}

Archivo audiovisual de Colombia, 2007. https://www.youtube.com/watch?v= Jbsed8p1nU4.

Canal de Límpido Colombia, 2011. https://www.youtube.com/watch?v=kCaU8Q $79 \mathrm{gc}$.

Flambil, 2007. https://www.youtube.com/watch?v=i4Rik7JqCX4.

57FmVideos, 2009. https://www.youtube.com/watch?v=3OZbjcOOdYk. 


\section{Publicaciones periódicas}

Revista Cromos. Bogotá, 2011.

Soho. Bogotá, 2011.

Universo Centro. Medellín, 2011.

\section{Fuentes secundarias}

Hellebrandová, Klára. "El proceso de etno-racialización y resistencia en la era multicultural: ser negro en Bogotá”. Universitas Humanistica, n. 77 (2014): 145-168.

Hellebrandová, Klára. “Escapando a los estereotipos (sexuales) racializados: el caso de las personas afrodescendientes de clase media en Bogotá”. Revista de Estudios Sociales, n. ${ }^{\circ} 49$ (2014): 87-100.

Hering, Max y Amada Pérez. "Apuntes introductorios para una historia cultural desde Colombia”. En Historia cultural desde Colombia: debates y categorías, editado por Max Hering y Amada Pérez, 15-51. Bogotá: Universidad Nacional; Pontificia Universidad Javeriana; Universidad de los Andes, 2012.

Lévi-Strauss, Claude. Antropología estructural: mito, sociedad, humanidades. México: Siglo XXI, 2004.

Oviedo, Gilberto. "La definición del concepto de percepción en psicología con base en la teoría Gestalt”. Revista de Estudios Sociales, n. 18 (2004): 89-96.

Pisano, Pietro. “Triunfadores, desplazados sociales y cenicientas: representaciones sobre raza y ascenso social en la segunda mitad del siglo $\mathrm{xx}$ ". Universitas Humanistica, n. 77 (2014): 95-119.

Pisano, Pietro. "Movilidad social e identidad negra en la segunda parte del siglo xx". Anuario Colombiano de Historia Social y de la Cultura, n. 41 (2014): 179-199.

Urrea Giraldo, Fernando, “La conformación paulatina de clases medias negras en Cali y Bogotá a lo largo del siglo xx y la primera década del XXI". Revista de Estudios Sociales, n. 39 (2011): 24-41.

Wade, Peter. "Definiendo la negridad en Colombia”. En Estudios afrocolombianos hoy: aportes a un campo transdisciplinario, editado por Eduardo Restrepo, 21-42. Popayán: Universidad de Popayán, 2013. 


\title{
Carlos Gardel: de la imagen al mito
}

\author{
Laura Andrea Vigoya Arango
}

[...] sé que soy el tango cuando al salir del hipódromo me siguen con la vista los muchachos de la popular; no me engaño cuando el sastre se esmera por hacerme su mejor traje o la vendedora me busca entre todas, la corbata más linda. Séque el homenaje es al tango. Yo soy para ellos el tango. Y me gusta, porque asi soy más criollo. Aun cuando entono una dulce canción francesa, aun cuando la gente me escuch a las bellas notas de Parlez Moi d'Amour, yo sé que soy el cantor de tangos que se presta para otras canciones. Carlos Gardel en una entrevista para Noticias Gráficas, 21 de septiembre de $1933^{1}$

Cuando nos dirigimos a alguien y le hablamos sobre algún personaje que fue históricamente reconocido, probablemente, su memoria se vea debatida entre lo que sabe de este y lo que realmente es. Sin embargo, cuando mostramos una imagen del mismo personaje, automáticamente, se crean algunos conceptos respecto a este, bien sea por temas de identidad o por simple conocimiento popular. La de Carlos Gardel, al igual que la de otras celebridades, se ha visto vinculada a las imágenes icónicas de los siglos Xx y xxI; su sonrisa, la cara perfilada, sus ojos y cejas grandes, piel cuidada y sombrero porteño han provocado grandes sensaciones, incluso en los individuos que no saben de él. Esto causa que la misma historia de su vida pase a un segundo plano para convertirse en una imagen mítica, vinculada al espectáculo

1 Citado en María Julia Carozzi, “Carlos Gardel, el patrimonio que sonríe, Horizontes Antropológicos 9, n. ${ }^{\circ} 20$ (2003): 76 . 
y la fama, influyente a su vez en la construcción de nuevos estereotipos, idealizaciones y representaciones de individuos o colectividades. ${ }^{2}$ Así es como en el presente trabajo se pretende analizar por qué la imagen de Carlos Gardel llegó a convertirse en un mito, saber qué hizo prevalecer a este personaje sobre los demás cantantes tangueros, para finalmente descubrir si el gran "Carlitos" Gardel debe su grandeza a su misma historia o a una construcción cultural de su personaje. La estructura del capítulo, por lo tanto, pretende hacer un seguimiento a los años más importantes de Gardel a través de la composición de sus imágenes y su gira por diversos países. Por esto, se abarca la historia de sus representaciones visuales no solo desde Argentina, sino también desde los lugares en los que estuvo y en los cuales se extendió su relevancia global. Empezamos por dar una mirada a sus inicios y raíces, luego su integración al gran mundo de la industria cultural y, al final, hacemos un breve análisis de su constitución icónica.

El tango tradicional, nacido en África y traído por diversos inmigrantes tanto europeos como africanos a Mar del Plata, tiene una acogida particular en Argentina y Uruguay, donde precisamente se da su consolidación, a pesar de que ya había pasado por un proceso de formación primigenio; hasta el momento en que estos dos países se apropian de él (principalmente Argentina) se empieza a generar un conocimiento más preciso del tango como música, letra, voz y danza. El tango tradicional se ve atravesado, entonces, por distintos momentos y significaciones: 1) la añoranza de los inmigrantes por sus tierras dejadas (lo que en un principio convirtió al tango en la combinación de letra y música). 2) El tango arrabalero (el famoso tango de "prostíbulo"), que empieza a crear un estigma sobre el género en sí, fragmentando las clases sociales y basando su composición en letras de pasión, muerte, traición, juegos, azar y amor; este estilo se caracteriza también por la composición musical simple, un sonido básico y la danza, la cual en un principio era entre hombres para impresionar a las prostitutas, pero que luego integra a mujeres socialmente excluidas. 3) El tango-vals, el cual se encarga de invertir el tema de clases, dejando de ser un género del pueblo, para convertirse en un género de la

2 La vida de Carlos Gardel siempre ha girado en torno a los mitos, unos por su nacimiento, otros por su muerte, otros por su sexualidad, otros por la forma en la que vivía su cotidianidad y otros por su apariencia física. Esto ha hecho que Gardel no solo no permanezca en el anonimato incluso después de su muerte, sino que además se construya como una imagen icónica del siglo xx, que ha mantenido su legado hasta la actualidad. Autores como María Julia Carozzi, Predro Orgambide, Julián y Osvaldo Barsky, entre otros, logran reconstruir muy bien lo que fue su historia y, sobre todo, la importancia que tuvo en la construcción de una identidad cultural global. 
élite; en este punto la composición musical es completamente adornada, los sonidos son mucho más elegantes y románticos, la danza también genera una armonía corporal y las letras generalmente son de amor. ${ }^{3}$ Sin embargo, esta transición entre el tango arrabalero y el tango-vals más estilizado no se podría entender sin el elemento unificador de Carlos Gardel, quien además de lograr reivindicar el tango en temas de clases, logró ser una llave esencial para la entrada del tango al mundo, promulgando su imagen y voz.

La contextualización de la historia del tango y sus orígenes en el exilio son elementos importantes para la introducción de un género popular; suma, además, que desde la imagen de Gardel este encuentra una reivindicación mucho más urbana. Gracias a este personaje, se da voz al imaginario de todo un pueblo: Gardel es la imagen de lo que sería el tango-canción, género que no solo trataba problemas entre las clases bajas, sino que en general se proyectaba en la vida cotidiana de toda una sociedad. Charles Romuald Gardel —mejor conocido como Carlos Gardel— nace en Toulouse (Francia) el 11 de diciembre de 1890, hijo del coronel Carlos Escayolay María Lelia Sghirla. Su padre se involucró con las tres hermanas Sghirla, al enviudar de la primera (la mayor), al casarse con la segunda (la del medio) y, probablemente (debido a la falta de estudios al respecto), al violar a la tercera (María, la menor), quien es la madre del artista. ${ }^{4} \mathrm{Al}$ ser Escayola un hombre reconocido por su carrera militar en Uruguay, decide, para no crear escándalos, llevarse a María a Toulouse para tener a su hijo y ser posteriormente entregado a Bertha Gardes, una francesa que aparece autentificada como su madre putativa. ${ }^{5}$

Los orígenes de Gardel, por lo tanto, y a pesar de tener un padre dentro de un rango social alto, fueron de clase baja. Esto influyó considerablemente en su vida, sin dejar de lado sus usuales hábitos como el cigarrillo y la gran pasión por las mujeres. ${ }^{6}$ Cuando Gardel empieza a triunfar dentro del mundo del espectáculo, se convierte en la idealización del criollo porteño en Argentina y Uruguay: su espléndida voz, acompañada de su fina estampa, ayudó a crear fuertes vínculos entre su imagen y la

3 Ramón Pelinski, El tango nómade: ensayos sobre la diáspora del tango (Buenos Aires: Corregidor, 2000), 2-52.

4 La vida de Carlos Gardel ha sido todo un misterio. Se sabe a ciencia cierta dónde y cómo murió, pero no dónde nació. Salen entonces varias especulaciones respecto a su nacimiento que se debaten entre Tacuarembó, 1887 (Uruguay), y Toulouse, 1890 (Francia).

5 Carlos Mario Urrego, Ser milonguero (Medellín: Artes y letras, 2008).

6 M. Aquiles Echeverri, Gardel, su historia y causa de su muerte (Medellín: Digital Express, 1999). 
sociedad a la cual estaba llegando. Gardel no solo era el creador del tango-canción, también era el ejemplo de todos aquellos que se sentían de alguna forma identificados con las canciones que interpretaba. Nacido en Francia, pero autenticado por él mismo como uruguayo en 1920, empieza a generar no solo un impacto dentro de las clases bajas, sino que además empieza a movilizar todo un sector alto en el cual el tango no encontraba cabida. Así, la transformación del tango pasaba por un nuevo momento en términos de letra, pero también de sociedad; Gardel introdujo un nuevo sector al tango e hizo que el contenido de su música (que antes se creía arrabalero y de poca clase) gozara de una apropiación generalizada.

Por consiguiente, el cantautor logró una inclusión del tango en materia de clase, al articular diferentes identidades culturales por medio de sus letras. Sin embargo, lo que lo llevó a una internacionalización de su estilo fue el introducir los medios masivos a la sociedad. Así es como el cine, la televisión y la radio se convierten en grandes cómplices de la propagación de la imagen de Gardel y su voz, y lo vuelven un ícono de adoración casi “religiosa”. A través de esta difusión mediática, Gardel llega a otros países de Latinoamérica, centrando sus itinerarios principalmente en lo que va a ser el Viejo Caldas (Colombia). ${ }^{7}$ En ese momento, la sociedad colombiana se veía atravesada por procesos sociales acordes con la narrativa del tango: el Viejo Caldas pasaba por un proceso de colonización donde campesinos y jornaleros buscaban nuevas formas de rehacer su historia, de reconstruir su identidad. El tango, a pesar de ser un género ajeno, fue altamente acogido en dicha región, pues representaba una realidad desde la experiencia de las clases bajas. Cuando llega Gardel a Colombia, el género deja de ser simplemente algo para escuchar y se convierte en un género de adorar, ya que la adoración ahora tenía voz e imagen. Sin embargo, el evento que dio inicio a su etapa más conocida fue su inesperado deceso, en Medellín, el 24 de junio de $1935,{ }^{8}$ donde se adquiere un nuevo sentido de la imagen del cantante, que ayuda también a generar nuevos lazos entre el público

7 El Viejo Caldas fue un departamento en Colombia que existió entre 1905 y 1966, el cual se componía de los actuales departamentos de Caldas, Risaralda y Quindío. Colonizado por la población paisa, entró en diversos conflictos políticos, económicos y sociales que lo llevaron a su posterior fragmentación. Véase: Manuel Rodríguez Becerra, El empresario industrial del Viejo Caldas (Bogotá: Universidad de los Andes, 1983), 1-18.

8 La muerte de Carlos Gardel el 24 de junio de 1935 en Medellín ha sido causa de una nueva apropiación por parte de los colombianos. Sin embargo, ha habido diversas sospechas que aseguran que su muerte fue intencional por problemas entre las compañías aéreas. 
y la construcción de un personaje que, aun después de su muerte, pertenece a una memoria viva.

A pesar de realizar un breve recuento del contexto histórico de Gardel, el presente trabajo no pretende analizar su biografía; al contrario, busca orientar el análisis hacia sus imágenes y las transformaciones que lo han hecho un personaje mítico. Por esto se abordan dos periodos históricos importantes para la consolidación de dicha imagen: 1) de 1917 a 1935, en el que surge la imagen del porteño de sonrisa pícara y ojos brillantes, acompañado de su fama y la inclusión a una industria cultural mundial. Se trata entonces del periodo en que "el gran Zorzal" " criollo murió en carne; pero se inmortalizó en alma e imagen. 2) El segundo momento es después de 1935, cuando, a partir de su muerte, la imagen de Gardel adquiere un nuevo significado. Por último, se plantean algunas conclusiones respecto a las idealizaciones de lo que ha sido su memoria y lo que implicó su muerte a tan temprana edad, a efectos de encontrar las razones para su permanente construcción, legitimidad y constitución como un "mito vivo".

\section{Industrializando al "morocho"10}

En la primera mitad del siglo xx, la modernización era la expectativa de los países "subdesarrollados" para generar proyectos sociales, económicos y políticos que los condujeran por el camino del progreso, a fin de reproducir la idea de desarrollo presenciada en Europa y Estados Unidos. El manejo de las imágenes y los medios lograba generar mayor impacto en la sociedad de la época, pues representaba una realidad soñada entre los individuos. La publicidad y los personajes impulsados en los medios de comunicación, sustentados por fotografías, lograban generar una relación mucho más íntima con el público y crear, en su mayoría, toda una cultura simbolizada en imágenes. Así es como la industria cultural se consolida como parte principal del siglo xx. ${ }^{11}$ ¿Cómo empezó Gardel a formar parte de este emergente universo cosmopolita?

9 Pseudónimo de Gardel en la jerga artística.

10 El término industria cultural se refiere a las actividades productivas y comerciales guiadas por una estrategia de rentabilidad económica que, según el contexto político y socioeconómico en el cual se desenvuelvan, podría integrarse también a estrategias de tipo social y de servicio público. Véase también: Octavio Getino, Las industrias culturales en la Argentina: dimensión económica y politicas públicas (Buenos Aires: Colihue, 1995), 11.

11 Max Horkheimer y Theodor Adorno, Dialéctica del iluminismo (Buenos Aires: Sudamericana, 1969). La serialización, la estandarización, la división del trabajo y el consumo de masas fueron los principales 
Una de las imágenes inmortales del tanguero fue tomada por el fotógrafo José María Silva (figura 1); sin embargo, esta solo logra volverse icónica hasta su muerte, ya que anteriormente Gardel se había encargado de cultivar y construir una imagen que en sí ya era bastante trascendental. La pieza nace realmente a partir de su primera película muda, Flor de durazno ${ }^{12}$ (1917), en la cual se puede ver a un Gardel bastante excedido de peso y con una actuación muy precaria, por su escaso conocimiento en pantalla. Sin embargo, los directores notaron en él un talento particular que logró impulsarlo hasta el punto de convertirlo en una estrella del espectáculo.

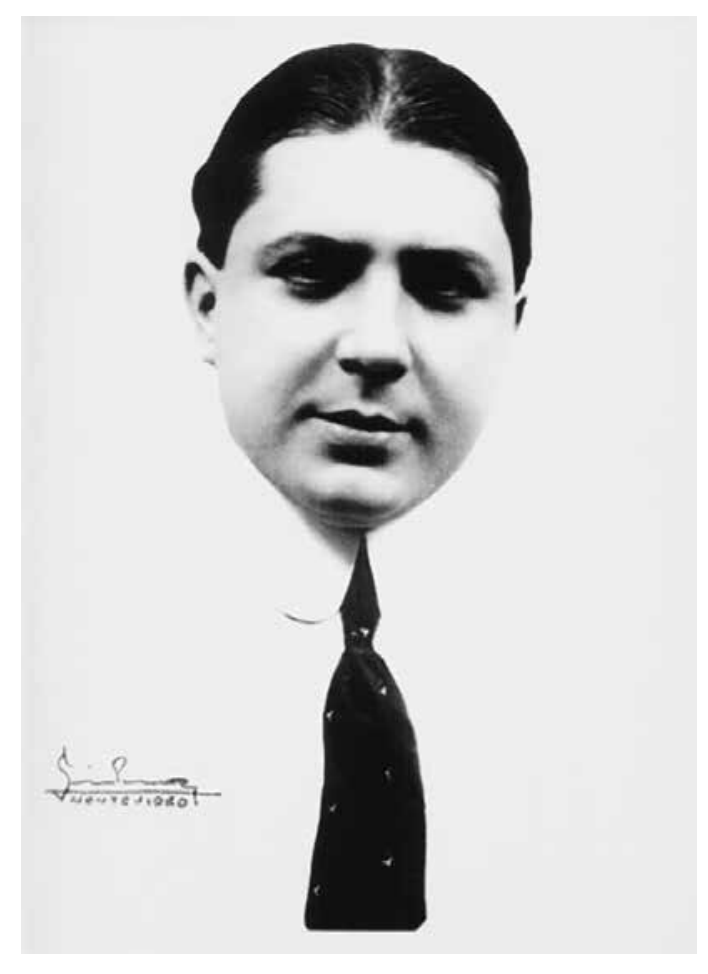

Figura 1. José María Silva, 1917, "Primera serie de fotos encargadas por Gardel" (fotografía, Archivo Gráfico de la Nación Argentina, Buenos Aires).

factores que llevaron a estos dos autores a pensar en el término industria cultural. Véase Getino, Las industrias culturales, 11.

12 Flor de durazno fue una película basada en la novela homónima de Gustavo Martínez Zuviría (Hugo Wast), adaptada y dirigida por Francisco Defilippis Novoa. Fue la única intervención en el cine silente y el único largometraje que se filmó en Argentina. Véase: Alberto Rasore, Carlos Gardel en el cine mudo (Buenos Aires: Vereda de Tango, 2006). 
El proyecto de modernización y las puertas abiertas de la industria cultural fueron la mezcla perfecta para que el "morocho" hiciera de su imagen un nuevo referente de identidad. Los estereotipos estéticos de la época, promulgados principalmente por Estados Unidos y Francia, ${ }^{13}$ le exigían una reinvención total de su imagen tanto en las pantallas como en la cotidianidad, y él, sin ninguna oposición, aceptó dicho reto para ser parte de ese nuevo mundo de las luces que significaba la industria cinematográfica. Entonces, 1917 es el año en el que la imagen del personaje se empieza a difundir no solo en la sociedad argentina y uruguaya, sino en varios países del mundo entero. A su corta edad, la imagen de Gardel generaba una relación especial con los jóvenes de la época: su cara limpia, su mirada seductora y profunda, su sonrisa encantadora y su siempre impecable vestuario representaba el auténtico porteño enamorador de la época.

\section{"Sentir que todo es mío, el sol, el aire, el limo de tu río... che, Buenos Aires... Mirá cuánta riqueza me ha brindado Dios que soy el dueño de tu voz"14}

Gardel empezó a construir de lleno su imagen y junto a ella vino toda la fama del espectáculo y la sociedad en sí. Se había vuelto un ícono latinoamericano y tenía, por lo tanto, la responsabilidad de mantener un estatus artístico que siguiera llevándolo al estrellato. A pesar de que muchas veces fuera cuestionada su orientación sexual, debido a su narcisismo y el gran aprecio que tenía hacia sus amigos, Gardel era considerado hombre de "muchas mujeres pero de un solo amor". Además de esto, la mayoría de su tiempo iba destinado a los juegos y sus amigos o a las giras que hacía permanentemente. ${ }^{15}$ Su vida y su imagen pertenecían al ámbito público, lo cual le permitía que la construcción estética de su apariencia generara la identificación que tanto buscaba con la gente común.

El artista, por lo tanto, se construía bajo el contexto y las necesidades que exigía el mundo social: fijándose en esto, modelaba su personaje. Al ser cuestionada su posible inclinación sexual, el tanguero procuró añadir a su imagen posiciones faciales y elementos estéticos masculinos. El cantante se convertía en una utopía de la cotidianidad y, como tal, procuraba mantener un estilo acorde a eso (figura 2).

13 Julián Barsky y Osvaldo Barsky, Gardel, la biografia (Buenos Aires: Taurus, 2004), 229.

14 Letra de la canción “Por qué amo a Buenos Aires” compuesta por Eladia Blázquez.

15 El gran amor de Carlos Gardel se llamaba Isabel del Valle, una muchacha de familia adinerada y más joven que él. Véase: Barsky y Barsky, Gardel, la biografia, 269-279. 


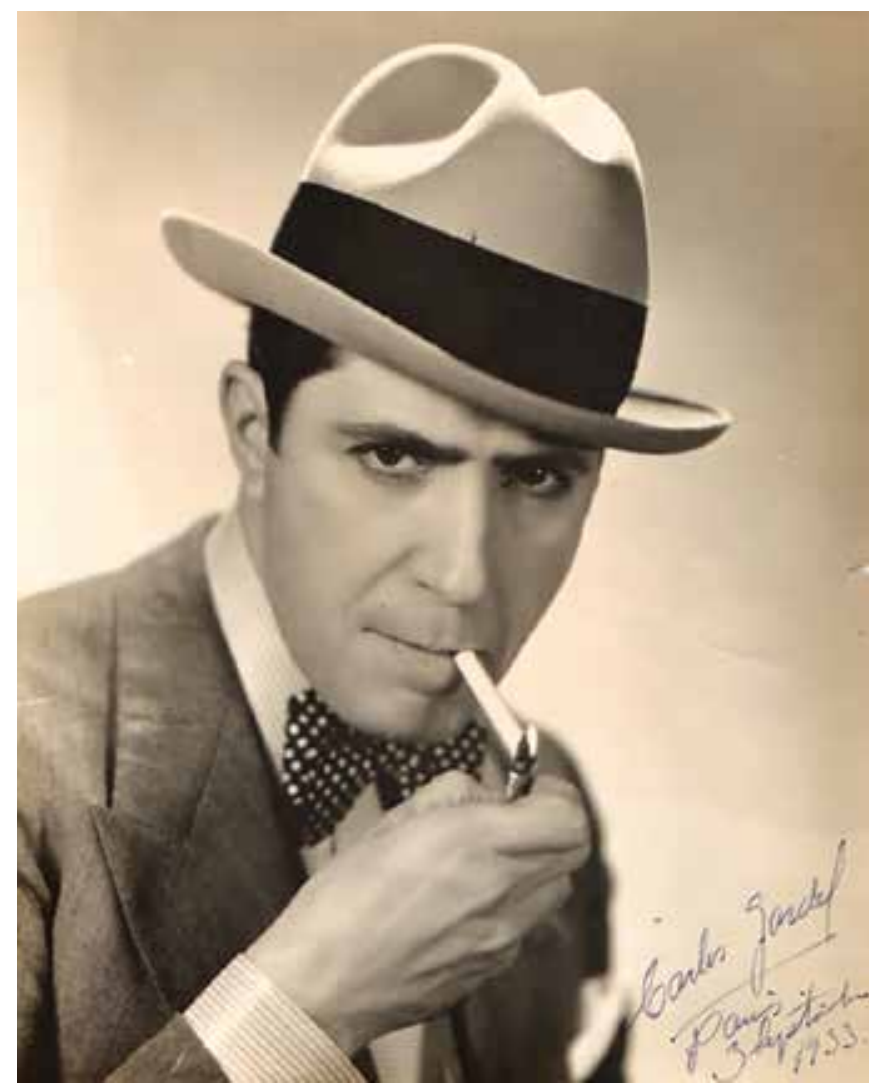

Figura 2. Anónimo, 1933, "Carlos Gardel tras el estreno de Melodía de Arrabal" (fotografía, Museo Casa Carlos Gardel, Buenos Aires).

En la figura 2, tomada en París, se puede ver uno de los elementos principales de la masculinidad de la época: el tabaco era el reflejo no solo de la adultez y la distinción, sino de la virilidad. ${ }^{16}$ Además de esto, el impacto que generó tanto económica como socialmente en las décadas de los veinte y los treinta aumentó su promulgación comercial; incluso llegaron a fomentarse políticas públicas que incentivaban su cosecha y producción. ${ }^{17}$ Gardel intentó incorporar en sus fotografías el cigarrillo como elemento esencial del típico tanguero: un sujeto elegante,

16 José Díaz Diego, “La i-lógica de los géneros: metrosexuales, masculinidad y apoderamientos”, Revista de Antropología Iberoamericana 1, n. ${ }^{\circ} 1$ (2006): 157-167.

17 Noemí Girbal-Blacha, "Poder político y acción privada en el agro argentino: la industria tabacalera (1900-1950)", Estudios Avanzados, n. 11 (2009): 49-78. 
adulto, masculino y un poco bohemio. La imagen denota, en general, un tango en proceso de transición de lo arrabalero a lo más estilizado; Gardel representaba así la entrada al mundo entero y, así mismo, la compaginación visual de clases.

Por otro lado, está la estructura de la fotografía, que presenta una composición diferente al resto de imágenes que habían sido tomadas de Gardel hasta el momento. Una primera diferencia es la cantidad de cuerpo que se ve en la pieza. La cara de Gardel, por lo general, era la protagonista de sus fotografías. Sin embargo, aquí se puede notar cómo la posición corporal es fundamental para transmitir una idea de masculinidad, así como una posición seductora y firme. Además, su mirada está completamente centrada en la cámara, un poco retadora. Una de las cosas que más había impactado a los directores de cine de la época sobre Gardel habían sido sus expresiones faciales. ${ }^{18}$ Por esto se le daba mayor importancia a su cara, en este caso los ojos y las cejas. Su vestimenta - como siempre—era impecable: el sombrero de medio lado muy característico del tanguero y el corbatín que le daba siempre un toque de elegancia.

Otro elemento importante y muy recurrente en sus imágenes era la guitarra (figura 3). A diferencia del cigarrillo, el instrumento dotaba a la imagen de un ambiente mucho más romántico y tranquilo, además de una sonrisa permanente en la cara del cantante cada vez que interpretaba algún tema musical. Por lo general, las fotografías tomadas a Gardel cantando y tocando guitarra eran de algún rodaje cinematográfico. Estas fotos, por lo tanto, encapsulaban el momento perfecto del cantor-galán; ${ }^{19}$ de hecho, no solo era una fotografía, sino también una composición entre la compenetración con los espectadores a través de su música, la aparición en la industria cinematográfica y su físico. La música era el componente perfecto en sus fotos, ya que mostraba el lado sensible y romántico del artista.

18 Barsky y Barsky, Gardel, la biografia, 238.

19 Ibid., 238-241. 


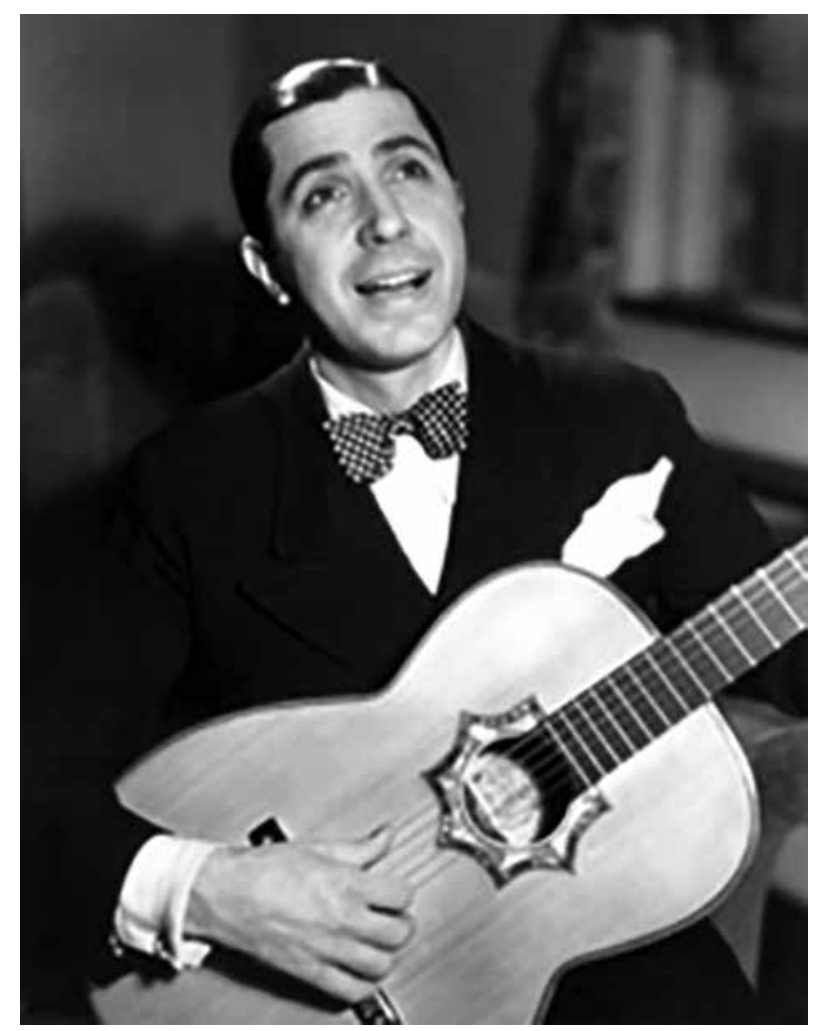

Figura 3. Exito Corporation, 1935, "Escena de la película Tango bar" (película, 62 m, museolibrogardel.blogspot.com.co).

La introducción de la guitarra al contenido de la imagen más el canto creaba una relación mucho más íntima con el público en general. Una parte fundamental de la pieza, en términos musicales, ayudaba a generar, además de la voz de Gardel como "reivindicación" del pueblo, la construcción de una identidad juvenil . ${ }^{20} \mathrm{Si}$ bien este no llegaba al punto de ser un intérprete de música protesta o social, su figura se había establecido entre los cantores populares del mundo. El cantante se debatía así entre el prototipo de un actor hollywoodense y el tanguero bohemio del pueblo.

El último elemento importante para la composición de sus fotografías y la construcción de su imagen fueron las mujeres. Como mencionaba, hubo varias 20 Jaime Hormigos y Antonio Martín Cabello, "La construcción de la identidad juvenil a través de la
música", Revista Española de Sociología, n. ${ }^{\circ} 4$ (2004): 259-270. 
indagaciones respecto a la orientación sexual de Carlos Gardel, pero así mismo muchas mujeres fueron cómplices y protagonistas de sus diversas aventuras amorosas. $^{21}$

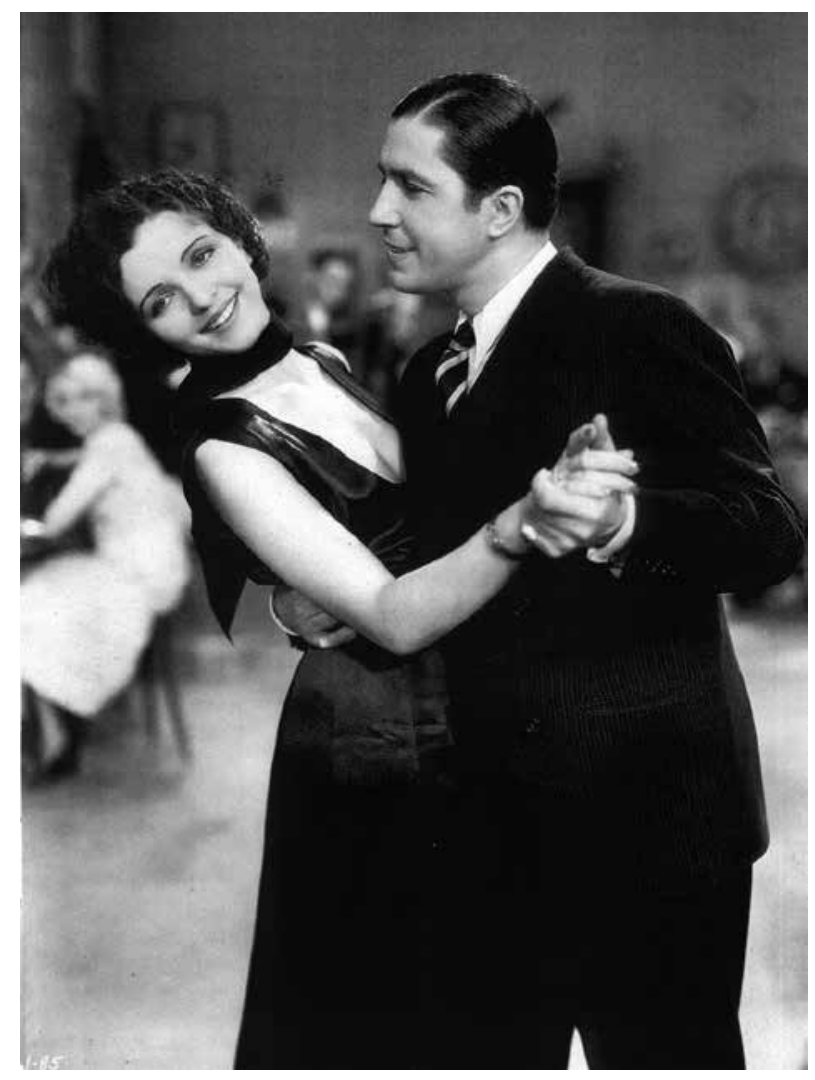

Figura 4. Paramount Pictures, 1934, "Escena de Cuesta abajo" (película, $1 \mathrm{~h} 14 \mathrm{~m}$, museolibrogardel.blogspot.com.co).

A pesar de ser tomada de una película, la figura 4 evidencia su lado seductor y encantador que tanto quiso resaltar en vida. Mona Maris, ${ }^{22}$ una actriz de la época, el abrazo del tango, las miradas enamoradas y las expresiones alegres en la cara, representaban ese Gardel romántico por el que las mujeres deliraban. El tango es

\footnotetext{
21 Barsky y Barsky, Gardel, la biografía, 565-586.

22 Mona Maris (1906-1991), actriz de cine argentina, impulsada principalmente en Estados Unidos y Europa durante el primer periodo del cine.
} 
un protagonista esencial en la composición de la imagen, ya que el abrazo permite tener una conexión particular entre los cuerpos; ${ }^{23}$ en otras palabras, el abrazo tanguero permite simbolizar lazos amorosos entre una pareja y precisamente Gardel, junto a la narrativa de la película, creaba una perfecta representación del tango, que dejaba de ser arrabalero y traicionero para desarrollarse dentro de los márgenes del enamoramiento.

La presencia de una mujer a su lado abre campo a la integración de otra parte importante de la sociedad, ya que no solo llega al público femenino por su belleza, sino también por su caballerosidad. Independientemente de ser imágenes sustraídas de películas, estas contribuyen desde dinámicas visuales más espontáneas a la configuración de todo un "mito gardeliano". Después de todo, la década de los treinta, en la industria cinematográfica argentina, fue denominada como la edad de oro, en la cual el cine sonoro había entrado en furor y los ojos de productoras extranjeras estaban puestos en el arte de aquel país. Esto provocó una acogida de los productos culturales argentinos en el mundo, así como intensificó la necesidad de rescatar las raíces y el folclor local. ${ }^{24}$

Así es como los tres elementos nombrados y pertenecientes a un ideal también propuesto por la industria cinematográfica en la cual Gardel ya estaba inmerso ayudan a entender la forma en la que se construyó su imagen mientras vivió. La masculinidad, la juventud y las mujeres permitieron que tuviera una forma particular de llegar a cada parte de la sociedad y lograr que se generara una identificación, al punto de considerarlo la representación de su propia vida y de sus deseos. Habiendo tratado estos tres elementos, se puede entender un poco más por qué su imagen tuvo tanta relevancia durante los primeros años del siglo xx; sin embargo, a partir de su muerte el señalado mito gardeliano gana fuerza para hacer icónica su figura, una pieza susceptible de reproductibilidad alrededor de la cual se formaron nuevos significados e identidades.

23 Natacha Muriel López-Galluci, “Tango, una filosofía del abrazo” (tesis de maestría en Filosofía, Universidade Estadual de Campinas, 2006).

24 Pablo Perelman y Paulina Seivach, La industria cinematográfica en la Argentina: entre los límites del mercado y el fomento estatal (Buenos Aires: Cedem; Estudios Especiales, 2005), 15. 


\section{"Sus ojos se cerraron"25}

El Gardel al que me he referido experimentaba su fama principalmente en Uruguay, Argentina, Europa y Estados Unidos; ya era importante en otros países de América Latina e, incluso, en 1934 había realizado diversas giras por el continente. No obstante, solo hasta su muerte llegó a convertirse en el "inmortal Gardel", con una connotación muy especial en el pueblo colombiano. A continuación se presenta el episodio de su muerte trágica como un momento crucial para la construcción de la imagen mítica. Brevemente, recuento los acontecimientos, con el fin de mostrar el punto crítico y la apertura de una construcción global de la imagen.

Todo sucedió el 24 de junio de 1935. Gardel estaba de gira por Colombia y había tenido la oportunidad de presentarse en Bogotá y Medellín: su siguiente destino era Cali. Varias personas habían acampado en el aeropuerto El Guabito, de dicha ciudad, para poder recibir a su ídolo. Él, mientras tanto, se disponía a emprender un nuevo viaje para conocer otra ciudad del país que tan bien lo había acogido. En esos años existían dos grandes compañías de vuelos: la SACO, en la que viajaba Carlos Gardel junto a sus músicos, y la SCADTA, que llevaba otros pasajeros a bordo. ${ }^{26} \mathrm{Al}$ parecer ya había antecedentes de provocaciones entre estas dos compañías, las cuales se jactaban de llevar a personas con gran influencia política, económica y social. No obstante, hasta ese día cruzaron el límite de la presunta rivalidad.

Cuando sale el vuelo en el que iba Gardel, un avión de la SCADTA avanzó sin autorización previa y llegó un momento en el que el choque de aeronaves resultó inevitable. Al estrellarse, el avión de la SACo empezó a arder en llamas, y con este, todos sus pasajeros. Únicamente sobrevivieron tres personas: dos músicos (Plaja y Aguilar), que quedaron con quemaduras y heridas permanentes, y el aeromozo (Flynn), que desapareció por supuestas amenazas. ${ }^{27} \mathrm{El}$ momento trágico se dio entonces cuando empezaron a cuestionarse acerca de la suerte de Gardel en el accidente. En un principio las noticias difundieron el rumor de que solo estuviera herido; incluso sus compañeros lo preguntaban constantemente. Sin embargo, luego, cuando empezaron a apagar las llamas y sacar a los pasajeros muertos, encontraron el cuerpo del tanguero completamente rostizado.

25 Título de la canción compuesta por Alfredo le Pera y música de Carlos Gardel.

26 Barsky y Barsky, Gardel, la biografía, 777-786.

27 Ibid., 777-786. 
Su última foto, junto a las diversas despedidas que le realizaron al cantante generó gran conmoción en la sociedad (figura 5). ${ }^{28} \mathrm{Su}$ madre adoptiva Bertha Gardes, quien se encontraba en París y no lo veía hacía varios meses, viajó de inmediato a Buenos Aires, donde pidió que llevaran los restos de su hijo. En Colombia se presentó el caso de una caleña que ingirió bastante medicina para suicidarse a raíz de la noticia y quien no cumplió con su cometido, por haberla intervenido a tiempo; por el mismo motivo, en Cuba se da el suicido de una joven. Alrededor del mundo conocedor de Gardel se presentaron varias tragedias y lágrimas por su inesperada muerte (figura 6). En lo que quedaba del año se rindieron homenajes, reportajes, titulares de prensa y toda una serie de publicidad que nombro más adelante en torno al "morocho" y su inmortalidad.

En Colombia inicia un proceso particular de apropiación del tango. Si bien en sus inicios este estilo ya gozaba de aceptación popular en el Viejo Caldas, ${ }^{29}$ por sus letras de añoranza y nostalgia hacia la tierra abandonada forzosamente, no había logrado tener un impacto nacional hasta que Gardel llegó a conocerse. Simultánea a la música de Gardel, fue la llegada de los medios a Colombia, lo que provocó una identificación más directa con el tango, ya que no solo tenía letras, baile y voz, sino además cara y belleza. Cuando el cantante muere en Medellín, Colombia entra en un momento de memoria que, por un lado, lamenta la tragedia del personaje y la no culminación de su gira; por otro, crea una relación más íntima con el significado de que su muerte haya sido allá. Actualmente, existen en Medellín la avenida Gardel, una casa de museo gardeliana, una estatua de Gardel, el bar Málaga, diversas tiendas con su nombre y la plaza donde murió, ubicada en las afueras del aeropuerto Olaya Herrera. ${ }^{30}$ Colombia prácticamente se ha vuelto el segundo hogar del tango, y Medellín, la segunda capital tanguera del mundo.

Después de este breve recuento sobre la configuración de la imagen de Gardel antes de su muerte — donde él era uno de los principales responsables de construirla hasta su trágico accidente-, en las siguientes páginas se da cuenta de una elaboración simbólica que, por causa de su deceso, empieza a ser producida por los medios y el público, al punto de hacer de la imagen de Gardel una figura icónica y mítica.

28 Ibid., 777-786.

29 Rafael Ortiz A., Medellín antiguo: el alma del arrabal (Medellín: s. n., 1992).

30 Para más información, véase: Rosa María Pérez Rivas, "Carlos Gardel en Medellín: 5 lugares que reviven su memoria”, MDE Ciudad Inteligente, 24 de 2015, http://www.mdeinteligente.co/estrategia/ carlos-gardel-medellin-un-recorrido-por-los-lugares-que-reviven-su-memoria/ (31/03/2017). 


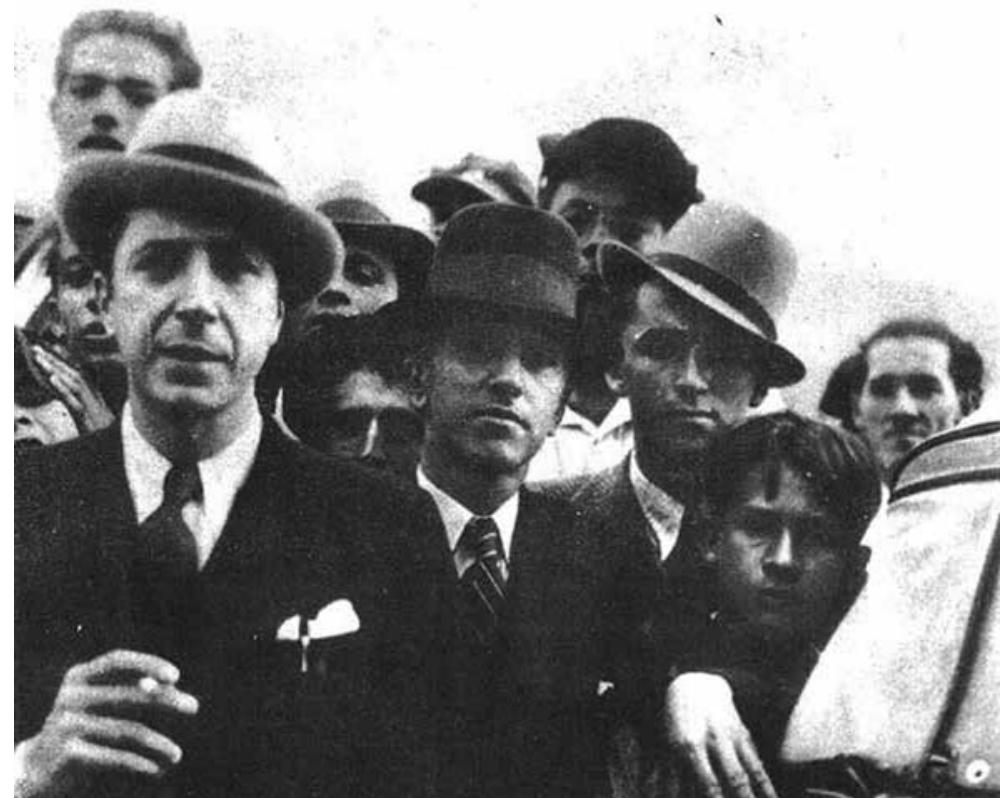

Figura 5. Anónimo, 1935, “Última foto de Carlos Gardel en Medellín” (fotografía anónima sacada en Medellín).

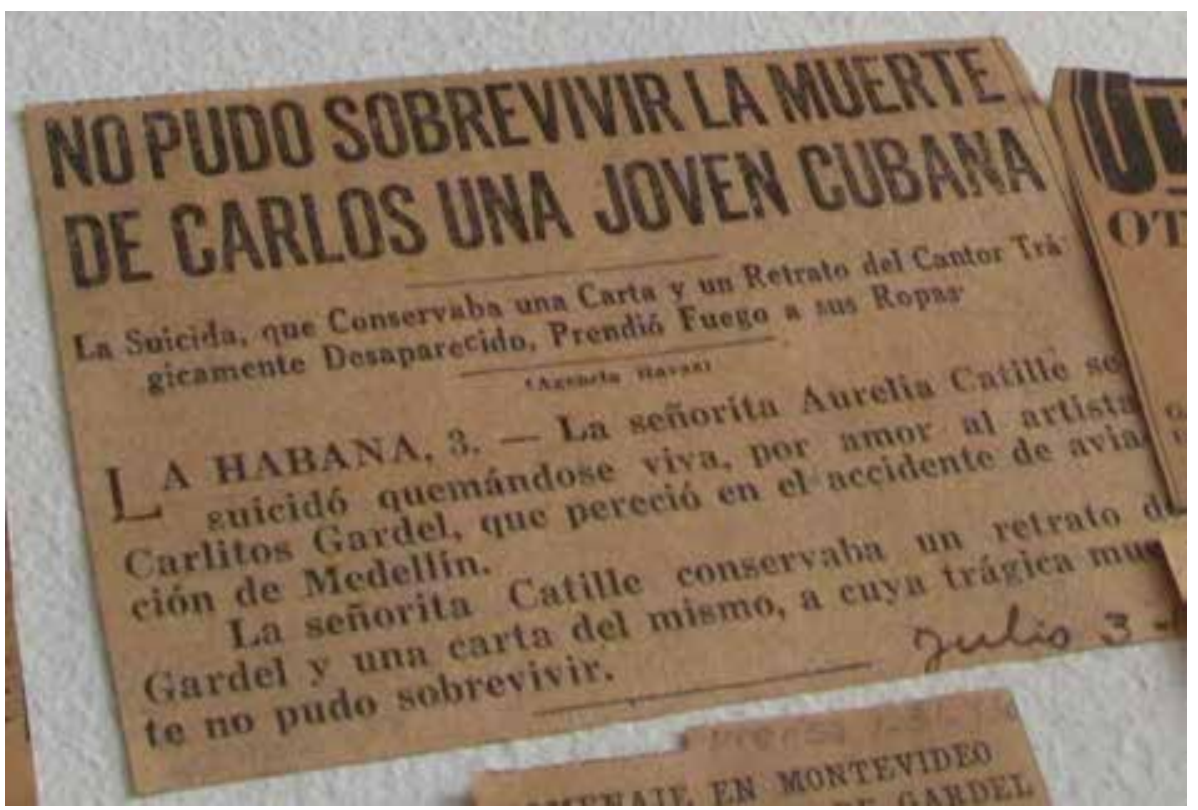

Figura 6. Laura Vigoya, 2014, "Titular de prensa sobre suicidio de una joven cubana por la muerte de Gardel” (fotografía, Museo Casa Gardel, Buenos Aires). 


\section{El mítico Gardel}

A menudo, cuando vemos una imagen de algún personaje, nos quedamos en la simplicidad de la contemplación. Sin embargo, no vemos quién o qué está detrás de su misma composición. A diferencia de Ernesto Guevara (Che Guevara), cuya foto más reconocida se hizo global sin planearlo, la imagen de "Carlitos" Gardel fue completamente deliberada para una de sus giras a Europa. La famosa imagen de 1933, que transformó la fama tanguera de Gardel en un ícono visual, fue tomada por su gran amigo y fotógrafo José María Silva, ${ }^{31}$ en Montevideo (figura 7). Anteriormente, Gardel había estado, en 1923,32 en el estudio de Silva para su primera gira por Europa. No obstante, las fotografías que le habían exigido vistiendo con el traje típico gaucho no trascendieron de la forma en que lo hizo su imagen de "porteño puro", como ya mencionaba. Así es como, el Morocho del Abasto, el Zorzal, el mudo, etc. logra posicionarse en lo icónico; es decir, en una imagen que, compuesta desde la esfera cultural, logra tener una trascendencia en el campo social.

Solamente los personajes que trascienden se dan el lujo de ser inmortales y lograr la promulgación mediática y social de su imagen. Carlos Gardel, evidentemente, fue uno de estos personajes que, aun bajo las diversas transformaciones sociales de casi un siglo después, ha perdurado en el corazón artístico y tanguero; su imagen se convirtió en un fenómeno cultural. Después de su muerte, Gardel tuvo varias facetas a partir de las cuales se promulgó su variada iconografía. En un primer momento, las fotografías que ya habían sido tomadas de él empezaron a aparecer como un homenaje rendido al ídolo. Sin embargo, con el tiempo, se empezaron a generar otro tipo de imágenes y narrativas que se basaban en la reproductibilidad de dos imágenes en particular. ¿ Por qué? A continuación, analizo de forma breve la importancia de estas imágenes y su reproductibilidad (figura 7).

31 Nacido en Galicia (España) en 1897, este fotógrafo español fue fundador de la Asociación de Fotógrafos Profesionales del Uruguay. Se vuelve famoso principalmente por las fotografías que tomó a Gardel, además de su amistosa relación. Tenía su tienda fotográfica La Fotografía del Indio, en Montevideo (Uruguay), donde entró por primera vez Gardel para realizarse un estudio fotográfico, en 1917. Silva muere en el 2000, en Montevideo, recordando por siempre su amistad y el gran corazón de Carlos Gardel. Véase también: “El fotógrafo de Carlos Gardel: José María Silva”,Zorzal Criollo, http://www. zorzalcriollo.com/gardel/el-fotografo-de-carlos-gardel-jose-maria-silva.php (31/03/2017).

32 En 1923, unos años después de una vida completamente exitosa como tanguero, actor y compositor, se le pidió su primera gira a Europa para la cual tuvo, sin su total acuerdo, que posar vestido de gaucho. Así es como las primeras imágenes del fotógrafo Silva a Gardel son de él vestido de gaucho. 


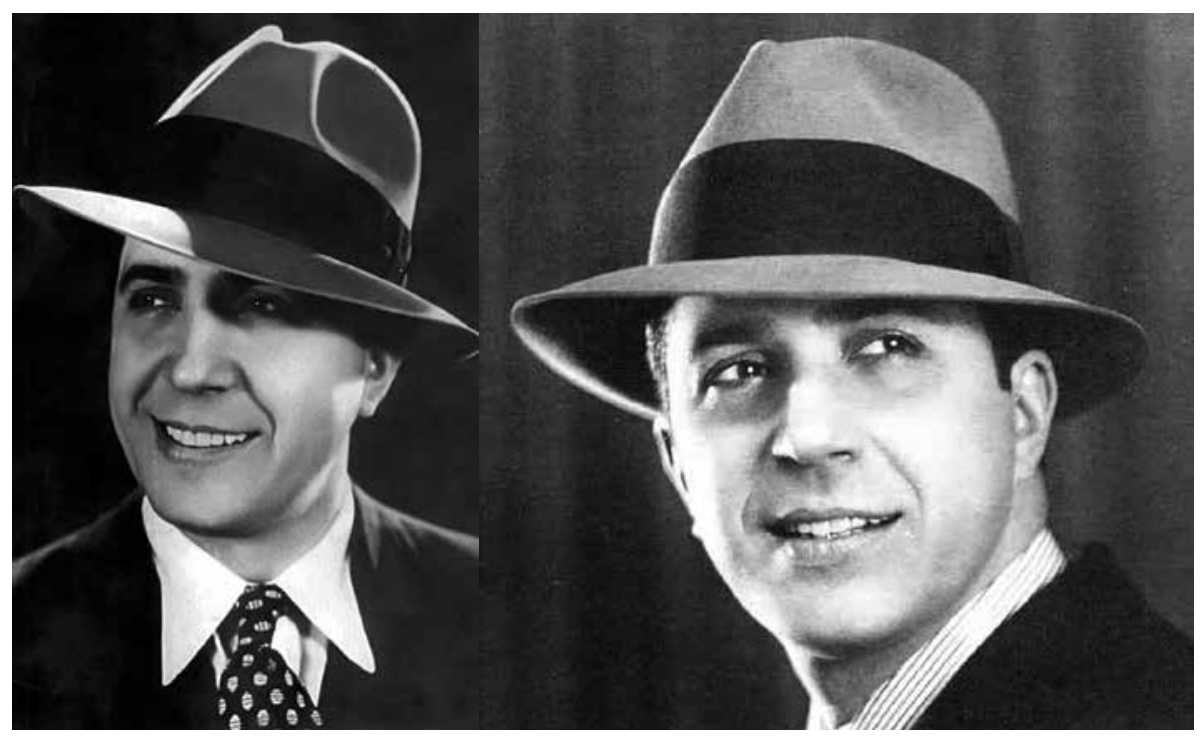

Figura 7. José María Silva, 1933, sin título (fotografía, Museo Casa Gardel, Buenos Aires).

¿Qué hizo que estas imágenes trascendieran hasta el punto de convertirlo en una figura mítica? Empecemos por la simple estructura de la fotografía. Como dije, Gardel había sido siempre elogiado por sus expresiones faciales; pero, además de esto, las personas que tuvieron la oportunidad de conocerlo siempre lo recuerdan como un hombre bastante alegre y amistoso. En primera instancia, se puede decir que la fotografía trasciende no solo porque estéticamente encierra la belleza y la elegancia tanguera, sino además porque sustenta el Gardel que todos amaban, con su sonrisa y sus ojos expresivos, un personaje que, a pesar de lograr una fama mundial, no perdía la conexión con su público y sus raíces. ${ }^{33}$

Gardel pertenecía a un ámbito público, aprehensible desde "lo visual"; en lugar de recoger experiencias sociales a partir de prácticas políticas o económicas, este manejaba todo un campo estético y publicitario de amplia difusión popular. Desde muy joven se acostumbró a estar con cámaras y a tener que cultivar una imagen. Según ya señalaba, sus fotografías no fueron tomadas por casualidad; fueron planeadas en sesiones especializadas, producto a su vez de la temprana mediatización latinoamericana de ciertas figuras públicas, lo cual refleja la importancia de Gardel para ser contemplado como cantante y actor; pero también como un

33 Barsky y Barsky, Gardel, la biografía, 99-123. 
estereotipo visual. Generalmente, sus fotografías privilegiaban los primeros planos de su rostro; sin embargo, Gardel no está mirando de frente, lo que tal vez se debe a una noción de realidad fotográfica diferente. $\mathrm{Al}$ mirar de frente a la cámara está muy consciente de ser el protagonista de la foto, además de generar una posición de seguridad; cuando no mira directo a la cámara, la imagen adquiere un poco más de “espontaneidad". Es importante también ver las posiciones de la cabeza en las cuales también se genera un aire de grandeza, pero no de petulancia.

Para entender los aspectos que han hecho de Gardel una imagen viva, incluso después de su muerte, hay que ubicarse en el contexto histórico que se ha venido dando desde el siglo xx hasta la actualidad. Por tal motivo se aborda esta reconstrucción desde la perspectiva mediática, ya que ha sido la más importante en la promulgación de personajes como el “morocho". Por lo tanto, esta reconstrucción va desde una perspectiva más nacional (principalmente dada en Argentina) hasta una más globalizada, en la cual se contempla el concepto identidad cultural, que se explica más adelante.

\section{Patrimonialización del morocho: ¿una imagen viva?}

La primera parte de la reconstrucción de la imagen gardeliana empezó por la publicidad. Anteriormente, los medios ya estaban vinculados, pero no usaban ni su imagen ni su nombre para propagar algunos productos. Entonces hasta su muerte Gardel había dejado de ser solamente el cantor-galán para convertirse en una especie de ídolo, con lo que probaba su inmortalidad en varios ámbitos (figura 8).

Detengámonos un momento en la figura 8 . El mate es una bebida característica del sur; generalmente se utiliza como acompañante para la socialización o simplemente como bebida de relajación, reflexión y tranquilidad. Teniendo en cuenta esto, el hecho de utilizar la imagen y el nombre de Gardel en un producto como este (una bebida fundamental y popular) no solo prueba la necesidad soñada de inmortalizar a Gardel, sino que incluso se llegaron a crear mitos donde la gente era cómplice de su aparición póstuma. ${ }^{34}$ Sin embargo, este tipo de publicidades lanzadas un año después de su muerte no volvieron a ser tan recurrentes, como sí lo fueron, por ejemplo, las caricaturas, los grafitis, las esculturas y las pinturas con su cara (figuras 9,10 y 11 ).

34 Carozzi, “Carlos Gardel, el patrimonio que sonríe”, 59-82. 


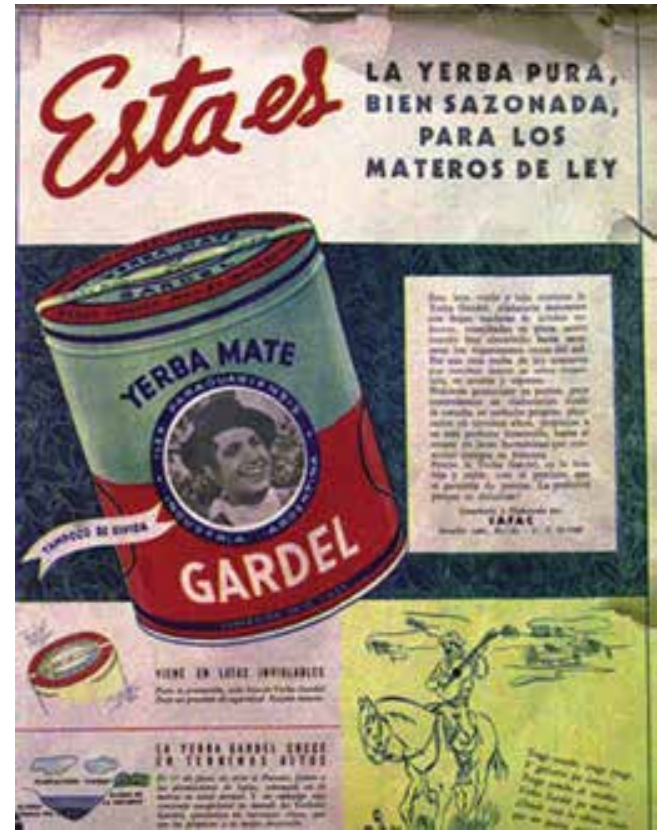

Figura 8. Anónimo, 1936, "Yerba mate Gardel" (pauta publicitaria, reproducida en Barsky y Barsky, Gardel, la biografia, 801-805).

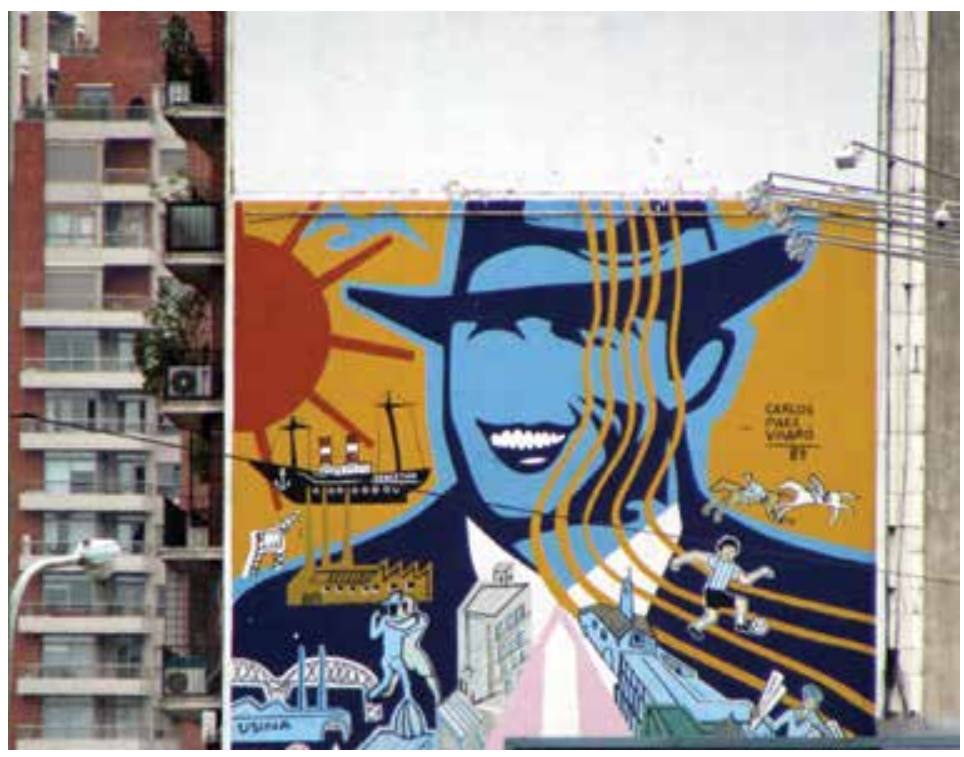

Figura 9. Laura Vigoya, 1989, "Mi Buenos Aires querido" (fotografía de un grafito de Carlos Páez Vilaró, Buenos Aires). 


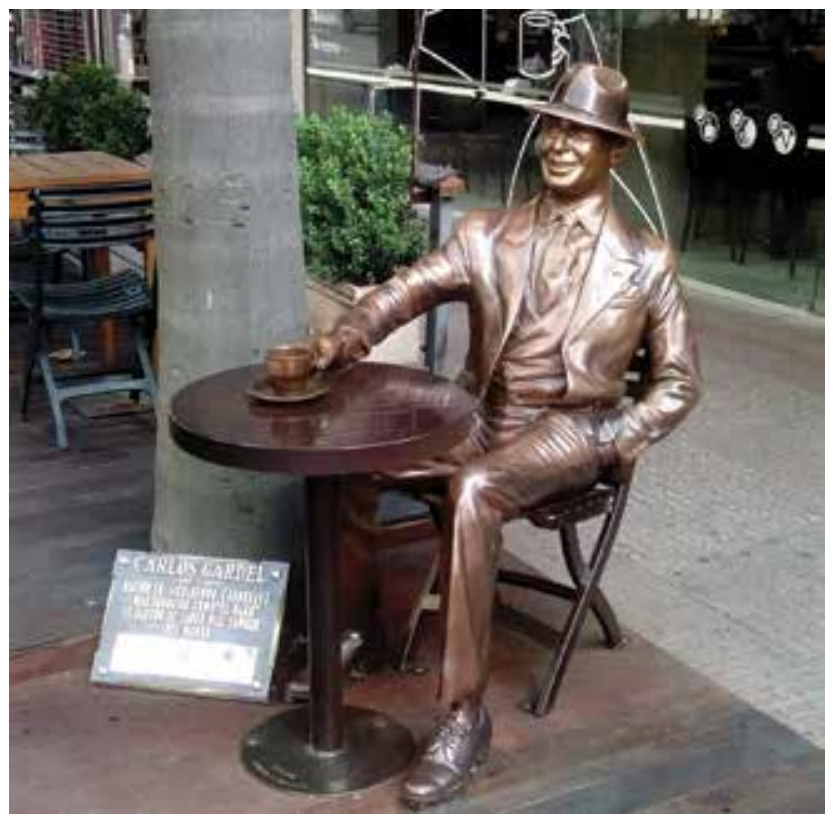

Figura 10. Laura Vigoya, 2015, "Monumento conmemorativo por los 100 años de la primera actuación de Gardel y 80 de su muerte" (fotografía de una escultura de Alberto Morales Saravia, Montevideo).

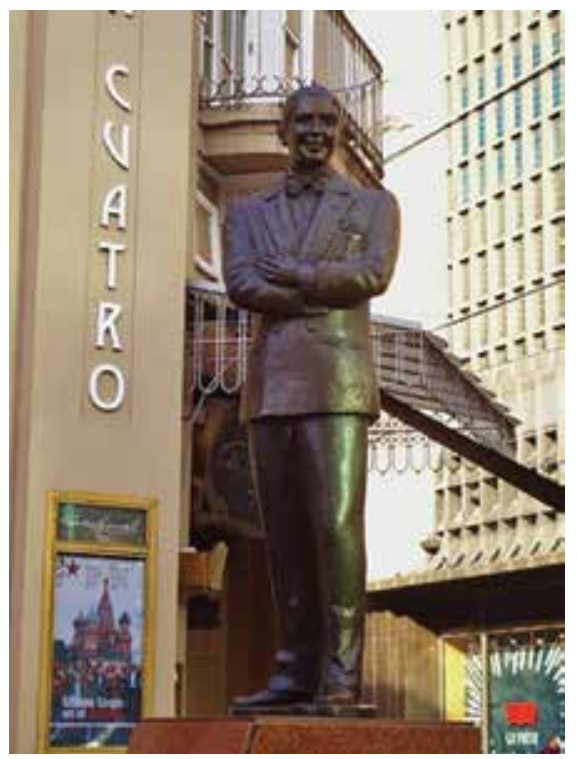

Figura 11. Laura Vigoya, "Estatua de Carlos Gardel en el barrio del Abasto" (fotografía de una escultura de Mariano Pagés, Buenos Aires). 
Como vimos, la fotografía de José María Silva fue esencial para que Gardel se estableciera como un personaje icónico; sin embargo, uno de los elementos que han causado mayor sensación en la reproductibilidad de su imagen es su sonrisa y su vestimenta. La "sonrisa", inevitablemente, rememora el carisma que muchos decían haberle conocido al "morocho", y esta misma en la actualidad ha generado multitudes de fanáticos que incluso la consideran el principal rasgo facial transmisor de un Gardel que aún sigue vivo.

La identidad cultural ${ }^{35}$ desempeña un papel muy importante en la construcción del mítico Gardel. Aquí es donde también podemos ver la gran influencia de los medios y de la industria cultural. La identidad, al igual que la cultura, ${ }^{36}$ han sido conceptos utilizados en varios análisis e investigaciones que intentan definirlas; sin embargo, precisarlas sigue siendo tarea difusa, ya que ambas suelen permanecer en constante cambio, dependiendo de los contextos sociales donde se desarrollan. A continuación, me acerco a la identidad cultural desde la importancia de Gardel dentro de esta.

En otros momentos, la identidad se concebía como un elemento estático de la cultura; ${ }^{37}$ el hecho de pensarla como algo radical e inamovible en el ser humano hacía parte de toda una noción clasificatoria dentro de lo tradicional y definitorio de una sociedad. Sin embargo, aspectos como la llegada de la globalización ${ }^{38}$

35 El concepto de identidad cultural encierra un sentido de pertenencia a un grupo social con el cual se comparten rasgos, costumbres, valores y creencias. Por esto la identidad no está fija en el tiempo, sino que, pertenece al contexto social en el que se vea envuelta. Véase también: Olga Lucía Molano, "Identidad cultural, un concepto que evoluciona", Revista Ópera, n. ${ }^{\circ} 7$ (2007): 73.

Algunos autores coinciden en que cultura es lo que le da vida al ser humano: sus tradiciones, costumbres, fiestas, conocimientos, creencias. Véase: Molano, "Identidad cultural", 73.

37 Ibid., 73.

38 La globalización tiene dos caras mediante las cuales se puede analizar: la inclusión y la exclusión. Por un lado, está su lado excluyente, acompañado de la noción de "crecimiento" social, político y principalmente económico. La poblaciones que no pueden seguir su ritmo económico, simplemente, quedan a un lado, ya que si no hay posibilidad de una inversión de capital financiero o tecnología en un país, ese país, ciudad, región o población quedarán a un lado de la economía global, lo que significa un mayor interés por todos los discursos (políticos y sociales) de emplear proyectos que no excluyan la capacidad de crecimiento de un país, por supuesto, poniendo en riesgo una gran parte de su población e incluso de su propio país. Sin embargo, está, por otro lado, la noción incluyente de la globalización, y eso en gran medida se debe a los sistemas mediáticos que han surgido a partir de la apertura de las fronteras tecnológicas y la facilidad con la que muchos personajes, sucesos, culturas, prácticas y otros han llegado a diversas partes del mundo e incluso han sido apropiados por poblaciones no pertenecientes a un mismo contexto cultural. Desde este punto de vista, este capítulo ha utilizado la forma incluyente de la globalización, como una herramienta disolvente de la identidad 
permitieron a la pregunta por la identidad adquirir un nuevo sentido, y ello abrió paso a las múltiples maneras en las que esta se podía generar. Así es como, a través de diversos medios de difusión que trae la globalización, los seres humanos empiezan a formar lazos en otras partes del mundo, creando formas de identidad entre ellos sin la necesidad de pertenecer a un mismo contexto geográfico. La identidad cultural llega entonces a ser un constructo social de pertenencia a algo, el cual se recrea individual y colectivamente ${ }^{39}$ y deja de lado una forma única de pensarse.

A principios del siglo $\mathrm{xx}$, la radio y el cine influyeron bastante en el concepto de identidad como uno arraigado a una nación. Los hábitos, las vestimentas, las formas de pensar, las cotidianidades, el lenguaje y la creación de héroes ${ }^{40}$ hacían parte de una construcción mediática nacional que, por supuesto, ayudaba a configurar toda una cultura de masas. Sin embargo, con la transnacionalización de la tecnología, la llegada de otros medios de comunicación, como la televisión, y el intento por desarrollar el proyecto de la modernización económica (ya mencionado) ${ }^{41}$ se promulgaron nuevas formas de generar cultura de masas: esta vez no solo ligadas a una nación, sino a un amplio sentido de globalidad.

¿Qué papel cumple Gardel en todo este tema? Él fue uno de los personajes que no solo permanecieron dentro del mundo del espectáculo, sino que además de los que tuvieron la facilidad de adaptarse y promover este tipo de transformación en conceptos como la identidad. La imagen de Gardel es mítica porque, además de pertenecer al grupo de los grandes propulsores de la identidad tanguera, genera una transformación global en su existencia. Es decir, su imagen no solo fue impulsada desde los proyectos nacionales principalmente dados en Argentina, sino que logró cubrir una globalidad hasta el punto de generar cohesión poblacional que se identificaba con él y su imagen.

como un concepto estático e inamovible y como un conector entre diversas poblaciones del mundo para el conocimiento en este caso artístico. Finalmente, gracias a la globalización, Gardel logró tener un impacto global hasta el punto de crear una sensación de familiaridad con su imagen y su canto. Véanse también: Manuel Castells, “Globalización e identidad”, 2uaderns de la Mediterrània, n. ${ }^{\circ} 14$ (2010): 257, y Nelly Arenas, “Globalización e identidad latinoamericana”, Nueva Sociedad, n. ${ }^{\circ} 147$ (1997): 9. 
La imagen de Gardel, por lo tanto, se convierte en una apropiación y reconocimiento global que causa una identidad cultural activa. Los "gardelianos" 42 son un ejemplo vivo de este tipo de identidad y lo que es aún más curioso es que no necesariamente se debe ser gardeliano para tener también una afinidad por este personaje que, indiscutiblemente, nos remite y nos sigue remitiendo a una época importante de las industrias culturales latinoamericanas. Para el mundo, Gardel es el gran exponente del tango; para Latinoamérica, Gardel era el tango hecho voz, cuerpo y carne. Así es como la identidad cultural generada en la población se convierte en un elemento principal en la reconstrucción de la imagen de Gardel, ya que no solo involucró su imagen en los canales principales de difusión, sino que, además, sobrepasó los límites en los que se encasillaba la identidad para generar de una manera globalizada nuevas formas de apropiarse y pensar al cantante.

\section{Conclusiones}

A partir del análisis hecho, podemos inferir que la construcción mediante imágenes de los personajes míticos que vemos hoy en día como una reproducción comercial se deriva de toda una historia política, económica y social (según el personaje). Es sugerente ver, por ejemplo, cómo la fotografía se convierte en una fuente privilegiada para los estudios sobre la memoria ${ }^{43} \mathrm{y}$, a su vez, por medio de la reproducción de esta, genera un campo social en el cual se crea y reproduce la identidad. La fotografía de Carlos Gardel, si bien en la actualidad tiene un sentido meramente comercial, sigue manteniendo un misticismo entre quienes la compran. Es decir, la problemática que se ha generado con otros personajes como el Che es que el sentido y uso que se le da a su imagen, en la mayoría de casos, se aleja de lo que el Che en vida representó para los movimientos sociales. Gardel, en cambio, no se aleja de lo que era en vida; de hecho, su imagen siempre perteneció al ámbito comercial. La diferencia es que ahora la reproductibilidad de la imagen ha causado que cualquiera pueda tener acceso a esta y que, al mismo tiempo, se generen otro tipo de apropiaciones. Es claro, por lo tanto, que Gardel continuará siendo un ícono del tango cuya imagen y legado cada vez irán adquiriendo nuevos significados transnacionales.

\footnotetext{
42 Personas que se reconocen como seguidores fieles de Gardel. Véase: Carozzi, "Carlos Gardel, el patrimonio que sonríe", 67.

43 Marta Cabrera y Óscar Guarín, “Imagen y ciencias sociales: trayectorias de una relación”, Memoriay Sociedad 16, n. ${ }^{\circ} 33$ (2012): 7-22.
} 
Es indispensable mencionar que otro elemento fundamental para ayudar a formar un Gardel icónico fueron sus múltiples viajes a diferentes países del mundo, y aunque esto va muy de la mano con el tema de la industria cinematográfica, no hubiera sido lo mismo una reproducción digital de su imagen que su misma presencia en tales países. Esto también muestra la importancia de su muerte en Colombia, ya que evidencia cómo la ausencia de su presencia física aumentó la idealización de su imagen.

Por otro lado, no hay que desconocer que la muerte de Gardel, aunque fue supremamente dolorosa, ayudó a que este se consolidara como un personaje mítico, hasta el punto de considerarlo una presencia casi religiosa. La muerte genera, por lo tanto, una idealización más fuerte basada en lo que fue, pero sobre todo en lo que pudo ser (contrafactual). La conservación de Gardel en el recuerdo no sería posible sin la ayuda de toda una red social que ha ayudado a mantenerlo vivo. Muchos personajes tienen una historia de fama y cuando mueren, su historia queda en el olvido; pero Gardel logra trascender eso porque crea una identidad y una patrimonialización de su imagen que le permite permanecer vivo aun casi un siglo después de su muerte. Como ejemplo de esto, podemos ver todos los festivales y especiales que se realizan alrededor del mundo en honor a su legado en que se recuerda su voz, su imagen, su biografía y sus películas.

Finalmente, tampoco podemos dejar de lado la gran experiencia que, en el caso de Gardel y de todos los personajes míticos, permitió y sigue permitiendo la inmortalidad de su existencia: la globalización. La llegada de esta y los medios ha sido muy criticada en algunos grupos sociales, porque hasta cierto punto ha generado una burbuja social en la cual solo algunos en una posición privilegiada han podido entrar. Sin embargo, gracias a ella y su gran expansión social se han podido conocer a todos estos personajes e, incluso, acceder a ellos así sea en la reproducción de su imagen en contextos distantes. La identidad cultural dentro de la globalización, como decíamos, es un concepto que es imposible contemplar como algo monolítico; la identidad se alimenta y se reestructura según el momento histórico en el cual se encuentre. Gardel es un elemento esencial dentro de esa identidad cultural, porque permite tener esa noción de cohesión social-global sin importar de dónde provenga cada quien; lo interesante es observar cómo, a pesar de haber sido impulsado por toda una industria cultural en vida, la preservación de su memoria hoy en día corre por cuenta de sectores heterogéneos que han hecho del tanguero un estandarte de sus historias colectivas. 


\section{Bibliografía}

\section{Fuentes primarias}

\section{Imágenes}

Archivo Gráfico de la Nación Argentina, Buenos Aires.

Museo Casa Gardel, Buenos Aires.

\section{Libros}

Barsky, Julián y Osvaldo Barsky. Gardel, la biografía. Buenos Aires: Taurus, 2004.

\section{Fuentes secundarias}

Arenas, Nelly. "Globalización e identidad latinoamericana”. Nueva Sociedad n. 147 (1997): 120-131.

Cabrera, Marta y Óscar Guarín. "Imagen y ciencias sociales: trayectorias de una relación”. Memoria y Sociedad 17, n. 33 (2012): 7-22.

Canclini, Néstor García. Consumidores y ciudadanos. México: Grijalbo, 1995.

Carozzi, María Julia. “Carlos Gardel, el patrimonio que sonríe”. Horizontes Antropológicos 9, n. ${ }^{\circ} 20$ (2003): 59-82.

Castells, Manuel. "Globalización e identidad". Quaderns de la Mediterrània, n. ${ }^{\circ} 14$ (2010): 254-262.

Diego, José Díaz. "La i-lógica de los géneros: metrosexuales, masculinidad y apoderamientos". Revista de Antropología Iberoamericana 1, n. 1 (2006): 157-167.

Echeverri, Aquiles M. Gardel, su historia y causa de su muerte. Medellín: Digital Express, 1999.

"El fotógrafo de Carlos Gardel: José María Silva”, Zorzal Criollo. http://www.zorzalcriollo.com/gardel/el-fotografo-de-carlos-gardel-jose-maria-silva.php (02/11/2015).

Getino, Octavio. Las industrias culturales en la Argentina: dimensión económica y politicas públicas. Buenos Aires: Colihue SRL, 1995.

Girbal-Blacha, Noemí. "Poder político y acción privada en el agro argentino. La industria tabacalera (1900-1950)”. Estudios Avanzados, n. ${ }^{\circ} 11$ (2009): 49-78.

Horkheimer, Max y Theodor W. Adorno. Dialéctica del iluminismo. Traducido por Héctor Murena A. Buenos Aires: Sudamericana, 1969.

Hormigos, Jaime, y Cabello, Antonio. "La construcción de la identidad juvenil a través de la música”. Revista Española de Sociología, n. ${ }^{4}$ (2004), 259-270. 
López-Galluci, Natacha Muriel. “Tango, una filosofía del abrazo”. Tesis de maestría en Filosofía, Universidade Estadual de Campinas, 2006.

Molano, Olga Lucía. "Identidad cultural un concepto que evoluciona”. Revista Ópera, n. 7 (2007), 69-84.

Ortiz, Rafael. Medellín antiguo: el alma del arrabal. Medellín: Licores de Antioquia, 1992.

Pelinski, Ramón. El tango nómade: ensayos sobre la diáspora del tango. Buenos Aires: Corregidor, 2000.

Perelman, Pablo y Seivach, Paulina. La industria cinematográfica en la Argentina: Entre los limites del mercado y el fomento estatal. Buenos Aires: Cedem, 2005.

Pérez Rivas, Rosa María. Carlos Gardel en Medellin: 5 lugares que reviven su memoria. Medellín: Medellín Ciudad Inteligente, 2015. Disponible en: http://www. mdeinteligente.co/estrategia/carlos-gardel-medellin-un-recorrido-por-loslugares-que-reviven-su-memoria/

Rasore, Alberto. Carlos Gardel en el cine mudo. Buenos Aires: Vereda del Tango, 2006.

Urrego, Carlos Mario. Ser milonguero. Medellín: Artes y Letras, 2008. 


\section{Construcción de memorias e identidades políticas en clave gráfica}




\title{
Un conflicto entre viñetas: historietas de la violencia política en el Perú (1989-2010*
}

\author{
Natalia Mahecha Arango
}

Desde mediados del siglo xx, las historietas empezaron a llamar la atención de distintas disciplinas académicas, al ser consideradas "síntomas sociales" de las sociedades que las producían. ${ }^{1}$ Ya fuese analizando sus aspectos formales y convencionales o indagando por sus procesos de significación, los académicos que se acercaron a ellas como objeto de estudio abrieron un horizonte investigativo que ha tenido continuidad hasta hoy día. ${ }^{2}$ Este interés académico surgió paralelamente a una nueva actitud hacia la historieta como producto cultural. Así, se empezaron a reevaluar los hábitos de pensamiento que ataban este lenguaje a un público infantil y a un tipo de lectura que inhibía el pensamiento y que podía, incluso, ser perjudicial. Creadores, académicos y la sociedad, en general, fueron reconociendo la complejidad temática y expresiva de la historieta, lo cual llevó a que desde su lenguaje se pudiera explorar un tema tan problemático como lo es la violencia.

* Este capítulo recoge los resultados de la investigación De la imagen de la nación a la imagen de la violencia: dos acercamientos a la historieta peruana, financiada por Colciencias y la Universidad de los Andes a través del programa Jóvenes Investigadores e Innovadores y el Concurso Otto de Greiff versión XVI. Agradezco profundamente la ayuda de mi tutor, Jaime Humberto Borja, y también los comentarios recibidos por mis compañeros en el Coloquio de Investigación de la ECH de la Universidad del Rosario.

1 Román Gubern, “Prólogo a la presente edición: Terenci explora la figuración narrativa”, en Historia social del cómic, de Terenci Moix (Barcelona: Bruguera, 2007), 7.

2 Jorge Fregoso Torres, La narrativa léxico-pictográfica: guía para el análisis y la producción de historietas (Guadalajara: Universidad de Guadalajara, 2005), 17. 
Desde una etapa muy temprana, la violencia ha habitado el espacio de la historieta a través de diversos géneros - e.g. bélico, de aventura- y de algunos de sus autores más destacados. La pregunta por el lugar que debe ocupar la violencia en la historieta ha tenido diversas respuestas, de las cuales la censura es una de las más comunes. En experiencias tan disímiles como la España franquista (1939-1975)3 y Estados Unidos y su Comics Code Authority (1954), se buscó erradicar toda representación de la violencia, por considerar que podía atentar contra el buen desarrollo de los lectores jóvenes. ${ }^{4}$ En estos casos, la prohibición de la violencia operó como una forma de reforzar el control estatal y parental sobre los historietistas y el público al que iban dirigidas sus obras.

No obstante, en otros casos, la historieta se ha considerado un lenguaje útil para acercarse a la violencia como experiencia humana. Este es el caso de historietas como Maus, Palestina o La Chelita, que han abordado el Holocausto judío, el conflicto palestino-israelí y el conflicto armado interno en El Salvador, respectivamente. En estas historietas, a las que se suman otros títulos, sus autores se han involucrado en un "proceso de construcción y deconstrucción de imaginarios y representaciones" sobre los actores inmersos en estos conflictos, además de utilizar sus obras con diferentes propósitos que van desde la denuncia hasta la reafirmación de consensos sociales oficiales acerca de los contextos de violencia que tratan.

En el caso de la historieta peruana, la violencia generada por el enfrentamiento entre la guerrilla de Sendero Luminoso (SL) y el Estado durante el periodo conocido como la Violencia Política (1980-2000) se convirtió en el foco temático de un conjunto de historietistas que, a partir de diferentes estilos y posturas, generaron representaciones sobre este fenómeno, ya fuese desde el testimonio o la memoria de los hechos. ${ }^{6}$ Haciendo uso de un lenguaje alegórico que obligara al lector a leer

3 Juan Manuel Díaz de Guereñu, Hacia un cómic de autor: a propósito de Arrugas y otras novelas gráficas (Bilbao: Deusto, 2014), 28.

4 En el caso estadounidense también fueron prohibidos otros temas que se consideraban subsidiarios a la violencia como el terror, la lujuria, el sadismo o la depravación. Véase: Joseph Witek, Comic Books as History: The Narrative Art of Jack Jackson, Art Spiegelman, and Harvey Pekar (Jackson: University Press of Mississippi, 1989), 49-50.

5 Guido Germán Hurtado Vera y Luis Eduardo Lobato Paz, Representaciones e imaginarios sobre la violencia colombiana en la prensa nacional: 1990-2004 (Cali: Universidad Autónoma de Occidente, 2009), 301.

6 La distinción realizada por Sotelo Melgarejo entre testimonio y memoria tiene como base la cercaníaseparación entre la ocurrencia de los hechos de violencia y el momento en que estos son convertidos en representaciones por la acción —en este caso— de los historietistas. Véase: Marco Antonio Sotelo 
“entre líneas” o, por el contrario, de uno más gráfico y directo, las historietas sobre la violencia política son una de las muchas fuentes a partir de las cuales los peruanos han (re)construido fragmentariamente los acontecimientos de este proceso histórico. Un ejemplo de este conjunto de historietas lo constituyen Confidencias de un senderista (1989) y Barbarie. Comics sobre violencia politica en el Perú, 1985 1990 (2010).

Confidencias de un senderista (1989) es una historieta dibujada por Luis Baldoseda. La narración está construida a partir del testimonio real de Jorge Cañari, exmiembro de este grupo armado, en la que da cuenta de su proceso de reclutamiento forzado y del "juicio popular" por medio de cual SL penetró violentamente en la comunidad campesina de Mollebamba. Esta historieta, la primera en tratar el tema de la violencia política en este país, fue elaborada por encargo de la Comisión de Cultura del Centro Naval en un formato comic book de 37 páginas para su distribución gratuita.

Barbarie. Comics sobre violencia politica en el Perú, 1985-1990 (2010) es una historieta escrita y dibujada por Jesús Cossio. Con una extensión de 88 páginas, esta obra se desarrolla a partir de cuatro episodios: "Asesinatos de Pucayacu II", "Matanza de Accomarca", "Masacre de Aranhuay-Masacre de Paccha” y "Matanza de los Penales". En cada una de estas historias, el autor aborda casos emblemáticos de algunas de las modalidades de violencia más representativas de este conflicto, como lo fueron la desaparición forzada, las ejecuciones extrajudiciales y las masacres.

A grandes rasgos, estas historietas se caracterizan por acercarse al conflicto armado interno en el que se vieron confrontados el Estado peruano y SL. Complejizan la tradicional distinción establecida entre fuentes escritas y fuentes visuales, pues en ellas interactúa un lenguaje tanto icónico como textual. Adicionalmente, estas historietas nos permiten identificar los "ecos de la historia en la historieta", en la medida en que sus historietistas van a recurrir a una serie de estrategias para reclamar el carácter "real” de sus narraciones.

Desde tal perspectiva, este capítulo busca desentrañar por qué estas historias fueron contadas de la manera en que sus autores lo hicieron y qué implicaciones históricas tienen sus elecciones narrativas y estéticas a la hora de representar la

Melgarejo, "Representación gráfica de la violencia política en el Perú 1980-2012: una aproximación a las historietas durante el tiempo de violencia interna", Pacarina del Sur 4, n. ${ }^{\circ} 14$ (2013): s. p.

7 Díaz, Hacia un cómic de autor, 63. 
violencia política peruana. Parafraseando a Campbell, ${ }^{8}$ las dos historietas que analizamos se seleccionaron no solo porque ocupan un lugar especial en el conjunto de historietas acerca de la violencia política, sino también por sus diferencias ideológicas a la hora de generar narraciones sobre este fenómeno. Para ilustrar esto, en primer lugar, se reconstruyen los paradigmas a partir de los cuales se elaboraron estas dos historietas. En segundo lugar, se analizan los contextos historietísticos que van a dar forma a los regímenes de producción, circulación y consumo de estos productos culturales. Por último, se miran algunas elecciones estilísticas y narrativas de las historietas para entender cómo están atadas a las elecciones ideológicas de sus autores.

\section{Imaginar el terror: ¿cómo representar la violencia política peruana?}

La pregunta sobre cómo representar la violencia ha generado una amplia discusión que tuvo un importante punto de inflexión en el contexto posterior al Holocausto judío. Calificado por muchos como la experiencia más extrema de la historia del siglo $\mathrm{xx}$, la posibilidad de una memoria del Holocausto originó un debate alrededor de las características y las posibilidades de la representación. Esta discusión “en torno al régimen expresivo del pasado histórico traumático"9 ${ }^{9}$ se materializó en dos posturas que se configuraron en oposición: por un lado, se ubicaron aquellos que creían en la imposibilidad de representar una experiencia que se escapaba a cualquier palabra o imagen; por otro, se situaron aquellos que consideraron necesario imaginar la experiencia traumática pese a todo. ${ }^{10}$ Aunque esta discusión progresivamente se ha zanjado a favor de los que consideran necesaria la representación, el debate se ha ampliado con el surgimiento de nuevas preguntas relativas al cómo representar el terror partiendo del reconocimiento de su naturaleza inefable.

8 Bruce Campbell, Viva la historieta: Mexican Comics, NAFTA, and the Politics of Globalization (Jackson: University Press of Mississippi, 2009), 19.

9 Pablo Dreizik, "Figuras del cuerpo rememorado", en Politicas de la memoria: tensiones en la palabra y la imagen, ed. por Sandra Lorenzano y Ralph Buchenhorst (México: Universidad del Claustro de Sor Juana, 2007), 430.

10 María Angélica Melendi, “Tumbas de papel: estrategias del arte (y de la memoria) en una era de catástrofes", en Políticas de la memoria: tensiones en la palabra y la imagen, ed. por Sandra Lorenzano y Ralph Buchenhorst (México: Universidad del Claustro de Sor Juana, 2007), 297-298 y Georges Didi-Huberman, Imágenes pese a todo: memoria visual del Holocausto (Barcelona: Paidós, 2004), 17-68. 
En el caso peruano, la circulación de imágenes y discursos respecto de la violencia política se desarrolló desde los mismos inicios del conflicto, inmediatez que dejó de lado una reflexión que en muchos casos está teniendo lugar solo en años muy recientes. Este flujo diverso de representaciones oficiales, no oficiales, académicas, artísticas, jurídicas e históricas ha reafirmado el carácter de la memoria como un "espacio de lucha política" en el que estas representaciones - muchas veces opuestas- han tratado de imponer su propia interpretación sobre lo sucedido. ${ }^{11}$ Estas luchas por el sentido del pasado han buscado determinar no solo lo que se debe o no recordar, sino también cómo se debe hacer. ${ }^{12}$ En este escenario, es posible identificar dos "memorias paradigmáticas" de las cuales las representaciones de la violencia política han sido subsidiarias — entre ellas nuestras historietas-. Se trata entonces de una memoria que se ha configurado alrededor del paradigma de la lucha antisubversiva, como lo veremos en la historieta Confidencias, y otra memoria que recientemente ha puesto a las víctimas en el centro de la discusión, memoria que encontraremos en el caso de Barbarie.

Aunque SL venía gestándose desde la década de los sesenta como proyecto político, esta guerrilla salió a la luz pública en 1980, cuando quemaron las urnas y cédulas de votación de la población de Chuschi (Ayacucho) en la víspera de las primeras elecciones presidenciales de un nuevo periodo de apertura democrática. ${ }^{13}$ $\mathrm{Al}$ presentarse como un grupo de corte maoísta a la cabeza de Abimael Guzmán - conocido como "presidente Gonzalo" - , la guerrilla de SL progresivamente fue haciéndose un espacio en el imaginario de los peruanos. La adopción del principio maoísta de las “dos líneas" llevó a que SL dividiera a la sociedad peruana entre aquellos que eran adeptos a la causa de la revolución y los que estaban en su contra. El Estado, que encarnaba la línea contrarrevolucionaria por antonomasia, debía entonces ser destruido para erigir uno nuevo. ${ }^{14}$ Pese a su propuesta de guerra popular prolongada en contra del Estado, sL logró durante mucho tiempo desarrollar sus acciones por fuera del radar.

\footnotetext{
11 José Luis Igue Tamaki, “Los silencios del gran relato", Histórica 29, n. ${ }^{\circ} 1$ (2005): 154.

12 Elizabeth Jelin, Los trabajos de la memoria (Lima: Instituto de Estudios Peruanos, 2012), 40.

13 Carlos Aguirre, “Terruco de m... Insulto y estigma en la guerra sucia peruana”, Histórica 35, n. ${ }^{\circ} 1$ (2011): 110-111.

14 Rodrigo Montoya, Al borde del naufragio: democracia, violencia y problema étnico en el Perú (Madrid: Talasa, 1992), 94-97.
} 
En un primer momento, SL fue leído por muchos peruanos como un "fenómeno pasajero" cuyo accionar no correspondía con el de una guerrilla armada. ${ }^{15}$ Reflejo de esto fue la postura que desde el Gobierno del presidente Fernando Belaúnde se tomó frente a sL, al calificarlo como una “'banda de delincuentes', 'abigeos', o simplemente 'locos”'.16 Esta situación fue aprovechada por SL para expandirse en otras zonas de Ayacucho y del país. En este proceso de crecimiento, SL logró establecer apoyos y simpatías entre la población que se sintió cercana al proyecto de una transformación profunda del Perú. No obstante, cuando sL quiso llevar su guerra popular a la etapa de "equilibrio estratégico", las relaciones con la población civil se vieron profundamente afectadas, debido a que el grupo empezó a exigirles una participación más activa. ${ }^{17}$

Los medios masivos de comunicación también participaron de esta etapa inicial de desconcierto, que los puso frente a la tarea de cubrir un conflicto que aún escapaba de su comprensión. Como señala Sotelo Melgarejo, la respuesta inicial de la prensa fue "atenuar los actos terroristas considerándolos episódicos y producto de mentes criminales". ${ }^{18}$ No obstante, con la progresiva escalada del conflicto, la mayoría de la prensa opta por dar un tratamiento sensacionalista a la violencia. De manera contraria a la inicial dulcificación, en este segundo momento los medios de comunicación recurrieron a la "sobreexposición" de la violencia, cuya consecuencia fue la creación de una "imagen del terror" que caló rápidamente en el imaginario de los peruanos, pero que no aportó significativamente al proceso de "comprender los orígenes y las posibles soluciones al conflicto". ${ }^{19}$

15 Aguirre, “Terruco de m...”, 111-112; Alexandra Montoya Salamanca y Carolina Suárez Baquero, “El papel de la Comisión de la Verdad y Reconciliación en el caso peruano”, en Elmosaico de la memoria: experiencias locales, no oficiales o parciales de búsqueda de la verdad histórica, ed. por María Paula Gómez Méndez (Medellín: Fundación Social; Alcaldía de Medellín; International Center for Transitional Justice, 2007), 251. José Gonzales Manrique, La prensa como reflejo de desarticulación social. Prensa y violencia en el Perú: el caso de Sendero Luminoso (Lima: Universidad de Lima, 1992), 51.

Carlos Iván Degregori, Violencia política y respuestas desde la sociedad y desde el Estado: caso peruano (New York: Columbia University; New York University Consortium, 1990), 10; Yerko Castro Neira, "Antropología de la violencia: ente los estudios del sufrimiento social y la antropología de la paz", en Memorias de un soldado desconocido: autobiografia y antropología de la violencia, de Lurgio Gavilán Sánchez (Lima: IEP; Universidad Iberoamericana, 2012), 21-32. 
De la mano de esta "imagen del terror", hubo otro acercamiento al conflicto que también hizo carrera entre la opinión pública y la intelectualidad peruana. En 1983, un grupo de ocho periodistas, un guía y un comunero que habían llegado a la población de Uchuraccay para cubrir una acción violenta ejecutada por SL en un municipio vecino fueron asesinados por sus pobladores, al confundirlos con miembros de esta guerrilla. La muerte de estas personas conmocionó de tal forma al país que para su investigación fue creada una comisión presidida por el escritor Mario Vargas Llosa. Como producto de su labor, fue emitido el Informe de la Comisión Investigadora de los Sucesos de Uchuraccay, texto que hace famosa una lectura muy particular de la violencia política. En este informe se consolidó una mirada al conflicto en la que se contraponían dos visiones del país: por un lado, se encontraba un "Perú oficial, [...] moderno y democrático"; por otro, un Perú “ajeno al progreso y al devenir histórico”, donde la violencia encontraba asidero. En una especie de reactualización de la tradicional oposición entre costa y sierra peruana, esta lectura ató los orígenes del conflicto a la "diferencia cultural". ${ }^{20}$

La "incapacidad para entender la naturaleza” del conflicto y de los actores alzados en armas, ${ }^{21}$ llevó a que los sucesivos gobiernos optaran por la vía militar como solución a la violencia, estrategia que naturalmente estuvo a cargo de las Fuerzas Armadas y Policiales del Perú. Desde la perspectiva de una política antisubversiva, el Estado no solo buscó combatir los grupos armados, sino también contemplaba la represión de la población civil que pudiera servirle como apoyo a estos grupos. Las violaciones a los derechos humanos se hicieron sistemáticas tanto en el accionar de las guerrillas como por parte de las instituciones de la fuerza pública, razón por la que la "lógica de la guerra sucia terminó por imponerse".22 Lo que llama la atención de esta política es que no solo logró consensos entre políticos y militares, sino también entre una porción significativa de la sociedad peruana. Como señala Igue, es importante no perder de vista que durante los años de la violencia política "una nutrida fracción de los peruanos no le importó demasiado que se violaran los

20 Juan Carlos Ubilluz, "El fantasma de la nación cercada", en Contra el sueño de los justos: la literatura peruana ante la violencia política, ed. por Juan Carlos Ubilluz, Alexandra Hibbett y Víctor Vich (Lima: Instituto de Estudios Peruanos, 2009), 22-29.

21 Aguirre, “Terruco de m..., 112-113. Además de sl también se encontraba el Movimiento Revolucionario Túpac Amaru (MRTA) y el Comando Rodrigo Franco. No obstante, estas guerrillas no se incluyen en este artículo debido a que las historietas se concentran en el senderismo.

22 Aguirre, “Terruco de m..., 112-113. 
derechos humanos de la gente si ello traía la paz o la realización del igualitarismo radical". 23

No obstante, con la crisis del Gobierno de Alberto Fujimori se produce un cambio sustancial en las representaciones de la violencia política. Con su salida del poder en el 2000, se llevó a cabo en el Perú una nueva transición democrática, espacio en el que encontraron eco los ya existentes reclamos de justicia y verdad por parte de las víctimas. ${ }^{24}$ Las principales acciones realizadas por el Gobierno como muestra de una nueva actitud política frente al conflicto fueron la creación de la Comisión de la Verdad y Reconciliación (CVR) y la publicación de su Informe final, en el 2003. Más allá de sus tareas enmarcadas en la ley, la CVR tenía como uno de sus propósitos más importantes el posicionar entre los peruanos una nueva narrativa de la violencia que fuese más comprensiva e inclusiva. Este deseo de transformar el imaginario social de los peruanos tuvo, incluso, un correlato visual en la exposición fotográfica y el libro Yuyanapaq. Para recordar: relato visual del conflicto armado interno, 1980-2000.25

Este nuevo escenario, que podemos conceptualizar bajo lo que Wieviorka denomina época de las víctimas, ${ }^{26}$ dio protagonismo a unos actores que bajo la lógica de la guerra contrainsurgente habían quedado marginados. Se plantearon nuevos debates que buscaron indagar por los efectos de la violencia política, con un horizonte a futuro condensado en el principio de la "no repetición". Con los nuevos actores también llegaron iniciativas no oficiales que buscaron sumarse a la tendencia marcada por la CVR. Las víctimas y sus demandas cobraron una preeminencia que antes no había logrado tener debido a las posturas que podríamos calificar de "negacionistas". ${ }^{27}$ No obstante, es importante tener en cuenta que esta

23 Igue, "Los silencios del gran relato", 160-161.

24 Félix Reátegui Carrillo, "Búsqueda oficial de memoria en Perú: la Comisión de la Verdad y Reconciliación”, en Elmosaico de la memoria: experiencias locales, no oficiales o parciales de búsqueda de la verdad bistórica, ed. por María Paula Gómez Méndez (Medellín: Fundación Social; Alcaldía de Medellín; International Center for Transitional Justice, 2007), 15.

25 Elena Goday Lucas, "Reconocimiento y dignificación de las víctimas del conflicto armado interno vivido en el Perú entre 1980-2000, a través de su representación visual en el libro fotográfico Yuyanapaq: para recordar: relato visual del conflicto armado interno, 1980-2000" (tesis de Licenciatura en Comunicación para el Desarrollo, Pontificia Universidad Católica del Perú, Lima, 2001), 36-38.

Michel Wieviorka, “Ante la violencia”, en El doble filo de la navaja: violencia y representación, ed. por Fernando García Selgas y Carmen Romero Bachiller (Madrid: Trotta, 2006), 36-37.

27 Como veremos más adelante, en el caso peruano este negacionismo actuó calificando a toda víctima como miembro de sL o como el resultado colateral de una lucha contrainsurgente en defensa de supuestos valores democráticos. 
memoria centrada en las víctimas no significó la desaparición de la memoria basada en el paradigma de la lucha contrainsurgente.

En lugar de una transición de una "memoria paradigmática” a otra, lo que se presentó fue una coexistencia conflictiva entre estas dos memorias. Aunque parte de la sociedad peruana empezó a revaluar la otrora irrefutable legitimidad del discurso estatal, las nuevas narrativas tuvieron que encontrarse y chocar con una memoria en la que personajes como Fujimori fungían de "gestores de paz", los militares eran considerados salvadores de la patria y los guerrilleros se mostraban como los únicos culpables de la violencia y sus estragos. ${ }^{28}$ Con lo anterior, estas dos memorias se configuraron como "núcleos distintos y en pugna para la articulación del relato". ${ }^{29}$

En el marco de estas disputas por la memoria, podemos entender las historietas de Baldoceda y Cossio como obras que apelan a la narración de episodios de la violencia política. De manera contraria a aquella "estética negativa" que privilegia el carácter hermético del pasado traumático, al considerarlo inimaginable e indecible, Confidencias y Barbarie se constituyen en representaciones que, desde la ausencia, buscan dotar de sentido la experiencia histórica de la violencia. Por esto, podemos analizar estas historietas desde el concepto de imagen-montaje, planteado por Didi-Huberman. Se trata entonces de representaciones compuestas por múltiples imágenes fragmentarias que solo pueden entenderse si "las diferenciamos y las hacemos resonar junto a otras fuentes, otras imágenes y otros testimonios".30

\section{Las historietas como productos culturales: sus ambientes historietísticos}

Para entender la manera en que se construyen las narraciones de Confidencias y Barbarie, no es suficiente con mirar las "memorias paradigmáticas" que articulan sus historias. También es fundamental detenernos en las prácticas y herencias de la historieta que sus autores retoman en el proceso de elaboración. Como señalamos en una investigación previa, ${ }^{31}$ las historietas que apelan a temas históricos no solo

28 Goday Lucas, “Reconocimiento y dignificación”, 36.

29 Pilar Calveiro, "Memoria, política y violencia”, en El mosaico de la memoria: experiencias locales, no oficiales o parciales de búsqueda de la verdad histórica, ed. por María Paula Gómez Méndez (Medellín: Fundación Social; Alcaldía de Medellín; International Center for Transitional Justice, 2007), 54.

30 Didi-Huberman, Imágenespese a todo, 179.

31 Natalia Mahecha Arango, "De épicas nacionales, indígenas temerarios y heroínas fatales: historietas históricas en Colombia (1969-1972)" (tesis de pregrado en Historia, Universidad de los Andes, Bogotá, 2011), 9 y 35-36. 
establecen lazos de intertextualidad con tradiciones históricas o historiográficas, sino que también se sirven de diferentes tradiciones historietísticas para construir sus relatos. Desde esta perspectiva, las historietas que analizamos en este capítulo deben ser atadas a unas condiciones de producción, circulación y consumo que nos permitan entender su importancia como representaciones de la violencia política.

\section{Confidencias de un senderista: herencias de la historieta popular para la lucha contrainsurgente}

Confidencias de un senderista es una historieta construida a partir del testimonio de Jorge Cañari, un exmiembro de sL que fue reclutado forzosamente por esta guerrilla en medio de un "juicio popular" llevado a cabo en la comunidad de Mollebamba. Elaborada a pedido de la Comisión de Cultura del Centro Naval (Ministerio de Marina), la historieta se pensó para ser distribuida gratuitamente entre los habitantes de los barrios marginales limeños. ${ }^{32}$ Pese a que SL ya había hecho presencia en varias ciudades del Perú, en 1989 -año en que es publicada Confidencias - comienza una nueva etapa de la operación de este grupo guerrillero con el aumento de sus acciones terroristas en zonas urbanas, principalmente en Lima. ${ }^{33}$ Aunque en la historieta no se hace referencia a este elemento de contexto, si lo valoramos a la luz de la "memoria paradigmática" que articula su narración, podemos ver cómo esta historieta hizo parte de una acción propagandística en contra del avance urbano de SL.

La entrega gratuita de estas historietas no operó en el vacío, pues los habitantes de estos barrios limeños habían tenido recientemente una experiencia con este lenguaje. Los llamados pueblos jóvenes de Lima habían aparecido en el paisaje de la ciudad como producto del proceso de urbanización que desde la década de los cuarenta trasladó una ola de migrantes andinos a la capital peruana. Dentro de los muchos problemas que tuvieron que enfrentar estos nuevos migrantes, el más apremiante fue el acceso limitado a la tierra y a la vivienda. Por esto, estos "pueblos" se constituyeron a partir de dinámicas de invasión de tierras y de prácticas organizativas que les permitieron a los migrantes defender los asentamientos recientes

32 "Confidencias de un senderista", Blog Weird Universe, s. f., http://www.weirduniverse.net/blog/ comments/confidencias_de_un_senderista/ (31/03/2017).

33 Comisión de la Verdad y Reconciliación, Hatun Willakuy: versión abreviada del Informe final de la Comisión de la Verdad y Reconciliación (Lima: CVR, 2004, 72), citado en Goday Lucas, "Reconocimiento y dignificación”, 33 . 
en contra de los desalojos. Estos nuevos habitantes conformaron organizaciones barriales que los conectaron a una red de políticos y burócratas, redes que supieron utilizar para reclamar títulos legales sobre las tierras invadidas y, posteriormente, acceso a servicios públicos. ${ }^{34}$

Con la llegada al poder del general Juan Velasco Alvarado (1968-1975), estas organizaciones barriales lograron consolidar un "movimiento popular sin precedentes que finalmente condujo a la trasformación de los movimientos en actores sociales y políticos por sí mismos". ${ }^{35}$ El Gobierno de Velasco implantó un modelo militar-populista de un corte diferente al que por esa época cogía fuerza en los países del Cono Sur. Las acciones más importantes que acometió Velasco durante su Gobierno fueron la nacionalización de empresas extranjeras, la instauración de un nuevo modelo industrial y la adopción de una Reforma Agraria con vocación redistributiva. Por medio de estas medidas, Velasco logró convertirse en un vocero legítimo de los intereses y demandas de los sectores excluidos de la política formal. ${ }^{36}$

Con el objetivo de canalizar por vías institucionales al movimiento popular, el Gobierno velasquista creó el Sistema Nacional de Apoyo a la Movilización Social (Sinamos). Con esta institución, Velasco buscó que la sociedad civil organizada le sirviera como una base de apoyo. Sinamos hizo presencia en diferentes poblaciones urbanas y rurales a través agentes culturales (e.g., artistas, maestros, dibujantes, teatreros) conocidos como promotores, actores que van a ser muy importantes para entender el desarrollo de la historieta durante este periodo. ${ }^{37}$

En relación con las historietas, Velasco desarrolla dos acciones que demuestran la importancia que tuvo este producto cultural durante su presidencia. ${ }^{38}$ En primer lugar, el Gobierno militar consideró la historieta un medio por el cual podía darse una "manipulación ideológica capitalista", razón por la que fue prohibido el ingreso al país de historietas extranjeras. Como alternativa, se buscó desarrollar un tipo de historieta "nacionalista", financiada por el Estado, que tuvo como medio de difusión la revista Avanzada. Esta tuvo una duración de quince años y logró llegar

34 Gerd Schönwälder, Linking Civil Society and the State: Urban Popular Movements, the Left, and Local Government in Peru, 1980-1992 (University Park: Pennsylvania State University Press, 2002), 61-62.

35

36

37

38

Ibid., 62.

Ibid., 63.

Ibid., 64-66.

Un análisis más completo del uso de la imagen y la propaganda durante el Gobierno de Velasco se encuentra en el capítulo de Anna Cant: "Representando la Revolución: la propaganda política del gobierno de Juan Velasco Alvarado en Perú (1968-1975)”, publicado en este mismo libro. 
a un número muy grande de lectores, gracias a su distribución directa en escuelas religiosas y públicas. Y, en segundo lugar, el Gobierno de Velasco fue el primero que "creó una campaña ideológica basada en material gráfico", producido en gran parte por dos de los dibujantes más destacados de Avanzada: Rubén Osorio y Hernán Bartra. ${ }^{39}$

En un contexto definido por los elementos expuestos en las páginas precedentes, surgió en el Perú la llamada historieta popular. Su desarrollo hizo parte de un boom más amplio de la comunicación popular (e.g., radio, prensa y teatro), cuyo fin era dotar a las poblaciones de los barrios marginales de las ciudades y de algunas comunidades rurales con las herramientas para que elaboraran sus propios medios y productos comunicativos. Para el caso de la historieta popular, la acción de algunos antiguos promotores de Sinamos fue determinante. Uno de ellos fue Juan Acevedo, el exponente más importante de este tipo de historieta. Acevedo adelantó su trabajo comunitario en el pueblo joven de Villa El Salvador (Lima), trabajo a partir del cual elabora una serie de talleres sobre historieta popular en varios lugares del país y de América Latina, dirigidos a niños, estudiantes, campesinos y obreros. ${ }^{40}$

Al igual que otros historietistas de este periodo, Acevedo planteaba la necesidad de que en los peruanos se generara una conciencia crítica frente a los productos culturales que consumían, por lo que parte de los talleres que realizó hacían hincapié en la comprensión del lenguaje de la historieta. Esta especie de campaña de “alfabetización visual” iba de la mano de una exploración de la historia nacional y, más exactamente, buscaba el "acce[so] al sentimiento de lo nacional a través de la imagen" ${ }^{41}$ Desde esta perspectiva, para Acevedo y los demás historietistas populares no solo era importante que los lectores de historietas actuaran como consumidores “críticos”, sino también que fueran productores de imágenes e historias propias.

La historieta popular se consolidó como una forma de producción artesanal de historietas que operaba en lo local, paralelamente a una producción de historietas

39 Carla Sagástegui, "Acevedo and His Predecessors", en Redrawing the Nation: National Identity in Latin/o American Comics, ed. por Héctor Fernández L’Hoeste y Juan Poblete (New York: Palgrave Macmillan, 2009), 139.

40 Juan Acevedo, "Historieta popular de los setenta", en Educación y comunicación popular en el Perú, ed. por Luis Peirano (Lima: Seminario sobre Experiencias en la Utilización de los Medios de Comunicación para la Promoción y la Educación Popular, 1988).

41 Mario Lucioni, "La historieta peruana I", Revista Latinoamericana de Estudios sobre la Historieta 1, n. 4 (2001): 59-67. 
de carácter industrial que tenía un alcance nacional. ${ }^{42}$ Como señalan Fernández y Poblete para varios países de América Latina, en este periodo las historietas - junto a otras formas de comunicación popular- las utilizó la población recientemente urbanizada como un "lenguaje mediador" que le facilitó asimilar las nuevas experiencias derivadas de su integración a las ciudades y a los proyectos nacionales de modernización. ${ }^{43}$ Con lo anterior, podemos ver que los potenciales lectores de Confidencias estaban familiarizados con la lectura y — posiblemente- con la producción de historietas.

Así mismo, esta familiaridad no solo es posible identificarla en el caso de los lectores, sino también en el mismo dibujante Luis Baldoceda. De su experiencia artística podemos destacar dos aspectos que permiten entender este señalamiento. De manera similar a Juan Acevedo, Baldoceda también hizo parte de Sinamos, entidad en la que trabajó como artista adscrito a la Unidad de Artes Plásticas. ${ }^{44}$ Adicionalmente, Baldoceda es hasta hoy recordado por haber creado la historieta “Teodosio", la cual publicó en el suplemento dominical del diario La Crónica entre 1974 y 1980. Esta historieta tenía como personaje principal a Teodosio, un campesino de la Sierra que a lo largo de las viñetas recreaba la vida cotidiana de los pobladores andinos. En esta historieta se llegaron a tratar temas como la Reforma Agraria impulsada por Velasco, las prácticas agrícolas y las tradiciones festivas serranas: ${ }^{45}$

[...] la historieta Teodosio tuvo una importante acogida ya que se nutría de parte de los ideales de la época: el rescate de temas peruanos, la celebración del hombre andino y la esperanza de un futuro mejor en una sociedad más solidaria. Pero la historieta trasciende a su época por la excelente narrativa y la magistral construcción de personajes. Teodosio es el personaje de mayor trascendencia y

42 Héctor Fernández L'Hoeste y Juan Poblete, “Introduction”, en Redrawing the Nation: National Identity in Latin/o American Comics, ed. por Héctor Fernández L’Hoeste y Juan Poblete (New York: Palgrave Macmillan, 2009), 8.

43 Fernández L'Hoeste y Poblete, “Introduction", 1-8.

44 “Luis Baldoceda”, http://www.lambiek.net/artists/b/baldoceda_luis.htm (31/03/2017).

45 Mario Lucioni, "La historieta peruana II", Revista Latinoamericana de Estudios sobre la Historieta 2, n. 8 (2002):17-32. 
popularidad durante los años [70]. El diario La Crónica editaba un mayor tiraje por la popularidad de su personaje. ${ }^{46}$

Gracias a esta historieta, Baldoceda empezó a ocupar un lugar importante en el ámbito artístico peruano. Derivado de este reconocimiento, trabajó en organizaciones del Estado como la ya mencionada Comisión de Cultura del Centro Naval. ${ }^{47}$ En Confidencias, Baldoceda retoma dos elementos que había desarrollado en su trabajo previo, particularmente en “Teodosio". Por un lado, en esta historieta el autor despliega su tradicional trabajo que visualmente se distingue por el manejo de colores vivos y de tonos intensos. Por otro, en Confidencias la historia vuelve a desarrollarse en el espacio de la sierra peruana, pero en esta ocasión los temas que habían marcado la vida rural hasta finales de los años ochenta (e.g., el conflicto por la tierra) son remplazados por el nuevo protagonismo adquirido por la violencia política. Con todos estos elementos, podemos identificar la existencia de una "experiencia común" 48 entre Baldoceda y sus lectores potenciales, factor que permite poner en contexto la aprehensión de esta narrativa sobre la violencia.

\section{Barbarie y el desarrollo de la historieta independiente}

Barbarie. Comics sobre violencia politica en el Perú, 1985-1990 es una historieta que se acerca a este periodo por medio de cuatro historias de victimización que Cossio considera representativas del conflicto entre el Estado y SL. Para el 2010, fecha en que se publica Barbarie, el panorama historietístico peruano había sufrido cambios trascendentales en comparación con el periodo de influencia de la historieta popular. En primer lugar, la historieta como producto cultural tomó distancia de la vida cotidiana de los habitantes de los “pueblos jóvenes” y de los poblados andinos para insertarse con mayor fuerza en las dinámicas internacionales de creación y lectura. Además de esto, el estatus de la historieta como un "género narrativo con

46 “Teodosio: La recuperación de un clásico de la historieta peruana”, Comic Perú, http://comicperu. wordpress.com/2006/12/05/teodosio-la-recuperacion-de-un-clasico-de-la-historieta-peruana/ (31/03/2017).

47 Baldoceda publica, junto al Centro Naval, otras historietas como Miguel Grau, almirante considerado un héroe nacional por su participación en la Guerra del Pacífico. Con el apoyo de las fuerzas militares fueron publicadas en esta época otras historietas como La Batalla Tarapacá, Francisco Bolognesi, José Quiñones y Expulsar al invasor, en las que participaron otros historietistas como Luis Sayán, Jorge Monterrey y Víctor Martínez Quintana.

48 Fregoso, La narrativa léxico-pictográfica, 18. 
las mismas posibilidades artísticas que cualquier otra manifestación narrativa” se afianzó gracias al esfuerzo de historietistas que le apostaron a desarrollar narraciones artística y literariamente innovadoras. ${ }^{49}$

La escena historietística limeña, de la cual Cossio hace parte, se diversificó a razón de transformaciones que se dieron en diferentes esferas. Sotelo, en un estudio sobre la historieta en Lima entre 1990 y 2005, señala que para esta época tuvo lugar una explosión de la historieta impulsada por el ingreso de nuevos estilos (gráficos y narrativos), la promoción y difusión de la historieta entre un público juvenil, la creación de clubes de historietas (tanto de creadores como de lectores), la realización de concursos y ferias, la proliferación de fanzines y la aparición de revistas especializadas publicadas en el Perú..$^{50}$

A estas dinámicas — más fuertes en Lima, pero que se pueden hacer extensivas a otras partes del país - se suma la consolidación de la "novela gráfica", siendo Barbarie un ejemplo de esto. Más allá de los debates sobre lo apropiado o no de este término, nos acercamos a los señalamientos de Díaz, quien considera que el concepto novela gráfica entraña un cambio en las formas de concebir, distribuir y consumir la historieta. ${ }^{51}$

Sobre la concepción de la historieta desde la novela gráfica, encontramos una renovada preeminencia de la figura del autor, que deja de lado la producción de historietas de manera anónima y genérica, para imprimir con más fuerza su carácter y estilo en las obras que produce. Como señala Díaz, el desarrollo de una historieta de autor ha facilitado que sus creadores expresen "preocupaciones o experiencias particulares, a menudo vividas al margen de la sensibilidad general o contra ella".52 En el caso de Cossio, esta apropiación de la novela gráfica le ha permitido desarrollar historietas sobre diferentes temáticas entre las cuales se localiza su interés por las otras historias del conflicto peruano.

Respecto a la forma de distribución, tanto en Perú como en otros países se ha creado un modelo que retoma las dinámicas de circulación desarrolladas alrededor

\footnotetext{
49 Lucioni, "La historieta peruana II".

50 Marco Antonio Sotelo Melgarejo, “Taxonomía de las historietas limeñas: propuesta para una clasificación de las historietas producidas y publicadas en la provincia de Lima Metropolitana entre los años 1990 a 2005" (tesis de licenciatura en Comunicación Social, Universidad Nacional Mayor de San Marcos, Lima, 2009), 95-98.

51 Díaz, Hacia un cómic de autor, 30-38.

52 Ibid., 38.
} 
del comix o comic underground estadounidense en las décadas de los sesenta y de los setenta. ${ }^{53}$ Se trata de un mercado de la historieta que pasa de los quioscos y las librerías de cadena a un circuito de librerías especializadas muy cercanas a las editoriales independientes. Estos cambios en la circulación influyeron en el público potencial de las historietas, pues ahora se trata de lectores que conocen estos circuitos y que tienen la capacidad adquisitiva suficiente para consumir sus obras. En relación con este punto, no es gratuito que Barbarie haya sido publicada bajo el sello de Contracultura, una editorial cuya apuesta es fortalecer la historieta alternativa publicando a autores peruanos que se aproximen a esta. ${ }^{54}$

Pese a que Barbarie ha seguido la lógica de distribución que señala Díaz para las novelas gráficas, el hecho de que Jesús Cossio tuviera en mente construir una representación del conflicto desde las víctimas lo obligó a buscar una circulación que fuera más allá de las tiendas especializadas. En pos de ello, este autor recurrió a una práctica que ya habíamos señalado para caracterizar el periodo de la historieta popular. Cossio ha acudido a la realización de talleres con víctimas y lectores en general, con el doble propósito de dar a conocer su obra y de poner de relieve el carácter político de su propuesta narrativa - como ejercicio de memoria histórica- Aunque muchos de estos talleres se han realizado de manera independiente, en el 2014 Cossio participó en un proyecto de la Comisión de Reparaciones a Afectados por la Violencia y el Ministerio de Justicia, que buscó acercar a estudiantes de secundaria al lenguaje de la historieta por medio de talleres en los que se brindaban nociones básicas. El objetivo de este proyecto era entonces que los estudiantes produjeran historietas cortas en las que abordaran diferentes aspectos del periodo de la violencia política.

Sobre la circulación, un aspecto que diferencia significativamente a Barbarie de Confidencias tiene que ver con los alcances geográficos de su distribución. Mientras que Confidencias fue pensada como una historieta para ser entregada gratuitamente en zonas específicas de la ciudad de Lima, la historieta de Barbarie ha hecho presencia en diferentes partes del mundo. Una labor conjunta de Cossio y Contracultura ha llevado a esta novela gráfica a librerías especializadas de varios

53 Ibid., 37-38.

54 En esta línea, desde el 2010 la editorial Contracultura ha organizado el concurso Premio de Novela Gráfica, precisamente, para destacar los nuevos talentos que se han venido desarrollando en esta escena. Véase: Evelyn Mabel Núnez Alayo, "Novela gráfica peruana” (tesis de maestría en Comunicaciones, Pontificia Universidad Católica del Perú, Lima, 2010), 2. 
países de América Latina y Europa. En esta misma línea, el episodio "Matanza de Accomarca" fue traducido al inglés y puesto a disposición del público en la red. Por medio de su participación en festivales internacionales y en exposiciones en el exterior, Cossio ha procurado que su historieta tenga una distribución más allá de las fronteras nacionales. Esta inserción de Barbarie en el "mercado cultural de la globalización" 55 plantea una cuestión fundamental sobre los alcances de los proyectos de memoria en la actualidad. De acuerdo con Rueda:

Los muy diversos elementos que entran en juego en la escritura, publicación y recepción de un libro adquieren un peculiar impacto cuando se habla de historias violentas, que por otro lado resultan intensamente atractivas para los lectores, pero por otro se adentran en las más profundas heridas de una socie$\mathrm{dad}$, heridas que pueden haber tocado de manera directa o indirecta a algunos de estos lectores. En el circuito local, donde se encontrarían por lo general situadas aquellas personas a quienes la violencia narrada toca más de cerca, el tipo de reacción que esta suscita tiene un sentido diferente al que tendrá para los lectores globales. ${ }^{56}$

En el caso de Barbarie, se establecen entonces dos niveles de circulación que determinan formas diferenciadas de leer esta historieta y de comprender su representación de la violencia. Al insertar su obra en los "circuitos transnacionales del libro y la lectura", 57 Cossio diversifica los contextos de recepción si se le compara con lo descrito para el caso de Confidencias.

Al detenernos en las herencias y los ambientes historietísticos de Confidencias y Barbarie, encontramos que - como cualquier producto cultural- no definen su sentido de manera exclusiva en el espacio de la producción. Aunque en esta investigación no fue posible ahondar en la recepción de estas dos historietas, un acercamiento a sus formas de circulación y consumo nos permiten entrever que sus representaciones de la violencia no solo responden a dos "memorias paradigmáticas" diferentes, sino también a los universos de lectores para los cuales fueron pensadas.

55 María Helena Rueda, La violencia y sus huellas: una mirada desde la narrativa colombiana (Madrid: Iberoamericana, 2011), 157.

56 Ibid., 160.

57 Ibid., 160. 


\section{Hacer la historieta: una mirada a las elecciones narrativas y estéticas}

La violencia política impactó de manera tal a la sociedad peruana que, a partir de diferentes disciplinas y expresiones artísticas, se manifestó la necesidad de reflexionar sobre ella. De manera similar a lo sucedido en el conflicto bosnio que estudia Díaz, en el caso peruano las muestras más patentes de esta inquietud provinieron de la literatura y del cine. ${ }^{58}$ Lo anterior no significó que desde otros campos no se produjeran respuestas importantes, pese a que nuestras dos historietas son un ejemplo de esto. Aunque tradicionalmente se ha considerado la historieta un lenguaje restringido al mundo de la fantasía, en trabajos como los de Baldoceda y Cossio se pone en evidencia una preocupación de sus autores por elaborar representaciones capaces de actuar como sustitutos plausibles y efectivos de la experiencia violenta. Esta preocupación condujo a que sus autores buscaran adecuar sus elecciones estéticas y narrativas a las representaciones que elaboraron sobre el conflicto.

En el proceso de construcción de estas representaciones, Baldoceda y Cossio recurrieron a diferentes estrategias narrativas y convenciones de la historieta con el objetivo de generar "efectos de realidad" que acreditaran el carácter histórico de sus narraciones. ${ }^{59} \mathrm{La}$ apelación a lo real que es posible identificar en Confidencias y Barbarie es fundamental para entender la función de estas historietas en el marco de la lucha por el sentido del pasado. De este conjunto de "efectos de realidad" analizamos las fuentes que utilizaron los autores para construir sus narraciones y el lugar que le dan a lo visual para representar la violencia.

\section{Historietas "reales": lo testimonial y ficcional}

La creación de historietas como Confidencias y Barbarie pasa por una reelaboración de las que, podemos considerar, son sus fuentes originales, proceso que implica la adaptación de estos "textos primeros" al lenguaje icónico-textual de la historieta. ${ }^{60}$ En el caso de Confidencias, el reclamo de "realidad" más importante que se hace desde la narración es el presentarse como el testimonio de un exsenderista que fue testigo de la llegada de SL a su comunidad. Y por el lado de Barbarie, esta cone-

58 Díaz, Hacia un cómic de autor, 61.

59 Roland Barthes, El susurro del lenguaje: más allá de la palabra y de la escritura (Barcelona: Paidós, 1987), 175.

60 Jesús Camarero, Intertextualidad: redes de textos y literaturas transversales en dinámica intercultural (Barcelona: Anthropos, 2008), 63. 
xión con lo real se sostiene cuando Cossio señala en su "Nota del autor" el haber desarrollado un trabajo de documentación previo sobre la violencia en el periodo 1985-1990.$^{61}$ Esta adaptación no puede entenderse como un simple traspaso de información de un "texto primero" a una nueva versión, pues el trabajo mismo de los historietistas deriva en la construcción de una nueva representación. Igual que debe evitarse la "ilusión referencial"62 cuando analizamos estas historietas en función del proceso histórico de la violencia política peruana, también debemos prescindir de ella cuando analizamos las fuentes a partir de las cuales trabajaron Baldoceda y Cossio.

En Confidencias de un senderista, gran parte de la legitimidad del relato recae entonces en el hecho de mostrarse como una narración testimonial. Desde el inicio, la historieta plantea una interlocución entre quien parece ser un entrevistador que está cubriendo la noticia de una exitosa operación contrasubversiva desarrollada por el Ejército peruano en la provincia de La Mar (Ayacucho). En esta operación se capturaron varios mandos de SL entre los cuales estaba incluido Jorge Cañari, conocido en SL como "Camarada Javier", con quien el entrevistador establece un diálogo. Esta preeminencia del testimonio se refuerza cuando el entrevistador cede la palabra y "desaparece" para darle lugar al relato de Cañari, creando la sensación de que no existe una mediación entre el testimonio y su plasmación en la historieta (figura 1).

61 Jesús Cossio, "Nota del autor", en Barbarie: comics sobre violencia política en el Perú, 1985-1990 (Lima: Contracultura, 2010), s. p.

62 La ilusión referencial es el proceso a través del cual una fuente se reduce a la condición de "reflejo" o "prueba” del acontecimiento histórico. Véase: Didi-Huberman, Imágenes pese a todo, 110 y 151-153. 


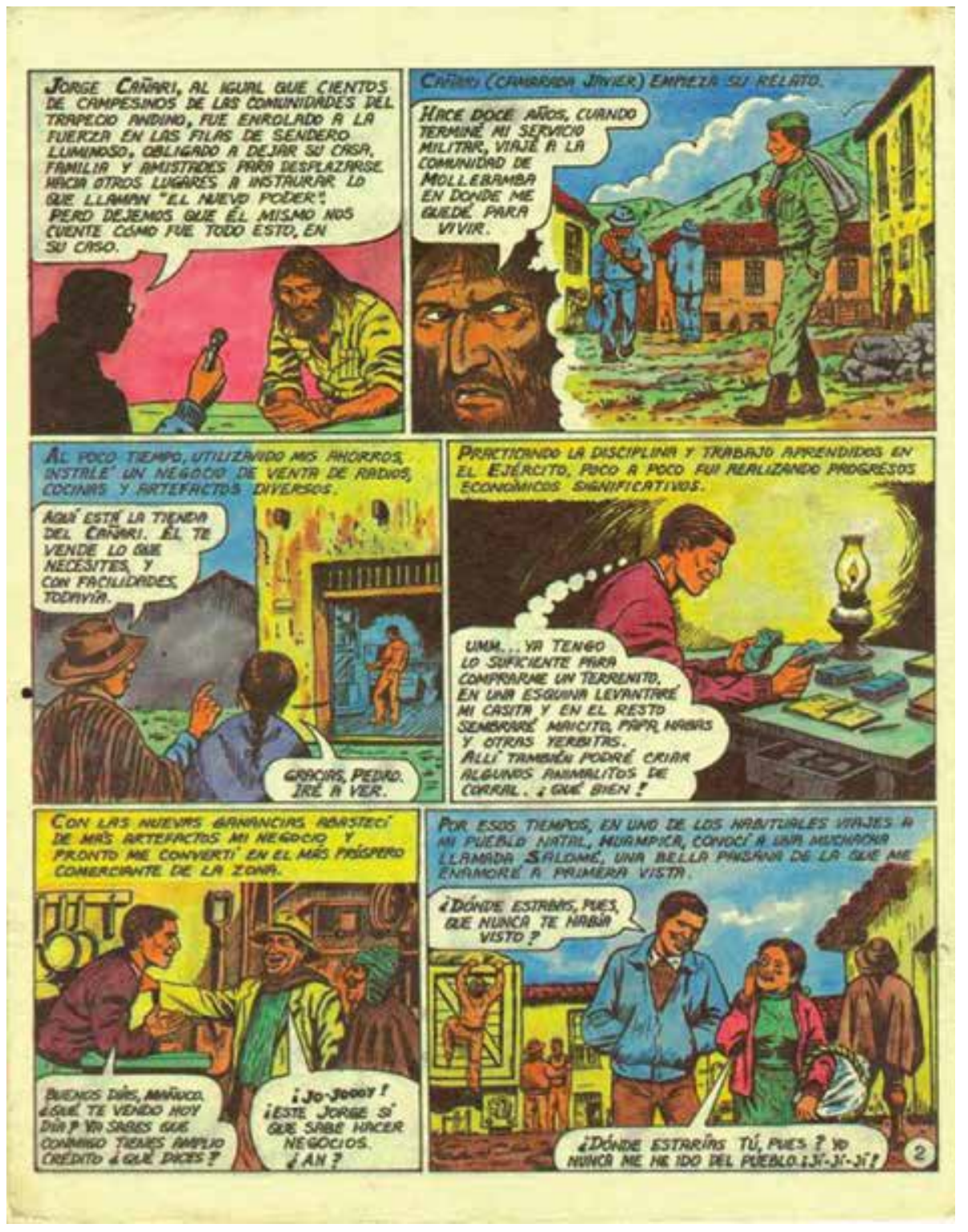

Figura 1. Luis Baldoceda, sin título, en Confidencias de un senderista (Lima: Comisión de Cultura del Centro Naval, 1989), 2. Esta página es un buen ejemplo de la importancia de la voz narrativa de Jorge Cañari para el desarrollo de la historia. En las dos viñetas superiores se muestra al entrevistador dando paso al relato de Cañari. De ahí en adelante, el entrevistador desaparece de la historieta y todas las viñetas empiezan a estar acompañadas de carteleras en las que se presenta el testimonio del exsenderista. 
Esta supuesta no mediación entre el relato de Cañari y sus posibles lectores también tiene una contraparte en la relación entre el guion y el dibujo. A diferencia de Barbarie, donde Cossio se encarga de estos dos componentes, Baldoceda trabajó a partir de un guion que fue suministrado por la Comisión de Cultura del Centro Naval. Con esto, el relato de Cañari cobra más protagonismo, pues se trata de una historieta que en la que Baldoceda "solo" se encargó de la ilustración. ${ }^{63}$ Esta separación entre el testimonio y su dibujo se refuerza cuando vemos que la historieta se publica sin la firma de este autor o alguna otra referencia a su trabajo. ${ }^{64}$ Pese a este intento de mostrar la historieta como un relato fiel a la experiencia de Cañari, el proceso de adaptación realizado por Baldoceda implicó su participación activa en la lectura que desde Confidencias se hace de la violencia política. Con esto, tenemos que en esta historieta se configuran "dos niveles de enunciación”. Por un lado, el que corresponde al relato de Jorge Cañari alrededor del juicio popular ejecutado por SL en Mollebamba; por otro, el que se centra en Baldoceda y sus elecciones narrativas y estilísticas. ${ }^{65}$

Como indica Rueda, las historias de la violencia construidas desde una voz narrativa que se presenta como testigo de los hechos que relata "prometen un contacto más directo con realidades violentas, aunque también en ell[a]s aparecen vacíos discursivos y alteraciones de la verdad [...] que apelan a la libertad del lector de manera similar a como lo hacen los textos literarios". ${ }^{66}$ Esto que Rueda llama vacios y alteraciones hace referencia a las diferentes formas en que un testigo puede relacionarse con la experiencia vivida, que lo llevan a elegir una determinada secuencia histórica de los hechos o a privilegiar ciertos actores sobre otros.

En Confidencias, donde tenemos el testimonio de un exsenderista que presenció la muerte de varios de sus vecinos y su reclutamiento forzado a las filas de SL, podríamos esperar que la narración le permitiera a Cañari recomponer un sentido de agencia en una situación que resultó "contraria al empoderamiento". ${ }^{67}$ No obstante,

63 En línea con lo anterior, en una nota del blog "Historietas peruanas sobre Confidencias", Baldoceda señala lo siguiente: "Yo soy un dibujante, un obrero del dibujo [...] me dijeron si podía hacer esta historia en historieta y les dije que sí". Véase: "Novela gráfica Confidencias de un senderista, ilustrada por Luis Baldoceda”, http://historetasperuanas.blogspot.com/2012_01_01_archive.html (31/03/2017). 
esta humanización de los actores del conflicto, que podemos encontrar en otros testimonios de exsenderistas como Lurgio Gavilán, ${ }^{68}$ no cumple en el caso de Confidencias con el mismo propósito. Al contrario, lo que vemos en la voz narrativa de Cañari y en los diálogos de los personajes que se construyen a partir de su recuerdo demuestra más un interés en ilustrar al lector con la estructura y modus operandi de SL (figuras 1 y 2 ).

En el caso de Barbarie, Cossio nos muestra un trabajo con fuentes entre las cuales incluye el Informe final de la CVR, documentos de organizaciones de derechos humanos, investigaciones académicas, periódicos y revistas de este periodo. ${ }^{69}$ Aunque Cossio señala que su historieta no es una versión dibujada del Informe final, este texto es central para entender Barbarie, pues define el lugar desde el cual Cossio pensó su elaboración. También es importante tener como precedente su interés en el cómic testimonial y documental, el cual plantea como uno de sus principios la necesidad de que el historietista adquiera una responsabilidad política frente a los temas que trata, compromiso retomado por Cossio en su trabajo.

Aunque la creación de la CVR y la publicación del Informe fueron vistas por muchos peruanos como un buen síntoma político, el impacto de sus propuestas se ha visto limitado por varias razones. Para Félix Reátegui Carrillo, coordinador del Informe, una de las circunstancias más importantes que ha producido este "bloqueo de la memoria" ha sido el aumento de la presencia pública y la recomposición de las alianzas entre aquellos actores políticos o institucionales "que no son partidarios de la agenda planeada por la Comisión" ${ }^{70}$ Particularmente, estos sectores cuestionaron varios de los hallazgos del Informe, por ejemplo, aquellos que calculaban las víctimas mortales en 69.280 casos señalaban el impacto diferenciado de la violencia en la población quechuahablante y demostraban la importante participación de agentes del Estado en la violación sistemática de derechos humanos. ${ }^{71}$

68 Lurgio Gavilán Sánchez, Memorias de un soldado desconocido: autobiografía y antropología de la violencia (Lima: IEP; Universidad Iberoamericana, 2012).

69 Jesús Cossio, "Nota del autor”. Cossio no incluye una bibliografía en la que haga referencia específica a cada uno de los documentos, investigaciones, periódicos y revistas que usó.

70 Reátegui, "Búsqueda oficial de memoria”, 24; Montoya y Suárez, "El papel de la Comisión”, 258-266.

71 Carlos Iván Degregori, "Presentación”, en Barbarie: comics sobre violencia política en el Perú, 1985 1990, de Jesús Cossio (Lima: Contracultura, 2010), s. p. 


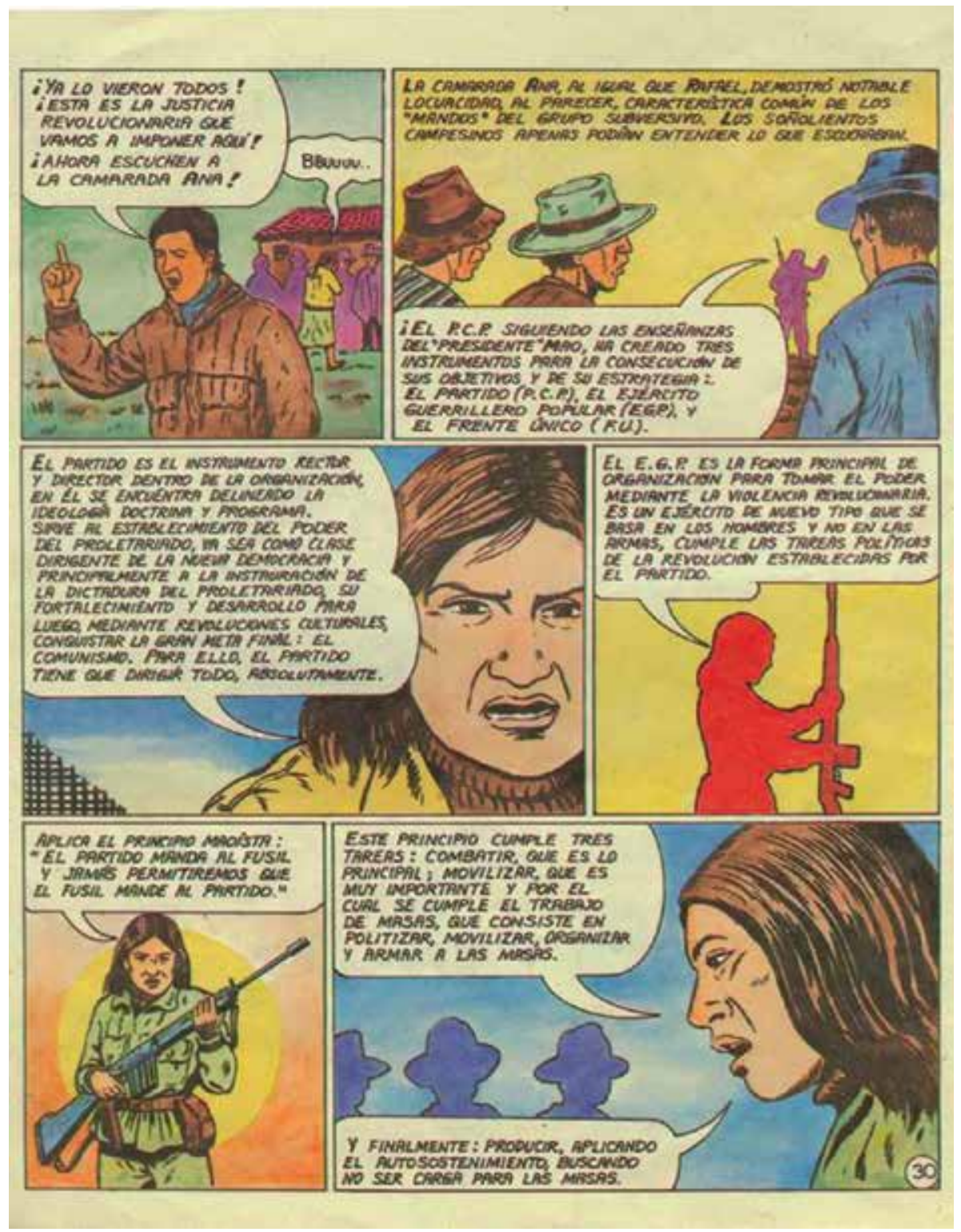

Figura 2. Luis Baldoceda, sin título, en Confidencias de un senderista (Lima: Comisión de Cultura del Centro Naval, 1989), 30. En esta página, la Camarada Ana se dirige a la población de Mollebamba para explicar las nuevas reglas de juego que funcionarían en la comunidad recién insertada en el proyecto de Estado senderista. Como se puede ver, su intervención es utilizada para explicar qué es el Partido Comunista Peruano, el Ejército Guerrillero Popular, el Frente Único y los comités populares. Un espacio importante de la historieta se dedica a desarrollar explicaciones de este estilo. 
En este contexto, Barbarie se presenta como un aporte para contrarrestar la creciente oposición al Informe, en especial la que se ha desarrollado en Lima. ${ }^{72}$ Con esto en mente, Cossio desarrolla cuatro historias diferentes que se conectan temáticamente en el relato común de la violencia política. En una entrevista realizada por el diario La Primera, Cossio señala las razones que lo llevaron a elegir estas historias:

Las cuatro muestran cosas específicas. En "Asesinatos de Pucayacu II" se plasma 'el método', que es lo que mucha gente que apoya a las Fuerzas Armadas dice que no hay: "secuestro, tortura y exterminio; llevas a alguien a un lugar planeado y ahí lo matas" [...]. En "Matanza de Accomarca" se señala la violencia y la brutalidad del operativo, la cantidad de personas que mueren, y, bueno, la justificación de Telmo Hurtado (Subteniente involucrado en la operación que genera la masacre) era lo que quería mostrar [...]. En "Masacre de AranhuayMasacre de Paccha” era básicamente la violencia contrastada con la supuesta racionalidad y lógica de Abimael Guzmán, este contraste de lo ilusorio de su retórica y el autoritarismo y el abuso de los senderistas en la práctica [...]. Y en "Matanza de los Penales" muestro que es bastante ingenuo pensar que en un contexto tú puedes tener a unos militares que se comporten civilizadamente, porque pasan por encima del orden democrático. ${ }^{73}$

Cossio construye a Barbarie en contraposición a lo que denomina historia oficial de la violencia politica, aquella que buscó - entre otras cosas - negar a las víctimas al considerarlas un efecto colateral de la lucha contra SL. Este compromiso con las víctimas que apuntala Cossio también está relacionado con la influencia que otros autores tuvieron en su trabajo. Uno de ellos es Art Spiegelman y su novela gráfica Maus (1991), en la que este autor muestra las vivencias de Vladek Spiegelman (su padre) durante el Holocausto en el marco de la política de exterminio emprendida por los nazis. ${ }^{74}$ Sin embargo, la más importante de estas influencias es la de Joe Sacco, un historietista y periodista que en obras como Palestina: en la franja de Gaza (1996) se ha acercado de una manera muy íntima al conflicto palestino-israelí. Del trabajo de Sacco, Cossio recoge particularmente la renuncia

2 Jesús Cossio, entrevista con Ana Marino, Iowa, abril de 2014.

73 Jesús Cossio, entrevista con André Sal y Rosas, Lima, 30 de junio de 2014.

74 Art Spiegelman, Maus (Barcelona: Ramdom House, 2014). 
a la objetividad que plantea este autor para tomar partido por los marginados. ${ }^{75}$ Además de esto, Cossio también retoma a Rupay. Historias gráficas sobre la violencia politica, 1980-1984, una historieta que este autor realizó colectivamente con Luis Rossell y Alfredo Villar, trabajo en el que abordan los primeros años del conflicto armado peruano.

A partir de los materiales seleccionados, Cossio reconstruye cada una de las historias recurriendo a la ficcionalización de los hechos violentos sin perder de vista las coordenadas marcadas por las fuentes que usa. Como él mismo señala en su "Nota del autor", la elaboración de la historieta pasó por imaginarse "situaciones y diálogos probables que cubrieran los vacíos dejados por la documentación histórica, periodística y fotográfica" ${ }^{76}$ Un muy buen ejemplo de esto son las historias sobre las masacres de Aranhuay y Paccha, que hacen parte del tercer capítulo. En este caso, el autor decide organizar estos dos hechos creando un contrapunteo entre su desarrollo y algunos fragmentos de la primera entrevista que Abimael Guzmán concedió a un medio de comunicación. Con esta entrevista, que fue publicitada por El Diario - un periódico prosenderista - como "la entrevista del siglo", busca contrastar las promesas del proyecto de Estado comunista con la violencia ejercida de SL en estas dos comunidades (figura 3).

Los dos ejemplos que tomamos de Confidencias y Barbarie (figuras 1 y 3 ) nos permiten entender mejor cómo las representaciones de estas historietas se construyen a partir de sus fuentes. Por un lado, en el caso de Confidencias los dibujos elaborados por Baldoceda solo se pueden entender en la relación que establecen con la narración omnipresente de Jorge Cañari, presentada en los carteles que acompañan la mayoría de viñetas. Por otro lado, en Barbarie, la narración se despliega en la interrelación sincrónica entre sus fuentes primarias (los fragmentos de la entrevista a Abimael Guzmán) y el despliegue de su imaginación (escenas y diálogos de las masacres). Estas distintas propuestas de articulación de la imagen-montaje no solo generan estéticas diferentes, sino también "dos éticas de la relación [...] entre imagen e historia" ${ }^{77}$

75 Sobre Palestina, Cossio señala: "Cuando dibujaba, yo tenía su libro a mi lado para saber por dónde iba a ir". Cossio, entrevista con André Sal y Rosas.

76 Cossio, "Nota del autor".

77 Didi-Huberman, Imágenes pese a todo, 186. 


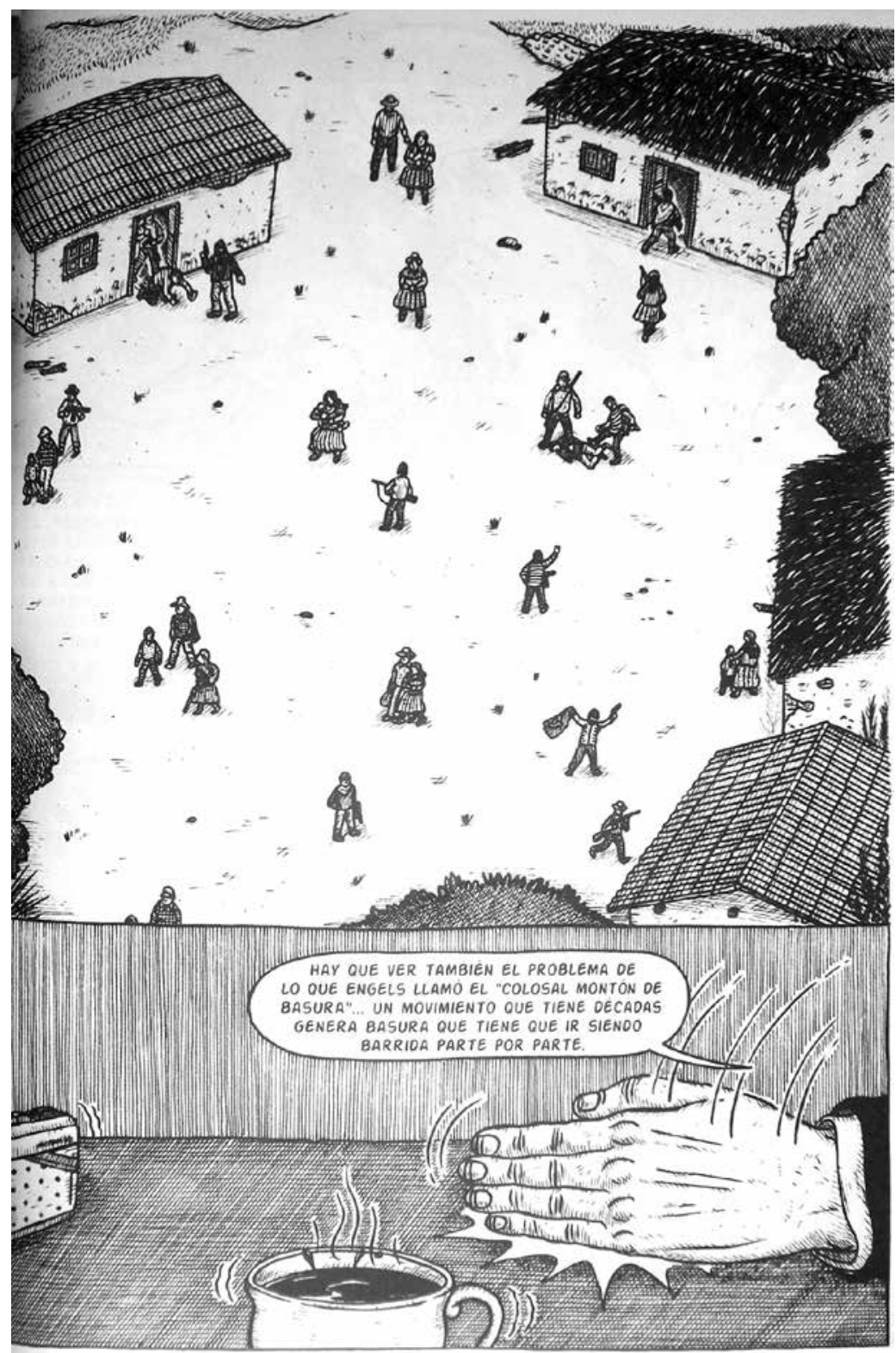

Figura 3. Jesús Cossio, "Masacre de Aranhuay-Masacre de Paccha”, en Barbarie: comics sobre violencia política e nel Perú, 1985-1990 (Lima: Contracultura, 2010), s. p. Esta página de Cossio está compuesta únicamente por dos viñetas. La primera de ellas muestra una vista panorámica en picado de la población de Aranhuay, donde se puede apreciar el inicio del hostigamiento a los civiles por parte de guerrilleros de SL. En la segunda viñeta, Cossio introduce un fragmento de la entrevista a Guzmán en la que, solamente mostrando su mano, hace hincapié en la contundencia de su discurso. La puesta simultánea de estas dos viñetas permite ver que en las dos se está hablando de la misma necesidad: barrer el "colosal montón de basura", representada en aquellos que se oponen al proyecto senderista. 


\section{La violencia efectista y la violencia expresiva}

Como señalamos en la primera parte de este capítulo, la discusión sobre la posibilidad de representar la violencia se ha desplazado hacia una pregunta por cómo hacerlo. Este nuevo interrogante está atado a una preocupación por la utilidad del uso de la violencia para hablar del trauma y a la necesidad de imprimir una dimensión ética en el ejercicio de la representación. Sobre este punto resulta interesante encontrar similitudes en la forma en que tanto Baldoceda como Cossio deciden representar la violencia, una decisión que tiene como premisa la idea de que los "efectos de realidad" necesitan hacer visible aquello que no se ha visto — el conflicto en ciudades como Lima en Confidencias - o aquello que se ha querido ocultar — las víctimas de la violencia en Barbarie-.

Esto lleva a que en ambas historietas encontremos varias escenas de violencia explícita, por lo que analizaremos dos de ellas a partir del concepto de "espectáculo". ${ }^{78}$ Alejándose de la idea tradicional que vincula este término con el tratamiento sensacionalista de la violencia, Bush propone un acercamiento más interesante, al definir espectáculo como aquello que es "dado para ser visto" por un espectador, el cual debe organizar y dotar de sentido aquello que le es mostrado (staged). Desde esta perspectiva, el "espectáculo" no solo hace referencia a la forma en que el trauma o el dolor son representados, sino también a la manera en que estas representaciones desafían ciertas formas de ver. ${ }^{79}$

En el caso de Confidencias, escogimos la parte del relato en que se muestra la primera ejecución desarrollada en la comunidad de Mollebamba. Los miembros de SL eligen al profesor Casa Lima como comisario-secretario del nuevo comité popular; no obstante, a cambio de perdonarle la vida y como prueba de lealtad, los senderistas le exigen asesinar al hacendado Miguelino Taipe (figuras 4 y 5).

78 Robert Buch, The Pathos of the Real: On the Aesthetics of Violence in the Twentieth Century (Baltimore: Johns Hopkins University Press, 2010), 16-20.

79 Buch, The Pathos of the Real, 16. 


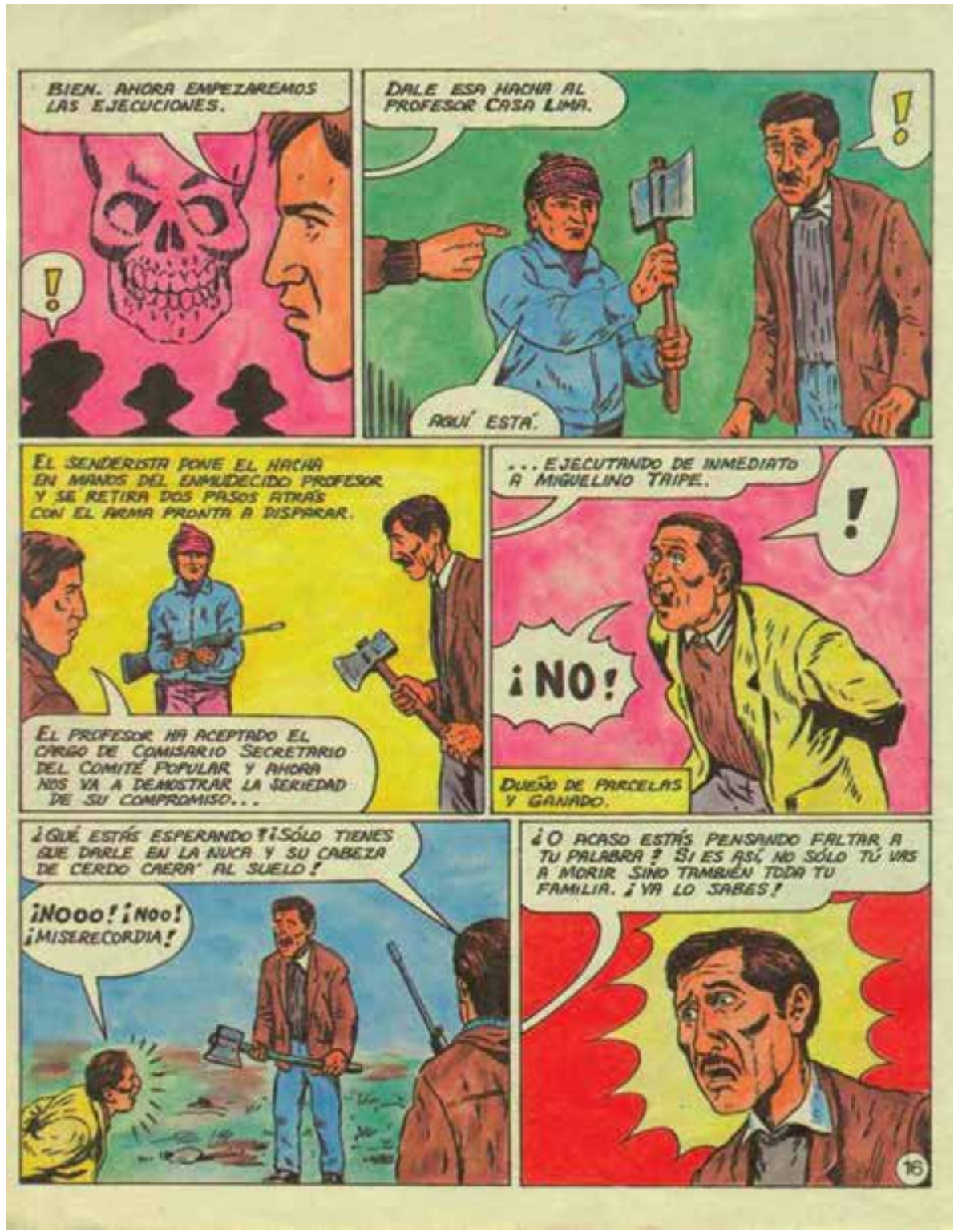

Figura 4. Luis Baldoceda, sin título, en Confidencias de un senderista

(Lima: Comisión de Cultura del Centro Naval, 1989), 16. 


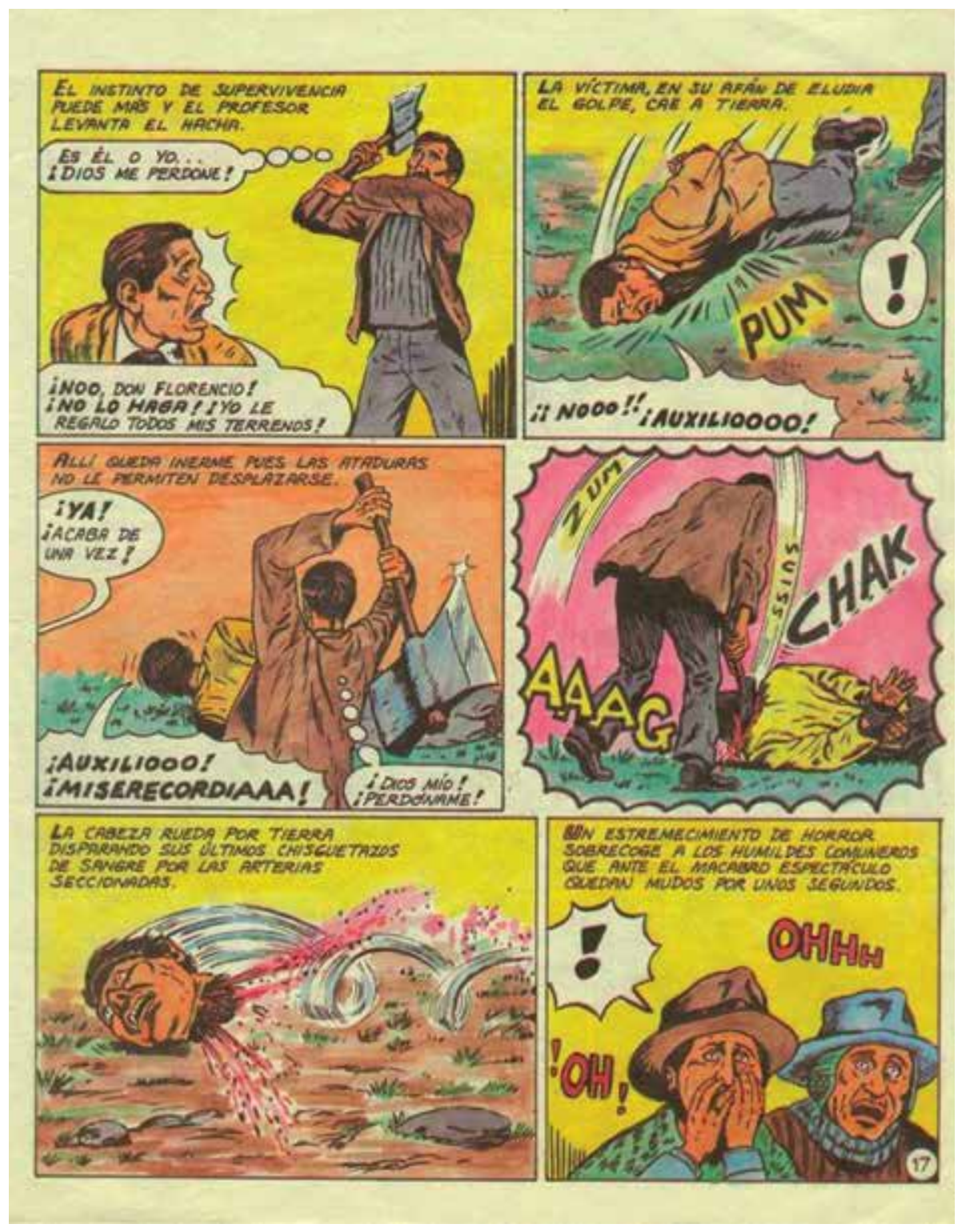

Figura 5. Luis Baldoceda, sin título, en Confidencias de un senderista

(Lima: Comisión de Cultura del Centro Naval, 1989), 17. 
La acción trascurre en doce viñetas que, pese a tener el mismo tamaño, no poseen el mismo peso narrativo. Esta similitud en el tamaño de las viñetas es compensada con el uso de varios recursos que sirven para generar diferentes grados de tensión en la escena. El primero de ellos está en la viñeta inicial, en la que se muestra una calavera que se cierne sobre las siluetas de algunos habitantes de Mollebamba, cuando el camarada Rafael indica que es hora de iniciar con el juicio popular. El segundo se desarrolla en el uso de diferentes onomatopeyas que apuntalan acústicamente aquello que se está mostrando de forma visual. También se utilizan líneas cinéticas para denotar que se trata de una escena con mucho movimiento y emociones. Y, por último, la viñeta en que el profesor ejecuta a Miguelino Taipe tiene un marco que la diferencia de las otras viñetas más convencionales. Este cambio de marco muestra que la ejecución genera en ese momento un rompimiento tanto en lo comunitario como en lo narrativo. Frente a esto, resulta muy interesante encontrar elementos usados por Baldoceda que nos recuerdan a las convenciones de las historietas de terror, pues el autor no solo utiliza calaveras, sino que también hace un tratamiento muy prolijo de las escenas sangrientas.

Por otra parte, en Barbarie elegimos la escena en que las fuerzas del Estado ejecutan a presuntos senderistas en Pacayacu y luego desaparecen los cuerpos en una fosa común (figuras 6 y 7). A diferencia de Baldoceda, Cossio sí recurre a diferentes formas de distribución de las páginas y de tamaños de la viñeta para apoyar el desarrollo narrativo de la historieta. En la primera página tenemos una distribución de tres filas en las que se tienen tres tipos de recuadros: en la primera, viñetas de detalle; en la segunda, viñetas de desglose, y en la tercera, una viñeta apaisada. La mayor tensión de esta página se concentra en la segunda fila, donde cada viñeta de desglose representa la descarga de siete balas — acompañadas de onomatopeyas_, mientras se intercalan perspectivas y encuadres de los ejecutados, el arma y los cartuchos. 


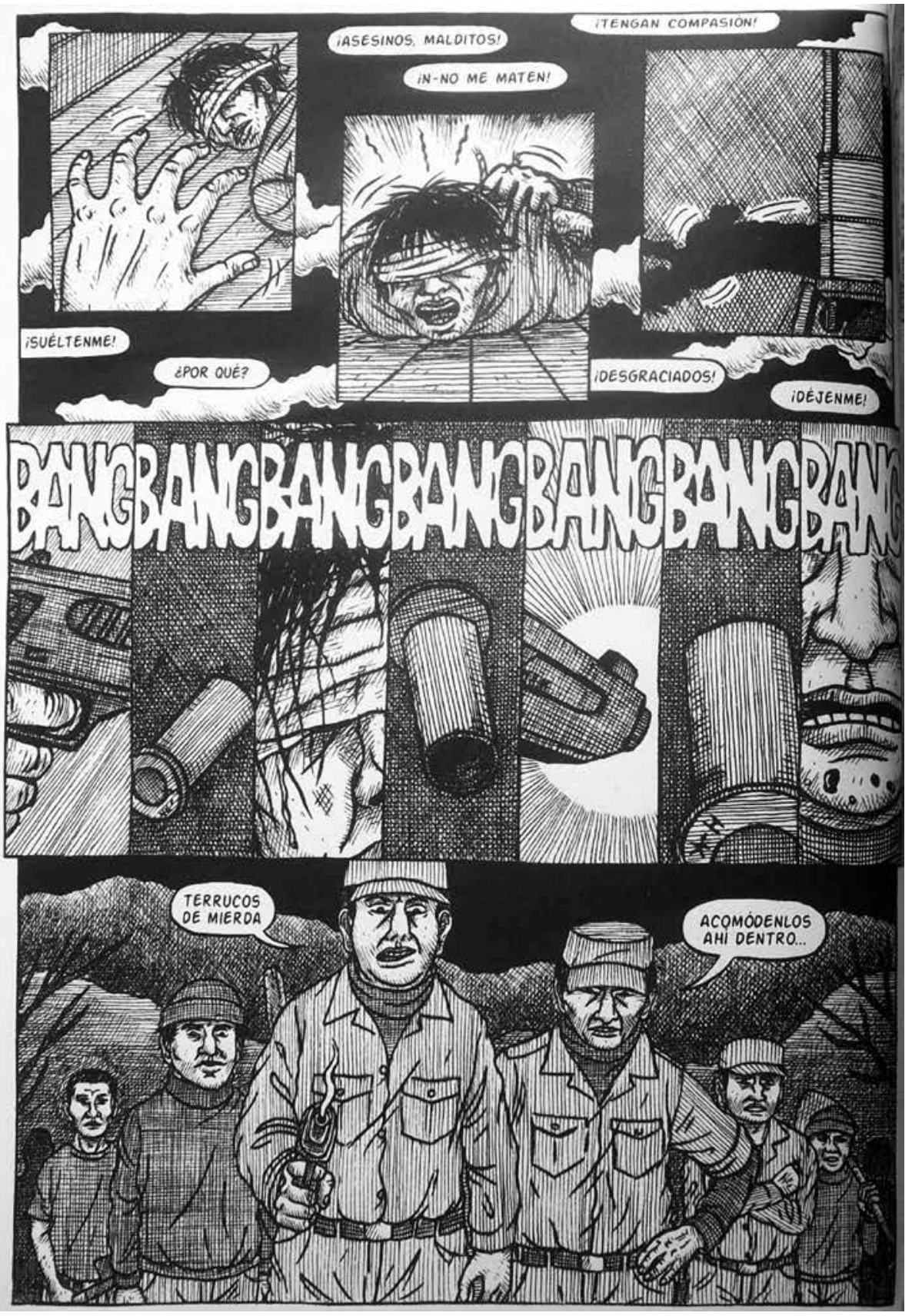

Figura 6. Jesús Cossio, “Asesinatos de Pacayacu II", en Barbarie: comics sobre violencia política en el Perú, 1985-1990 (Lima: Contracultura, 2010), s. p. 


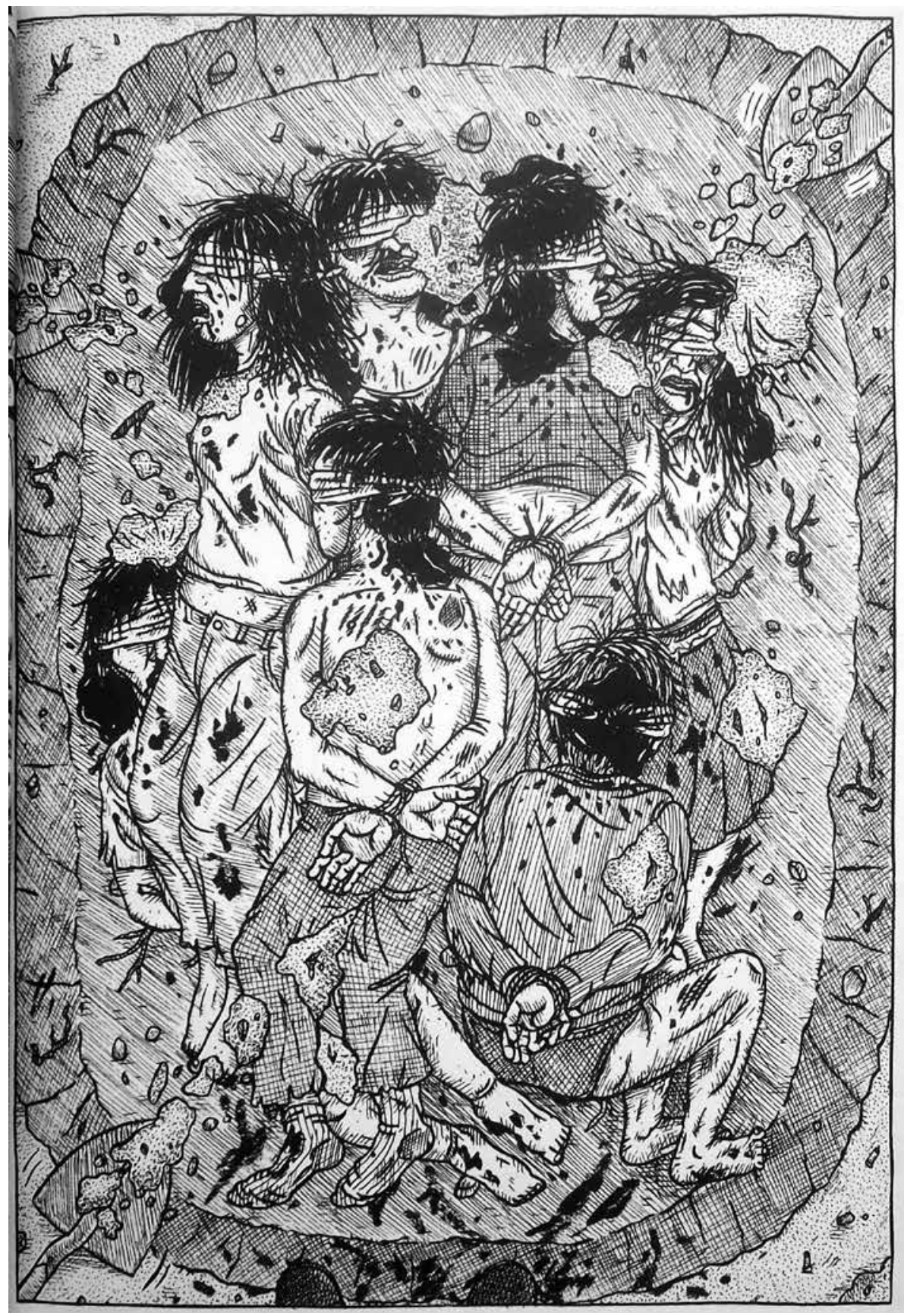

Figura 7. Jesús Cossio, “Asesinatos de Pacayacu II", en Barbarie: comics sobre violencia politica en el Perú, 1985-1990 (Lima: Contracultura, 2010), s. p. 
Después de esta secuencia intrincada de imágenes, la tensión cae frente a un conjunto de militares que en diferentes planos observan a los presuntos senderistas asesinados. La segunda página cierra el dramatismo de la escena con una imagen que resulta bastante fuerte. Se trata de una página completa (splash page) que muestra desde un ángulo completamente picado la fosa en que fueron arrojados los cuerpos ejecutados. En esta segunda página vemos que la narración recae completamente en la imagen, pues carece de texto y, además, el autor recurre al contraste entre la anterior agitación de movimiento y balas, a la resultante quietud de los cuerpos sin vida.

Frente a este tipo de escenas, que son una constante en ambas historietas, se evidencia el deseo de los historietistas de mostrar, de convertir al lector en espectador de los hechos que se están narrando. El uso de ángulos, perspectivas, encuadres y estilos de dibujo específicos, les permite tanto a Baldoceda como a Cossio presentizar ${ }^{80}$ en el marco de la viñeta una serie de procesos que buscan atar con mayor fuerza a la experiencia de sus lectores. Este peso enorme que se le confiere a lo visual como el espacio por excelencia para representar el horror y la crudeza nos obliga — como señala Didi-Huberman a propósito de Auschwitz- a "pensar de nuevo la[s] im[ág]en[es]"81 que se han producido sobre este episodio de la historia peruana.

Con estos dos ejemplos, vemos cómo la representación de la violencia puede ser "efectista", en la medida en que choca, en que nos obliga a detenernos en ella o, por el contrario, a apartar nuestra vista. Pese a esto, estas representaciones no buscan solamente generar estas reacciones inmediatas; su propósito también es reforzar las lecturas que se han realizado de manera simultánea en otros planos de la historieta (i.e., paradigmas y fuentes). En el caso de Confidencias, la violencia explícita sirve para "hacer ver" al espectador un mensaje que ya estaba recibiendo a través de los medios masivos de comunicación. Las imágenes de esta historieta son una extensión de la "imagen del terror" que se construyó con el propósito de darle más peso a la idea de que las razones del conflicto solo podían ser imputadas a SL. Posteriormente, Cossio vuelve a revisar esas imágenes, pero ahora con el objetivo de invitarnos a asumir una postura crítica frente a la memoria del pasado y al lugar de la población civil en un conflicto que había sido pensado en función de solo dos actores.

\footnotetext{
80 Peter Burke, Eyewitnessing: The Uses of Images as Historical Evidence (Ithaca: Cornell University Press, 2001), 158.

81 Didi-Huberman, Imágenes pese a todo, 97-98.
} 


\section{Conclusiones}

La representación de la violencia política desarrollada en las historietas trabajadas está fuertemente influenciada por dos lecturas centrales que en su momento se hicieron sobre el conflicto: por un lado, el paradigma de la lucha contrainsurgente (Confidencias) y, por otro, el paradigma de las víctimas (Barbarie). A su vez, estas historietas son herederas de dos tradiciones historietísticas que son fundamentales para entender sus procesos de producción y circulación. Por un lado, Confidencias de un senderista, de Luis Baldoceda, recoge como herencia la tradición de la historieta popular que tuvo lugar entre la década de los setenta y los inicios de los años ochenta en este país. Por otro lado, Barbarie es producida y difundida en un periodo en el que las historietas han cobrado una renovada vigencia y legitimidad como productos culturales. Cossio elabora su historieta recogiendo las convenciones y formas de circulación establecidas por la novela gráfica contemporánea.

La representación histórica de la violencia ha generado un debate que se ha movido entre aquellos que sostienen que es imposible representar el terror a razón de sus propios efectos devastadores (la violencia se hace indecible, inefable e irrepresentable) y aquellos que sostienen que la representación es necesaria como parte de la comprensión del trauma. Sin pretender resolver esta extensa discusión, el análisis de estas dos historietas nos mostró la importancia de generar representaciones históricas sobre la violencia, ya que son una pieza clave en los procesos de reconstrucción y reconciliación social.

Desde esta perspectiva, las historietas resultan útiles como un lenguaje y un medio para generar representaciones históricas de experiencias de violencia. No obstante, en este escenario surge una pregunta necesaria sobre la ética de la representación. Los trabajos de Baldoceda y Cossio son un buen ejemplo de los diferentes usos que puede tener la historieta como generadora de representaciones, ya sea reafirmando consensos sociales alrededor de una historia oficial del conflicto o ampliando el espectro hacia visiones más críticas y centradas en la necesidad de reconocer a las víctimas y sus daños. 


\section{Bibliografía}

\section{Fuentes primarias}

\section{Impresas}

Baldoceda, Luis. Confidencias de un senderista. Lima: Comisión de Cultura del Centro Naval, 1989.

Cossio, Jesús. Barbarie: comics sobre violencia politica en el Perú, 1985-1990. Lima: Contracultura, 2010.

Gavilán Sánchez, Lurgio. Memorias de un soldado desconocido: autobiografía y antropología de la violencia. Lima: IEP; Universidad Iberoamericana, 2012.

Spiegelman, Art. Maus. Barcelona: Ramdom House, 2014.

\section{Entrevistas}

Cossio, Jesús. Entrevista con Ana Marino, Iowa, abril de 2014.

Cossio, Jesús. Entrevista con André Sal y Rosas, Lima, 30 de junio de 2014.

\section{Fuentes secundarias}

Acevedo, Juan. "Historieta popular de los setenta”. En Educación y comunicación popular en el Perú, editado por Luis Peirano. Lima: Seminario sobre Experiencias en la Utilización de los Medios de Comunicación para la Promoción y la Educación Popular, 1988.

Aguirre, Carlos. "Terruco de m... Insulto y estigma en la guerra sucia peruana.. Histórica 35, n. ${ }^{\circ} 1$ (2011): 103-139.

Barthes, Roland. El susurro del lenguaje: más allá de la palabra y de la escritura. Barcelona: Paidós, 1987.

Buch, Robert. The Pathos of the Real: On the Aesthetics of Violence in the Twentieth Century. Baltimore: Johns Hopkins University Press, 2010.

Burke, Peter. Eyewitnessing: The Uses of Images as Historical Evidence. Ithaca: Cornell University Press, 2001.

Calveiro, Pilar. "Memoria, política y violencia". En Elmosaico de la memoria: experiencias locales, no oficiales oparciales de búsqueda de la verdad histórica, editado por María Paula Gómez Méndez, 53-62. Medellín: Fundación Social; Alcaldía de Medellín; International Center for Transitional Justice, 2007.

Camarero, Jesús. Intertextualidad:redes de textos y literaturas transversales en dinámica intercultural. Barcelona: Anthropos, 2008. 
Campbell, Bruce. Viva la historieta: Mexican Comics, NAFTA, and the Politics of Globalization. Jackson: University Press of Mississippi, 2009.

Castro Neira, Yerko. "Antropología de la violencia: entre los estudios del sufrimiento social y la antropología de la paz". En Memorias de un soldado desconocido: autobiografia y antropología de la violencia, de Lurgio Gavilán Sánchez, 17-48. Lima: IEP; Universidad Iberoamericana, 2012.

Degregori, Carlos Iván. Violencia política y respuestas desde la sociedad y desde el Estado: caso peruano. New York: Columbia University; New York University Consortium, 1990.

Díaz de Guereñu, Juan Manuel. Hacia un cómic de autor: a propósito de Arrugas y otras novelas gráficas. Bilbao: Deusto, 2014.

Didi-Huberman, Georges. Imágenes pese a todo: memoria visual del Holocausto. Barcelona: Paidós, 2004.

Dreizik, Pablo. "Figuras del cuerpo rememorado". En Politicas de la memoria: tensiones en la palabra y la imagen, editado por Sandra Lorenzano y Ralph Buchenhorst, 429-442. México: Universidad del Claustro de Sor Juana, 2007.

Fernández L'Hoeste, Héctor y Juan Poblete. “Introduction”. En Redrawingthe Nation: National Identity in Latin/o American Comics, editado por Héctor Fernández L’Hoeste y Juan Poblete, 1-16. New York: Palgrave Macmillan, 2009.

Fregoso Torres, Jorge. La narrativa léxico-pictográfica: guia para el análisis y la producción de historietas. Guadalajara: Universidad de Guadalajara, 2005.

Goday Lucas, Elena. "Reconocimiento y dignificación de las víctimas del conflicto armado interno vivido en el Perú entre 1980-2000, a través de su representación visual en el libro fotográfico Yuyanapaq: para recordar: relato visual del conflicto armado interno 1980-2000". Tesis de licenciatura en Comunicación para el Desarrollo, Pontificia Universidad Católica del Perú, Lima, 2001.

Gonzales Manrique, José. La prensa como reflejo de desarticulación social. Prensa y violencia en el Perú: el caso de Sendero Luminoso. Lima: Universidad de Lima, 1992.

Gubern, Román. "Prólogo a la presente edición. Terenci explora la figuración narrativa”. En Historia social del cómic, de Terenci Moix, 7-12. Barcelona: Bruguera, 2007.

Hurtado Vera, Guido Germán y Luis Eduardo Lobato Paz. Representaciones e imaginarios sobre la violencia colombiana en la prensa nacional: 1990-2004. Cali: Universidad Autónoma de Occidente, 2009. 
Igue Tamaki, José Luis. "Los silencios del gran relato". Histórica 29, n.o 1 (2005): 151-161.

Jackson, Michael. The Politics of Storytelling: Violence, Transgression, and Intersubjectivity. Copenhagen: Museum Tusculanum Press; University of Copenhagen, 2006.

Jelin, Elizabeth. Los trabajos de la memoria. Lima: Instituto de Estudios Peruanos, 2012. Lucioni, Mario. "La historieta peruana I". Revista Latinoamericana de Estudios sobre la Historieta 1, n. 4 (2001): 257-264.

Lucioni, Mario. "La historieta peruana II". Revista Latinoamericana de Estudios sobre la Historieta 2, n. ${ }^{\circ} 8$ (2002): 203-218.

Mahecha Arango, Natalia. "De épicas nacionales, indígenas temerarios y heroínas fatales: historietas históricas en Colombia (1969-1972)”. Tesis de pregrado en Historia, Universidad de los Andes, Bogotá, 2011.

Melendi, María Angélica. “Tumbas de papel: estrategias del arte (y de la memoria) en una era de catástrofes". En Politicas de la memoria: tensiones en la palabra y la imagen, editado por Sandra Lorenzano y Ralph Buchenhorst, 295-308. México: Universidad del Claustro de Sor Juana, 2007.

Montoya Salamanca, Alexandra y Carolina Suárez Baquero. "El papel de la Comisión de la Verdad y Reconciliación en el caso peruano”. En Elmosaico de la memoria: experiencias locales, no oficiales o parciales de búsqueda de la verdad histórica, editado por María Paula Gómez Méndez, 247-274. Medellín: Fundación Social; Alcaldía de Medellín; International Center for Transitional Justice, 2007.

Montoya, Rodrigo. Al borde del naufragio: democracia, violencia y problema étnico en el Perú. Madrid: Talasa, 1992.

Núñez Alayo, Evelyn Mabel. "Novela gráfica peruana”. Tesis de maestría en Comunicaciones, Pontificia Universidad Católica del Perú, Lima, 2010.

Reátegui Carrillo, Félix. "Búsqueda oficial de memoria en Perú: la Comisión de la Verdad y Reconciliación”. En Elmosaico de la memoria: experiencias locales, no oficiales o parciales de búsqueda de la verdad histórica, editado por María Paula Gómez Méndez, 10-25. Medellín: Fundación Social; Alcaldía de Medellín; International Center for Transitional Justice, 2007.

Rueda, María Helena. La violencia y sus huellas: una mirada desde la narrativa colombiana. Madrid: Iberoamericana, 2011. 
Sagástegui, Carla. "Acevedo and his Predecessors". En Redrawing the Nation: National Identity in Latin/o American Comics, editado por Héctor Fernández L'Hoeste y Juan Poblete, 131-150. New York: Palgrave Macmillan, 2009.

Schönwälder, Gerd. Linking Civil Society and the State: Urban Popular Movements, the Left, and Local Government in Peru, 1980-1992. University Park: Pennsylvania State University Press, 2002.

Sotelo Melgarejo, Marco Antonio. “Representación gráfica de la violencia política en el Perú 1980-2012: una aproximación a las historietas durante el tiempo de violencia interna”. Pacarina del Sur 4, n. ${ }^{\circ} 14$ (2013): s. p.

Sotelo Melgarejo, Marco Antonio. “Taxonomía de las historietas limeñas: propuesta para una clasificación de las historietas producidas y publicadas en la provincia de Lima Metropolitana entre los años 1990 a 2005”. Tesis de licenciatura en Comunicación Social, Universidad Nacional Mayor de San Marcos, Lima, 2009.

Ubilluz, Juan Carlos. "El fantasma de la nación cercada”. En Contra el sueño de los justos: la literatura peruana ante la violencia política, editado por Juan Carlos Ubilluz, Alexandra Hibbett y Víctor Vich, 19-85. Lima: Instituto de Estudios Peruanos, 2009.

Wieviorka, Michel. "Ante la violencia”. En El doble filo de la navaja: violencia y representación, editado por Fernando García Selgas y Carmen Romero Bachiller, 29-44. Madrid: Trotta, 2006.

Witek, Joseph. Comic Books as History: The Narrative Art of Jack Jackson, Art Spiegelman, and Harvey Pekar. Jackson: University Press of Mississippi, 1989. 


\title{
¿El mito Allende? Representaciones visuales y murales de Salvador Allende en el movimiento estudiantil de Chile (2011-2013)
}

\author{
Christiane Hoth
}

Allende vive en el corazón del pueblo, con su ejemplo nos interpela a seguir luchando y construyendo la más amplia unidad. El mejor homenaje a Salvador Allende será cuando logremos educación gratuita y de calidad para todos y una Constitución Democrática. ${ }^{1}$

La cita inicial, publicada el 11 de septiembre de 2015 en Facebook y Twitter por la diputada chilena Camila Vallejo — 42 años después del golpe de Estado de 1973-, confirma el importante papel que aún desempeña el expresidente Salvador Allende en la política contemporánea del país austral. Vallejo, elegida diputada en las elecciones parlamentarias de 2013, ha sido una de las protagonistas más conocidas del movimiento estudiantil chileno iniciado en el 2011. Su cita es un ejemplo, entre tantos, que presenta a un Salvador Allende rememorado, festejado, adorado e instrumentalizado por una considerable parte de la población, incluso cuatro décadas después de su muerte.

A partir de 1990 y después de 17 años de dictadura, distintos actores políticos se encontraron frente a varios desafíos, el principal de ellos: cómo posicionarse en el sistema democrático. En especial, se puede decir que los grupos indígenas, la izquierda, los estudiantes y los sindicatos se vieron confrontados en su relación

1 Camila Vallejo Dowling, https://twitter.com/camila_vallejo y https://www.facebook.com/CamilaVallejo-Dowling-170911349635410/timeline/ (31/03/2017). 
con el Estado, la Iglesia y las Organizaciones de Derechos Humanos, sobre todo después de tanto tiempo en el anonimato o la clandestinidad.

De cara a las identidades vigentes y preservaciones culturales de la dictadura, los discursos estaban por cambiar de orientación a causa del nuevo sistema político. Según Tomás Moulian, para el caso del Chile contemporáneo se usa la metáfora de la "matriz", ya que la misma implica la idea de un "espacio donde lo actual se fue constituyendo, modelando y tomando forma, hasta llegar a ser un cuerpo, una sociedad". 2 Se puede constatar que la sociedad civil principalmente - y no los gobiernos oficiales - ha sido la que ha tomado iniciativas como la de "recuperar la memoria" y que, aún más, ha encontrado un potencial simbólico en una política particular sobre el pasado. ${ }^{3}$

A principios de la segunda década del siglo XXI, los estudiantes chilenos fueron - por así decirlo - el grupo más débil que llamó la atención de manera global; se posicionaron en la agenda local y traspasaron la frontera con su llamado al cambio y la gratuidad en la educación. Las movilizaciones "marcaron un punto de inflexión en el ciclo político a partir de 1990". ${ }^{4}$ Después de un proceso de despolitización ocurrido entre 1974 y 2011,5 fue notable el regreso a la actividad política, y el movimiento, que dejó de ser exclusivamente estudiantil, impactó en el grueso de la sociedad: ${ }^{6}$ las demandas formuladas por los estudiantes sobrepasaron así el carácter "particular y sectorial” de las agendas iniciales. ${ }^{7}$

2 Tomás Moulian, Chile actual: anatomía de un mito, 19a ed. (Santiago de Chile: LOM, 1998), 17.

3 Cath Collins y Katherine Hite, "Memorials, Silences, and Reawakenings", en The Politics of Memory in Chile: From Pinochet to Bachelet, ed. por Cath Collins, Katherine Hite y Alfredo Joignant (Boulder: Lynne Rienner Publisher, 2013), 133-163; Stefan Rinke y Sylvia Dümmer Scheel, “'Der Sold Chiles' Gedenken an die Opfer politischer Gewalt im 19. und 20. Jahrhundert”, en Gefallenengedenken im globalen Vergleich: nationale Tradition, politische Legitimation und Individualisierung der Erinnerung, ed. por Manfred Hettling y Jörg Echternkamp (München: Oldenbourg, 2013), 83-90. Stefan Rinke, “¿Comienzo o fin de la historia?: el 11 de septiembre y las luchas por la memoria en Chile", en Memorias de la nación en América Latina: transformaciones, recodificaciones y usos actuales, ed. por Hans-Joachim König, Andrea Pagni y Stefan Rinke (México: Ciesas, 2008), 171-194.

4 Octavio Avendaño, "Fracturas y representación política en el movimiento estudiantil, Chile 2011", Última Década, n. 41 (2014): 43.

5 Alberto Mayol, No al lucro: de la crisis del modelo a la nueva era politica (Santiago de Chile: Debate, 2012), 362.

$6 \quad$ Ibid., 363 y 378.

7 Avendaño, "Fracturas y representación política”, 43. 
Esta interferencia entre continuidades y discontinuidades es la que inspira el análisis de esta temática. ${ }^{8}$ ¿Cuáles eran y todavía son las nuevas formas de actuar y presentarse como grupo social? ¿Cuáles son las formas más tradicionales y reproducidas? Estas interferencias pueden explicarse mediante un espejo histórico o revisión de contexto. Entonces, la pregunta más importante se refiere a ese 'antes', con el cual los estudiantes se identifican y que es necesario precisar. En ese orden de ideas, este análisis se concentra en los aspectos del pasado con los que el movimiento estudiantil se identifica para apoyar su actual y futura actuación, así como los elementos referidos a la memoria o potenciales simbólicos acogidos por dichos actores sociales. ${ }^{9}$

La hipótesis principal de este trabajo plantea que el movimiento estudiantil chileno se puede clasificar como movimiento social y que su inspiración y motivación se basan — en gran medida - en la figura del expresidente Salvador Allende. Es posible analizar dicha hipótesis a partir de las innumerables manifestaciones visuales que se presentan en el espacio público chileno.

Manifestaciones de otro tipo que denoten la figura de Allende como mítica son, por ejemplo, El Mochilazo, en 2001, o el Movimiento "Pingüino", de 2006. La movilización social contemporánea - liderada tanto por estudiantes universitarios como por estudiantes de las escuelas secundarias y otros actores - se basan en manifestaciones de acción colectiva, entendidas como olas de protestas que responden a la construcción de su marco de acción desde la reinstauración democrática de $1990 .^{10}$

No obstante, por la masiva cantidad de fuentes visuales, el enfoque de esta investigación está especialmente dirigido al análisis de murales como fuentes históricas, las cuales nos muestran cómo Allende fue percibido, representado y acogido entre 2011 y 2013. Dicha categoría de imágenes podríamos explicarla como producción de memorias y mitos por parte de estudiantes y activistas de importantes

8 Fernando Codoceo, Demokratische Transition in Chile: Kontinuität oder Neubeginn?(Berlin: wvB, 2007).

9 Rolf Reichhardt, "Bilder- und Mediengeschichte", en Kompass der Geschichtswissenschaft, ed. por Joachim Eibach y Günther Lottes (Göttingen: Vandenhoeck \& Ruprecht, 2006), 219-230.

10 Sofía Donoso, "La reconstrucción de la acción colectiva en el Chile post-transición: el caso del movimiento estudiantil", Clacso (2014): 1-45; véase también el "Archivo General del Movimiento Estudiantil", que ofrece varios documentales y comentarios de marchas y manifestaciones: http:// movimientoestudiantil.cl/multimedia/videos/ (31/03/2017). 
sectores. ${ }^{11}$ El periodo de esta investigación empieza en el 2011, año que presentó el clímax de las movilizaciones, y culmina en el 2013 con ocasión del cuadragésimo aniversario del golpe de Estado. En este periodo se manifiesta el 'mito Allende' como narración y visibilización histórica, sobre todo por su visualidad. Pero hay que tener en cuenta que el 'mito Allende' no es un fenómeno nuevo desarrollado en los últimos años; algunas publicaciones ya habían señalado esta apropiación del legado del expresidente chileno, como Salvador Allende: el fin de un mito y Chile actual, anatomía de un mito. ${ }^{12}$

Antes del análisis principal, el trabajo empieza con una base teórica sobre la cultura de protesta, el movimiento social, el muralismo y el mito como conceptos importantes que deben explicarse antes. En un segundo momento se precisa el contexto histórico, es decir, el periodo que va desde el Gobierno de Allende hasta la transición dictadura-democracia, donde se intensificará el movimiento estudiantil chileno entre el 2011 y el 2013. En general, se supone metodológicamente que las imágenes deben ser analizadas en su contexto histórico-social y que su función en momentos específicos permite interpretarlas como agentes de la historia. Finalmente, se enuncian algunas conclusiones y perspectivas respecto al tema aquí tratado.

11 Edgar Wolfrum, Geschichtspolitik in der Bundesrepublik Deutschland:Der Wegzurbundesrepublikanischen Erinnerung (Darmstadt: Wissenschaftliche Buchgesellschaft, 1999), 25-26 y 32. La política de memoria apunta a la construcción de imágenes históricas e identificables y se caracteriza por su agitación simbólica.

12 La monografía llamada Salvador Allende: el fin de un mito, escrito por Víctor Farías, en el 2006, y que ya se encuentra en su tercera edición. Sin embargo, mirándola más de cerca, dicha publicación se revela como un análisis unilateral que se aleja del contexto histórico de Salvador Allende, a quien Farías intenta presentar como un racista y antisemita. Víctor Farías, Salvador Allende: el fin de un mito. El socialismo entre la obsesión totalitaria y la corrupción. Nuevas revelaciones, 3 a ed. (Santiago de Chile: Maye, 2007).

Otra obra relacionada con el término (mito) es el clásico Chile actual, anatomía de un mito, de Tomás Moulian. Este lúcido análisis versa sobre el 'mito' del Chile de los años noventa, criticando su carácter neoliberal. La obra, que ya cuenta con diecinueve ediciones en el segundo año de publicación, es una de las más vendidas en los últimos tiempos. También trata del rol del presidencialismo antes de la dictadura y de la Unidad Popular (UP). Véase: Moulian, Chile actual.

Así mismo, existen otras publicaciones más generales, que han abordado la utilización de imágenes, como formas de representación y protesta. Por ejemplo, Ernesto Raúl, Pintura social en Chile (Santiago de Chile: Quimantu, 1972); Gaspar Galaz y Milan Ivelic, Chile, arte actual (Valparaíso: Universidad de Valparaíso, 1988); Donatella della Porta y Mario Diani, Social Movements: An Introduction, 2a ed. (Malden: Blackwell, 2006), 131-134. 


\section{Cultura de protesta y movimiento social}

Al igual que en el resto del mundo, en el contexto latinoamericano se habla de antiguos y nuevos movimientos sociales. ${ }^{13}$ En la investigación actual existe el consenso general de que los movimientos recientes ya no están afiliados a partidos políticos ni tienen una base social homogénea, tal como sucedía con los grupos más antiguos. Adicionalmente, podemos precisar que — a partir de los años ochenta - nuevos actores como cooperativas autónomas, organizaciones de mujeres, de derechos humanos, indígenas, comunidades cristianas y grupos ambientalistas comenzaron a llamar cada vez más la atención. Entonces, las 'misiones' u 'objetivos históricos' (como revoluciones) e, incluso, las ideologías como el socialismo comenzaron a ceder su protagonismo frente a otros grupos de interés. ${ }^{14}$ Los nuevos movimientos sociales son capaces de involucrar una buena parte de la población y, por eso, son reconocidos como movimientos heterogéneos.

A pesar de una innumerable cantidad de definiciones acerca de los movimientos sociales, el enfoque de Charles Tilly es el más aceptado desde varias disciplinas. ${ }^{15}$ Los estudios de caso relacionados con las culturas de protesta y los movimientos sociales, muchas veces, utilizan el método de observación. ${ }^{16}$ Concretamente, se observa siempre con una mirada histórica, pues cada grupo reacciona a injusticias sociales ocurridas en el pasado. ${ }^{17}$ Se entiende la sociedad como una red de actuación comunicativa en la que están implicados distintos actores. Dichos actores se

13 Mario Diani, "Simmel to Rokkan and Beyond: Towards a Network Theory of (New) Social Movements", European Journal of Social Theory 3, n. ${ }^{\circ} 4$ (2000): 387-406.

14 Jaime Sperberg, "Aufschwung in der Diktatur-Demobilisierung in der Demokratie? Soziale Bewegungen in Chile”, en ¿El pueblo unido?: Soziale Bewegungen und politischer Protest in der Geschichte Lateinamerikas, ed. por Jürgen Mittag y Georg Ismar (Münster: Westfälisches Dampfboot, 2009), 218-219.

15 Charles Tilly, referiéndose a nuevos movimientos sociales, habla de “identity” as the key, in contrast to the ostensibly instrumental aims of earlier social movements". Charles Tilly y Lesley Wood, Social Movements 1768-2012, 3a ed. (Boulder: Paradigm Publisher, 2013), 71.

16 Por ejemplo, Donatella della Porta, Hanspeter Kriesi y Dieter Rucht, Social Movements in a Globalizing World (Basingstoke: Palgrave MacMillan, 2002); Jürgen Mittagy Helke Stadtland, eds., Theoretische Ansätze und Konzepte der Forschung über soziale Bewegungen in der Geschichtswissenschaft (Essen: Klartext, 2014); Arturo Escobar, ed., The Making of Social Movements in Latin America: Identity, Strategy, and Democracy (Boulder: Paradigm Publisher, 1992); Olaf Kaltmeier, Jens Kastner y Elisabeth Tuider, eds., Neoliberalismus - Autonomie - Widerstand. Soziale Bewegungen in Lateinamerika (Münster: Westfälisches Dampfboot, 2004); Sperberg, "Aufschwung in der Diktatur".

17 Niklas Luhmann, Protest: Systemtheorie und soziale Bewegungen, ed. y coord. por Kai-Uwe Hellmann (Frankfurt am Main: Suhrkamp, 1996), 209. 
mueven dentro de un espacio público y un constructo de identidades. Entonces, el mismo movimiento puede estar formado por distintas demandas fusionadas, ${ }^{18}$ tal como Carlos Flores Navarrete lo señala: “[se realizaron exigencias en] la salud, la previsión social, el empleo, el medio ambiente, la infancia, la vejez, la mujer, las minorías, en fin; la participación, la política y la misma democracia". ${ }^{19}$ A la luz de estos conceptos, la realidad chilena nos permite evidenciar que el movimiento estudiantil en Chile también emerge por distintas demandas. Camila Vallejo, la gran protagonista del movimiento y ahora diputada de la República de Chile, comentaba en el 2011 durante una entrevista:

[...] la crisis de la educación es parte de la crisis de un modelo general, neoliberal, que repercute en la educación pero que en general reproduce la desigualdad, no solamente a través de la educación sino también del sistema económico y el sistema político. ${ }^{20}$

Por otro lado, la variedad de actores y sus intereses, a veces, llega a causar resistencia de algunos dirigentes o grupos que no están de acuerdo con sus exigencias. Estos fraccionamientos son capaces de provocar luchas por la conducción de los movimientos sociales. ${ }^{21}$ De igual manera, movimientos de este tipo no solo afectan a su propia generación, sino también a las generaciones siguientes y a las anteriores, pues están rememorados por muchos grupos de interés a través de una comunicación intergeneracional. Según el humanista e historiador alemán Jan Assmann, cada grupo social intenta crearse lugares de memoria y símbolos de identificación, ${ }^{22}$ dentro de los cuales están incluidos los movimientos. No son lugares topográficos, sino más bien lugares o puntos mentales que forman parte de una red, la que hoy en día podemos llamar global, sobre todo por los entrelazamientos a través de los

18 Jürgen Habermas, Faktizität und Geltung: Beiträge zur Diskurstheorie des Rechts und des demokratischen Rechtsstaates (Frankfurt am Main: Suhrkamp, 1992), 436-437.

19 Carlos Flores Navarrete, Auge \& caída de la educación chilena: desde Inés de Suárez a Camila Vallejo (Santiago de Chile: LOM, 2011), 211.

20 Hernán Ouviña, “Somos la generación que perdió el miedo: entrevista a Camila Vallejo Dowling”, Revista del Observatorio Social de América Latina. Consejo Latinoamericano de Ciencias Sociales 13, n. ${ }^{\circ} 31$ (2012), 15.

21 Avendaño, "Fracturas y representación política".

22 Jan Assmann, Daskulturelle Gedächtnis: Schrift, Erinnerung und politische Identität in frühen Hochkulturen (München: C. H. Beck, 2007), 39. 
medios sociales. La juventud, entendida como un "sismógrafo" de actuación social, actualmente está presente y en acción en Europa, Estados Unidos, el mundo árabe, China y América Latina. Cada generación se ve como un catalizador entre lo propio y el otro, entre lo que ya está, lo nuevo y lo radical. ${ }^{23}$

\section{El muralismo y el mito}

Según el historiador del arte Martin Warnke, las imágenes públicas son "señales políticas" de un mensaje que persiste constantemente ante el público en general. ${ }^{24}$ Este mensaje se desarrolla mediante distintos discursos que se manifiestan — de forma gradual - en la memoria colectiva. Las imágenes analizadas en el presente capítulo muestran a Salvador Allende en escena como un ícono, gracias a los medios visuales. Dichas images aún tienen un carácter de performance por su formación de realidades y recepciones. ${ }^{25}$ Principalmente murales, carteles y banderas son medios visuales usados por el movimiento social, del mismo modo que lo hicieron las brigadas durante la campaña presidencial de Allende y, muy activamente, durante su corto mandato, que se destacan por la creación de murales en las principales ciudades chilenas. ${ }^{26}$

Para limitar la amplia cantidad de fuentes visuales, el enfoque del análisis está en los murales como representaciones artísticas callejeras del movimiento. Aparte de las aulas y pantallas, la calle se entiende como uno de tres espacios de la actuación juvenil, ${ }^{27}$ a través del cual los jóvenes expresan su mensaje político y, así, se constituyen en un referente para su memoria histórica expresado en el espacio público.

23 David Harvey, Rebel Cities: From the Right to the City to the Urban Revolution (London: Verso, 2012), 115-119; Christian Schneider, Cordelia Stillke y Bernd Leineweber, Trauma und Kritik: Zur Generationengeschichte der Kritischen Theorie (Münster: Westfälisches Dampfboot, 2000), 35.

24 Martin Warnke, "Politische Ikonografie", Kunsthistorische Arbeitsblätter, n. 2 (2003), 11.

25 Erika Fischer-Lichte, "Performance, Inszenierung, Ritual. Zur Klärung kulturwissenschaftlicher Schlüsselbegriffe", en Geschichtswissenschaften und 'performative turn'. Ritual, Inszenierung und Performanz vom Mittelalter bis zur Neuzeit, ed. por Jürgen Martschukat y Steffen Patzold (Köln: Böhlau, 2003), 33-54.

26 Leonor Abujatum Berndt, "Chile: Ein Land im Umbruch? Wie aus dem Unmut über soziale Ungleichheit eine neoliberalismus-kritische Bewegung wurde", en Soziale Proteste in Lateinamerika. Bolivars Erben im Kampfum Eigenmacht, Identität und Selbstbestimmung, ed. por Torben Ehlers (Hamburg: Argument, 2013), 290.

27 Camila Cárdenas Neira, "Representación de la acción política de los estudiantes chilenos: movilización de significados en redes sociales", Última Década, n. ${ }^{\circ} 40$ (2014): 61. 
El Muralismo nació en México a principios del siglo xx y, posteriormente, fue traído a Chile. A partir de la década de los sesenta, llegó a ser medio de publicidad antes de las elecciones presidenciales. En este contexto, se desarrollaba el rayado mural, es decir, la unión del grafiti con el mural por brigadas politicas como Ramona Parra (BRP), Elmo Catalán (BEC) y la Brigada Chacón. Después de muchos años en la clandestinidad, entre 1987 y 1989 reaparecieron tímidamente estas brigadas muralistas, las cuales volvieron a la actividad, usando en esta ocasión colores puros y delineadores negros como típicas técnicas y mensajes, o incluso frases con una estrella roja. ${ }^{28}$ Mediante algunos ejemplos escogidos, analizamos las narrativas de estas imágenes con respecto a un mito. Es importante tener en cuenta que todas las imágenes de este trabajo son fotografías de murales, por lo que dependen siempre de la perspectiva, la percepción y de las condiciones técnicas del fotógrafo igualmente.

El mito, como categoría fundamental en las humanidades, es una noción muy usada y sobrevalorada en nuestra vida cotidiana. Como término o concepto, está definido muy pocas veces en el mundo académico, aunque exista una amplia cantidad de explicaciones. En muchos contextos se usa la palabra mito para destacar un fenómeno como si fuera mentira, una imaginación falsa o como si se tratara de un secreto. Por lo tanto, muchos autores usan la palabra para oponer el mito a la realidad. Al contrario, Karen Armstrong constata en su breve historia del mito que este es más bien "una forma de arte que señala lo que es atemporal en la existencia humana". 29 Partiendo de esto, entendemos el "caso Allende" como forma de arte que implica pensar su figura como elemento de un mito.

Referirse al mito como término se traduce con $\mu \tilde{v} \theta \circ \varsigma$, que significa "narración". Podemos mencionar que se trata de una historia presentada de una manera especial, remarcada por personajes particulares. En un proceso de mitificación, dicha historia llega a ser descontextualizada y elevada a un plano supratemporal. Roland Barthes, a quien veremos con mayor detalle, entiende el mito como una modificación o deformación de algo; lo describe como un habla, un mensaje. Según Barthes, la sociedad conserva diferentes mensajes en su memoria; es la activación y la apropiación de un objeto o sujeto la que le permite convertirse en un objeto o sujeto de mito. Este mito, según Barthes, siempre tiene una dimensión histórica

\footnotetext{
28 Juan Bragassi, "El Muralismo en Chile: una experiencia histórica para el Chile del bicentenario", http://www.memoriachilena.cl/602/articles-123178_recurso_2.pdf(31/03/2017).

29 Paráfrasis de la autora. Para la referencia original, véase: Karen Armstrong, $A$ Short History of Myth (Edinburgh: Canongate, 2005), 7.
} 
que se aprovecha de declaraciones elegidas y transmitidas por la sociedad. Con respecto a fuentes visuales como carteles, cuadros, caricaturas, pinturas, fotografías, monumentos, películas o murales, estas pueden operar como 'materias primas' de cualquier mito. En su obra Mythologies, el autor habla de una vida cotidiana llena de construcciones mitológicas. ${ }^{30}$ Existen mitos en cada nación, en cada sociedad y en cada cultura. Asimismo, grupos étnicos, movimientos y clases sociales forman sus propios mitos para designarse cierta identidad, así como dar sentido tanto al pasado como al presente. En la historia se muestra el ímpetu del mito para el futuro, haciendo llamamientos a sujetos, ya sea figuras y épocas.

La rememorización de Salvador Allende en Chile es una construcción que produce una línea de continuidad del pasado con el presente. La activación y la apropiación del expresidente a través del movimiento estudiantil chileno y su escenificación en murales, carteles o banderas, lo transforman no solo en un ícono, sino también en un mito y a partir del cual se producen nuevos mensajes: hablamos de un mito tanto político como personal. La historia está hecha por imágenes ${ }^{31}$ que, en suma, generan imágenes históricas permanentes. Se puede hablar de un mito si los mensajes de dichas imágenes se manifiestan en la memoria visual de una sociedad. Los estudiantes de hoy forman la tercera generación después del golpe de Estado en Chile; son ellos los que imponen la historia del camino chileno hacia el socialismo y la historia de la dictadura a la sociedad democrática. ${ }^{32}$

\section{Desde el Gobierno de Allende (1970-1973) hasta la transición hacia la democracia}

Salvador Allende Gossens, nacido en 1908 en Valparaíso, estudió medicina en Santiago y participó activamente en el movimiento estudiantil que luchó contra la dictadura del general Carlos Ibáñez del Campo. Allende, que ya había sido presidente del Senado desde 1966, fue finalmente elegido en 1970 como primer mandatario marxista de su país, después de haber sido derrotado en tres oportunidades (1952, 1958 y 1964). El programa de su coalición, la Unidad Popular (UP),

30 Roland Barthes, Mythologies (Paris: Seuil, 1970), 193-224.

31 Gerhard Paul, "Die Geschichte hinter dem Foto: Authentizität, Ikonisierung und Überschreibung eines Bildes aus dem Vietnamkrieg", Zeithistorische Forschungen/Studies in Contemporary History, n. ${ }^{\circ} 2$ (2005): 225.

32 Abujatum Berndt, “Chile: Ein Land im Umbruch?”, 297. Véase también Peter Cummings, “Democracy and Student Discontent: Chilean Student Protest in the Post-Pinochet Era”, Journal of Politics in Latin America 7, n. 3 (2015): 49-84. 
pidió un paquete de reformas de corte socialista que dividió a la sociedad chilena..$^{33}$ Gracias a pilares económicos y la participación de los grupos más vulnerables como los obreros, impulsó su reforma educacional dirigida a terminar con la educación científico-humanista, en pro de una "politécnica" más inclusiva, participativa e igualitaria que fuera el motor de la actividad económica del país. Cuando comenzó la nacionalización de industrias y expropiación de campos, los miembros de la derecha chilena reaccionaron con una fuga de capitales; mientras crecía la euforía de la izquierda. Sin embargo, a partir de la década de los cincuenta, hubo innumerables conflictos entre el presidente y su coalición, según menciona Dieter Nohlen:

Eduardo Frei y Salvador Allende moldearon sus respectivos partidos con un grado de liderazgo casi místico. [...] el liderazgo de Allende no ha sido compensado en la izquierda chilena y en una medida no despreciable, es un factor que explica su segmentación actual, especialmente dentro del Partido Socialista. ${ }^{34}$

El mismo Allende dijo en 1972, durante un discurso en Valparaíso, que no era presidente de todos los chilenos en el sentido de un líder carismático. Más bien, se entendía como cabeza de la UP:

Lo he dicho, yo no soy Presidente del Partido Socialista. Yo soy Presidente de la Unidad Popular. Tampoco soy presidente de todos los chilenos, no soy el hipócrita que lo dice, no, yo no soy el presidente de todos los chilenos; otra cosa muy distinta es que se respete a todos los chilenos, que las leyes se apliquen para todos los chilenos [...]. Tengo sí, una obligación de ocuparme de todos los chilenos. Eso es muy distinto. ${ }^{35}$

La Up vió la oportunidad de construir un camino hacia el socialismo. Aparte de la reforma agraria, el control del comercio internacional y las nacionalizaciones crecientes en todas las áreas de la sociedad, las medidas características del Gobierno de Allende incluyeron una política cultural socialista, la llamada Concientización,

33 Stefan Rinke, Kleine Geschichte Chiles (München: C. H. Beck, 2007), 144-145.

34 Dieter Nohlen, "Presidencialismo, sistema electorales y sistemas de partidos: reflexiones para América Latina”, en Presidencialismo versus parlamentarismo, América Latina, ed. por Dieter Nohlen y Mario Fernández (Caracas: Nueva Sociedad, 1991), 68.

35 Salvador Allende, El Siglo, 7 de febrero de 1972, 5. 
que se opuso a una influencia estadounidense. ${ }^{36}$ En 1973, fracasó el modelo de la Escuela Nacional Unificada al ser retirado el proyecto del Senado, lo que terminó por enterrar las pretensiones de una educación nacionalizada. ${ }^{37}$ Dicha Escuela consistía en una de las reformas principales del Gobierno de Allende, que concluiría en una educación participativa y pluralista. Este proceso de Concientización causó miedo y rechazo hacia el 'humanismo socialista' en varias élites políticas y sociales, así como en la Iglesia católica. Del mismo modo, causó el temor al control político de instituciones educativas, por lo cual creció la oposición y la resistencia contra Allende.

En junio de 1973, el Regimiento Blindado n. 2 protagoniza un intento de golpe de Estado - más tarde denominado Tanquetazo o Tancazo- con cerca de una docena de tanques y un número cercano a los cien soldados, que se dirigieron en dos caravanas para atacar el Palacio de La Moneda y el Ministerio de Defensa. Con una medida enfocada en evitar un nuevo levantamiento militar, Allende decide incluir al titular del Ejército, general Carlos Prats, como ministro de Defensa. Sin embargo, esta idea de dar la sensación de unidad entre las Fuerzas Armadas y el Gobierno de la up no prospera y Carlos Prats renuncia a volver como titular del Ejército y recomienda como nuevo comandante en jefe del Ejército a un general de su confianza: Augusto Pinochet. Sin embargo, tras intensos llamados a una intervención armada por parte de los empresarios chilenos y algunos líderes políticos, el Ejército materializa el golpe de Estado el 11 de septiembre de 1973. Después del bombardeo al Palacio de La Moneda, Allende decide no entregarse y se quita la vida en el mismo palacio presidencial. Poco antes habló por última vez al pueblo chileno, a través de un emotivo mensaje transmitido por Radio Magallanes y Radio Corporación, ${ }^{38}$ acto con el cual podríamos decir que dio vida al mito Allende. Por ejemplo, las gafas rotas del mandatario simbolizan la marca más importante de su persona que, actualmente, se encuentran en el Museo Histórico Nacional, en Santiago de Chile (figura 1).

36 Rinke, Kleine Geschichte Chiles, 150.

37 Flores Navarrete, Auge \& caida, 108-110.

38 Rinke, Kleine Geschichte Chiles, 152-158; Fernando Diego García y Óscar Sola, Salvador Allende: Das Ende einer Ära (Berlin: Aufbau-Verlag, 1998), 162-179. 


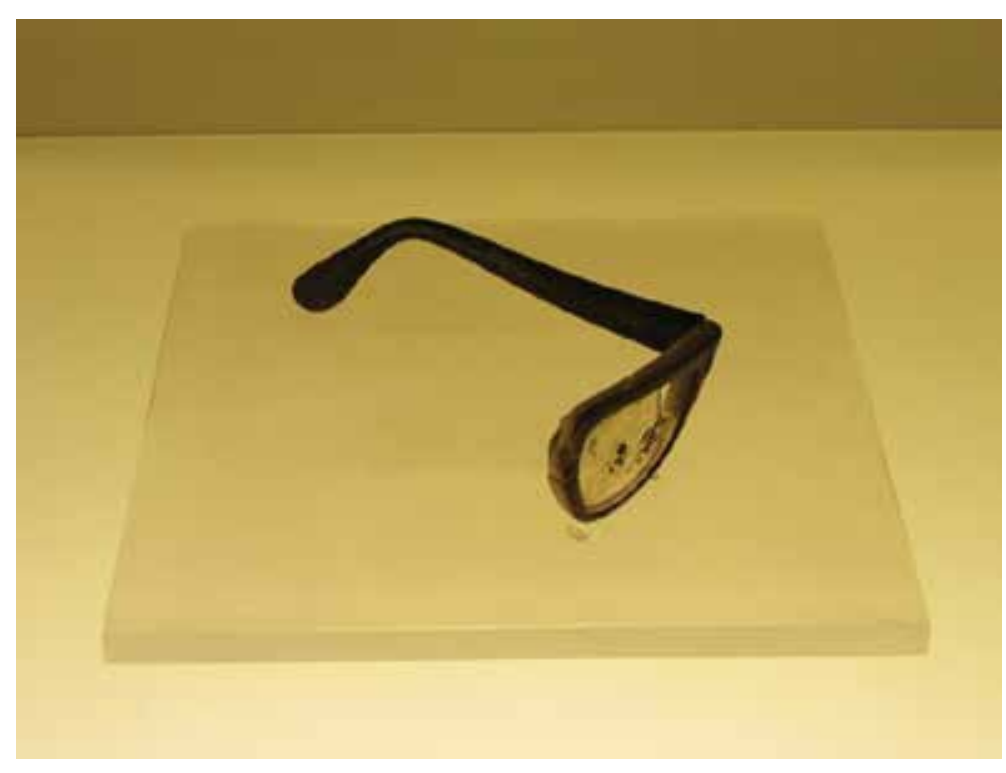

Figura 1. Christiane Hoth, 2013, "Gafas de Salvador Allende" (fotografía, Museo Histórico Nacional, Santiago de Chile).

Augusto Pinochet Ugarte se erigió como líder de la Junta Militar que tomó el poder tras el 11 de septiembre, al tiempo que guardaba las apariencias de una constitucionalidad. A finales de 1974, asume oficialmente el título de presidente del país. ${ }^{39}$ Una nueva Constitución en 1980 da la impresión de que el país volverá a la democracia; pero, en realidad, el objetivo era consolidar los preceptos neoliberales con los que el Gobierno de Pinochet pretendía la tan ansiada modernización del país. Para la oposición del momento, el objetivo principal de la Constitución de Pinochet era el afianzamiento del poder de los militares, a largo plazo. ${ }^{40}$

En esa época, muchos estudiantes, opositores políticos y obreros fueron relacionados con el Gobierno de Allende. Además de las torturas sistemáticas, persecuciones y asesinatos, hubo también encarcelamientos de víctimas dado que el Gobierno Militar declaró ilegal al Partido Comunista, por lo que muchos de sus

\footnotetext{
39 Rinke, Kleine Geschichte Chiles, 160; Rinke, “¿Comienzo o fin de la historia?”, 171-194.

40 Ricardo A. Yocelevzky, Chile: partidos politicos, democracia y dictadura 1970-1990 (México: Fondo de Cultura Económica, 2002), 133-146.
} 
miembros fueron condenados al exilio. ${ }^{41}$ Por otro lado, los militares interfirieron y dificultaron la intervención de los jóvenes y de nuevos rostros en la escena política y social. ${ }^{42}$

En 1988, Pinochet — según lo establecido por la Constitución de 1980realizó un plebiscito en el cual los chilenos debían elegir entre prolongar un nuevo mandato suyo por otros ocho años o forzar una elección presidencial para el año siguiente, lo que llevaría a una vuelta a la democracia. Con el $55 \%$ de los votos, la opción del No logró imponerse a la del sí y fijar elecciones presidenciales en Chile tras diecinueve años. A partir de ese momento, comenzó la llamada transición a la democracia, modelo que ha sido comparado con el que se desarrolló en España tras la muerte de Francisco Franco; pero hay que mencionar que dicha transición tuvo muchas lagunas. Por ejemplo, las torturas y las humillaciones han sido juzgadas de manera muy insuficiente. ${ }^{43}$ De todas formas, el retrato de Allende logró sobrevivir a los dieciséis años de régimen militar y se instaló en la memoria colectiva de la sociedad chilena. La imagen del mandatario con sus gruesas gafas negras (figura 2) llegó a ser una plantilla para todo tipo de visualización después de su muerte: se podría interpretar como un lugar de memoria y como base de su iconización póstuma. ${ }^{44}$

41 Augusto Samaniego y Carlos Ruiz, Mentalidades y politicas wingka:pueblo mapuche, entre golpe y golpe (de Ibáñez a Pinochet) (Madrid: Consejo Superior de Investigaciones Científicas, 2007), 355-356.

42 El tema de la participación política de jóvenes chilenos durante la primera etapa del régimen ha sido estudiado por Víctor Muñoz Tamayo, politólogo chileno quien investiga las transformaciones socioeconómicas, sociopolíticas y socioculturales de jóvenes en Chile. Víctor Muñoz Tamayo, "'Chile es bandera y juventud': efebolatría y gremialismo durante la primera etapa de la dictadura de Pinochet (1973-1979)", Historia Crítica, n. ${ }^{\circ} 54$ (2014): 195-219. Véase también su obra Generaciones: juventud universitaria e izquierdas politicas en Chile y México (Universidad de Chile-UNAM 1984-2006) (Santiago de Chile: LOM, 2011).

43 Stephan Ruderer "Hybride Erinnerung: Geschichtspolitik in Chile", Geschichte und Gesellschaft. Zeitschrift für Historische Sozialwissenschaft 36, n. ${ }^{\circ} 1$ (2010): 130.

44 Gerhard Paul, "Bilder, die Geschichte schrieben: Medienikonen des 20. und beginnenden 21. Jahrhunderts. Einleitung", en Bilder, die Geschichte schrieben. 1900 bis heute, ed. por Gerhard Paul (Bonn: bpb, 2011):7-16. 


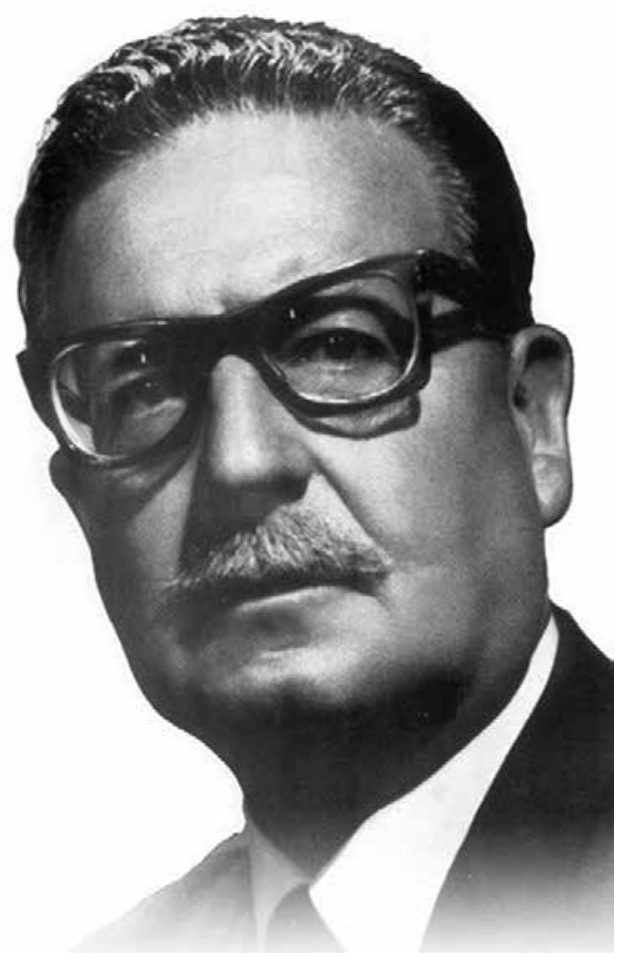

Figura 2: Anónimo, s. f. “Salvador Allende” (fotografía, Fundación Salvador Allende, http://www.fundacionsalvadorallende.cl/salvador-allende/).

Las brigadas, con sus papelógrafos y murales de las décadas de los sesenta y de los setenta, volvieron con un mensaje nostálgico, no excento de demandas políticas, el cual mostraba que no solo la memoria de Allende sobrevivió a la dictadura, sino también a la pintura, como representación artística callejera. ${ }^{45}$

En la figura 3 se puede ver a un joven pintando el retrato de Allende en el estilo usual de las brigadas. Usando técnicas muy simples — colores puros y delineados negros - se identifica a Allende por sus gafas y la estrella que simboliza el socialismo. A su izquierda y derecha se pueden ver dos figuras femeninas que parecen muy seguras y decididas. Al lado derecho está escrito “Chile vencerá”, una cita que destaca la pintura como propia de Allende, porque hace referencia a la canción "Venceremos", de su campaña presidencial. El uso de ese tiempo verbal hace visible el entramado del pasado, del presente y del futuro. Como el mural fue pintado en

45 Rinke y Dümmer Scheel, “'Der Sold Chiles”, 83-90. 
enero de 1989, es decir, dos meses después del plebiscito, menciona que la identificación y la memoria de Allende sobrevivieron a dieciséis años de dictadura.

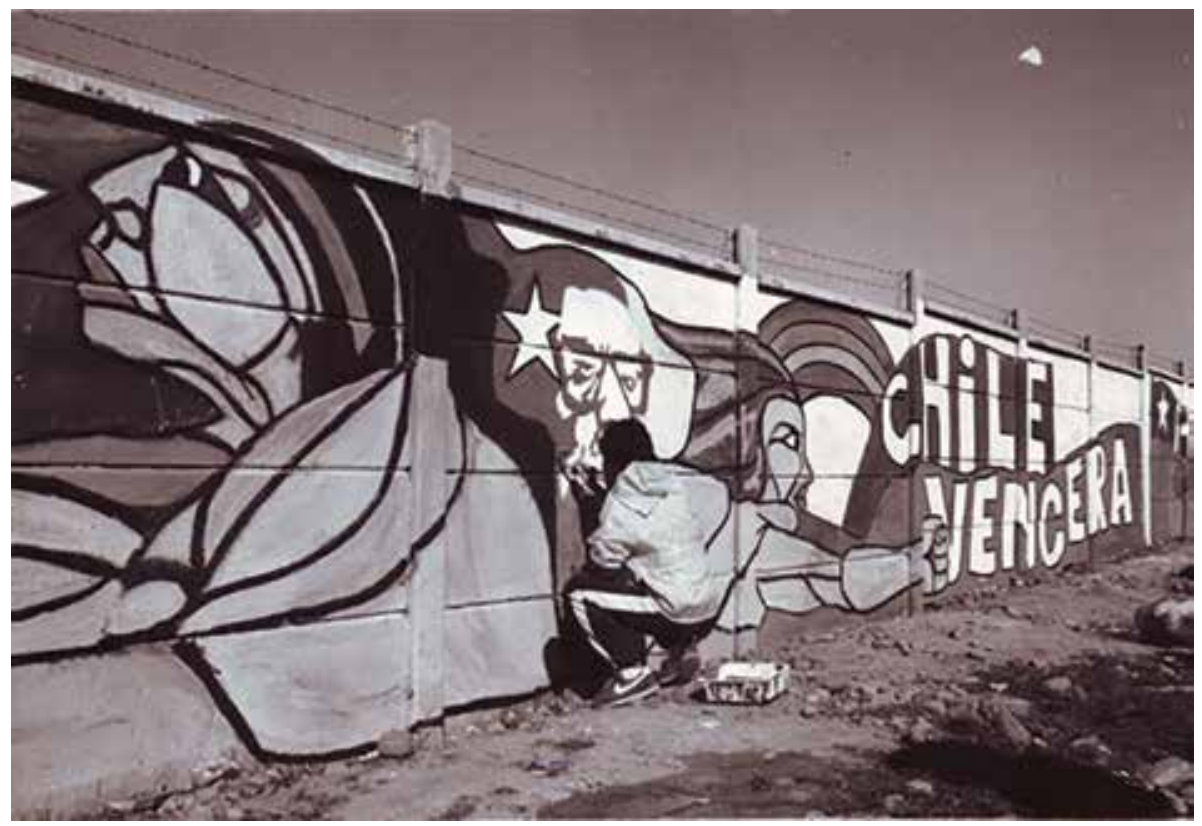

Figura 3. Anselmo Córdoba, 1989, "Joven pintando un gran mural, en el que sale el rostro de Allende y la frase 'Chile vencera’” (fotografía, http://www.archivofortinmapocho.cl/imagenes/mural/).

\section{El movimiento estudiantil chileno}

Los movimientos sociales chilenos, en general, ya habían desempeñado un papel importante en mantener y exigir derechos en las décadas de los sesenta y de los setenta (hasta 1973). Aunque los nuevos movimientos presentan varias formas de actuación, podemos hablar de una tradición o una continuidad de manifestaciones callejeras, paros, marchas y tomas en Chile. Después de las elecciones de finales de los años noventa, se produjeron movilizaciones, principalmente en 1997. Los estudiantes demandaron mayor democratización, participación y financiamiento. Fue también este periodo cuando se fundó la Confederación de Estudiantes de Chile (CONFECH) ${ }^{46} \mathrm{El}$ año de 1998 se presenta como uno importante también por el arresto de Pinochet, en Londres, que causó diversas acciones para fortalecer

46 Avendaño, "Fracturas y representación política”, 47-48. 
la memoria acerca del pasado, tanto de sus adherentes como de sus opositores. Para mediados de la siguiente década, hubo aún más disturbios y protestas. A diferencia de los gobiernos de Aylwin (1990-1994), Frei (1994-2000) y Lagos (2000-2006), que fueron menos agitados, el 2006 se caracterizó por protestas más fuertes con el Gobierno de Michelle Bachelet. ${ }^{47}$ Estas se tranformaron en un movimiento más intenso que logró mostrar su poder frente al Estado.

Con el comienzo del Gobierno de Bachelet, empezaron las protestas de los denominados Pingüinos, es decir, de los estudiantes secundarios que cuestionaron la concepción sobre la educación de una forma muy intensa. ${ }^{48}$ Se habla de la "Revolución de los Pingüinos", por el uniforme tradicional utilizado por dichos estudiantes. Bachelet respondió a las demandas con algunas promesas, por ejemplo, el remplazo de la Ley Orgánica Constitucional de la Enseñanza o simplemente LOCE, de 1990, ${ }^{49}$ por la Ley General de Educación, cuyo objetivo es la equidad y calidad de la educación en todo el sistema escolar. Sin embargo, estas promesas causaron todavía más protestas, aunque por la larga duración del movimiento se diluyeron hacia octubre de ese mismo año. En el 2009, luego de que la Universidad Tecnológica Metropolitana comenzara una movilización indefinida, miles de estudiantes, profesores y ciudadanos se unieron a sus demandas y formularon nuevos objetivos en distintos congresos de educación, que se transformaron también en la base de las protestas de los años siguientes..$^{50}$ Después de que el candidato de centro-derecha, Sebastián Piñera, fuera elegido presidente y después de la convulsionada experiencia que despidió el Gobierno de Bachelet, en febrero del 2010 - y que tuvo a todo un país ocupado en su recuperación-, en el 2011 volvió el movimiento estudiantil con nuevas demandas, mucha fuerza y gran capacidad de convocatoria. A partir de ese año empieza un fuerte 'terremoto social', presente en una intensificación de la movilización pública que se ha prolongado hasta nuestros días. ${ }^{51}$ Hay que hacer constar que quienes eran estudiantes universitarios en el 2011

47 Rinke, Kleine Geschichte Chiles, 99 y 184-186.

48 Manuel Antonio Garretón, Del postpinochetismo a la sociedad democrática: globalización y política en el Bicentenario (Buenos Aires: Debate, 2007), 117.

49 Sperberg, "Aufschwung in der Diktatur", 226.

50 Abujatum Berndt, “Chile: Ein Land im Umbruch?”, 285.

51 Ibid., 276. Las relaciones entre el terremoto y el movimiento estudiantil, en particular en lo que se refiere a la solidaridad y la participación de los ciudadanos durante las protestas y la reconstrucción, muestra Liliana Mayer, "Schooling System, Earthquakes and Beyond: The Chilean Experience of 2010", Iberoamericana 14, n. ${ }^{\circ} 55$ (2014): 147-162. 
fueron estudiantes secundarios en el 2006. El sociólogo Alberto Mayol sostiene en su obra No al lucro:

Entre el 1 de julio del 2011 y el 30 de junio del 2012, Chile no vivió solo un año calendario. En esos doce meses toda la lentitud de los procesos sociales y políticos que nos acompañó desde 1990 se volvió vértigo y transformación. Lo que era silencio se convirtió en palabra, lo que era muro se transformó en derrumbe, lo que era respuesta se hizo pregunta, lo que era sólido se desvaneció en el aire..$^{52}$

Durante los últimos años, se han cerrado muchas universidades o los estudiantes han bloqueado las entradas, con sillas y mesas. También los profesores y los padres se unieron, por primera vez, para participar activamente en las protestas. El sistema educativo chileno - muy privatizado - es uno de los sistemas educativos más costosos del mundo: solo entre el 15 y el $20 \%$ de los costos totales de la educación están a cargo del Estado, el resto lo pagan las familias..$^{53}$ Por lo tanto, Alberto Mayol habla de una "industria educativa" y de un "modelo de negocio". 54

La CONFECH es la organización estudiantil más conocida e importante del país. Muchos estudiantes siguieron su convocatoria para movilizarse contra el sistema educativo. En el 2012, viajaron a Europa los protagonistas y miembros de las juventudes comunistas del movimiento, entre estos Karol Cariola y Camila Vallejo, con el fin de dar visibilidad al movimiento estudiantil chileno, además de solicitar el apoyo de las confederaciones de estudiantes en Europa. Otros voceros principales, como Giorgio Jackson, llegaron a ser reconocidos en el ámbito internacional. La primera convocatoria se llevó a cabo por iniciativa de la CONFECH, en abril del 2011. Ese día, la Dirección Nacional de la Junta Nacional de Auxilio Escolar y Becas — una organización estatal que da becas a estudiantes - fue tomada. 55 Participaron estudiantes de la Universidad de Chile, la Universidad de Santiago de Chile (USACH) y la Universidad Metropolitana de Ciencias de la Educación. El diario La Tercera publicó ese mismo día:

\footnotetext{
52 Mayol, No al lucro, 10.

53 Ibid., 56 y 282-283; Juan Urra Rossi, “La movilización estudiantil chilena en 2011: una cronología”, Revista del Observatorio Social de América Latina. Consejo Latinoamericano de Ciencias Sociales 13, n. ${ }^{\circ} 31$ (2012): 24.

54 Mayol, No al lucro, 55, 188.

55 Urra Rossi, "La movilización estudiantil chilena”, 25-26.
} 
Las demandas de los universitarios son el aumento del gasto público en educación, la democratización de acceso y funcionamiento de las instituciones, y la reestructuración de becas y ayudas estudiantiles. Giorgio Jackson, presidente de la Federación de Estudiantes de la Universidad Católica, señaló que la manifestación "estuvo muy por sobre las expectativas, ya que esperábamos a tres mil personas y llegó más del doble: Estamos muy contentos. Se nota que hay un movimiento muy fuerte y unido. 56

A pesar de la exposición que le han significado las innumerables conferencias de prensa, es notable que el movimiento estudiantil a partir del 2011 haya resistido tanto tiempo y tan constantemente. Como Urra Rossi destaca, es un hecho que resulta de nuevas posibilidades comunicativas, sobre todo por el uso de Facebook y Twitter, que forman una red cada vez más global. Asimismo, el internet como 'lugar' es una gestión estratégica y un canal con fines políticos muy importantes en el área urbana. ${ }^{57}$ Hubo también movilizaciones como la del 12 de mayo del 2011 , en las que participaron más que 50.000 personas, un $50 \%$ de ellos solamente en Santiago de Chile. ${ }^{58}$ El presidente Piñera respondió el 21 de mayo y presentó el Gran Acuerdo Nacional por la Educación, rechazado por la CONFECH. Lo mismo pasó después de un encuentro entre la Confederación y el Ministro de Educación, Joaquín Lavín, quien dijo a ElMercurio, el 31 de mayo, que "el paro que ellos quieren hacer lo iban a realizar de todas maneras, cualquiera fuera el resultado de esta reunión".59

Al recordar las protestas contra Pinochet en la década de los ochenta, hubo un cacerolazo el 4 de agosto del $2011 .^{60}$ Entonces, en agosto, el movimiento entró en una nueva fase, al integrar nuevas formas de acción como el cacerolazo o la paralización de facultades. Un punto culminante político del 2011 fue, sin duda, el cuestionario en línea para el cual más de un millón de chilenos participó. Votaron

\footnotetext{
$56 \quad$ La Tercera, 29 de abril de 2011.

57 Cárdenas Neira, "Representación de la acción política”, 61.

58 Urra Rossi, “La movilización estudiantil chilena”, 27.

59 ElMercurio, 31 de mayo de 2011.

60 Es una forma de protesta que se caracteriza por el uso de ollas y sartenes para ocasionar el mayor ruido posible por parte de ciudadanos en las calles. Abujatum Berndt, "Chile: Ein Land im Umbruch?”, 293.
} 
por internet por un sistema educativo más justo. ${ }^{61}$ Fue el momento en el que "el movimiento fue adquiriendo fuerza propia”. ${ }^{2}$ El Gobierno aprovechó algunas tensiones crecientes entre distintos actores "para dilatar decisiones, manejar los tiempos y apostar al desgaste y el debilitamiento de las movilizaciones". ${ }^{63}$ Como medio de presión, el Gobierno amenazó con la cancelación de becas, lo que llevó a muchos estudiantes a no participar de más protestas. A esto se sumó la Ley Hinzpeter, llamada así por el ministro del Interior de entonces. Esta ley implicaba el aumento de castigo para gente que causara desmanes con su cara cubierta (encapuchada), con un máximo de tres años de cárcel. ${ }^{64}$ Como ya hemos mencionado, no fueron solamente estudiantes los que participaron en las movilizaciones, sino también sus profesores. ${ }^{65}$ Eran y todavía son acciones contra estructuras sólidas, cuya eclosión por el Gobierno en uso de medios legítimos parecía y parece imposible. Como Camila Vallejo, muchos chilenos veían una continuidad de un sistema heredado de Pinochet: "Está también la demanda de la Constitución Política, porque para nosotros Pinochet sigue vivo, debido a que todavía su legado perdura en una Constitución que nunca se cambió”. 66 Una gran parte de la sociedad chilena se da cuenta de estas injusticias en el sistema educativo, pero son — sobre todo- los jóvenes los que se movilizan. Para Camila Vallejo, es un fenómeno que tiene que ver con la retención y el miedo de las generaciones mayores durante la dictadura de Pinochet y la década de los noventa:

Somos una generación que no vivió directamente las consecuencias del golpe militar, porque si uno se fija, por ejemplo, en los padres, en las madres o incluso las abuelas que salen a las calles, que plantean lo mismo que estamos planteando, como el tema de la renacionalización de los recursos naturales, pero no lo decían

61 Urra Rossi, “La movilización estudiantil chilena”, 35-36. Fue un cuestionario nacional por parte del Colegio de Profesores de Chile. Como no tuvo valor vinculante y legal; por ende, fue un medio más bien simbólico.

62 Avendaño, "Fracturas y representación política", 49-50.

63 Ibid., 51.

64 Abujatum “Berndt, Chile: Ein Land im Umbruch?”, 295.

65 Urra Rossi, "La movilización estudiantil chilena”, 29.

66 Ouviña, "Somos la generación”, 17. 
por el miedo a revivir el periodo de la Unidad Popular y que esto se vuelva a tener que enfrentar a una nueva dictadura militar. ${ }^{67}$

Como conclusión, podemos hablar de movimientos jóvenes, referiéndonos al comienzo del siglo xxI, en los que, sin embargo, participan otras generaciones también. Dichos movimientos se caracterizan por ser performativos o "realizativos" por sus múltiples acciones y distintas formas de comunicación. No solo el uso de redes sociales, sino también representaciones artísticas callejeras como coreografías oflash mobs hasta huelgas de hambre forman el carácter único del movimiento. ${ }^{68}$

El movimiento está presente en un plano visual en el mundo urbano. Hay, por ejemplo, un mural al lado del Centro Cultural Gabriela Mistral, en el centro de la capital chilena. Data del 2012 y es del reconocido colectivo muralista Ramona Parra (figura 4). De izquierda a derecha, podemos identificar cuatro representantes de los diferentes grupos de la sociedad chilena, que juntos forman una imagen grande: un minero, una estudiante, un mapuche y un pescador. Cada uno tiene atributos típicos. Las demandas que salen en las banderas tienen una función que apela al observador, como muestra el ejemplo de la estudiante. "Queremos educación de excelencia para todos los chilenos" y “[i]Educación gratuita e incluyente! ¡Ahora!!” forman parte de la pintura en la que podemos ver, también, libros y un lápiz como atributos. El mural, ubicado en una zona estratégica, goza de muchos espectadores cada día, al insertarse dentro de su cotidianidad; es un ejemplo de varias demandas unificadas por medio de un espacio visual compartido.

67 Ibid., 18.

68 Urra Rossi, "La movilización estudiantil chilena”, 31. 


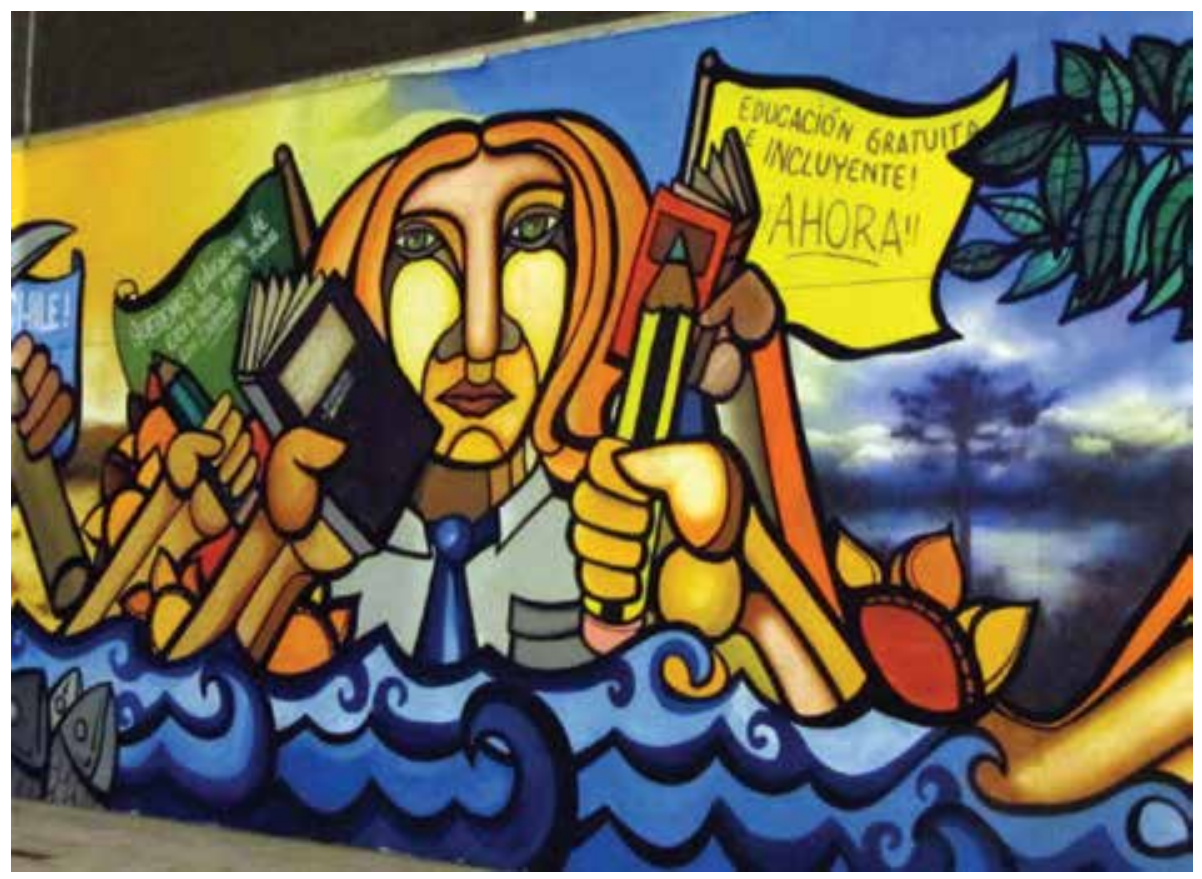

Figura 4. Christiane Hoth, 2012, "Mural-colectivo Ramona Parra" (fotografía, Centro Cultural Gabriela Mistral, Santiago de Chile).

\section{El mito Allende entre 2011 y 2013}

Principalmente, en Santiago de Chile y Valparaíso —es decir, en áreas urbanasencontramos diversos murales, papelógrafos, banderas, citas, folletos, carteles y afiches que se refieren a Allende. Especialmente en Valparaíso, se usan casas como cuadros para enumerar las distintas demandas. Por ejemplo, presentamos un mural que se encuentra en dicha ciudad en la sede del Partido Socialista, situada en una bifurcación de dos importantes calles (el lugar, hace casi imposible obviar la pintura). Aunque no existe ninguna cita ni nombre, se puede identificar a la persona como Allende: las gafas, el bigote, la ropa y — sobre todo- la banda que le muestran como presidente. En el fondo, podemos ver el panorama de Valparaíso: dos niños que están mirándole desde abajo (figura 5). Como Allende está al medio de unas escaleras, parece como si quisiera caminar hacia nosotros. Por otro lado, resulta el efecto cuando bajamos y nos movemos hacia él —automáticamente— en conjunto, este mural muestra a Allende como un presidente caminando hacia el pueblo por la integración simultánea de la arquitectura a la pintura. 


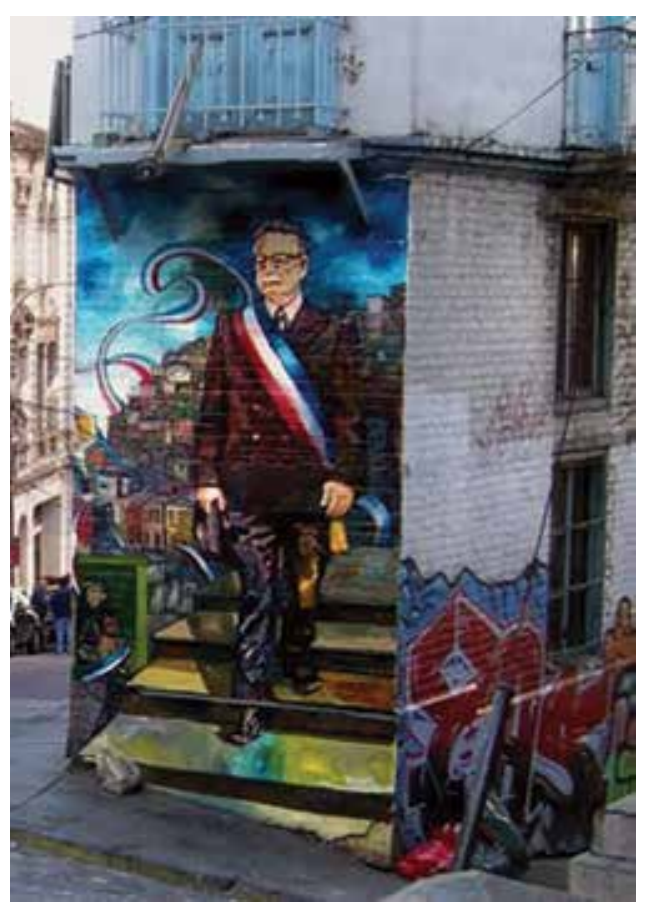

Figura 5. Christiane Hoth, 2010, "Mural de Salvador Allende” (fotografía, calle Almirante Montt, Valparaíso).

Como ya queda claro, en el primer ejemplo analizado es especialmente el retrato de Allende y los colores nacionales chilenos (azul, blanco y rojo) los que presentan al expresidente como ícono nacional. Sobre todo, durante los primeros días de septiembre del 2013, muchos murales fueron pintados en los centros de las ciudades, en honor al primer marxista y socialista elegido democráticamente. La mayoría de estas visualizaciones provienen de aniversarios, por ejemplo, el Centenario del Partido Comunista de Chile, en el 2012. En este caso, vemos el retrato de Allende y la bandera nacional de Chile luego de cuarenta años del golpe (figura 6). Aunque el Partido Comunista, fundado en 1912, solo fue parte de la coalición que llevó a Allende al Gobierno, es interesante ver que hoy en día se vincula directamente a él, siendo el expresidente miembro, diputado, senador y fundador del Partido Socialista. 


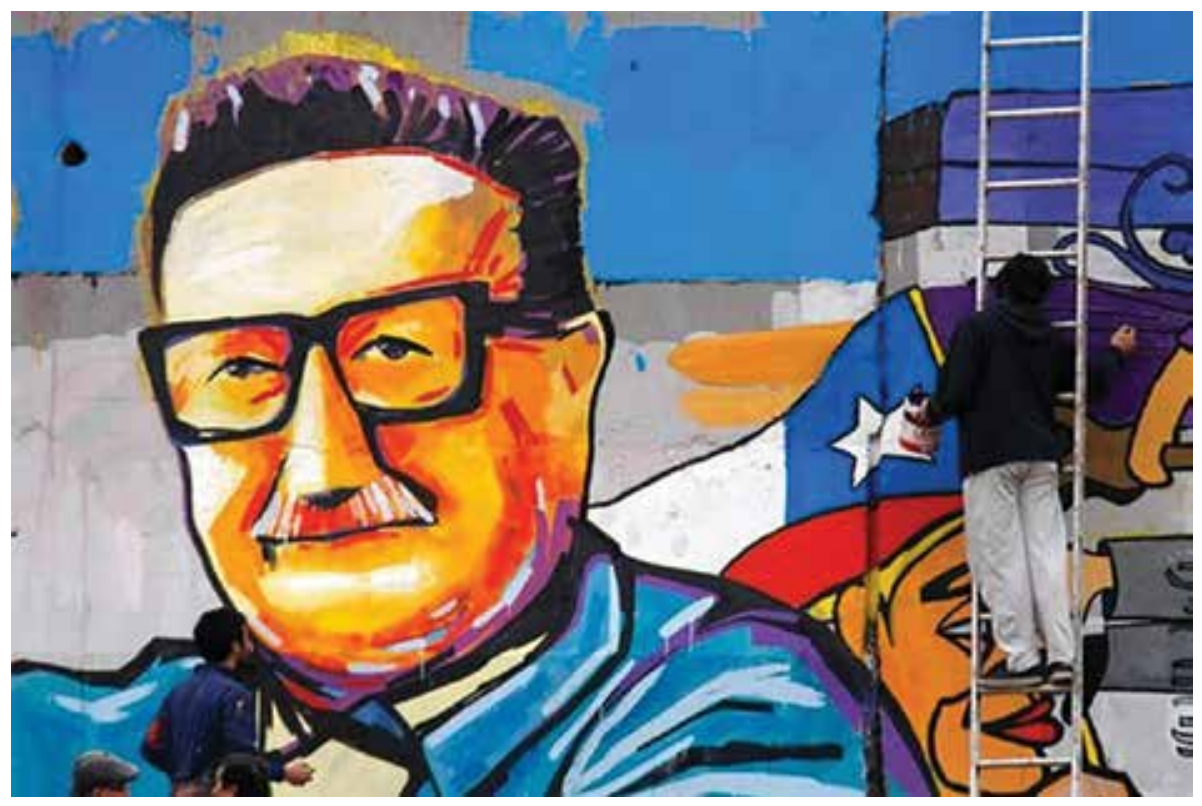

Figura 6. Anónimo, 2012, "Mural en el río Mapocho de Santiago de Chile en el centenario del Partido Comunista de Chile” (fotografía, https://prensapcv.files.wordpress.com/2013/09/mural-centenario_001. jpg \%3Fw \%3D474\%26h\%3D315).

Otro mural (figura 7), localizado en el campus de la USACH, en el 2013, apela directamente a los estudiantes chilenos por su declaración y lugar: es un conjunto de varias imágenes. ${ }^{69}$ Analizando la figura 8, el título a la izquierda Sin perdón ni olvido 40 años se refiere al golpe militar acontecido en 1973. Debajo del título, se ve el retrato de una mujer con la cita "por la vida... siempre!". A la derecha, encontramos la imagen de un minero al estilo brigada, que lleva sus herramientas típicas. A su lado está pintada una mujer en una pose muy dinámica: en el brazo izquierdo sostiene un libro estirándolo hacia arriba, abajo de su falda naranja se ve una pierna. A la derecha, vemos la bandera chilena y en el fondo la insignia de la Universidad Técnica del Estado. Para entender este conjunto de varias imágenes, tenemos que contextualizarlo: dicha universidad fue cerrada por Pinochet en 1981, supuestamente por su vinculación política con la izquierda. ${ }^{70}$ Anteriormente, diarios

69 La mayoría de murales en la USACH ya se encuentra borrada por orden oficial.

70 María José Lemaitre, “Aseguramiento de la calidad: una política y sus circunstancias", en La educación superior de Chile: transformación, desarrollo y crisis, ed. por Andrés Bernasconi (Santiago de Chile: Universidad Católica de Chile, 2015), 306-307. 
como El Mercurio ya habían mencionado y criticado las tendencias marxistas en las universidades chilenas:

En las universidades la acción juvenil marxista aprovecha también el alero cultural para intentar expandirse. [...] Si los sectores marxistas, o quienes ellos controlan, se empeñan en seguir utilizando la pantalla cultural para llevar a cabo tareas de otra índole, deben afrontar, entonces, la adopción de medidas legales por el Gobierno, el cual tiene el deber de hacer repetar tanto el orden público, valor juridico que es esencial en una sociedad, como el receso político, que reviste carácter transitorio. ${ }^{71}$

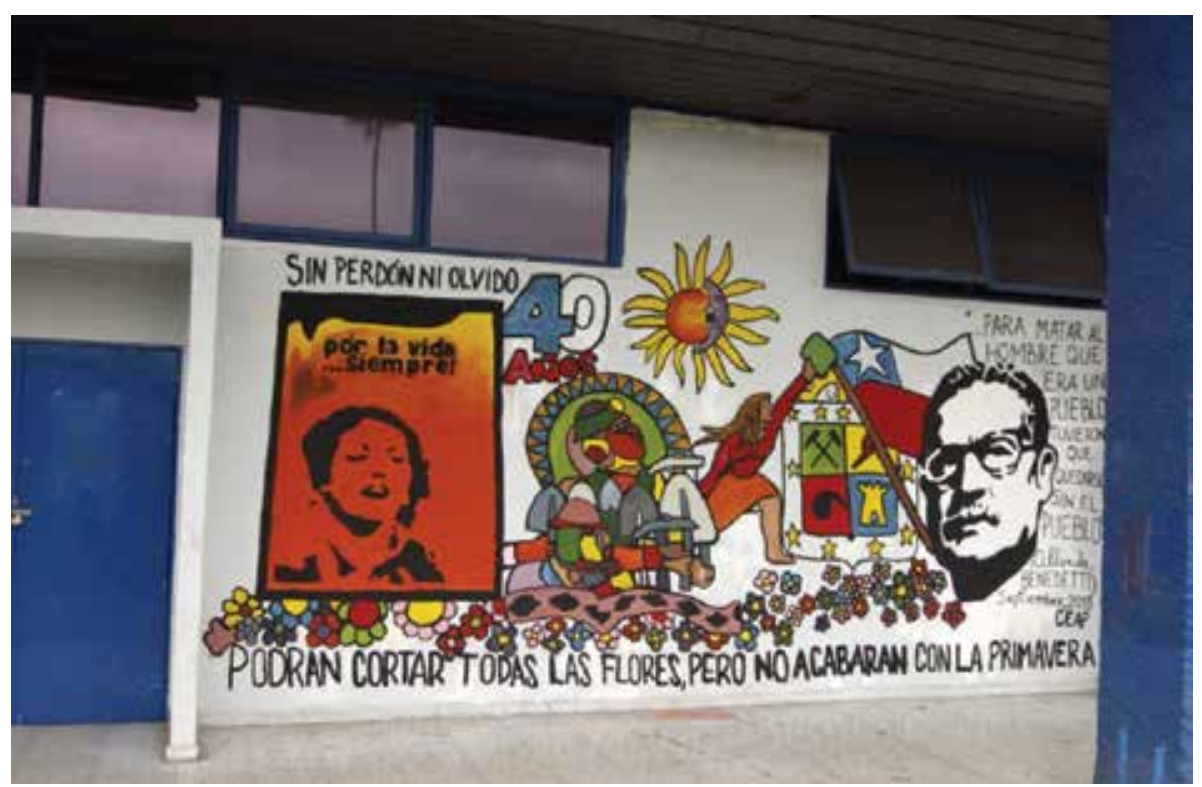

Figura 7. Christiane Hoth, 2013, "Sin perdón ni olvido" (fotografía, Santiago de Chile).

El artículo 6 del Decreto Ley 3541 de 1980 reza que: "la autonomía y la libertad académica no autoriza a las universidades para amparar ni fomentar acciones o conductas incompatibles con el orden jurídico, ni para permitir actividades orientadas a propagar, directa o indirectamente, tendencia político partidista alguna”.72

71 ElMercurio, 14 de junio de 1980.

72 Ley 3541, Congreso Nacional, diciembre de 1980, http://www.leychile.cl/Navegar?idNorma=3394 $(31 / 03 / 2017)$. 
El retrato de la mujer alude a una exposición en la Universidad Técnica del Estado que hubiera sido visitado por Allende el 11 de septiembre de 1973. El cartel de la figura 8 menciona dicha convocatoria:

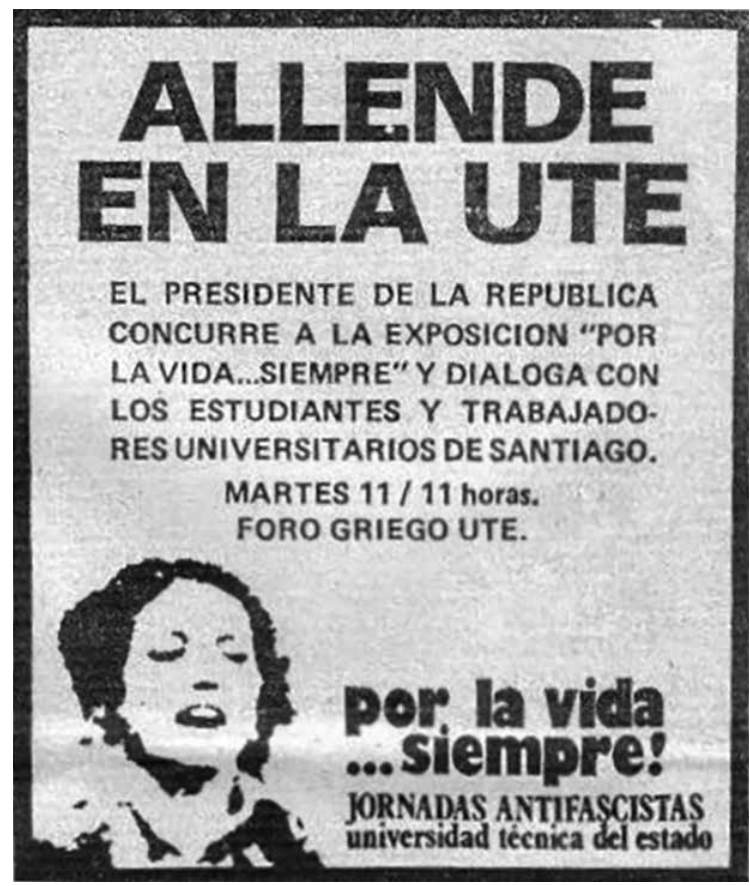

Figura 8. Anónimo, 1973, "Allende en la UTE [Universidad Técnica del Estado]" (pancarta, https://upload.wikimedia.org/wikipedia/commons/c/c2/Allende_en_la_UTE.jpg).

"Por la vida... siempre!" fue el nombre de la exposición que intentó informar y charlar sobre la prevención de una guerra civil. ${ }^{73}$ Como demuestra el cartel, fue planteado un diálogo entre el presidente, los estudiantes y los trabajadores universitarios; un evento que, de hecho, nunca tuvo lugar a causa del golpe militar. Lo interesante es que tanto el blasón de la Universidad Técnica del Estado como el cartel de la exposición de 1973 fueron utilizados para actualizar declaraciones antiguas en un lugar como la USACH, transformándolo así en un lugar de memoria

73 Museo de la Memoria y los Derechos Humanos, ed. "Por la vida... siempre!" 1973, la exposición inconclusa de la Universidad Técnica del Estado (Santiago de Chile: Museo de la Memoria y los Derechos Humanos, 2011), http://issuu.com/museomemoria/docs/por_la_vida_siempre_issu/3?e=0 (31/03/2017). 
donde se presentan nuevos mensajes en contextos cambiantes, tal como lo evidencia la figura 7.

En la mitad de la figura 7 se ven el sol y la luna. A la derecha, encontramos el retrato de Allende. Abajo de algunas flores está escrita la frase "podran cortar todas las flores, pero no acabarán con la primavera”. El mensaje que implica esta declaración es la siguiente: aunque muchas flores —entendida la gente como la vida - fueron destruidas por los militares en 1973, sobrevivirá la primavera, que simboliza lo primordial, en este caso, la ideología política. La primavera funciona también como metáfora para un comienzo, para un movimiento que empezó con Allende en 1970 y que hoy en día - después de cuarenta años de su supresión por los militares - vuelve a la vida. Son los mineros, los estudiantes como Camila Vallejo, los que no han olvidado a Allende y su obra; son ellos los que quieren mantener el recuerdo de Allende a través de murales como este.

Al lado del retrato podemos leer la frase: "Para matar al hombre que era un pueblo, tuvieron que quedarse sin el pueblo (Allende, BENEDETTI) Septiembre 2013 CEAP", referiéndose al poeta uruguayo Mario Benedetti. Dicha frase forma parte de un poema sobre Allende que interpela el asesinato del exmandatario, como si fuera un asesinato al pueblo chileno. ${ }^{74}$ La sigla CEAP significa Centro de Estudiantes de Administración Pública, que es una confederación estudiantil de la USACH.${ }^{75} \mathrm{El}$ mural es un homenaje a Allende por dicha confederación estudiantil, la cual quería recordar su obra después de cuarenta años del golpe. Según Barthes, esto se entiende como activación y apropiación de un mensaje conservado en la memoria colectiva.

\section{Conclusiones y perspectivas}

Este capítulo quería mostrar la existencia del mito Allende, a través de visualizaciones - concretamente por murales — producidas principalmente entre 2011 y 2013 y presentes en el ámbito urbano de las principales ciudades de Chile. La activación de este mito es resultado de la acción de un gran grupo de ciudadanos. En busca de emancipación y —según el sociólogo francés Pierre Bordieu-de un habitus propio, el movimiento estudiantil intenta romper conscientemente con lo pasado, es decir, con la continuidad de la dictadura. Por otro lado, es el movimiento el que crea una línea de continuidad desde el Gobierno de Allende hasta su escenificación

\footnotetext{
74 Mario Benedetti, Inventario: poesía completa (1950-1985), 8a ed. (Madrid: Visor, 1990), 59.

75 Cada carrera o bachelor en la USACH tiene su propio órgano representativo o vocerías.
} 
como ícono en nuestro presente. Los mensajes creados por estas construcciones se manifiestan en la memoria visual del movimiento, lo que afecta — tanto de forma positiva o negativa - al propio mito.

El movimiento estudiantil en Chile es un buen ejemplo de cómo se usa el pasado para proyectarse hacia el futuro. Utiliza medios visuales, símbolos y emociones para tematizar el pasado. Incluso, este puede considerarse un movimiento de generaciones. Lo que antes los mayores no podían criticar públicamente - debido a dictadura - está hoy presente en este movimiento, junto con las generaciones jóvenes.

Este trabajo tiene su enfoque en el análisis del mito desde una perspectiva visual. La limitación de este tema tan amplio ha sido establecida por la variedad de fuentes, por la dificultad de limitar el espacio y por el efecto del movimiento hacia una gran parte de la sociedad. Por ejemplo, sería interesante analizar la instrumentalización de Allende como un mito por otros actores como el Partido Socialista de Chile, el Partido Comunista y otras agrupaciones de izquierda. También se podría poner la atención en los casos fuera de Santiago y Valparaíso, incluso, hasta un posible carácter internacional. Una investigación más amplia debería analizar también aspectos como la música, la literatura, las películas, el teatro y, quizás más importante, internet y el 'uso' de Allende como ícono. Adicionalmente, es necesario destacar el efecto de este movimiento en función del mito que "promovió una nueva generación de líderes con figuración y protagonismo político a nivel nacional".76

Teniendo en cuenta que el mito que hemos encontrado en el análisis de los murales evidencia un referente político del expresidente Allende, en el futuro sería muy interesante investigar la conexión entre los murales y el presidencialismo, no solo con respecto a verdaderos presidentes como Allende, sino al mismo movimiento y sus dirigentes:

Incluso, todas las federaciones tienden a ser notoriamente 'presidencialistas'. Si bien los estatutos de muchas federaciones velan para que sean lo más democrática y representativas posibles, es fundamental el rol que cumple la mesa directiva central y quien ocupa la presidencia. Del mismo modo, es fundamental el rol que cumplen los voceros en la CONFECH, aunque eso implique un distanciamiento entre la estructura central y el universo de estudiantes universitarios. ${ }^{77}$

76 Avendaño, "Fracturas y representación política", 43.

77 Ibid., 62. 
En fin, el movimiento sí enseña estructuras centralizadas con líderes carismáticos como Camila Vallejo, Giorgio Jackson o Karol Cariola. Esta tendencia ha causado nuevos conflictos con la izquierda más radical y los grupos anarquistas. Aunque "el éxito y la masividad del movimiento hasta inicios de septiembre [de 2011] fue producto de su heterogeneidad y diversidad" 78 podemos constatar que las transformaciones de algunos líderes en figuras nacionales ha conducido a nuevas representaciones. En el Chile de hoy se produce una identidad colectiva a través de nuevos símbolos. ${ }^{79}$ Como muestra el último ejemplo (figura 9), no es solamente Allende, sino también figuras menos conocidas como Yuri Zuñiga, fundador de la Biblioteca Popular Salvador Allende y excandidato a alcalde por Valparaíso, los que se han transformado en íconos. En la pintura también aparece Camila Vallejo, como símbolo del movimiento y representante de su generación pero, asimismo, como esperanza de lucha del legado de Salvador Allende.

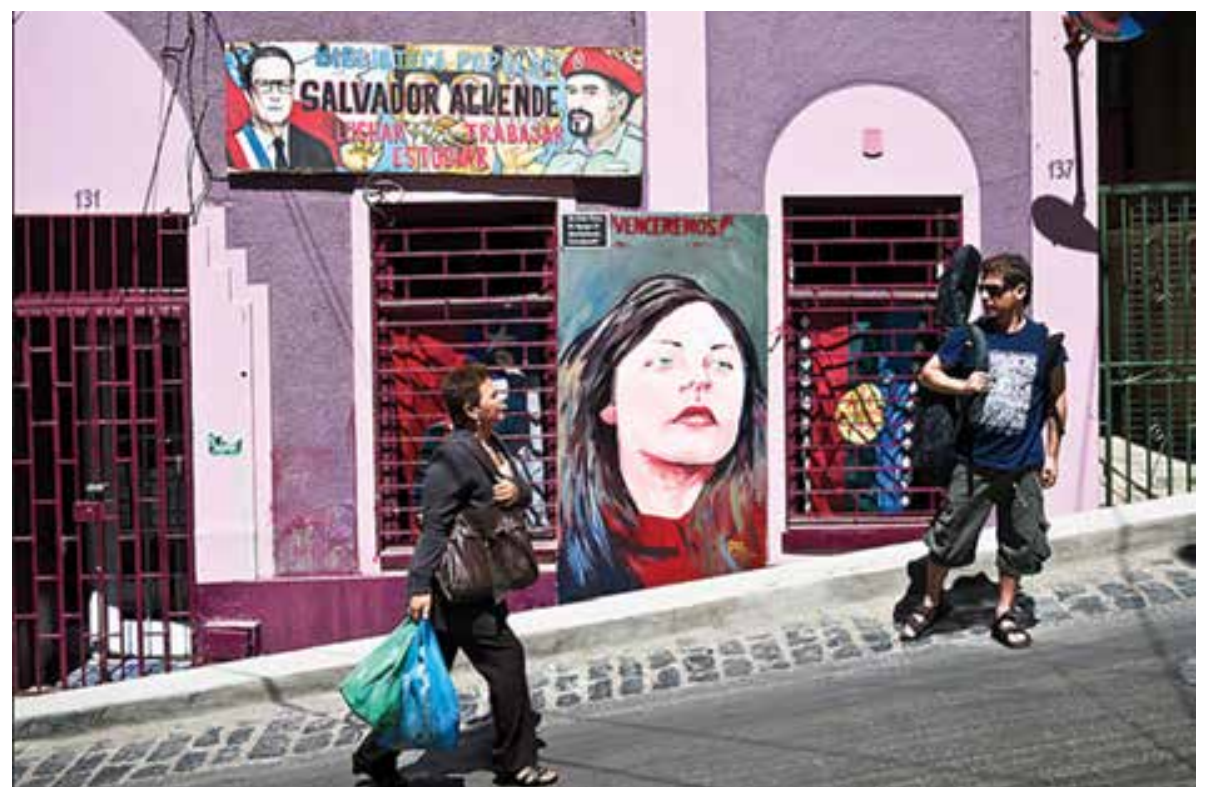

Figura 9. Francisco Osorio, 2012, “Camila Vallejo Street Portrait Valparaíso” (fotografía, https://www.flickr.com/ photos/francisco_osorio/6789859644/in/photostream/).

78 Ibid., 64.

79 Carmen Silvia Dreyer y Javier Romero Ocampo, “:Qué es un movimiento social fuerte?: Conceptualizaciones de la noción de fortaleza y aplicación al caso del movimiento estudiantil 2002-2011 en Chile", Última Década, n. ${ }^{\circ} 38$ (2013): 100. 
Entre la bandera nacional y la bandera del Consejo de Todas las Tierras, una organización mapuche, su retrato está acompañado por la famosa cita “[i]Venceremos!" de Salvador Allende. No solo podemos identificar esquemas simbólicos y tradiciones activadas a través de lo visual. El ejemplo nos muestra que el movimiento también necesita nuevos héroes. Como íconos, sus líderes ganan más capital simbólico por su circulación, apropiación y recepción.

La multiplicación masiva de murales en el país andino, nos presenta la creación de universos simbólicos por el movimiento estudiantil, y por este solo hecho, les dan un sentido a sus acciones o una validación política a sus propuestas. Rescatando la teoría de Barthes, podemos decir que los ejemplos elegidos muestran dichos mensajes conservados en la memoria chilena, los cuales transforman íconos a sujetos de mito en un plano intergeneracional.

Para finalizar, y a modo de resumen, podemos plantear tres grandes conclusiones. En primer lugar, los actores analizados retomaron elementos históricos para fundamentar su acción política. Segundo, dichos actores constituyeron el mito y que refleja la memoria chilena. Finalmente, los íconos actuales son referentes políticos hoy en día y se están constituyendo ya en sujetos de mito.

\section{Bibliografía}

\section{Fuentes primarias}

\section{Publicaciones periódicas}

El Mercurio. Santiago de Chile, 1980 y 2011.

El Siglo. Santiago de Chile, 1972.

La Tercera. Santiago de Chile, 2011.

\section{Impresas}

Ley 17.729, Congreso Nacional, septiembre de 1972, http://www.leychile.cl/ Navegar idNorma $=29250$.

Ley 3541, Congreso Nacional, diciembre de 1980, http://www.leychile.cl/ Navegar ?idNorma $=3394$.

Benedetti, Mario. Inventario:poesía completa (1950-1985). 8ª ed. Madrid: Visor, 1990. Ouviña, Hernán. "Somos la generación que perdió el miedo: entrevista a Camila Vallejo Dowling”. Revista del Observatorio Social de América Latina. Consejo Latinoamericano de Ciencias Sociales 13, n. ${ }^{\circ} 31$ (2012), 13-20. 


\section{En línea}

Archivo General del Movimiento Estudiantil, http://movimientoestudiantil.cl/ multimedia/videos/.

Camila Vallejo Dowling, https://twitter.com/camila_vallejo y https://www.facebook. com/Camila-Vallejo-Dowling-170911349635410/timeline/.

\section{Imágenes}

Archivo Fortín Mapocho, http://www.archivofortinmapocho.cl/imagenes/mural/. Centro Cultural Gabriela Mistral, Santiago de Chile.

Flickr,https://www.flickr.com/photos/francisco_osorio/6789859644/in/photostream/. Fundación Salvador Allende, http://www.fundacionsalvadorallende.cl/salvadorallende/.

Hoth, Christiane, fotografías privadas de la autora.

Museo Histórico Nacional, Santiago de Chile.

Wikimedia Commons.

\section{Fuentes secundarias}

Abujatum Berndt, Leonor. "Chile: Ein Land im Umbruch? Wie aus dem Unmut über soziale Ungleichheit eine neoliberalismus-kritische Bewegung wurde”. En Soziale Proteste in Lateinamerika: Bolivars Erben im Kampf um Eigenmacht, Identität und Selbstbestimmung, editado por Torben Ehlers, 274-302. Hamburg: Argument, 2013.

Armstrong, Karen. A Short History of Myth. Edinburgh: Canongate, 2005.

Assmann, Jan. Das kulturelle Gedächtnis: Schrift, Erinnerung und politische Identität in frühen Hochkulturen. München: C. H. Beck, 2007.

Avendaño, Octavio. "Fracturas y representación política en el movimiento estudiantil, Chile 2011". Última Década, n. 41 (2014): 41-68.

Barthes, Roland. Mythologies. Paris: Seuil, 1970.

Bragassi, Juan, "El Muralismo en Chile: una experiencia histórica para el Chile del bicentenario", http://www.memoriachilena.cl/602/articles-123178_ recurso_2.pdf(31/03/2017).

Cárdenas Neira, Camila. "Representación de la acción política de los estudiantes chilenos: movilización de significados en redes sociales”. Última Década, n. ${ }^{\circ} 40$ (2014): 57-84.

Codoceo, Fernando. Demokratische Transition in Chile. Kontinuität oder Neubeginn? Berlin: wvB, 2007. 
Collins, Cath y Katherine Hite. "Memorials, Silences, and Reawakenings”. En The Politics of Memory in Chile: From Pinochet to Bachelet, editado por Cath Collins y Katherine Hite, 133-163. Boulder: Lynne Rienner Publisher, 2013.

Cummings, Peter. "Democracy and Student Discontent: Chilean Student Protest in the Post-Pinochet Era”. Journal of Politics in Latin America 7, n. 3 (2015): 49-84.

Della Porta, Donatella y Mario Diani. Social Movements: An Introduction, $2^{\text {a }}$ ed. Malden: Blackwell, 2006.

Della Porta, Donatella, Hanspeter Kriesi y Dieter Rucht. Social Movements in a Globalizing World. Basingstoke: Palgrave Macmillan, 2002.

Diani, Mario. "Simmel to Rokkan and Beyond. Towards a Network Theory of (New) Social Movements". European Journal of Social Theory 3, n. 4 (2000): 387-406.

Donoso, Sofía. "La reconstrucción de la acción colectiva en el Chile post-transición: el caso del movimiento estudiantil”, Clacso (2014): 1-45.

Dreyer, Carmen Silvia y Javier Romero Ocampo. “¿Qué es un movimiento social fuerte?: conceptualizaciones de la noción de fortaleza y aplicación al caso del movimiento estudiantil 2002-2011 en Chile”. Última Década, n. 38 (2013): 91-108.

Escobar, Arturo, ed. The Making of Social Movements in Latin America: Identity, Strategy, and Democracy. Boulder: Paradigm Publisher, 1992.

Farías, Víctor. Salvador Allende: Elfin de un mito. Elsocialismo entre la obsesión totalitaria y la corrupción. Nuevas revelaciones, $3^{\text {a }}$ ed. Santiago de Chile: Maye, 2007.

Fischer-Lichte, Erika. "Performance, Inszenierung, Ritual: Zur Klärung kulturwissenschaftlicher Schlüsselbegriffe”. En Geschichtswissenschaften und 'performative turn': Ritual, Inszenierung und Performanz vom Mittelalter bis zur Neuzeit, editado por Jürgen Martschukat y Steffen Patzold, 33-54. Köln: Böhlau, 2003.

Flores Navarrete, Carlos. Auge \& caida de la educación chilena: desde Inés de Suárez a Camila Vallejo. Santiago de Chile: Lom, 2011.

Galaz, Gaspar y Milan Ivelic, eds. Chile, arte actual. Valparaíso: Universidad de Valparaíso, 1988.

García, Fernando Diego y Óscar Sola. Salvador Allende: Das Ende einer Ära. Berlin: Aufbau-Verlag, 1998.

Garretón, Manuel Antonio. Delpostpinochetismo a la sociedad democrática: Globalización y politica en el Bicentenario. Buenos Aires: Debate, 2007. 
Habermas, Jürgen. Faktizität und Geltung: Beiträge zur Diskurstheorie des Rechts und des demokratischen Rechtsstaates. Frankfurt am Main: Suhrkamp, 1992.

Harvey, David. Rebel Cities: From the Right to the City to the Urban Revolution. London: Verso, 2012.

Kaltmeier, Olaf, Jens Kastner y Elisabeth Tuider, eds. Neoliberalismus - Autonomie Widerstand. Soziale Bewegungen in Lateinamerika. Münster: Westfälisches Dampfboot, 2004.

Lemaitre, María José. “Aseguramiento de la calidad: una política y sus circunstancias”. En La educación superior de Chile: transformación, desarrollo y crisis, editado por Andrés Bernasconi, 295-344. Santiago de Chile: Universidad Católica de Chile, 2015.

Luhmann, Niklas. Protest: Systemtheorie und soziale Bewegungen, editado y coordinado por Kai-Uwe Hellmann. Frankfurt am Main: Suhrkamp, 1996.

Mayer, Liliana. "Schooling System, Earthquakes and Beyond: The Chilean Experience of 2010". Iberoamericana 14, n. ${ }^{\circ} 55$ (2014): 147-162.

Mayol, Alberto. No al lucro: de la crisis del modelo a la nueva era politica. Santiago de Chile: Debate, 2012.

Mittag, Jürgen y Helke Stadtland, eds. Theoretische Ansätze und Konzepte der Forschung über soziale Bewegungen in der Geschichtswissenschaft. Essen: Klartext, 2014.

Moulian, Tomás. Chile actual, anatomía de un mito, 19a ed. Santiago de Chile: LOM, 1998.

Muñoz Tamayo, Víctor. “'Chile es bandera y juventud’: efebolatría y gremialismo durante la primera etapa de la dictadura de Pinochet (1973-1979)". Historia Critica, n. ${ }^{\circ} 54$ (2014): 195-219.

Muñoz Tamayo, Victor. Generaciones: Juventud universitaria e izquierdas politicas en Chile y México (Universidad de Chile-UNAM 1984-2006). Santiago de Chile: LOM, 2011.

Museo de la Memoria y los Derechos Humanos, ed. "Por la vida...siempre!” 1973, la exposición inconclusa de la Universidad Técnica del Estado. Santiago de Chile: Museo de la Memoria y los Derechos Humanos, 2011). http://issuu.com/ museomemoria/docs/por_la_vida_siempre_issu/3?e=0 $(31 / 03 / 2017)$.

Nohlen, Dieter. "Presidencialismo, sistema electorales y sistemas de partidos: reflexiones para América Latina”. En Presidencialismo versus parlamentarismo, América Latina, editado por Dieter Nohlen y Mario Fernández, 51-70. Caracas: Nueva Sociedad, 1991. 
Paul, Gerhard. "Bilder, die Geschichte schrieben. Medienikonen des 20. und beginnenden 21. Jahrhunderts. Einleitung". En Bilder, die Geschichte schrieben. 1900 bis heute, editado por Gerhard Paul, 7-16. Bonn: bpb, 2011.

Paul, Gerhard. "Die Geschichte hinter dem Foto. Authentizität, Ikonisierung und Überschreibung eines Bildes aus dem Vietnamkrieg”. Zeithistorische Forschungen/Studies in Contemporary History, n. ${ }^{\circ} 2$ (2005): 224-254.

Raúl, Ernesto. Pintura social en Chile. Santiago de Chile: Quimantu, 1972.

Reichhardt, Rolf. “Bilder- und Mediengeschichte”. En Kompass der Geschichtswissenschaft, editado por Joachim Eibach y Günther Lottes, 219-230. Göttingen: Vandenhoeck \& Ruprecht, 2006.

Rinke, Stefan y Sylvia Dümmer Scheel. “'Der Sold Chiles’. Gedenken an die Opfer politischer Gewalt im 19. und 20. Jahrhundert”. En Gefallenengedenken im globalen Vergleich: nationale Tradition, politische Legitimation und Individualisierung der Erinnerung, editado por Manfred Hettling y Jörg Echternkamp, 69-92. München: Oldenbourg, 2013.

Rinke, Stefan. “¿Comienzo o fin de la historia?: el 11 de septiembre y las luchas por la memoria en Chile". En Memorias de la nación en América Latina: transformaciones, recodificaciones y usos actuales, editado por Hans-Joachim König, Andrea Pagni y Stefan Rinke, 171-194. México: Ciesas, 2008.

Rinke, Stefan. Kleine Geschichte Chiles. München: C. H. Beck, 2007.

Ruderer, Stephan. "Hybride Erinnerung: Geschichtspolitik in Chile”. Geschichte und Gesellschaft. Zeitschrift für Historische Sozialwissenschaft 36, n. 1 (2010): $129-156$.

Samaniego, Augusto y Carlos Ruiz. Mentalidades y politicas wingka: pueblo mapuche, entre golpe y golpe (de Ibáñez a Pinochet). Madrid: Consejo Superior de Investigaciones Científicas, 2007.

Schneider, Christian, Cordelia Stillke y Bernd Leineweber. Trauma und Kritik: Zur Generationengeschichte der Kritischen Theorie. Münster: Westfälisches Dampfboot, 2000.

Sperberg, Jaime. "Aufschwung in der Diktatur-Demobilisierung in der Demokratie?: Soziale Bewegungen in Chile”. En ¿El pueblo unido?: Soziale Bewegungen und politischer Protest in der Geschichte Lateinamerikas, editado por Jürgen Mittagy Georg Ismar, 217-228. Münster: Westfälisches Dampfboot, 2009. Tilly, Charles y Lesley Wood. Social Movements 1768-2012, $3^{\mathrm{a}}$ ed. Boulder: Paradigm Publisher, 2013. 
Urra Rossi, Juan. “La movilización estudiantil chilena en 2011: una cronología”. Revista del Observatorio Social de América Latina. Consejo Latinoamericano de Ciencias Sociales 13, n. 31 (2012): 23-37.

Warnke, Martin. "Politische Ikonografie”. Kunsthistorische Arbeitsblätter, n. 2 (2003): 5-16.

Wolfrum, Edgar. Geschichtspolitik in der Bundesrepublik Deutschland: Der Weg zur bundesrepublikanischen Erinnerung. Darmstadt: Wissenschaftliche Buchgesellschaft, 1999.

Yocelevzky, Ricardo A. Chile: partidos politicos, democracia y dictadura 1970-1990. México: Fondo de Cultura Económica, 2002. 


\section{Los autores}

Alejandra Buenaventura (Colombia). Historiadora de la Universidad del Rosario, Bogotá. Desarrolló su tesis de pregrado sobre infanticidios en la Provincia de Antioquia (Nueva Granada) entre 1765 y 1803 . Ha sido coordinadora del semillero de investigación Historias Conectadas, Memoria e Imagen y es joven investigadora en el proyecto Colombia en las exposiciones internacionales del IV Centenario, dirigido porSven Schuster. Correo electrónico: alejandrabuenaventuragomez@gmail.com

Anna Cant (Reino Unido). Investigadora afiliada al departamento de Historia de la Universidad de los Andes, Bogotá. Doctora en Historia por la Universidad de Cambridge (Reino Unido). Escribió su tesis doctoral sobre el impacto cultural y político de la reforma agraria en el Perú durante el Gobierno militar de Juan Velasco Alvarado (1968-75). Está interesada en varios aspectos de la historia latinoamericana del siglo $\mathrm{xx}$, en especial en los medios de comunicación, las luchas por la tierra y los debates sobre la ciudadanía. Actualmente está trabajando en un proyecto de investigación financiado por el Leverhulme Trust sobre la educación radiofónica en el campo colombiano durante los años sesenta y setenta. Correo electrónico:annacant@gmail.com

Paulo Córdoba (Colombia). Historiador de la Universidad del Rosario y estudiante de Maestría en Filosofía en la misma universidad. Sus intereses gravitan sobre teoría de la historia y sobre procesos históricos de contextos iberoamericanos del siglo xx, como son los casos de Colombia, Brasil y México. Correo electrónico: paulo.cordoba@urosario.edu.co

Sebastián Gacha (Colombia). Estudiante de Historia en proceso de grado de la Universidad del Rosario, Bogotá. Líneas de interés: gramática y política en el siglo XIX, historia del libro, historia de las ideas. Correo electrónico: sebastian. gacha@urosario.edu.co 
Liliana Gómez-Popescu (Colombia). Profesora de la Swiss National Science Foundation (SNSF), Universidad de Zúrich, donde obtuvo su posdoctorado (habilitación) en Literatura y Análisis Cultural. Tiene un Doctorado en Estudios Literarios y Culturales de la Freie Universität Berlin. Ha sido visiting scholar en el Departamento de Historia de Arte y Arquitectura y en el Departamento de Filología Románica de la Universidad de Harvard (2013-2016), así como profesora visitante en la Universidad del Rosario, Bogotá (2016), y la Columbia University (2008-2010). Ha sido profesora asistente en la Martin-Luther-Universität HalleWittenberg (2011-2017). Entre sus publicaciones más recientes se destacan el número especial "History through Photography", en la revista Estudios Interdisciplinarios de América Latina y el Caribe (2015), y como autora Lo urbano. Teorias culturales y politicas de la ciudad en América Latina (Pittsburgh, 2014). Su libro $A$ Laboratory of the Modern. The Caribbean in Photographic Archives se encuentra en proceso de edición. Correo electrónico: lgomezpopescu@gmail.com

Óscar Daniel Hernández Quiñones (Colombia). Historiador y profesional en Artes Liberales de la Universidad del Rosario, Bogotá. Estudiante de Maestría en Estudios Sociales de la misma universidad. Sus intereses de investigación se ubican en los siglos XIX y XX, principalmente en las apropiaciones políticas y culturales de la modernidad industrial en Colombia, así como en la relación teórica entre historia económica e historia cultural. Miembro activo del semillero Historias Conectadas, Memoria e Imagen. Correo electrónico: oscardhq@hotmail.com

Christiane Hoth (Alemania). Profesora asistente del Departamento de Historia de la Universidad Católica de Eichstätt-Ingolstadt, Alemania. Estudió Historia, Filología Alemana y Filología Española en esa misma universidad (2009-2016) y en la Universidad de Salamanca (2011-2012). Su tesis de maestría versa sobre las construcciones nacionales y visuales de los países latinoamericanos en la Exposición Histórico-Americana de 1892, en Madrid. Correo electrónico:gga419@ku.de

Natalia Mahecha Arango (Colombia). Analista de Contexto de la Unidad de Restitución de Tierras. Politóloga e historiadora de la Universidad de los Andes. Fue becaria del programa Quiero Estudiar de la Universidad de los Andes (2007-2011) y del programa Jóvenes Investigadores e Innovadores de Colciencias (2012). En el plano de la docencia, ha dictado los cursos de Historia de Colombia, Historia del Mundo y la Cátedra Basta Ya Colombia: Memorias de Guerra y Dignidad, en la 
Universidad Sergio Arboleda y la Universidad del Rosario. Entre sus publicaciones se destacan los documentos de investigación "Descosiendo la historia: una mirada al mundo de lo femenino a través de las máquinas de coser Singer" (2012) y "Linchamientos, crimen y protesta: justicia popular en Colombia, 1990-2010” (2011), y el artículo "De lo distractivo a lo instructivo: algunas aproximaciones al uso de la historieta histórica en la enseñanza de la historia” (2012). Correo electrónico: natalia.mahechaa@urosario.edu.co

Lery Munar (Colombia). Estudiante de pregrado en Historia de la Universidad del Rosario, Bogotá. Miembro del semillero de investigación Historias Conectadas, Memoria e Imagen y del proyecto audiovisual Charlas sobre la historia. Entre 2015 y 2016, ha sido estudiante de intercambio en la Universidad París 1 PanthéonSorbonne. Correo electrónico: lerydaniela7@gmail.com

Andrés Pérez Carvajal (Colombia). Investigador en el Centro de Estudios Políticos e Internacionales (CEPI) de la Facultad de Ciencia Política de la Universidad del Rosario, Bogotá. Politólogo e Historiador de la misma institución. Es miembro de los semilleros Historias Conectadas, Memoria e Imagen y La Ingeniería de lo Social. Sus intereses se concentran en los estudios sociales del Estado y la historia cultural. Correo electrónico: andresm.perez@urosario.edu.co

Daniela Prada (Colombia). Historiadora de la Universidad del Rosario y estudiante de Maestría en Derecho con énfasis en Derechos Humanos y justicia transicional en la misma universidad. Sus intereses de investigación se centran en los siglos XIX y Xx. Del primero ha trabajado los espacios femeninos en la esfera pública y la historia política republicana. Del segundo, la producción historiográfica de los distintos momentos del conflicto armado, así como la producción académica y jurisprudencial de la esfera política colombiana de los años ochenta en adelante. Integrante de iniciativas estudiantiles como Charlas sobre la historia y la revista colombiana de estudiantes de historia, Artificios, financiada por el Instituto Colombiano de Antropología e Historia. Correo electrónico: daniela.prada.ar@ gmail.com

Camila Ramírez Maldonado (Colombia). Historiadora y socióloga de la Universidad del Rosario, Bogotá. Sus intereses de investigación están dirigidos hacia la geografía histórica, enfocados en la apropiación y representación del espacio. 
Actualmente trabaja como consultora en el área social de proyectos y asesoramientos geográficos de carácter social como planeación territorial. Correo electrónico: maldonador.camila@gmail.com

Sven Schuster (Alemania). Profesor asociado de la Escuela de Ciencias Humanas de la Universidad del Rosario, Bogotá. Doctor en Historia de América Latina por la Universidad Católica de Eichstätt-Ingolstadt (Alemania). Fue profesor asistente en esa misma universidad (2005-2013), profesor visitante en la Pontificia Universidad Católica de Río de Janeiro (2011) y la Universidad Federal de Goiás (2012), así como resident fellow de Smithsonian Institution Libraries en Washington, D. C. (2014). Ha publicado varios ensayos y monografías sobre historia colombiana y brasileña, siglos XIX y Xx. Correo electrónico: svenb.schuster@urosario.edu.co

Laura Andrea Vigoya Arango (Colombia). Estudiante en proceso de grado de Antropología de la Universidad del Rosario, Bogotá. En este momento, está terminando su tesis sobre la construcción de cuerpos en el Tango Queer. Temas de interés: antropología del cuerpo, del género, musical y visual. Ha publicado un artículo sobre antropología del cuerpo y clase en la revista Antropología, de estudiantes de la Pontificia Universidad Javeriana. Además, ha sido partícipe de la expedición Abya Yala en Colombia y Ecuador. Correo electrónico: lauravigoyaarango@gmail.com 
Este libro fue compuesto en caracteres Garamond Premier Pro 11,5 puntos, impreso sobre papel propal de 70 gramos y encuadernado con método Hot Melt, en el mes de septiembre de 2017, en Bogotá D. C., Colombia

Paramericana Formas e Impresos S. A. 